Coastal Management

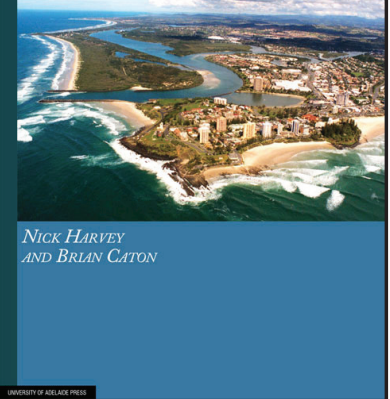

Welcome to the electronic edition of Coastal Management in Australia.

The book opens with the bookmark panel and you will see the contents page. Click on this anytime to return to the contents. You can also add your own bookmarks.

The whole document is fully searchable.

Enjoy. 


\section{Coastal Management in Australia}

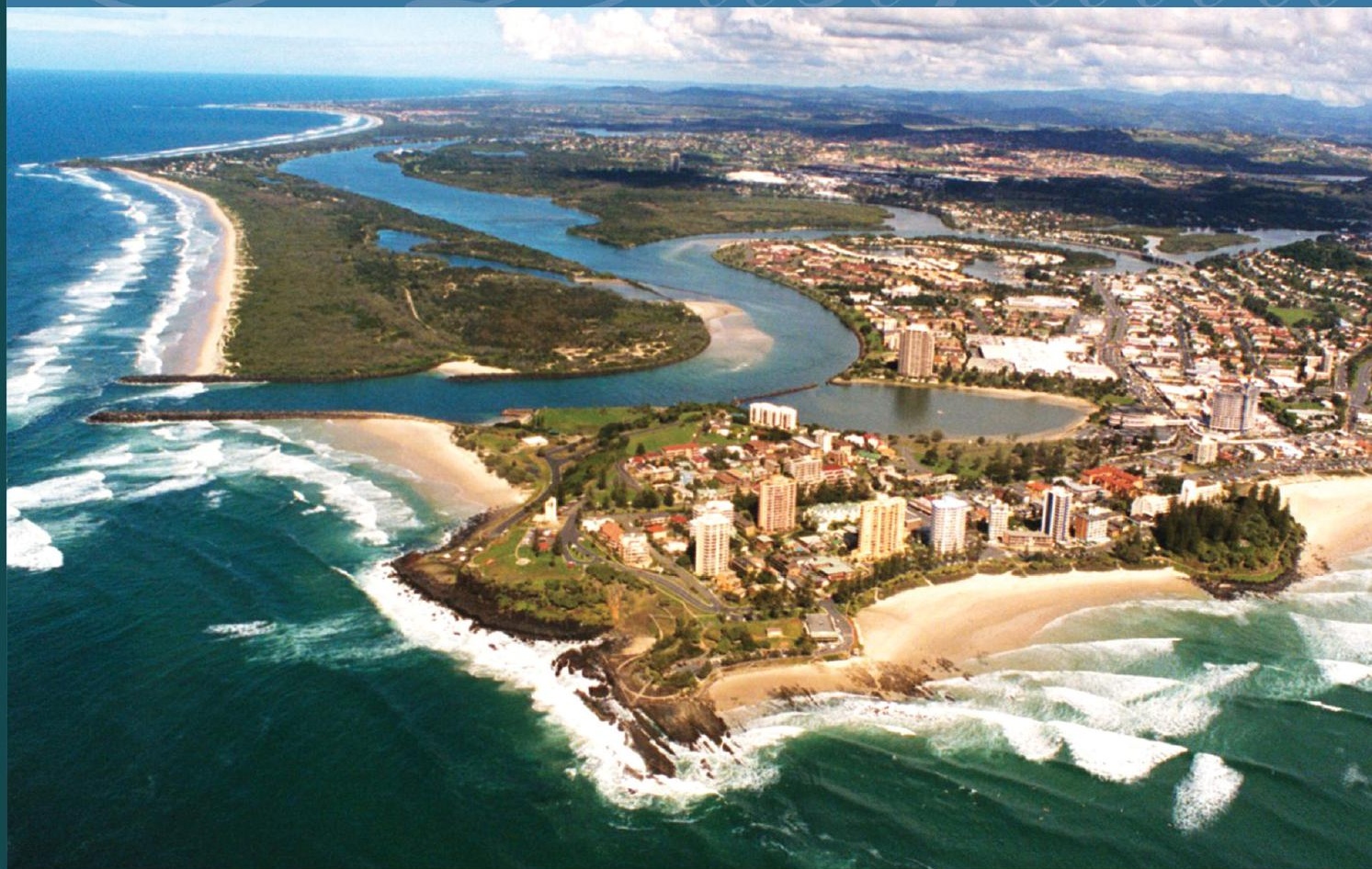

NICK HARVEY

AND BRIAN CATON 


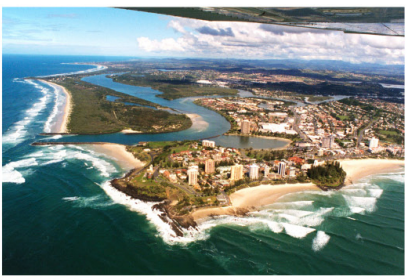

\section{Coastal Management in Australia}

The coast is one of our most valuable assets but how is it being treated and what is being done to look after it? Coastal Management in Australia is the first book to provide a comprehensive overview of this important subject. Interesting case studies are used to illustrate human impact on coastal processes as well as demonstrating the global significance of the coast and the international imperative to manage it properly.

Coastal Management in Australia introduces the background to the various coastal management systems operating in Australia and illustrates these with 'real world' examples from the different states and territories.

Since this book was first published yet another parliamentary inquiry has been added to some 30 years of national inquiries into coastal management, with further calls for national co-ordination. In addition, the Australian government has focused attention on the potential risks of climate change for the Australian coast.

Both authors have national and international coastal expertise; significant academic teaching experience in coastal processes and coastal management; coastal planning and policy skills; and have extensive government expertise in coastal management.

Nick HarveY is Executive Dean of the Faculty of Humanities and Social Sciences and Professor of Geography and Environmental Studies at the University of Adelaide. He was also a Lead Author on the Fourth Assessment Report of the Intergovernmental Panel on Climate Change.

Brian Caton is an Adjunct Lecturer with the School of Environment at Flinders University and a consultant for the Coastal Branch of the Department of Environment and Heritage, South Australian Government.

Front cover picture: The Tweed River marks the boundary between New South Wales and Queensland where the training walls at the mouth of the river have interrupted the northward littoral drift of sand. The coastal management response has been a joint agreement between the two State governments for a sand bypassing system. Accumulated sand is pumped northwards from Letitia Spit (top left of photo) in New South Wales across the border and onto Kirra and Greenmount (middle of photo) beaches in Queensland. The photograph was taken by Fran West who, in 1999, became the first woman pilot to fly around Australia in a light aircraft.

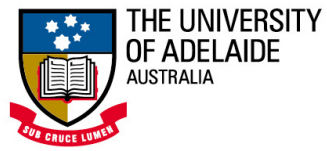




\section{Coastal Management in Australia}





\title{
Coastal Management in Australia
}

\author{
NICK HARVEY \\ AND BRIAN CATON
}

Series Editors

Deidre Dragovitch

Alaric Maude

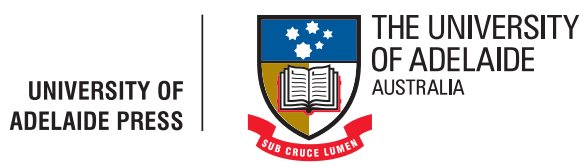




\section{Published in Adelaide by the}

University of Adelaide Press

Barr Smith Library

The University of Adelaide

South Australia

5005

press@adelaide.edu.au

www.adelaide.edu.au/press

The University of Adelaide Press publishes externally refereed scholarly books by staff of the University of Adelaide. It aims to maximise the accessibility to its best research by publishing works through the internet as free downloads and as high quality printed volumes on demand.

Electronic Index: this book is available from the website as a down-loadable PDF with fully searchable text. Please use the electronic version to complement the index.

(C) Nick Harvey and Brian Caton 2003, 2010

First published 2003 by Oxford University Press

Republished 2010 by University of Adelaide Press with a new Foreword by Nick Harvey

This book is copyright. Apart from any fair dealing for the purposes of private study, research, criticism or review as permitted under the Copyright Act, no part may be reproduced, stored in a retrieval system, or transmitted, in any form or by any means, electronic, mechanical, photocopying, recording or otherwise without the prior written permission. Address all inquiries to the Director at the above address.

\section{Subject Keywords}

Coastal zone management Australia - Shore Protection Australia - Coastal engineering Australia

For the full Cataloguing-in-Publication data please contact National Library of Australia: cip@nla.gov.au

ISBN 978-0-9807230-3-8 (electronic)

ISBN 978-0-9807230-4-5 (paperback)

Original book design by Racheal Stines reprinted with permission Front cover: Céline Lawrence

Paperback printed by Griffin Press, South Australia 


\section{Foreword}

The Australian coast and its thousands of beaches have an iconic status in the Australian culture and way of life. Most Australians live on or near the coast where there is continuing population and development pressure, particularly along non-metropolitan coastlines. There is also a heavy use of coastal resources and added pressure from recreational users. We need to understand how these activities affect coastal processes so that we can limit our impacts. If we can avoid changing the natural balance of processes as far as possible we are more likely to maintain the iconic status of the Australian coast.

There are some good examples where human impact on the Australian coast has been managed quite successfully but the mechanisms for coastal management vary considerably between the various state and territory governments. There have also been numerous coastal inquiries into how we manage the coast but by the turn of the century there was still no single comprehensive overview of Australian coastal management. In order to fill that void, this book was published in 2003. It has had favourable reviews and has been popular as a text.

Since it went out of print in 2009 there have been a number of requests for copies of the book and questions about when we will be writing a new book. In order to meet the immediate demand we arranged to make the book available as a reprint through The University of Adelaide Press, which could produce a cost effective print version in addition to offering an e-publishing option making it accessible to a wider audience.

The next task will be to prepare a revised edition over the next year or two which will incorporate recent and proposed changes to coastal management, particularly at the state and territory level of government, since the book was written. These can be accessed easily through the various government websites or through links on national coastal websites such as the recently formed Australian Coastal Society www.australiancoastalsociety. org, which takes an advocacy role for sustainable management of the Australian coast. Notwithstanding these changes, the fundamental structure of the book remains relevant as it provides the global context to integrated coastal management, a background to understanding Australian coastal processes, and 'real world' case studies of how coastal management operates in the various states and territories.

However, since the book was published the national government has become re-engaged in the debate over what is the most effective way forward for managing the Australian coast. There have been numerous national inquiries into coastal management, with the most recent parliamentary report, Managing our Coastal Zone in a Changing Climate, appearing in late 2009. In fact it was the same parliamentary standing committee, which produced the first national coastal inquiry in 1980, almost 30 years earlier. Most of these national inquiries call for a greater level of national involvement and coordination 
in coastal management but so far there has been a lack of significant action. It is interesting that the most recent parliamentary coastal inquiry into coastal management had as its sub-title 'the time to act is now'. It also re-iterated the calls for national co-ordination for Australian coastal management. It remains to be seen what action will come from this largely bi-partisan parliamentary review.

The national government has also raised awareness of the coastal risks we face from the prospect of predicted climate change, particularly the threat of increased sea-level rise. In early 2010 the government released a report Climate Change risks to the Australia's coast, which not only provides a background to the variable nature of the Australian coast and coastal processes but outlines the different risk levels illustrating the consequences of these for coastal management and planning. Most states have now incorporated sea-level rise predictions into coastal planning regulations and while there has been some recent debate over what sea-level rise figure to adopt for different state planning jurisdictions, it is interesting to note that the highest figure, as described in this book, has been in place in South Australia for some 18 years.

Brian Caton and I wrote this book from our own perspective of a long-standing interest in the coast, extensive coastal research on different parts of the Australian coast, involvement with international coastal research and organizations, many years of academic teaching in coastal processes management, and government experience in dealing with 'real world' coastal management, policies and regulations. It was the latter involvement with government, which made us realise that there is often a gap between coastal science and policy and that an understanding of both is needed for effective management. For that reason, our book provides an international context to coastal management before providing an essential introduction to an understanding of coastal processes. The book then examines human impact on the Australian coast. Collectively these first three sections comprise over half of the book.

The main section of the book gives an overview of Australian coastal management, including the various government roles and responsibilities and the role of the community. It then compares the different legislative mechanisms, policies, strategies and plans that are used in the different states and territories. It is here that there has been some change and the reader is encouraged to examine relevant websites. The final section of the book attempts to look toward the future and it is interesting to note that the debate around issues such as national coordination of coastal management and mechanisms for incorporating climate change into coastal planning are as current today as when the book was first published.

Nick Harvey

Adelaide, May 2010 


\section{Contents}

Foreword v v

List of Figures $\quad$ ix

List of Tables $\quad$ xii

About This Book xiv

Acknowledgments $\quad$ xvi

1 An Era of Change 1

1.1 Global imperatives for coastal management 1

1.2 Global influences on Australian coastal management 3

1.3 Action in the 1990s: changes to Australian coastal management 8

$\begin{array}{ll}1.4 & \text { What is the Australian coast? } \\ \end{array}$

$\begin{array}{ll}1.5 \text { Conclusion } & 16\end{array}$

2 Understanding Coastal Processes 19

$\begin{array}{lll}2.1 \text { The dynamics of coastal systems } & 19\end{array}$

2.2 Global change and Australian coastal processes 45

2.3 Australian case studies of coastal processes 52

3 Human Impact on the Australian Coast 126

$\begin{array}{ll}3.1 \text { Coastal impacts from our cities } & 126\end{array}$

3.2 Non-metropolitan expansion along the coast 136

$\begin{array}{lll}3.3 & \text { Catchment to the coast } & 144\end{array}$

3.4 Commercial use of coastal waters 154

3.5 Tourism and recreational pressure on the coast 166

$\begin{array}{ll}3.6 \text { Coastal mining and industry activities } & 175\end{array}$ 
4 Managing the Australian Coast

4.1 The need for management

4.2 Government roles and responsibilities 202

4.3 Coastal planning 231

4.4 The role of the community 238

4.5 Sustainable coastal management and scientific uncertainty 250

4.6 Coastal environmental management systems 258

4.7 Management of places of high conservation and landscape value 273

5 Conclusions and Future Directions 292

5.1 The state of coastal management in Australia 293

5.2 Coastal management for the 21st century 299

References $\quad 304$

Index 330 
Figure 1.1 Factors for late 20th century reform of Australian coastal management

Figure 1.2 Definition of the Australian Coast based on administrative boundaries

Figure 1.3 Definition of the Australian Coast based on catchment boundaries

Figure 2.1 Inman and Nordstrom's classification of coasts based on plate tectonics, with some modification by Davies 1972

Figure 2.2 Australian climatic regions and coastal wind systems

Figure 2.3 Coastal sedimentary environments 26

$\begin{array}{lll}\text { Figure 2.4 Spring tide range at locations around the continent } 27 & 27\end{array}$

$\begin{array}{ll}\text { Figure 2.5 Tide gauge at Spring Bay, Tasmania } & 29\end{array}$

Figure 2.6 Major ocean currents affecting Australia 30

Figure 2.7 Wave climate 32

Figure 2.8 Types of coasts around the continent 33

Figure 2.9 The variety of coastal types of the Australian continent 37

Figure 2.10 Blue hole on Molar Reef in the Pompey Complex 46

Figure 2.11 Sedimentary evidence of higher sea level events from the south-east $\quad 47$

Figure 2.12 The south-east barriers in South Australia 48

Figure 2.13 Geological warping of the last interglacial shoreline $\quad 49$

Figure 2.14 Sea level change during the last glacial cycle 50

Figure 2.15 Approximate position of the Australian coastline 51

Figure 2.16 Sedimentary evidence from the South Australian gulfs demonstrating the rapidity of sea level rise 51

Figure 2.17 Time-scales and processes related to coastal evolution $\quad 52$

Figure 2.18 Variability of relative highstand of the 6000 year BP shoreline

Figure 2.19 Rapid post-glacial sea level rise illustrated for Gulf St Vincent

Figure 2.20 Holocene sedimentation rate, LeFevre Peninsula 56 
Figure 2.21 Sea level trends for the Australian coastline

Figure 2.22 Sea level trends at Port Pirie and Port Adelaide 58

Figure 2.23 Port Adelaide anthropogenic localised land subsidence $\quad 59$

Figure 2.24 Historical shoreline change, Byron Bay 64

Figure 2.25 Predicted littoral drift rates, Byron Bay 66

Figure 2.26 Locations and sand movement at the Adelaide metropolitan beach

68

Figure 2.27 The growth of the LeFevre Peninsula 69

Figure 2.28 The beach model of Wright and Short (1983) 71

Figure 2.29 Some dune types commonly seen along the coast of south-eastern Australia

Figure 2.30 The movement of the Ten Mile Drift near Beachport, South Australia

Figure 2.31 The Cooloola Sand Mass

82

Figure 2.32 Two estuaries types from New South Wales

Figure 2.33 The Shoalhaven River estuary
Figure 2.34 The catchment of the South Alligator River

Figure 2.35 Phases in the development of the South Alligator River and Estuarine Plain

Figure 2.36

Mangrove distribution Hinchinbrook Island

Figure 2.38 Major areas of seagrass die back around the continent $\quad 100$

Figure 2.39 Seagrass loss in Cockburn Sound, 1954-1978 103

Figure 2.40 Seagrass recession of metropolitan Adelaide 105

Figure 2.41 Location of seagrass beds in the Gulf of Carpentaria 106

Figure 2.42 The Great Barrier Reef 113

Figure 2.43 Different reef and island types on the Great Barrier Reef 113

Figure 2.44 Aeolianite cliffs at Robe, South Australia 122

Figure 2.45 Cracking in cliff top, Hallett Cove, South Australia 124

Figure 3.1 Population distribution in Australia, 2000 127

Figure 3.2 River Murray turbidity (median values 1978-88) 152

Figure 3.3 Australian ports affected by ballast 156

Figure 3.4 Status of fisheries wholly or jointly managed by the Commonwealth government

Figure 3.5 Yorke Peninsula beach shacks

Figure 3.6 Mining locations and mineral processing and export in Australia

Figure 3.7 Fraser Island, Queensland

Figure 4.1 Zoning of the Great Barrier Reef (Cairns Section) 200

Figure 4.2 Australia's Maritime Zones

Figure 4.3 Preliminary large marine domains regionalisation and marine planning

Figure 4.4 Schematic view of zones of jurisdiction of Victorian state agencies, 1993 
Figure 4.5 The Townsville foreshore beach before reconstruction 225

Figure 4.6 The Townsville foreshore beach after reconstruction 227

Figure 4.7 Planning zones for the Port Elliot area of the South Australian coast

Figure 4.8 Integrated approvals process for private and public land 237

Figure 4.9 IPCC predicted sea level rise to $2100 \quad 254$

Figure 4.10 Locations of the National Coastal Vulnerability Assessment case studies $\quad 257$

Figure 4.11 Adaptive Management Systems 259

Figure 4.12 The OECD's pressure-state-response model for state of the environment reporting 261

Figure 4.13 Australia's territorial waters 276

Figure 4.14 Location and boundaries of Ningaloo Marine Park 279

Figure 4.15 The interim marine and central regionalisation of Australia divides coastal waters into 60 bioregions 281

Figure 4.16 Nuyts Archipelago 283 
Table 1.1 Australian coastal management changes in the 1990s 9

Table 2.1 CSIRO aerial photographic survey of the Australian coast 23

Table 2.2 Description of the coasts of Australia 35

Table 2.3 Sea level trends calculated from South Australian tide gauge data

Table 2.4 Sediment budget for Cape Byron to Hastings Point 67

Table 2.5 Distribution and areas of estuarine habitat types 81

Table 2.6 Distribution of estuary types in Australia 83

Table 2.7 An overview of the condition of Australian estuaries $\quad 89$

Table 2.8 Distribution and area of saltmarsh in Australian bioregions, $1982 \quad 91$

Table 2.9 Processes that form platforms 121

Table 2.10 Average erosion of Cape Dombey cliffs, 1896-1987 123

Table 3.1 Changes in population in metropolitan areas, 1971-91 127

Table 3.2 Pollutants discharged in wastewater in Australia 129

Table 3.3 Some examples of contemporary stormwater projects and research

Table 3.4 Most rapid coastal population growth, 1971-91 136

Table 3.5 Various estimates of run-off (ML/year) from the Willunga Basin

Table 3.6 Land cover change in Australia, 1788 to 1988, by major vegetation types

Table 3.7 Soil loss on sloping land

Table 3.8 Diffuse source nutrient generation rates for various land uses in the Hawkesbury-Nepean Basin

Table 3.9 Estimated average sediment yields to the Great Barrier Reef Lagoon

Table 3.10 Commercial fishing by State-approximate annual catch and value

Table 3.11 Aquaculture by state or territory, 1997-98 164

Table 3.12 Total nights spent by tourists in Far North Queensland 
Table 3.13 Recreational activities permitted in the Great Barrier Reef Marine Park 171

Table 3.14 Economic valuation of the Great Barrier Reef, 1991-92 172

Table 3.16 Example of coastal industries and their effects 185

Table 4.1 Some international conventions signed by Australia 205

Table 4.2 Major management instruments of states and territories 214

Table 4.3 Two scales of citizen control over planning and management 241

Table 4.4 Types of activities funded by Coastcare, 1995-96 to 1999-2000 245

Table 4.5 Types of community groups funded by Coastcare, 1997-99 246

Table 4.6 Commonwealth and state government commitments to SoE reporting 260

Table 4.7 Selected key indicators for estuaries and the sea 262

Table 4.8 Monitoring and management table 266

Table 4.9 IUCN guidelines for protected area management categories 275

Table 4.10 Marine protected areas in Australia 277

Table 4.11 South Australian coastal parks 281

Table 4.12 Numbers of coastal reserves by state in IUCN category V 286

Table 5.1 Coastal management arrangements in different states 296

Table 5.2 Success in meeting ICM criteria 299 


\section{About This Book}

This book provides an introduction to Australian coastal management, primarily for university students. It will also be of use to government employees and coastal planning consultants in drawing linkages between coastal processes and management. The book will give a better understanding of Australian coastal issues in a global context and also provide an overview of current Australian coastal management practices. It draws heavily on case studies from different states in order to make the text as relevant and practical as possible.

The first chapter of this book attempts to place Australian coastal management in a global context by outlining the importance of the world's coasts for humans and illustrating the international concern for unsustainable coastal resource use and development-related pressure on coastal ecosystems. This chapter clearly outlines how there is a growing international consensus of the need for integrated coastal management as the most effective way forward for the sustainable use of coastal resources. The factors influencing the recent reform of Australian coastal management are then examined. It is noted that there have been significant international influences, such as global change, integrated resource management, sustainable development, and a call for greater community participation. This chapter then outlines some of the major changes to Australian coastal management that have taken place in the 1990s and notes the complexity of management responsibilities and legislative mechanisms between the Commonwealth, state and local governments. This introductory chapter of the book then asks the question 'What is the coast?' and illustrates the diversity of scientific and management definitions, concluding with management definitions of the Australian coastline. This sets the scene for chapter 2 .

While the focus of the book is on Australian coastal management and not coastal processes, chapter 2 of the book illustrates the importance of understanding coastal processes in order to effect proper coastal management. Chapter 2 does not attempt to take a traditional approach for discussing and categorising various coastal processes in a 'lock-step' fashion because this is better done by a number of other books which provide a good background to 
coastal processes from an Australian perspective (e.g. Bird 2000, Davies 1980, Thom1984) or an international perspective (e.g. Carter 1991, Carter \& Woodroffe 1997, Davis 1996, Pethick 1997, Viles \& Spencer 1995, Woodroffe 2003). The reader should refer to these for a better understanding of specific coastal processes. However, in order to draw the linkages between science and policy and the need for coastal managers to better understand coastal processes, chapter 2 provides a number of selected coastal process case studies (such as nearshore processes and beaches, coral reef and seagrass development) that illustrate the relevance of understanding processes in the context of policy formulation and implementation.

Chapter 3 of the book focuses on human impact on the Australian coast. Rather than attempting an inventory of various impacts, this section uses selected case studies to outline the character and trends of human use; the major locations and extent of impact; and the conservation significance of impacts. Examples include the impact from urban development (metropolitan and non-metropolitan), the importance of catchment impacts on the coast, pressure from tourism and mining, and impacts from the commercial use of coastal waters.

Chapter 4 is the longest section of the book and deals with the need for coastal management. It examines in detail the various government roles and responsibilities, using specific examples of the various mechanisms for coastal management in the different states. It also outlines the role of environmental impact assessment, regional and strategic plans, local action plans and links to LA21. The chapter provides an overview of the role of the community in Australian coastal management, particularly with the introduction of schemes such as Coastcare. Another important aspect of management is determining priorities within the context of scarce management resources. In order to explore this, the chapter examines nature conservation issues, coastal areas of high conservation significance and landscape value. Finally, this chapter places planning and management in the context of sustainable coastal development and the need to consider the issue of scientific uncertainty and the precautionary principle in coastal planning.

The final chapter of the book - chapter 5-attempts to provide an overview of the current state of coastal management in Australia. This is particularly relevant as there have been a number of coastal management changes occurring in the 1990s at all levels of government, along with greater community involvement that are collectively changing the way coastal management operates in this country. Given these recent changes, the concluding part of the book looks to the future for Australian coastal management particularly in the context of global change and the international imperative to develop effective integrated coastal management programs. 


\section{Acknowledgments}

First and foremost, we would like to thank Kris James for her excellent work as a research assistant in chasing up background material and diagrams for the book and for her keen eye for detail in editing. Thanks also to Chris Crothers for her cartographic skills in drafting or re-drawing most of the diagrams for the book. We would particularly like to thank Jill Henry who, as a former publisher with Oxford University Press, could see the value of an Australian book on coastal management and had the persistence and encouragement to get the book through its first draft status. Together with Alaric Maude and Deidre Dragovich, Jill provided useful comments on the book's structure.

There are a number of people who deserve special mention for contributing material or offering advice on different sections of the book such as Tony Belperio, Bob Bourman, Bev Clarke, Doug Fotheringham, Angela Hale, Mike Hilton, Megan McCarthy, Bill Mitchell, Damien Moroney and Bruce Thom.

We are also extremely grateful to Fran West for proving a number of aerial photographs from her pioneering flight around the Australian coast in 1999. When we learned of her expedition as the first woman to circumnavigate the Australian continent in a light aircraft, we asked her if she would take some photographs for our book, particularly for the less accessible parts of our coast.

Finally, we thank our partners Meredith Hugo (NH) and Angela Hale (BC) for their patience while the book project gradually started to eat its way into precious family time. 


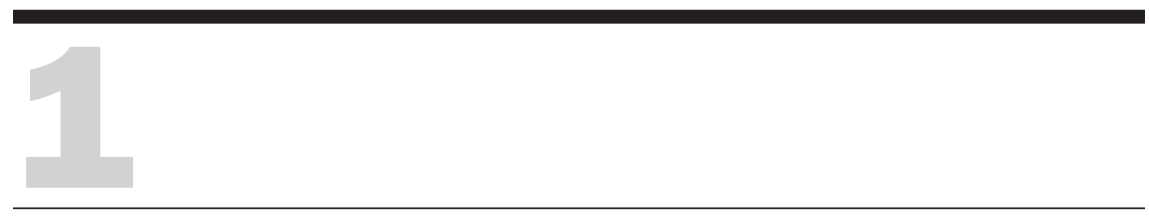

\section{An Era of Change}

Each coastal State should consider establishing, or where necessary strengthening, appropriate coordinating mechanisms ... for integrated management and sustainable development of coastal and marine areas and their resources, at both the local and national levels.

\section{Global imperatives for coastal management}

The above quote clearly illustrates the international importance of coastal and marine management. This is one of the major program areas dealt with in Chapter 17 of Agenda 21 (UNCED 1992), which is essentially the United Nations' blueprint for sustainable development (see page 207 for definition and discussion). At the United Nations Conference on Environment and Development (UNCED), often referred to as the 'Earth Summit', held in Rio de Janiero in 1992, there was a recognition that the world was beginning to live beyond its ecological means and that rapid action was necessary to avert future disaster (UNCED 1992). In this global context, the coast is particularly important for three reasons.

First, most of the world's population lives around the coast. There have been various estimates for just how many people live around the coast, and these estimates will differ depending on what definitions of 'the coast' are 
used. Agenda 21 (17.3) stated that in 1992 more than half of the world's population lived within $60 \mathrm{~km}$ of the coast, and that by the year 2020 this proportion could rise to two thirds. Hinrichsen (1998) quotes a figure of 3.2 billion people living within $200 \mathrm{~km}$ of the coast, on about $10 \%$ of the Earth's land area, and two thirds of the world's population already living within $400 \mathrm{~km}$ of the coast. Estimates of current world population are around 6.2 billion people (US Census Bureau 2000). Global population concentrations in coastal areas have been illustrated graphically through the population density maps of the Global Demography Project (Tobler et al. 1995). These maps also clearly depict regional differences; for example, major concentrations around the coasts of the Indian and Asian subcontinents, but a sparsely populated Australian coast. The majority of the world's largest cities are located on the coast, and in some areas they have expanded into what have been termed coastal megacities (cities with a population of over 10 million people). There are now more than 20 of these, and many are in Southeast Asia.

Second, humans are highly dependent on coastal resources. Although the coastal ocean accounts for only $8 \%$ of the global ocean surface and less than $0.5 \%$ of its volume, it accounts for about $14 \%$ of its production; up to $50 \%$ of its denitrification; up to $80 \%$ of global organic matter burial; $90 \%$ of global sedimentary mineralisation; 75 to $90 \%$ of the global sink of suspended river load and associated elements/pollutants; in excess of $50 \%$ of present-day global carbonate deposition; and approximately $90 \%$ of the world's fish catch (Pernetta \& Milliman 1995, p 16). Given the importance of the coastal zone for humans, it is interesting to consider what value it has, in broad terms. A recent study attempted to estimate the contribution of various ecosystems to the total economic value of the planet (Costanza et al. 1997). Here, it was estimated that the coastal biome contributed a total global flow value of ecosystem services amounting to \$US12 x e12 per year out of the total global flow value of \$US33 e12 per year. If Costanza et al.'s tidal marsh and mangrove category is also included in the coastal figure, this increases the coastal value to \$US14 e12 per year, or more than $40 \%$ of the total global flow value (Costanza et al. 1997).

Third, the coast is being subjected to increasing development-related impacts as a consequence of the combined effect of increasing population pressure together with the high dependency on coastal resources. In 1995, the World Resources Institute published the results of a study which concluded that half of the world's coastal ecosystems are already suffering from severe development-related impacts (WRI 1995). This study used cities, major ports, road density and pipeline density as key development indicators in addition to population density data. It is this increasing global pressure on coastal ecosystem 
resource use which has provided the imperative for developing better approaches to managing the world's coastal zone.

In addition, special attention to management is needed because the coast is naturally dynamic at a variety of time scales. Important changes are not only brought about by human use, but also by natural forces. For example, coastal wetlands are lost through local relative sea level change as well as through reclamation and development. Coasts are eroded by wave action, as well as by human activities such as harbour construction. Sand dunes are destabilised by storms or fires, as well as by vehicle impact. A common problem in coastal management is how to separate rapid natural change from human-induced change.

\section{Global influences on Australian coastal management}

The international push for improved coastal management which gained prominence following the Earth Summit has a number of identifiable themes and influences. Thom \& Harvey (2000) isolated four key factors which they suggested have been critical in stimulating reform of Australian coastal management at the end of the 20th century (figure 1.1).

Figure 1.1 Factors for late 20th century reform of Australian coastal management

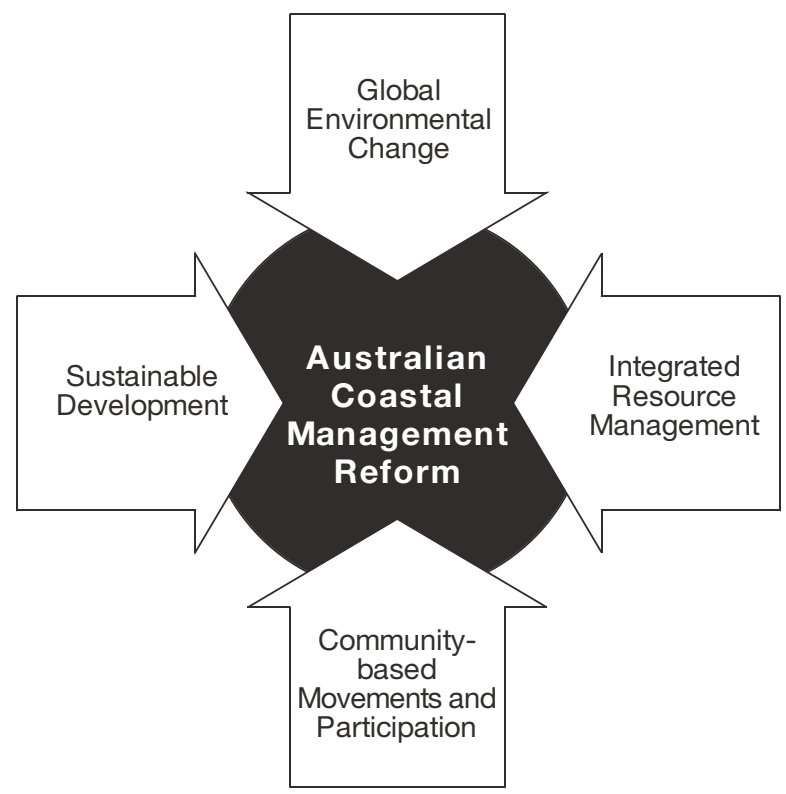

Source: Thom \& Harvey 2000 


\section{Global environmental change}

The influence of global environment change can be seen in the increasing acceptance of the concept of sustainable development and wise use of global resources. Awareness of the magnitude of change is due in large part to the work of the Intergovernmental Panel on Climate Change (IPCC) climate change projections and the debate about the enhanced greenhouse effect (Houghton et al. 1991, 1992, 1996, 2001). Some of the early projections highlighted the need for reduced output of greenhouse gases, but they also created a fear about the impacts of potential sea-level rise, particularly for small island nations and heavily populated coastal deltas. In an attempt to assess the global magnitude of the problem, the IPCC produced its Common Methodology for Assessing Coastal Vulnerability (IPCC 1991; see also Harvey et al. 1999a). At the same time there was a realisation that changing environmental conditions associated with the various projections required different approaches to coastal management systems. The impact of global change on the coast is discussed in more detail in chapter 2 .

\section{Sustainable development}

The influence of sustainable development (see chapter 4 for a full discussion) was most noticeable following the World Commission on Environment and Development (WCED) and its publication of Our Common Future, also known as the Brundtland Report (WCED 1987). In this report, sustainable development was defined as 'that which meets the needs of the present without compromising the ability of future generations to meet their own needs' (WCED 1987, p.8). This report raised the alarm that the world's population growth and associated development was beginning to exceed the global ecological means to sustain the associated resource use.

The report also suggested that economic development and environmental well-being are not mutually exclusive goals. The influence of sustainable development as a concept was given further impetus by the Earth Summit (UNCED 1992). The need for a sustainable approach to development and wise use of global resources was in large part related to the IPCC predictions and the greenhouse debate (noted above). It is also strongly linked to a more integrated approach to coastal management, as outlined below.

It is important to note that the peculiarly Australian concept of ecologically sustainable development (ESD) equates with what is generally known elsewhere in the world as sustainable development. The Australian definition of ESD (Commonwealth of Australia 1992a, p. 6) is: 'using, conserving and enhancing the community's resources so that ecological processes, on which 
life depends, are maintained, and the total quality of life, now and in the future, can be increased'. The Australian approach to sustainable development of the coast is discussed in more detail in chapter 4.

\section{Integrated resource management}

Integrated resource management as a concept recognises the need for a holistic approach to managing human use of resources in a sustainable way.

An increasing acceptance of integrated resource management has resulted in the development of integrated coastal management (ICM), which has been referred to by many specialists in the field as the best approach for the management of coastal resources. According to Sorensen (1997) the ICM concept has been around for more than 30 years. However, it was the Earth Summit in 1992 that created an international push for its adoption: 'Coastal states commit themselves to integrated management and sustainable development of coastal areas and the marine environment under their national jurisdiction ...' (UNCED 1992, chapter 17.5).

Similar objectives are contained within the UN Framework Convention on Climate Change (1992): 'develop and elaborate appropriate and integrated plans for coastal zone management'. Since the Earth Summit, ICM has been accepted by many nations with coastal management programs and associated legislation, including the United States, United Kingdom, Belize, Brazil, Costa Rica, Ecuador, Sri Lanka, Turkey, Australia, Canada, Italy, China, Mexico, Nigeria, Venezuela, and Pohnpei State (Federated States of Micronesia) (CicinSain \& Knecht 1998).

Chapter 17 of Agenda 21 (UNCED 1992) focuses on the protection of the oceans, all kinds of seas (including enclosed and semi-enclosed seas) and coastal areas, and the protection, rational use and development of their living resources. It recognises the need for new approaches to marine and coastal area management and development at the national, subregional, regional and global levels. As noted by Knecht and Cicin-Sain (1993), the UNCED 'Rio Declaration' sees the need for new approaches to coastal management that are integrated in content, and precautionary and anticipatory in ambit. The Rio Declaration (Section 17.5) spells out the need to 'inter alia: provide for an integrated policy and decision-making process, including all involved sectors, to promote compatibility and a balance of uses' (see Hildreth 1994, p. 106).

Following the Earth Summit, the Council of the Organisation for Economic Cooperation and Development (OECD) and the first World Coastal Conference (1993) adopted and produced guidelines for the integrated management of coastal resources: 'Integrated coastal zone management involves the compre- 
hensive assessment, setting of objectives, planning and management of coastal systems and resources, taking into account traditional, cultural and historical perspectives and conflicting interests and uses; it is a continuous and evolutionary process for achieving sustainable development' (IPCC 1994, p. 40).

Coastal management around the globe is moving to a more integrated approach that recognises the links between activities in coastal lands and waters. There have been international attempts to develop guidelines for ICM, stressing the importance of strengthening and harmonising crosssectoral management. While there are various approaches towards achieving ICM, most agree that horizontal and vertical integration and coordination must be part of any ICM attempt.

A key work on the need for integrating ocean and coastal management was produced by Cicin-Sain and Knecht (1998). They pointed out that traditional ocean management issues related to activities such as maritime boundaries, freedom of navigation, and conservation of highly migratory species. They noted that, with the increased use of the ocean by activities such as mariculture and ocean mining, a new approach to ocean management which stresses the links between land, coast and ocean systems has been necessary. Cicin-Sain and Knecht (1998, p. 18) suggested that the rationale for an integrated approach is twofold. First, it examines the effects of ocean and coastal use, as well as activities further inland, on ocean and coastal environments; and second, it examines the effects that ocean and coastal users can have on one another. They defined the dimensions of integration as:

- intergovernmental integration/vertical integration among national, provincial and local governments

- intersectoral integration/horizontal integration - integration among government agencies in different sectors, and among different marine and coastal sectors (industries, conservation, recreation, tourism, beach protection), and integration between coastal and marine sectors and land-based sectors

- spatial integration - integration between the land, ocean and coastal zone

- science-management integration - among different disciplines, and among scientists and managers

- international integration - integration among nations when needed.

In Australia, at the local government level, there has been a growing acceptance of the need for the development of 'Local Agenda 21' policies geared toward sustainable development and the adoption of integrated local area management strategies. This has been highlighted in coastal areas, where marine pollution has required an integrated approach to catchment management and environmental protection regulations. There has also been a recognition of 
problems associated with the fragmentation of decision-making between the three levels of government in Australia. A further impetus for ICM has been the signing of memoranda of agreement between all three levels of government in order to implement various aspects of the national coastal action plan under the Commonwealth's Coastal Policy.

\section{Community participation}

The influence of community-based movements and the desire for increased public awareness, and public contribution to decision-making has also become an accepted part of international declarations. The recognition of cultural differences indicates an appreciation of the need to incorporate local, regional and national perspectives into the development of management policies and plans. The Rio Declaration clearly intended to broaden the participation of all stakeholders in determining how coastal resources are used, and specifically refers to the involvement of community-based managers.

If ICM is to be achieved, there must be national or regional coastal zone management programs that include community-based coastal management initiatives. For this reason, there is a global trend toward greater community involvement in coastal management: 'Experience around the world is building in community-based coastal management wherein the people who live and work in coastal areas and depend on these resources are enabled to take an active and responsible role and increasingly share planning and decision making responsibilities with government' (Hildebrand 1997).

A variety of initiatives around the globe have been used to involve communities in managing coastal resources; see Cicin-Sain and Knecht (1998) for a review of these initiatives. While there are different models and techniques for community participation, there are also differences between various initiatives, depending to a large extent on how dependent the community is on the coastal resource for livelihood. There are other factors that influence the community-based coastal management initiatives, such as styles of governance, national coastal policy and effectiveness, and the existence and effectiveness of non-governmental organisations (NGOs).

Community-based coastal management has been described (by Ferrer \& Nozawa 1998) as

... people-centred, community-oriented and resource-based. It starts from the basic premise that people have the innate capacity to understand and act on their own problems. It begins where the people are i.e. what the people already know, and build on this knowledge to develop further their knowledge and create a new con- 
sciousness. It strives for a more active people's participation in the planning, implementation and evaluation of coastal resource management programs.

Harvey et al. (2001a) note that community-based coastal management is growing rapidly in developing countries where there is a reliance on coastal environments for food and livelihoods but an increasing pressure from population growth and over-exploitation of coastal resources. They quote examples of centralised top-down forms of national governance acquiescing to local initiatives which rely on local knowledge and capacity, such as in the Philippines, Thailand and eastern Africa. There is also the influence of key international agencies such as the World Bank, USAID and the United Nations agencies (WHO, ILO, FAO, UNCRD and UNESCO) which issue mandates for the involvement of communities in development programs. As a result of a change in the focus and activities of these agencies, community-based coastal management has emerged. More recently it has been realised that coastal environments require specific initiatives because their ecosystems and corresponding communities are distinct from those of inland communities.

South Africa and Canada are good examples of more developed countries whose national coastal policies acknowledge the importance of community involvement in coastal management. South Africa, for example, has recently developed a coastal policy that endorses and proposes a style of management that facilitates and increases the responsibility of the community. This approach replaces the previous South African 'top-down' sectoral focus. Canada has also reduced the government role in its Coastal Action Program of the community, whereas in the United States a state-based coastal management system is complemented by a wide-spread volunteer program run via an intraagency partnership within the National Oceanic and Atmospheric Administration (Harvey et al. 2001a).

\section{Action in the 1990s: changes to Australian coastal management}

It is clear from the above that there is international acceptance of the need to improve and integrate coastal management practices for the sustainable use of global coastal resources. It is also possible to identify some key international issues or themes in coastal management that have influenced the late 20th century reform of Australian coastal management. (Current Australian coastal management practices are discussed in more detail in chapters 4 and 5.)

Australia is working within an international context in coastal management, and this work is stimulated by the four factors of global climatic change, sus- 
tainable development, the need for integrated management, and community participation in policy development. These changes have been occurring at various levels of government; they are discussed in chapter 4 .

It is important to note that Australia has a three-tier system of government consisting of the Commonwealth, the state and territory governments, and local government. Most coastal management powers are spelt out in various pieces of state and territory legislation. These include a variety of approaches, from specific coastal legislation and policies to a lack of legislation or policies. Most of the coastal legislation has strong links to other pieces of legislation such as planning or pollution control, but generally much of the responsibility for coastal management and development control falls on local government authorities.

In the 1990s, Australian coastal management was subjected to an extensive period of review, both at the Commonwealth and the state level (see table 1.1; refer also to Harvey 1999, Thom \& Harvey 2000). At the Commonwealth level, a key document was the Resource Assessment Commission's (RAC) Coastal Zone Inquiry Final Report, which attempted to examine coastal management responsibilities at the three levels of government (RAC 1993a). The timing of this report was important because there was already a Commonwealth government coastal inquiry being conducted by the House of Representatives Standing Committee on Environment, Recreation and the Arts (1991). In addition, the

Table 1.1 Australian coastal management changes in the 1990s

\begin{tabular}{ll}
\hline Key Commonwealth coastal inquiries, reports or programs \\
\hline 1991 & House of Representatives Injured Coastline Report \\
1992 & Commonwealth Draft Coastal Policy Document \\
1993 & Resource Assessment Commission Coastal Zone Inquiry \\
1995 & State of the Marine Environment Report \\
1995 & Commonwealth Coastal Policy 1995 \\
1997 & Commonwealth Coasts and Clean Seas Program \\
1998 & Australia's Ocean Policy \\
\hline Changes and initiatives at state/territory level \\
\hline 1995 & Coastal Management Act, Victoria \\
1995 & Queensland Coastal Protection and Management Act \\
1996 & Tasmania State Coastal Policy (revised 1999 and subject to \\
1997 & legal challenge in 2002) \\
1997 & NSW Coastal Policy \\
\hline
\end{tabular}


Commonwealth government was preparing for the 1992 UNCED by developing, national strategies on 'greenhouse' and ecologically sustainable development (ESD). In the same year the Commonwealth, state and territory governments drew up an Intergovernmental Agreement on the Environment (Commonwealth of Australia 1992b). The Commonwealth also produced a document assessing the role of the Commonwealth in the coastal zone. Consequently, the findings of the RAC Inquiry were made within the context of these other national reports and agreements which were being prepared contemporaneously with the RAC Inquiry.

Apart from all these reports prepared in the early 1990s, there was also a plethora of previous inquiries into coastal management and related issues in Australia. In fact, the RAC had to produce its own review of previous inquiries and look at the recommendations of 29 previous national and state inquiries. This highlighted the need for something new, rather than yet another inquiry which would come up with similar conclusions. In particular there had already been a major Commonwealth coastal review over a decade earlier by the House of Representatives Standing Committee on Environment and Conservation (HORSCEC 1980). This report commented on the need for the development and promulgation of national policies and objectives for the conservation and preservation of the Australian coastline in consultation with the states (HORSCEC 1980, p. 38). Thirteen years later the RAC Inquiry recommended a National Coastal Action Plan, with adoption by the Council of Australian Governments of a set of common objectives (Resource Assessment Commission 1993). Both the HORSCEC and the RAC reports comment on the lack of integration of coastal management at different government levels. It is interesting to note that very little national integration had been done over the 13 -year period between these two reports. However, significant advances have been made since the RAC Inquiry (see chapter 5 for further discussion).

\section{Australia's National Coastal Zone Inquiry, 1993}

The national RAC Coastal Zone Inquiry (Resource Assessment Commission 1993) was significant because it came at a time when there was a need for greater national cooperation in the early 1990s across a number of environmental areas, and it was also underpinned by the concept of ecologically sustainable development, or ESD (Harvey 1999). The inquiry, conducted by three commissioners, covered aspects such as:

- the resources, values and uses of the coastal zone

- a national approach

- a national coastal action program 
- institutional arrangements

- the role of community and industry

- the role of indigenous people

- ways of improving management at the local and regional level

- approval systems and impact assessment

- economic and financial instruments

- funding and implementation.

It should be noted that one of the three commissioners disagreed so significantly with the other two, that the final report had a special section on this dissenting view, more than a hundred pages long.

The key recommendations of the report included:

1 National Approach

2 Coastal Resource Management Act

3 National Coastal Action Program (including Coastcare)

4 National Coastal Management Agency

5 National Coastal Consultative Council.

It is significant that the RAC report stressed the need for a more integrated approach in which the environment is treated in a holistic sense rather than treating different elements of the environment separately. The RAC recommended a national approach because of increasing population and development pressure on the coast. It also proposed a Commonwealth Coastal Resource Management Act to incorporate the objectives and principles for coastal management agreed by the states and the Commonwealth. This Act was intended to link funding of activities in the coastal zone to nationally agreed objectives and principles. However, recommendations such as the Coastal Resource Management Act and the National Coastal Management Authority did not proceed, largely because of opposition from state governments.

Of the five recommendations above, one of the most important was the national Coastal Action Program, which had the following main elements:

- adoption by the Council of Australian Governments of a set of common objectives

- establishment of arrangements for implementing and managing the program

- greater community and industry consultation (such as the proposed Coastcare program)

- wider and better use of modern management and economic tools.

This Coastal Action Plan was instrumental in making sure that the RAC report was not just another inquiry that ended up sitting on a shelf along with all the others. Thus the RAC report was able to set the groundwork for the development of a national coastal policy, and together with the Coastal Action Plan provided the impetus for getting basic agreement on coastal issues from 
the chief ministers in all three tiers of government. The inquiry emphasised the role played by local government in state-based coastal strategies, and also provided a mechanism for integration between different levels of government and the community through the proposed Coastcare Program.

\section{Australian coastal policy, 1995}

Although there had been various coastal inquiries over a 15-20 year period, it was the RAC inquiry that finally provided the trigger for action on developing a national coastal policy. A Commonwealth coastal policy, entitled Living on the Coast, was finally produced (Commonwealth of Australia 1995). This policy built upon the RAC inquiry, which had the concept of ESD as one of its key aims. In addition to an aim of promoting the ecologically sustainable use of Australia's coastal zone, the policy also has specific objectives and principles, such as sustainable resource use, integrated assessment, the precautionary principle, resource allocation, the user-pays principle, resource conservation, public participation, and knowledge and understanding.

An important aspect of the Commonwealth coastal policy is that it endorsed the RAC inquiry's recommendation that there was a need for action. The policy set out a definable program of action in order to improve community involvement in coastal management, address issues such as coastal development and pollution, increase education and awareness of coastal issues, and promote coastal management expertise in neighbouring regions. The action program included a number of components:

- Coastcare program

- Commonwealth coastal strategic planning

- local water quality management plans

- Ocean Rescue 2000 program

- capacity building

- CoastNet and Coastal Atlas.

- National Coastal Advisory Committee and Indigenous Reference Group

The Australian coastal policy is realistic in acknowledging that halting development and use of the coastal zone is not an option, although it notes that $86 \%$ of Australians live near the coast. The objectives and principles of the policy received general agreement because the states had been involved when it was being developed. A significant outcome of the policy and its coastal action plan is the Coastcare program, which is integrative in nature and involves extensive public participation (see Harvey et al. 2001a). However, the policy was a Commonwealth rather than a national policy, and its implementation was achieved through the negotiation of a memorandum of understanding with individual states in 1995-96. 
The action plan was extended in 1997 through the Commonwealth government's \$125 million Coast and Clean Seas program over a four-year period. This program, which requires cooperation between community, local government and state government, provides for a number of new activities (taking $65 \%$ of the funding) - Clean Seas, Coastal and Marine Planning, Marine Species Protection, Fisheries Action, Introduced Marine Pests, Coastal Resource Atlas, and Oceans Policy. These were in addition to the original activities - Coastcare, Marine Protected Areas, Capacity Building, and Coastal Monitoring and Vulnerability.

Thus, in 1995, the Commonwealth created its own coastal policy which encouraged sustainable resource use and integrated coastal management. The action plan associated with this policy earmarks specific funding for integrated coastal management through programs such as Coastcare (Tailby \& Lenfer 1996, Harvey et al. 2001a), improved management tools with the Coastal Resource Atlas and the Coastal Monitoring and Vulnerability programs, and increased knowledge base and coastal management expertise through the Capacity Building program (Morvell 1996).

At the same time, the states and local government—-driven by both Commonwealth encouragement and community demands - continued the reform of coastal management through the late 1990s; this is detailed in chapters 4 and 5 .

\section{What is the Australian coast?}

In the preceding discussion it was assumed that the reader understood what was meant by the Australian coast. However, definitions of what is meant by 'the coast' vary at both global and national levels. In fact, one of the first tasks for the RAC Inquiry was to decide what definition it should use for the Australian coast. One of the reasons for the variation in coastal definitions is that scientific definitions become broader as they become more inclusive of those catchmentrelated or marine-related physical processes which affect the boundary zone between the sea and the land. Similarly, definitions from government or bureaucratic organisations vary considerably because each has its own purpose for defining the coast.

For example, the International Council of Scientific Unions' scientific study of global change (the International Geosphere-Biosphere Programme, IGBP) included a coastal scientific core project investigating the 'Land-Ocean Interaction in the Coastal Zone' (LOICZ). This LOICZ Science Plan defined the coastal zone as 'extending from the coastal plains to the outer edge of the continental shelves, approximately matching the region that has been alternately flooded and exposed during the sea level fluctuations of the late Quaternary 
period' (IGBP 1993). In the LOICZ Implementation Plan (Pernetta \& Milliman 1995, p. 16) this coastal domain was referred to as being from 200 metres above to 200 metres below sea level. Another coastal process-related definition of the coast was given by Sorensen (1997): 'that part of the land affected by its proximity to the sea and that part of the ocean affected by its proximity to the land $\ldots$ an area in which processes depending on the interaction between land and sea are most intense'. These broad scientific definitions attempt to include all the various processes influencing the coast. The LOICZ definition clearly recognising the importance of past processes, particularly the last two million years, in shaping our modern coastline.

Apart from the scientific definitions relating to coastal processes, there is also an issue of scientific measurement of the coast which can produce different length estimates for the same piece of coastline. For example, Galloway and Bahr (1979) noted that the official length of the Australian coastline was estimated as only $19320 \mathrm{~km}$ in the 1974 Australian Handbook but $36735 \mathrm{~km}$ in the 1974 Year Book of Australia (ABS 1974, AIS 1974). They studied various means and results of measuring coastline length and from statistical calculations concluded that 'the length is indeterminate but varies consistently with the accuracy of the measurement' (Galloway \& Bahr 1979, p. 244). Of their various calculations, it is their higher figure of $69630 \mathrm{~km}$, based on $1: 250000$ maps with a divider intercept of $0.1 \mathrm{~km}$, which is used in recent official estimates, such as the 1996 Australian State of the Environment Report (State of the Environment Advisory Council 1996). This report also noted that the continental shelf adjacent to the Australian coast covers an area of some 2.5 million $\mathrm{km}^{2}$ and varies in width from $15 \mathrm{~km}$ to $400 \mathrm{~km}$.

However, scientific definitions of the coastal zone based on coastal processes or coastal form are not usually practical for management purposes so that another suite of coastal definitions is designed for policy purposes. For example, the Environment Directorate of the international Organisation for Economic Cooperation and Development (OECD) suggests that the definition of the coastal zones should vary according to the nature of the problem being examined and the objectives of the management. This approach is reflected in the Commonwealth government's definition of the coastal zone, which states that: 'The boundaries of the coastal zone extend as far inland and as far seaward as necessary to achieve the policy objectives, with a primary focus on the land/sea interface' (Commonwealth of Australia 1992a, p. 2). This definition is quite different to various definitions used by state governments in Australia (see box 1.1). 


\section{Box 1.1 Various Australian state government definitions of the coast}

\section{New South Wales (Coastal Policy, 1997)}

- $1 \mathrm{~km}$ coastal strip landward of the open coast high water mark

- a distance of $1 \mathrm{~km}$ around all bays, estuaries, coastal lakes, islands and tidal waters of coastal rivers

Note that the policy does not apply to the Greater Metropolitan Region, and the urban areas of Newcastle, Central Coast and Sydney are excluded.

\section{Northern Territory (Coastal Management Policy, 1985)}

The coastal zone of the Northern Territory comprises the sea, land and waterways close to, or interacting with, the coastline, including offshore islands and seas controlled by the Northern Territory Government.

\section{Queensland (Coastal Protection and Management Act 1995)}

The coastal zone includes coastal waters and all areas to the landward side of coastal waters in which there are physical features, ecological or natural processes that affect, or potentially affect, the coast or coastal resources. The coastal zone includes catchment areas where activities have impacts on coastal resources, as well as all the coastal waters of the state.

\section{Tasmania (State Coastal Policy 1996; revised 1999 and legally challenged in 2002)}

The coastal zone includes at least the following primary elements:

- the seabed, tidal waters and foreshore

- dunes, beaches, seacliffs, wave cut platforms and hardrock areas

- the water, plants and animals

- the atmosphere above

- wetlands, marshes. lagoons and swamps along and immediately inland of the coast

- associated areas of vegetation

- associated areas of animal habitats

- associated areas of human habitat and activity.

The zone extends seaward to the outer limits of the territorial sea, and extends inland to the extent necessary to embrace activities uses and developments which may have a significant effect on the amenity and environment of the coast as constituted by the primary elements listed above.

The zone extends inland to the extent necessary:

- to embrace proposed activities, uses and developments which in the opinion of the relevant planning authority may, if allowed to proceed, impact on the coast, and

- to achieve the principles, objectives and outcomes of this policy. 


\section{South Australia (Coast Protection Act 1972-Regulations)}

One hundred metres above high water in urban areas $(550 \mathrm{~m}$ in rural areas) to 3 nautical miles seaward of mean low water. Includes all land within any estuary, inlet, creek, bay or lake subject to the ebb and flow of the tide. Landward boundary may be varied by legislation.

\section{Victoria (Coastal Management Act 1995)}

The coastal zone includes:

- land and waters on the seaward side of coastal watersheds

- the sea and seabed to the state limit (generally 3 nautical miles from the high water mark).

\section{Western Australia (Government Position Paper, 1983)}

Coastal waters to a depth of $30 \mathrm{~m}$, reefs, estuaries, tidal rivers and land which is presently subject to coastal processes such as mobile sand dunes, areas inundated by storm surge and vegetated foreshore areas exposed to onshore winds.

The difference between the Commonwealth and state definitions is indicative of differences in Commonwealth and state legislation and a variation in roles and responsibilities for coastal management. A major Commonwealth coastal inquiry into the coastal zone, conducted in 1993 by the Resource Assessment Commission (RAC), took the marine boundary to be the boundary of the Australian Fishing Zone, 200 nautical miles seaward of the low water mark. This area (approximately 9 million $\mathrm{km}^{2}$ ) is larger than the entire Australian land mass. The inquiry then used two operational definitions of the zone for identifying and describing the extent of resources and human activities in the coastal zone. It used an administrative definition when describing the extent of human uses and activities (1.318 million $\left.\mathrm{km}^{2}\right)$, but a definition based on recognisable drainage basins ( 1.327 million $\mathrm{km}^{2}$ ) when describing the extent of physical and biological resources (figures 1.2 and 1.3). Both of these definitions account for an area equivalent to about $17 \%$ of the Australian land mass (Resource Assessment Commission 1993).

\section{Conclusion}

This introductory chapter has illustrated that there is clearly a global imperative for coastal management that has the sustainable use of coastal resources as an underlying goal. This has become particularly important with the realisation that humans are now having a measurable impact on global change. Coastal 
Figure 1.2 Definition of the Australian Coast based on administrative boundaries

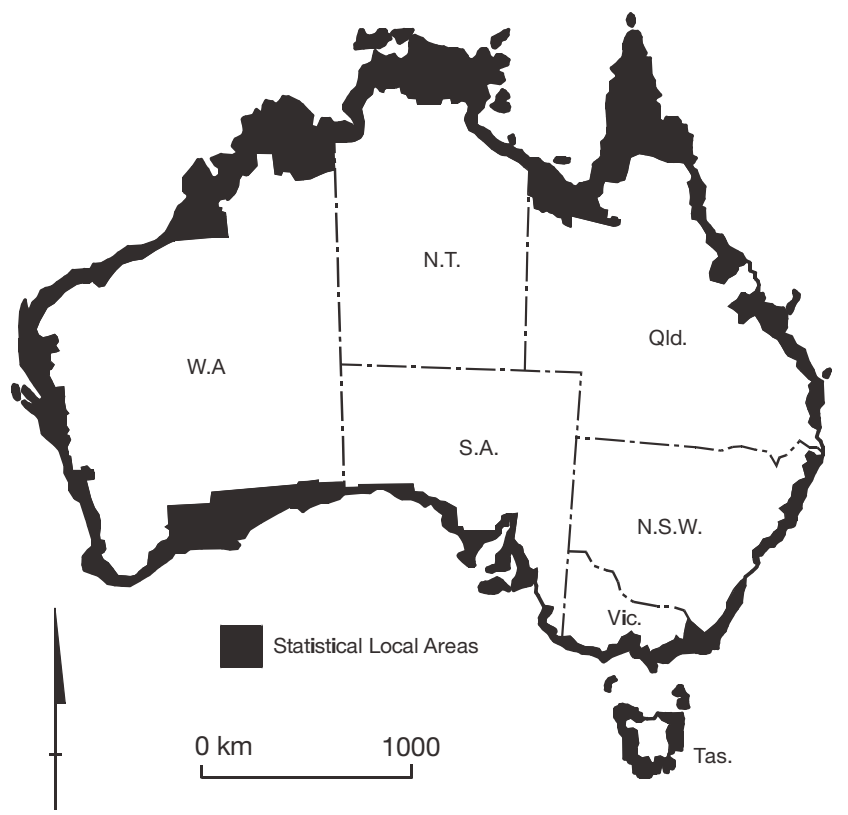

Source: after RAC 1993b

Figure 1.3 Definition of the Australian Coast based on catchment boundaries

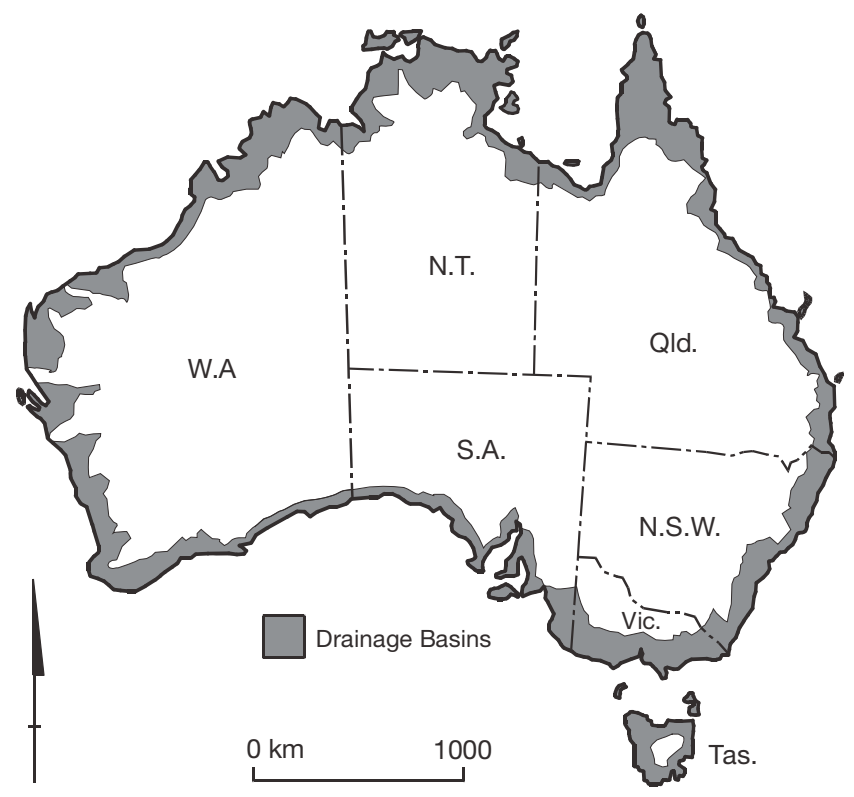

Source: after RAC 1993b 
management needs to be integrative in its approach, and participatory for stakeholders.

In Australia there has been considerable change in coastal management during the 1990s. This change, however, has not been uniform across all jurisdictions, so that some states have introduced new coastal legislation or policies whereas others still have outdated legislation or no central coastal authority. There have also been significant initiatives at the Commonwealth level following the most recent of numerous national coastal inquiries. Subsequent funding programs, such as the community-based Coastcare program, have assisted the momentum for change in Australian coastal management.

Finally, this chapter notes that it is difficult to discuss coastal management without first addressing the question, 'What is the coast?' It was pointed out that each state and the Commonwealth have different definitions of the coast for management purposes. However, there are also various scientific definitions of the coast, and even different estimates of the length of the Australian coast. Hence it is important to realise that the coast is defined differently for different purposes and, as noted for Tasmania, can become the subject of legal challenge. 


\section{Understanding Coastal Processes}

It's just the way it changes

... Like the shoreline and the sea

Cohen 1968

\section{The dynamics of coastal systems}

The previous chapter noted the difficulty of finding a single definition for the Australian coast. This becomes more complex when we realise that the modern coast is not a static line, even though it is often used as boundary marker. While some changes are very visible to the human eye, more subtle changes that may be just as important are occurring all the time. For this reason it is necessary to consider the time context for any coastal processes so that we can provide useful information that is relevant to coastal management.

At time scales of hundreds of millions of years, continental evolutionary processes have less influence on the coast, although many coastal forms may have resulted from older geological processes. For example, the occurrence of large granite erratic boulders along the South Australian gulf coastline does not relate to modern coastal processes but to glacial processes 250 million years ago. Since that time, Australia has split away from Antarctica and is currently drifting north at a rate of approximately $6 \mathrm{~cm}$ per year. A coastal classification based on the longer time scale processes of plate tectonics is discussed below. 
At time scales of millions of years there have been major changes, such as the rapid climatic and associated sea-level changes of the last two million years during the Quaternary period. Within this time scale, there is also a different periodicity of hundreds of thousands of years between cold glacial cycles and intervening warmer interglacial cycles. These changes have had major impacts on the coast, and in some places the cyclical record can be seen in coastal sediments and coastal landforms (see 'Global Change and Australian Coastal Processes, page 45). More recently in geological time (i.e. thousands of years), the Australian coast has been affected by a rapidly rising sea, which has been a major influence in shaping our modern coastline. This is discussed in more detail on page 54 .

At the shorter time scales of tens to hundreds of years, it is easier to detect the impact of more rapid coastal processes, particularly where they affect humans. For example, in Queensland the rapidly moving sand bars near the Burdekin River cut off the beach at the Alva Beach township within 30 years. The rapidly moving Murray River mouth in South Australia created changing administrative boundaries. Similarly, coastal sediment movement at the Tweed River mouth crosses the state boundaries of New South Wales and Queensland (Harvey 1988).

Even shorter time scales are associated with coastal processes such as daily tidal movements or complete tidal cycles (18.6 years). Long-term weather patterns such as El Niño may have coastal effects lasting for a number of years, whereas the effects of shorter-term storm events may last only a matter of days. The weather results in coastal processes of wind and waves which can vary rapidly in direction and periodicity. At these shortest of time scales, waves can be measured in seconds.

Thus it is important to think of the coast as a dynamic system which is constantly responding to changes at a variety of time scales. This chapter first explores the nature of Australia's coastal form and processes from different perspectives, at different spatial and temporal scales. It then examines a number of case studies that focus on different types of processes.

\section{Large-scale processes and features of the Australian coast}

The coast of Australia displays enormous variety, from tropical rainforest with fringing reefs in the Daintree of North Queensland to the arid sands at Coffin Bay in South Australia; from the hot arid cliffs of the Kimberley coast of northwest Western Australia to the cool, wet, cliffed coast of Western Tasmania; from the alluvial flats and mangroves of the Gulf of Carpentaria (Northern Territory) to the saline samphire flats of the Gulf St Vincent (South Australia). Its marine waters (excluding Antarctic and offshore territories), range from tropical at $10^{\circ}$ south to cool temperate at $45^{\circ}$ south, and extend over $55^{\circ}$ of 
longitude. A survey of the terrestrial coast by aerial photography shows the dominance of sand coasts; division by states shows the importance of rock coasts in Tasmania and mud in the Northern Territory.

The coastal zone of Australia is a dynamic meeting area of earth (lithosphere) and atmospheric forces (atmosphere), of oceans and rivers (hydrosphere), and of terrestrial and marine life (biosphere). Changes, over a variety of time scales, are a characteristic of all coasts, and are an important driver of coastal management.

There is no universally accepted classification of coasts that would enable Australian coasts to be neatly categorised and comparisons to be made on a world scale. However, a number of biological, lithological, atmospheric and hydrological characteristics of the Australian region provide the framework for a basic description of the coast that is relevant to its management.

\section{Tectonics}

Compared with other continents, Australian coasts are relatively stable tectonically, undergoing few episodes of crustal movement or vulcanism. This may be explained by the continent's central position on its lithospheric plate. Inman and Nordstrom (1971) produced an important classification system based on plate tectonics and the relationship of the coastline to global plate margins and movements (figure 2.1). This system divides coasts into the following types:

1 Collision coasts, on the collision and subduction sides of continents and island arcs; these are the young mountain zones, with narrow continental shelves and high seismicity and volcanicity. These active areas are characterised by the delivery of coarse sediments from mountain catchments to a narrow or absent coastal plain and narrow continental shelf. Shorelines are often rocky with only small beaches.

2 Trailing-edge coasts, on the sides of continents and island arcs that are moving away from the rising and spreading ocean ridges. Generally wide coastal plains, fine sediments from large catchments delivered to broad shallow continental shelves; deltas and barrier islands are common:

(a) neo-trailing edge coasts, where new rifts have recently opened and only a small amount of separation has taken place, e.g. Red Sea

(b) Afro-trailing edge coasts, where both east and west coasts are trailing, as in Greenland and Africa; these have plateaux, plains and narrow continental shelves

(c) Amero-trailing edge coasts, where the other side of the continent has a collision coast. These are characterised by extensive coastal plains, broad continental shelves, and low seismicity and volcanicity.

3 Marginal seacoasts that lie on the protected side of island arcs. 
Figure 2.1 Inman and Nordstrom's classification of coasts based on plate tectonics with some modification by Davies 1972

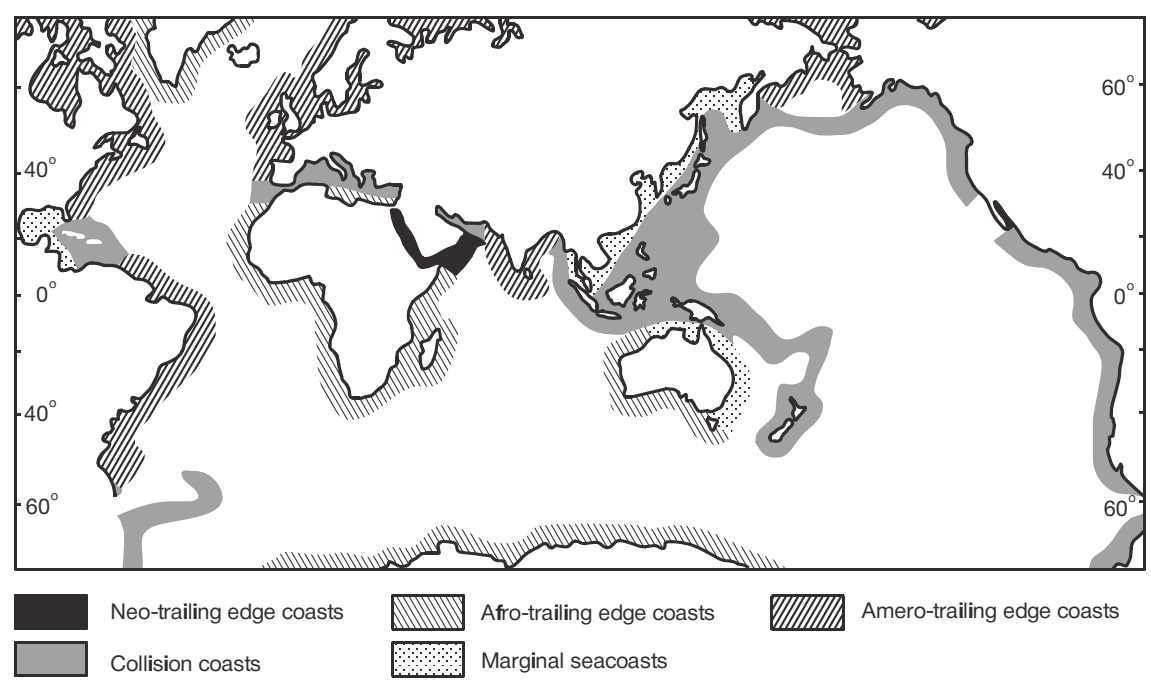

Source: Davies 1972

This classification does not separate Australian coasts in any significant way, as the continent is relatively remote from plate boundaries, tectonically stable throughout, and characterised by unusually ancient landforms. The classification thus points to an important characteristic of Australian coasts. Air and ocean climate variables appear more significant around the Australian shores. However, Australian coastal areas are subject to warping due to loading effects that are a consequence of sea level change. These movements are small in amplitude, but significant in the management of low-lying coastal areas. (See section 'Sustainable coastal management and scientific uncertainty'.)

\section{Lithology}

An examination of the main structural elements around the Australia coast reveals that there are a number of areas of very old crystalline basement rocks which outcrop in Western Australia (Yilgarn Block, Pilbara Block and Kimberley Block); Northern Territory (Litchfield/Pine Creek Block); Queensland (Coen Inlier); and South Australia (Gawler Craton and Mount Lofty Ranges). There is also the major influence of the Tasman Geosyncline stretching along the east coast of Australia through Queensland, New South Wales, Victoria and Tasmania. In places these old structural elements are exposed along the coast, 
such as in the Gawler Craton, which produces a number of rocky headlands in South Australia. Elsewhere, cliffs and shore platforms are found where consolidated rocks outcrop at the shore, such as in the Kimberleys, or where the eroded sandstone tablelands of the Sydney Basin run to the coast. The CSIRO survey (table 2.1) shows that cliffs and shore platforms make up about a fifth of the length of the coastline. These hard rock landforms have evolved slowly. When sea level was near its present level, as happened repeatedly during the Pleistocene, they evolved under coastal conditions; at other times subaerial conditions prevailed. As a result, the cliffs and shore platforms we see today are often relict features, the legacy of conditions changing over thousands of years, rather than simply the result of present processes.

Table 2.1 CSIRO aerial photographic survey of the Australian coast

\begin{tabular}{lllll}
\hline \multicolumn{5}{l}{ Proportion of substratum types (\%) } \\
\hline State & Sand & Rock & Mud & Aeolianite \\
\hline Queensland & 61 & 10 & 29 & 0 \\
New South Wales & 69 & 30 & 1 & 0 \\
Victoria & 68 & 19 & 10 & 4 \\
South Australia & 63 & 15 & 8 & 13 \\
Western Australia & 49 & 26 & 20 & 5 \\
Northern Territory & 45 & 7 & 47 & 0 \\
Tasmania & 49 & 50 & 1 & 0 \\
Totals & 54 & 20 & 22 & 3 \\
\hline
\end{tabular}

Notes:

The above represents the materials at the waters edge, estimated per $10 \mathrm{~km}$ section on aerial photos

Sand: sand beach, backed by dune or aeolianite; sand in front of mangroves is sand; behind mangroves-mud

Rock: hardrock shores, except where the shore platform has a beach at the back (sand); fringing coral reefs are rock

Mud: mainly Northern Australia and associated with mangroves

Aeolianite: found along great stretches of coast, but usually fronted by a beach (thus sand)

Source: Galloway et al. 1984

The rapid rise in sea level from 20000 to 6000-7000 years BP brought the sea into contact with a variety of geological structures, rocks and sediments that have had a profound influence on the modern coast. For example, in South Australia, Kangaroo Island and the Mount Lofty Ranges consist of old, uplifted, resistant rocks which typically produce rugged rocky coasts. In some cases, such as Backstairs Passage and Christmas Cove, resurrected glacial 
topography of the Permian period (around 250 million years ago, when Australia was still part of Gondwana) was drowned by the postglacial sea-level rise, producing very distinctive coastal features. A good illustration of this can be seen at Hallett Cove in South Australia, where glacial striations on exposed coastal rocks clearly show the movement of ice in a northerly direction relative to Australia's current position. This is also the cause of the erratic granite boulders found along the coast and mentioned at the start of this chapter.

In central and southern New South Wales the Hawkesbury Sandstone is an extensive feature along the coast. In South Australia and Western Australia many hundreds of kilometres of cliffs, shore platforms and reefs have been eroded in the Pleistocene dunerock, also known as aeolianite and calcarenite (see figure 2.44, page 122). The Tertiary limestones of the Nullarbor coast and the granites of south-west Western Australia are also extensively developed in cliffs. The spectacular cliffs and sea stacks at Port Campbell National Park in Victoria (see figure 2.9(1))are composed of friable sandstone of Cretaceous age.

\section{Climate and run-off}

Australia is a dry flat continent, and rivers generally supply low volumes of water and sediment to the coast; significantly, some areas have little or no runoff to the sea. The average flow of the Murray-Darling Basin to the sea, under natural conditions, is about $12000 \mathrm{GL} /$ year, a tiny figure on world scales for a river system which drains one seventh of the continent. Moreover, all Australian catchments have great variability, in the swings from the dry El Niño years to the wet La Niña years. For example, in dry years the effective discharge of the Murray to the sea ceases, but in wet years the discharge rises to about 40000 GL. Diversions for irrigation have reduced flows in many catchments; thus, the flow at the Murray's mouth now averages $21 \%$ of the natural annual flow (MacKay \& Eastburn 1989).

Only the Eastern Highlands and some rivers of Northern Australia have rapid run-off, and hence regular sediment delivery to the sea; the arid South and West of the continent have virtually no sediment discharge to the sea.

\section{Beach and dune sediments}

Beaches are common on Australia's coasts (see table 2.1) and are constructed of sand-sized comminuted fragments of carbonate or quartz. Other fragments, including suites of heavy minerals, are found within beaches, but these make up less than $1 \%$ of the coastal sands. There are also some gravel beaches-for 
example, some Northern Territory beaches are of ironstone fragments from laterite-but gravel is not common in Australia, as it is on the coasts of Europe and other regions strongly affected by the debris of Pleistocene glaciation. A few shelly beaches are found in Australia, but they are rare.

A national review of beach materials by Bird (1978) described a broad contrast between the south and west of the continent where calcareous materials predominate, the east coast where quartzose sands are common and the Northern Territory where a variety of fine sediments are frequently found at the coast.

The cause of this continental scale contrast in beach sediments is climatic. In the south and west of the continent, long-term aridity has rendered fluvial transport of weathered rock fragments to the shore slight to non-existent. Between Broome and Bass Strait the only major river outlet is the Murray. At the present sea level, many of the minor streams reaching the coast are simply

Figure 2.2 Australian climatic regions and coastal wind systems

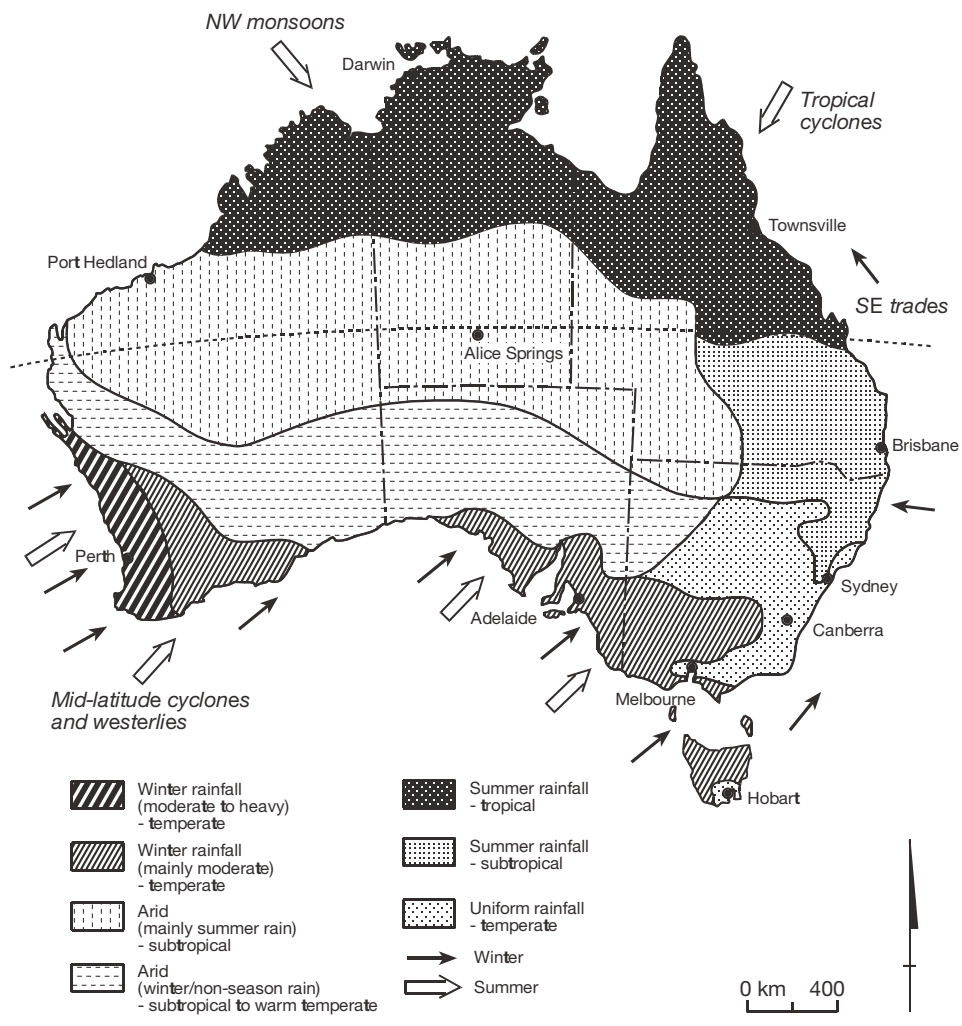

Source: modified from Colls \& Whitaker 2001, and Short 1993 
depositing their sediment load within the estuary; sediment from the Murray is infilling its terminal lakes, Albert and Alexandrina. The beach sediments of Australia's arid coast are predominantly shelf-derived biogenic carbonate material: fragmented shell and skeletal material. These have been delivered to the shore by the successive marine transgressions of the Pleistocene period. On

Figure 2.3 Coastal sedimentary environments

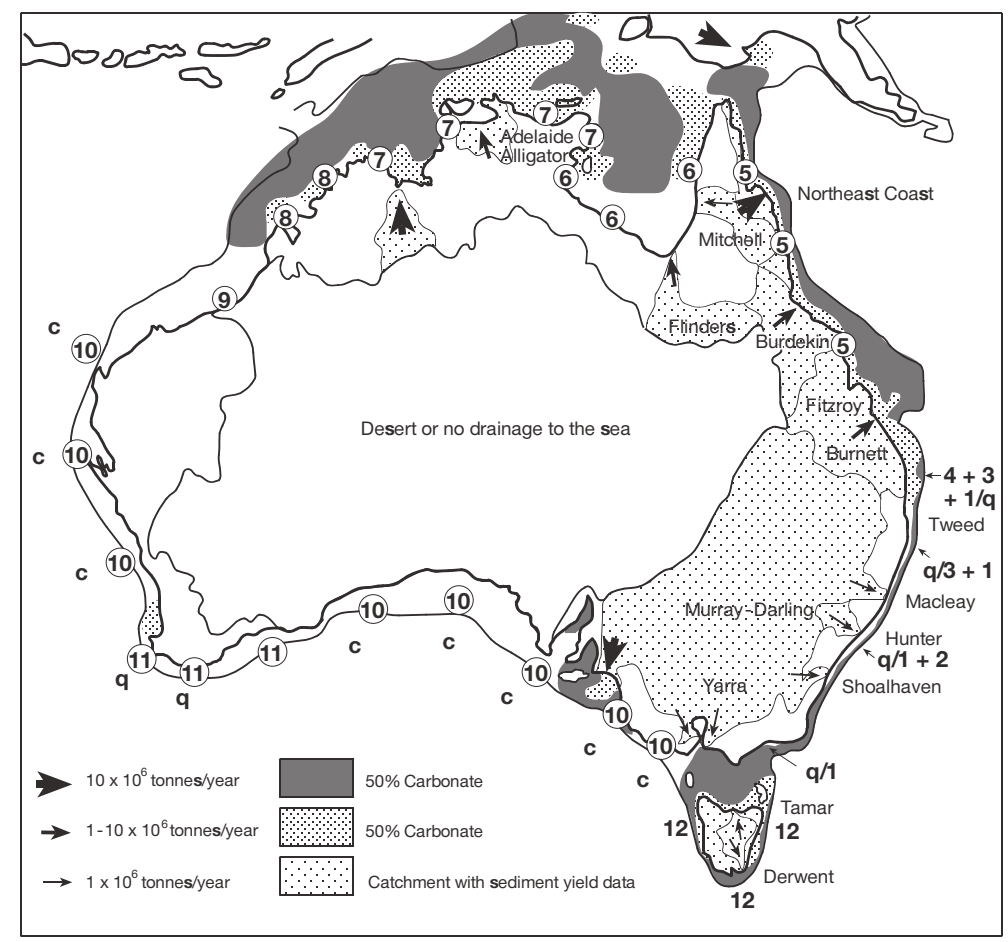

1 Sand from sea floor during Pleistocene transgressions. Local direct accession of supply from large rivers, depending on lithology of catchment

2 Local erosion of sandstone cliffs

3 Supply from large rivers (from granite province) and littoral drift

4 Supply from large rivers of NSW [rarrow] littoral drift

5 Mainland coast behind GBR. Quartz of local fluvial origin; often weathering slow. Few coral sands, except where fringing reefs close

6 Fluvial silts and clays and shellgrit and cheniers

7 Varied clay/silt lowlands/local sands/laterite gravel/shell

8 Fluvial coarse quartz and re-worked desert sands

9 Local sandstones and re-worked desert sands

10 Shelf derived carbonate sands and re-cycling from local aeolianite and localised quartz and other from nearby sources and sea floor (bryozoan limits)

11 Localised quartzose materials

12 Strong compartmentalisation and relationship to local sources, some shelf carbonates on western coast

Source: after Atlas of Australian Resources (1980-90), Zann \& Kailola (1995), annotations from Bird 
Figure 2.4 Spring tide range at locations around the continent

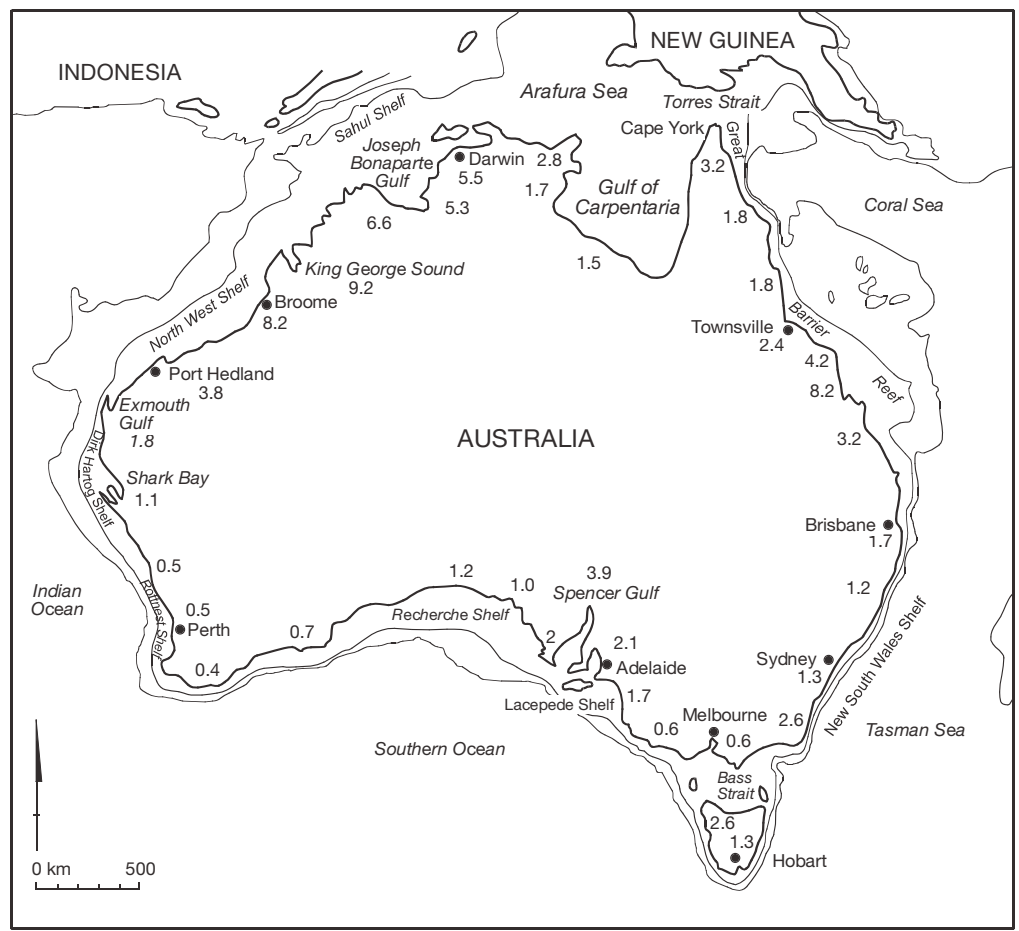

Source: data from Australian National Tide Tables 1993

southern and western coasts large carbonate dune accumulations are found at the more exposed high-energy shores, where large swells have been able to transport the carbonate detritus to the beach. Once at the shore the sediments have been redistributed by littoral drift into embayments and by wind into dune fields. Over time, many of the large carbonate-rich dunes, which have accumulated during the sea level oscillations of the Quaternary, have become lithified to aeolianite through ground water movement, solution and redeposition and calcrete formation. The resulting 'dunerock' may exhibit dune bedding, buried soils, root casts and multiple calcrete layers.

On the south-east coast of South Australia a series of aeolianite dunes or 'ranges' are arranged sub-parallel to the coast on a flat coastal plain (see figure 2.11). Because the coastal plain has been slowly rising tectonically, the dunes are arranged as a time series, with the oldest furthest inland. They bear witness to the repetition of the process of rising seas transporting quantities of carbonate sands to the highest shore of successive Pleistocene transgressions. On the Swan coastal plain in Western Australia aeolianite ranges are found, and they continue in succession offshore, with reefs and islands sub-parallel to the shore. 
Quartzose sands of the south-east and east of the continent are, in contrast, of terrestrial origin.

\section{Tides and currents}

The gravitational and centripetal forces of the Earth, Moon and Sun ('gravitational' tides) cause tidal movements in the oceans which are modified by interaction with the shape of the ocean basins and continental shelves ('equilibrium' tides). These processes are explained in standard works, such as Open University (1989).

Standard records and description of tides in Australian coastal waters are found in the Australian National Tide Tables (1993), and Radok (1976) produced an atlas of tides.

Microtidal conditions (spring tide range less than $2 \mathrm{~m}$ ) are found around the south-east, south and south-west coasts of Australia, from Brisbane to north of Perth, so the principal ports of the country (other than Port Hedland, $3.6 \mathrm{~m}$ ) have spring tidal ranges near to 1 metre. In contrast, northern Australia is macrotidal (spring tide range more than $4 \mathrm{~m}$ ). Darwin, for example, has a spring tide range of $5.5 \mathrm{~m}$. Some northern gulfs and estuaries have ranges twice this value. In general, tidal amplitude is greatest where the continental shelf is wide and low where the shelf is narrow. Along the narrow continental shelf of the New South Wales coast, strong and persistent onshore winds may raise coastal water levels more than the variation caused by neap tides. In inlets and gulfs, funnelling tidal movement may also affect amplitude; thus spring tide range at Port Lincoln in South Australia is $2.0 \mathrm{~m}$, but at Port Augusta (at the head of the tapering Spencer Gulf) it is $3.9 \mathrm{~m}$.

Tidal fluctuations of water level affect the configuration and stability of both sandy and rocky shorelines, and have an important bearing on the distribution of coastal biota. Plants and animals of the intertidal zone form a narrow shoreline ribbon along the microtidal coasts of southern Australia, in contrast to the wide mangrove belt of the Northern Territory, where tidal range often exceeds 6 metres.

At macrotidal coasts, tidal movement generates powerful currents which may transport sediment, flush pollutants, or disperse eggs and seeds. Tidal current streams are an important mechanism contributing to the flushing of inshore waters and estuaries. Tides thereby play a fundamental role in the health of these inshore and estuarine systems. Tidal currents may reach considerable velocities where water movement is constrained.

A knowledge of tidally driven water-level fluctuations is important for many reasons, including commercial and recreational fishing, navigation, 
design and construction of coastal and offshore engineering structures, and an understanding of the development of coastal landforms. At many ports and entrances knowledge of water depth is critical, and even a few hours warning of deviation from forecast tide heights may allow great efficiencies in the management of shipping movements. Tides are most significant in coastal management at the extremes of variability, or when some unpredicted change occurs; for instance, an extreme high tide leading to flooding, or an unforeseen very low tides leading to exposure of oyster racks.

A number of factors may lead to water level being different to the forecast tide; these factors are known as 'residuals'. They include: variation in water temperature; variation in salinity; change in atmospheric pressure; run-off from rivers; and winds. Thus, for example, sea level may seasonally vary due to regular atmospheric pressure changes (the 'inverse barometer' effect). Interannual variation in sea level occurs along Australia's east coast during El Niño-Southern Oscillation (ENSO) events: changing seasonal winds and pressures lead to a lowering of tide levels during the El Niño years.

Storm surges, which are caused by low atmospheric pressure, strong onshore winds (wind set-up) and large waves (wave set-up), may locally raise sea level

Figure 2.5 Tide gauge at Spring Bay, Tasmania, part of the 'Seaframe' set of precision gauges collecting data for the National Tidal Facility

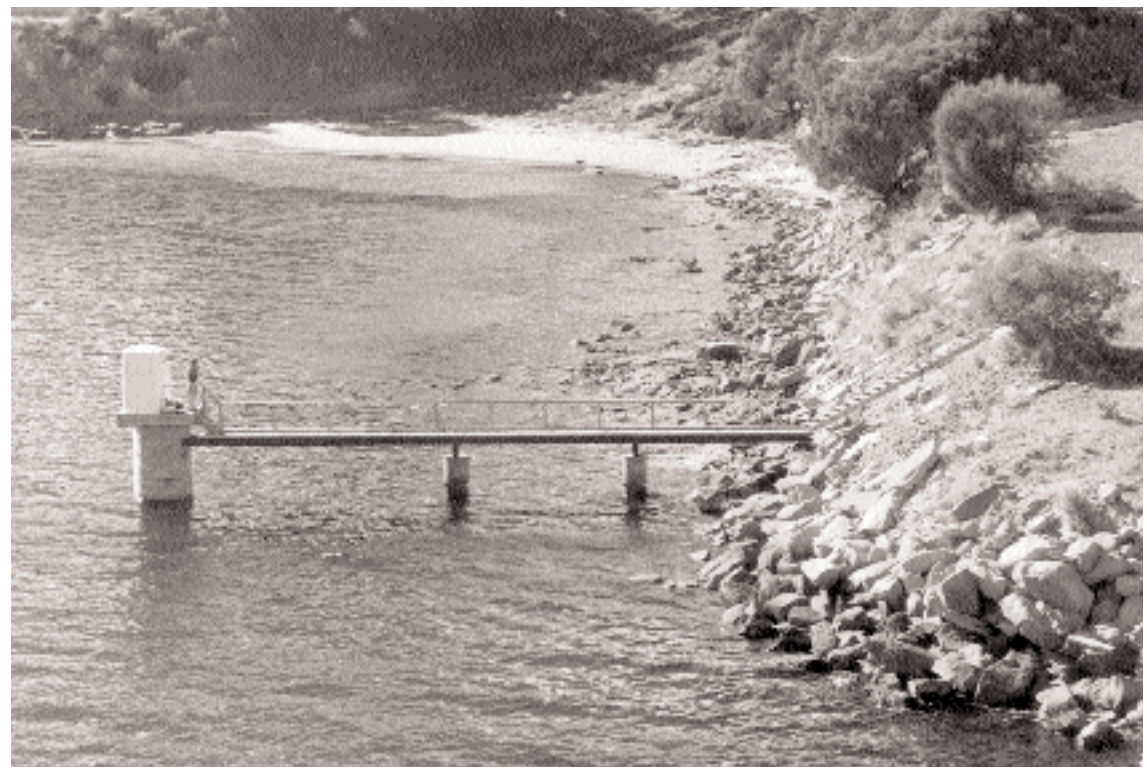

Photography: Bill Mitchell 
Figure 2.6 Major ocean currents affecting Australia

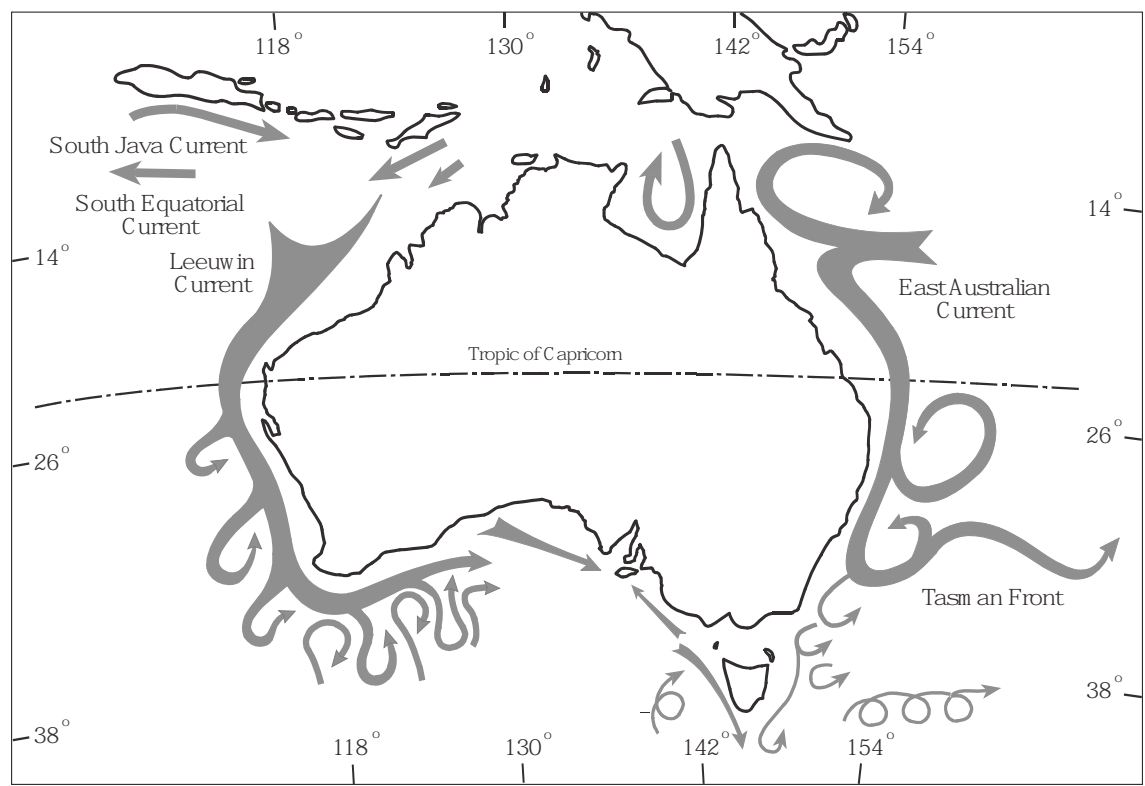

Source: after SEAC 1996

above tide height, leading to coastal erosion and flooding. At Port Adelaide on 4 July 1981, the recorded water level was $1.5 \mathrm{~m}$ above the forecast tide, due to low atmospheric pressure and strong westerly winds. The largest recorded surge in Australian waters was over 7 m, observed in 1892 at Bathurst Bay, Queensland. Storm surges are especially damaging at the coast when they coincide with high tide. For example, Cyclone Tracy inflicted disastrous wind damage on the city of Darwin on Christmas Day 1974, but little flooding or erosion occurred because the cyclone passed over the shore at the time of low tide.

Very accurate measurement of tides is undertaken by the Australian Baseline Sea Level Monitoring Project under the national Greenhouse Climate Change Core Research Program. This project (and the South Pacific Sea Level and Climate Monitoring Project) are managed and supported from the National Tidal Facility, Flinders University. Driven by the search for a sea level change that would be a signal of Greenhouse climate change, this major monitoring project has a wide range of applications for coastal managers. Very accurate monitoring of changes in absolute sea level also involves monitoring the vertical motion of the Earth's crust at the tide gauge location. 
Figure 2.6 shows the major ocean currents affecting Australia. These currents operate seaward of the continental slope, only occasionally operating strongly in the shallow waters of the continental shelf. Nevertheless, the East Australian Current and the Leuwin Current are responsible for the warm temperate conditions of the continent's eastern and western coastal waters, in contrast to the cool waters of the southern coast. The temperature gradient at the SE and SW waters of the continent appears to mark a boundary which has contributed to the uniqueness of the species of Australia's southern coastal waters (Poore 1995).

The East Australian Current, the westerly limb of the great South Pacific gyre, is a powerful and persistent force moving polewards along the east coast of the continent, and spinning off eddies as it meanders its way south. In contrast, the Leeuwin Current, driven by thermal expansion effects in the warm waters of the North West Shelf, is more irregular in its pulses down the Western Australian coast. The Antarctic Circumpolar Current, driven by the strong winds of the 'Roaring Forties' (and fifties), runs well south of the continent.

\section{Waves}

Waves deliver energy to coasts, where they power littoral currents, determining sediment mobility and hence the stability of many coastal landforms. The level and range of wave energy, the 'wave climate', may limit the use of a coast, determining for example the location of favourite surfing beaches, boat ramps, or safe family recreation. A detailed knowledge of wave climate is needed in the design of coastal structures, since 'flexible' structures such as boulder walls may progressively deteriorate in response to high wave energy, while some rigid structures may suddenly and catastrophically fail if a critical design energy is exceeded.

There are few Australian coasts that do not at some time experience great peaks of wave energy during storms. Wave climate also is a powerful limitation on the survival of life forms in the coastal zone: plants and animals have evolved quite different adaptations to high-energy coasts, where habitat and niche opportunities contrast sharply with low-energy zones.

The offshore wave climate of Australia is dominated by a persistent moderate-energy wave regime with waves of 2 to 4 metres in height. It is characterised by south to south-westerly swells along the south and west coasts, and low-energy waves from the west and north-west along the northern coast. The east coast of Australia is characterised by a strong south-easterly swell, interrupted only briefly by a locally generated choppy north-easterly following the passage of an anticyclone. The inshore wave energy along the northern coasts of the continent is generally low, since it is dissipated across a 
Figure 2.7 Wave climate

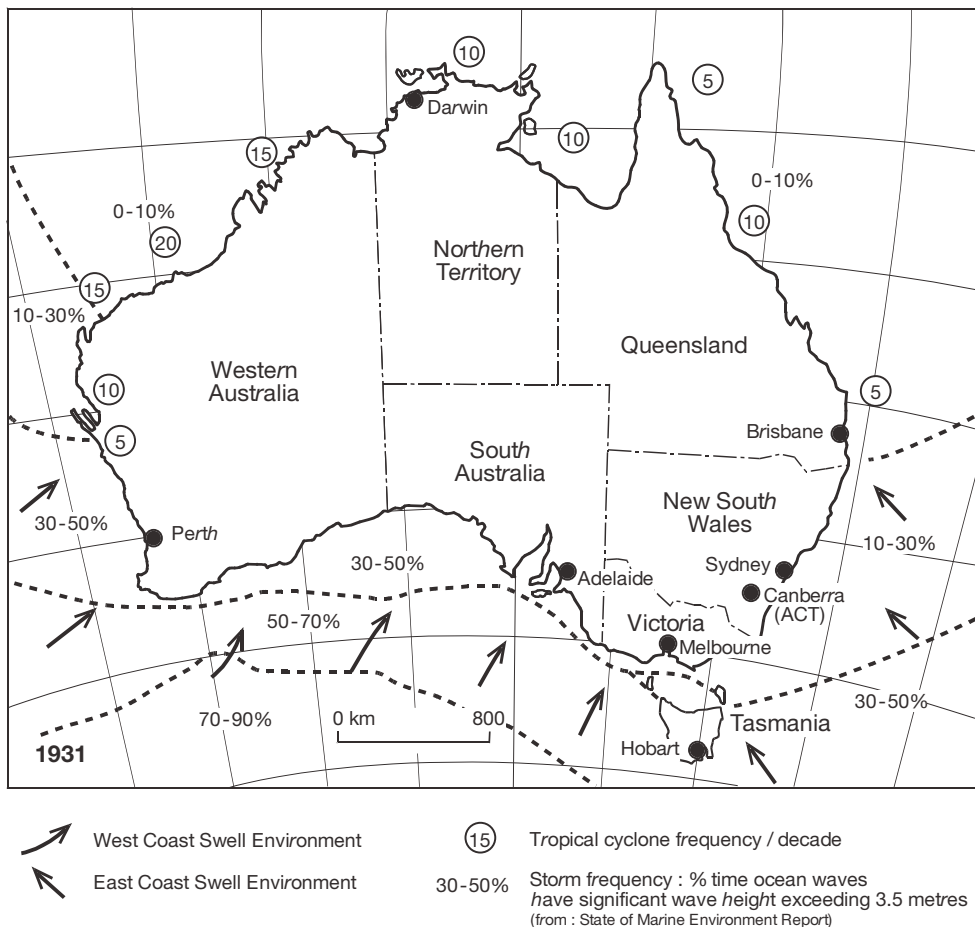

Source: after Harris 1995, and Davies 1972

broad continental shelf. In late summer and autumn, tropical cyclones may generate high-energy waves during intense but short-lived storms.

The swells of the west, south and east coasts are generated in the storm belt of the Southern Ocean, between $50^{\circ}$ and $60^{\circ}$ S. As Davies (1972, p. 30) stated:

The consistent occurrence of a large number of gale force winds ... their relative persistence in location and the long sea distances over which they blow make the southern storm belt much the most important and clearly definable wave generating area in the world. Although very few of these southern gales impinge on the coast, or produce storm waves impinging on the coast, they produce a very high proportion indeed of world ocean swell ... there is direct evidence that the effect of this swell is felt even along coasts in the northern hemisphere.

Davies categorised temperate Australia's coastal wave climate (average wave conditions) into West Coast and East Coast Swell Environments (see figure 2.7); in contrast, tropical Australia has, on average, more gentle wave conditions. 
Despite the strong to moderate offshore wave energy of south-western Australia, the inshore wave energy is considerably less due to dissipation via refraction and diffraction processes around reefs and headlands. This effect is particularly apparent on the west coast, where an extensive reef chain parallels the coast and may attenuate wave energy by up to $50 \%$. Hence, the shoreline of south-western Australia experiences modally low wave energies. Isolated reefs and offshore islands offer some degree of local protection of the beaches along the southern coast. However, wave dissipation along the southern coast is considerably less than on the west coast and beaches there are subjected to a moderate to heavy south-westerly swell. Refraction around headlands is an important form of wave energy dissipation along the southern and eastern coasts of the continent. The shelter provided by gulfs and estuaries from the strong swells of the open coast continues to be significant to trade, traffic and recreation at the shore, as in Moreton Bay, Sydney Harbour, the Derwent Estuary, Port Phillip Bay and the Gulf St Vincent.

Inshore, the wave climate responds rapidly to the afternoon onset of the sea breeze. Wind waves associated with the sea breeze have a significantly shorter period and length than the swell, and are less affected by the inshore bathymetry.

Figure 2.8 Types of coasts around the continent

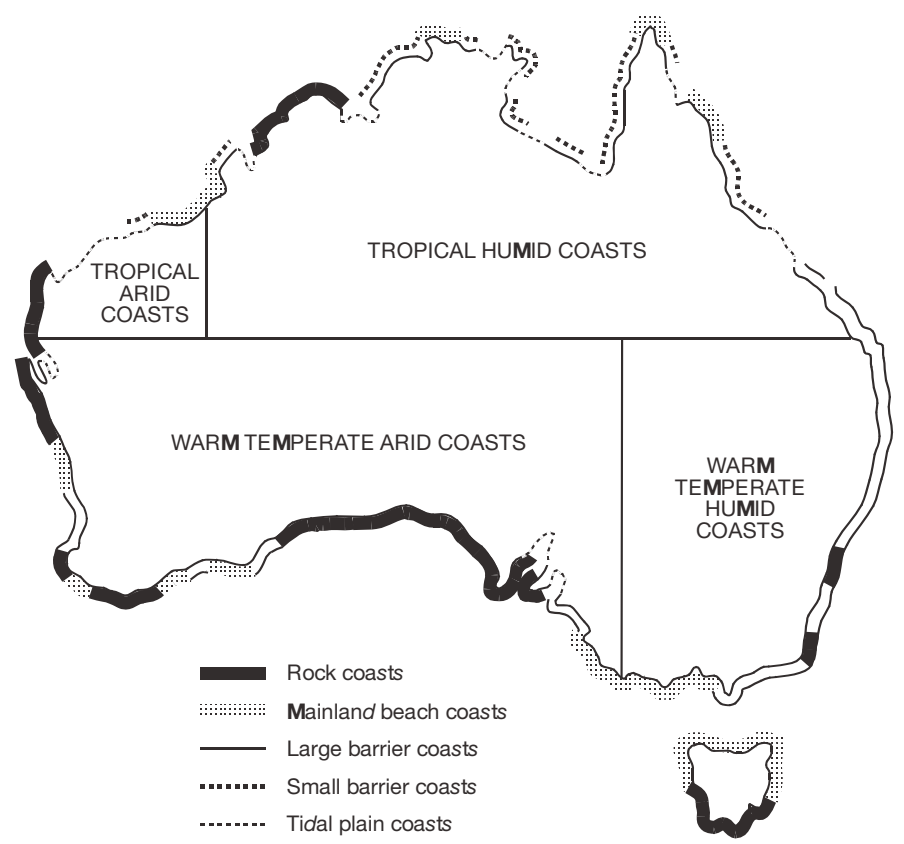

Source: after Davies 1977 
As the sea breeze continues to blow the sea waves increase in period and height. Towards late afternoon or early evening, along the West Coast, the sea-breeze generated waves may exceed the energy of the prevailing swell.

\section{Summary regional descriptions of the Australian coast}

Davies (1986) undertook a systematic description of the physical characteristics of Australian coasts which has not been superseded. Davies divides Australia's coastal landforms into four regions, based on:

- climate (particularly as it affects run-off)

- geological history (as it affects outcrop, landform and sediment supply)

- oceanographic variables (tide, width and slope of continental shelf, and wave climate).

The regions are termed 'Warm Temperate Humid', 'Warm Temperate Arid', 'Tropical Arid', and 'Tropical Humid' (figure 2.8). Table 2.2 summarises Davies description and adds data from a variety of sources.

\section{A typology of coasts by LOICZ}

The classifications discussed above have been developed by expert opinion: experts in coastal processes have evaluated the available data and then synthesised it to give a classification and description of the Australian coast.

The Land-Ocean Interactions in the Coastal Zone (LOICZ) project of the International Geosphere-Biosphere Program (IGBP) has taken a different approach. It has sought to establish a typology of coasts (that is, an analysis or classification based on types). This typology focuses on carbon, nitrogen and phosphorus (CNP) fluxes in all parts of the global coastal zone. The process has been to assemble existing data, such as run-off, evaporation, tidal range and wave climate, and then to cluster for $0.5^{\circ}$ (latitude and longitude) points. Clustering has been accomplished using traditional methods (LOICZ 2002); in this case, vector quantification has been used. Data clusters have been calibrated with published CNP budgets to establish a typology of coastal nutrient flux. This is being generalised to areas where CNP budget information is not available in detail.

The methodology has been tested in Australia, at a clustering of $1^{\circ}$ (Buddemeier \& Maxwell 2000), giving a mapped result similar to the classification developed by expert opinion, above. Further refinement of this method appears to be capable of providing a more detailed classification of the coast, using methods that may be replicated. Clearly it has the potential to isolate significant coastal descriptors which can best be used to typify CNP flux, and hence biogeochemical activity, at the coast. 


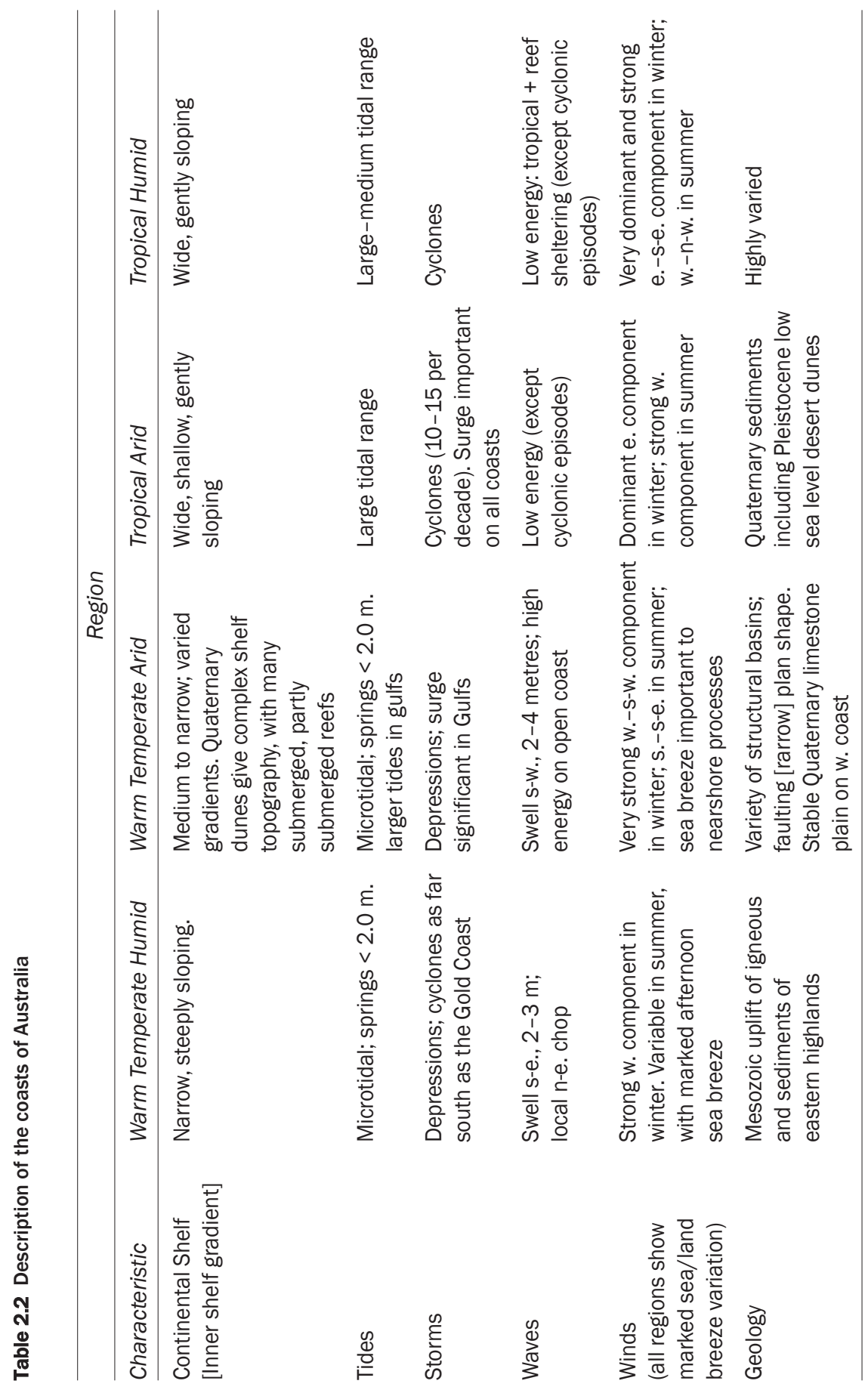




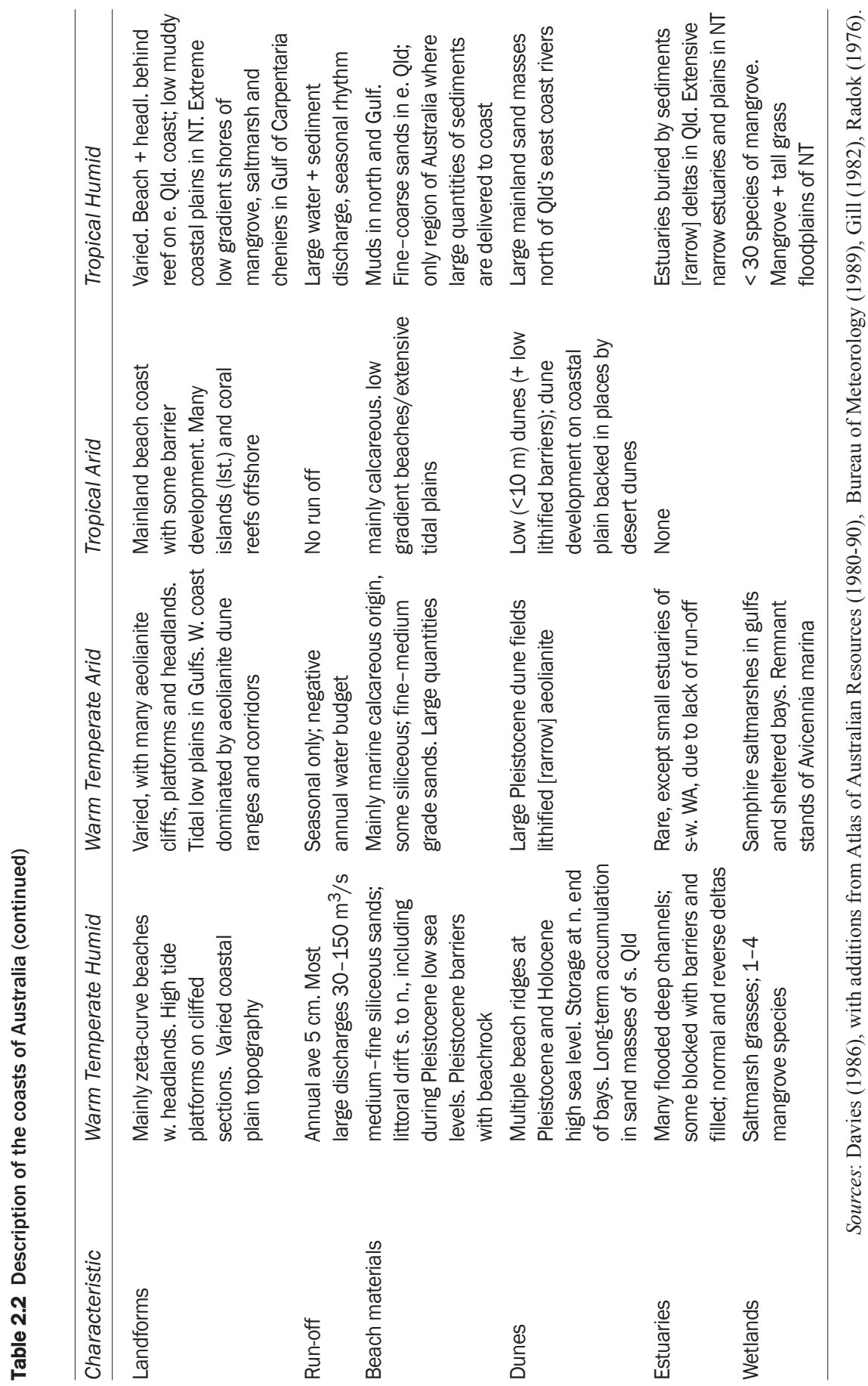


Figure 2.9 The following set of photographs has been chosen to illustrate the variety of coastal types of the Australian continent, as well as something of the variety of resource use discussed later in this book

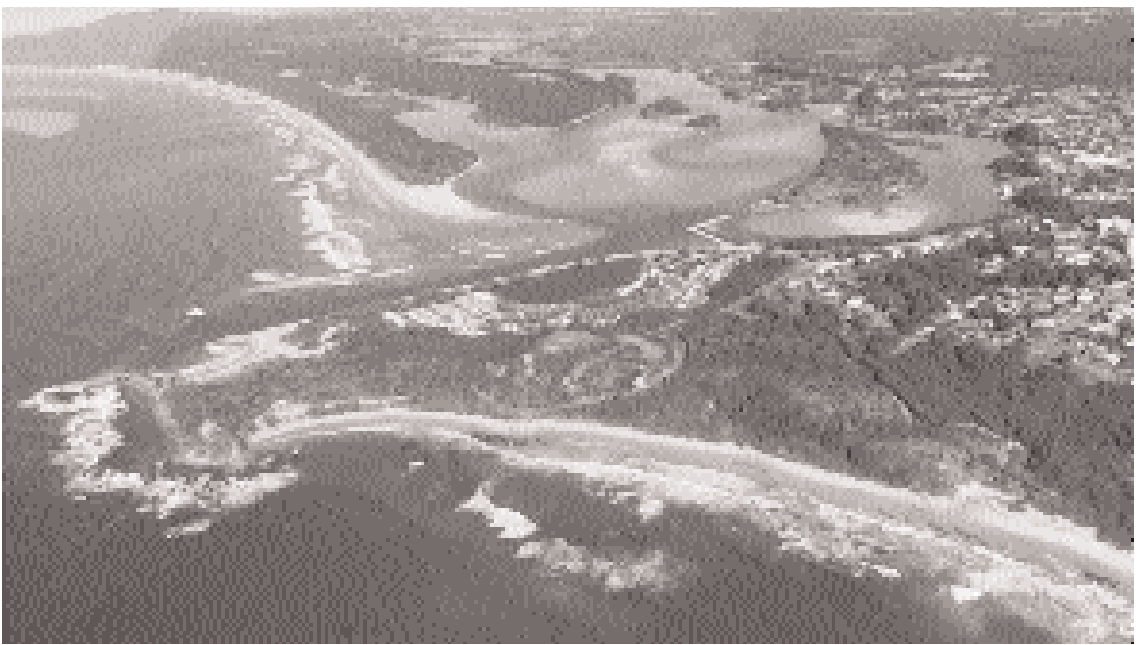

(a) NAMBUCCA HEADS, NEW SOUTH WALES

Nambucca Heads, like many east coast holiday and retirement towns, saw rapid growth in the 1990s. The Nambucca River, which rises on the New England Plateau, runs through a complex estuary protected by a long beach and dune sand barrier (photography Fran West)

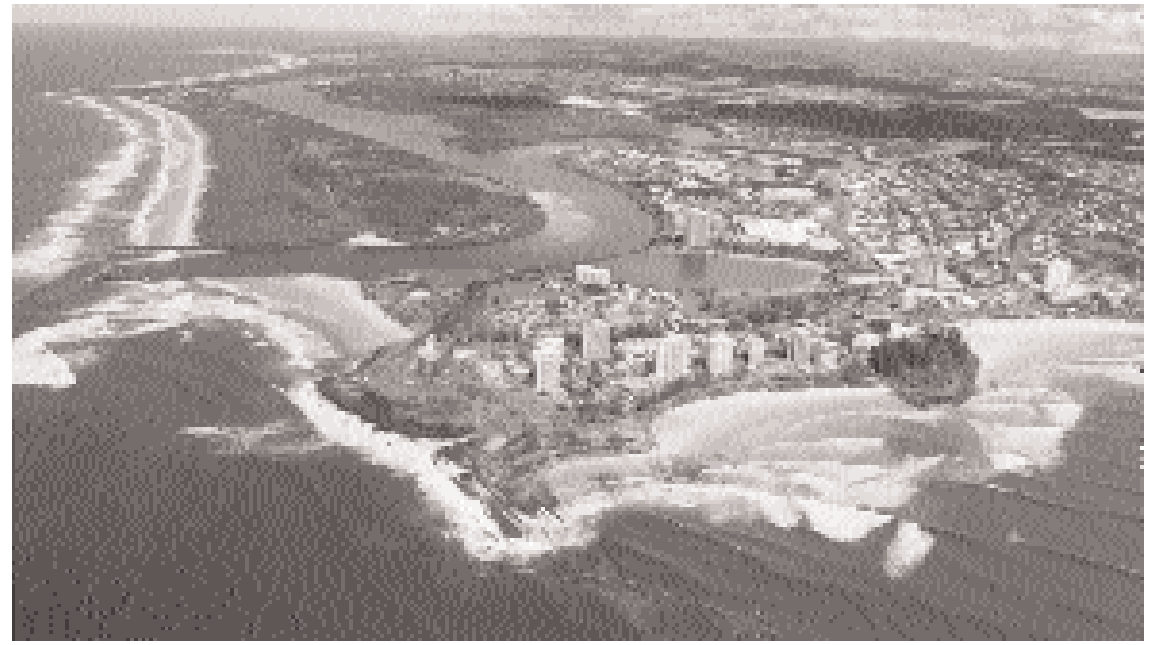

(b) TWEED HEADS, NEW SOUTH WALES

The Tweed River marks the boundary between New South Wales and Queensland. Waves cause a net movement of sand to the north here, but the training walls at the mouth of the river have in the past retained sand on the southern (NSW) side of the state border. Following agreement between the two states in 1993, accumulated sand is now pumped from Letitia Spit, south of the river, to Kirra and Greenmount Beaches in Queensland (photography Fran West) 


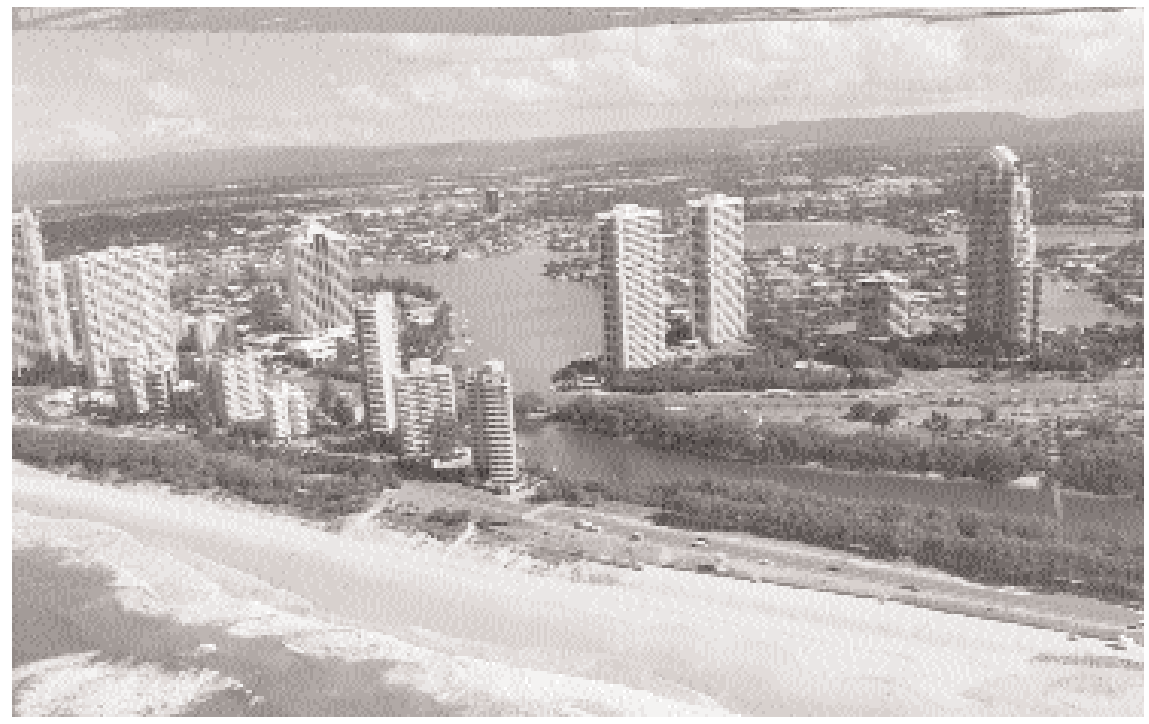

(c) SURFERS PARADISE, SOUTH-EAST QUEENSLAND

Surfers Paradise grew rapidly as a holiday resort in the 1960 s and 1970 s. Space is limited on the narrow sand spit between the Nerang estuary and the beach and high land values have led to high-rise accommodation near the beach and canal development around the estuary (photography Fran West)

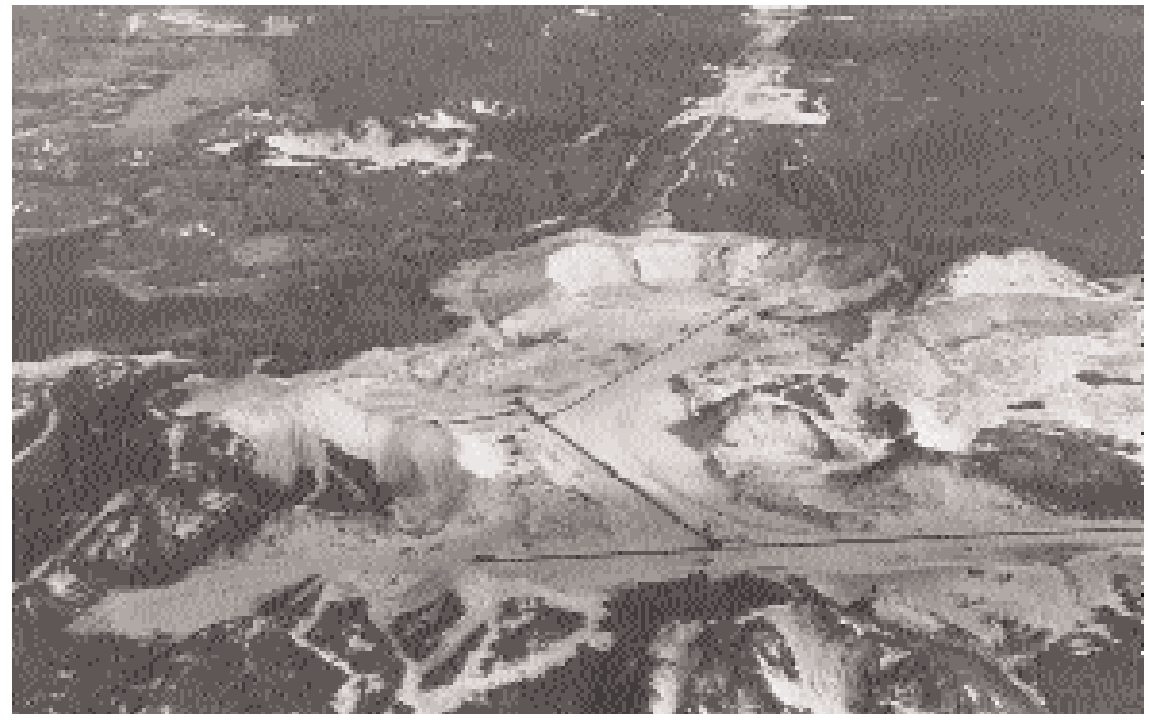

(d) CAPE FLATTERY, NORTH QUEENSLAND

An extensive sand mass form high coastal dunes on the far north-east coast of the Cape York Peninsula. Here the pure siliceous sands are quarried, for glass-making (photography Fran West) 


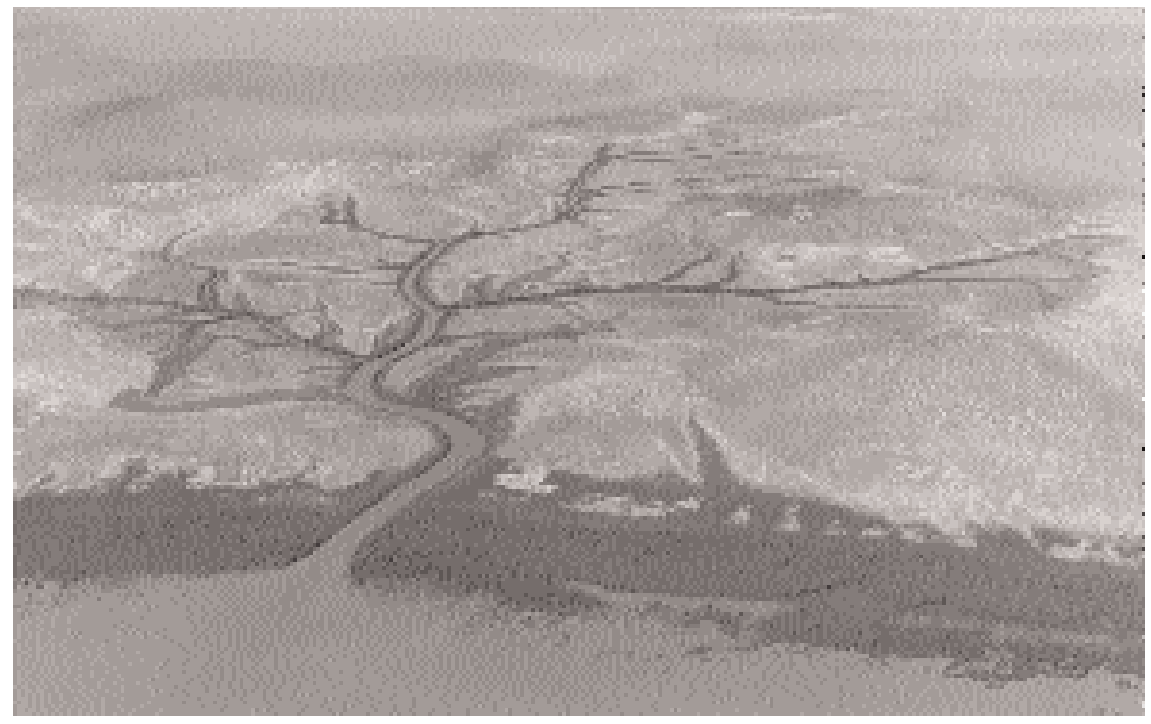

(e) MORNING INLET, GULF OF CARPENTARIA, QUEENSLAND

The saline mudflats of the coastal plain show clear zonation of intertidal mangroves and supratidal samphires. The tidal inlet exhibits a dendritic pattern (photography Fran West)

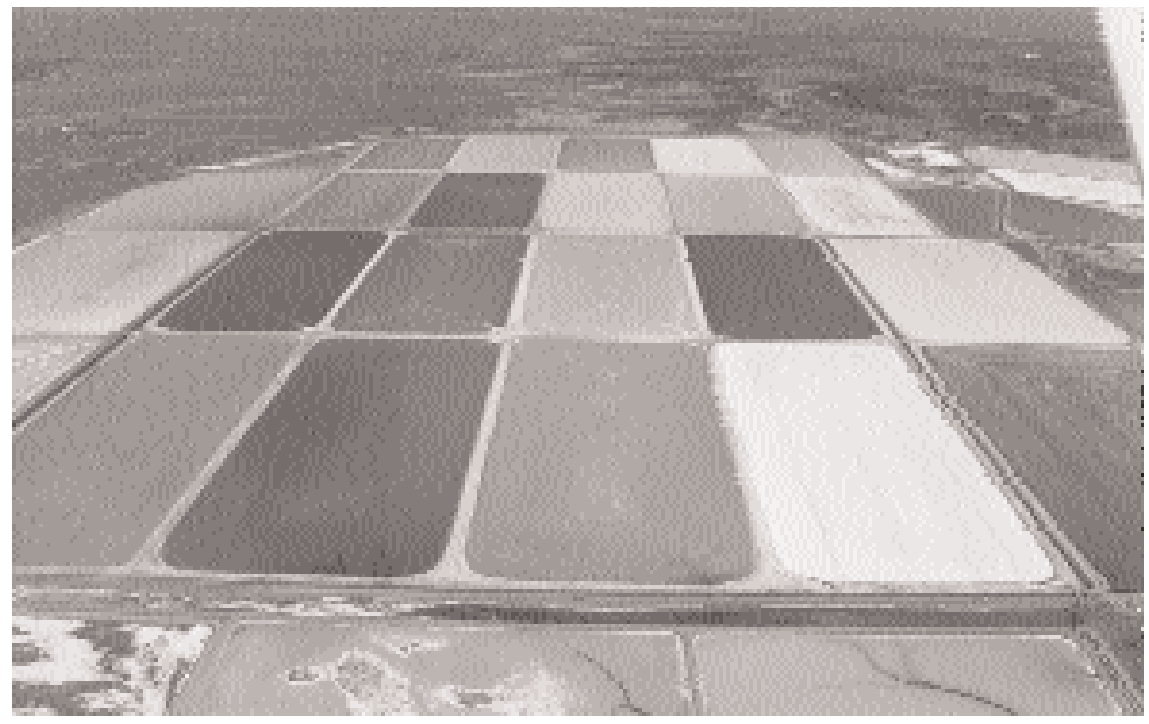

(f) PORT HEDLAND SALT PANS, WESTERN AUSTRALIA

Salt making is a significant industry on the WA coast. Seawater is concentrated by evaporation and led through a series of pans, where different salts are precipitated (photography Fran West) 


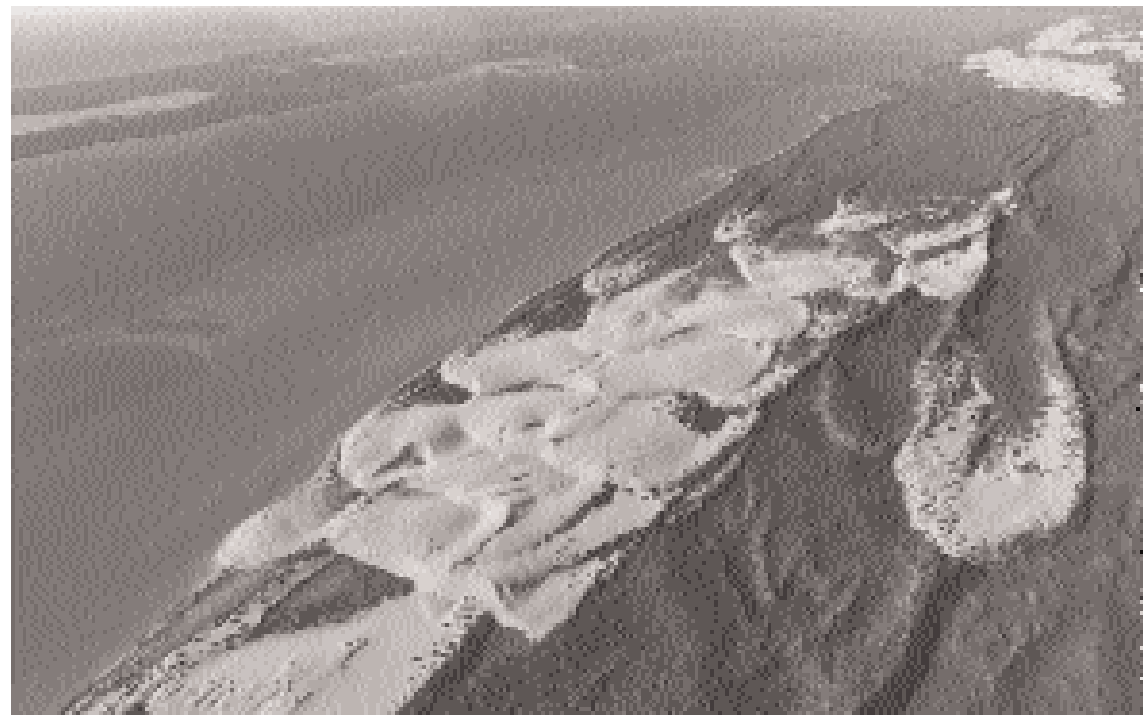

(g) BELLEFIN PRONG, WESTERN AUSTRALIA

Partly de-vegetated transgressive dunefield on the remote arid Western Australian coast (photography Fran West)

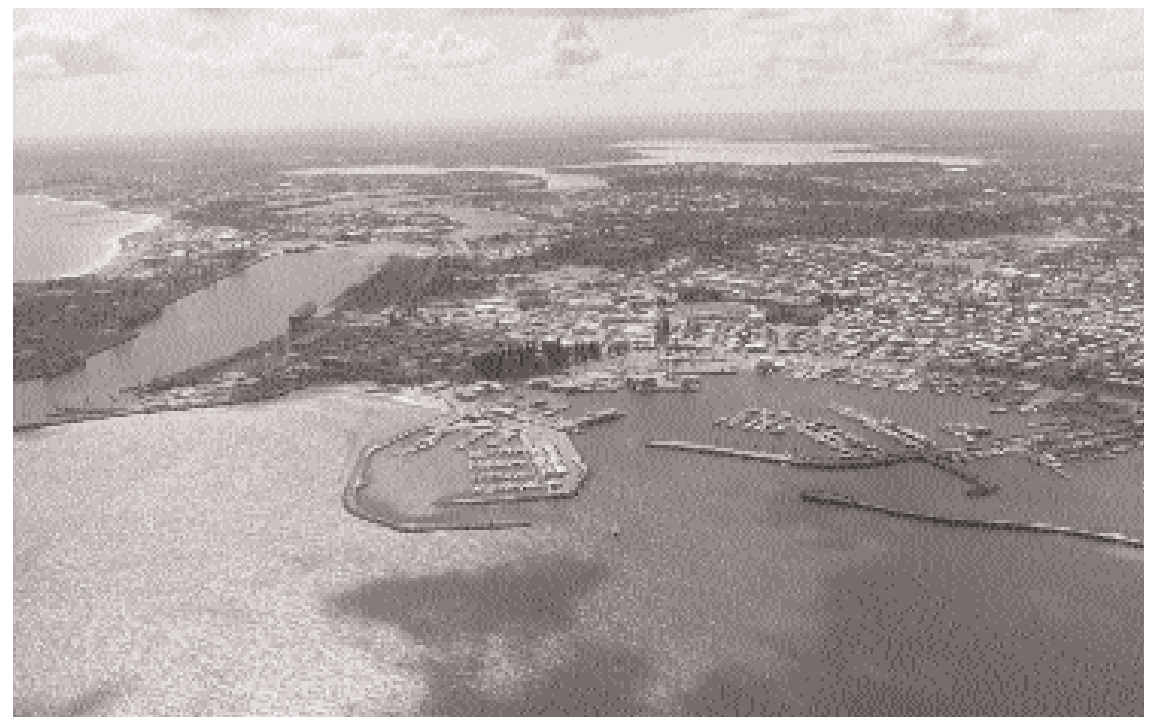

(h) FREMANTLE, WEST AUSTRALIA

Fremantle was established as a major port in the nineteenth century, and is located at the mouth of the Swan River, $20 \mathrm{~km}$ south west of Perth. Modern port and marina development has considerably modified the shoreline at Fremantle (photography Fran West) 


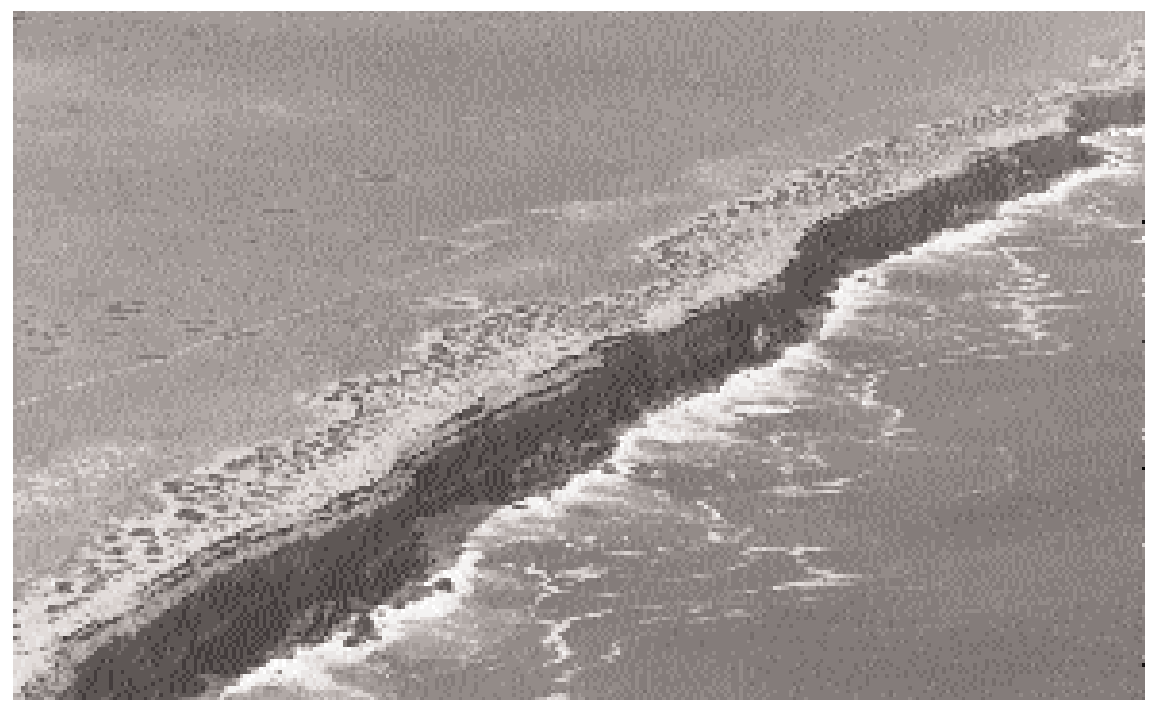

(i) CLIFFS ALONG THE GREAT AUSTRALIAN BIGHT

The near vertical Nullarbor cliffs extend for $300 \mathrm{~km}$ across the Western Australia - South Australia border. The flat, arid limestone land, with clifftop dunes, has no surface drainage to the sea. The clear, sediment-free waters of the Southern Ocean support a great variety of lifeforms, including the Southern Right Whale (photography Fran West)

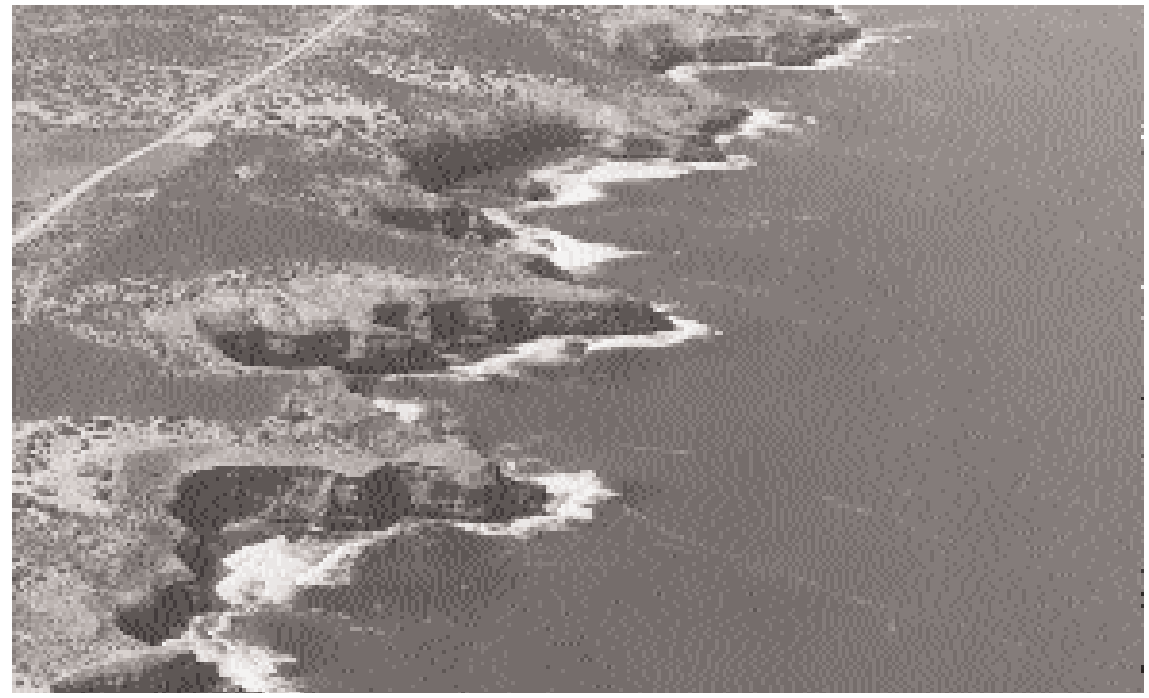

(j) CAPE BAUER, SOUTH AUSTRALIA

On the arid west coast of South Australia, low coastal heath and chenopod shrubland has been impacted by off-road vehicles, in search of fishing spots and scenic views. Clifftop dunes are especially vulnerable to traffic. Cliff nesting bird habitat is also affected by access to formerly remote places (photography Fran West) 


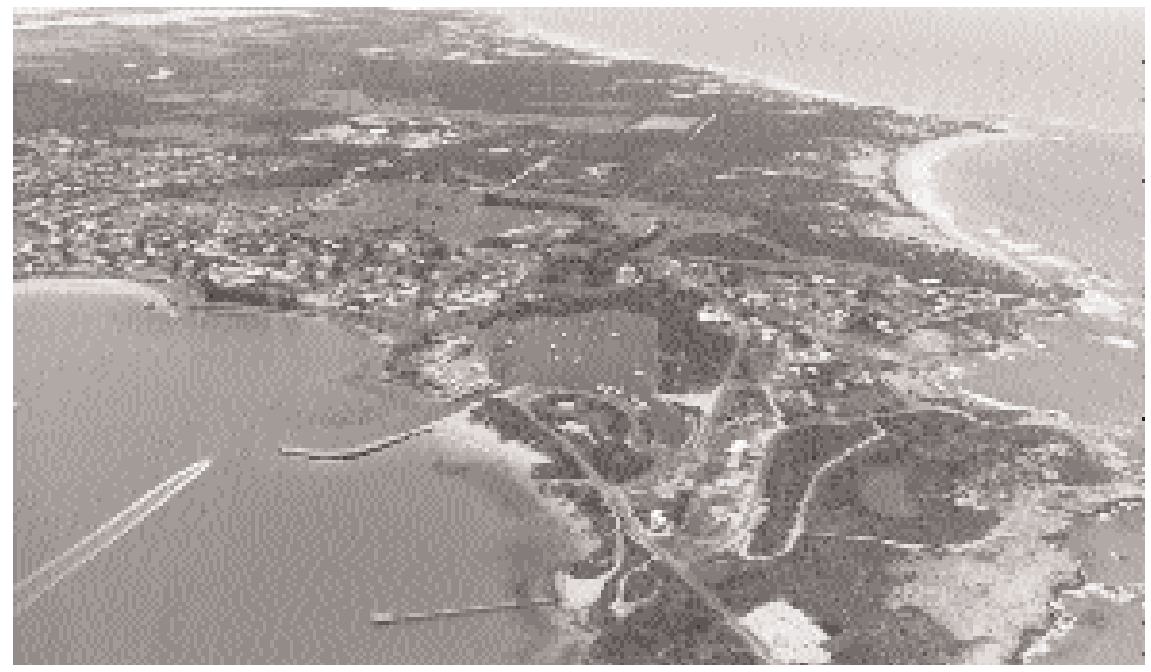

(k) ROBE, SOUTH-EAST SOUTH AUSTRALIA

The cliffs and low hills of the ocean coast on the right of the photograph are the aeolianite of the Robe Range. A major breach in the range has flooded lowlands to form Guichen Bay on the left of the photograph. The harbour of the crayfish port of Robe has been developed by an artificial cut to a circular lake (centre) within the aeolianite range (photography Fran West)

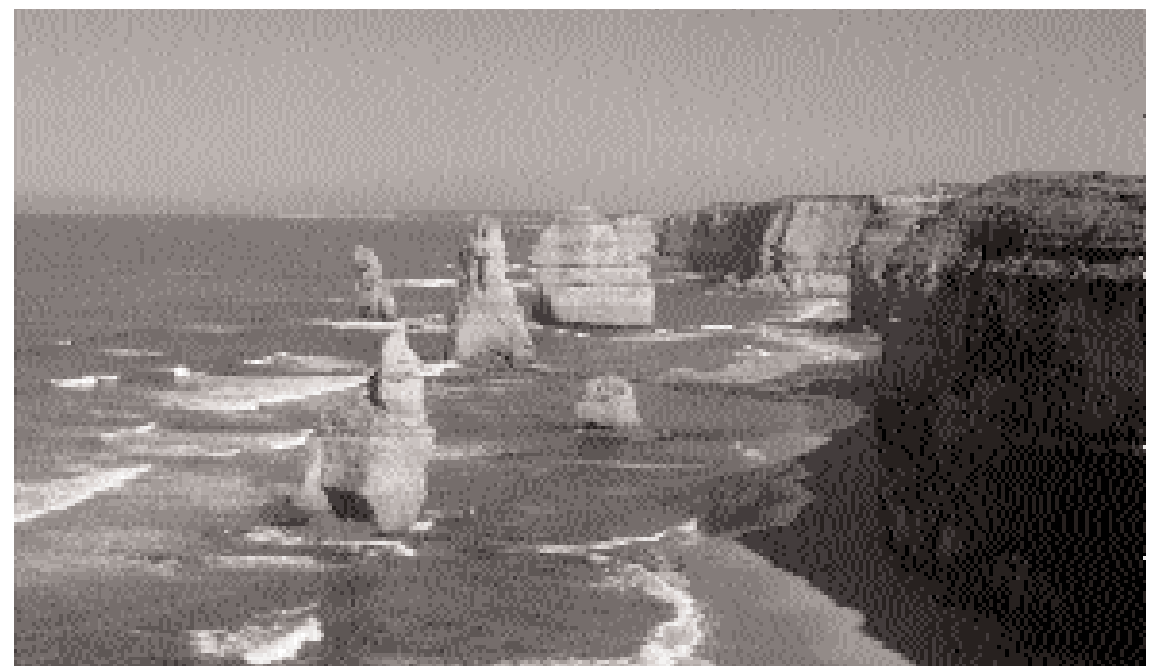

(I) TWELVE APOSTLES

Spectacular vertical cliffs, up to 70 metres high, are eroded into a single formation, the Port Campbell Miocene Limestone. This is a high-energy shore, facing south-west to the Southern Ocean. Weathering and wave energy have exploited weaknesses in the sandy limestone to cause rapid cliff recession and leading to the formation of stacks, arches and islands. The spectacular coastal scenery is the basis of a significant tourist industry along the Great Ocean Road (photography Nick Harvey) 


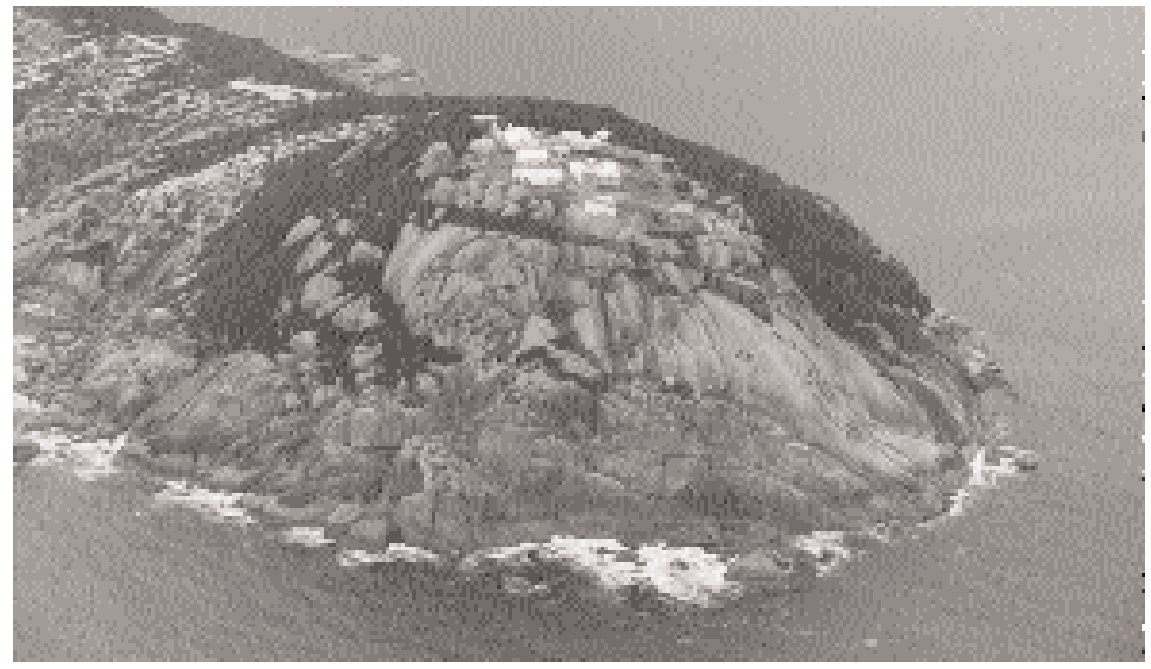

(m) THE LIGHTHOUSE, WILSONS PROMONTORY, VICTORIA

Wilsons Promontary National Park is a large coastal wilderness with varied vegetation including temperate rainforest, heath, swamp and dune communities. Granite hills and tors, bays and small estuaries make this a spectacular coastline. Offshore, in the Wilsons Promontary Marine Park, high-energy and protected areas, and hard and soft bottoms give rise to a variety of nearshore habitats. The Wilsons Promontary Lightstation is the southern-most settlement of mainland Australia (photography Fran West)

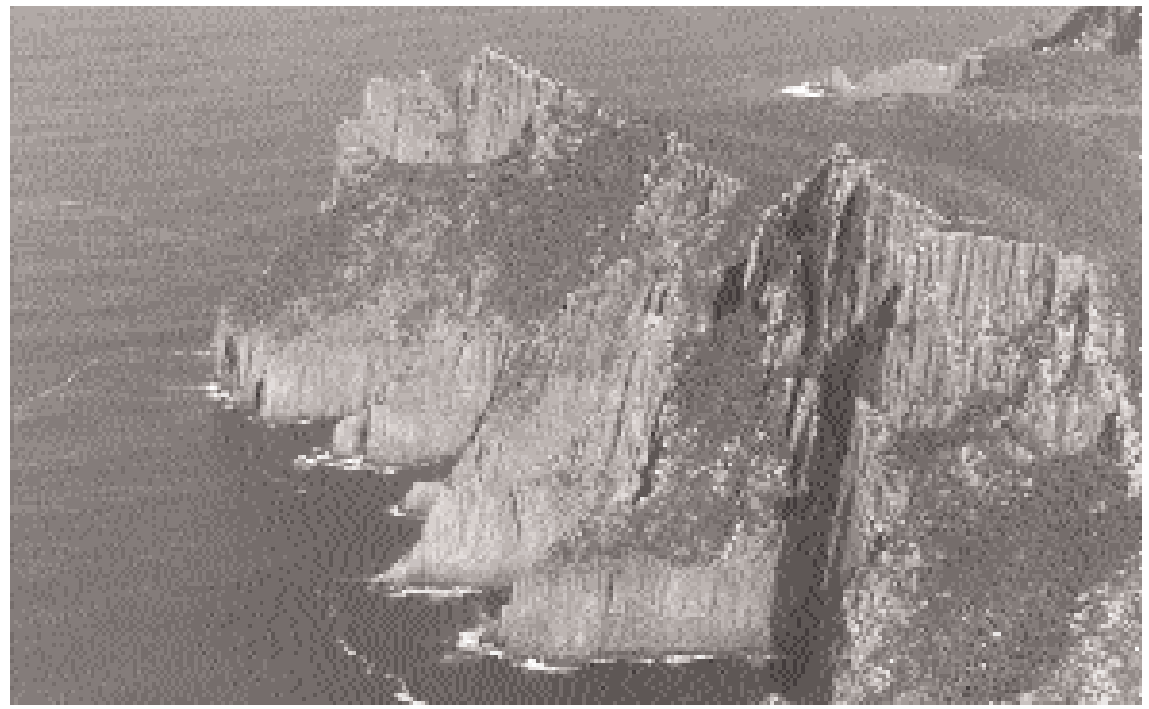

(n) CAPE PILLAR, TASMANIA

A stormy, rocky wilderness coast at the south-eastern tip of Tasmania. The form of the towering cliffs results from the weathering and erosion of dolerite columns (photography Fran West) 


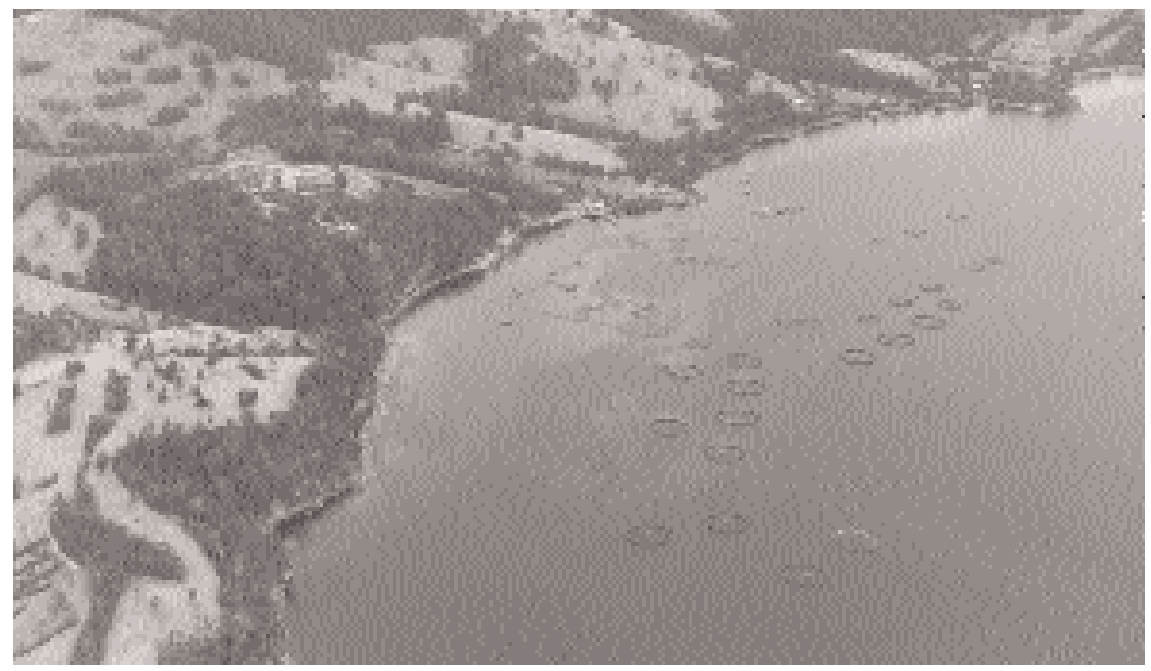

(o) AQUACULTURE, HUON ESTUARY, SOUTH-EAST TASMANIA

Fish fattening in moored pens has grown as a mariculture technique in recent years. In many parts of the Australian coast aquaculture is bringing significant income to remote coastal communities, as well as attendant pollution and disease vector problems (photography Fran West)

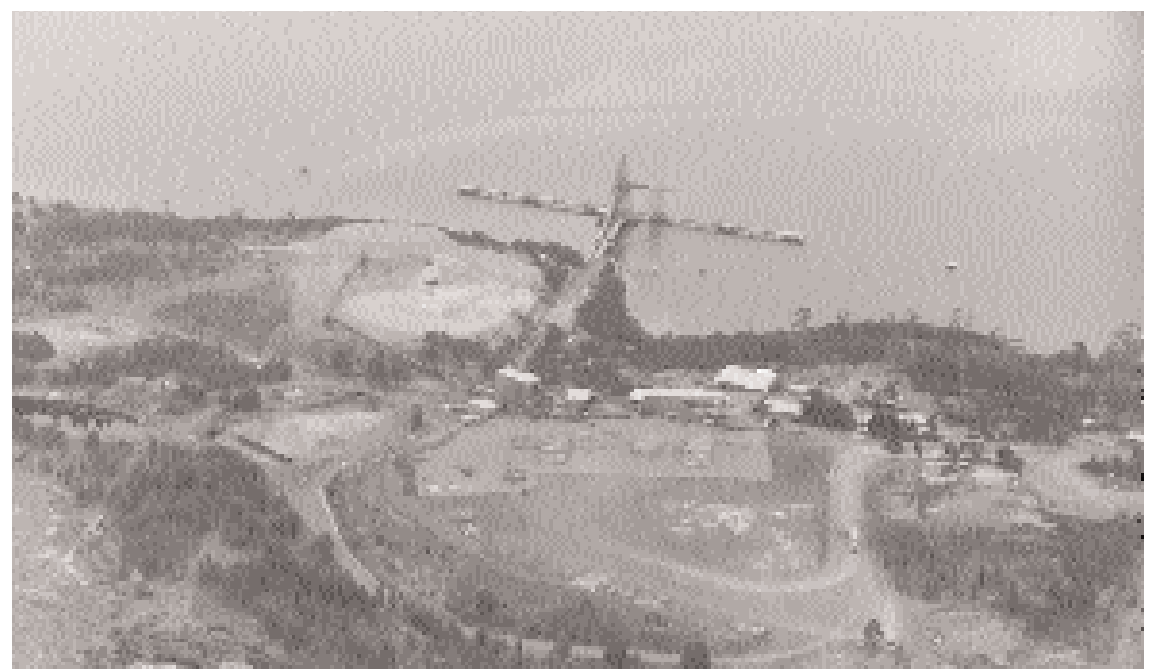

(p) TRIABUNNA WOODCHIP MILL, TASMANIA

The Triabunna Woodchip Mill, located at Point Home, $90 \mathrm{~km}$ north-east of Hobart, has been sited to facilitate the export of its product. The jetty and wharf site is sheltered from the Southern Ocean by Maria Island (photography Fran West) 


\section{Conclusion}

Australia's coast is varied and dynamic. As table 2.2 suggests, combinations of differing geological, climatic, oceanographic and biotic factors give great contrasts in coastal environments. These combinations can be regionalised to some extent, largely on the basis of climate and wave energy. Coastal management in Australia takes place within a series of varied and dynamic environments. From the Top End to Tasmania there is great pressure of uses: everywhere in the varied coastal environments, management is complex, challenging, and needed.

\section{Global change and Australian coastal processes}

It was noted earlier in this chapter that the IPCC has been instrumental in providing climate change projections related to the predicted effects of enhanced global greenhouse warming and associated sea-level rise (Houghton et al. 1991, 1992, 1996, 2001). These predictions and their implications for Australia's future coastal management are discussed in chapter 5 of this book. However, it is also important in the context of coastal evolution to look at past global changes, specifically the rapid environmental changes that took place during the Quaternary period. These changes have had the most dramatic effects on the appearance of the modern Australian coastline, such as the creation of extensive coastal barrier and dune systems, back-barrier lagoons, tidal plains, and subtidal sediment accretion associated with reef and seagrass growth.

\section{Impact of Quaternary global changes on the Australian coast}

Being the most recent geological period (the last 1.8 million years), the Quaternary has had a significant effect on the Australian coast because of the impacts of oscillating sea levels and alternation between wet and dry phases in the landscape. Unlike many northern hemisphere coastlines, the Australian coast has not been affected by ice during the Quaternary. However, global climate changes have caused repetitive build-up and decay of continental-scale ice sheets, resulting in alternate flooding and exposure of continental margins, associated with periods of erosion and sedimentation.

These global climatic changes demonstrate a pattern that is linked to variations in the Earth's orbit. The resulting differences in solar radiation were predicted by Milankovitch (1930) and subsequently termed Milankovitch cycles. The Earth's orbit has three key elements that influence climate, each with a different period. The orbital eccentricity cycle (a stretching of the Earth's orbit) occurs about every 100000 years; the axial tilt cycle (a rolling of 
the axis of rotation) occurs about every 41000 years and the precessional cycle (wobble of the axis of rotation) occurs about every 23000 years. The influence of these cycles has varied. In the early part of the Quaternary (up to 850000 years ago) the axial tilt cycle was dominant, but since then the orbital eccentricity cycle has been dominant. The result has been a series of glacial cycles with a period of around 100000 years, punctuated by warmer interglacial events such as our modern-day climate.

The major features of the glacial-interglacial fluctuations have been outlined by Emiliani (1955), who measured oxygen isotope ratios $\left({ }^{18} \mathrm{O}:{ }^{16} \mathrm{O}\right)$ of planktonic foraminifera extracted from deep ocean sediments. Using these ratios he was able to interpret global temperature changes over time. He established a quasiperiodic cycling of climate that had recurred many more times than the four major glaciations recognised from previous northern hemisphere stratigraphic studies.

These global climatic changes affected the Australian coastal environment by repeated sea level transgressions (rising sea level) and regressions (falling sea level) across the continental shelf, leaving an associated sedimentary record. Today, the Quaternary sedimentary legacy can be seen around the coast in sedimentary deposits such as relict and active coastal dunes, beach ridges, and estuarine and back-barrier sediments. In addition to the exposed coastal deposits, there is significant sedimentary evidence of former sea levels below

Figure 2.10 Blue hole on Molar Reef in the Pompey Complex. This hole is more than $30 \mathrm{~m}$ deep and more than $250 \mathrm{~m}$ wide. It is also related to karst processes during the Quaternary, when fluctuating sea levels alternately exposed the reef structure a number of times subjecting it to periods of erosion.

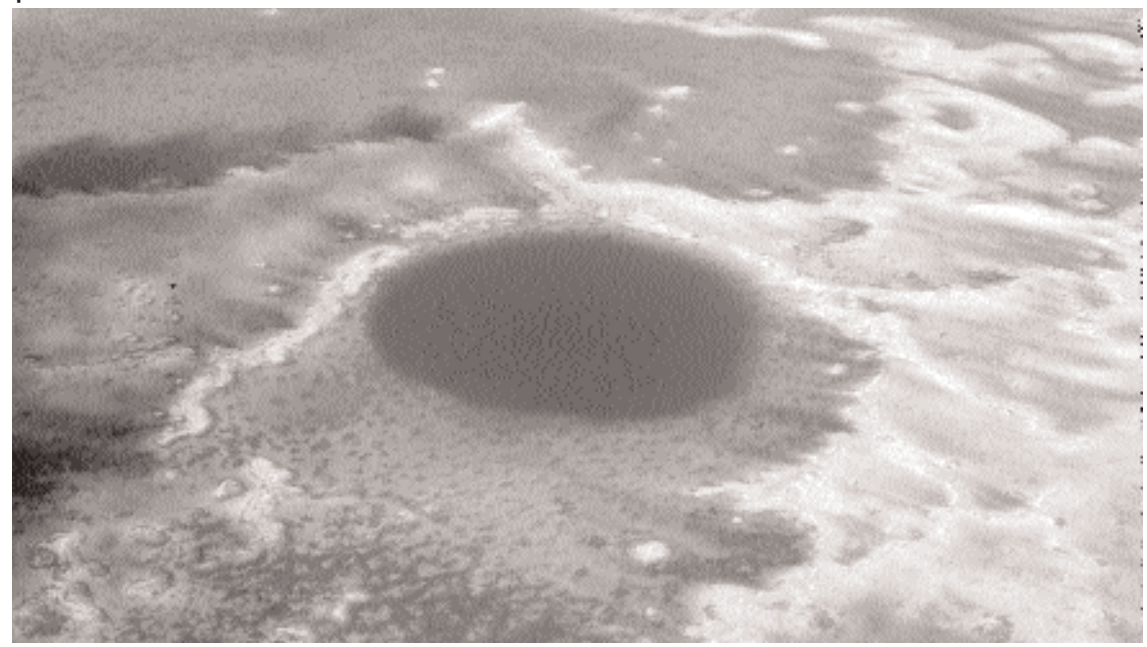

(photography Nick Harvey) 
present sea level because the high-stands associated with each transgression were rarely higher than the high-stand of today.

Elsewhere on the Great Barrier Reef there is good anecdotal evidence of the effects of these repeated sea level transgressions and regressions through successive periods of coral accretion and erosion. This is most marked in the Pompey Complex (about $250 \mathrm{~km}$ east of Mackay) where blue holes (see figure 2.10) occur within reefs of $100 \mathrm{~km}^{2}$ or more (Backshall et al. 1979). These blue holes are dolines or collapsed caves caused from multiple periods of limestone weathering during each regressive phase.

In South Australia there is a spectacular series of uplifted coastal barriers, which dates back to around 800000 years BP on the evidence of the Bruhnes-Matuyama magnetic reversal data (see figure 2.11). These major bar-

Figure 2.11 Sedimentary evidence of higher sea level events from the south-east

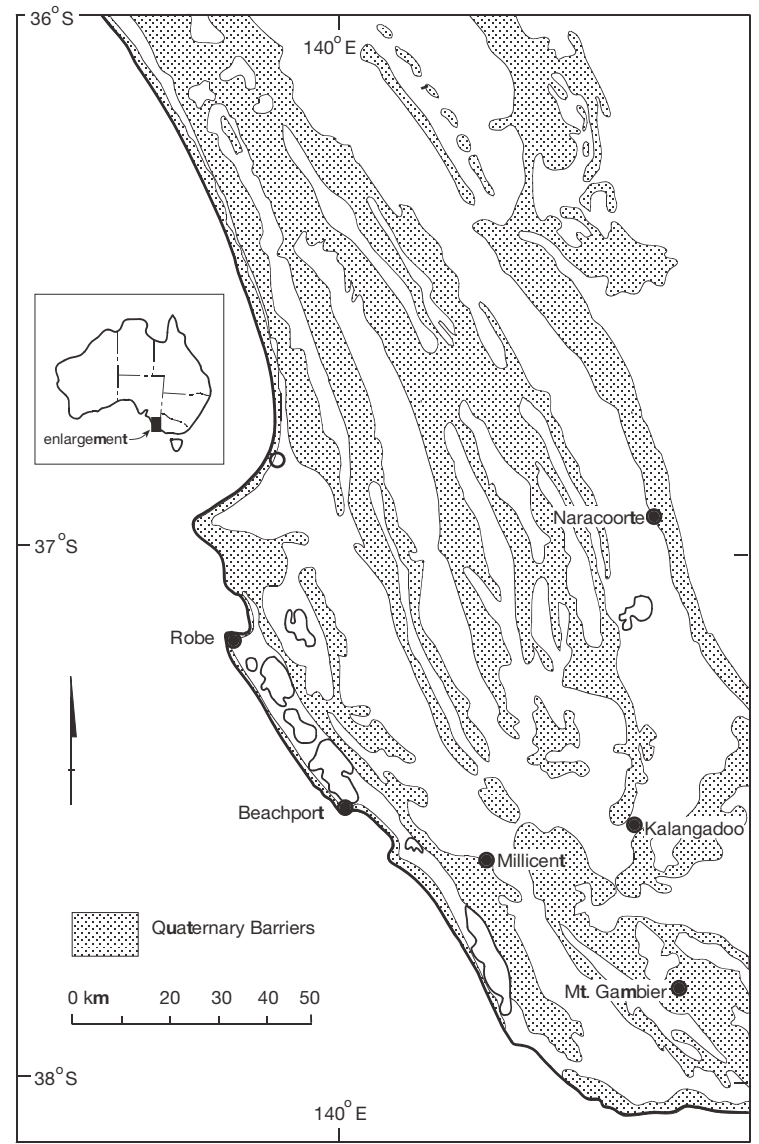

Source: modified from Gilbertson \& Foale 1977 
riers were formed by the accumulation of calcareous sand dunes during interglacial periods of a relative high-stand of sea level. In the intervening glacial periods, the sea retreated and a slow tectonic uplift of the region resulted in the stranding of the former barrier. During the following interglacial cycle, sea level rose again to form a new barrier some distance seaward of the earlier stranded barrier. Thermoluminescent dating of the whole series of barriers has demonstrated a correlation between the barriers and the deep sea oxygen-isotope records, with evidence of the 100000 year cycle of climate and sea-level change (see figure 2.12). Of approximately 27 major glacial-interglacial cycles recognised in the Quaternary, at least 13 sea level highstands are preserved as elevated shorelines (high-energy coastal barriers) on the south-east coastal plain of South Australia, one of the best on-land preserved sequences in the world. 
2 and $8 \mathrm{~m}$ higher than today (Chappell 1987). Since then, sea level fluctuations have always been lower than at present, with evidence from the Australian region of a lowest sea level of between 130 and $165 \mathrm{~m}$ below the present level, 18000 yrs BP (Chappell 1987).

Evidence of former shorelines is often very patchy with only occasional sedimentary exposures, but the last interglacial shoreline, which stood higher than the present sea level, is sufficiently preserved around the Australian coast to enable a good reconstruction (Murray-Wallace \& Belperio 1991). This not only indicates the position of this previous coastline, but also provides evidence of geological movements that have taken place since that time. Whereas Murray-Wallace and Belperio have mapped this at a broad scale for Australia, it is also possible to see more detailed evidence at the regional level, such as in South Australia (Bourman et al. 1999, Harvey et al. 2001b). The coherence in palaeo-shoreline elevation from site to site in South Australia allows geological warping since the last interglacial to be confidently determined. The lack of upwarping on the west coast and Eyre Peninsula indicates relative tectonic stability in the region. Localised upwarping in parts of the Mount Lofty Ranges demonstrates large relative land or sea-level changes over short distances. Tectonic effects are most noticeable along the south-east coastal plain, between Lake Alexandrina and Mount Gambier, where Quaternary volcanism has resulted in ongoing uplift and tilting of the coastal plain (Murray-Wallace et al. 1998). The scale and variability of this upwarp can be illustrated by the chang-

Figure 2.13 Geological warping of the last interglacial shoreline

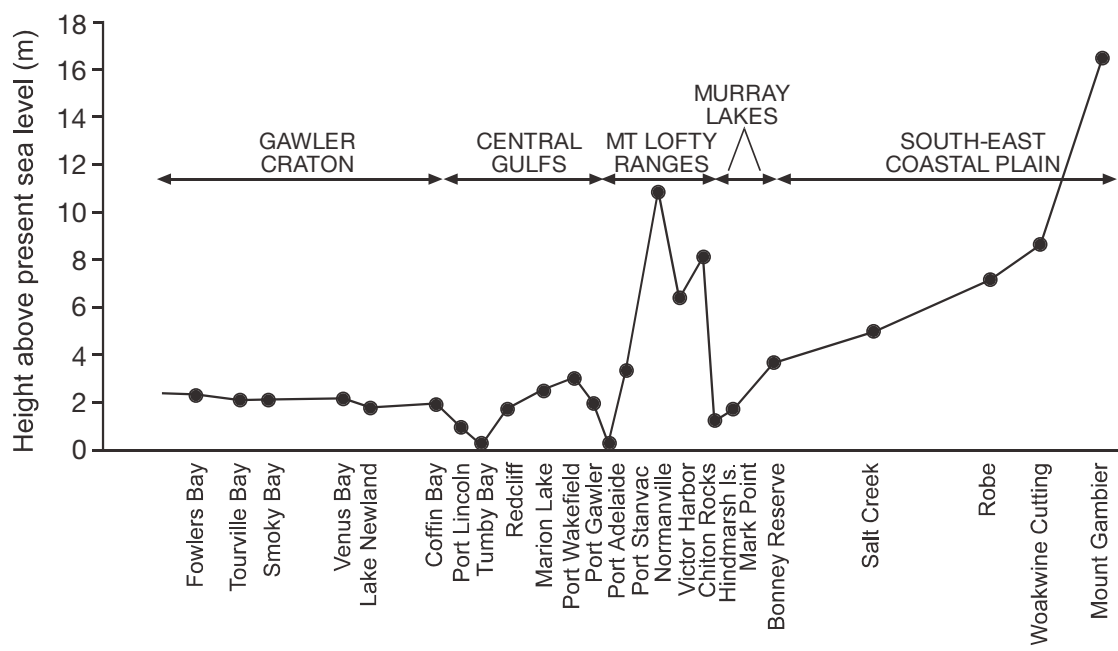


ing elevation of the last interglacial shoreline, which rises progressively southwards from $5 \mathrm{~m}$ above present sea level at Salt Creek to over $18 \mathrm{~m}$ near Port MacDonnell. Uplift rates in the Port MacDonnell region are $0.07 \mathrm{~mm} /$ year if averaged out over this entire time period.

Following the higher sea level and warm climatic conditions of the last interglacial, sea level began to fall as the Earth entered the last glacial period. Although sea level rose and fell a number of times during this time, it was always lower than it is today and remained so for around 100000 years. It is difficult to find detailed evidence for sea level changes during the glacial period because much of the evidence is either below modern sea level or is buried under sediments. Some of the best evidence of detailed sea level changes during the most recent glacial cycle (from around 125000 years BP to the present day) can be found to the north of Australia, on the Huon Peninsula in New Guinea. Here a flight of coral terraces is preserved on a tectonically uplifted coast, where the rapidity of the uplift has stranded each coral fringing reef produced during significant relative sea level still-stands (periods long enough for a new fringing reef to grow). From this series of terraces it has been possible, using modern dating methods, to plot the pattern of sea level change during the last glacial cycle (Bloom et al. 1974, Chappell 1974).

As noted above, sea level was at its lowest during the maximum of the last glacial cycle (around 20000 years BP), exposing the continental shelf and creating land bridges across areas of former inundation (figure 2.15). After this event, the rapid global warming and retreating polar ice caps produced a sea level rise with an average rate of between 6 and $12 \mathrm{~mm} /$ year before reach-

Figure 2.14 Global sea level change during the last glacial cycle

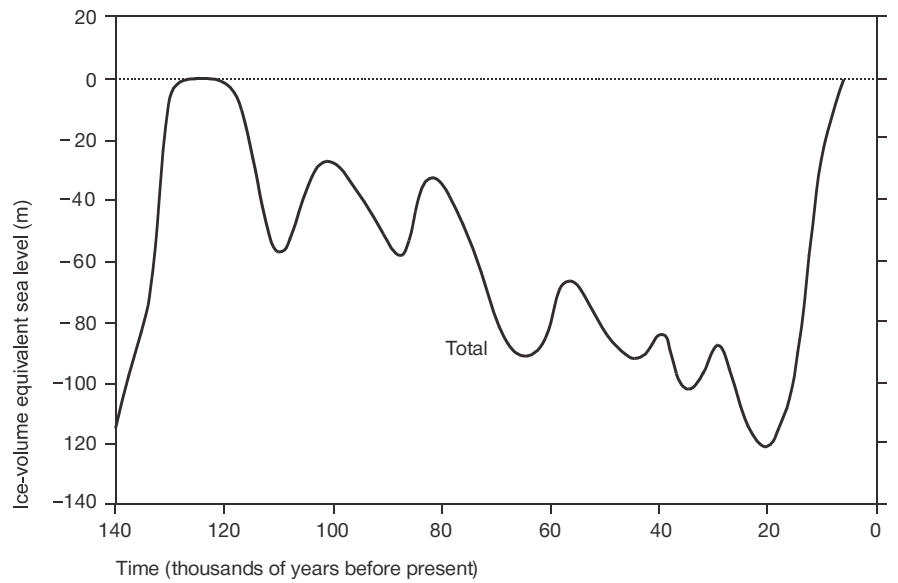

Source: modified from Church et al. 2001 
ing its present level between 6000 and 7000 years BP. This rapidly rising sea cut off Tasmania around $12000-13500 \mathrm{BP}$, and New Guinea around 6500-8000 years BP (Jennings 1971). Coast-dwelling Australian Aborigines would have witnessed this rapidly rising sea, and would have had to retreat inland. In the South Australian gulfs region the rapidly rising sea created Kangaroo Island and cut off the indigenous population from the mainland. There is also good sedimentary evidence from the South Australian gulfs to demonstrate the rapidity of the sea level rise in this region (see figure 2.16).

Figure 2.15 Approximate position of the Australian coastline 20000 years BP (left) and the present day (right)
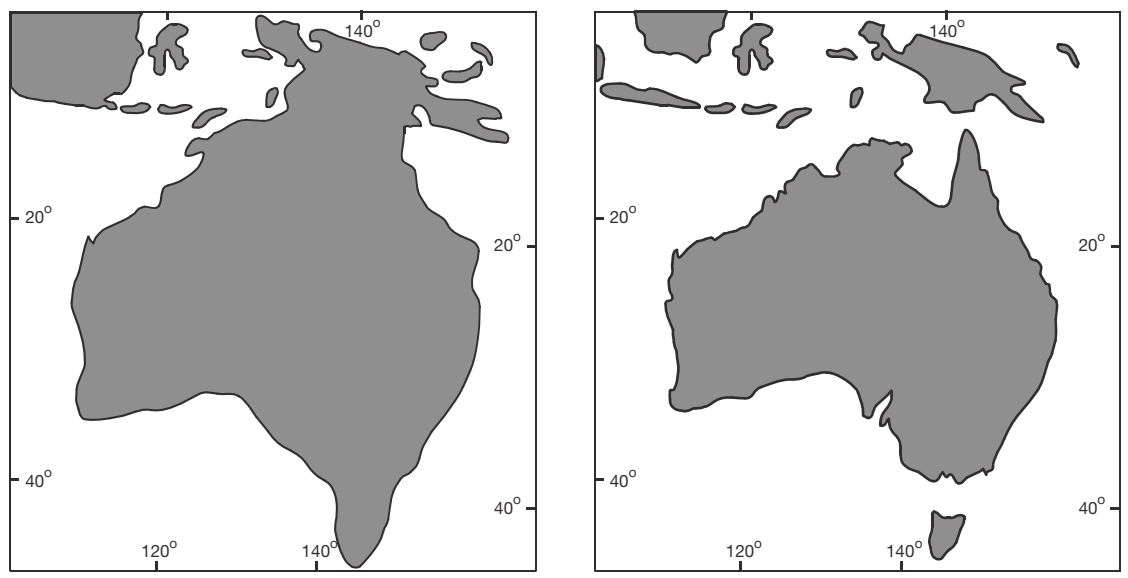

Figure 2.16 Sedimentary evidence from the South Australian gulfs demonstrating the rapidity of sea level rise

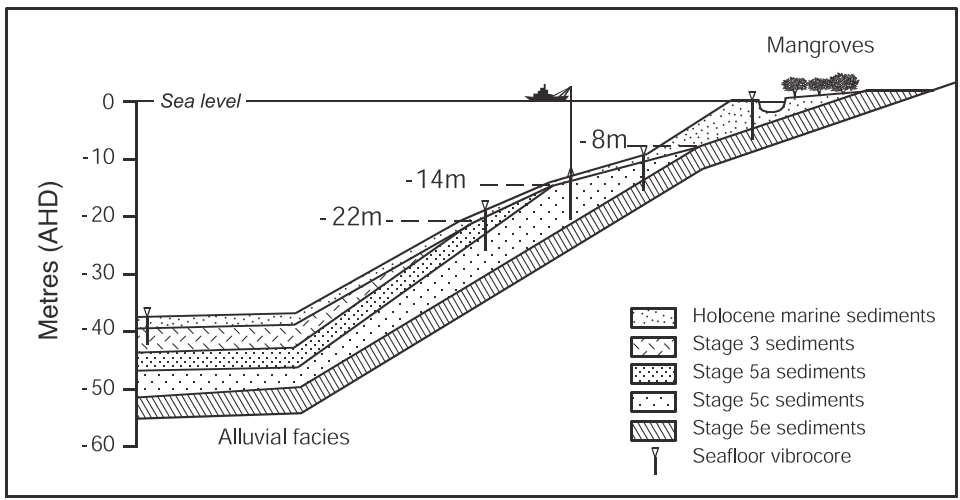

Source: Harvey et al. 2001b, after Belperio 1995 
It is this significant postglacial sea level transgression that has had a major impact on the Australian coast, and much of the coast is still responding to this event in various ways. In addition to the sea-level rise, there has also been a climatic change that has produced different river flows and altered the amounts of sediment being transported to the coast. In some parts of the coast, historical supplies of sediment are still being redistributed and moved along the coast following the postglacial marine transgression. Elsewhere, the effect of water loading on the continental shelf has caused localised coastal warping (known as hydro-isostatic adjustment) causing relative land-sea level changes. It is important to note that the effect of this rising sea has not been uniform around the globe because of different crustal responses to the water loading. This has been modelled in some detail on a global basis by Peltier (1999), and for Australia by Nakada and Lambeck (1989). This is discussed in more detail in the next section.

\section{Australian case studies of coastal processes}

In the previous section it was pointed out that it is important to understand the dynamics of coastal processes and the time-scale of coastal evolution (see figure 2.17) before discussing strategies for coastal management. We have not attempted to provide a detailed background to coastal processes because there are numerous books that do this quite adequately (e.g. Carter 1988, Carter \& Woodroffe 1994). However, we have provided an introduction to understanding these processes, which will now be illustrated with eight Australian examples of

Figure 2.17 Time-scales and processes related to coastal evolution

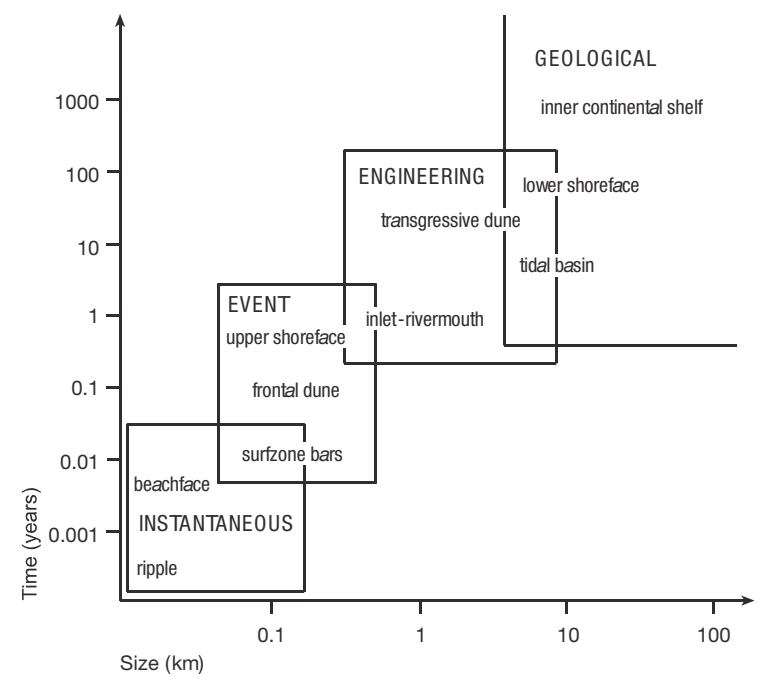

Source: modified from Cowell and Thom 1994 
different types of coastal processes and resultant coastal forms. These examples are intended to demonstrate the relevance of understanding coastal processes for coastal management purposes, and also to illustrate the variety of processes and how these are intrinsically linked to the use of coastal resources. While the focus here is on the processes, the focus in chapter 3 is on human impact.

The eight examples have been selected for a number of reasons. First, as noted at the start of this chapter, sea level changes have had a profound influence on the shape of the modern Australian coast. For this reason, the first example relates to sea level change and coastal response. Second, as described above, there is considerable variety of coastal types and processes around Australia and there have been various attempts to classify these. In order to represent this variety, the examples have been selected according to the abundance of coastal types (e.g. beaches, dunes, cliffs and platforms, estuaries, and wetlands), climatic differences between coastal processes (e.g. the importance of temperate dune formation and highenergy environments compared to tropical lower-energy environments and the importance of biological processes (e.g. coral reefs and mangroves). Third, there is a recognition in this book of the importance of integrated management, but this often neglects the marine processes. For this reason, examples of coastal processes relating to seagrasses and coral reefs are presented.

\section{Recent sea level change}

Following the low sea level some 20000 years ago, the sea rose rapidly until approximately 6500 years ago, when it reached its current position. Over the same time, there were changes in coastal sedimentation and land movement which complicate the interpretation of the position of former sea levels. For example, an area of rapid tectonic uplift such as New Guinea might show evidence of a 'relative' sea level fall for a specific location which is larger than any global sea level rise. Thus it is necessary to incorporate both land and sea level movements in order to get an accurate picture of 'relative' sea level change.

Australia is often referred to as a stable continent from which absolute sea levels may be measured, but in reality there are subtle land movements caused by structural, geoidal and isostatic processes, together with factors such as sediment compaction. These affect the Australian coast at different spatial and temporal scales and complicate the interpretation of past sea level changes. A number of reviews of Australian Holocene sea level changes (see Barnett \& Harvey 2001, Hopley 1983) have attempted to compile some of the extensive geomorphological and geological evidence for Holocene sea-level variations around Australia's margin. Barnett and Harvey (2001) noted the difficulties of interpreting past sea levels because of (a) the need to establish the relationship 
Figure 2.18 Variability of relative highstand of the 6000 year BP shoreline around the Australian coast

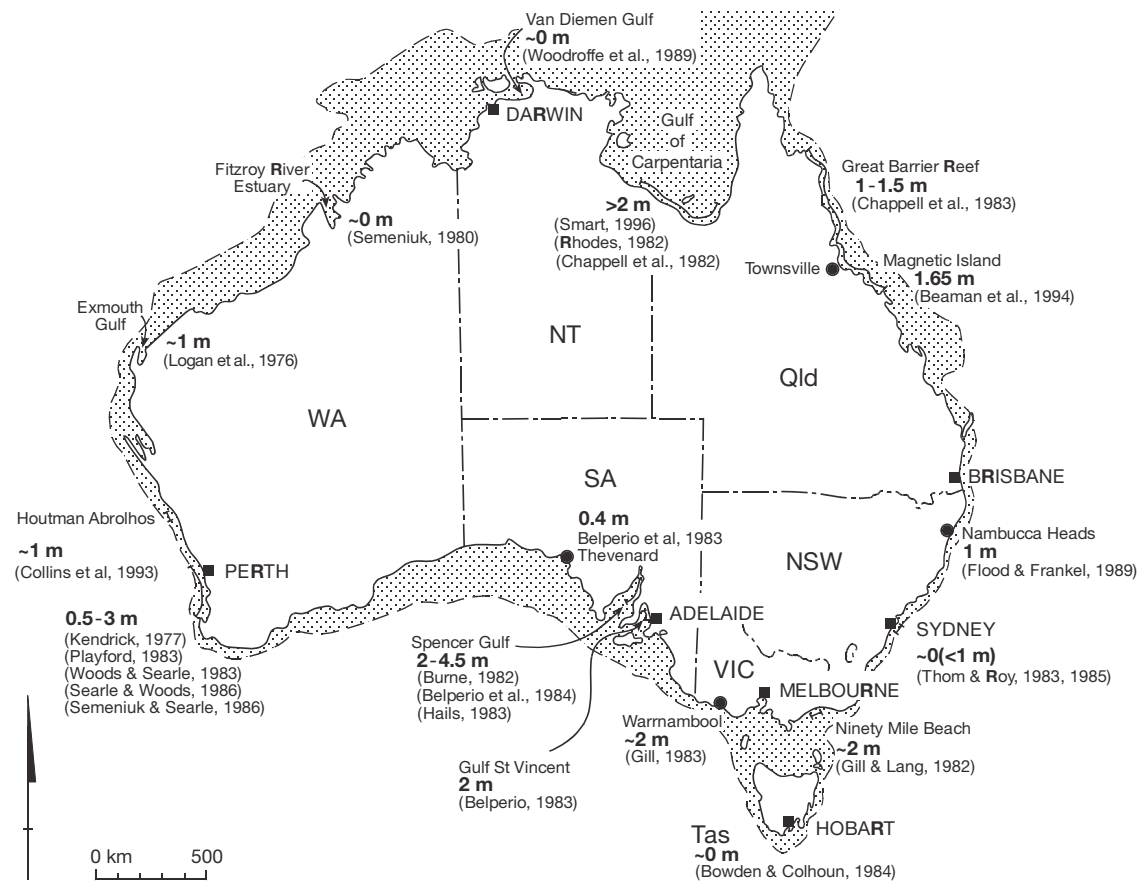

of each indicator to sea level at the time of its formation, (b) the relationship of the submerged or elevated shoreline indicator to present sea level datum, and (c) dating errors.

Barnett and Harvey (2001) also demonstrated the variability of the relative highstand of the 6000 years BP shoreline around the Australian coast (figure 2.18). The majority of this evidence is based on geomorphic, sedimentological or biological data such as chenier ridges, beach ridges, microatolls, coral reefs, oysters, intertidal calcareous worms, in situ tree stumps, mangroves, and shell bed evidence. As can be seen from figure 2.18, the evidence of the 6000 year BP sea level gives values that vary from 0 to $6 \mathrm{~m}$ above the present level.

Most of these studies provide evidence of variations in Holocene sea levels around Australia, but it is not easy to link these to present sea-level variations estimated from tidal data. The reason for this is that very few of the studies have been conducted close enough to modern tide gauges to produce any meaningful results. Three exceptions to this are studies from Townsville (Harvey et al. 2002), Port Adelaide (Belperio 1993) and Port Pirie (Harvey et al. 1999a). The latter two are 
both from South Australia in an area where several of Australia's longest tidal records exist. In the following case study, isostatic and anthropogenic contributions to vertical land movements were deduced from evidence within the tidal sediments deposited near the tide gauge stations.

\section{South Australian case study}

The rapid rise in sea level following the last glacial cycle can be illustrated for Gulf St Vincent (figure 2.19) in South Australia where, by 9700 years BP, the rising sea had broken through what is now known as Backstairs Passage. By 9500 years BP the sea had cut off what is now known as Kangaroo Island, and by around 6500 years BP had reached its present level in Gulf St Vincent. Since then, coastal and shelf processes and coastal sedimentation have progressively stabilised, producing a range of depositional styles that relate

Figure 2.19 Rapid post-glacial sea level rise illustrated for Gulf St Vincent

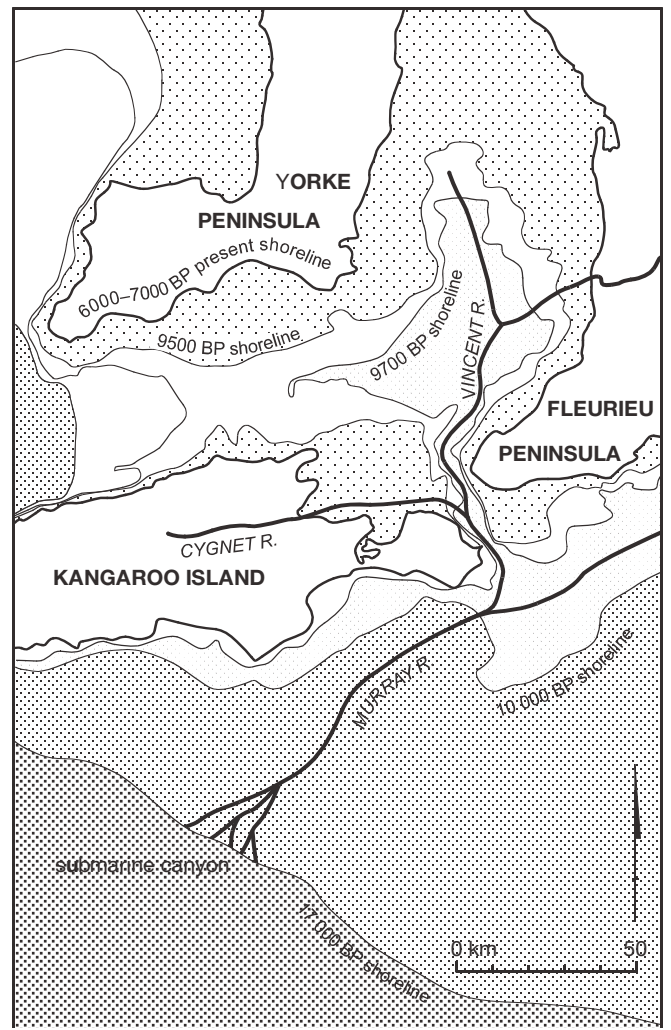

Source: Harvey et al. 2001b, after Lampert 1981 
Figure 2.20 Holocene sedimentation rate, LeFevre Peninsula

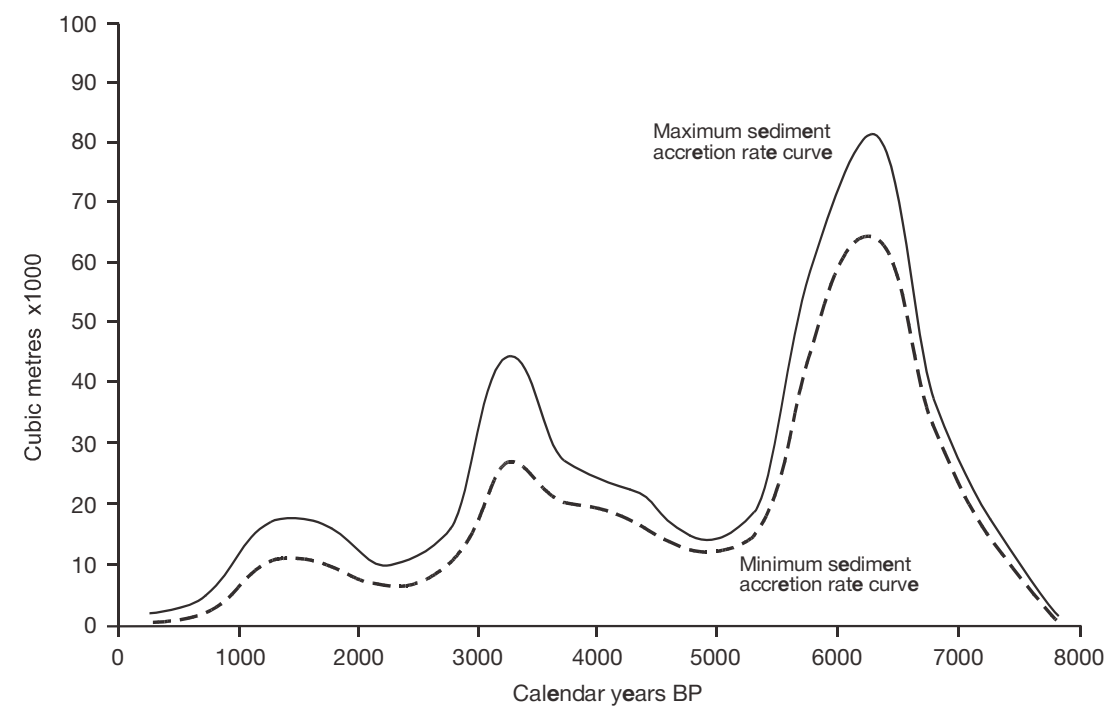

Source: Harvey and Bowman 1987

increasingly to the modern hydrodynamic regime. For example, a detailed geochronological study of a Holocene beach ridge system for the Lefevre Peninsula near Port Adelaide (Bowman \& Harvey 1986, Harvey \& Bowman 1987), demonstrated that the large volumes of sediment being moved onshore in the early Holocene have progressively declined, to the extent that beaches have to be artificially supplied by modern management (figure 2.20).

At the same time that coastal sediments were adjusting to the new sea level, hydro-isostatic loading of the continental shelf by the rising sea also resulted in different degrees of coastal warping and a geographically variable apparent sea level regression. This loading factor (see Barnett and Harvey 2001) results from the flexure of the continental margins because of the added weight of the post-glacial sea water once it has risen and moved across the continental shelf. Major factors affecting the variable response to this hydro-isostatic loading are the different water depths and the spatial extent of the continental shelf.

The variation of this relative mid-Holocene highstand has been described in detail for the South Australian coast by Belperio et al. (2002). This highstand was at a maximum of $4.5 \mathrm{~m}$ in the northern Spencer Gulf (the greatest distance from the continental shelf), $3.0 \mathrm{~m}$ in northern Gulf St Vincent, and $1.0 \mathrm{~m}$ along the south-eastern and western Eyre Peninsula coastlines. The variation in levels is directly attributable to different amounts of coastal warping and land adjustment following the post-glacial sea level rise. 


\section{Modern sea level changes}

More recent, or historic, sea level change is measured using modern tide gauges. A number of these have been maintained around the South Australian coast, and a few of them are considered reliable enough for establishing long-term sea level trends. Australian tide gauge records from 1897 to the present (figure 2.21) have been monitored and analysed by the National Tidal Facility (NTF) at Flinders University in South Australia. Although there is a variation in the quality of tidal records available, the NTF analysis of tidal data from gauges with an acceptable datum stability indicate an Australian average rate of rise of $0.68[ \pm] 0.08 \mathrm{~mm} /$ year at the $95 \%$ confidence level. South Australian sea level trends based on tide gauge data have been presented by Mitchell (1991) and discussed in relation to geological effects (Belperio 1993, Harvey et al. 1999b, 2001b, 2002).

Figure 2.21 Sea level trends for the Australian coastline (least squares analysis)
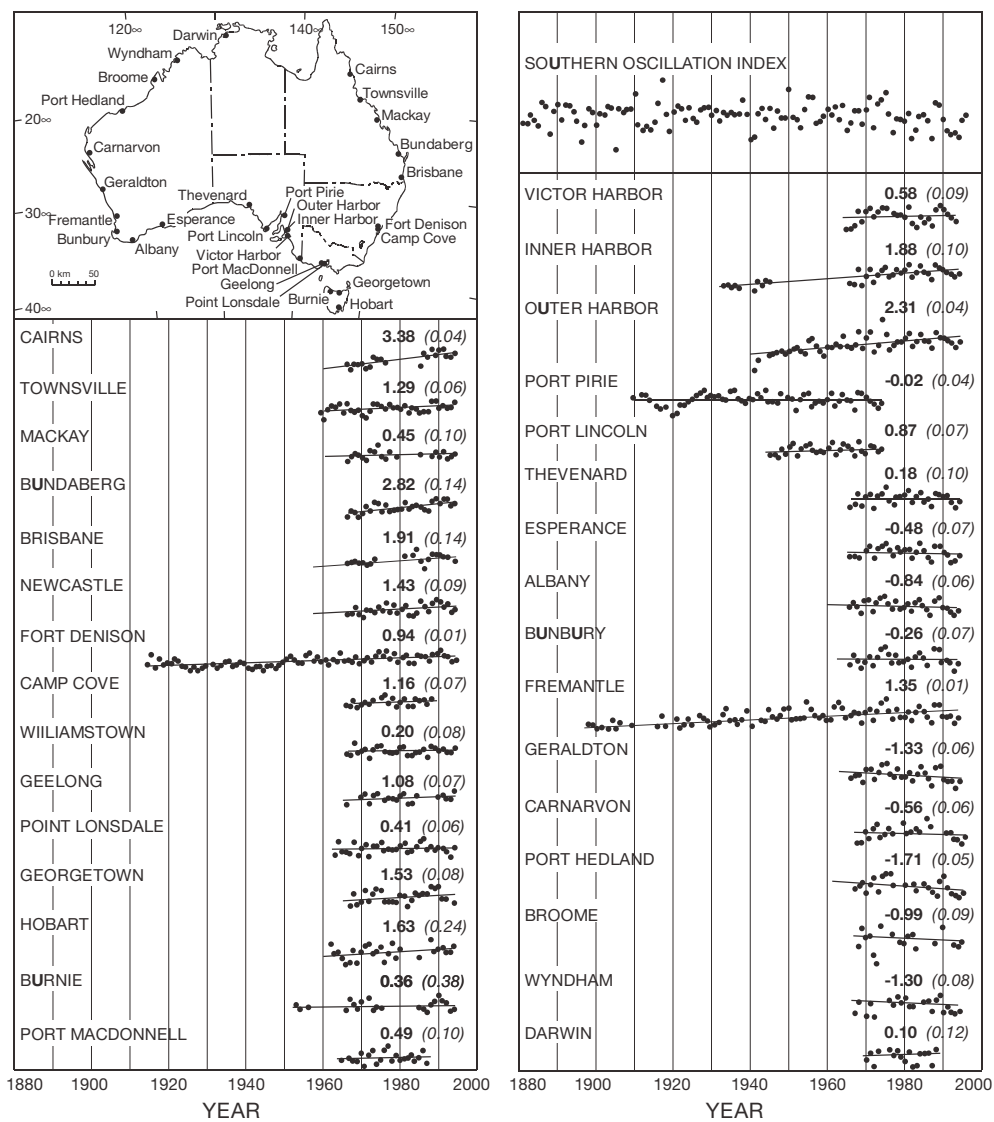

Source: National Tidal Facility 
It is useful to examine just two tide gauge locations, Port Pirie and Port Adelaide, to illustrate how sea level trends measured from tide gauge data alone can be misleading without correcting for other factors. The tidal records for these sites are among the longest (Port Adelaide, over 55 years; Port Pirie, over 63 years) and most reliable in South Australia. These records have also been used in calculations of global average sea level rise. Figure 2.22 shows that the sea level trends at these two sites are quite different, even though they are only $200 \mathrm{~km}$ apart. At Port Pirie it appears that sea level is falling fairly slowly at $-0.19 \mathrm{~mm}$ per year, whereas at Port Adelaide the sea-level appears to be rising very rapidly at $2.08 \mathrm{~mm}$ per year. Obviously, there must be some local or regional reason for this difference.

Figure 2.22 Sea level trends at Port Pirie and Port Adelaide

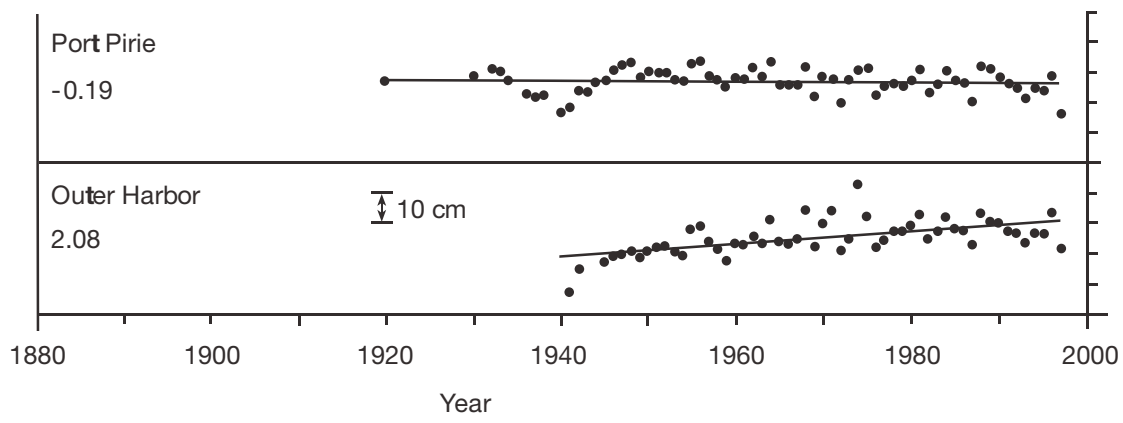

Source: National Tidal Facility

\section{Geological evidence of former sea levels}

In order to understand the coastal processes that are responsible for relative sea level differences, it is necessary to go back in time to examine the geological record. First, it is necessary to identify reliable sea level indicators in the geological record. Modern sea level indicators in the coastal environment of the South Australia gulfs have been described by Belperio (1993) and Barnett et al. (1997). Intertidal environments regularly inundated by neap-to-spring tides are characterised by intertidal sand flats that are bare or support seagrass (Zostera), and by mangrove-algal and halophyte-algal marshes. Areas of bare saline flats with isolated stranded beach ridges occupy the supratidal zone. On shorelines exposed to south-westerly winds and wind-generated waves, small beaches with a wide frontal sand flat are developed. Monospecific stands of the mangrove Avicennia marina form a low woodland from about mean sea level to spring high-tide level. Progressively higher vegetation zones are a Halosarcia-Sarcocornia samphire marsh, a Sclerostegia-Halosarcia samphire marsh, 
and an Atriplex saltbush community. Each of the distinctive intertidal facies is related to inundation frequency or tidal elevation. Thus, by identifying these modern analogues in the geological record it is possible to decipher past relative sea level change. This has been done in geological studies at both the Port Adelaide and the Port Pirie tide gauge sites.

At Port Adelaide the tide gauge record shows a rapid sea level rise. There is also evidence of inland mangrove migration in response to a real sea level rise (Kucan 1979). Detailed geological investigations were conducted by Belperio (1993) using vibrocoring techniques and radiocarbon dating of sedimentary palaeo sea level indicators. In this study, Belperio identified marker boundaries between seagrass, sandflat, mangrove and samphire facies within the sediment cores. Each sediment sample used was accurately logged within the core, and each core was accurately levelled to the modern tidal datum. Belperio then obtained radiocarbon dates from the palaeo-sea level sediments to reconstruct a palaeo sea level curve. This sea level curve was about a metre lower than expected. Belperio concluded that the apparent rise in sea level is a local phenomenon, resulting chiefly from land subsidence. He concluded that up to $1.0 \mathrm{~m}$ of subsidence had occurred as a result of wetland reclamation, increasing urban and industrial utilisation, and groundwater withdrawal. Variable rates of land subsidence, between 1.8 and $10 \mathrm{~mm} /$ year, were estimated to be occurring over different parts of this region. He also suggested that some three quarters of the secular rise of sea level indicated by the Outer Harbor tide gauge data could be attributed to land subsidence over the last 50 years at this location Belperio (1993).

Figure 2.23 Port Adelaide anthropogenic localised land subsidence

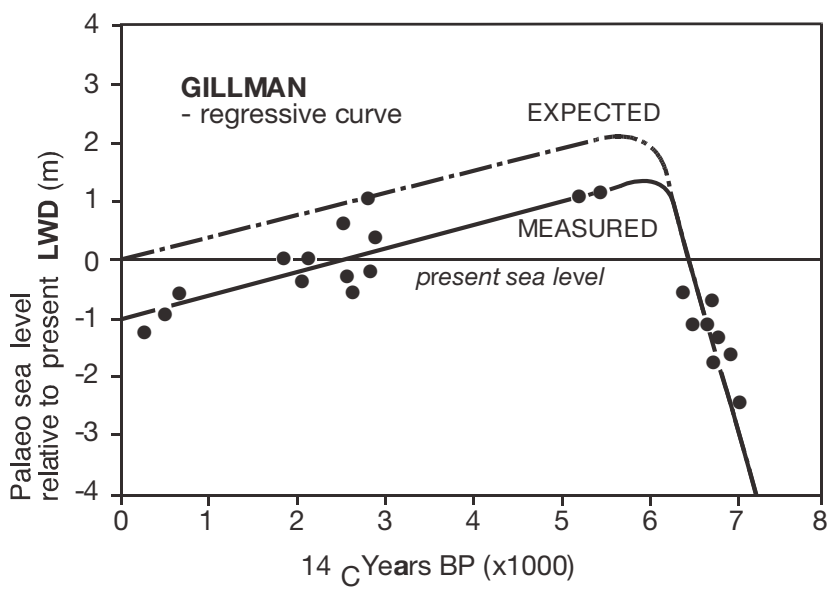

Source: Harvey et al. 2002, after Belperio 1993 
A similar study was conducted in the mesotidal coastal environment at Port Pirie, where the tide gauge record showed an apparent sea level fall. Barnett et al. (1997) documented specific palaeo sea level indicators from the region and discussed local and regional differences in the reliability of the indicators. Dated material from these horizons were then used to reconstruct a palaeo sea level curve using key indicators. Two curves were constructed, one using the top of the subtidal seagrasss as an indicator and the other using the top of the sand flat as an indicator (Harvey et al. 1999b). The subsurface data at Port Pirie contained less reliable mangrove facies compared with Belperio's study. Harvey et al. reconstructed a long-term rate of sea level fall of $0.33 \mathrm{~mm} /$ year, from a $2.2 \mathrm{~m}$ Holocene highstand 6700 years BP to the present level, in response to isostatic adjustment of the continental shelf and coast (Harvey et al. 1999b). Adjustments using present sea level trends, derived from adjacent tidal data, revealed that the sea level, when corrected for Holocene relative land and sea movements, is now rising at a rate of around $0.31 \mathrm{~mm} /$ year (Harvey et al. 2001b); see table 2.3 .

The isostaic adjustment of the shelf identified at Port Pirie causing coastal progradation and shoreline regression is even greater (up to $4.5 \mathrm{~m}$ over the past 6000 years) in the northern part of Spencer Gulf. This is directly attributed to hydro-isostatic upwarping of the distal parts of the gulf relative to the continental shelf. This has resulted in extensive areas of stranded or inactive supratidal flats along the eastern shoreline and stranded shingle and cobble beach ridges along the western shore. Elsewhere, stranded beach ridges relate to the onshore movement of local sediment immediately following the Holocene sea-level transgression.

When the same type of adjustments are made using Belperio's data for Port Adelaide (table 2.3) it can be seen that the isostatic effects are outweighed by the anthropogenic effects of subsidence. When the sea level rise of 2.08 $\mathrm{mm} /$ year derived from tide gauge data is corrected for Holocene relative

Table 2.3 Sea level trends calculated from South Australian tide gauge data

\begin{tabular}{llllll}
\hline $\begin{array}{l}\text { Tide gauge } \\
\text { sea }\end{array}$ & Years of & Sea level & Isostatic & Anthropogenic & Adjusted \\
& record & $\begin{array}{l}\text { trend } \\
(\mathrm{mm} / \text { year })\end{array}$ & $\begin{array}{l}\text { adjustment } \\
(\mathrm{mm} / \text { year }) \\
(\text { highstands })\end{array}$ & $\begin{array}{l}\text { effects } \\
(\mathrm{mm} / \text { year })\end{array}$ & $\begin{array}{l}\text { level trend } \\
(\mathrm{mm} / \text { year })\end{array}$ \\
\hline Port Pirie & 63.29 & $-0.19^{\mathrm{a}}$ & $+0.33(2.2 \mathrm{~m})$ & $0.0^{\mathrm{b}}$ & +0.14 \\
Outer Harbor & $55.1^{\mathrm{a}}$ & $+2.08^{\mathrm{a}}$ & $+0.35(2.1 \mathrm{~m})$ & $-2.2^{\mathrm{c}}$ subsidence & +0.23 \\
\hline
\end{tabular}

a source: National Tidal Facility records up to 1997

b assumed value

c source: Belperio 1993 
land-sea movement, the sea level is found to be actually rising at a rate of around $0.23 \mathrm{~mm} /$ year (Harvey et al. 2001b).

Thus the two modern sea-level monitoring sites of Port Pirie and Port Adelaide reveal dramatically different sea level trends even though they are only $200 \mathrm{~km}$ apart. Port Pirie shows a relative sea level fall of $-0.19 \mathrm{~mm} / \mathrm{year}$ and Port Adelaide shows a relative sea-level rise of $2.08 \mathrm{~mm} /$ year, but after adjustments for hydro-isostatic and anthropogenic effects the data the sea level trends are very similar: a rise of $0.14 \mathrm{~mm} / \mathrm{yr}$ for Port Pirie and $0.23 \mathrm{~mm} / \mathrm{yr}$ for Port Adelaide.

\section{Conclusion}

This case study demonstrates the variability of coastal processes in response to recent sea level changes. It is clear that the coast has responded in a variable manner to Holocene sea level rise. The example of LeFevre Peninsula demonstrates the rapid sediment accretion and reworking of sediment immediately following the postglacial marine transgression. Elsewhere in Australia there may be different forms of accretion, such as the flooding of the Queensland shelf and the colonisation and development of the present Great Barrier Reef. In other parts of the country the sea level rise could equally be marked by a prolonged period of erosion.

What is clear from the South Australian study is that the picture of sea level change measured by modern tide gauge data alone is not necessarily a true picture. It is apparent that geologically recent sea level changes have had a major impact on the distribution of modern coastal sediments and the shape of the current Australian coastline. What is of interest is that we cannot ignore the subtle effects that sea level change has had on coastal geology and consequently on our actual measurement of sea level change itself. In some places coastal uplift is occurring and elsewhere there is subsidence, whether for geological or anthropogenic reasons. These movements distort the interpretation of raw tide gauge data and consequently need to be taken into account for management purposes.

The most recent sea level rise following the last glacial has had a profound influence on the coast, but it is the historic, current and projected rates of sea level rise that are of significance for coastal managers. Geological studies are useful in detecting local changes in relative land/sea level, particularly near tide gauges where there may be an influence on the historic record, and also in providing data on coastal erosion and general coastal response scenarios for sea level rise predictions associated with global warming. These are discussed in chapter 5 . 


\section{Nearshore processes and beaches}

About half the Australian coast is made up of beaches, which receive the greatest impact of recreational and residential use of all the continent's varied coastal types. Often, dunes backing the beaches have been levelled for development, with houses, roads, and carparks crowding close to the shore. For the beach user, beach cleanliness and safety, knowledge of surf and rip currents - all changing on a short-term basis - are issues (Short 1993). For those responsible for urban infrastructure, seasonal and inter-annual beach changes and storm frequency are important considerations. Most Australian states set up coast protection agencies in the 1960s and 1970s in response to concerns over storm damage at beaches.

The character and mechanics of beach change has been intensively studied in Australia since the 1970s. Form and process are closely interlinked in beach studies, and this work has often been termed the morphodynamics of beaches. Many available texts and review articles summarise the great volume of work in this area, and it is not proposed to repeat this here. The reader is referred to Viles and Spencer (1995), Carter (1988), Carter and Woodroffe (1994), Psuty (1988), Short (1993, 1999), Woodroffe (2003), and Komar (1976, 1983).

This section details three studies of beaches in Australia to illustrate the variety of beach systems through the description of the supply and loss of beach materials, the variation of wave energy levels, tidal range, and patterns of beach change. Thus Byron Bay, on the northern coast of New South Wales, is a high-energy microtidal beach with a strong northward littoral drift; Adelaide, within the shelter of the Gulf St Vincent, is a medium- to low-energy microtidal beach with significant littoral drift; and Cable Beach, near Broome in Western Australia, is a low-energy macrotidal beach with little littoral drift.

\section{Case study: Byron Bay to Hastings Point, New South Wales}

\section{Location}

The sand beach curves northwards from the rocky headland of Cape Byron in an open 'zeta curve' for some $30 \mathrm{~km}$ to Hastings Point, a short distance south of the Queensland border. The curve of the beach is broken only by the outlets of Belongil Creek, Brunswick River, and Pottsville Creek; training walls at Brunswick Heads and Pottsville and reefs at Brunswick Heads also influence the alignment of the beach.

\section{Wave, wind and tide}

This is a moderate to high-energy East Coast Swell coastal environment (Davies 1972). Wind and wave records from Cape Byron and Coffs Harbour 
show a marked dominance of the south-easterly swell. Offshore wave records (in Gordon et al. 1978) show that significant wave height was $1.75 \mathrm{~m}$ or greater on $50 \%$ of occasions and that during storms significant wave heights of $3.75 \mathrm{~m}$ or greater occurred; wave period values of 7 seconds and greater occurred on $50 \%$ of occasions.

Tidal range is approximately $1.1 \mathrm{~m}$ for spring tides - a microtidal environment (Davies 1972) - but records show that the 100-year storm causes a $1.2 \mathrm{~m}$ surge above this and on beaches wave set-up may cause a further $2.6 \mathrm{~m}$ rise. The low frontal dunes north of Brunswick Heads may in places be overtopped by waves during a large surge, as was the case at Sheltering Palms during Cyclone Pam in May 1974 (Caton 1975). In this situation saltwater intrudes into the coastal swamps, and beach materials are deposited as overwash at the fringe of the swamp. The damage caused by the exceptional wave and surge conditions of Cyclone Pam caused the township of Sheltering Palms to be abandoned.

\section{Interannual variation}

Long-term tidal records at Sydney (Chapman et al. 1982, p. 68) show an interannual variation of sea level along the New South Wales coast, with a range of about $7 \mathrm{~cm}$. While such a variation may have a variety of causes, including changes in atmospheric pressure, ocean currents and salinity, it is now recognised that low sea levels are associated with El Niño years along the eastern Australian coast.

Also during El Niño years, there is some evidence of a slight deflection of average wind direction towards the south, leading to some reorientation of beach plan shape within the sandy embayments of central and northern New South Wales, including an erosive phase at the southern end of east coast beaches.

\section{Beach and dune materials}

Beach materials in this region are fine to medium grade sands derived from the denudation of the granitic highlands of the New England district. Following river transport to the coast, the materials have been recycled between beach and dune and across the continental shelf during the sea level oscillations of the late Pleistocene to Holocene. As a result the sands are well rounded and sorted; shell and feldspar content is minimal, and the sands are almost entirely composed of quartz with a minor heavy mineral component.

While there are Pleistocene barrier sand masses fronting coastal swamps and small estuaries, there is no extensive store of Holocene or recent sands within the embayment. Bore log data (Gordon et al. 1978) shows a thin veneer 
of Holocene sands over Pleistocene sands. There is no tendency for sands to be stored at the northern (downdrift) end of the embayment, as is the case with many New South Wales embayments.

Pleistocene 'inner barrier' sands have been widely identified across the embayment in shallow bore log data and outcrops behind the modern dune between Byron Bay and Brunswick Heads. The presence of indurated sands on the shore and in the surf zone suggests inner barrier erosion and shoreline recession during the Holocene. If 'outer barrier' beach ridges were developed

Figure 2.24 Historical shoreline change, Byron Bay

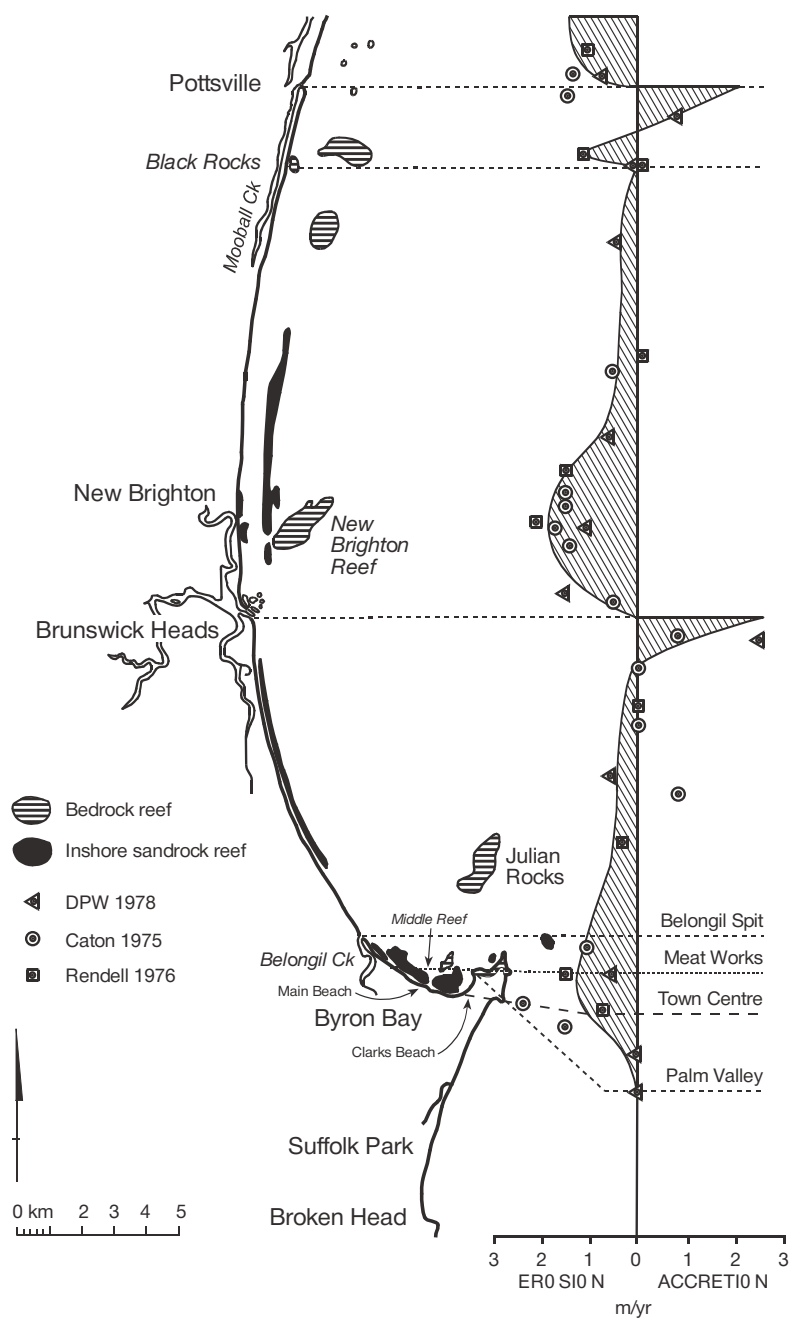

Source: Gordon et al. 1978 
at the end of the last postglacial marine transgression (6500-6000 years BP), they have been subsequently eroded.

In many New South Wales embayments, barrier development is more extensive where the bay forms a sand trap. Holocene barriers may be prograding, stationary or receding, mainly due to variation in sand supply. Some embayments show Pleistocene barriers dating to about $120000 \mathrm{BP}$, with low degraded topography, sandy podsol soil development, as well as Holocene barriers (6000-3000 BP) which have higher relief and little soil development.

\section{Historical shoreline change at Byron Bay}

Within the historical period the trend of shoreline changes has been recession. Analyses of early cadastral maps and mining lease maps show losses of land averaging 1 metre per year for over a century. Three separate studies show that this trend is confirmed by measurement from a time series of aerial photographs from 1947 to 1977 (figure 2.24). Only the local effects from groyne construction at New Brunswick and Pottsville offset this general trend of erosion.

\section{Nearshore dynamics}

Short-term change at Byron Bay is wave-dominated, and the beaches range from intermediate to dissipative states. Intermediate nearshore rhythmic topography is common, often with beachface cusps, though after a rise in wave energy one or more bars parallel the shore and beaches are low and narrow (figure 2.28).

Although the plan shape of the shallow embayment is an open 'zeta curve' typical of many mid to northern New South Wales beaches, and this form is adjusted to the form of the predominant refracted south-easterly swell, the adjustment is not perfect. As a result, the swell breaks at a slight angle with the shore. Where this occurs, a littoral current is generated in the surf zone which transports sand along the shore. The net result of waves of varying energy and frequency approaching from between east-north-east and east-south-east is an annual balance of sand movement from south to north.

Gordon et al. (1978) modelled the breaker energy and angle resulting from waves of various dimensions approaching the Byron Bay embayment, showing potential sand transport along the beach. Wave heights, wave period and directional frequency have been recorded at Coffs Harbour and Cape Byron, and these are combined with the refraction modelling to give sand transport potential over a year. These values, of up to $200 \mathrm{~m}^{3} / \mathrm{m} /$ year reflect the high-energy nature of this coastline. 


\section{Sand budget}

Using the modelling above, field measurement of nearshore currents within the embayment, and inference from sedimentary analysis, it is possible to estimate a sand budget for the embayment as an open shoreline compartment as well as for subcompartments along the beach. The budget shows a net sand deficit for the compartment as a whole, accounting for the erosive trend within the embayment. Sand budgets for sub-compartments within the embayment predict variation of loss along the shore, due to variation in wave-induced littoral drift as well as continuing adjustment consequent upon the construction of

Figure 2.25 Predicted littoral drift rates, Byron Bay

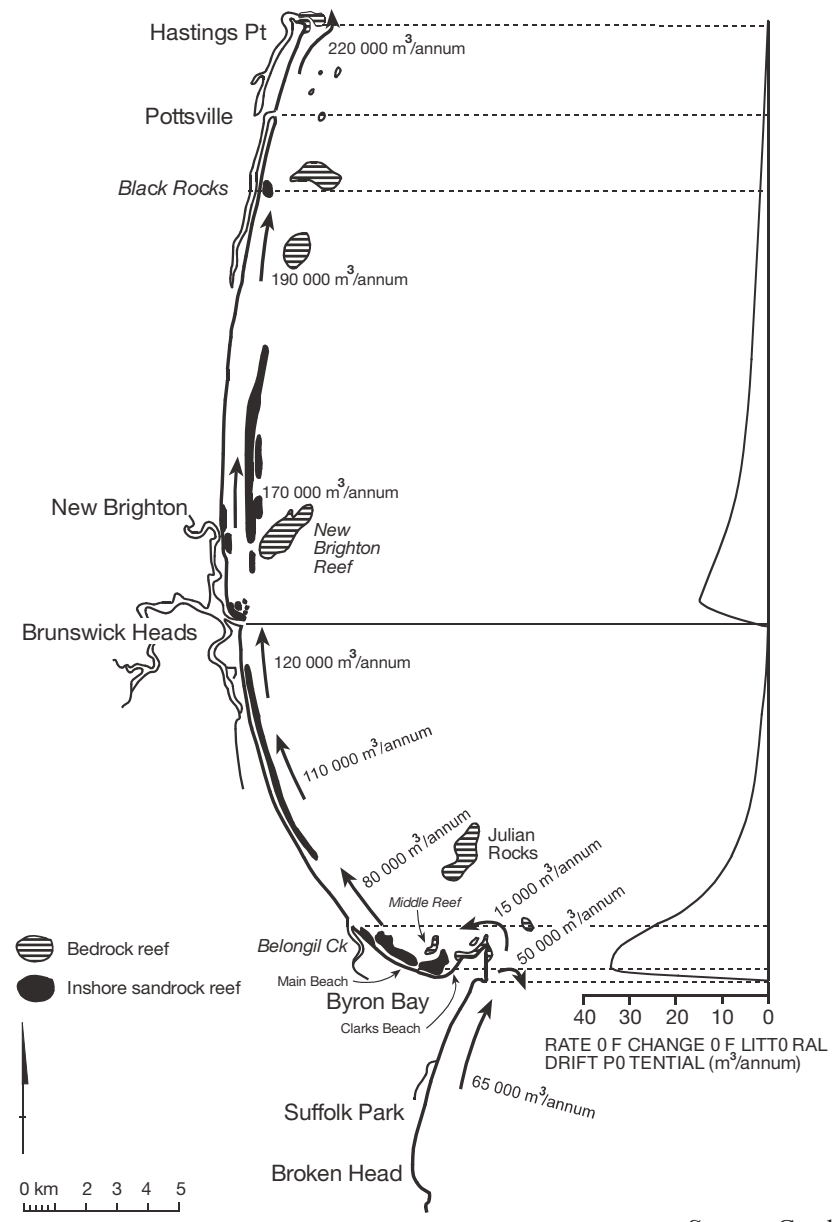

Source: Gordon et al. 1978 
training walls at Brunswick Heads. This modelling predicts changes at the same locations and the same order of magnitude as a number of studies of historical records of coastal change in the embayment over approximately 110 years based on cadastral and mining lease survey records.

From a wider perspective it could be said that the studies of nearshore processes at Byron Bay concur with the regional long-term pattern of sand movement: transport down the rivers of northern New South Wales and intermittently northwards during the sea level oscillations of the late Quaternary, including temporary storage in the dunes and barriers of the embayments until larger stores are reached in the giant sand islands of southern Queensland: Stradbroke, Moreton, and Fraser Islands. This pattern appears to hold north of the Clarence River (Chapman et al. 1982); south of the Clarence, headlands largely confine littoral drift within embayment 'compartments'.

Table 2.4 Sediment budget for Cape Byron to Hastings Point

\begin{tabular}{llll}
\hline Source & Value $\left(\mathrm{m}^{3} /\right.$ year $)$ & Sink & Value $\left(\mathrm{m}^{3} /\right.$ year $)$ \\
\hline $\begin{array}{l}\text { Longshore } \\
\text { transport in }\end{array}$ & 65,000 & $\begin{array}{l}\text { Longshore } \\
\text { transport out }\end{array}$ & 200,000 \\
Dune & 180,000 & Offshore & \\
erosion & 245,000 & current loss & 50,000 \\
\hline Total sources & & Total sinks & 250,000 \\
\hline
\end{tabular}

Source: Gordon et al. 1978 p.182

\section{Case study: Adelaide metropolitan beach, South Australia}

\section{Location}

The Adelaide metropolitan beach is located on the eastern shore of the sheltered Gulf St Vincent (figure 2.26). The beach and narrow dune system extend from Seacliff to Outer Harbor.

\section{Wave, wind, and tide}

Tidal range is small (microtidal or mesotidal), with a spring tide range of $2.1 \mathrm{~m}$. The highest recorded storm surge was 2.0 metres, in 1981.

Wind records show a dominance of south-westerly winds from the Southern Ocean. These are reinforced in summer by the late afternoon sea breeze, which exceeds $20 \mathrm{~km} / \mathrm{h}$ in favourable pressure conditions. 
Figure 2.26 Locations and sand movement at the Adelaide metropolitan beach

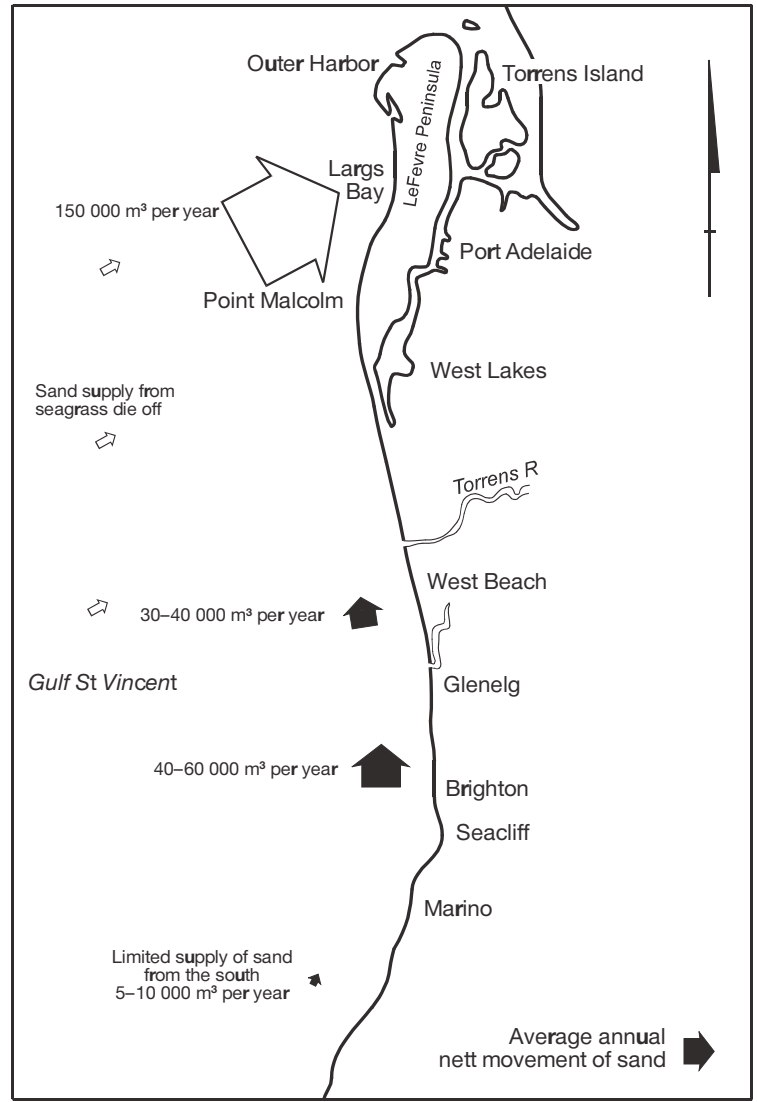

Source: DENR Reference Group 1997

Wave records at Seacliff indicate a medium- to low-energy shore. Most wave heights are below $1.5 \mathrm{~m}$, and very few are above $2.5 \mathrm{~m}$; wave periods are commonly 4 or 5 seconds. A south-westerly ocean swell dominates, although swell energy is much reduced by attenuation in the shallow water of Investigator Strait, and within the Gulf, north of Point Malcolm there is a fall in wave energy.

\section{Sea level}

While little interannual difference of sea level has been recorded, there is seasonal variation with pressure changes. There is a local long-term sea level rise at Port Adelaide (in addition to global rise) because of local neotectonic sinking due to groundwater abstraction and wetland reclamation (Belperio 1993). 


\section{Beach and dune materials}

The beach is composed of fine to medium grade sands made up predominantly of quartz, with up to $10 \%$ shell. The bulk of these sands were laid down at the end of the postglacial marine transgression (see figure 2.27), 7500-5500 BP (Bowman \& Harvey 1986). These sands were moved onshore at the end of the transgression, forming a dune barrier 300-1000 m wide fronting a low swampy coastal plain. The major sediment pulse of 7500-5500 BP produced rapid northward progradation of a sand spit, extending northwards from Semaphore Park. After 5500 BP a reduced sediment supply and a change in coastline orientation contributed to spit recurvature and a flared beach ridge orientation.

Figure 2.27 The growth of the LeFevre Peninsula

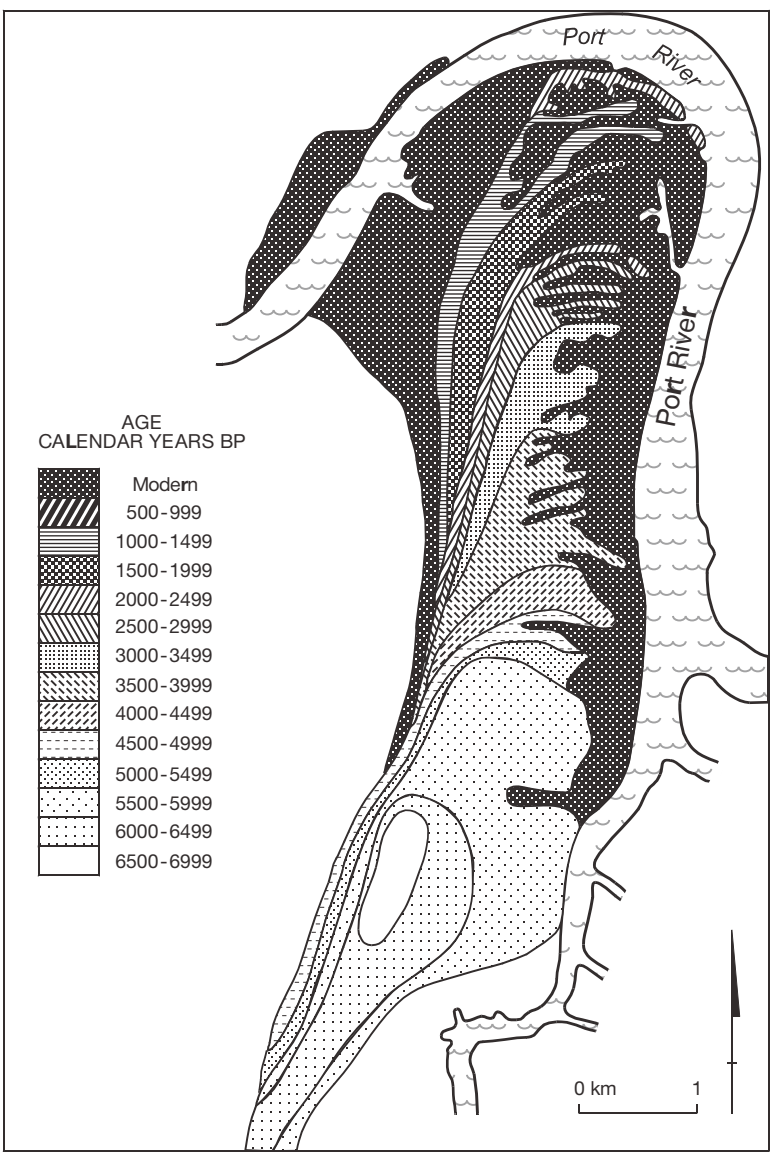

Source: Bowman \& Harvey 1986 
This contrasts with barrier development in New South Wales where shorenormal development of barriers is common in the swash-aligned situation. Here, the LeFevre Peninsula can be described as 'drift-aligned' (Davies 1972), with the barrier extending along the shore.

\section{Nearshore dynamics}

An intermediate beach morphology (see figure 2.28) with rapidly changing surf zone and beach face conditions are common along the Adelaide foreshore, whereas at the northern end of the system dissipative multiple bars have developed in a situation of abundant fine sand accumulation. This latter morphology is stable, and beaches north of Point Malcolm are not subject to the storm damage evident further south.

Most of the Adelaide beaches, south of Point Malcolm, show clear offshore-onshore movement with a variation in wave energy. Beaches erode rapidly (in a matter of hours) in heavy weather, and the sand builds a nearshore bar which serves to further protect the beach (i.e. a negative feedback loop). Fine weather and low waves slowly (over days to weeks) rebuild the beach. The low waves drive the bar onto the foreshore, where it is pushed up the beach face to build a berm and wider backshore. At what point is there a changeover? Observation suggests the following:

- All storm seas and sea breezes with wave heights of more than 0.5-0.6 m will build bars, and subaerial beaches will fall.

- Swell waves (at the tail of a storm) of period 6-8 seconds and height $<$ $0.6-0.7 \mathrm{~m}$ will restore beaches.

- Short-period waves will restore beaches only when waves are lower than $0.4-0.5 \mathrm{~m}$.

There is no clear seasonal pattern, since storms can occur in any season, but they are usually more common in winter.

One pattern is clear: the south-to-north direction of net littoral drift dominates the Adelaide beaches. In the past it dominated the drift-aligned construction of the narrow sand barrier; today it dominates the pattern of change on the beach.

\section{Sand budget}

Slow littoral drift due to wave action gives a net northerly movement of sand along the Adelaide metropolitan beach. There is very little sand supply from the south past Marino, and no sand is delivered by the urban creeks (stormwater channels) to the beach. Thus, sand that has been eroded from the southern and central beaches and moved north is, on average, not fully replaced during 
fine weather, so these beaches erode. Sand is lost from the central and southern beaches, but accumulates with the fall in energy at the northern end of the system, in the shallow water of Largs Bay and off Outer Harbor.

Figure 2.28 The beach model of Wright and Short (1983). Profile form and surf zone circulation are shown for six beach states, a-f. Beach characteristics, including wave energy, tide, sand grain size, and prior change, determine beach state

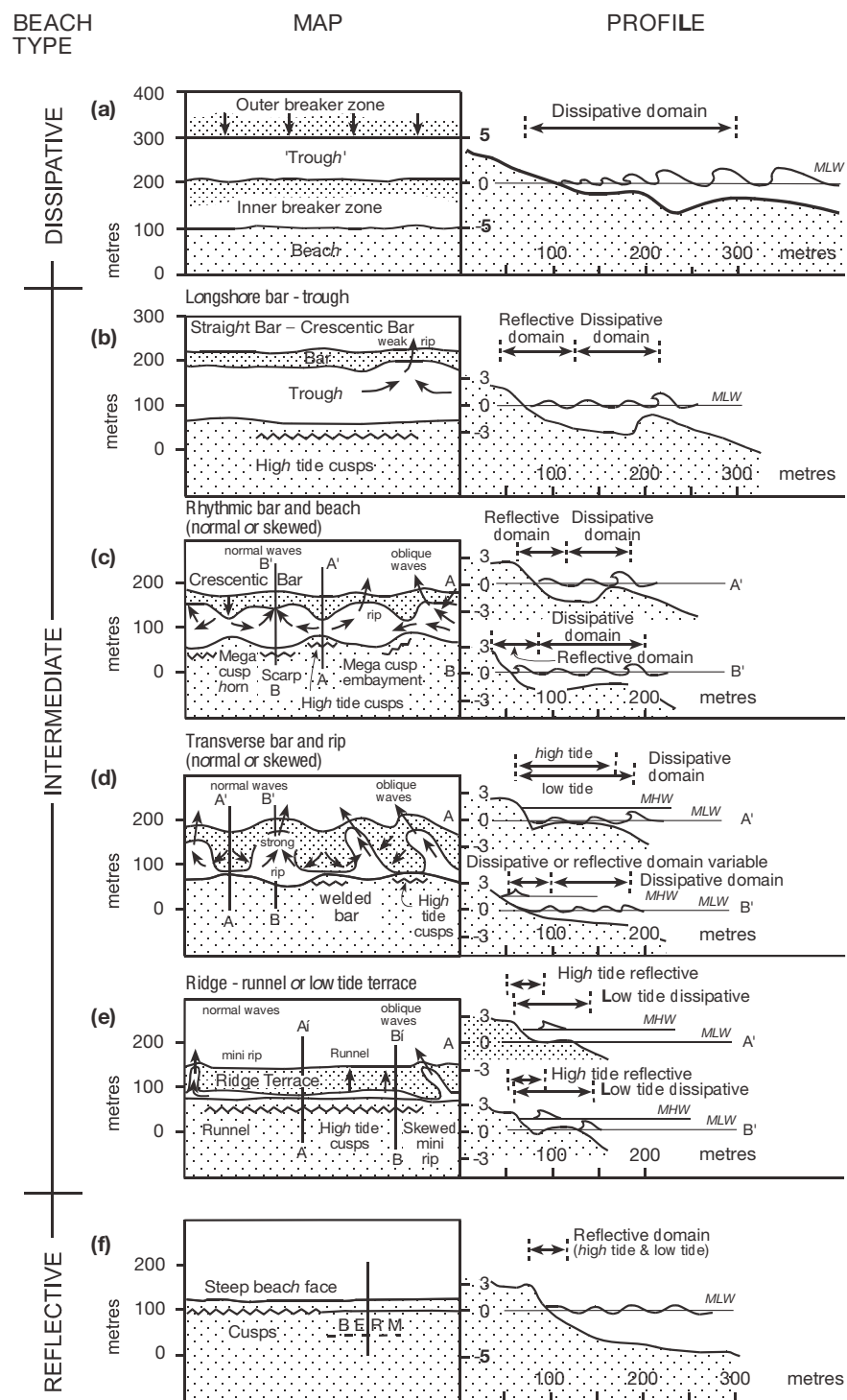


It is clear that there have been recent complications to this pattern. Pollution of the Gulf has led to seagrass loss off Adelaide (450 ha since 1970); the landward edge of the sea-grass beds has retreated up to $1 \mathrm{~km}$. Surveys show that where the seagrass has been lost the sandy substrate has been eroded to a depth of $30-50 \mathrm{~cm}$. Over such a large area this is an enormous volume of sand - a million cubic metres or more. Beach and nearshore monitoring at Adelaide suggests that this has moved onshore and is accumulating at the northern end of the system.

\section{Case study: Cable Beach, Western Australia}

\section{Location}

Cable Beach at Broome is a wide, 16-kilometre long beach, nearly flat, steepening, and concave on the landward (high tide) end. At low tide the wide, exposed, intertidal beach is marked by changing patterns of low ridges or bars, separated by slight troughs or runnels.

\section{Wave, wind, and tide}

Wave energy is low to medium, with wave heights generally less than a metre. However, a great deal of tidal energy affects this beach: the 9.5-metre spring tides (macrotidal) produce an intertidal zone of several hundred metres and generate longshore tidal currents strong enough to entrain sand.

\section{Beach and dune materials}

The beach sands are composed of both organic and mineral materials, consisting of about $70 \%$ calcareous and $30 \%$ quartz. The sands are fine, which is commonly associated with low-angle beach profiles.

\section{Nearshore dynamics}

Wright et al. (1982) provided a detailed description and analysis of the morphodynamics at Cable Beach. Surf processes were dominant only in the top of the profile, where low energy reflective conditions prevailed. These conditions occurred at high tide, where very low wave energy, following shoaling, led to a relatively steep, short profile. The constant variation of water level through the large tidal range suppressed the development of resonant surf phenomena and did not lead to nearshore currents, rips or waves moving along the shore through the surf zone. Rhythmic topography, with regular variation from storm to fine weather profiles and a series of intermediate states, did not occur. However, erosion occurred at the back of the beach during the surge conditions of 
very large storms. The mid to low intertidal part of the profile was characterised by shoaling waves, becoming rapidly attenuated across the wide shallow water with many low bars. It was in this section of the beach that tidal longshore currents transported sand, although with a low annual flux.

Wright et al. noted that the change, which occurred with variation of energy showed very little depth of scour. It seems likely that this beach profile is in equilibrium with normal tidal change and wave energy.

\section{Sand budget}

Gains and losses at Cable Beach do not show a clear trend. Tidal currents parallel to the shore combined with the turbulence of shoaling waves to entrain some sands, but the beach appeared stable.

\section{Conclusion}

These three case studies illustrate that beach behaviour and form varies with wave energy and direction, tidal range, and sediment characteristics. Thus, all three are dynamic, changing over weeks and months, with Cable Beach being the least so. All three studies show exchange of sediments between the nearshore zone, beach and dune, through both wind and wave transport.

All beaches and their associated dune areas fluctuate in form between storms and fine weather, this change is most marked at the high energy mesotidal to microtidal range. At some beaches, storm frequency dictates a regular seasonal pattern of change. In addition there may be interannual variability due to slight variations in sea level or in the pattern of wind and wave direction. Many beaches show a trend of change - gain or loss - and a global survey in the 1980s suggested that about $70 \%$ of beaches are eroding (Bird 1985). However, because of natural variability, it may often be hard to detect a clear trend over less than 10 years of observations. Few beaches have reliable monitoring of shoreline change over such time periods, yet management decisions often require such information. This is especially true of those beaches that show marked erosion near the development of infrastructure.

In the absence of monitoring of form, or adequate information to calculate sand budgets, managers frequently rely on historical aerial photographs or old maps to provide a guide to local trends of change. There are a number of technical problems with such data on shoreline change, which justifies a cautious approach (for a review of these, see Baily and Nowell 1996), although they might be all that is available. The natural fluctuation of beaches, described above, also underlines the need for a cautious approach to maps or photographs that record one point in time within a constantly changing situation. 


\section{Coastal dunes}

A coastal dune is an accumulation of windblown sand immediately landward of the beach that acts as an important store of sand in the coastal sediment budget. During periods of shoreline erosion the sediment stored within the coastal dunes helps to mitigate the effects of shoreline change: dunes act as a protection against storm erosion and flooding during short-term seasonal change, and as a buffer or sand store to counteract a long-term erosive trend.

Just over half of the Australian coastline is sandy, and about half of this again is backed by sand dunes. South Australia has a higher proportion of dune coast than other states (53\%), Western Australia has 30\%, while the Northern Territory has the smallest proportion (6\%). Dune fields along the eastern coast of the continent are almost entirely composed of quartz sands. The southern and western coast dunes are of quartz and carbonate sands in varied proportions, while the northern coasts are characterised by a lack of dune-building sand sediments. The European impact on Australia's coastal sand dune areas has been massive, due mainly to building, mining, and grazing. While the extent of clearance has not been documented, it can be said that there are few coastal areas that remain in a pristine state, little affected by burning or introduced plants or animals. Managing these unstable landforms has proved a challenge to land managers all round Australia.

Coastal dunes may extend inland from the highest tide mark for only a few metres or for several kilometres inland; they may be great sand masses more than 200 metres high or a series of low dune ridges on a flat coastal plain. The immediate source of sediment for the formation of coastal dunes is from the dry beach, and the development of coastal dunes is primarily due to the transport of sand by wind. Coastal vegetation, which operates to stabilise the wind-blown sand, is a vital element in the formation and maintenance of many dunes. Thus, coastal dunes are best developed in areas with strong onshore winds and an abundant sand supply, and where there is sufficient rain for vigorous vegetation growth.

\section{Coastal dune types}

Incipient dunes are formed at the back of the beach when sand is blown across the beach and deposited in the lee of minor obstructions such as wrack. Once formed, the incipient dune acts to slow down winds and encourage sediment deposition. A low, undulating ridge vegetated by small shrubs, grasses and herbs may form parallel to the shoreline landward of the incipient dunes, termed a foredune. A series of low foredunes may develop at the coast; these 
have been termed relic foredune plains (Hesp 1984). On an accreting shore these ridges represent the depositional history of the coast, in the same fashion that tree rings represent the growth history of a tree.

The loss of vegetation exposes the dune surface to wind action. Funnelling of the winds into these low dune areas can result in the rapid removal of sands and the development of an exposed section of dune, termed a blow-out. In time, as the blow-out grows, it may form into a horseshoe-shaped parabolic dune in which the horns of the dune are 'anchored' by vegetation and face into the wind, and the centre of the dune is blown downwind. The low-lying areas between coastal dunes have been termed swales or dune slacks. These areas are generally at or near the level of the watertable. As a result, a swale may be characterised by swamp vegetation, and the damp sands of swales inhibit sediment transport by wind.

Large mobile dunes with little or no vegetation are termed transgressive dune sheets. These dune forms are commonly found inland from beaches where the sand supply is great. The sand is free to move with the wind and often forms long straight or sinuous crests perpendicular to the wind. On the leeward side of this crest a precipitation ridge may form, which is a slip face whereby the dune sheet moves forward over established vegetation or other objects. Peaked dunes may also occur on these transgressive dune sheets. The precipitation ridge is so named

Figure 2.29 Some dune types commonly seen along the coast of south-eastern Australia. The occurrence of different dune types is associated with variations in mean breaker height and sand supply

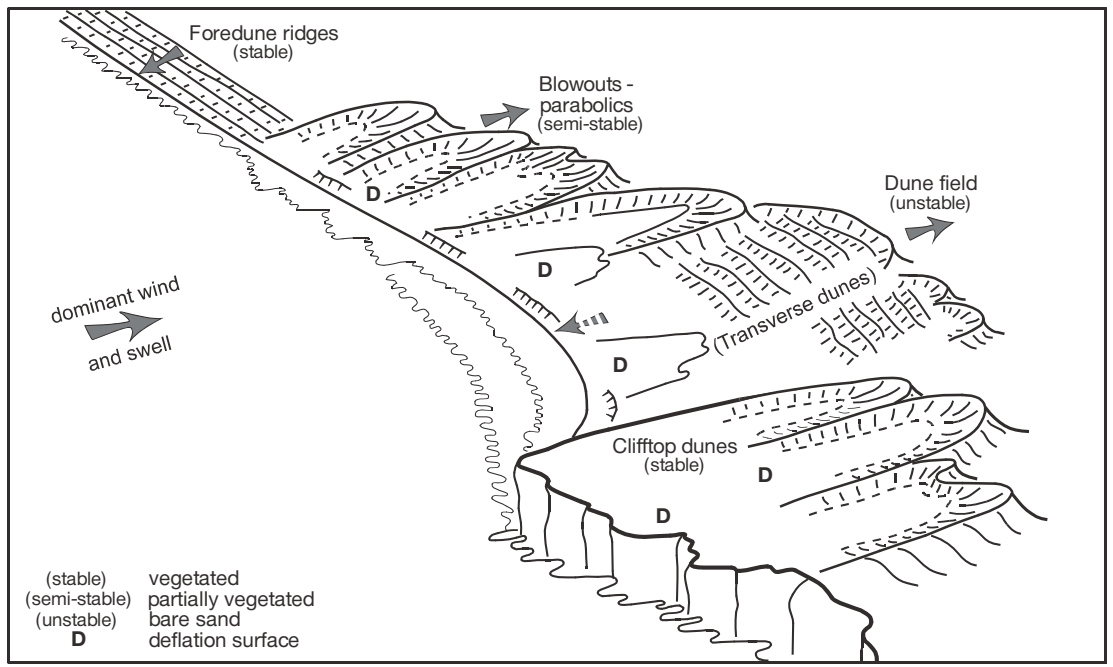


because sand 'precipitates' down onto the lee slope. The movement of these transgressive dune sheets may not be rapid, usually less than $10 \mathrm{~m}$ per year, but where large sand masses are involved it may be hard to stop. Near Beachport in South Australia the Ten Mile Drift was mobilised by grazing from 1860 onwards. By 1890 the Beachport to Robe coach road was blocked by the advancing sand, and today the Drift spills into Lake George down a steep 30-metre-high lee slope.

The coastal sand dunes of Queensland and New South Wales vary in form, from low ridged bay barriers to giant sand masses with parabolic dune forms up to $8 \mathrm{~km}$ long and $300 \mathrm{~m}$ high. Massive parabolic dune forms are found in southern Queensland at North Stradbroke, Moreton and Fraser Islands and the Cooloola sand mass. Large parabolic dune fields are also found in the far north, on the eastern coast of the Cape York Peninsula. These dunes are well vegetated and stable, attaining a climax of rainforest in some locations; however, at Cape Flattery in the far north, some active parabolic dunes are found.

Figure 2.30 The movement of the Ten Mile Drift near Beachport, South Australia

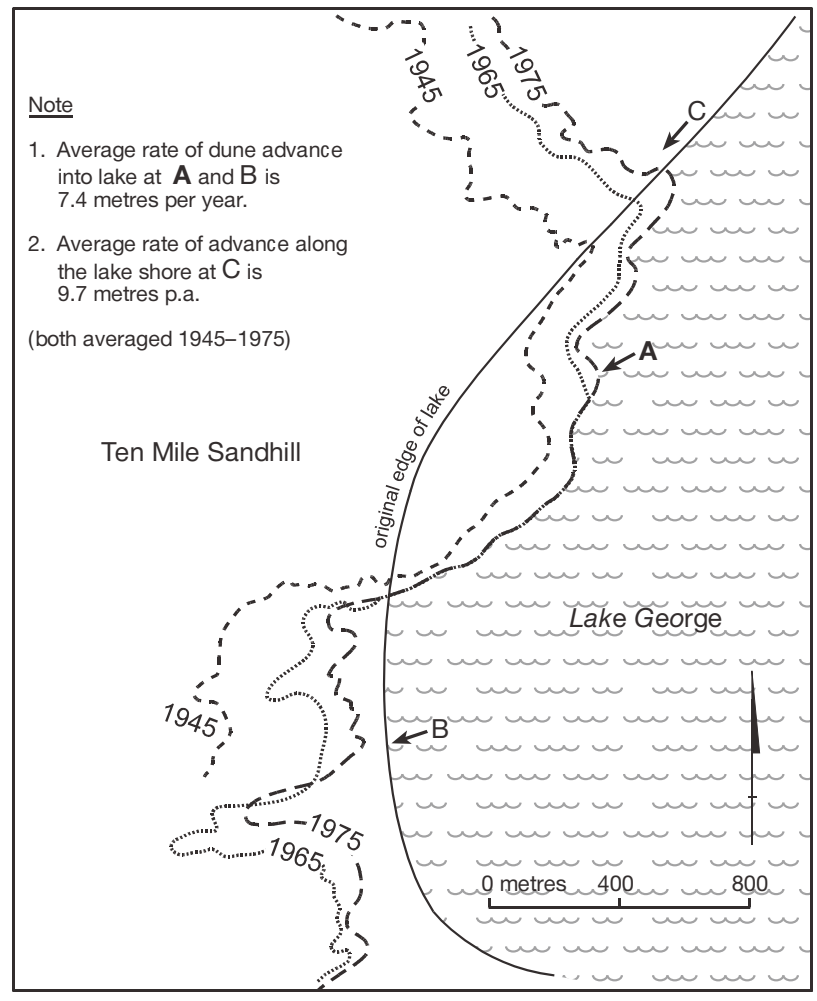

Source: based on data in Armstrong 1977 
In New South Wales, low-lying embayments of Quaternary barriers and swamps are more characteristic. The most notable dune forms are two sets of foredune ridges, parallel with the present shore: an inner barrier (c. 125000 BP) of low ridges, widely spaced and set back in the embayments, separated from a younger outer barrier (c. 7000-3000 BP) by low ground and swamps. The ridges of the outer barrier are higher, more tightly spaced, and fresher in form than the older foredune ridges; they usually back the modern foredune and have frequently been eroded by modern beach recession.

Bird (1978) noted that sediment supply from the inner continental shelf to the beach and dune is, along the southern and western margins of the continent, dominantly carbonate, with local mineral additions near those outcrops from which sand-sized regolith has been weathered. He pointed out the association of hinterland aridity (and hence reduced fluvial delivery of terrestrial sediments), biogenic dominance of shelf sediments, and carbonate sands in coastal deposits of the south and west. Conversely, near the mouth of the one large river to flow to the southern coast, the River Murray, there is an increase in the proportion of mineral sands. On southern and western coasts large carbonate dune accumulations are found at the more exposed, high-energy shores, where large swells have been able to transport the carbonate detritus to the beach.

The large carbonate-rich dunes have accumulated during the sea level oscillations of the Quaternary, and these have, over time, become lithified to calcarenite (dunerock or aeolianite; see figure 2.44) through groundwater movement, solution and redeposition, and calcrete formation. Through these processes of many cycles of dune formation and movement followed by induration, the resulting dunerock may exhibit dune bedding, buried soils, root casts and multiple calcrete layers.

\section{Soil and vegetation development of coastal dunes}

Where coastal dunes receive sufficient rainfall to support vegetation and are free draining, they commonly exhibit the soil and vegetation features linked to environmental gradients from foredune to hind dune. The incipient foredune supports low grasses, herbs and succulents, and some low shrubs are added to this assemblage on the foredune. Larger shrubs are able to flourish in the swale, protected by the foredune, although they may be replaced by grasses and dwarf shrub forms on the next seaward facing slope. Further landward across the dunes, plant forms usually become larger and more densely spaced: thus grasses with occasional shrubs on the foredune are replaced by dense low shrubland, then tall shrubland and finally dense, low, eucalypt woodland on some hinddunes. This landward change of structure may also be accompanied 
by increasing species diversity. For example, at Waitpinga Dunes south of Adelaide, the simplicity of half a dozen or so species in one kind of niche on the foredune contrasts with the complexity of more than 50 species within a variety of niches a hundred metres landward.

The most precarious environment in the dunes is at the incipient foredune. Here plants must survive burial and blasting by blown sand, high salt levels from blown spray, periodic high surface sand temperatures, periods of drought, and low to zero nitrogen and humus levels. Sometimes the drift or strand line of seaweed or seagrass may provide shelter, a source of nutrients and promote water retention in the underlying sand, giving pioneer plants a vital toehold. Plants such as Sea Rocket (Cakile maritima), Spinifex (Spinifex hirsutus) and Pigface (Carpobrotus glaucescens) have the capacity to rapidly establish themselves on the backshore: in the struggle to stabilise the wind-blown sand these plants are the front-line troops, the specialists. They cope with the harsh location through a variety of adaptations: high seed production (Sea Rocket), the development of an extensive and dense root network to overcome the water and nutrient deficiency (Spinifex), succulence (Pigface), and leaf-curling to overcome high evaporation rates. All these plants are salt tolerant, although not halophytic.

Behind the foredune the environmental stresses are reduced. There is some protection against wind blasting for low shrubs such as the Coast Daisy-bush (Olearia axillaris), and a variety of other plants obtain a footing on the partially stabilised sand, such as the Knobby Club Rush (Isolepis nodosa), and in damper hollows rushes and sedges (e.g. Lepidosperma gladiatum) may be found. Only slightly less salt tolerant than the Coast Daisy-bush is the Coast Wattle (Acacia longifolia var. sophorae) and the Native Currant-bush or Coast Beard-heath (Leucopogon parviflorus).

Further landward, the environmental gradients continue to change, and biodiversity increases as the environmental stress reduces. Biomass increases and more humus is found in the soil, wind speeds and salt levels decline, and nitrogen-fixing bacteria enrich the soil. Where these older dunes are quartzose and free-draining, podsol development is advanced, often with a marked pan or humate layer.

\section{Case study: The Cooloola Sand Mass}

The Cooloola Sand Mass in south-eastern Queensland has been the subject of a series of investigations by the CSIRO (see Thompson \& Moore 1984). The investigations have shown a remarkable interplay of vegetation, soil development on dunes, and time in developing a complex sand landscape. The studies illustrate the fragility of coastal dune areas. 
Cooloola is located immediately north of the Sunshine Coast in southern Queensland. The sand mass is made up of fine to medium quartzose sands in a series of eight overlapping systems of complex dunes, each representing a dunebuilding period. The two oldest of these are buried by overlap. The land surfaces of the four youngest dunes (series one to four) are extensive sands with transgressive parabolic forms up to $200 \mathrm{~m}$ in height. Series one to six (figure 2.31) represent a time series in which depth of weathering and soil development increase with age at the exposed surfaces. Soil depth is up to $1 \mathrm{~m}$ on the youngest dunes, increasing to $20 \mathrm{~m}$ on parts of series six, although this occurs on high and gently sloping parts of the sand mass where deep watertables have allowed giant podsol development. Preliminary thermoluminescence dating suggests that dune series five and six are indeed very ancient, representing deposition during the last interglacial (125000 years BP) and that series 4 was 40000 years old. Pedological and morphological similarities with dated dunes on Fraser and Moreton Islands place series 1and 2 in the Holocene.

The dunes are almost entirely forested, though past logging has thinned the woodland in places and left tracks. From time to time, fire and storm damage

Figure 2.31 The Cooloola Sand Mass
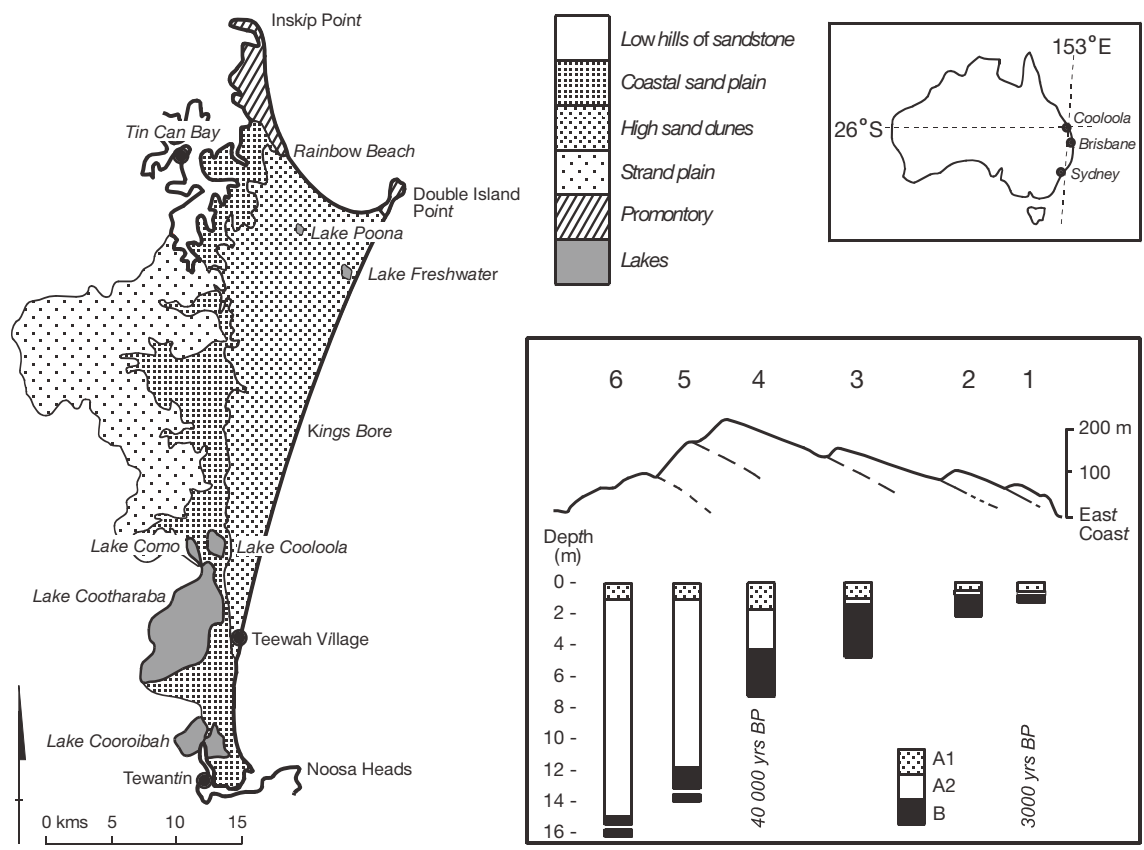

Source: modified from Thompson \& Moore 1984 (part a) and Thompson 1981 (part b) 
at the coast lead to small local unvegetated surfaces. These are vigorously invaded by ground-covering pioneer plants, thus maintaining a sand mass almost unaffected at present by aeolian action. On these dunes many of the plant root systems are assisted in their role of gathering nutrients and binding the soil by dense networks of mycorrhizal fungi. The fungi, which live in association with the plant roots, send long hair-like hyphae through the sand, vastly extending the root network. The fungi are able to make available nutrients within the soil that the plants could not easily access, particularly phosphorus.

Dense shrubby banksia woodlands characterise the youngest dunes, grading through eucalypt woodland on series two and three to rainforest in favourable parts of series three and four. The eucalypt and banksia species (notably Eucalyptus pilularis and Banksia serrata) on the younger series are also found on series five and six, but here they take on stunted and mallee forms. The rainforest of series four collapses to a heathy shrubland on the two oldest dune series, five and six, because long-term leaching has extended podsol depths to more than 20 metres, leaving the plant roots in a heavily leached, nutrient-deficient soil.

Thus, on the extensive, deep, well-watered, sands of Cooloola, there is a vegetation succession over time. Plant assemblages have accumulated organic and inorganic nutrients in a developing soil structure over 40000 years. With further development over longer time periods, soil profile deepening allows the leaching of essential minerals at depths lower than the root zone. As the minerals are reduced in availability, the climax plant community collapses from a closed wet sclerophyll forest to an open shrubland.

Australia has many thousands of kilometres of coastal dunes, yet throughout every state these fragile landforms are under pressure.

Because of the problems associated with residential development on sand dunes, some coastal management authorities have advised that a prohibition should be placed on further building (e.g. the South Australian Coast Protection Board's policy on new development, 1991). In view of the high real estate values generated by coastal views, it is clearly difficult to maintain such a policy. However, such policies are necessary because of continuing pressure, as many coast dunes have become heavily degraded. For some less degraded areas there is a pressing need for regional strategies to conserve remaining undeveloped dune areas as a matter of high priority.

Often dunes are threatened by piecemeal planning decisions, made on individual parcels of land, without regard to the more strategic considerations. Nowhere has the 'tyranny of small decisions' been better illustrated than in the dunes. 


\section{Estuaries and wetlands}

\section{Estuaries}

Estuaries are inlets or bays that have both saltwater and freshwater inflow (and may include river mouths and barrier lagoons), and thus through tide and river mixing show a variety of hydrodynamic conditions. This variation may be extreme - from turbulent freshwater floods to the raised salinity of droughtand so the species that live there must be able to withstand or avoid these extremes.

A national survey (Bucher \& Saenger 1989) identified 783 Australian estuaries, nearly half of them in the wet tropics of the northern coast of Western Australia, the Northern Territory, and north-eastern Queensland (table 2.5).

Estuaries are a valuable coastal resource: they provide sheltered environments, well supplied with nutrients and rich in habitat niches. Estuaries are biologically productive areas, particularly their mangroves and seagrass beds, and provide spawning, nursery, and feeding grounds for many species of fish and bird. They are important points of human settlement as harbours for ocean and river shipping, and frequently their hinterland is suitable for crops and grazing. Estuaries are important fishing grounds, especially for recreational fishing, as well as for a range of other recreation including boating and diving. Unfortunately, estuaries and the rivers flowing into them have also been seen as useful for the disposal of wastes - industrial, treated sewage, and urban and farm run-off — but because of their restricted flushing, estuaries frequently trap

Table 2.5 Distribution and areas (square $\mathrm{km}$ ) of estuarine habitat types

\begin{tabular}{lllllll}
\hline State or territory & $\begin{array}{l}\text { Open } \\
\text { water* }\end{array}$ & $\begin{array}{l}\text { Intertidal } \\
\text { flats }^{\dagger}\end{array}$ & Mangroves & Seagrass & Saltmarsh & Total \\
\hline New South Wales & 1323 & na & 107 & 153 & 57 & 1487 \\
Victoria & 2682 & 444 & 41 & 364 & 125 & 3292 \\
Queensland & 4093 & 1574 & 3424 & 68 & 5322 & 14413 \\
Western Australia & 17825 & 2891 & 1561 & 11 & 2965 & 25241 \\
South Australia & 760 & 219 & 111 & na & 84 & 1173 \\
Tasmania & 1825 & 274 & 0 & na & 37 & 2136 \\
Northern Territory & 5187 & 821 & 2952 & 23 & 5005 & 61707 \\
\hline
\end{tabular}

* includes subtidal seagrass beds

$\dagger$ includes intertidal seagrass beds 
Figure 2.32 Two estuarine types from New South Wales

A. BARRIER ESTUARY
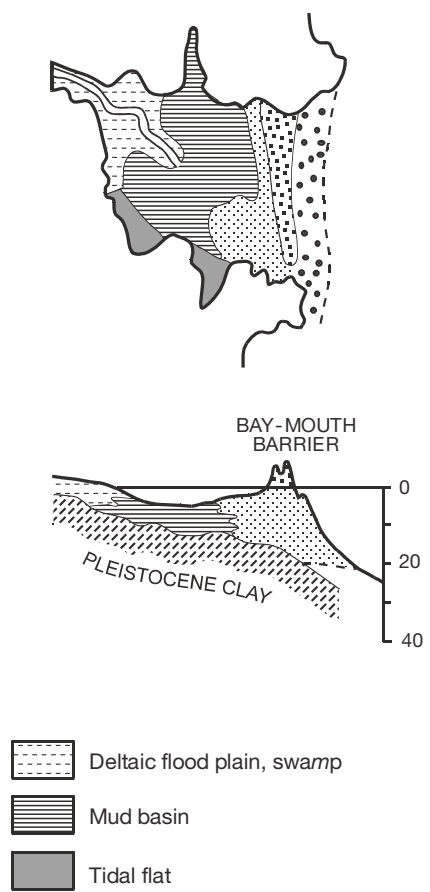

B. DROWNED RIVER VALLEY
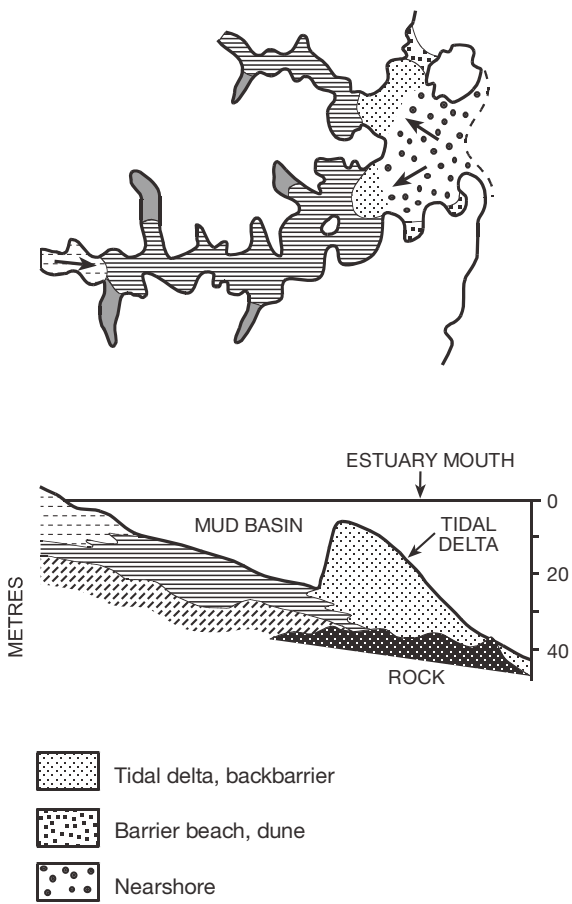

Source: modified from Chapman et al. 1982

and accumulate pollutants. The accumulated industrial pollution of the Derwent estuary, for instance, was of great concern to the citizens of Hobart in the 1970s. In New South Wales the Healthy Rivers Commission $(2000,2001)$ has recently classified 'coastal lakes' (a designation overlapping in part with estuaries), noting that, for those lakes it classifies as highly modified, the opportunity for restoration has passed, although improvement can be achieved.

\section{Geomorphology of estuaries}

Estuaries are low-lying areas of non-marine origin that have been invaded by the sea. Australia is a flat, dry continent with mainly small coastal catchments, and it has few of the large drowned river valleys (and no drowned glacial valleys) that dominate the coastal landscapes of, for example, north-western North 
America. Only the Hawkesbury, Georges Rivers, Port Hacking, and Port Jackson (in New South Wales) and the Derwent River (in Tasmania) represent this scale of drowned river valley topography. The postglacial marine transgression (about 20000 to 6000-7000 BP) affected the whole coastline, drowning low embayments, large gulfs, coastal floodplains, and numerous small river valleys. During the sea level oscillations of the Pleistocene, drowning of valleys and coastal lowlands occurred repeatedly, together with a variety of erosive and sedimentary processes. Infilling of these drowned features has varied greatly around the continent, because of differing river and tidal flow, sediment supply from the land and the continental shelf, and pre-existing topography. Figure 2.32, adapted from Chapman et al. (1982), gives two idealised examples from New South Wales.

Table 2.6 Distribution of estuary types in Australia

\begin{tabular}{|c|c|c|c|c|c|}
\hline Region & $\begin{array}{l}\text { Annual } \\
\text { rainfall }(\mathrm{mm})\end{array}$ & $\begin{array}{l}\text { Total } \\
\text { runoff } \\
\left(10^{10} \mathrm{~m}^{3}\right)\end{array}$ & $\begin{array}{l}\text { Tidal range } \\
\text { variation }(m)\end{array}$ & $\begin{array}{l}\text { Dominant } \\
\text { morph. } \\
\text { estuary type }\end{array}$ & $\begin{array}{l}\text { Seasonal } \\
\text { mixing regime }\end{array}$ \\
\hline Timor Sea & $600-1200$ & 0.138 & $2.0-10.5$ & $\begin{array}{l}\text { Macrotidal } \\
\text { drowned river } \\
\text { valleys. Mature. }\end{array}$ & $\begin{array}{l}\text { Dry: inverse estuary } \\
\text { Wet: short lived } \\
\text { freshwater flushes }\end{array}$ \\
\hline $\begin{array}{l}\text { Gulf of } \\
\text { Carpentaria }\end{array}$ & $\begin{array}{l}600-1600 \\
\text { summer max. }\end{array}$ & 0.099 & $2.2-7.7$ & $\begin{array}{l}\text { Macrotidal } \\
\text { drowned river } \\
\text { valleys. Mature. }\end{array}$ & $\begin{array}{l}\text { Dry: inverse estuary } \\
\text { Wet: short lived } \\
\text { freshwater flush } \\
\text { may occur }\end{array}$ \\
\hline $\begin{array}{l}\text { North-east } \\
\text { coast }\end{array}$ & $800-4000$ & 0.183 & $1.6-6.3$ & $\begin{array}{l}\text { Barrier drowned } \\
\text { river }\end{array}$ & $\begin{array}{l}\text { Dry: well mixed. } \\
\text { Wet: highly stratified } \\
\text { in high flows }\end{array}$ \\
\hline $\begin{array}{l}\text { South-east } \\
\text { coast }\end{array}$ & $600-1600$ & 0.136 & $1.1-1.8$ & $\begin{array}{l}\text { Barrier drowned } \\
\text { river }\end{array}$ & $\begin{array}{l}\text { Well mixed; short } \\
\text { period of } \\
\text { stratification } \\
\text { after flood }\end{array}$ \\
\hline Tasmania & $600-3200$ & 0.690 & $0.9-2.5$ & Drowned river & Salt wedge \\
\hline $\begin{array}{l}\text { Sth Australian } \\
\text { Gulfs }\end{array}$ & $\begin{array}{l}300-800 \\
\text { winter max. }\end{array}$ & 0.007 & $0.5-2.0$ & Barrier & No data \\
\hline $\begin{array}{l}\text { South-west } \\
\text { coast }\end{array}$ & $\begin{array}{l}400-120 \\
\text { winter max. }\end{array}$ & 0.052 & 0.4 & Barrier & $\begin{array}{l}\text { Dry: highly stratified. } \\
\text { Wet: freshwater flush }\end{array}$ \\
\hline Indian Ocean & $200-400$ & 0.012 & $0.5-5.8$ & Drowned river & $\begin{array}{l}\text { Permanent inverse } \\
\text { circulation }\end{array}$ \\
\hline
\end{tabular}




\section{River flow, tides and mixing}

Fluvial discharges to Australian estuaries are low and highly variable (see table 2.6). For example, the Burdekin River in Queensland is one of the largest and most reliable rivers in the Australian context, but in world terms it is not a major river. There is regular seasonal variation across the continent-summer flows in the north, winter flows in the south - but interannual change associated with El Niño cycles adds great variability.

Variation of conditions depends on estuary form, and on variations in both tidal and river flow. Where there is a strong river flow and a low tidal range, 'salt wedge' estuaries may form, with the lighter fresh water flowing out over the denser salt water into the open ocean. 'Partly mixed' and 'fully mixed' types also occur, depending on the relative power of river and tide. Thus, many New South Wales estuaries vary according to tidal flows, since river flows have little seasonal change, whereas estuaries in south-west Western Australia vary greatly following large seasonal variation in rainfall and river discharge. Some estuaries with minimal river input may become more saline at the landward end due to poor circulation and high evaporation; the 'reversed estuary' of Gulf St Vincent in South Australia is one such case.

\section{Case studies}

\section{Shoalhaven River estuary}

The Shoalhaven River, in New South Wales, is tidal throughout its coastal floodplain section to the sea. The river and associated creeks, drainage channels, wetlands, floodplain and coastal sand barrier occupy an extensive coastal lowland.

In the past the river eroded a wide valley, which was flooded by the postglacial marine transgression to form a broad embayment by $6000 \mathrm{BP}$. This embayment has been infilled subsequently by fluvial sediments and barrier sands.

Dating of the barrier sand shows that it began accumulating at the beginning of the present stillstand when shelf sands were moved on onshore to accrete as beach ridges. This continued until 3000 BP. As the sand barrier built up, the relatively high sediment discharge filled the embayment behind the barrier. Today floods continue to transport silts sand and gravel to the coastal floodplain and the river mouth. Sedimentary analysis shows that river sands are found in the beach ridge nearest the shore: it has been suggested that this supply locally offsets potential erosion of the beach ridge system.

Under normal conditions the estuarine section of the river is well mixed, although after flood flows stratification (fresh over salt) becomes briefly established. Although flow in the river is well maintained throughout the year, 
Figure 2.33 The Shoalhaven River estuary: post-glacial sea level rise flooded the embayment, which has subsequently been infilled by barrier sands and fluvial mud $\&$ sands

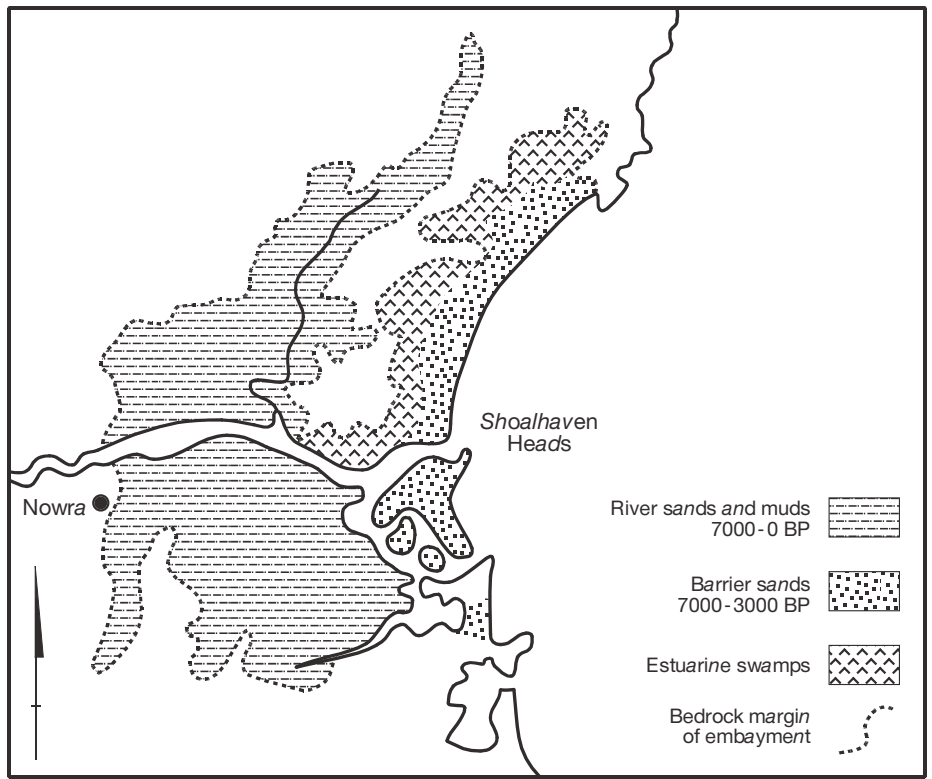

Source: modified from Chapman et al. 1982

considerable variation of flow is usual. The daily discharge total in a flood can exceed the mean by more than 150 times; total flow in a wet year may be more than 50 times the flow of a dry year. The humid climate of the South Coast ensures that even a dry year applies minimal stress to the estuary. There are seven major diversions on the Shoalhaven, including storage and interconnection to the Sydney water supply, and numerous minor diversions. However, the survey (quoted in Healthy Rivers Commission 1999) suggests that biologic stress was low in the river at times of drought.

The Healthy Rivers Commission Final Report on the Shoalhaven records a number of issues in the estuary section of the catchment which are frequently found at eastern coast estuaries:

1 Inappropriate land management practices and rapid population influx is leading to cumulative impacts on water quality. This includes cattle access to creeks, weed invasion, creek bank erosion and erosion due to track and culvert construction. The flow of septic tank wastes and secondary treated effluent to the river was also identified. In a situation where ratepayers carry infrastructure costs of development, few rural councils can avoid difficulties in dealing sustainably with wastewater disposal. At Nowra the cost 
of two schemes have been borne by the Commonwealth Coasts and Clean Seas program.

2 In the estuary, particular stress was associated with development, deep drainage and recreational activities on the river. Floodgates have blocked fish passage into small creeks. On the main channel, bank erosion is common from a variety of causes, and is severe near popular water skiing areas. The most serious problems are found on the estuarine floodplain:

'Drains have lowered the water table, destroying several wetlands, drying potential acid sulfate soils and releasing acid waters to creeks with impact on fish populations' (Healthy Rivers Commission 1999, p. 196).

Acid sulfate soils, containing iron sulfides, have formed in the last 8000 years, near the end of the last sea level rise. When the land was inundated, sulfate in sea water mixed with iron oxides and organic matter in the soil. The reaction produced large quantities of iron sulfides in the waterlogged sediments. This process is occurring today in some mangrove and saltmarsh areas. When undisturbed and waterlogged these soils are not harmful, but when drained they react with oxygen in the air to produce sulfuric acid. The sulfuric acid may be mobilised by run-off or groundwater and can cause fish kills in creeks and estuaries, as well as damage to oyster farms. Sandy soils may release acid quickly; clays soils may continue to release acid over decades.

Drainage works that lead to this problem are commonly carried out as part of farm improvement, or as part of residential building development.

Estuaries along the eastern coast of Australia commonly contain potential acid sulfate soils, and the soils have been found in all coastal lowlands, except the south-west. There are an estimated $40000 \mathrm{~km}^{2}$ of coastal acid sulfate soils.

\section{The South Alligator River}

The South Alligator River flows from the Arnhem Land Plateau through a broad coastal plain to Van Diemen Gulf. Much of its catchment is within the Kakadu National Park and World Heritage Area. The coast and the tidal part of the river are fringed with mangroves; along the shore of the Gulf the mangroves are limited on the landward side by chenier ridges parallel to the shore. (These are low narrow ridges of sand and shell grit laid down by a storm surge flood.) Inland from the chenier are saline flats with samphire, before grasses and sedges appear. The river floodplain shows a range of classic landforms, including levees, cutoffs, backswamps, and lagoons; the floodplains are mainly in grasses and sedges (in a process of adaptation to an annual burning regime). At the mouth of the river, sediment infill has constructed a deltaic plain rather than a barrier coast. The flat, low coastal plain ( $0-2 \mathrm{~m}$ above high tide) is extensively flooded in the 
Figure 2.34 The catchment of the South Alligator River

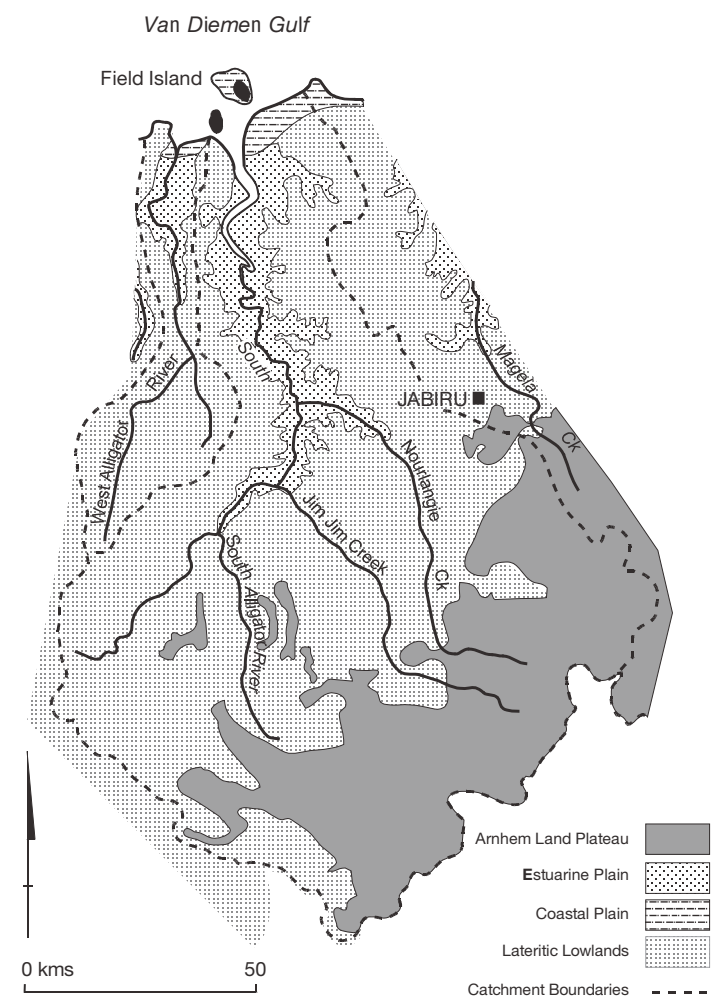

Source: modified from Woodroffe 1988

wet season. Water, nutrients, and heat foster abundant plant and animal life; this is a significant wetland for waterbird breeding.

Flow within the estuary changes with the seasons. At 4-7 m, the tidal range is large and affects the river up to $100 \mathrm{~km}$ from the sea. In the dry season sediment movement is into the estuary. However, during the floods of the wet season, flushing occurs throughout the lower course, and a large sediment plume shows the transport of sediment and nutrients offshore. Very dry years can show dry season salinities increasing inland towards the edge of the Arnhem Land Plateau.

The evolution of the estuary and floodplain has been described by Woodroffe and others (e.g. Woodroffe 1993) as a four-phase development following the postglacial marine transgression:

1 A transgressive phase, 8000-6800 BP, at the closing stage of the postglacial marine transgression, of marine incursion into a large prior valley, creating an estuary. 
2 A 'big swamp' phase, 6800-5300 BP, as sea level stabilises there is widespread mangrove development, trapping fine sediments to infill the estuary and prograde the coastal plain.

3 A 'sinous' phase of floodplain development, 5300-2000 BP, during which the tidal river has meandered and re-worked earlier estuarine sediments.

4 'Cuspate River phase', 2000 BP to the present: frequent river cut-off development leads to a straighter and shallower stream in the upper estuary section. Delta sediment and chenier deposition occurs at the stabilising coast.

In the nearby Mary River, the coastal plain tidal creek network within infilled palaeochannels has grown rapidly in the last five decades (Knighton et al. 1992). A very slight local sea level rise may possibly be the cause. It is obvious that greenhouse-induced acceleration in sea level rise has the potential to radically alter these very extensive, low-lying flat wetlands of macrotidal northern Australia.

Bucher and Saenger's survey of estuaries in Australia concluded that 'they remain relatively undisturbed, especially in the northern half of the country'. Table 2.7 shows an overview of the state of Australian estuarine waters.

Figure 2.35 Phases in the development of the South Alligator River and Estuarine Plain

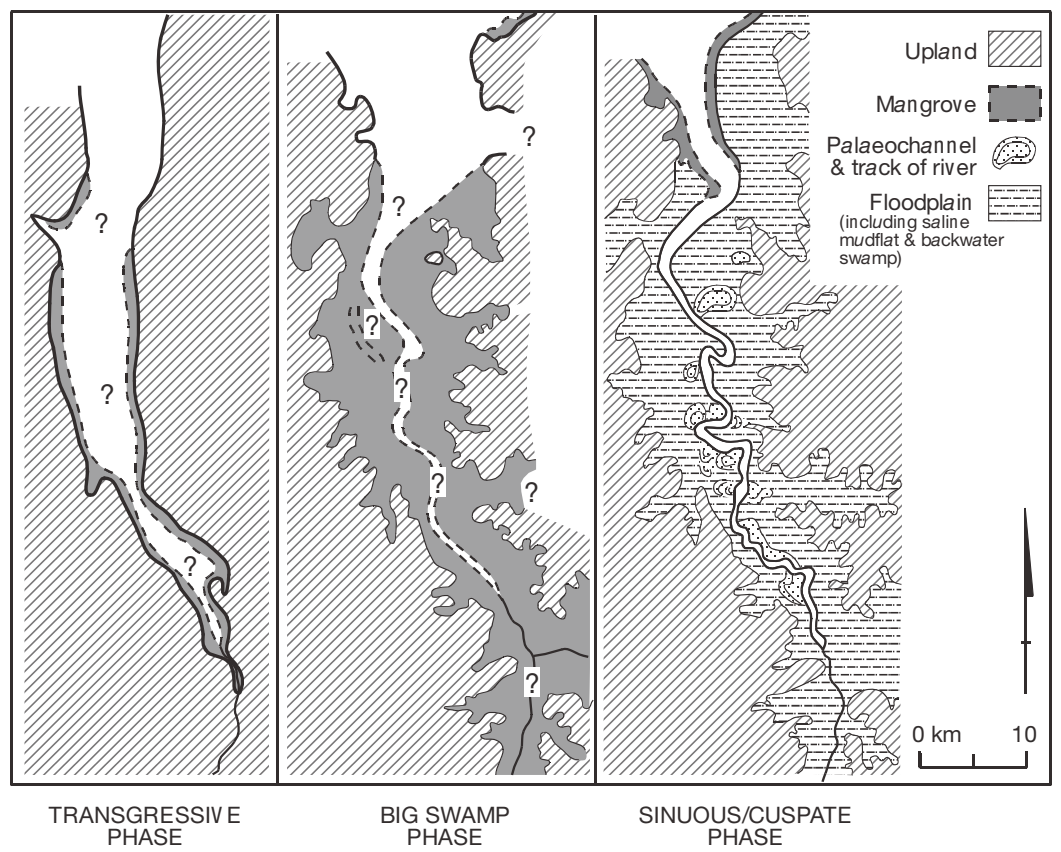

Source: Woodroffe et al. 1993 
Table 2.7 An overview of the condition of Australian estuaries (values are percentages)

\begin{tabular}{lllllll}
\hline State or territory & $\begin{array}{l}\text { Uncleared } \\
\text { catchments }\end{array}$ & $\begin{array}{l}\text { Excellent } \\
\text { water } \\
\text { quality }\end{array}$ & $\begin{array}{l}\text { High } \\
\text { fisheries } \\
\text { value }\end{array}$ & $\begin{array}{l}\text { High } \\
\text { conservation } \\
\text { value }\end{array}$ & $\begin{array}{l}\text { Threats to } \\
\text { conservation } \\
\text { value }\end{array}$ & $\begin{array}{l}\text { Adequate } \\
\text { state of } \\
\text { knowledge }\end{array}$ \\
\hline New South Wales & 24.7 & 0.0 & 24.7 & 16.0 & 21.0 & 100.0 \\
Victoria & 22.9 & 14.3 & 14.3 & 48.6 & 22.9 & 31.4 \\
Queensland & 55.4 & 48.5 & 18.9 & 21.8 & 2.3 & 11.1 \\
Western Australia & 86.2 & 83.4 & 7.6 & 7.6 & 2.8 & 7.6 \\
South Australia & 0.0 & 0.0 & 6.7 & 20.0 & 6.7 & 13.3 \\
Tasmania & 27.0 & 25.4 & 0.0 & 6.3 & 4.8 & 6.3 \\
Northern Territory & 99.3 & 97.1 & 17.5 & 22.6 & 0.7 & 5.1 \\
Total & 60.8 & 54.2 & 15.2 & 18.6 & 5.2 & 19.2 \\
\hline
\end{tabular}

The table and the conclusion inevitably draw the comment that a great deal of research is needed into the state of our estuaries, since there appears to be an adequate state of knowledge for only a fifth of them. In the Northern Territory and the north of Western Australia, catchments remain uncleared, industry and settlement is extremely sparse, and estuaries remain relatively pristine. In the south and east of the continent most catchments have been cleared and consequent soil erosion has led to increased estuarine sedimentation as well as raised nutrient and turbidity levels. Development, transport and recreation also add to the pressure on these south-eastern estuaries. The State of the Marine Environment Report (1995) identified a number of the estuaries in the south-east of the continent as having suffered severe impact. Two of the three most serious regional issues concerned estuaries: 'The widespread degradation of estuaries, coastal lakes and bays in NSW, Victoria, Tasmania, South Australia and south western Western Australia is a serious local and national problem. Major causes are elevated nutrients, sedimentation, pollution, coastal strip development, and overfishing.' Not surprisingly, most impact was seen as being where most people live: 'Estuaries and coastal waters near the State capitals are generally the most disturbed parts of the marine environment.'

Zann (1995) noted that more than $60 \%$ of estuaries in the south-east of the continent have suffered major modification. Estuary conservation is a major management need in Australia. A detailed investigation of the management of sixteen estuaries (Smith et al. 2001), chosen to represent the variety of biophysical conditions and the variety of management regimes around Australia, highlighted the following: 
- diversity of approach and inconsistent spatial scale of management

- limited interaction of science and management

- the community lacks power and is poorly informed

- lack of cooperation between management groups.

These concerns, which are not limited to estuaries, are discussed in chapter 4.

\section{Saltmarshes}

Saltmarshes are flat areas of soft sediments extending between high water neap and high water spring tide levels. Since they are unstable in the face of high wave energy, they are found only at low energy coasts, in estuaries, gulfs, or sites sheltered by islands, reefs, sand bars or spits. The surface of the saltmarsh is a complex web of tidal and run-off channels, pools, and salt flats, together with areas of grass, herbs and low heath. The muds, silts and shell grits of the saltmarshes are generally waterlogged. However, the salinity, while generally near to that of seawater, may vary considerably following run-off, leading to low salinities, or salinities as high as 10 times that of seawater in the evaporating pools left after the recession of a big tide.

Where mangroves are found in Australia, saltmarsh is often found immediately landward; the exception is Victoria, where cordgrass flats have developed seaward of some mangrove stands.

The flat coastline of parts of the Northern Territory, Western Australia, and South Australia have sizeable areas of saltmarsh. In contrast, the narrow strips of saltmarsh lining the estuaries and confined by the steep sides of the drowned valleys of New South Wales total only a tiny area.

Saltflats are inhabited by plants specially adapted to cope with the high salinities of the intertidal zone: the halophytes. Species diversity varies considerably, increasing from north to south. The broad saltflats of northern Australia may be inhabited by only one or two plant species, while the samphire flats bordering the South Australian Gulfs support up to 30 species, with a high degree of endemism. Grasses are the predominant plants in the saltmarshes of the humid northern and eastern coasts, while the semi-arid coasts of South Australia and Western Australia support mainly herbs and dwarf shrubs that are able to cope with the lower freshwater and sediment run-off, and the higher salinities.

Although there is not a high species diversity within the saltmarshes, both tide and run-off bring nutrients which are processed through the plants and the subsoil bacteria to achieve a high productivity. As a result, these areas support populations of crustaceans and molluscs, and transient populations of fish and birds. Seasonally large numbers of waders, ducks, and seabirds benefit from the 
Table 2.8 Distribution and area (square km) of saltmarsh in Australian bioregions, 1982

\begin{tabular}{llll}
\hline Bioregion & $\begin{array}{l}\text { Grasses, herbs, } \\
\text { and sedges }\end{array}$ & Shrublands & Total area \\
\hline North Coast & 4719 & 3954 & 8673 \\
North-West Coast & 1542 & 1653 & 3195 \\
West Coast & 585 & 939 & 1524 \\
South-West Coast & 21 & 12 & 33 \\
Great Australian Bight & 21 & - & 21 \\
South Gulfs Coast & 225 & 951 & 1176 \\
South Coast & 258 & 1317 & 1575 \\
Bass Strait & 615 & 45 & 660 \\
Tasmanian Coast & 498 & - & 498 \\
South-East Coast & 171 & - & 171 \\
East Coast & 183 & - & 183 \\
North-East Coast & 1644 & 105 & 1749 \\
Gulf of Carpentaria & 3399 & 465 & 3864 \\
Total Australia & 13881 & 9441 & 23322 \\
\hline
\end{tabular}

Source: SEAC 1996, p. 8-22

low human traffic through these productive coastal wetlands, making them of considerable conservation and potential ecotourism value.

Other than passive recreation and fishing, most human uses of the saltmarshes are sharply destructive. The construction of flood banks and subsequent drainage or filling to create farm or building land, excavation for ports or canal estates and marina development, rubbish dumping, and use by off-road vehicles all destroy rather than modify saltmarshes. For example, 21\% of the saltmarshes adjacent to Moreton Bay in Queensland have been lost to such uses, including the building of Brisbane Airport. In addition, pressure is created by cattle grazing as well as the accumulation of pollutants through catchment practices or adjacent uses. Marine pollution, notably oil spills, has been significant in some saltmarshes. The State of the Environment Advisory Council (1996) suggested that saltmarsh area is a key indicator that should be monitored through remote sensing every four to five years.

Saltmarshes have traditionally not had a charismatic image; they were thought of as 'dismal' swamps, useless for cultivation, the home of fever and drowning bogs. In modern perception this is reinforced by the lack of substantial woodland. This has made these areas unattractive for research and difficult to defend for conservation reasons. Although we know that about half of the 
saltmarsh of south-eastern Australia has been lost to a variety of uses, a great deal of basic research on Australian saltmarshes is, as yet, not done. In his review for the State of the Marine Environment Report, Adams (1995) suggests three priorities here:

1 the effects of insect control measures on saltmarsh ecology

2 the control of invasive weeds

3 the effects of pollutants.

It should be emphasised that for those many areas of saltmarsh, for which the conservation status cannot confidently be identified, it is not possible to make responsible planning and management decisions; yet development pressure constantly forces such decisions. This current situation is compounded by a forecast acceleration of the sea level rise, which critically affects these intertidal areas (see section 1.2); decisions regarding flood banks and planned retreat become survival matters, not adaptation questions, for the specialist habitats of the saltmarsh. The background documents to the 1996 national State of the Environment Report noted that there were no ongoing monitoring programs for saltmarsh species.

\section{Mangrove coasts}

'Mangroves are the rainforests by the sea' (Quarto 2000), and they are highly productive, dynamic and unique 'edge' ecosystems which link land and sea environments. The term 'mangrove' can refer to a particular species of mangrove (of which there are approximately 69 species worldwide), but can also refer to the overall habitat associated with this vegetation, including the estuarine region, the waterways, the forests, and the fauna within. Within Australia, mangroves cover an area of 11600 square kilometres, with an estimated 39 species present, most of which occupy the tropical areas of Australia (Kelleher et al. 2000). Although previously believed to be 'wastelands', their importance to maintaining healthy coastal ecosystems is now recognised, but nonetheless mangroves are 'one of the most threatened' habitats in the world (Quarto 2000).

Approximately $70 \%$ of mangroves in Australia are located within estuaries (Kelleher et al. 2000), but mangrove species composition and distribution vary because of several factors, including climate/rainfall, water temperature, estuary size, sediment availability, river run-off, tidal patterns, degree of shelter from wave energy, salinity, local sea levels, coastal geomorphology, and geology. Broad differences in distribution and species composition are pronounced in terms of location and climate/rainfall. The greatest species diversity occurs within tropical regions, and the least diversity is evident within temperate 
regions (e.g. see Ball 1998, Duke et al. 1998). The mangroves around Hinchinbrook Island, Queensland, provide an excellent example of the former, while the mangroves within the Port River Estuary in South Australia provide an excellent example of temperate mangroves within Australia.

\section{Hinchinbrook Island mangroves}

In Queensland there are approximately $4600 \mathrm{~km}^{2}$ of mangroves (Faulkner 1994). No matter where mangroves are located in the temperate or tropical zones, they tend to occupy sheltered intertidal zones that are characterised by low gradients, low wave energy, and usually muddy shorelines, although mangroves can also occupy sandy or rocky locations.

One of the world's highest zones of mangrove productivity and species diversity (with an estimated 27-30 species) is located around Hinchinbrook Island, Queensland ( see figure 2.36) (AIMS 1998, Bunt \& Bunt 1999). Within this area, mangroves cover an area of 120 square kilometres, and the mangroves are generally tall (up to 40 metres), with a closed canopy, although height tends to vary depending on proximity to the shoreline (Bunt 1982, Kelleher et al. 2000). On the seaward edge of the mangroves, communities are relatively simple, while greater diversity becomes evident in more sheltered zones and at the landward zone of the mangrove community (Environment Australia, n.d.).

The largest areas of mangroves are located along the Hinchinbrook Channel (a flooded valley between the island and a low coastal plain on the mainland with shifting sand dunes), and in Missionary Bay at the northern end of the island, which is located within a flooded valley sheltered by sand dunes (AIMS 1998, Bunt \& Bunt 1999, Environment Australia n.d.). The location of these latter mangroves is an example of a 'drowned bedrock valley' coastal setting as described by Thom (1984). An existing and soft substrate must exist for mangrove colonisation (usually from silt deposition from rivers, or from seabed sand). Once established, mangroves enhance sedimentation accumulation as they trap sediments and organic material.

The mangroves in the Hinchinbrook area (and in general) are adapted to highly dynamic environments which are intermittently inundated by saline tides and occasionally by freshwater from land during heavy rainfall and low tides (Lear \& Turner 1977). In the Hinchinbrook region, the greatest influence on sediment movement and the establishment, distribution and composition of mangroves is tidal action, rather than freshwater run-off and groundwater (Boto \& Wellington 1988). It is usually only during periods of heavy monsoonal rains that the mangroves are influenced by freshwater, but even with heavy rains the salinity is still high in the Missionary Bay mangrove system 
Figure 2.36 Mangrove distribution Hinchinbrook Island

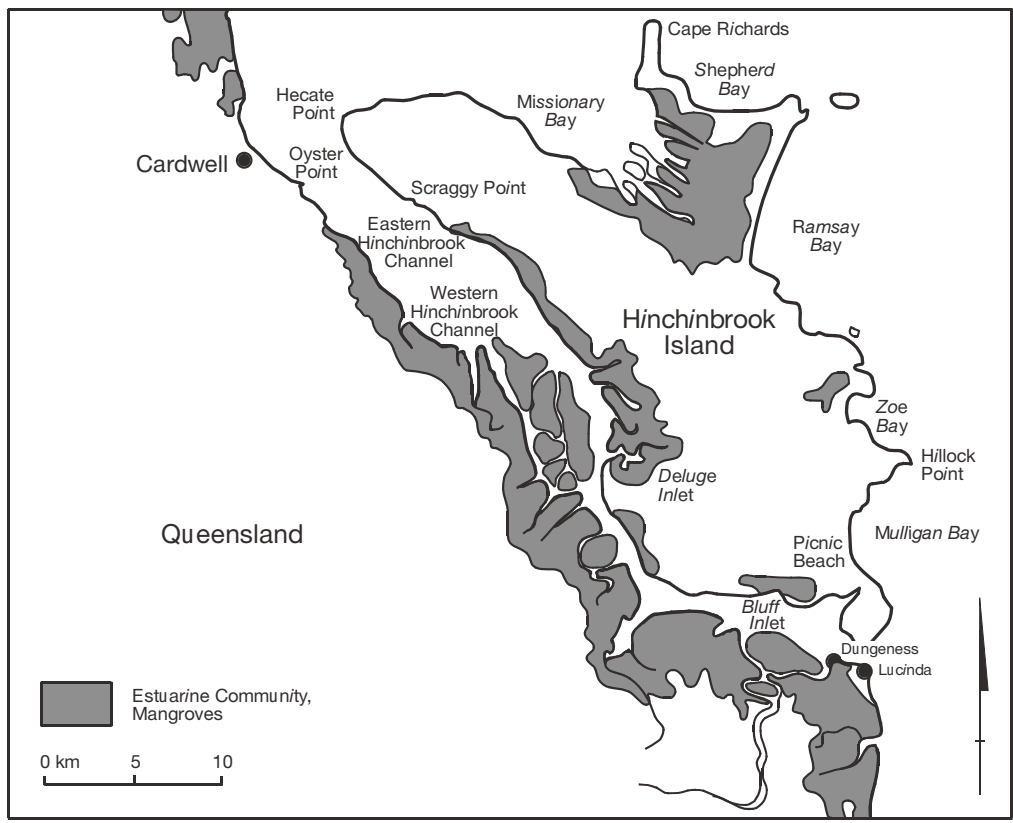

Source: modified from Queensland Government 2001

(Boto \& Wellington 1988). However, in the Hinchinbrook Channel area, freshwater catchments discharge into each side of the channel (Environment Australia n.d.).

Mangroves can either be stable or unstable; boundaries may retreat inland, or extend seaward by a process of progradation and sediment entrapment and accumulation. This in turn is dependent on local sea levels, where, for example, a lowering of sea level or land uplift results in mangrove colonisation of new intertidal areas, with higher sea levels (or land subsidence) leading to inland retreat. This is also influenced by rainfall, and in the Hinchinbrook area there is evidence of landward migration of mangroves and the replacement of saltpan areas, because of increasing rainfall and reductions in salinity in landward zones (Saintilan \& Williams 1999, p. 120).

The roles of the Hinchinbrook (and other) mangroves are quite diverse. They trap sediments and organic material, in part, via specialised and exposed root systems (pneumatophores) which reduce wave energy and allow the mangroves to breathe during flooding (AIMS 1998, Duke et al. 1998). In trapping sediments and nutrients, the mangroves prevent coastal erosion and provide a buffer zone between land and sea against agricultural run-off and other pollution. The mangroves also protect the coasts from cyclones and floods, they act as a sink for 
atmospheric carbon, provide an important habitat for fauna (including fish, dugongs and numerous bird species), and provide an important link in the coastal food chain, where detritus from the mangroves is consumed by bacteria and higher organisms (Faulkner November 1994, McCormick 1994, AIMS 1998, Ewel et al. 1998). Marine vegetation including mangroves, seagrass, algae and microalgae 'are now recognised as being the primary source of productivity in detritus based marine food chains' (PPK 1992, p. 62). Moreover, 75\% of commercial fish and crustacea in Queensland are directly dependent on mangrove ecosystems (EPA 2000).

Tropical mangroves are highly productive, and organic matter and nutrients are transported between land and sea by complex hydrodynamics. Water circulation and the transport of nutrients and sediments differs within the mangrove creeks (strong tidal flows which flush detritus out to sea) and the forested areas, causing friction, slow water movement, and water entrapment, and resulting in waterlogged and anaerobic soils (Robertson \& Alongi 1999, Bridgewater \& Cresswell 1999). Through this water movement and stagnation, inorganic matter and nutrients are imported (e.g. via rainfall, riverflows, run-off, chemical release, and human influences) and utilised by the mangroves, while organic matter is believed to be exported and provides a basis for the estuary food chains (e.g. via tidal transport and soil leaching by freshwater). The exact contribution of nutrients from the mangroves is unclear, given that AIMS (1998) found that only a small amount of nutrients is released offshore from the Missionary Bay area each year. However, mixing of mangrove coastal and offshore waters does occur through a 'coastal boundary layer' which provides a buffer between mangrove coastal and offshore waters (Wolanski et al. 1997).

Because of the importance of the Hinchinbrook Island mangroves, much of the area is protected within a national park, a fish habitat reserve which was declared in 1983 (in the southern part of the Channel), a state marine park, and a portion of the Great Barrier Reef World Heritage Area (Environment Australia 1997). Hinchinbrook Island was also declared a 'feature protection area' in 1932 (Environment Australia 1997). Land-uses within the area include restricted tourism and recreation, aquaculture, agriculture (primarily sugar cane) and urban development, but aside from indirect impacts from agricultural run-off and coastal development, the mangroves of this area have had little disturbance by human activities (Environment Australia n.d., Bunt \& Bunt 1999).

Some mangroves were, however, cleared in the early 1970s, and a marinaresort development proposed in the late 1980s at Oyster Point resulted in the clearance of some mangroves. The main concerns associated with the clearance was bank destabilisation, coastal erosion, and the smothering of important sea grasses in the region, in addition to the increased impacts associated with tourism 
(Hansard 1999). Although this development was halted in 1994 by the Commonwealth government because of the impact on the mangroves, it was resumed in 1996 (Hansard 1999). The impacts of this development on the mangroves and their role in coastal stabilisation are as yet unclear.

\section{Port Adelaide River estuary-Barker Inlet}

In contrast to Queensland, a much smaller area is occupied by mangroves in South Australia - approximately $230 \mathrm{~km}^{2}$ (Banham 1992). The diversity of mangrove species in temperate zones is also relatively limited, and only one species of mangrove has been documented in South Australia: Avicennia marina, which is known there as the Grey Mangrove (Banham 1992, PPK 1992). This species, which is the most adaptable to conditions of higher salinity within temperate mangroves, is scattered along the coast within low energy and warmer waters in Gulf St Vincent and Spencer Gulf. Like the tropical mangroves, most mangroves grow on mudflats, but in some areas of higher wave energy they have been known to grow on sandy substrates (e.g. near Torrens Island), which emphasises the significance of marine sediment sources (Banham 1992).

The mangroves of Barker Inlet in the Port River (figure 2.37) have received the most extensive attention in mangrove research within South Australia, although this has primarily been descriptive in nature. Approximately $14 \%$ of South Australia's mangroves occur within the Barker Inlet area, which is dominated by mudflats and mangrove forests with tidal creeks and channels. Within this area, the mangroves are established on the Holocene 'St Kilda formation' (soft and highly organic marine sediments), which was created 6000 years ago when sea level reached about its current height.

Temperate mangroves, such as those in South Australia, are influenced more by the marine environment than by the land environment. This is a similar scenario to the Hinchinbrook mangroves in Missionary Bay, although tropical mangroves are generally influenced more by land environments and freshwater run-off. However, freshwater also drains naturally into the Port River estuary, allowing a mix of fresh and saline waters, and rainfall influences the mangroves during winter months, bringing with them terrestrial sediments. The tides in the Barker inlet may swamp mangroves for periods of 24 hours over many hectares, and this standing water increases sediment-water interactions and results in dieback and recolonisation (PPK 1992). Like the mangroves in Queensland, soils are saline, anoxic, highly organic and poorly drained, and are also encompassed by mats of cyanobacteria (blue-green algae), which help to bind the substratum (Banham 1992).

Parts of the Barker Inlet mangroves are also similar to the Hinchinbrook mangroves in that they are dense and have a closed canopy, but the height of the 
Figure 2.37 Mangroves of Barker Inlet, Port River, Adelaide, South Australia

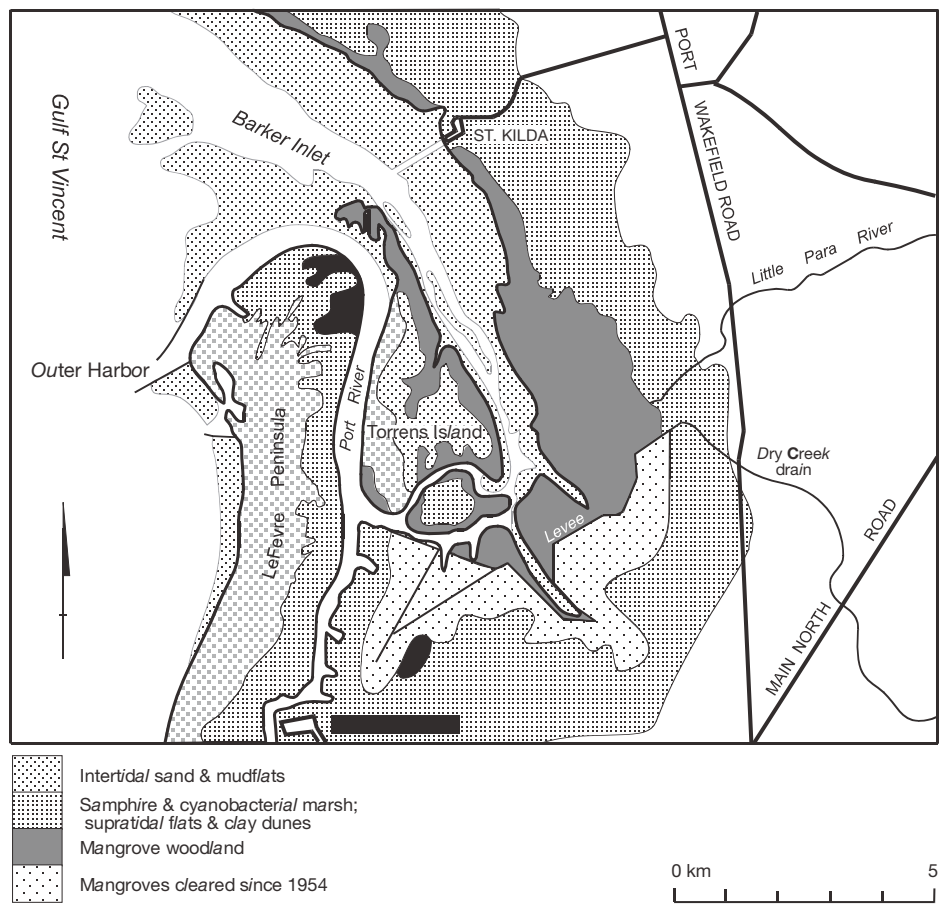

Source: modified from Belperio 1995

mangroves in South Australia contrasts strongly with those in the Hinchinbrook area. In the Barker Inlet, the taller mangroves are on the seaward side (maximum height of 6 metres, compared to 40 metres in Queensland), with a transition to mangroves of 3-4 metres inland and 1-2 metres at the landward edge of the mangroves (characterised more by open woodland). Immediately adjacent to the mangroves on the landward side are significant samphire mudflats which buffer the land and mangroves, while on the seaward side, seagrasses dominate. Such samphire areas or saltmarshes are more prevalent in temperate regions, and it has been suggested that they provide a limited source of nutrients to the mangroves (Banham 1992).

Despite the lesser complexity and diversity of the mangroves in Barker Inlet, they fulfill roles that are similar to those in the Hinchinbrook area, including:

- maintaining bank stability and preventing erosion

- acting as a pollution and nutrient trap/ponding/recycling area (which protects the Inlet from stormwater discharge in the area)

- protecting local industries against damage from wave energy (e.g. salt evaporation ponds) 
- acting as important nursery and breeding ground for aquatic species

- acting as important habitat/breeding area for birds and other fauna

- providing educational, research, recreational and scenic values (e.g. an extensive boardwalk has been established in the St Kilda mangroves) (Banham 1992, PPK 1992).

Moreover, 'mangrove and seagrass areas of Barker Inlet are considered to be one of the most important nursery areas for a number of commercially and recreationally important fish and crustacean species in the Gulf' (Janes 1984/1985 in PPK 1992, p. 69).

However, the full productivity of the mangroves, and the nutrient recycling and transportation processes, are still not completely understood (Banham 1992). It has been suggested that the mangroves are more important for providing structural supports for sediments, rather than as transporters of nutrients into the surrounding environs; that is, the nutrient cycle operates within a closed system (Banham 1992). This is similar to findings for the Hinchinbrook mangroves noted by AIMS (1998), with limited transportation of nutrients outside of the mangrove system. However, further research is necessary to determine the degree of nutrient export, and it was noted by Ferguson (1986) that the mangroves were still important for the provision of organic matter as the basis of the estuary food chain.

Like some areas of the Hinchinbrook mangroves, the mangroves in parts of the Barker Inlet are migrating inland, partly because of local sea level rise associated with land subsidence (Kucan 1979, Banham 1992, PPK 1992). In the Swan Alley Creek mangroves of the Inlet, there has been an estimated landward increase of 865 hectares, while further up the South Australian coast there has been a seaward increase (or progradation) of approximately 365 hectares (PPK 1992). Saintilan and Williams (1999) noted that the inland migration of mangroves occurred at a rate of about 17 metres per year in the Gulf St Vincent between 1949 and 1979. The lack of progradation in the St Kilda area has been attributed to changing sedimentation processes, land subsidence, and increases in the growth of Cabbage Weed (Ulva sp.), which is associated with increased nutrient levels in the area arising from human activity (PPK 1992). This alga tends to smother both new mangrove seedlings and the mangrove's pneumatophores. However, Coleman (1998) found that there had been some progradation (approximately 25-30 m from 1979 to 1993) in the North Arm Creek area of Barker Inlet.

Unlike the Hinchinbrook mangroves, which have remained relatively pristine, the mangroves in the Barker Inlet area have been significantly affected by human activity since European settlement, primarily because the mangroves coincide with human settlement areas. Impacts that disrupt the natural processes within the mangroves include, for instance, oil spills, mangrove and 
samphire clearance, the construction of port facilities, the creation of local industries (e.g. extensive salt evaporation ponds, sewage treatment works and discharge of nutrients into the estuary, power stations and thermal discharge), stormwater drains and water pollution, the construction of causeways which interrupt tidal flows and cause mangrove dieback, the establishment of boat clubs and associated traffic (resulting in erosion of shorelines), and the creation of waste or landfill areas and flood mitigation ponds. The construction of levees for flood mitigation (these levees mark the landward boundary of the mangroves) have also had a significant impact by preventing inland migration of much of the mangroves, inhibiting the natural drainage of freshwater into the estuary, and reducing terrestrial sediment loads.

Due to the significance of the Barker Inlet as a fisheries habitat and nursery, the Barker Inlet-St Kilda area was declared an aquatic reserve (2055 hectares) under the Fisheries Act 1971 to protect the fisheries habitat, and a draft management plan for the Port Adelaide-St Kilda reserve was prepared to protect the mangroves (Ferguson 1986). Torrens Island, which is in the inlet and also contains mangroves, was declared a conservation park in 1963 under the National Parks and Wildlife Act 1972.

\section{Seagrasses}

Seagrass are flowering plants (angiosperms) which grow on soft bottoms below neap low tide and to depths of about $20 \mathrm{~m}$. Extensive seagrass meadows are widely distributed around the Australian coast, but they are best developed in estuaries and bays or within the shelter of reefs. They are significant for their biological productivity and they form the basis for a number of food chains. They are also important in stabilising sediments and in providing habitat for a variety of fauna, including Dugongs (Dugong dugon), Green Turtles (Chelonia mydas) and a number of commercially important fish species. Seagrasses are often found immediately seaward of saltmarshes and mangroves, benefiting from the capacity of those areas to filter sediments, and together with mangroves and saltmarshes they provide nursery habitat for numbers of fish and crustaceans.

Within Australian waters there are 30 species of seagrasses. In temperate Australia Amphibolis, Halophila, Heterozostera, Posidonia and Zostera are the most common genera, often growing in dense and extensive beds. In tropical Australia Cymodocea, Halophila, and Thalassodendron are most prevalent, growing in low densities but widely distributed along the shore. A recent review by the CSIRO (Butler \& Jernakoff 2000) noted that most research has focused on temperate Australia, and that much of the seagrass of northern Western Australia and the Northern Territory is unstudied. 
Many and diverse organisms are associated with seagrasses, including bacteria living on the seagrass and in the detritus of the seabed, epiphytes on the seagrass leaves, infauna among the sediments and seagrass rhizomes, epifauna on the seafloor and the plants, and larger mobile animals moving in and out of seagrass beds. Fish feed on the plankton and other small creatures found in seagrass. Among the many fish that spend part of their life cycle within seagrass meadows are various whiting, leatherjackets and pipefish. Some studies support the notion that particular seagrass beds attract more fish than others, possibly because of their position relative to currents: if this is generally the case, it could be significant in estuarine management, and underlines our need for detailed knowledge of these environments.

The 1995 State of the Marine Environment Report highlighted widespread dieback amongst seagrasses in all parts of the coast, but particularly near the cities (see figure 2.38).

Figure 2.38 Major areas of seagrass die back around the continent

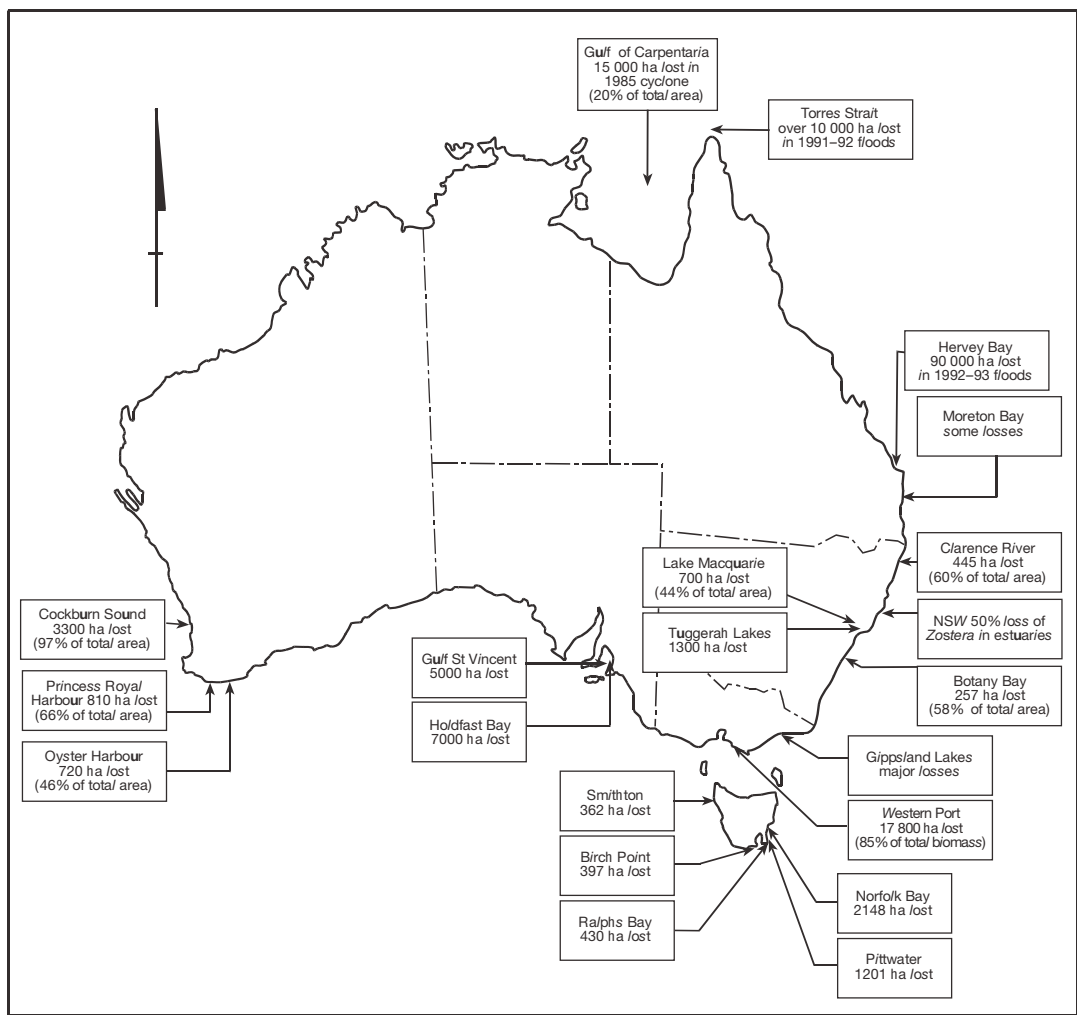


While there is a lack of detailed study on the subject, there is a clear association of seagrass dieback with increased growth rates of the epiphytic algae normally found on seagrass leaves, and also an association with an increase in turbidity (and the consequent reduced light levels). Epiphytes normally flourish in the elevated nutrient levels provided by stormwater and treated sewage discharge, and by farm and factory run-off. Increased turbidity is also associated with these conditions; but may in addition be caused by a variety of catchment management practices, coastal erosion, and particular storm events. Seagrasses may also be locally affected by a variety of activities, and sound coastal management seeks to minimise these effects. These activities include hard engineering structures, aquaculture, and trawl netting. For example, breakwater and groyne construction may lead to sediment entrainment and raised turbidity levels, oyster racks and pontoons may shade out the seagrass, aquaculture wastes may raise nutrient levels, and some trawling practices may scrape the seabed, physically disturbing the seagrass. In shallow water, small boat propellers may raise turbidity, to the detriment of seagrasses, and boat anchors may physically affect the meadows.

Seagrass meadows do not readily regrow, often because their loss is followed by erosion of the substratum and raised local energy conditions, and attempts to regenerate beds have had limited success. Lord, Paling and Gordon (in Butler \& Jernakoff 2000) reviewed Australian efforts to rehabilitate and restore seagrass up to 1999. Detailed observation (e.g. Clarke 1987) suggests seagrass loss may often be patchy, and where it has occurred sediment may be eroded, leading to the development of small $(<2 \mathrm{~m}$ high $)$ scarps, which recede under wave and current action, leading to further seagrass loss.

However, about $1000 \mathrm{~m}^{2}$ of Posidonia sinuosa, P. coracea and Amphibolis griffithii are reported to have been successfully transplanted on Success Bank, off Fremantle in Western Australia (Paling 1999) as part of a \$6 million restoration scheme, following the seabed mining of shellgrit by Cockburn Cement Ltd. The seagrass is mechanically removed in $0.25 \mathrm{~m}^{2}$ sods ahead of the mining dredge and replanted after storage.

\section{Cockburn Sound}

Cockburn Sound, $30 \mathrm{~km}$ south of Perth, has been the site of major investigations into seagrass decline, its causes, reduction in pressure, and attempts at rehabilitation. The Sound is a deep-water anchorage on an exposed coast, sheltered by reefs and by Garden Island. Following the establishment of a deep-water channel through the northern reef, it has become an industrial and naval port. In the 1950s an oil refinery, blast furnace, steel rolling mill, superphosphate factory, and alumina and nickel processing works, became 
established around the Sound. Following a population rise in the area a sewage treatment works was established in the mid 1960s, discharging into the northern end of the Sound.

Several species of seagrass are found in Cockburn Sound, including Posidonia sinuosa, P. australis, P. angustifolia, Amphibolis antarctica and A. griffithii.

In a major study by Cambridge et al. $(1984,1986)$, aerial photos and coring were used to establish the loss of seagrass over time (figure 2.39). Widespread dieback began in 1969, and by 1978 some 3300 ha of meadow had been lost, representing $97 \%$ of the former seagrass area. Attempts to re-establish seagrass in the Cockburn Sound failed in the 1980s, but there was some success in nearby Warnbro Sound. A number of causes for the losses at Cockburn were advanced. Through observation and experiment, Cambridge et al. were able to eliminate the notions that grazing by sea urchins and the effects of effluent from the oil refinery were the causes of the decline. Their enquiry focused on nutrient concentrations and epiphytic algal growth on seagrasses. Phytoplankton blooms indicated an increasing eutrophication of the Sound, and it appeared that nitrogen was a limiting nutrient for growth (in summer). Changes in water quality within the Sound included increasing turbidity, and indicated that lower light levels were associated with Posidonia dieback at depths greater than $7 \mathrm{~m}$. Also, the epiphytic algal growth, which was always present on seagrass leaves, was more abundant in areas of seagrass thinning. Experiments showed that seagrass simply provided a platform for epiphytic algal growth, which flourished on raised nutrient levels in water. Epiphytes were found to be reducing light levels by $30-60 \%$, and this was drastically reducing seagrass growth: decreases in the rates of leaf growth correlated with increases in epiphyte mass.

Land-based discharge of nitrogen load to Cockburn Sound increased from about $100 \mathrm{~kg}$ /day in 1950 to about $3000 \mathrm{~kg} /$ day in 1975. It was concluded that this led to raised epiphyte growth rates and seagrass loss.

Following the construction of a deep ocean outfall in 1984 for the effluent formerly discharged into the Sound, the nutrient load fell (Hillman 1986), and by 1988 the seagrass decline was arrested.

Further attempts have been made to re-establish seagrass in Cockburn Sound (see Lord et al. 1999), but to date there has been a poor success rate.

\section{The Gulf St Vincent}

Seagrasses are the most common plants growing on the seabed of the Gulf St Vincent, where they create a variety of habitats on an otherwise smooth sedimentary bottom. Amphibolis (Wire Weed), Halophila (Paddle Weed), Heterozostera (Gar Weed) and Posidonia (Ribbon Weed) are common. 
Figure 2.39 Seagrass loss in Cockburn Sound, 1954-1978
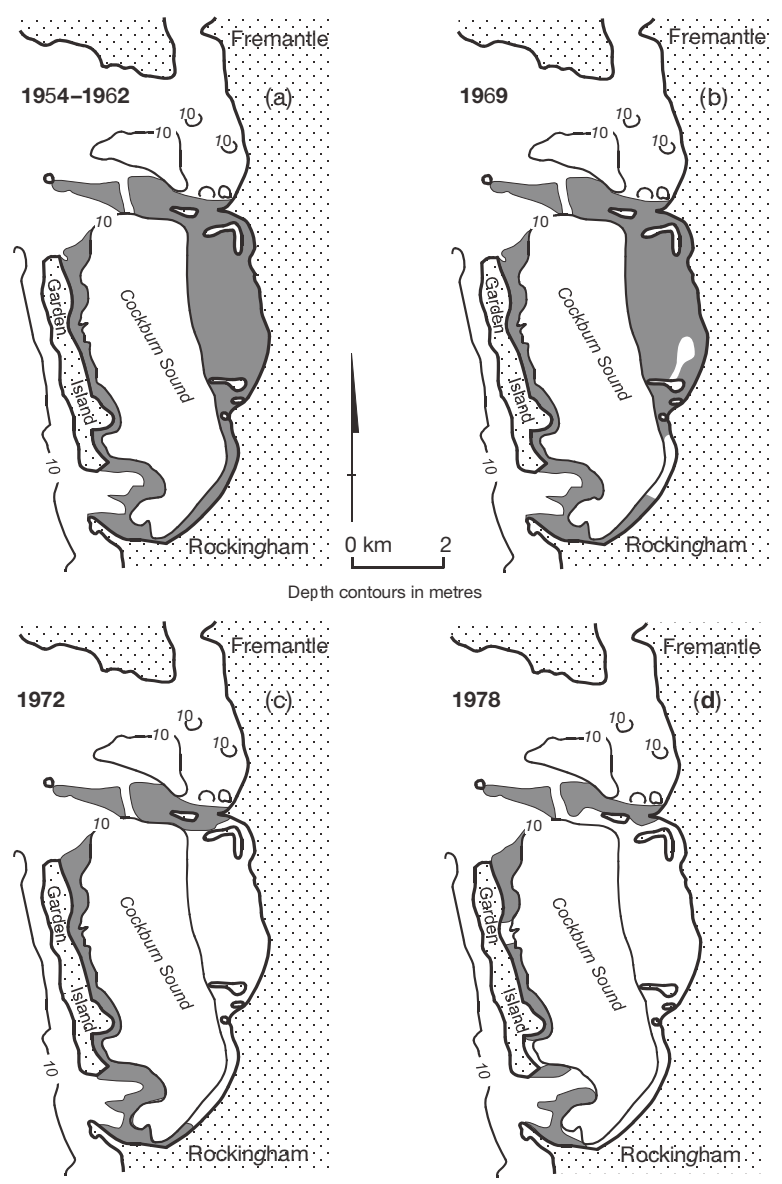

Source: modified from Cambridge \& McComb 1984

The shallow low-medium energy waters of the Gulf St Vincent have in the past been an ideal environment for the growth of seagrass, and the production of great volumes of detritus are part of the normal seasonal cycles for these seagrass meadows. The major growth is in spring and summer; leaves are shed throughout the year, but mainly in autumn. The high productivity of the seagrasses of the Gulf St Vincent constantly adds leaf detritus to the seafloor. A proportion of the undecomposed detritus is carried away by tides and currents and is distributed by waves along the shore.

When shedding occurs, the seagrass leaves are buoyant at first but then sink to form drifts on the bottom (Kinloch 1999). Much of the resultant detritus remains within the seagrass meadows, where it is slowly broken down by bac- 
teria and consumed by plankton, thus forming a significant basis for fish and crustacean life in the Gulf. About $20 \%$ of the detritus, together with seagrass leaf sheaths and rhizomes, is entrained by storms. This moves with wind and tide-induced currents in clumps and layers just above the seabed until it comes to rest at low-energy points such as hollows, where it may be buried with sediment, or it may reach the shore.

Seagrass detritus (together with algae and other matter) in the breakers, on the shoreface, and buried by sand on the beachface is a normal feature of Adelaide's beaches. Because of their high cellulose content, seagrass leaves break down slowly and may remain in the nearshore zone for many months. Wrack on and within the beachface provides an important food source for beach meiofauna, as well as affording some protection to the beach during minor storms. At Adelaide, seagrass detritus accumulates at the low-energy, downdrift northern end of the beach system and also adjacent to and within the three small boat harbours at Glenelg, West Beach, and North Haven. At these locations it is important to clear seagrass detritus promptly: it fouls boat propellers and clogs cooling systems; the smell from the anaerobic decay of detritus buried within the sediment ingress to the harbour leads to complaints from residents and from boat owners in the marina facilities; and when decaying material is dredged and disposed of downdrift in the breaker zone, complaints come from recreational beach users. These problems require frequent monitoring, a rapid response to storm events that move sediment and detritus into the harbour, and good communication between harbour management and the users of the facilities and neighbouring beaches. In this way the function of the harbour in trapping the normal movement of seagrass detritus leads to an expensive complication to maintenance dredging.

The Adelaide Metropolitan coast also provides a detailed picture of the inter-relationship of seagrass loss and its effects on nearshore sand movement. Following the rise of metropolitan wastewater discharge to the Gulf in the 1960s, the loss of seagrass - especially adjacent to sewage outfalls - in the 1970s was spectacular. Subsequently the rate of loss has declined. Comparison of a time sequence of aerial photographs and some field truthing (Hart 1997) suggests that about 7000 ha has been lost in waters off Adelaide; there has been considerable thinning of the beds, and the shoreward edge of the seagrass has in many areas retreated by $500 \mathrm{~m}$. Neverauskas (1987) considered that the loss was due both to increased turbidity and to epiphyte growth in the nutrientenriched waters.

Detailed annual profiling of the Adelaide beaches and coastal waters to $1 \mathrm{~km}$ offshore has been carried out since 1973, primarily to monitor sand movement and the effects of the beach replenishment scheme. This record 
shows that in the areas of seagrass loss the substratum has been eroded to an average amount of $0.3 \mathrm{~m}$. Loss of this depth of sand over several thousand hectares constitutes a large volume which appears to have moved onshore, accounting for the much higher volume than expected of sand accumulated at the northern (downdrift) end of the metropolitan beach system by 1995 (DENR 1997). In addition to this one-off increment of sand to the beaches (suggesting that the Adelaide beach sand replenishment rates will need to be increased in the future), it is inferred that seagrass loss has led to an increase of wave energy at the shore, with a consequent rise in littoral drift speeds.

At Adelaide, knowledge of both the biological and physical connections within the dynamic Australian coastal zone is clearly vital to sustainable coastal management.

Figure 2.40 Seagrass recession off the metropolitan coast of Adelaide

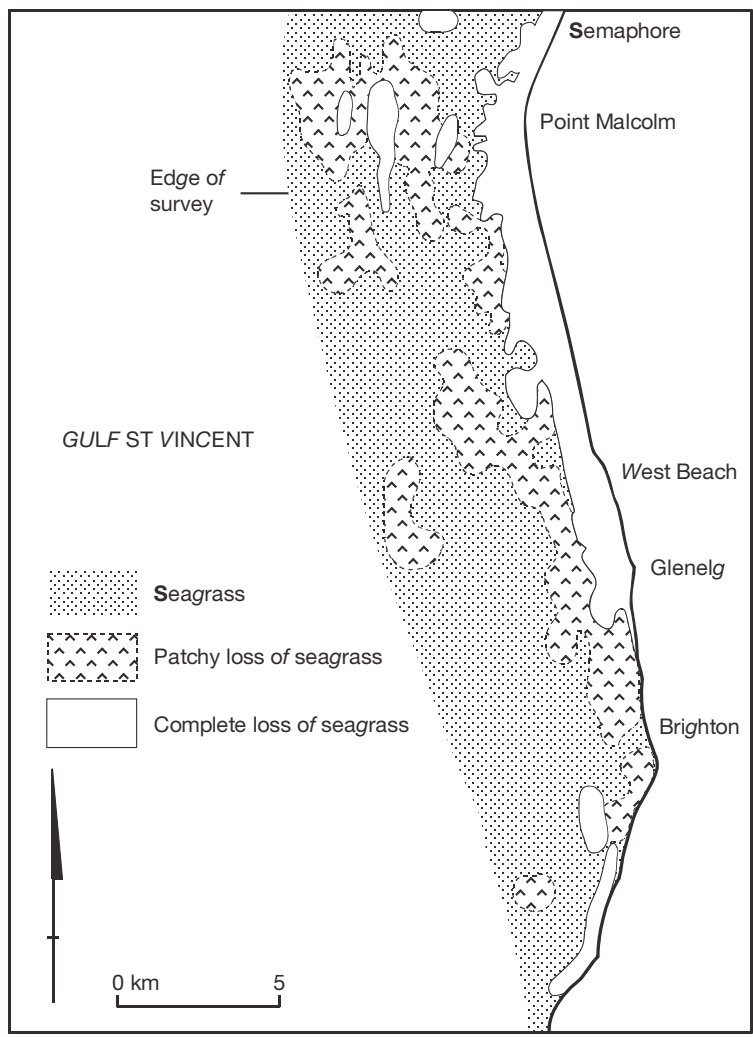

Source: Hart 1997 


\section{Gulf of Carpentaria}

The Gulf of Carpentaria is an extensive embayment of about $370000 \mathrm{~km}^{2}$, situated entirely within the tropical zone. Marked climatic seasonality and variation in river run-off results in a considerable variation in temperature and salinity conditions in the shallow gulf; and storm events occur each year and affect the coast and seafloor. Over $900 \mathrm{~km}^{2}$ of seagrass meadows are found in intertidal and shallow subtidal areas, mainly in the western Gulf where coastal river discharge is less (see figure 2.41). Seagrass communities are depth-zoned: Halodule uninervis and Halophila ovalis dominate intertidally, Syringodium isoetifolium and Cymodocea serrulata subtidally and Halophila ovalis and Halophila spinulosa offshore. Thalassia hemprichii is common in reefed areas, while Halodule uninervis is often associated with river mouths (Poiner \& Peterken 1995).

The nearshore seagrasses of the western Gulf are an important habitat for juvenile Tiger Prawns (Penaeus esculentus) and Endeavour Prawns (Metape-

Figure 2.41 Location of seagrass beds in the Gulf of Carpentaria

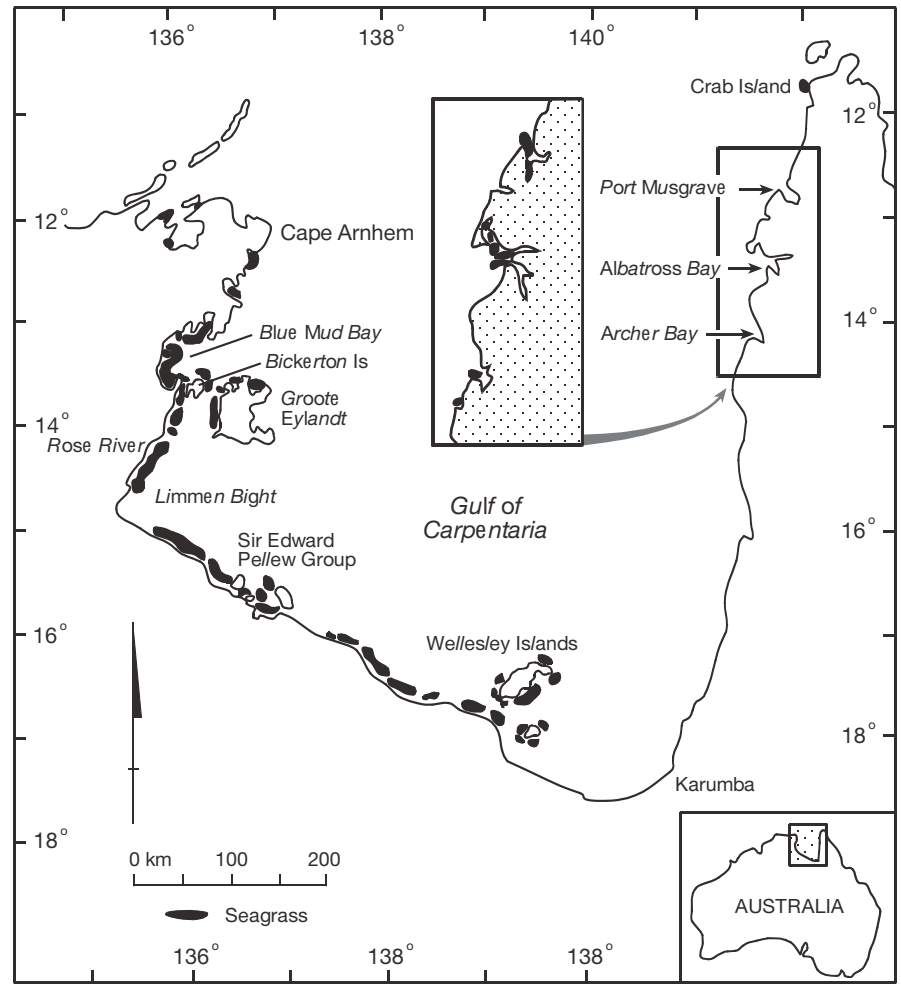

Source: after Poiner et al. 1987 
naeus endevouri and $M$. ensis). Poiner et al. (1987) note that most juveniles are associated with seagrass areas, and that their abundance correlated with aboveground seagrass productivity. The complexity and amount of seagrass appeared important in determining juvenile numbers. The prawn fishery is significant to the economy of the region and an important export industry for Australia, and its sustainability is closely linked to the health of the shallow subtidal seagrass beds.

The CSIRO study of the impact of cyclones on the region showed that only one of the four that affected the Gulf since 1984 caused significant seagrass loss. However, Cyclone Sandy destroyed the majority of seagrass within its path. Subsequent monitoring showed re-colonisation took place, and by 1994 the area had recovered to pre-cyclone conditions. This slow recovery contrasts with a lack of recovery of seagrass meadows lost in temperate Australian waters.

\section{Box 2.1 Who manages seagrass?}

A recent survey found that the activities of a great many Commonwealth, state and local government agencies play a part in managing seagrass in Australia. The agencies are of the following types (adapted from Leadbitter et al. 2000):

- Fisheries agencies with powers relating to fishery management and direct impact on seagrass, but little control over indirect impact

- Environmental protection agencies with powers to control pollution (usually from point sources)

- Parks, flora and fauna agencies concerned with conservation, biodiversity and ecological integrity

- Land and water conservation agencies concerned with the management of soil water and vegetation

- Land-use planning and development control agencies controlling development in coastal areas and catchments

- Ports, harbours, airport and defence agencies with development powers in defined areas.

Problems arise from inadequacies in protection, policy setting and inform ation sources with regard to seagrass.

Management of these important habitats is not only a matter of resource allocation, but also of monitoring and research. Large areas of the Australian coast have yet to be systematically mapped for seagrass; in key areas the health of seagrass beds needs regular assessment (Poiner \& Peterkin 1995). Seagrass health is a vitally important indicator of the condition of the coastal environment and, over time, of the success of coastal management. 
Land dwellers are often conscious of the presence of seagrass meadows offshore only when they find seagrass detritus and algae on a recreational beach. Here some may consider 'seaweed' or 'beach wrack' a nuisance: an attractant for flies and the source of foul smells. In Europe the desire for a clean beach has been taken to the point of daily raking and removal for amenity reasons; some fashionable beaches in France are even perfumed. However, Pearce (1998) reminds us that such sanitisation has its costs, reporting a local loss of seabirds following the commencement of raking. Members of Birds Australia have recorded a similar local loss of species here, following 'harvesting of seaweed' (McCulloch 1996). When seagrass meadows are lost offshore, fish and crustacean populations decline.

There are strong arguments for coastal management to seek to retain seagrass meadows and also to ensure that seagrass detritus stays on the beach and in the water. Most states have regulatory instruments to protect seagrass, but there is a need to develop management practices to carry through the task.

\section{Coral reef coasts}

Australia as a nation has the greatest area of coral reefs anywhere in the world. This includes the largest coral reef complex, the Great Barrier Reef, in addition to reef areas in the Torres Strait, the Coral Sea Territories, and central and northern Western Australia. Of these, the Great Barrier Reef in Queensland and the Ningaloo Fringing Reef in Western Australia are two of the more popular tourist destinations, which consequently require well-defined coastal management strategies. Apart from tourism, other pressures on Australian coral reefs include the effects of fishing, sediments and nutrients, and threats of oil spills. Specific threats to coral processes include 'elevated nutrients in the inner Great Barrier Reef; outbreaks of crown-of-thorns starfish in the outer central and northern Great Barrier and Tasman reefs; damage from the passage of tropical cyclones; and outbreaks of coral eating 'Drupella' snails in Ningaloo Reef, Western Australia' (Zann 1995, p. 14).

In discussing coral reef processes it is important to realise the dominant role of biological factors in reef development, and also the importance of understanding these processes for coastal management. As noted by Bennett, 'the Great Barrier Reef off the Queensland coast is the only considerable area of the globe, visible to the human eye, which is dominated by animals rather than plants' (Bennett 1974, p. 238). Coral reefs are complex ecosystems, which have a high diversity and productivity, an interdependence of animals and other organisms, and many symbiotic relationships. This high diversity of coral reefs is the reason why they are often referred to as the marine equivalent of the terrestrial rainforests. 
Reef-building or hermatypic corals are distinguished by the presence of zooxanthellae, which are minute unicellular algae living within the coral tissue. These have a symbiotic relationship with the coral polyp by assisting it to lay down its skeleton (a corralite) through photosynthesis, taking up polyp wastes, and supplying the coral with about $98 \%$ of its food requirements. Over thousands of years the build-up of corallite forms a porous limestone that forms the basis for reef building, along with calcareous algae. There is a great variety in the hard reef-building corals; over 350 species have been identified. Some corals live as individuals, but most are in colonies. The variety of species, their life-forms, and their colour give the reef much of its tourist appeal. The colour, however, comes from the soft tissue; the skeleton, once bleached, appears as a white limestone.

Growth rates of corals are fastest in shallow, well-lit waters, and can be up to $20 \mathrm{~mm} / \mathrm{yr}$ for massive corals and up to $100 \mathrm{~mm} / \mathrm{yr}$ for branching corals. However, some species are soft corals which do not have the same role as reefbuilding corals. Coral reefs depend on other organisms, particularly algae, which are the primary energy source through photosynthesis. However there are also crustose corraline algae which are important reef-builders. In some places algae can form up to $80 \%$ of reef sediments, particularly the platey Halimeda. Boring algae are also important in reef breakdown.

The north-eastern Australian region is particularly rich in coral diversity and abundance by world standards. A major reason for this is the favourable environmental conditions for corals, which only grow in warm waters where the temperature in the coldest months is 20 to $26^{\circ} \mathrm{C}$. The temperature range for coral growth is $16-36^{\circ} \mathrm{C}$, so that Lord Howe Island, for example, supports some of the southernmost Pacific reefs. Corals can be almost self-sufficient in terms of nutrients provided there is no oversupply. They have an asexual reproduction phase involving major spawning events, which have been the subject of a number of recent scientific studies. Corals grow in the warm water down to a depth of $100 \mathrm{~m}$, where they become light limited. Other factors restricting their growth are excessive freshwater and sediment deposition, so that they tend not to grow near areas of high river discharge.

There is great variation in growth rates, depending on the position of the reef surface relative to sea level, and vertical reef growth may be negligible on most reef surfaces that are exposed at low tide. Vertical reef growth will also be significantly altered once it comes directly under the influence of surface wave conditions, thus suffering modification and lateral accretion. Kinsey and Davies (1979) observed that most reef flats are between 100 and $400 \mathrm{~m}$ wide, and suggested that $400 \mathrm{~m}$ represents an equilibrium situation where the production of calcium carbonate balances the loss. Another important factor in reef 
growth is the role of corraline algae. On the Great Barrier Reef, the algal rim has been described as an elevated Lithothamnion ridge consisting of a hard, wave-resistant, stepped pavement of encrusting corralline algae, predominantly Lithothamnion and Porolithon.

\section{Reef morphology and reef zones}

On individual reefs there is also variation in the coral growth and species distribution depending on the actual position of the coral species on the reef itself. Each reef can be divided into general zones which are characterised by different physical conditions. These have been described by a number of authors including Hopley (1982), who referred specifically to Australian reefs. He classified the different reef zones as the windward reef front, the outer reef crest, the inner reef flat, lagoons, and leeward margins.

\section{Windward reef front}

In this zone, corals are exposed to the highest wave energy on the reef in the upper $15 \mathrm{~m}$. The reef front is usually steep and rich in coral growth, often dominated by rapidly growing, branching coral forms. The high wave energy is also responsible for mechanical destruction of the coral and the production of detritus, which is moved either down the reef slope or up onto the reef itself. Sediments in the reef front are usually poorly sorted and comprise coarse coral detritus, and in some places scree slopes with boulder-size sediments. Other features of the reef front are marginal channels, terraces and multiple reef fronts, and spur-and-groove systems. The latter give a toothed or notched form to the edge of the reef with alternating spurs and grooves.

\section{The outer reef crest and reef flat}

The edge of the reef often contains some of the most luxuriant coral growth, which is interspersed with surge channels that are often connected to spur-andgroove systems. The reef crest or algal rim takes the main force of the breakers. This zone is usually a smooth or bare surface with very little coral growth, but is dominated by encrusting corraline algae. On some reefs the algal rim is a very flat surface with the appearance of a massive sheet of concrete. In some places major storms can dislodge massive chunks of reef material and throw them up as large blocks on the reef crest or the outer reef flat. The reef crest grades into an outer reef flat, which tends to be lower and gives way to a more irregular surface of boulders, rubble, pools, and a diverse community of algae, corals and other organisms. 


\section{The inner reef flat}

This area is usually less well-defined, but generally receives sediment from the productive reef margins. Hopley (1982) identified three types of inner reef flat zones: an aligned coral zone, a nonaligned coral zone, and a sanded reef flat. These reef flats, although varying in form, can each be covered by up to $0.5 \mathrm{~m}$ of water at even the lowest tide.

\section{Lagoons}

Many of the larger reefs contain a well-defined lagoon or multiple lagoons. These features take various forms and can be up to $40 \mathrm{~m}$ deep, although more commonly they are 5-10 m deep. As noted by Hopley, there is considerable variation in lagoon form, depending on the position on the reef, the relief of the underlying substratum, and the nature of sediment supply and infill.

\section{Leeward margins}

The leeward margins of the reef are characterised by prograding sand sheets and large coral patches within a kilometre or so of the main reef. These zones illustrate the diversity of the reef form and associated coral and algal growth within and across reefs. The living reef, however, is only a veneer on a much larger reef structure which may be hundreds of metres thick. This structure has been built in response to changes in sea level. Coral growth during periods of high sea level has been followed by subaerial erosion during periods of low sea level. Different types of reef structures are formed around continental margins, continental islands or oceanic islands. For example a key difference between the development of the Australian Great Barrier Reef and some of the Pacific atolls relates to different rates of subsidence and the consequently different 'relative' rates of sea level change. The classic Darwinian discovery of atoll evolution provides an explanation for the progression of different reef types around oceanic islands. These islands slowly subside as they move across the ocean by the process of sea-floor spreading. Once an island forms it gradually develops a fringing reef around its margin, but as the island begins to subside the fringing reef develops into a lagoonal reef. Then, as the island disappears completely, all that remains is the circular shape of an atoll reef with a central lagoon. However, the Great Barrier Reef of Queensland and the Ningaloo Fringing Reef in Western Australia have developed on a relatively stable continental margin, so that the processes of fluctuating sea levels, climate change, and alternating periods of submergence and exposure have been more important than factors of subsidence. 
In addition to the generic reef zones described above, there is also a suite of supra-reefal deposits and islands. Reef islands made up entirely of reefal deposits vary in form and location on the reef. Sand cays are usually formed as sand islands deposited on top of the reef in the lower energy conditions on the leeward side of the reef. The extent of sand cay build up depends on the size and shape of the reef relative to the wave conditions, the height of the reef surface and the amount of sediment that is produced. Where the sediment build up is significant, cays can become semi-permanent features with dense vegetation. Reef islands of coarser coral shingle can also form on the reef top in higher energy environments than the sand cays and for this reason it is not uncommon to find them closer to the windward margins. In addition to the larger coral islands, there are a number of reef deposits such as unconsolidated or consolidated shingle ridges, cemented reef rock and ramparts and on the islands themselves there is often consolidation of sediment into beach rock.

Modern reef growth in Australia has been in response to the Holocene sealevel rise. As the transgressing sea moved across the continental shelf, corals began to colonise suitable substrate around the coast. As the sea continued to rise, corals responded with vertical growth where they could keep pace with the rate of sea-level rise. Rates of vertical coral growth vary around the world but have reached over $15 \mathrm{~mm}$ yr in Atlantic reefs with an Acropora Palmata (branching coral) reefal structure. In Mexico, MacIntyre et al. (1977) discovered a total Holocene coral reef accretion of $33.5 \mathrm{~m}$. In Australia the modern coral veneer is up to $26 \mathrm{~m}$ thick (Harvey, 1986).

\section{Case Study: The Great Barrier Reef}

The Great Barrier Reef (GBR) is a continental margin reef which has developed on the continental shelf, and is quite different in origin to the classic coral atolls of the nearby Pacific. It is the largest coral reef system in the world, with an outer perimeter about $2300 \mathrm{~km}$ in length and a total area approaching $350000 \mathrm{~km}^{2}$ (figure 2.42). Although it forms a semicontinuous barrier in certain locations, the term barrier reef is misleading, because it is made up of over 2900 individual reefs, including about 750 fringing reefs attached to the mainland or numerous islands. The thousands of individual reefs range in size from small reef pinnacles up to reefs of 20 to $30 \mathrm{~km}$ long and more than $125 \mathrm{~km}^{2}$ in area. They vary in shape from flat platform reefs to the elongate ribbon reefs of the continental shelf margin, such as to the north-east of Cairns. In some places individual reefs are separated by channels $200 \mathrm{~m}$ wide, whereas in other places they could be $20 \mathrm{~km}$ apart. There are about 300 reef island sand cays, of which 87 are permanently vegetated. There are also about 600 continental or 'high' islands (see figure 2.43(a)). 


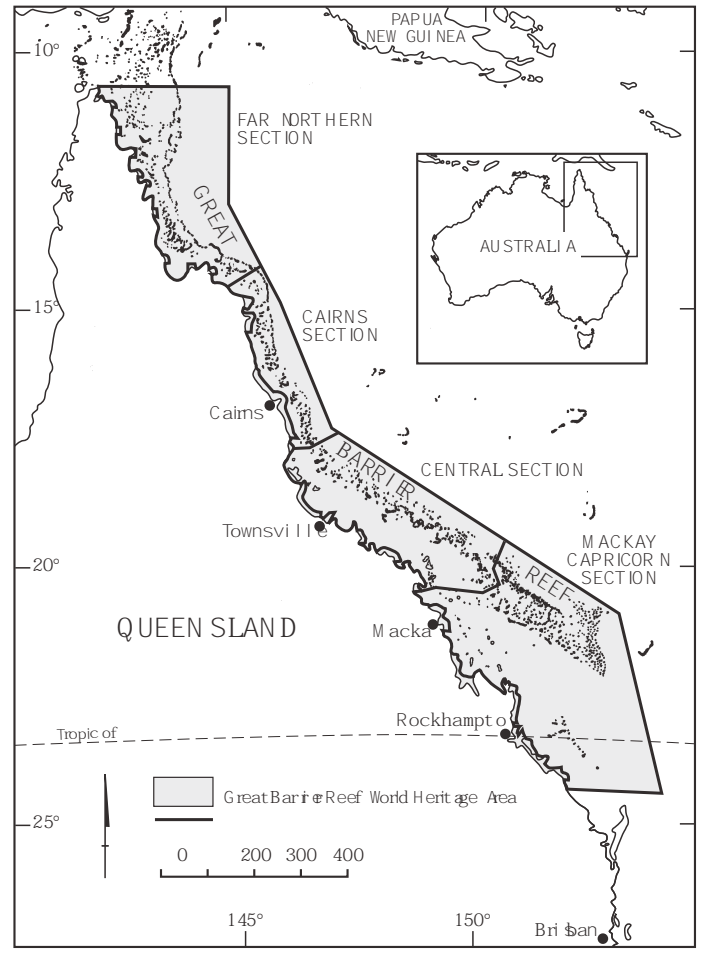

Figure 2.42 The Great Barrier Reef, showing boundaries of the Marine Park and World Heritage Area

Source: Commonwealth of Australia 1993

Figure 2.43 Different reef and island types on the Great Barrier Reef

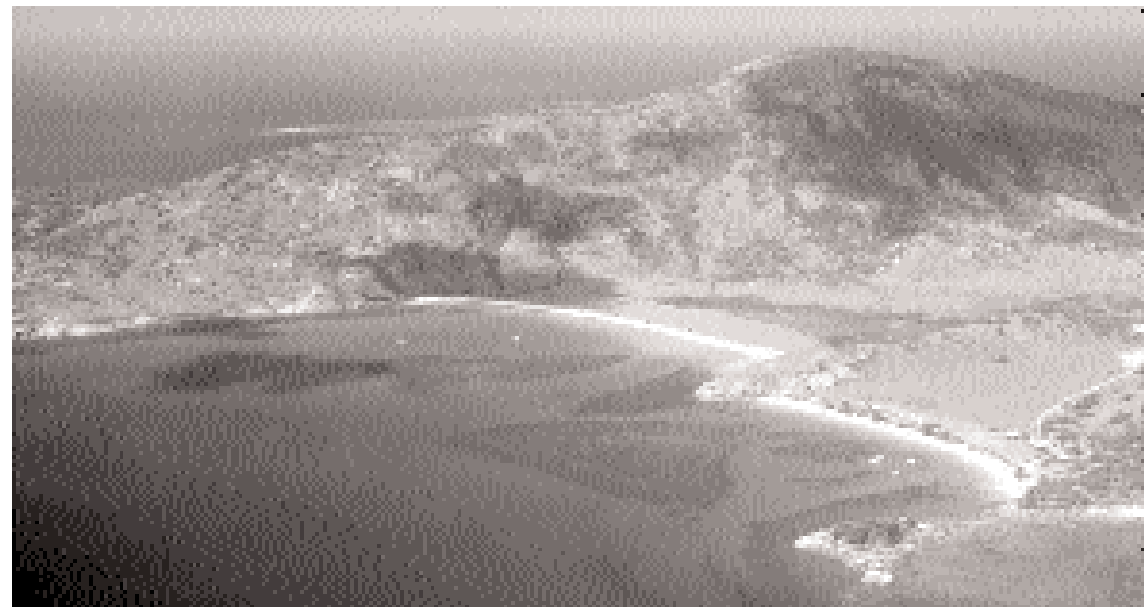

(a) LIZARD ISLAND-A HIGH ROCKY ISLAND

This island is of mainland rather than reefal origin although it has a fringing reef in the foreground. The peak is Mount Cook, where James Cook climbed to obtain a view of the reef in order to plan his escape route through the outer barrier (photography Nick Harvey) 


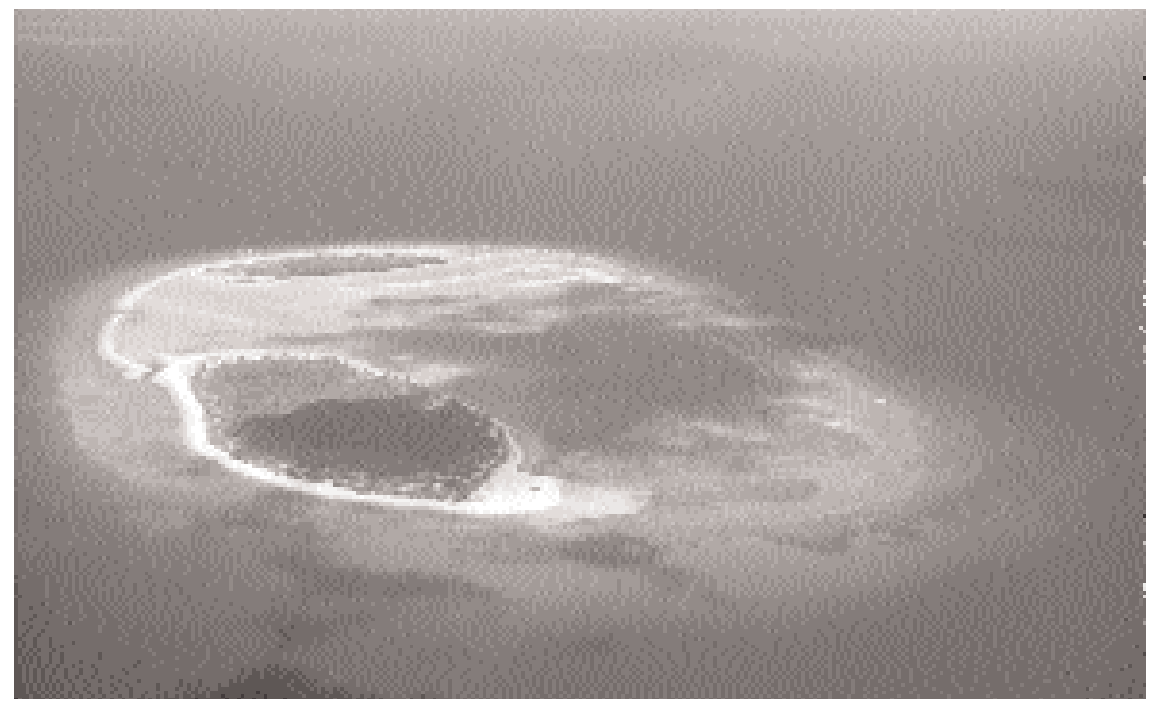

(b) THREE ISLES-A LOW WOODED ISLAND

This shows a vegetated sand cay in the foreground and a large mangrove island on the far side. Around the margins of the reef shingle ramparts are visible (photography Nick Harvey)

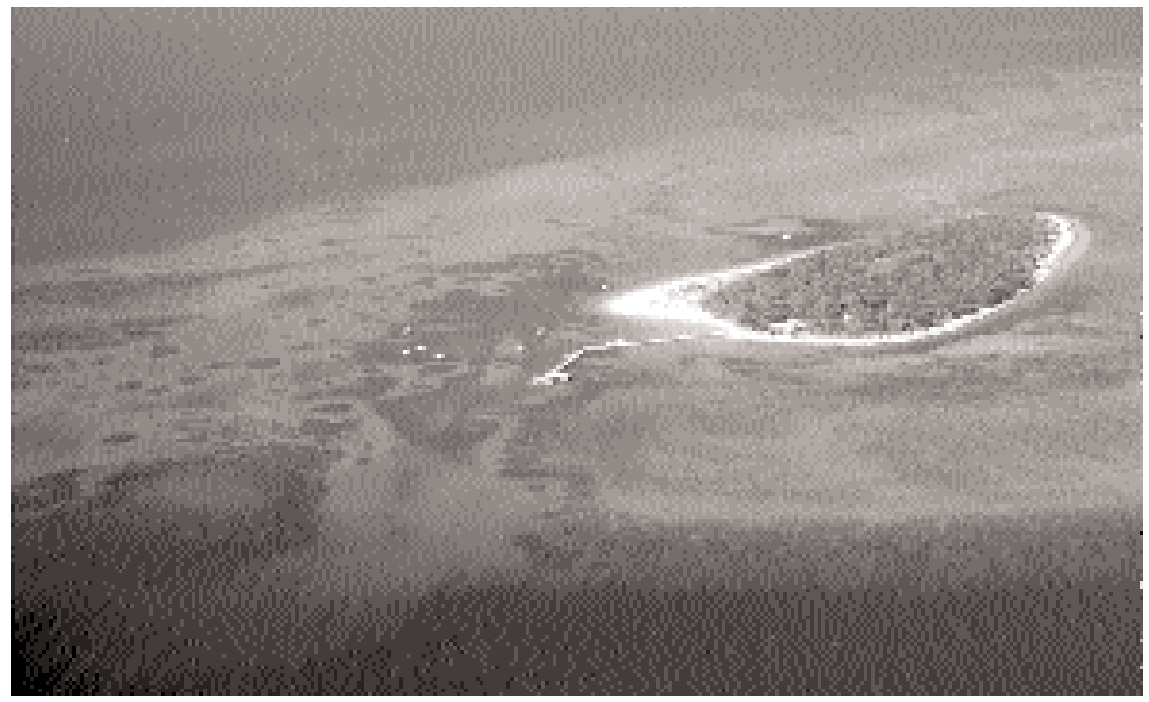

\section{(c) GREEN ISLAND-A SAND CAY}

This is a vegetated sand cay of reefal origin near Cairns. It is a popular tourist location and is one of the more accessible true reef islands. The dark area to the left of the island is seagrass which has appeared on the reef flat since 1945 and is probably related to elevated nutrients from tourism (photography Nick Harvey) 


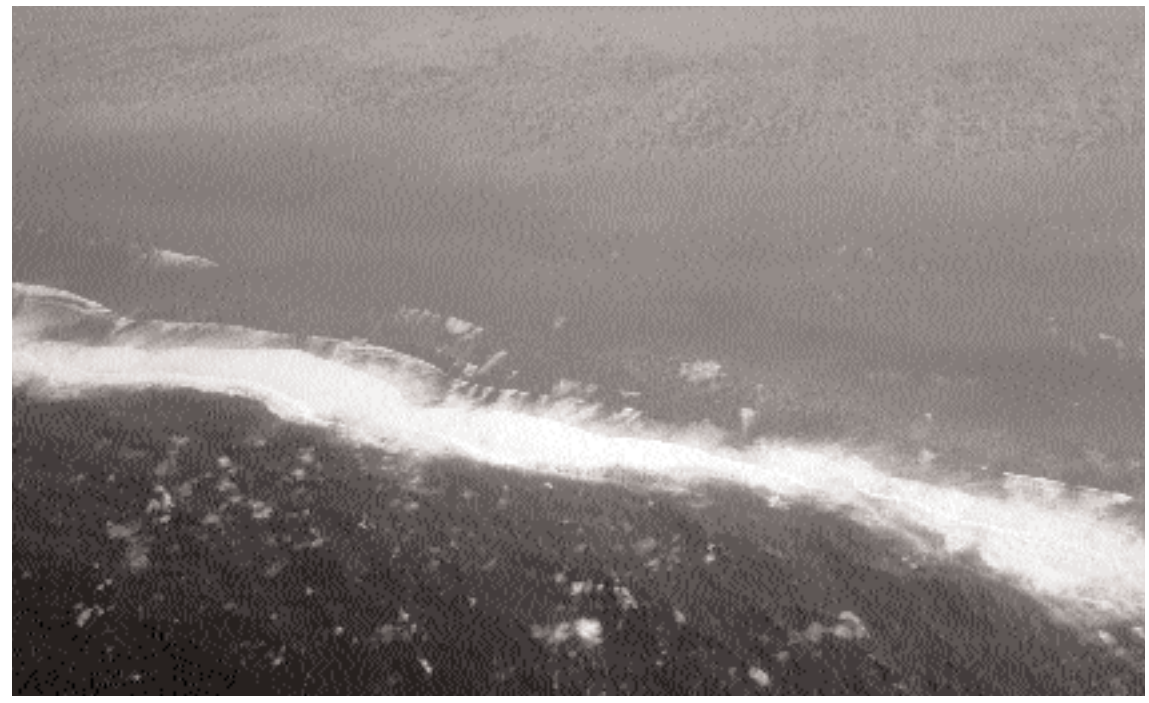

(d) RIBBON REEF ON THE OUTER EDGE OF THE CONTINENTAL SHELF

The reef rises steeply out of the deep water in the foreground. Large breakers can be seen on the reef and in the background shallow water is associated with back-reef deposits (photography Nick Harvey)

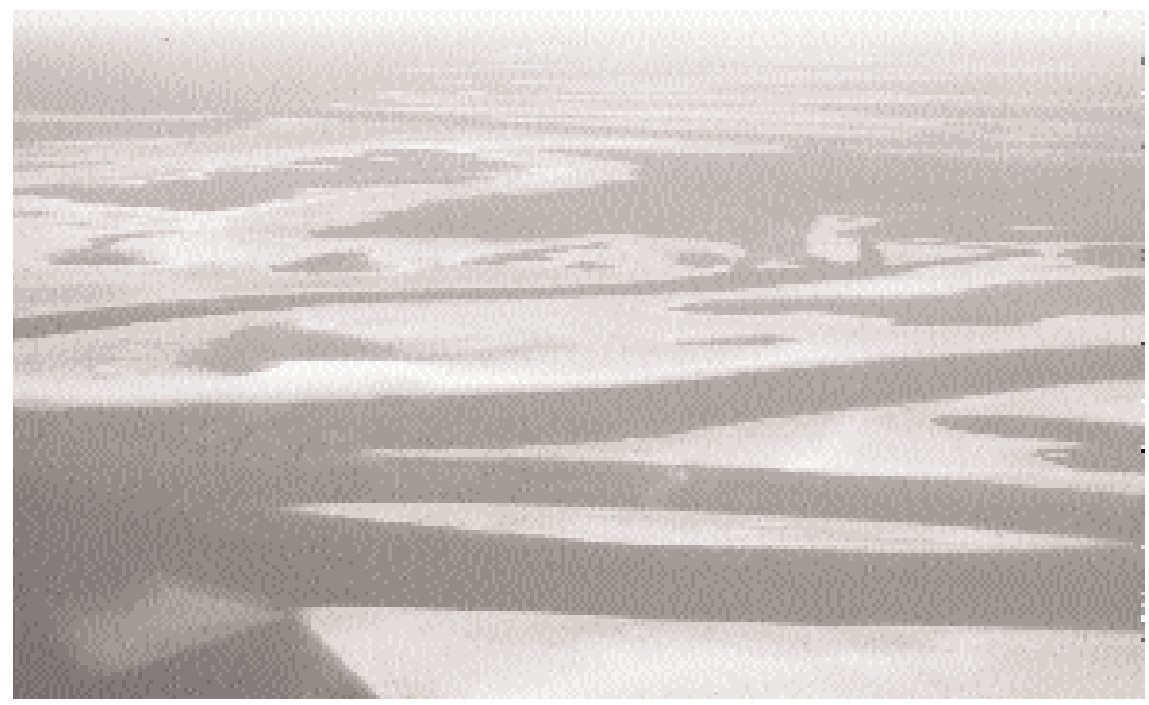

(e) INTER-REEF CHANNELS OF THE POMPEY COMPLEX

These channels are up to $100 \mathrm{~m}$ deep and mostly less than $1 \mathrm{~km}$ wide. They separate massive reefs up to $100 \mathrm{~km}^{2}$ in area. The origin of the channels relates in part to karst erosion during low stands of sea level. The channels are maintained by strong currents (over $4 \mathrm{~m} / \mathrm{sec}$ ) in an area of high tidal range (4 $\mathrm{m}$ plus) (photography Nick Harvey) 
The variation in reef development can best be illustrated using three different sections of the Reef: the northern section from around Cairns up to $14^{\circ} \mathrm{S}$, the central section south of Cairns and down to the Capricorn Channel, and the southern section off the coast from Gladstone.

The northern section of the reef is situated on one of the narrowest sections of the continental shelf, which in places is less than $50 \mathrm{~km}$ wide. The distinctive features of the area are related to this narrow, box-shaped shelf structure, which has generally less than $50 \mathrm{~m}$ of water across it. However, the water increases to greater than $1 \mathrm{~km}$ in depth within a kilometre of the outer reefs, where the continental shelf drops away steeply. Across the shelf in the northern section it is possible to recognise four major zones of reef development:

1 A line of fringing reefs which vary in size and have an irregular distribution along the coast. Their distribution is related to local hydrological conditions and sediment budgets.

2 An inner zone of 'low wooded island' reefs and small reefs with sand cays, generally within $20 \mathrm{~km}$ of the coast. These islands of reef origin generally include cemented deposits, extensive shingle ridges, spits or islets and vegetated sand cays, and often extensive mangrove development (see figure 2.43(b)). The southern limit of the low wooded islands is $16^{\circ} 30^{\prime} \mathrm{S}$ although some of the characteristic features are found on the high islands of continental origin further south.

3 A mid-shelf zone of reefs up to $26 \mathrm{~km}$ long and $12 \mathrm{~km}$ wide, often with narrow intervening passages. In the same zone are a number of smaller, irregularly spaced reefs, separated from others by up to $8 \mathrm{~km}$ of open water. These mid-shelf reefs are characterised by extensive reef flat development, algal rims, and often predominant orientation to the trade winds. Sand cays (see figure 2.43(c)) have developed on the lee side of a number of these reefs, but only a few are stable enough to maintain any vegetation.

4 A zone or line of 'ribbon reefs' (see figure 2.43(d)) less than $600 \mathrm{~m}$ wide but individually up to $28 \mathrm{~km}$ long with narrow intervening passages, and situated on the outer edge of the shelf. The southern limit of these is at $16^{\circ} 30^{\prime} \mathrm{S}$. Behind the barrier is seemingly open water which often contains coral patches or 'bommies'. The water may be $50 \mathrm{~m}$ or so deep, in contrast to the steep drop off beyond the shelf edge reefs.

The central section of the Great Barrier Reef is defined here as the area between $17^{\circ}$ and $23^{\circ} \mathrm{S}$. This area shows marked contrast in the distribution and morphology of reefs. Nowhere in this region is there a zonation of inner shelf low wooded islands, mid-shelf reefs and linear ribbon reefs as described above for the northern section. However, many of the high islands (continental origin) have deposition features similar to the low wooded islands. In parts of the 
outer shelf, reefs form a complex, closely spaced reef pattern of 'hardline' reefs which to some extent parallels the continuity of the narrow ribbon reef development north of Cairns. In the northern part of the central section there is a narrow shelf, 50-100 km wide, which merges into the wider continental shelf off Townsville and Bowen $(125-150 \mathrm{~km})$. The reefs in this northern central section occupy up to $50 \%$ of the outer shelf and come within $20 \mathrm{~km}$ of the mainland, but there are no shelf-edge ribbon reefs as are found further north. However, there are similar submerged ribbon reef features north of Innisfail. Where the coastal orientation changes from north-south to north-west-southeast, the shelf widens and the reefs occupy the outer $35 \%$ of the shelf and do not come within $50 \mathrm{~km}$ of the coast. The reefs in this region are irregular patch reefs, generally much smaller than the reefs to both the north and the south. Even the largest reefs are less than $15 \mathrm{~km}$ long, and the majority of reefs are $5-10 \mathrm{~km}$ long and up to $5 \mathrm{~km}$ wide. South of Cairns down to Whitsunday Islands there are no true reef islands made up of reef deposits alone, although there are many high islands in the area, such as Hinchinbrook Island. The reefs in this section tend to be fairly low (not so exposed at low tide) and relatively few have permanent sand cays. There are none with permanent vegetation.

Further south in the central section of the Reef is a number of massive reef complexes with deep narrow intervening channels (see figure 2.43(e)). These extend south-east from $19^{\circ} \mathrm{S}$ to $20^{\circ} \mathrm{S}$ where they merge with the Pompey Reef complex. The shelf edge reefs, from $20^{\circ}$ to $21^{\circ} \mathrm{S}$ from the hardline Pompey Complex, up to $250 \mathrm{~km}$ offshore, which consists of massive individual reefs up to $100 \mathrm{~km}^{2}$ in area with narrow passes separating them, often only a few hundred metres in width. These passes form a dendritic pattern through the reefs and generally coalesce towards the north-east. The channels have recorded depths of around $100 \mathrm{~m}$, some $40 \mathrm{~m}$ deeper than the general shelf depths. It is in this area of the Pompey Complex that the Blue Holes are found (see page 46). These features are similar to blue holes found elsewhere in the world, and are erosional features formed by limestone solution during periods of low sea level, rather than being modern growth features.

The southernmost section of the Reef is an isolated group of reefs referred to as the Capricorn and Bunker group, situated about $80 \mathrm{~km}$ off the coast from Gladstone. The reefs have little in common morphologically with the hardline or ribbon reefs in the northern part of the Reef, but are more similar to some of the mid-shelf patch reefs. The reefs in this southern section vary in size from 1 to $40 \mathrm{~km}^{2}$ and exhibit a diversity of features. A major feature of the reefs here is the abundance of reef-top sediments and the presence of 15 coral cays, most of which support dense vegetation. The reefs tend to be oriented toward the pre- 
vailing winds and have a well-developed high algal rim, especially on the windward margins. Some of the reefs have large, deep lagoons with varying degrees of reef flat development around them.

This variety in reef types reflects the variation in reef-building processes in response to a number of factors. The actual distribution of the reefs is governed to a large extent by the shape of the continental shelf, together with factors such as water depth, suitable substrate, nearshore sediment, and river run-off. Each reef has evolved under a unique set of physical processes that occurred in a specific location. In some cases reefs have reached modern sea level relatively early and have had time to accumulate supra-reef deposits which have been consolidated into reef islands. Elsewhere, some reefs have grown up to modern sea level much later and consequently have no reef deposits above high tide level. These different reef types attract different types of human impacts.

Major activities on the reef are tourism and fishing. The only activities that are specifically prohibited are commercial mining and oil drilling. Tourism is now the fastest growing activity and has been expanding at an estimated $10 \%$ per year. Recent technological changes have also meant that the type of tourism has changed in style from a less sophisticated, inexpensive family style tourism to rapid-transit, high-capacity and high-technology vessels which can move hundreds of tourists at a time and compact the 'reef experience' into a relatively short time frame. The other major reef user is the commercial and recreational fishing industry.

The great extent of the reef and the variety of reef forms pose unique coastal management problems to cope with different uses. For example, the popular southern reefs are readily accessible and have a number of reef islands which create different human use patterns and associated impacts, compared to some of the less accessible outer reefs in the central section where there are no reef islands. The management of the Reef became important when there was talk of mining and drilling in the 1960s, on which two royal commissions deliberated. The first commission, in 1970, investigated oil drilling on the Reef. Then in 1973, the Commonwealth passed its Seas and Submerged Lands Act to establish federal jurisdiction below low water mark. In 1975 the Great Barrier Reef Marine Park Act was passed. This Act has a number of key elements, including the establishment of a Great Barrier Reef Marine Park Authority (GBRMPA) and a consultative committee, prohibition of mining and oil drilling and, most importantly, allows for the regulation of activities.

In 1981 the Reef was inscribed on the World Heritage List. The Great Barrier Reef World Heritage Area contains almost the entire Reef (figure 2.42), 
extending from the tip of Cape York to just north of Fraser Island and from the low water mark to the edge of the shelf. It is $348700 \mathrm{~km}^{2}$ and comprises the Great Barrier Reef Marine Park (93\%), Queensland waters not in the park (2\%) and islands (5\%). In 1994 a 25-year strategic plan was prepared for the Great Barrier Reef World Heritage Area.

The management of the Reef, its associated Marine Park Act of 1975, and the Great Barrier Reef World Heritage Strategic Plan of 1994 have been quoted (Harvey 1999) as a good Australian example of integrated coastal management. This is discussed further in chapter 4. A key reason for the success has been the use of education rather than enforcement, and also the provision for the regulation of activities where there are clearly competing uses for coastal resources.

\section{Conclusion}

Coral reefs are unique in coastal management because they are predominantly animals rather than plants or sediments. They are also unique in that through their growth and development they are capable of building massive coastal structures, such as the Great Barrier Reef in Queensland and the Ningaloo Fringing Reef in Western Australia, which pose their own unique management problems. The Ningaloo Reef (see page 279) is very accessible because of its proximity to the land. This raises particular issues for linking land-based management to coastal management. The Great Barrier Reef is less accessible, but with modern tourism operations it has now become possible to get hundreds of people out to a single reef and back in a day. This has different management implications. What has been illustrated in this section is that there is a great diversity in reef processes, reef types, and reef islands.

The Great Barrier Reef demonstrates the complexity of managing such diversity in a single marine park which is larger than Victoria. There are other issues that are discussed elsewhere in this book, such as the influence of catchments in the Great Barrier Reef area, where elevated nutrients or sediment levels can affect reef growth and productivity. This requires an integrated approach that deals with land-based farming practices along with other coastal issues. There is also a need to have biological and scientific strategies to understand and control coral predators such as the Crown-of-thorns Starfish. At a broader scale, there is a need to minimise global warming to reduce the number and scale of coral bleaching events. Thus, the complexity of processes affecting the health of coral reefs requires a similar complexity and integration of coastal management strategies. 


\section{Cliffs and platforms}

Cliffs and shore platforms are found where consolidated rocks outcrop at the shore. Australia is one of the flattest of the continents, with no extensive mountains, but where its denuded ranges run to the sea as in the Kimberley, or where the eroded sandstone tablelands of the Sydney Basin run to the coast, or where the lithified calcareous dunes (aeolianite) of the south and west outcrop, extensive cliff-dominated landscapes are found. A national survey of Australia's coastal landforms from aerial photography, carried out by the CSIRO, shows that cliffs and shore platforms makes up about a fifth of the length of the coastline. Tasmania has the largest proportion (51\%) of hardrock coast, and Northern Territory (7\%) and Queensland (9\%) the least. In central and southern New South Wales the Hawkesbury Sandstone is an extensive feature along the coast. In South Australia and Western Australia many hundreds of kilometres of cliff, shore platform, and reef have been eroded in the Pleistocene dunerock, also known as aeolianite or calcarenite. The Tertiary limestones of the Nullarbor coast and the granites of south-west Western Australia are also extensively developed in cliffs.

Davies' generalised map of coastal types (see figure 2.8) shows those coasts with extensive continuous cliffed areas, but a continent-scale map cannot show the many visually and geomorphologically significant headlands within sand coast areas.

\section{Shore platforms}

A variety of denuding processes lead to the development of rock platforms sloping gently seaward and within the intertidal zone. These shore platforms are formed by cliff retreat and are best developed where wave energy is high and moderately erodible strata are exposed. Once formed, shore platforms are shaped by the processes listed in table 2.9.

The dolerites, sub-horizontally bedded sandstones and siltstones of southern New South Wales, Tasmania and western Victoria show magnificent examples of platforms sloping gently from just above the high tide mark to the low tide mark, beyond which they fall steeply away. These are known as high tide platforms. While these features are partly structurally developed in horizontal strata, it is clear that many such features have been eroded extremely slowly in resistant rock. This leads to the suggestion that they have not been formed entirely during the sea level stand of the last 6000 years, but can be attributed to a series of Pleistocene high sea levels.

In the following case study, cliff and platform forming processes at Robe South Australia are discussed in some detail, including some historic evidence 
of recession rates. This case study has been chosen because the rock type, aeolianite, is a common feature-forming lithology at the coast in southern and western Australia.

Table 2.9 Processes that form platforms

\begin{tabular}{|c|c|c|}
\hline Process & Description & Visible signs \\
\hline Wave quarrying & $\begin{array}{l}\text { Air forced into crevices under } \\
\text { great pressure by waves. }\end{array}$ & $\begin{array}{l}\text { Enlargement of rock crevices } \\
\text { to form the notch. } \\
\text { Angular rock breakage. }\end{array}$ \\
\hline Abrasion & $\begin{array}{l}\text { Waves move sand and rock } \\
\text { fragments across platform. }\end{array}$ & $\begin{array}{l}\text { Smoothing of shore platform. } \\
\text { Drilling of potholes by pebbles. }\end{array}$ \\
\hline Water-layer weathering & Alternate wetting and drying. & $\begin{array}{l}\text { Pitting; honeycomb } \\
\text { appearance; solution hollows } \\
\text { with overhanging rims. }\end{array}$ \\
\hline \multirow[t]{2}{*}{$\begin{array}{l}\text { Dissolution by seawater } \\
\text { and spray }\end{array}$} & $\begin{array}{l}\text { Rate of lime dissolution in } \\
\text { seawater falls with rise in } \\
\text { temperature (diurnal). }\end{array}$ & $\begin{array}{l}\text { Platform destruction. } \\
\text { Caves, joint enlargement, } \\
\text { pitting and hollows in the }\end{array}$ \\
\hline & $\begin{array}{l}\text { Seawater spray and aerosols } \\
\text { dissolve lime-rich rocks. }\end{array}$ & supratidal zone. \\
\hline Biological erosion & $\begin{array}{l}\text { Cyanobacteria (blue-green } \\
\text { algae) secrete acids. } \\
\text { Browsers (e.g. molluscs) } \\
\text { break rock surface. Borers } \\
\text { (e.g. molluscs, worms, some } \\
\text { echinoderms) drill surfaces. }\end{array}$ & $\begin{array}{l}\text { Indentations and holes in } \\
\text { platform surfaces; rocks } \\
\text { pitted below algae. }\end{array}$ \\
\hline
\end{tabular}

\section{Case study: Cliffs near Robe, South Australia}

From Robe south-east to Cape Banks, low but spectacular cliffs are a feature of the coast (figure 2.44). Many of the attractive features of the coastal scenery here are associated with rapid erosion: jagged overhanging rocks, caves, stacks, islands and arches give the coast a dramatic quality which draws visitors to this cool, windy place.

The cliffs are made of lithified calcareous sands of Pleistocene age, where the sea has cut into the youngest of a series of parallel dune ranges which line the Naracoorte coastal plain. Each ridge is a former barrier dune coastline, constructed of calcareous sands, transported from the continental shelf by rising seas. The barrier forming the present cliffs is called the Robe Range and has been dated at 80000 to 100000 BP (Schwebel 1983). Following deposition the barrier, sands have been hardened under subaerial conditions by 
dissolution (of the carbonate) and redeposition (of the bicarbonate) due to groundwater fluctuation. Hardening also occurs where evaporation draws limerich groundwater to the surface to leave a hard crust, sometimes thickening to a tough, 10 to $15 \mathrm{~cm}$ thick 'calcrete'. These hardened sands are known as aeolianite or calcarenite. The aeolianite shows wind-blown sedimentary structures such as cross-bedding, and curved 'aerodynamic' former dune surface forms. In the eroded cliff faces, former soil layers may also be seen, together with calcified root cavities.

Active erosion has breached the Robe Range, notably at Guichen Bay and Rivoli Bay, created numerous offshore reefs and islands, and formed large platforms and reefs. Although storm waves are slowly abrading the seaward edge of the platforms, it appears that dissolution under subaerial conditions has been a major process in forming these platforms. Together with other weathering processes, dissolution appears to have lowered the platform to low tide level. Once the platform is permanently under water this process stops (seawater is saturated for lime), and platform extension at the landward edge continues. In this way remarkably flat, extensive, platforms at low tide level are formed.

Resistant calcrete layers ensure that many aeolianite cliffs are steep or overhanging. Cliff recession proceeds by wave quarrying, water layer and solution weathering, leading to undercutting and collapse. At Robe, high wave energy ensures the rapid removal of collapsed material and further undercutting.

Figure 2.44 Aeolianite cliffs at Robe, South Australia. The aeolianite cliffs are part of older lithified dune barriers associated with high sea level stands during the Quaternary. The original dune bedding is preserved within the cliffs and an indurated calcrete layer can be seen at the top of the cliff

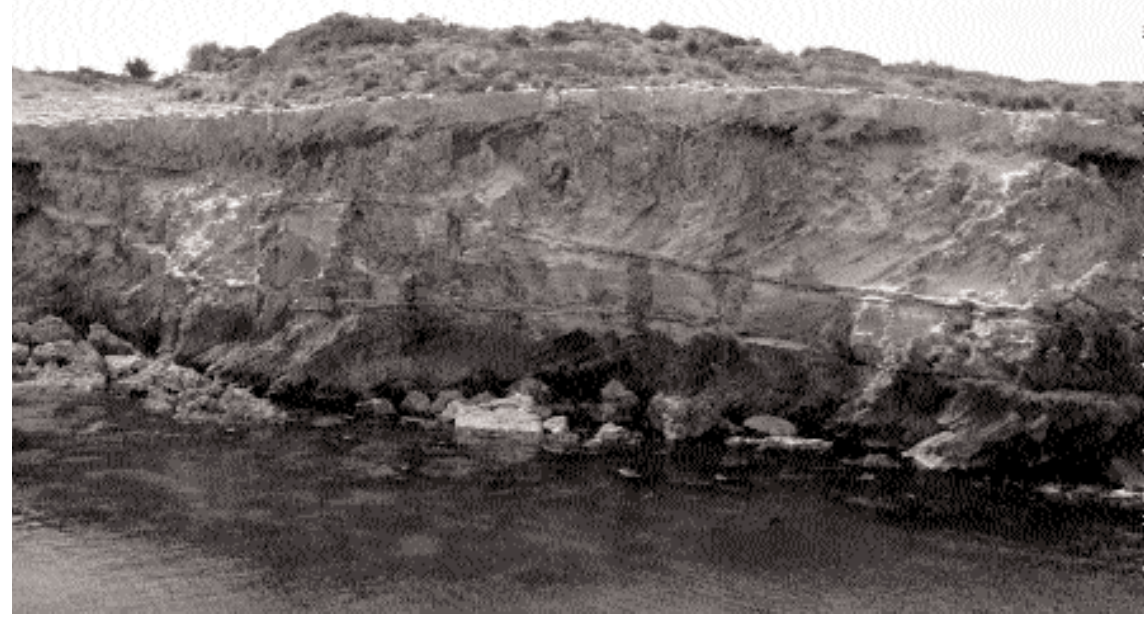

(photography Nick Harvey) 
Records of a detailed town survey near Cape Dombey in 1896 and a careful resurvey by the Coast Protection Board of South Australia in 1987 have allowed the cliff recession there to be measured (table 2.10).

It is clear that average recession rate of the aeolianite cliffs in the exposed open ocean sites is rapid, and also that there is great local variation in erosion speed. However, the most exposed places, such as promontories, are not eroding most rapidly; rather, erosion appears to follow lines of weakness within the rock to further recess inlets and bays. In this way the coast is becoming more indented.

Table 2.10 Average erosion of Cape Dombey cliffs, 1896-1987

\begin{tabular}{lll}
\hline Category of site & Average erosion $(\mathrm{m})$ & Average rate of erosion $(\mathrm{cm} /$ year) \\
\hline Straight & 6.1 & 6.8 \\
Protected sites & 1.14 & 1.3 \\
Open ocean sites & 6.6 & 7.3 \\
Embayments & 7.38 & 8.2 \\
Promontories & 3.89 & 4.3 \\
All sites & 5.9 & 6.6 \\
\hline
\end{tabular}

\section{Case Study: The Port Campbell coast}

The Port Campbell Coast, is famous throughout Australia for its scenic beauty. Its management is concerned with minimising the impact of the many visitors seeking to enjoy the views of the cliffs, stacks, caves, and arches.

The cliffed coast from Cape Otway to Port Campbell and on to Warrnambool is famous for its scenic beauty (see figure 2.9(1)): the Great Ocean Road undulates close to the clifftop for more than a hundred kilometres, taking in a succession of wide panoramic views.

Geologically, the cliffs are cut into the Port Campbell Limestone, a yellowish brown calcareous clay and limestone capped by the thin, dark Hesse Clay. Typically the cliffs rise vertically $40-80 \mathrm{~m}$ from an energetic wave zone, and offshore stacks, reefs and arches are features of a striking scenic coastline. The cliffs face south-west, directly into the swell and storms of the Southern Ocean, which are only slightly reduced in energy by the narrow continental shelf. The cliffs truncate an undulating coastal plain, and in places valleys have been left 'hanging' by the rapid recession of the shoreline, estimated by Bird (1993) to average $17 \mathrm{~cm} /$ year. Many cliffs have a top of bare soil for a few metres from the edge, eroded by wind and spray down to the limestone. This is backed by a low $(<2 \mathrm{~m})$ bluff in Hesse Clay. The 
clay soils are also vulnerable to foot traffic and gully erosion; in places runoff in the past from the coast road has cut deep trenches into the slope to the cliff.

The long, spectacular coastline is dominated by one major use - car-based scenic tourism. From the Great Ocean Road, short feeder roads lead to defined car parks, thence fenced walkways to lookouts. Management is based on access control and interpretive signs. Vegetation loss, packed topsoil and gullying are the clear impacts of past uncontrolled foot traffic, now much reduced by active management.

In many parts of Australia the scenic values of cliffed coastlines have been compromised by building close to edges or ridgetops, thus encroaching on skyline and horizon views. This is not the case along the Port Campbell coast, where public ownership has averted the problem. The coastline is almost entirely within the Port Campbell National Park, which is managed by Parks Victoria.

Several issues need to be addressed in the management of cliff and shore platform areas. Many cliffs and shore platforms are significant habitat in Australia; often they have been protected by their inaccessibility. Small crustaceans, molluscs and various algae may survive on platforms that are rarely visited, but are quickly depopulated by collecting and disturbance. Nesting sites and rare plant species clinging to steep cliff refuges may be lost in one

Figure 2.45 Cracking in cliff top, Hallett Cove, South Australia. This cliff is hard, partly metamorphosed, sedimentary rocks. It began to collapse, following several days of heavy rain, at locations where stormwater was discharged to the top of the cliff. The local council decided to repurchase four houses earlier approved for development, including the one shown here

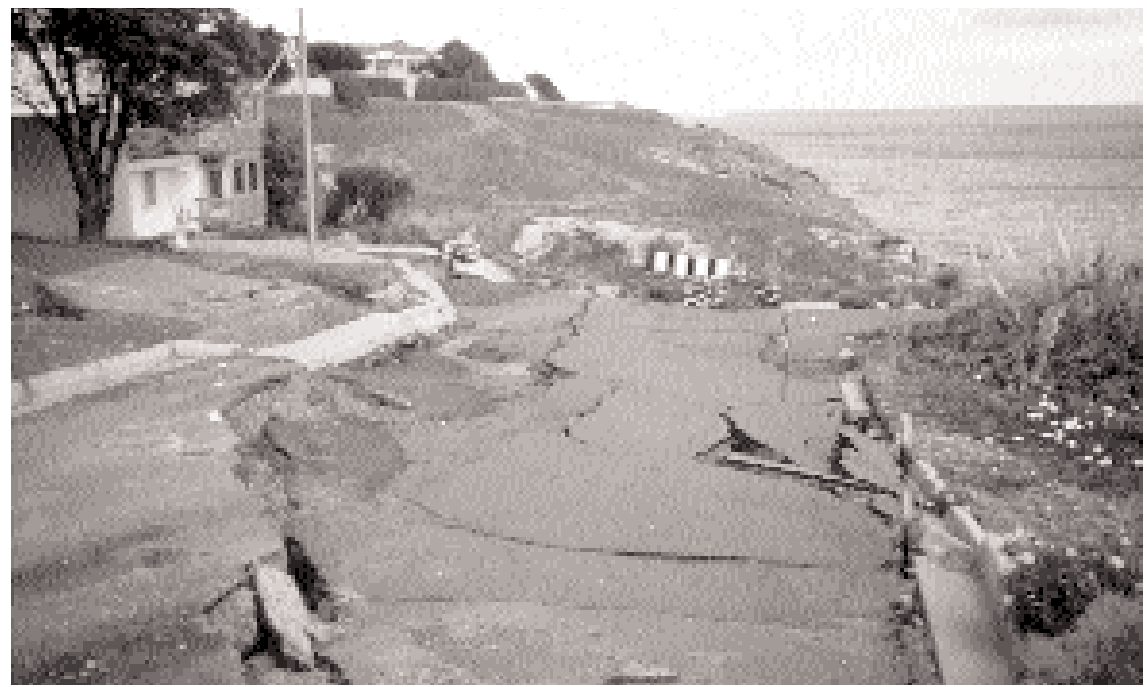

(photography Nick Harvey) 
season of sheep grazing. These pressures are not readily perceived, but constitute an ongoing challenge to coastal management in Australia, in recording, monitoring and protecting.

Everywhere cliff erosion has the potential to be a management issue. Longterm natural erosion is to be expected on steep areas that are subject to temperature changes, water flow and seepage (see figure 2.45). Many human activities can exacerbate the erosion or make it a matter of concern. Pedestrian traffic on cliff footpaths in unstable rock can accelerate erosion by orders of magnitude, as can vegetation removal through grazing. Stormwater that is allowed to run over clifftops may destabilise even apparently resistant cliffs.

Decisions to zone sites for development that are later found to be unstable can prove a very costly process for governments too ready to respond to the demand for houses with a wide coastal view. Likewise, engineering works to stabilise cliffs or to protect the eroding toe of a cliff are usually very expensive. Natural erosion of cliffs may proceed episodically, with cliffs that have been apparently stable for decades becoming locally mobile after a long period of exceptionally heavy rain that coincides with a very high tide. Such an episodic, irregular process may encourage a perception of stability in places where a cautious management approach, such as the use of buffer zones or special building foundation regulations, is more appropriate.

The collapse of easily undermined strata, such as aeolianite, raises safety and liability issues for coastal managers, especially where such places are at the back of well-used recreation beaches. It can be addressed in a fairly straightforward way using notices or access control, provided there is an awareness of the potential of the problem.

Headlands and cliffs provide some of the most spectacular scenery in Australia; the rugged beauty of headlands form key landmarks as well as being popular viewpoints. The character and visual amenity of such places is critically affected by their management: clearance, inappropriate plantings, poorly located tracks, the intrusion of buildings - particularly in skyline silhouette locationsmay have a significance for a wide area. These are places where sensitive planning and landscape architecture can make a particularly significant contribution to the amenity of the coast (see 'Protected coastal areas' in chapter 4). 


\section{Human impact on the Australian coast}

The previous chapter focused on the importance of understanding coastal processes in order to better inform coastal management. Although the emphasis was on the processes themselves, the eight coastal examples linked the understanding of coastal processes to the management issues for each of the respective examples. This chapter, however, attempts to place a focus on the human impact rather than the processes but, as will become apparent, it is necessary to place this in context of the coastal processes that are being affected by the impact.

\section{Coastal impacts from our cities}

The great majority of Australians live on or near the coast (see figure 3.1) in the east of the continent, in Queensland, New South Wales and Victoria. To a lesser extent there is a population concentration at the south-western tip of the continent. Australia has been an urban country for 200 years, and at the start of the 21 st century about $70 \%$ of its population lives in urban centres of more than 100000 people. Almost all these centres are at the coast. This includes all capital cities (except Canberra) and large urban centres such as Cairns, Townsville, Sunshine Coast, Gold Coast, and Wollongong. Smaller towns and cities are also mainly at the coast, and today more than $80 \%$ of Australians live within the coastal zone.

The RAC Coastal Zone Enquiry showed that more than half of the total population growth in Australia between 1971 to 1991 (see table 3.1) took place in capital cities, and that growth rates were most rapid in the immediate coastal divisions (RAC 1993b). 
Figure 3.1 Population distribution in Australia, 2000

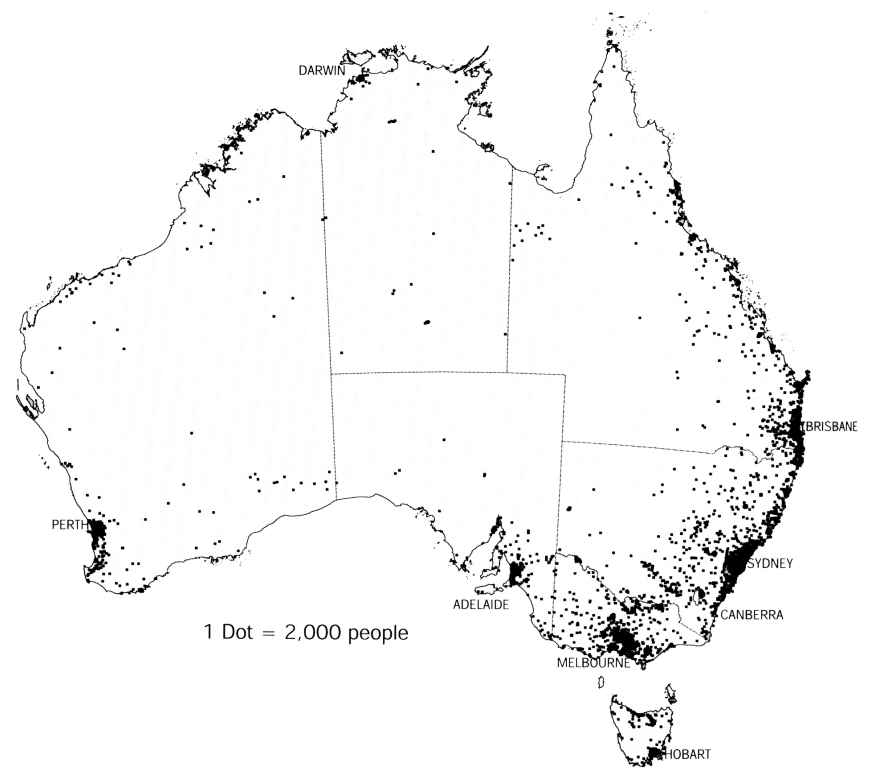

Source: ABS 2002

Table 3.1 Changes in population in metropolitan areas, 1971-91

\begin{tabular}{lll}
\hline Statistical division & Population change & Percentage change \\
\hline Sydney & 603033 & 21 \\
Coastal region & 140067 & 157 \\
Melbourne & 488540 & 20 \\
Coastal region & 111088 & 202 \\
Brisbane & 465167 & 53 \\
Coastal region & 166688 & 271 \\
Moreton ${ }^{1}$ & 343296 & 201 \\
Coastal region & 312662 & 246 \\
Adelaide & 180924 & 21 \\
Coastal region & 9515 & 327 \\
Perth & 440066 & 63 \\
Coastal region & 194894 & 604 \\
Hobart & 28622 & 19 \\
Coastal region & 16375 & 133 \\
Darwin & 40957 & 110 \\
\hline
\end{tabular}

1 Gold Coast included as a metropolitan area 
Pressures from human activities that affect the coastal and marine environment are at their greatest where population is most concentrated within the coastal zone, as in the metropolitan areas. The numerous impacts include clearance and construction in sensitive areas such as sand dunes and coastal wetlands, erection of structures such as breakwaters, groynes and seawalls, excavation dredging and the disposal of sediments, land reclamation, canal development, construction of marinas and small craft facilities, and the discharge of wastewater-stormwater and effluent.

\section{Urban wastewater}

Stormwater and treated sewage from Australia's coastal towns and cities is discharged to rivers, estuaries, nearshore waters and beaches. The first State of the Marine Environment Report, or SOMER (Zann 1995), identified coastal waters adjacent to major coastal population centres as major pollution 'hotspots', which have been affected by discharges of nutrients, pathogens, heavy metals, sediments, industrial wastes and rubbish through the urban wastewater systems.

Table 3.2 is indicative of wastewater pollution which has occurred near many major urban centres. The significance of this pollution depends on residence time, water circulation and the severity of impact on life forms in the receiving area.

The majority of Australian urban areas have wastewater treatment plants. A very few towns do not, for example Swansea in New South Wales, which pipes untreated wastes to the sea. There is a wide variety of technologies available for the treatment of effluent, and their effectiveness varies with cost. The description of these technologies commonly refers to primary, secondary and tertiary treatment of wastes. Primary treatment involves removal of all large solids (screening) and some suspended solids. Secondary treatment removes the remaining gross pollutants and organic matter by bacteria in 'activated sludge' or a 'trickling filter'. Tertiary treatment involves filtering, disinfection and nutrient stripping. Metropolitan treatment plants mainly discharge secondary treated wastes to the marine environment, usually a few hundred metres offshore, or to nearby rivers and estuaries. Since 1990, most of Sydney's sewage has been delivered $5 \mathrm{~km}$ offshore to the continental shelf by deep ocean outfalls at North Head, Bondi and Malabar. Woodmans Point treatment plant in Perth discharges some $3 \mathrm{~km}$ offshore (see page 102).

Stormwater is normally discharged straight to a river, beach or ocean, taking with it solutes and solids from roofs, paths, streets and cultivated land in accelerated and enlarged flows. Not only have city and agricultural pipes 
Table 3.2 Pollutants discharged in wastewater in Australia

\begin{tabular}{|c|c|}
\hline Pollutant & Examples, concerns and indicators \\
\hline \multirow[t]{3}{*}{ Nutrients } & Examples-nitrogen, phosphorus, iron, silica \\
\hline & $\begin{array}{l}\text { Concerns-secondary treatment of sewage is widespread and does not } \\
\text { remove nutrients; also there are many diffuse sources, most commonly } \\
\text { fertilisers; increases phytoplankton and algal growth, potentially reducing } \\
\text { light and oxygen levels; eutrophication of poorly circulating waters }\end{array}$ \\
\hline & Indicators-total phosphorus; total nitrogen \\
\hline \multirow[t]{3}{*}{ Pathogens } & Examples-enteric viruses, hepatitis A and $\mathrm{E}$ \\
\hline & $\begin{array}{l}\text { Concerns-0ver } 100 \text { bacteria and viruses have been identified in sewage and } \\
\text { stormwater, sourced from human and animal wastes }\end{array}$ \\
\hline & Indicators-E. coli counts are common, but do not indicate virus status \\
\hline \multirow[t]{2}{*}{$\begin{array}{l}\text { Toxic organic } \\
\text { chemicals }\end{array}$} & $\begin{array}{l}\text { Examples-chlorinated pesticides, polynuclear aromatic hydrocarbons } \\
\text { Concerns-contaminated sediment may be a secondary source; } \\
\text { bio-accumulation }\end{array}$ \\
\hline & $\begin{array}{l}\text { Indicators-Various specific tests. Assays of bio-accumulation } \\
\text { of pesticides }\end{array}$ \\
\hline \multirow[t]{3}{*}{ Heavy metals } & Examples-cadmium, arsenic, copper, lead \\
\hline & $\begin{array}{l}\text { Concerns-of great concern in some localities (e.g. lead at Port Pirie, mercury } \\
\text { in the Derwent Estuary) but not widespread; } \\
\text { bio-accumulation. }\end{array}$ \\
\hline & Indicators-chemical analyses \\
\hline \multirow[t]{3}{*}{ Sediment } & $\begin{array}{l}\text { Examples-the result of rural soil erosion; soil loss from } \\
\text { construction sites. }\end{array}$ \\
\hline & $\begin{array}{l}\text { Concerns-turbidity levels in estuaries and nearshore waters affects nearly all } \\
\text { life forms, notably seagrass meadows }\end{array}$ \\
\hline & $\begin{array}{l}\text { Indicators-water clarity, measured in nephelometric turbidity } \\
\text { units (NTU) }\end{array}$ \\
\hline \multirow[t]{3}{*}{$\begin{array}{l}\text { Other hazardous } \\
\text { materials }\end{array}$} & $\begin{array}{l}\text { Examples-oil; spills rare, but important; many small unpublicised spills } \\
\text { (e.g. engine oil disposed of down the storm drain) }\end{array}$ \\
\hline & Concems-hazardous to littoral fauna and especially birdlife \\
\hline & Indicators-number of complaints \\
\hline \multirow[t]{3}{*}{ Plastics, floatables } & $\begin{array}{l}\text { Examples-beach rubbish; and marine origin, e.g. fishing line, plastics, } \\
\text { needles }\end{array}$ \\
\hline & $\begin{array}{l}\text { Concems-often dangerous to wildlife; sometimes hazardous to } \\
\text { beach users }\end{array}$ \\
\hline & Indicators-trash quantities, by classes \\
\hline $\begin{array}{l}\text { Biological oxygen } \\
\text { demand (BOD) }\end{array}$ & $\begin{array}{l}\text { Concems-high levels are very locally of concern, near sewage outfalls } \\
\text { Indicators-chemical analyses }\end{array}$ \\
\hline
\end{tabular}


reduced storage and infiltration, but also many natural wetlands, where floods would formerly soak away or evaporate and silt would accumulate, have been 'improved' out of existence.

As a diffuse source of pollution with a great variation of concentration, there has been much uncertainty over the importance of stormwater to the pollution load of nearshore waters. This uncertainty is being reduced by the considerable research activity currently under way or recently completed. This is driven by public concern over the pollution of beaches and nearshore waters: investigations undertaken recently at both Sydney and Melbourne illustrate this.

The Sydney Region had a population of approximately 4 million at the end of the 20th century. Extending $50 \mathrm{~km}$ from Emu Plains to Sydney Heads and $140 \mathrm{~km}$ from Wyong to Appin, it is the least densely populated major world city. For many years there has been strong public concern about the pollution of Sydney's beaches and bathing waters. This large area is almost completely sewered and has established piped storm drainage to rivers and directly to the coast: there are 200 major $(450 \mathrm{~mm})$ storm drains discharging to coastal waters between Palm Beach and Cronulla (NSW EPA 1993). In much of the metropolitan area sewage pipes overflow into stormwater systems at times of flood, and the sewage is then transported untreated to the sea. Sydney Water (1995) noted that of the region's 3000 sewer overflow points, 200 were reported to be overflowing even in smaller storms. A study by the Sydney Water Board (1992) showed that, in three of five small Sydney coastal catchments (Bondi, Whale Beach and Greendale), dry weather faecal coliform counts exceeded the NSW Clean Waters Act standards for primary contact on $98 \%$ of occasions, and that nutrient levels were also high. The Sydney Water Board has undertaken investigations on stormwater in a number of catchments. The NSW EPA (1993, p. 43) noted: 'The information to date suggests that, in highly developed areas such as Port Jackson and the Georges River, the main contributor to nutrient and sediment load is stormwater. Water Board results indicate that, while nutrient loads from stormwater and sewage sources vary between catchments, in Port Jackson the split has been found to be $60 \%$ from stormwater and $40 \%$ from sewage overflow.'

Much concern in Sydney has been about the cleanliness of recreational beaches and waters, but recent investigations in Melbourne have had a different focus. The CSIRO Port Phillip Bay Study (Harris et al. 1996), funded by Melbourne Water, has examined the state of the whole of the Bay waters, all the inputs to it, material and energy flows, life forms and productivity. There is small likelihood that the high-energy, open ocean Sydney coastal waters could suffer nutrient build-up because of water circulation, but deterioration of Port 
Phillip Bay waters has been a matter of concern, because of its enclosed nature. Port Phillip Bay receives stormwater run-off from a large, intensively cultivated agricultural area and a metropolis of 3.4 million people, as well as treated sewage from half those people, yet the study demonstrates that the Bay shows few signs of eutrophication. The waters and floor of the Bay have a wide variety of flora and fauna and, except adjacent to limited pollution sources, the waters are clear and healthy. Although the sewage treatment works and the Yarra River (principally) deliver large quantities of nitrate and ammonia to the bay, nitrogen $(\mathrm{N})$ does not accumulate. This is not achieved by tidal flushing, since changeover time for water between the bay and the ocean is one year; rather, it is accomplished by denitrification by bacteria of the microplankton and microphytobenthos within the Bay's floor sediments. 'The single most important discovery of the Port Phillip Bay Environment Study (PPBES) is that denitrification in the sediments prevents soluble and available $\mathrm{N}$ (ammonia and nitrate) from accumulating in the water column because it is removed from the main Bay environment as nitrogen gas $\left(\mathrm{N}_{2}\right)^{\prime}$ ' (Harris et al. 1996).

Nitrogen is the limiting factor for algal growth in the Bay. It is thus the particular dynamics of the Bay ecosystem that has allowed it to cope with raised nitrogen inputs without the response of excessive algal growth. Rubbish and bacterial pollution near stormwater outfalls is present on Melbourne beaches, as at Sydney, but it is not a matter of such strong public concern. In response to the concern expressed over the state of the Port Phillip Bay waters the CSIRO study has demonstrated conclusively that the Bay can cope with raised nutrient inputs at or near their present level. However, exotic ballast-water hitchhikers, such as the sabellid worm Spirographis spallanzani, threaten the stability of the benthic ecosystem which is vital to the dynamics of the Bay.

A generation ago, any concerns with stormwater focused only on the adequacy of the system in dealing with urban floods. Today this has changed to concerns over water quality and conservation of stormwater for storage and reuse. State, territory and Commonwealth agencies, local governments, and universities are now undertaking a multitude of stormwater projects and applied research to address these concerns throughout Australia. The Coasts and Clean Seas component of the Commonwealth Coastal Action Program has, since 1996, been a significant funding source in this area, as well as a stimulus to innovation through its criteria.

There are a number of chronic problems in dealing with urban wastewater:

- the need to modify large and expensive urban pipe systems

- uncertainty over relative impacts of stormwater and sewage and the links in the chain of changes that follow pollution 
Table 3.3 Some examples of contemporary stormwater projects and research

\section{Clean Waterways Program}

(Sydney Water Corporation, NSW EPA, local councils)

A wide variety of projects: catchment studies and monitoring; trials of various gross pollutant traps; artificial wetland trials.

\section{Study of Sydney's coastal stormwater systems}

(Sydney Coastal Councils Group)

Various guidelines on stormwater management for local government. Driven by public concern over the state of recreational waters and beaches.

\section{Melbourne Waterways Program}

(Melbourne Water)

Arose from public anxiety over the state of the rivers and the Bay, leading to a series of state projects to alleviate this.

\section{Port Phillip Bay Environmental Study}

(CSIR0, various state agencies)

Extensive 'State of the Environment' examination of the Bay 1992-96, including stormwater pollution.

\section{Various urban and suburban projects}

(SA Department of Environment and Natural Resources, University of South Australia)

In Adelaide, research and project development has focused on the replacement of parts of the reticulated supply and groundwater replenishment with harvested stormwater, although success in this area will also improve pollution levels in the Gulf of St Vincent. Small-scale trials at new suburbs in Thebarton, Salisbury and Willunga are currently in progress.

\section{Water-sensitive urban design (concept development)}

(Murdoch University, Water Authority of Western Australia)

A strategic planning approach which emphasises the need to integrate water planning (including stormwater) and urban planning and design throughout the development process.

\section{Brisbane River and Moreton Bay Wastewater Management Study}

(Queensland state agencies, local government)

Examination of the state of the Bay, pollution, and its causes, including stormwater.

- public concern over pollution is not matched by a realisation that the causes are related to individual actions and choices

- the belief among agencies and governments that the cost of addressing the problem is too great as compared with the benefits that would flow from a more comprehensive attack on the problem.

The issue of wastewater illustrates the interconnectedness of a wide range of activities and responsibilities involved in coastal management, as well as the need for both a flexible definition of the coastal zone and the need for a means of setting common priorities across a number of agencies. Within the present Australian context, public concerns over coastal water pollution are marching 
together with concerns over the loss of usable water. Much water that presently runs to the sea (often after expensive treatment to potable level) could be recycled through wetlands, treatment plants or groundwater for reuse. The list of examples of recent or current research in table 3.3 points to changes in ways of thinking about wastewater going on all around the continent.

This change in perception is not only beginning at the institutional level; it is beginning to appear at the community level in a growing realisation that what goes down the drain in the suburban street or from the workshop, may well end up on the beach — see the 'Save our Surf' report of the Surfrider Foundation (Wilkinson 1996). Campaigns, community and council stormwater guidelines and water-sensitive urban design are vital to the health of coastal waters around cities. The extensive replacement of an urban stormwater infrastructure that was designed to use the ocean as a sump does not at this time appear feasible: it is possible, however, that much more water could be retained on suburban blocks, in roadside swales, in parks, and in the soil under porous paving.

\section{Living on the edge}

Real estate values in coastal towns and cities show that, after the CBD, the very edge of the beach, the cliff or the quay is the most desirable place to own property: the harbour view, the varied seascape, the ambience of the tranquil waters of the coastal lagoon, can be a significant multiplier of the cost of residential, commercial and office property. This powerful desire for the water view, or simply proximity to the beach, has led to the invasion and destruction of numerous dynamic and fragile coastal environments. Consequent flood and erosion protection costs often prove expensive.

Adelaide is examined as a case study of long-term management effort to contain the protection problem of building to the foredune, while maintaining a recreation beach.

\section{Case study: Adelaide}

Metropolitan Adelaide extends for $30 \mathrm{~km}$ along the eastern shore of the Gulf St Vincent, from Seacliff in the south to Outer Harbor in the north (see figure 2.26, page 68). The entire coastal plain, including sand dunes up to $500 \mathrm{~m}$ wide and extensive coastal wetlands, has been settled right to the edge of the beach. While some centres such as Glenelg were established in the 19th century, most beach suburbs were built between 1930 and 1970. The suburbs were constructed across the dunes, including the foredune, with an expectation of both protection 
from storm and the maintenance of a recreational beach. These two conditions are maintained today only through beach replenishment to offset the natural trend of recession along most of the beach. The erosive trend is largely of geological origin, but is exacerbated by ecological changes brought about by pollution of the Gulf.

Adelaide has a protection problem, not only because development involving many thousands of people has encroached into the active beach-dune zone, but also because this particular coast is actively receding. Relative sea level rise, derived from uncorrected tide gauge data at Port Adelaide, is 2.08 $\mathrm{mm} /$ year (refer to 'Recent sea level change' in chapter 2). While this rise is significant, the most important factor leading to recession is a deficit sand budget. The beach and dune sands were deposited along the metropolitan coast from about $7000 \mathrm{BP}$, by the advancing postglacial marine transgression. Predominant winds in the Gulf and south-westerly swell established a net northerly littoral drift, which led to the formation of the LeFevre Peninsula between 7000 and 3000 BP (Bowman \& Harvey 1986; see figure 2.27, p. 69). This northerly drift continues: today it is of an order of $40000-50000$ $\mathrm{m}^{3} /$ year, leading to beach accretion north of Point Malcolm and in shallow water north of Outer Harbor. However, there is only minimal supply of sand alongshore from the rocky shore to the south of Seacliff and so the drift to the north can be supplied only by erosion, particularly at the southern end of the metropolitan beach.

The erosion issue became apparent as a result of storm damage in the 1950s and 1960s. At that time the metropolitan Adelaide coastal councils were responsible for coastal protection, and after a series of severe storms the Metropolitan Seaside Councils Committee asked the University of Adelaide Engineering Department to study the causes of the problem and to recommend solutions. The Culver Report of 1970 (Culver 1970) proposed a sand nourishment strategy, with rock revetment as reserve protection. The strategy, which was commenced in 1972, has succeeded in maintaining a recreation beach, and storm damage has been confined to seawalls and jetties. It is not possible to verify that storm damage plus the cost of nourishment have been less than storm damage would have been had nothing been done, but estimates of the value of the beach are much larger than the costs of maintaining it. Had nothing been done, some parts of the beach would have been lost. Three reviews of the strategy, in 1984, 1992, and 1996, have not proposed any major change of direction, and it appears that the majority of the populace support the strategy, in spite of the seasonal presence of heavy machinery on the beaches.

The beach replenishment strategy at first involved simply trucking sand from points of accumulation to depleted beaches; for example, from the Torrens Outlet 
to North Glenelg. It took some while to establish the scheme, as sand placed on the beach disappeared quickly offshore to fill the whole active profile, but by the early 1980s some recovery was apparent. At Brighton, where the beach had been very narrow, it was even possible to re-establish dunes in front of the esplanade. However, West Beach and North Glenelg did not improve until large quantities were barged from Torrens Island (187 $000 \mathrm{~m}^{3}$ ) and offshore Outer Harbor $\left(100000 \mathrm{~m}^{3}\right)$ in 1989 and 1990.

From 1991 to 1997 sand was dredged $\left(600000 \mathrm{~m}^{3}\right)$ off Port Stanvac $(10 \mathrm{~km}$ south) and barged to Brighton, but this supply is no longer viable and new sources of sand are needed to replace what had been locked up under the beach suburbs. At present, only the long-term accumulation immediately offshore at Outer Harbor has been located as a possible major source. More distant sources are constrained by cost.

Physical evaluation of the scheme has been possible by a system of monitoring. Profiles from the dune to approximately $1000 \mathrm{~m}$ offshore, at approximately $500 \mathrm{~m}$ intervals have been measured annually (or more frequently) since 1977. Measurement has been by land survey to wading depth and echo sounding offshore; repeated analysis has shown the accuracy to be $\pm 3 \mathrm{~cm}$ on land and $\pm 10 \mathrm{~cm}$ at sea. Checks on survey accuracy are given by rods fixed in the seabed along 16 of the survey lines. For key areas, more detailed information has been added through more closely spaced survey and remote sensing. Spatial information system software has placed this detailed information into digital terrain models of the beach and nearshore zone (Noyce 1993). Comparison of successive models of the same areas shows gain and loss in 'surface difference maps', as well as allowing calculation of sand volume change. In this way it has been possible to judge the vulnerability of certain beaches coming into the winter storm season, the response to replenishment, and to infer the movement of major sand bodies.

The results have yielded some surprising insights. For example, it appears that seagrass loss in the zone 500-1000 m offshore, which occurred mainly in the 1970s (as a result of wastewater pollution), has led to the mobilisation of seafloor sands (to a depth of $<0.3 \mathrm{~m}$ ). This sand appears to have moved inshore in the late 1980s (DENR 1997). For example, the sediment budget for the inner seabed from North Glenelg to the Torrens River outlet shows, after allowance for replenishment and littoral drift, an unexplained annual gain of 25000 $\mathrm{m}^{3} / \mathrm{km}$ from 1989 to 1996 . The seagrass beds immediately offshore have receded and the surface lowered, but the link is not proven. A 'once-off' offshore source for the excess sand means that the level of replenishment to date has been less successful than was previously thought, implying larger quantities of sand may be needed to maintain the beaches in the future. At the far 
north end of the metropolitan beach, a very large accumulation of sand and seagrass fibre (of $150000 \mathrm{~m}^{3} /$ year) cannot be explained by drift and replenishment activity, but could be accounted for by loss from adjacent and updrift former seagrass meadows.

There is no doubt, however, that the increased water depth in the offshore profile and the removal of the damping effect of seagrasses has increased wave energy reaching the beaches, accelerated littoral drift and increased storm erosion. This surprising change would not have been detected but for the ongoing monitoring scheme, and underlines the importance of keeping a record of environmental management actions.

\section{Non-metropolitan expansion along the coast}

Since so much of Australia's population is concentrated in the capital cities, and since the Australian coastline is so extensive and the numbers of people so small by world standards, it might be thought that there would be few coastal management problems in the non-metropolitan areas. However, homes and holiday houses have spread extensively along the coast, especially in the east, and this together with the high national rate of off-road vehicle ownership, means that 19 million Australians have made a marked impact through development along considerable stretches of the coast.

A population analysis carried out for the RAC's Coastal Zone Inquiry (RAC 1993a) showed that in the latter part of the 20th century, population growth in Australia was most rapid in the coastal outer metropolitan areas, away from the older parts of the metropolitan centres, and also the New South Wales central

Table 3.4 Most rapid coastal population growth, 1971-91

\begin{tabular}{ll}
\hline Coastal region & Increase (\%) \\
\hline Sydney & 157 \\
Richmond-Tweed & 132 \\
NSW Mid-North Coast & 126 \\
Melbourne & 202 \\
Brisbane & 271 \\
Queensland, Far North Coast & 93 \\
Adelaide & 327 \\
Perth & 604 \\
Hobart & 133
\end{tabular}


and northern coasts, the south-west of Western Australia and the south-eastern Queensland coast. With the exception of Hobart and Adelaide which remained static, the trend of growth in the major population centres continued into the 1990s (ABS 1999).

Suburbanisation of the coast in recent decades has resulted in the loss of recreational amenity and conservation values. For example, Frankston on Port Phillip Bay was, in 1960, a recreational area with holiday homes, wide recreational spaces, and open beaches. Now with the spread of suburbs along the shore of the Bay it has become a dormitory suburb, not a holiday venue. Frequently the problem of linear expansion along the coast is compounded by lack of setback from the dune or cliff, often leading to protection costs.

The scale of the problem is extreme in south-eastern Queensland. In 1991, Gold Coast and Sunshine Coast had populations of 273000 and 154000 respectively; according to Queensland Department of Planning projections, these will increase to 486000 and 310000 by 2011. However, these figures alone represent a conservative view for the region, since the hinterlands of these coastal areas are currently growing even more rapidly: Albert and Logan Shires between Brisbane and the Gold Coast have easily been the Australian leaders in numbers of building approvals in recent years.

In many areas of coastal land, suburbanisation is the latest point in a typical sequence of change. This commences with clearance for farming, which begins the establishment of infrastructure in the area, usually dirt roads and power. This basic infrastructure encourages the establishment of holiday homes and shacks, as close to the sea as is practicable and often on the coastal reserve. Holiday homes in groups bring about the development of some holiday facilities: a ramp or launching facility, a shelter shed and barbecue near the foreshore, a car park and toilet. Landward of the holiday homes, rural subdivision allows the development of hobby farms. Together with retirees moving into the holiday homes, this leads to the rise of permanent resident numbers, which attract more facilities, including the first shops. Coastal strip development has thus occurred. Where intensification and consolidation of coastal strip development occurs, a consolidated urban community becomes established.

The form of this suburbanisation of the coast is that of the discontinuous strip: the various coastal ecosystems are quickly affected by even low-density development. For example, in low-density housing among natural bush:

- niches are created for exotic plants and weeds

- domesticated and feral animals are introduced

- changes in microclimate and run-off follow clearance and the construction of buildings and roads

- high sediment run-off is generated during road and house construction. 
As settlement proceeds, the bush tends to become fragmented; and as the number of species is reduced, interdependent species do not recover and species loss is intensified. For example, in the period $1974-89$ some $40 \%$ of the littoral vegetation was lost from the mainland coast in south-eastern Queensland, and little coastal vegetation remains in a natural state (AURDR 1995, p. 89). Supratidal areas, subcoastal lagoons and wetlands are often lost to 'improvement' at this stage; some may be drained for farming, and others become filled for building. Australia's coastal water ecosystems have evolved in low-nutrient and low-sediment conditions. Because coastal development immediately raises nutrient and sediment flow to the sea, there is a marked impact. Intertidal reef and seagrass communities are affected by sedimentation and raised nutrient levels from suburban run-off and by wastewaters. For example, in Western Port, Victoria, clearing, farming and urbanisation of the hinterland has led to the deposition of 6.5 million $\mathrm{m}^{3}$ of silt and sand in the bay, resulting in the loss of $85 \%$ of the seagrass and a deterioration in fisheries.

A CSIRO study of the south coast of New South Wales divided the coast as a $3 \mathrm{~km}$ wide strip into $10 \mathrm{~km}$ sections and examined the population changes between 1971 and 1981, 1986 and 1991. Every section between Batemans Bay and Eden showed rapid population growth: usually of several hundred percent, and in two cases over $1300 \%$. The study emphasised, that even though the absolute numbers are small, they are significant: 'This is because the maximum environmental impact during the urbanisation process usually occurs at the very earliest stages: direct habitat loss, infrastructure expansion, introduction of nonnative plants and animals ...' (Hamilton \& Cocks 1994).

Just as suburbanisation of the coastline has gone through a sequence of change, the development of stormwater and wastewater infrastructure has gone through a sequence of adjustments to the coastal environment. Many small coastal settlements begin with septic disposal schemes for individual houses, with impacts on the coastal environment varying with local site conditions and with planning regulations. For example, South Australia and Queensland allow subdivision to the edge of the river bank and do not control littoral clearance, leading often to septic overflow into water courses and bank erosion. At beaches, septic overflow directly to nearshore waters from beachside shacks and homes occurs where regulations allow the subdivision size to be too small for adequate septic disposal, where development has been allowed on the foredune, and where local groundwater conditions are unsuitable for septic disposal. For example, on the shore of northern Spencer Gulf south-west of Whyalla in South Australia, the siting of a group of 250 holiday homes on a thin veneer of permeable shellgrit over hard clay has resulted in frequent septic flow to the foreshore, including to mangrove areas. 
Individual septic disposal has often been followed by common effluent disposal schemes by councils (STED schemes), with impacts subject to the same considerations. Thus, for example, at Streaky Bay on the far western coast of South Australia, the downslope end of the pipes of the common effluent scheme was sited near the foreshore. Stress to this system from increased visitor numbers in summer results in overflow to the beach and nearshore waters, to the considerable alarm of the developing oyster farming enterprises in the bay.

The history of urban wastewater disposal in Australia (see Smith 1998, chapter 4) shows that there was a considerable backlog in the development of sewage treatment schemes in urban areas in the 1950s and 1960s; for example, only $50 \%$ of Sydney was sewered by 1960 . Federal funding in the Whitlam years (1972-75) allowed a considerable improvement but, because of the technology and habit of the times, disposal of treated effluent was to marine and estuarine waters. By the 1990s a range of disposal arrangements was in place in the non-metropolitan coastal urban areas. The 1995 State of the Environment Report for New South Wales noted that the discharge in ML/day from the 38 sewage treatment works that pump directly to the ocean was: primary 1049.5; secondary 174.3; tertiary 48; no treatment 7.1. (Primary treatment involves the screening of solids only.) In south-eastern Queensland, wastewater is discharged to streams after secondary treatment; for example, Oxley Creek which enters the Brisbane River, and the Logan and Albert River estuaries that empty directly into Moreton Bay, where deterioration to mangrove and seagrass areas has been recorded.

Federal funding again began to influence this situation in the late 1990s; the major criterion for grants under the Coasts and Clean Seas program is the reduction of marine pollution. New treatment schemes, together with aquifer storage and reuse, indicate the beginning of a change in a situation that has arisen from 40 years of urban coastal expansion. The national State of the Marine Environment Report (Zann 1995) showed the need for an expensive continuing program of remediation in coastal urban infrastructure. Revised planning codes to ensure minimal marine disposal are essential to prevent a compounding of the impacts.

Urban spread along the coast has also been accompanied by marked changes in run-off from the rural and urban stormwater systems. Farm drain systems and urban surfaces reduce infiltration and accelerate flow to coastal creeks and to the sea, leading to higher flood peaks and greater water and sediment discharge. This process is at its peak at the time of building construction (Wolman \& Schick 1967). The Willunga Basin in South Australia provides a case study of change through clearance, grazing, horticultural development and coastal urban growth. 


\section{Box 3.1 Willunga Basin}

The district was cleared of native scrub shortly after European invasion in the 1840 s, to be followed by a long, productive period of wheat farming and grazing. In the 1900s almond growing and viticulture began its growth to its modern preeminence in the Basin. During this period coastal swamps were drained and the run-off from the Willunga Scarp was directed to the sea, the flow supplemented by drains from the paddocks. Much water that formerly infiltrated and fed the groundwater is now discharged directly to the sea. Along the coast Adelaide's outer southern suburbs have spread in a narrow strip. As a result of these land use changes, surface water run-off to the Gulf has been greatly increased, as shown in table 3.5. The right-hand column of the table shows the anticipated future increase in run-off as the coastal suburbs consolidate and grow.

Table 3.5 Various estimates of run-off (ML/year) from the Willunga Basin, under different development scenarios

\begin{tabular}{lllll}
\hline Stream & Pre-clearance & $\begin{array}{l}\text { Cleared, } \\
\text { pre-urban }\end{array}$ & Present & $\begin{array}{l}\text { Ultimate } \\
\text { development } \\
\text { scenario }\end{array}$ \\
\hline Pedler Creek & 2600 & 5395 & 5883 & 6610 \\
Maslins Creek & 900 & 1584 & 1701 & 2180 \\
Port Willunga Creek & 700 & 1176 & 1611 & 2670 \\
Washpool Drain & 690 & 1751 & 1977 & 2400 \\
Sellicks Creek & 360 & 1657 & 1660 & 1290 \\
\hline
\end{tabular}

Source: Hale 1997, p. 35

These estimates were obtained from sources that estimated pre-clearance flows through comparison with other creeks, and using surface run-off coefficients.

The table shows doubling of total run-off in today's situation, but does not reflect sharp flood peaks of fast run-off, nor the raised sediment load of high flows, which affect the Aquatic Reserves, Aldinga Reef and Noarlunga Reef.

The effect of storm drain construction on coastal dunes can be spectacular, especially at a high-energy beach subject to heavy rainstorms, as the following account from Noosa in Queensland testifies:

Sunshine Beach is the northern end of the strip of sandy coastline that extends from the Noosa National Park southwards to Coolum. Behind the beach there is a triangular sand mass having dunes which rise about 250 feet above sea level. Much of 
this sand mass was freeholded early in the century, but remained undeveloped until about 20 years ago.

Since then, seaside development has progressed at an accelerating rate so that there are now several miles of roads and more than 100 houses in the area. Most of this development has occurred in the last ten years and it is in the latter part of this period that we have witnessed the predictable effects of discharging stormwater on to or near the beach.

Instead of falling on to vegetated dunes where it can be harmlessly absorbed and discharged later into swamps at the rear of the dunes, rain now falls on to impervious road surfaces where it is concentrated by kerbing and channelling into a few outlets located on or near the beach. So instead of a gradual flow to the sea by means of the existing creeks, there is now an explosive discharge every time rain occurs. When this is combined with storm surge, as it so often is, the results can be catastrophic.

Before Sunshine Beach was developed there were four natural creeks which carried water steadily all the year round from the swamps. There are now six additional outlets, all of which have been associated at some time or another during the past three years with severe scouring. (Three examples chosen.)

'The first outlet was damaged when Cyclone 'Daisy' struck the coastline in February 1972. This outlet was originally constructed so that stormwater was discharged into a depression 100 feet behind the foredune. Instead of being absorbed into the depression, as was intended, concentrated stormwater rapidly filled it, overtopped the dune and flowed in a torrent towards the ocean, which meanwhile entered the scour and enlarged it to a depth of 15 feet and a width of 20 feet.

The second outlet was grafted into a seepage line behind two dunes which, when it ran under normal conditions, carried only a minimal flow of water. It survived until May 1973, when stormwater from a rain depression suddenly caused it to collapse right back to the road. At the same time, a scour, 20 feet deep, formed in front of it, right down to beach level, and much of the foredune disappeared.

The third outlet originally carried storm water across the beach to highwater. It began breaking up with Cyclone 'Daisy' and with each storm it disintegrated further as lengths of pipe broke away and lay on the beach. Finally, the pipe fractured beneath the road some distance away during heavy rain and formed a completely new scour, 150 feet long, as the water forced its way through to the ocean.

The story of these three stormwater outlets illustrates graphically the failure of three different methods of storm water disposal. In each case the fault lay in directing storm water from sub-divisions directly towards the sea, in underestimating the volume and the force of the stormwater discharge, and in not anticipating the force of the accompanying storm surge. Consequently, whether the water was conveyed to 
a depression in the dunes, channelled into a seepage line or taken directly to the beach, the effect was the same, namely gross overloading at the outlet, with severe scouring and local destruction of the foredune, all of which are factors which contribute needlessly to beach erosion.

'Beach Conservation' 21, Beach Protection Authority, Queensland (1975)

Experiences such as this have caused many coastal management authorities around Australia to look seriously at rerouting piped flows inland, to avoid the problems of discharge through the dunes or across the beach. However, this may not always be practicable. Thus, examination of the alternatives to a proposed piped discharge of farm drainage waters from near Kingston in the south-east of South Australia, left little choice but a pipeline over the Coorong lagoon and through the Younghusband Peninsula, to exit 100 metres back from the shore among aeolianite and modern dunes. An average coastal recession of $1.5 \mathrm{~m} /$ year, calculated from land title surveys of 1890 and 1990, is an added hazard to the structure at this particular location.

Rapid urbanisation in low-lying coastal land in New South Wales and southern Queensland has lead to unexpected drainage impacts, which have been the focus of considerable recent research. Acid sulfate soils-soils containing iron sulfides - accumulated in some low-lying coastal sediments following the sea level rise at the end of the postglacial marine transgression. When the sea inundated coastal sediments, sulfates in the seawater combined with iron oxides and organic matter in the sediments, producing quantities of iron sulfides.

It has been estimated that there are 2 million ha of potential acid sulfate soils throughout the coastal lands of all Australian states. While these soils and sediments are waterlogged the iron sulfides come in contact with the air on very rare occasions, but where excavation or drainage has exposed these sediments to the air the resulting oxidation has produced quantities of sulfuric acid. Large amounts of acid groundwater may thus be released to estuarine streams, affecting estuarine biota. In recent years, incidents of fish kills in New South Wales and Queensland estuaries have been linked to adjacent clearance and drainage for development, such as housing, marina development or farm improvement. The release of acid from drained acid sulfate soils in slow-draining clays can continue for decades. Current management action involves identification of potential areas and the development of drainage techniques to minimise acid release. The CSIRO and state government agencies are involved in disseminating advice on this problem. 


\section{Conclusions}

There is good evidence of continuing strong population growth in nonmetropolitan coastal areas in the south-east and far south-west of Australia.

If conservation and recreation values are not to be further compromised, serious planning action has to be carried out. The Resource Assessment Commission's Coastal Zone Inquiry stated that the main source of coastal problems is coastal sprawl, leading to unintended degradation (RAC 1993a, p. 104). Most states have a multiple use coastal strategy, which seeks to balance conservation and recreational values with residential and economic development. The Coastal Zone Inquiry Final Report implies that this can be done through 'integrated planning' and that the competing uses can be reconciled. The Green Cities planning review (AURDR 1995) took the view that this is not possible and choices must be made. 'The experience with coastal management in Australia is that they (i.e. competing uses) frequently cannot be reconciled and that if suburban sprawl is to be stopped, priority must be accorded to recreational and conservation values' (AURDR 1995, p. 177). In order to stem the loss of conservation and recreation values, it is necessary both to accommodate people more sensitively at the coast and to provide living space inland. Actions of this kind require a strategic approach by all tiers of government.

Many planning authorities in Australia and overseas have taken the important first step of 'articulating strategic planning objectives that give high priority to preserving coastal environments'. These may go on to require local plans to reflect this priority. Essentially it is necessary to require that existing settlements will not expand along the coast and that coastal areas will be reserves or in broad acre farming. This has broken down often because local plans do not conform to strategic directions, because earlier inappropriate zonings are too expensive to revoke, or because of the perception that individual non-conforming decisions will not affect the broader strategic approach. Many state and national reviews have commented on this situation (most notably the 'Injured Coastline' report, HORSCERA 1991), but the trend of sprawl along the coast has not been reversed. While all tiers of government are involved, it seems that strong national leadership may be necessary to budge this apparently intractable problem. Within the constitutional powers of the parties, it is possible for the Commonwealth to establish that the future of coastal land is of national priority, to assist with funding for the repurchase of developments that have been sited inappropriately, and for the purchase or reservation of areas of valuable coastal land. 


\title{
Catchment to the coast
}

\begin{abstract}
Australian coastal ecosystems are particularly vulnerable to eutrophication and sedimentation as they evolved under very low nutrient and sediment regimes and are widely dominated by nutrient sensitive corals in the north, and seagrass in the south. Estuaries and coastal lagoons whose upper river catchments have been cleared for intensive agriculture and whose lower reaches are subject to major urban and industrial developments are at particular risk.
\end{abstract}

Zann (1995), p. 55

Although much of the Western Australian and South Australian coasts have virtually no run-off to the sea, coastal catchments discharge to the sea at least seasonally around the south-eastern, north-eastern and northern coasts of the continent (see chapter 2). The impact in the coastal zone of pollutants within this surface and subsurface flow, gathered through natural drainage networks, farm drains, and stormwater drains from rural and peri-urban catchments, is the subject of this section. Within these catchments, land-use changes alter total discharge, flow regime, sediment and nutrient discharge, salinity and trace element concentration in catchment waters.

The gathering of pollutants across catchment lands is referred to as diffuse source pollution. Within Australia this pollution load is often unknown because of limited monitoring. Smith (1998, p. 75) commented: 'Notwithstanding the almost universal warnings of declining quality from studies (mainly funded by government agencies) that cover every aspect of water quality, monitoring of the differing forms of agricultural pollution is little short of a national disgrace.'

Pollution from specific sources, such as a sewage treatment works or a quarry, is known as 'point source pollution'. The amount of pollutants from such sources are often known, although the monitoring of impacts remains sporadic to rare.

The extent to which pollution from catchments affects estuarine and nearshore waters depends on the volume of the receiving waters, seasonality, and flushing time, as well as the resilience of the biota. Localised impact may often be readily apparent after a large flow, while more widespread slow change may be much harder to detect.

\section{Sediment load}

Before European settlement and clearance, river flow in coastal catchments was more even, and flood peaks were lower. Most commentators estimate that 
sediment discharge by rivers to the marine environment was much lower, and that the increase following the institution of European farming practices was of the order 2-10 times.

While the amounts of soil loss would vary greatly with many factors, but especially soil type, slope and rainfall intensity, clearance of native vegetation has everywhere been a major precursor to erosion.

Table 3.6 Land cover change in Australia ('000 km²), 1788 to 1988 , by major vegetation types

\begin{tabular}{lll}
\hline Vegetation type & Area in 1788 (km2) & Area in 1988 (km2) \\
\hline Forest & 690000 & 390000 \\
Woodland & 1570000 & 1070000 \\
Open Woodland & 1650000 & 2000000 \\
Shrubland & 3080000 & 2880000 \\
Grassland/ Pasture & 500000 & 1150000 \\
\hline
\end{tabular}

Clearance led to degradation of the soil structure through loss of organic matter and surface packing, infiltration was reduced and run-off increased, leading to erosion through sheet wash, stream bank erosion and gullying. The major disturbance of the native vegetation/soil complex, which had formerly held the soil on the land, resulted in major loss of topsoil within the catchments of humid Australia. Since vegetation cover is vital for soil retention, land use affects the erosion rate: because many factors are involved a great range of sediment yield values are found. Some indicative values are given in table 3.7. Wasson (1997)

Table 3.7 Soil loss on sloping land

\begin{tabular}{lll}
\hline Land management system & Region & $\begin{array}{l}\text { Soil loss on sloping } \\
\text { land (t/ha/year) }\end{array}$ \\
\hline $\begin{array}{l}\text { Tropical cropping, e.g. } \\
\text { sugar, pineapple }\end{array}$ & Queensland, NT & $100-500$ \\
Cereal cropping & Southern Queensland, South Australia & $1-50$ \\
Forested catchments & South-eastern Australia & $0-11$ \\
Pastures (well managed) & Southern Australia & $50-100$ \\
Bare fallow & Southern Australia & $50-100$ \\
\hline
\end{tabular}

${ }^{1} 10-50$ after bushfires 
estimated that currently the total yield of sediments delivered to the coast is 244 million tonnes/year.

However, land use and vegetation cover are only two of the factors affecting sediment quantities delivered to the coast. Soil loss occurs through gullying, stream bank erosion and sheet and rill erosion. Networks of gullies often form quickly on cleared land in humid Australia, with the networks enlarging for decades until they reach maturity. Estimates suggest that gullies (while their networks are growing) may well be the most important form of erosion: in the uplands of New South Wales and Victoria, gullied catchments yield about eight times more sediment than ungullied ones, regardless of land use (Neil \& Galloway 1989).

Wasson (1997) noted that in small catchments sediment yield varies with hill slope and form. Thus a steep hillslope with gullies leading straight to a creek may deliver sediment rapidly to the creek, but where the gully leads to a floodplain the storage of sediment within the floodplain may be of the order of hundreds of years. Changes in run-off, and consequently river discharge, also have channel effects, altering channel slope and pattern. Thus, for example, a rise in discharge will usually lead to channel widening, a greater meander curve and a greater meander amplitude. Channel changes erode materials stored in the valley floor and floodplain; the silts and clays eroded in this way are moved rapidly through the system to estuaries and the sea, while the sands and gravels move more slowly in the form of slugs of material transported at times of flood. The journey time of such coarse sediment slugs to the sea may be slow, but because of the sediment bulk the effects may be locally overwhelming for estuarine and marine life forms. Very large bodies of coarse sediment may be moved in stages down rivers from sand and gravel works and other types of mining. The 1996 State of the Environment Report (SEAC 1996, p. 7-15) mapped areas of major channel change in south-eastern Australia. The incision of valley floors was reported throughout the south-eastern highlands of New South Wales and Victoria, mainly in the headwaters of the Murray-Darling catchment. Channel widening was reported on the slopes and coastal plains of New South Wales. River changes associated with sand and gravel works are marked around Sydney and Brisbane.

\section{Concentration of suspended solids in estuaries and nearshore waters}

To the casual observer, turbidity in marine waters is one of its more obvious qualities. We quickly notice the outflow of muddy river waters, or the plume of sediment behind a dredge. The term turbidity refers to suspended material: silt, clay, organic fragments, microalgae and plankton. Turbidity is measured by fil- 
tration to give concentration in milligrams per litre, or estimated in nephelometric turbidity units (NTU) using a Secchi disc.

The turbidity of coastal waters varies greatly with circumstances. Large floods deliver large amounts of sediment, but there is not a straightforward relationship of rainfall total and sediment quantity. Heavy rain following drought may cause erosion peaks from land surfaces and creek banks. Building, clearance, fires or dirt road construction often cause erosion, sending giant sediment slugs down channels to the sea.

Dispersion within an estuary or at the shore may depend on local wave turbulence or tidal flow. Measured levels of suspended solids in coastal waters are rare, and those that exist show variation in one location of several orders of magnitude over time. SEAC (1996, p. 8-39) reported measured values in the sheltered waters of Barker Inlet, South Australia, averaging $25 \mathrm{mg} / \mathrm{L}$, falling to $3.5 \mathrm{mg} / \mathrm{L}$ in calm weather and rising to $300 \mathrm{mg} / \mathrm{L}$ in a storm.

\section{Effects of suspended solids on the marine environment}

The major effects of suspended solids on the marine environment are indirect:

- Suspended solids transport nutrients and heavy metals lightly adhering to the surfaces ('adsorbed') of sediment grains. These are released slowly once the sediment has settled in the estuary, coastal wetland or nearshore waters.

- Reduction of light levels, affecting all life forms in coastal waters dependent on photosynthesis, notably coral zooxanthellae, seagrass and algae.

More directly, suspended solids may alter seabed levels and sediment grain sizes, they can smother sedentary life forms and, where stirred up, can clog gills.

\section{Nutrients}

The nature and quantities of nutrient pollutants varies greatly from catchment to catchment, depending on land use, geology, and annual water regime; this is illustrated by CSIRO estimates of diffuse source pollution from various land uses on Sydney's western urban fringe (see table 3.8). The high generation rates for recently sewered urban land and disturbed land is striking, and illustrates that an early effect of development is to contribute a sharp rise in nutrients to run-off, as well as a peak of sediment in the flow.

It should be emphasised that a change in nutrient levels in surface waters following land use change varies greatly with both soil type and management practice. Levels of fertiliser application are now worked out carefully because of the long-term rise in fertiliser costs, but the retention of nutrients within the paddock may also depend on subtleties of farm water management, varying 
Table 3.8 Diffuse source nutrient generation rates for various land uses in the Hawkesbury-Nepean Basin

\begin{tabular}{|c|c|c|}
\hline Land use & Phosphorus (kg/ha/year) & $\begin{array}{l}\text { Nitrogen } \\
\text { (kg/ha/year) }\end{array}$ \\
\hline Bushland & $0.10[+/-] 0.10$ & $1.50[+/-] 0.50$ \\
\hline Established sewered urban & $1.30[+/-] 0.40$ & $5.0[+/-] 2.0$ \\
\hline Recent sewered urban and disturbed & $20[+/-] 10$ & $63[+/-] 40$ \\
\hline Unsewered peri-urban & $0.60[+/-] 0.30$ & $4.0[+/-] 3.0$ \\
\hline Industrial and commercial & $1.8[+/-] 0.40$ & $6.0[+/-] 2.0$ \\
\hline Intensive vegetable growing & $8.0[+/-] 4.0$ & $8.0[+/-] 3.0$ \\
\hline Orchards & $0.30[+/-] 0.20$ & $4.70[+/-] 3.0$ \\
\hline Turf farming & $8.0[+/-] 4.0$ & $8.0[+/-] 3.0$ \\
\hline Fertilised grazing & $1.25[+/-] 0.50$ & $8.0[+/-] 4.0$ \\
\hline Unfertilised grazing & $0.25[+/-] 0.10$ & $0.90[+/-] 0.50$ \\
\hline Extensive agriculture & $2.50[+/-] 2.30$ & $12.50[+/-] 12.50$ \\
\hline
\end{tabular}

Source: Marston 1993

greatly from one farm to another. For example, laser levelling on the Lower Murray floodplain grazing lands allows precise adjustment of flood irrigation to minimise return of irrigation waters (and nutrients) to the river, but many farmers do not carry this out. There is a range of social and economic factors leading to the adoption or rejection of this particular practice

The effects of raised nutrient levels on coastal and estuarine waters were discussed earlier in this chapter. Algal and dinoflagellate blooms, and epiphytic algal growth have been widely reported. Zann (1995, p.11) identified raised nutrient levels as a particular concern in many nearshore seagrass meadows.

\section{Case study: The Great Barrier Reef Lagoon}

Concern over reports of locally raised nutrient and sediment concentrations within the inshore parts of the Great Barrier Reef Lagoon and near to a number of island resorts led to a review and recommendations to GBRMPA (Baldwin 1990). This review concluded that locally nutrients had reached concentration levels that have caused detrimental effects to corals elsewhere, but that damage to coral on the Reef could not conclusively be assigned to this cause. Thus further research was needed to clarify this issue.

Point-source pollution from discharges at island and coastal resorts and pontoons within the World Heritage Area was detailed by the review, which proposed that these be dealt with by regulation. The State of the Environment 
Table 3.9 Estimated average sediment yields (million tonnes/yr) to Great Barrier Reef Lagoon

\begin{tabular}{llllll}
\hline Catchment & $\begin{array}{l}\text { Area } \\
\left(\mathrm{km}^{2}\right)\end{array}$ & $\begin{array}{l}\text { Moss et al. } \\
(1993)\end{array}$ & $\begin{array}{l}\text { Neil \& Yu } \\
(1996), \\
\text { natural }\end{array}$ & $\begin{array}{l}\text { Neil\& Yu } \\
(1996), \\
\text { current }\end{array}$ & $\begin{array}{l}\text { Ratio of } \\
\text { current to } \\
\text { natural }\end{array}$ \\
\hline Burnett-Kolan & 39470 & 0.724 & 0.641 & 2.381 & 3.7 \\
Curtis Coast & 9225 & 0.374 & 0.133 & 0.476 & 3.6 \\
Fitzroy & 142645 & 1.774 & 2.57 & 10.466 & 4.1 \\
Shoalwater Bay & 11270 & 0.924 & 0.166 & 0.568 & 3.4 \\
Pioneer-0'Connell & 3925 & 0.657 & 0.064 & 0.24 & 3.8 \\
Proserpine & 2485 & 0.349 & 0.039 & 0.132 & 3.4 \\
Don & 3985 & 0.175 & 0.057 & 0.225 & 3.9 \\
Burdekin-Haughton & 133510 & 2.711 & 2.116 & 8.52 & 4.0 \\
Ross-Black & 2890 & 0.265 & 0.043 & 0.133 & 3.1 \\
Tully-Murray & 2825 & 0.66 & 0.069 & 0.124 & 1.8 \\
Herbert & 10130 & 0.624 & 0.155 & 0.536 & 3.5 \\
Johnstone & 2330 & 0.582 & 0.056 & 0.159 & 2.8 \\
Mulgrave-Russell & 2020 & 0.521 & 0.05 & 0.137 & 2.7 \\
Barron & 2175 & 0.137 & 0.035 & 0.094 & 2.7 \\
Mossman-Daintree & 2615 & 0.528 & 0.06 & 0.096 & 1.6 \\
North-east Cape York & 43300 & 2.387 & 0.649 & 2.008 & 3.1 \\
Total & 450515 & 15.25 & 7.35 & 28.03 & 3.8 \\
\hline
\end{tabular}

Report for the Reef 1998 (p.110) reported that as a result of regulation 'most outfalls within the Park' do not release effluent that is not tertiary treated to the marine environment.

The review saw terrestrial run-off as a major external source of nutrients to Reef waters, and stated that further investigation and regulation would also be needed in this area. Moss et al. (1993), Neil \& Yu (1995), and Mitchell and Furnas (1997) have undertaken further work on sediment and nutrient discharge to the Lagoon, but variability between the different sets of monitoring and estimates remains large. Wasson (1997) suggested that further monitoring is needed to achieve focused and targeted catchment management. It is clear that land use practices and catchment management have a significant impact on the water quality of the rivers discharging to the Great Barrier Reef Lagoon, but the key areas contributing to the sediment and nutrient levels have yet to be defined.

Sixteen sizeable coastal catchments between Bundaberg and Cape York drain to the Lagoon (table 3.9). 
It appears that the current sediment yield is about two to four times the natural yield, and that catchments with the largest pristine and timbered areas (Tully-Murray and Mossman-Daintree both about 60\% uncleared) show the least increase. The major land use in the catchments listed above is cattle grazing. The two very large catchments (the Burdekin and the Fitzroy together make up over half the area draining to the reef), which are both used almost entirely for grazing, show an increase of about 300\% in sediment yield.

Wasson (1997) noted that there was a variation of approximately three times in contemporary estimates of quantities of phosphorus and nitrogen carried by rivers to the Reef, and concluded that ongoing monitoring is essential. One difficulty in assessing change and trends in river discharge and sediment and nutrient concentrations is the great natural variability. There is a large variation in total seasonal rainfall, and in the frequency of intense rainfall events, over the years, so long-term monitoring is necessary to clarify change as well as to calibrate models of catchment behaviour.

Locally there are some indications of changed water quality within the Lagoon, but there appears to be no clearcut evidence of degradation as a result of land based discharges, except at specific locations or associated with particular events. The State of the Environment Report for the Great Barrier Reef (Wachenfeld et al. 1998, p. 31) stated that raised nutrient levels can lead to seagrass destruction, but concluded that more detailed monitoring was needed to show the extent of this. The report also noted (p. 42) that low salinity and high turbidity from storm river flows can kill coral: 'In general, terrestrial run off is considered to be one of the greatest potential threats to the Great Barrier Reef, however there are very little data to demonstrate that coral communities have been directly impacted by this threat.' A similar conclusion for macroalgae was reached (p. 35): 'It has been suggested that the abundance of macroalgae on inshore reefs is unnaturally high and is a sign of eutrophication and reef degradation, due to increased sediment and nutrient inputs from the land. However, in the absence of good historical data, it is still uncertain whether current abundances are natural or human induced.' Management implications of this report provide a challenge to all in the careful interpretation of the precautionary principle.

The lagoon is naturally characterised by low nutrient levels. Phytoplankton have been shown to be productive in Reef waters, and nutrients for this productivity are recycled through the mineralisation of organic matter. Nitrogen is added to the system by the $\mathrm{N}$-fixing cyanobacterium Trichodesmium, but the extent of this input has not been quantified. Rivers are the major external source of nutrients to the lagoon. The indications are that river 
waters do not mix extensively through the lagoon: wind-induced currents tend to trap these near to the shore, where they are driven north along the shore to accumulate in embayments. Although the freshwater and sediment plume of very large storm events may rarely extend to the mid to outer reef in low wind conditions (as happened, for example, during Cyclone Sadie in 1994), storm plumes are more usually held near the coast by strong southeast winds.

In inshore waters the prevailing south-east trades, as well as storm events may resuspend sediments within the water column (Wachenfeld et al. 1998, p. 13); nutrient release from re-suspended sediment stimulates phytoplankton growth and chlorophyll concentrations may be raised to three times normal background levels during strong trades and 30 times following cyclones. Measurements of suspended solids, phosphate and nitrate levels in coastal waters near Cairns from 1989 to 1995 show distinct variability over time, and no trend. Chlorophyll concentration in the central Reef, measured from 1975 to 1995, is also highly variable, but shows no trend up or down over that time. The outcome of a decade of monitoring and debate is the adoption in 2002 of a 'Water Quality Action Plan' by the Great Barrier Reef Marine Park Authority and the Commonwealth and Queensland governments. This sets pollution reduction targets for 2012 for all reef catchments and processes to achieve the targets.

\section{Case study: The River Murray}

Under natural flows the River Murray was an important source of sediment to the coastal waters off its mouth. Harris (1995, figure 5) estimates that it would deliver on average 30 million tonnes of sediment per year to the sea (compare with the Burdekin, which averages 45 million), thus creating a significant area of near shelf surface sediments not primarily of marine carbonate materials, rarely found between Victoria and north-west Western Australia. This natural discharge has now been altered. Massive clearance and elaborate river regulation have altered flows of water and sediment across and within slopes and floodplains, from river banks and channel floors, so that sediment entrainment, movement and deposition are now quite different from the situation in the mid nineteenth century. Most notably in this context, the River Murray Barrages, completed in 1939, now separate the river and terminal lakes Albert and Alexandrina from the sea.

Shaffron et al. (1990) noted that turbidity varies with flow within the Murray-Darling Basin: turbidity in the Darling was 25 NTU in May 1983 during drought, while in the flood of the following month this rose to 500 NTU. However, average turbidity generally increases downstream (figure 3.2). 
Figure 3.2 River Murray turbidity (median values 1978-88)

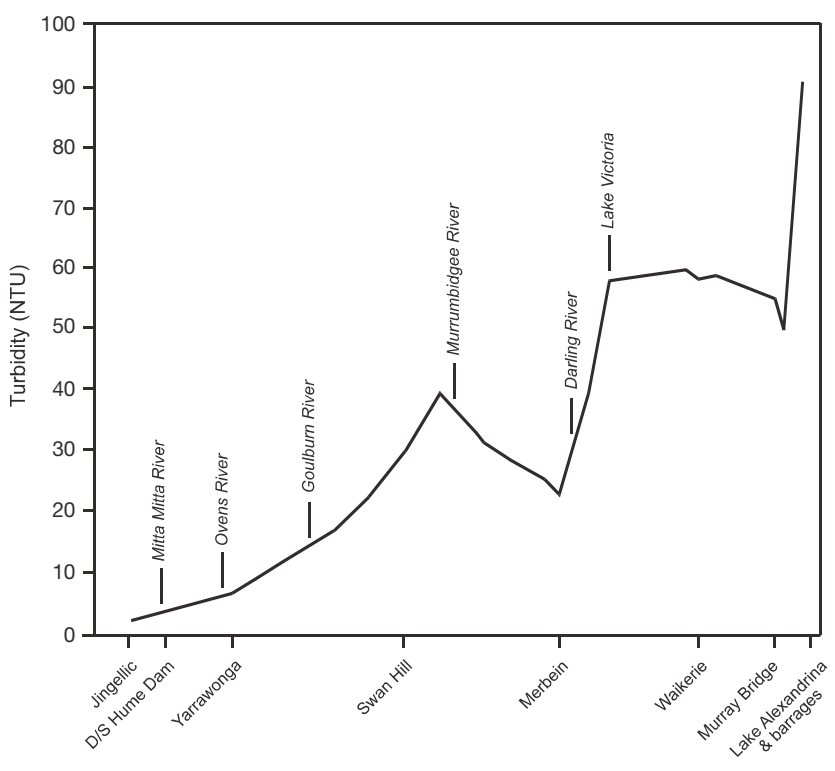

Source: Shaffron et al. 1990, p. 152

While the concentration of suspended sediment increases downstream, water discharge decreases rapidly. This was the case under natural flow, as the waters from the eastern highlands were reduced by the high evaporation conditions of western New South Wales and South Australia. This loss of flow is greatly increased by diversions for agriculture: over half the natural flow is taken up in this way. The extent to which this reduces sediment discharge is uncertain. The greatest sediment transport could be assumed to occur at times of flood. The very largest floods (every 10-20 years) are allowed to flow through the system. However, small to medium size floods, which might occur once or twice a year, have been almost eliminated through river regulation.

Within the Murray-Darling Basin, urban sewage treatment plants are more important sources of nutrients than irrigation drainage or urban stormwater systems. Creagh (1992) noted that 500 tonnes of phosphorus is added to the river annually from treated sewage, irrigation drainage adds 260 tonnes in a wet year and 120 in a dry year, and urban stormwater adds 130 tonnes in a wet year and 60 in dry years. Comparable figures were given for nitrogen: urban sewage treatment plants adds 280 tonnes to the river. While it is clear that nutrient levels in the river are much higher than under natural circumstances, the significance of this to the estuarine and marine areas of the Murray Mouth 
and the Coorong lagoon is uncertain, except in as far as releases from the barrages may often contain algal blooms from the high-nutrient terminal lakes.

Today most sediment from the Murray-Darling Basin is accumulating in the terminal lakes, as well as in the storages constructed throughout the drainage basin. Discharge past the barrages is managed to release large flows and at other times to reduce shoaling at the Murray Mouth. Outflow to the Murray Mouth is now only four fifths of natural flow (Jensen et.al, 2000) and there may be periods of up to five years when no flow is released. 'It appears that closure of the mouth is likely to be a reasonably regular occurrence in the future' (Close 1990, p. 71). The water released from Lake Alexandrina is always turbid, as wind turbulence within the shallow lake resuspends sediment; large numbers of cyanobacteria are also common in these waters. These releases occur as flows of brown turbid water through the estuary and to the sea, and appear to remain in the nearshore zone.

A current review of the operation of the 'Cap' (on diversions in the Murray-Darling Basin) suggests that the quantity of fresh water allowed to pass the barrages is critical to the health of the estuarine and Coorong lagoon environment. Whittington et al. (2000) stated that 'salinity is the over-riding determinant of the distribution of plant and animal communities in the Coorong' (and Murray Mouth). During prolonged times of no flow (e.g. the El Niño phase of the early 1980s), salinity rose from seawater levels at the mouth (34 parts per thousand) to four times this value at the far end of the Coorong. Closure of the mouth (and therefore lack of tidal movement) simply exacerbates the problem of lack of fresh water flow, through evaporation effects. Although the Murray Mouth and the Coorong lagoon are Ramsar sites, and since 12 December 2000 have been reserves within the South Australian system, the most significant player in their management may prove to be the Murray-Darling Basin Commission.

The Great Barrier Reef Marine Park Authority and the Murray-Darling Basin Commission are often cited as leading examples of integrated natural resource management programs. Through the published results of monitoring and investigation within these programs it has been possible to indicate some of the impacts of catchment management on coastal areas. For most Australian coastal catchments this is not the case. As the 1996 State of the Environment Report for Australia noted (SEAC 1996), there is a lack of systematic monitoring of our catchment waters. The work on the catchments draining to the Great Barrier Reef Lagoon has shown (Wasson 1997) that detailed work may be needed in order to justify the expensive changes of management needed to reduce pollution. 


\section{Commercial use of coastal waters}

This section focuses on the trends in three important commercial uses of coastal waters in Australia, and their coastal impacts: shipping (particularly the impacts of ballast water), commercial fishing, and the expansion of aquaculture. These three areas are significant in that they are not only associated with several adverse impacts on the coastal and marine environment, but also have high economic value for Australia. In the early 1990s, the Australian Marine Industries and Sciences Council estimated that shipping had a domestic value of \$2212 million, fishing \$360 million and aquaculture \$118 million (1993-1994 values; updated figures from McKinnon 1993, quoted in Wescott 2000). The figures for fishing and aquaculture are likely to be underestimates, given that in the late 1990s the gross economic value of fisheries and aquaculture combined was estimated at $\$ 1.86$ billion (Caton \& McLoughlin 2000). What these figures indicate is that a reduction in such activities is unlikely, so there is a need to focus on management and mitigation of impact. This is, however, confounded by a lack of knowledge about the interactions between these activities and the coastal and marine environment.

\section{Shipping and ballast}

According to the International Maritime Organisation (IMO), 90\% of goods on the international trade market are transported by ships (e.g. by bulk carriers, ore carriers, woodchip carriers and chemical tankers; Kerr 1994, IMO 1998). Shipping activities are particularly significant for Australia, which on an international scale, is the fifth largest user of shipping (ANZECC 1996a), with approximately $98 \%$ of goods transported in this manner (AQIS 1999). The coastal environmental impacts associated with shipping are numerous, and relate primarily to pollution and the transportation of marine species. For example, shipping activities are associated with:

- marine and coastal pollution by the generation and disposal of waste or 'marine debris', with approximately 6500 tonnes discharged into the marine environment from shipping activities each year in Australia (ANZECC 1996a; waste is predominantly characterised by plastics which can, for example, be ingested by birds). Monitoring of the total extent of the problem is difficult, and there is still a lack of information on this issue (ANZECC 1996a)

- marine and coastal pollution by oil or other spills due to accidents or faulty equipment. Oil spills were considered to be a major risk in Australian ports by a government inquiry into human impacts on the coastal environment (Commonwealth of Australia 1991) 
- the transfer of marine species between regions on ships' hulls. Some of these become 'pests' because they foul the hulls, with the accumulation of seaweeds, barnacles and other species (EPA Vic 1999);

- the use of antifouling paints, many of which contain copper and tributyl tin (TBT), although this latter is being phased out (Rooyen 2000). TBT has been described as one of the most toxic pollutants to be released into the marine environment (Foale 1993). The paint prevents organisms from attaching to a ship's hull, to improve speed and fuel economy (EPA Vic 1999). The compounds in these paints, which accumulate in sediments, are highly toxic and have been linked to deaths of rainbow trout eggs, adverse impacts on commercial shellfish farms (e.g. oyster farms in New South Wales), and the development of male characteristics in female snails (otherwise known as 'imposex'; Commonwealth of Australia 1991, Foale 1993, Nias et al. 1993, Rooyen 2000)

- the transfer of marine species between regions by the release of ballast water. The issue of ballast water, which is used in this section as a case study of shipping impacts, is particularly significant and has received increasing attention since the 1970s (Kerr 1994, Paterson 1994, IMO 1998). Ballast can refer to both a solid or a liquid, and is used to provide ship stability and hull strength, and to ensure that the propellers remain submerged when a ship is empty of cargo. Since the 1880 s, sea water rather than solid materials has been used as ballast because of the more efficient uptake and improved ship stability (IMO 1998). Sea water is siphoned and transferred into special holding bays at the start of a ship's journey (when it is empty of cargo), and discharged at the point where cargo is received. As a result, coastal waters (and marine organisms within this water) have been transported between regions around the world.

The introduction of exotic marine species into new regions via ballast water was recognised by the World Bank as 'one of the four major imminent threats' to international waters (Raaymakers 1998, p. 8), and in 1992 it was acknowledged as a 'major international concern' at the United Nations Conference on Environment and Development (IMO 1998). At an international level, approximately 10 billion tonnes of ballast water are transported between coastal regions each year, with the daily transfer of an estimated 3000 species of animals and other organisms (IMO 1998, AQIS 1999). Although only about 3\% of these species will survive in a new location, the IMO noted that it takes only one introduced species to cause major impacts (IMO 1998). Not all introduced organisms will cause environmental problems; those that do have an impact are commonly termed 'pest' species (EPA Vic 1999).

In the Australian context, there are 72 international ports which are affected by the transport of ballast water from approximately 300 overseas 
Figure 3.3 Australian ports affected by ballast

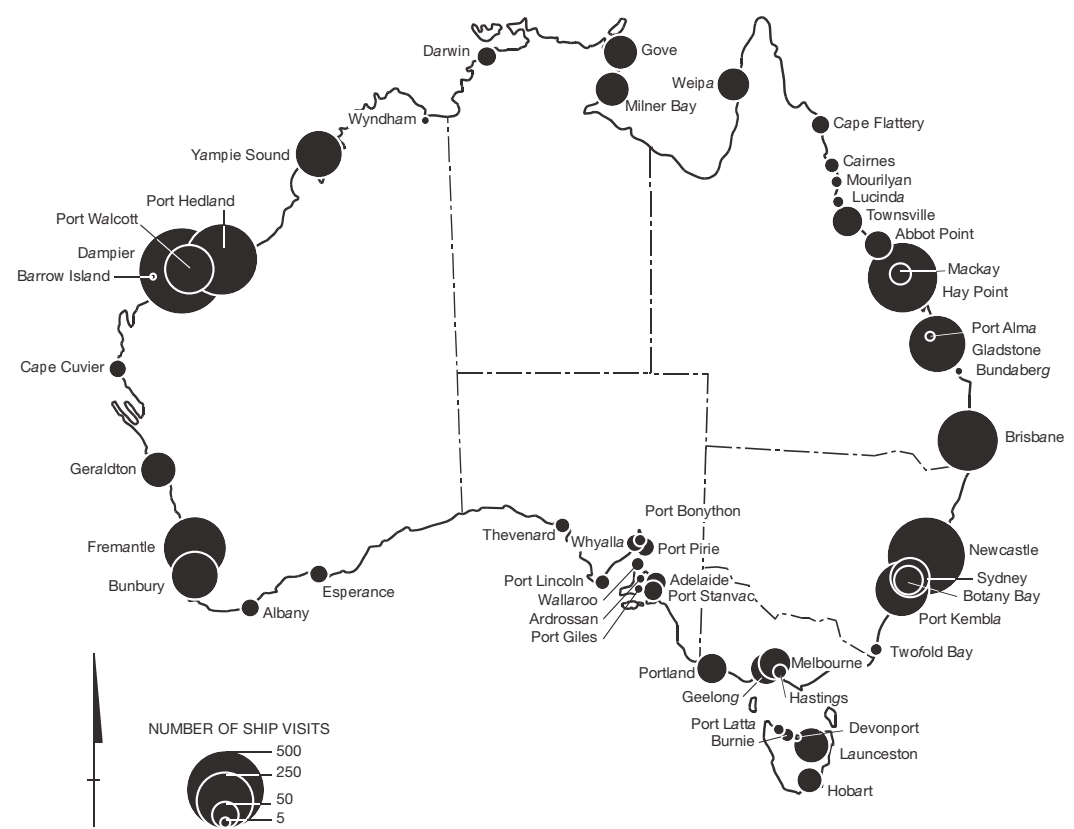

Source: modified from Kerr 1994

ports (McEnnulty et al. 2000, IMO 1998). Figure 3.3 provides an illustration of some of the Australian ports affected by ballast, with the majority of ships visiting ports in Western Australia, Queensland, and New South Wales. Most of the foreign ballast water entering Australian ports, which is estimated at 150 million tonnes each year, is introduced from Asian countries, particularly from Japan (T. Thwaites 1999). The source of coastal ballast in Southeast Asia is frequently polluted, there is limited treatment of sewage discharge, and it often contains aquaculture diseases (Hutchings 1992). Approximately 34 million tonnes of ballast water is also transported between Australian ports via domestic shipping around the Australian coast (Paterson 1994, IMO 1998), and this further serves to spread exotic species arriving from foreign ports.

The extent of the environmental and economic impacts of ballast water and exotic marine species in Australia are still not known, particularly given the lack of efficient monitoring and testing mechanisms for ballast water. There is also uncertainty about how many exotic species have actually been introduced. In the early 1990s, fourteen exotic species were known to have been introduced into Australian coastal waters (Paterson 1994), but in 1997 the Australian Quar- 
antine and Inspection Service (AQIS) suggested that up to 170 species may have been introduced, with ballast water being the main mechanism of transport (IMO 1998; see also Raaymakers 1998). Later, AQIS (1999) and McEnnulty et al. (2000) estimated that at least 200 marine species had been introduced, primarily via ballast and shipping.

Given that surveys have been conducted at only 21 Australian ports, these figures are believed to be an underestimate (McEnnulty et al. 2000). However, only about 12 of the introduced species are considered to be in pest proportions (McEnnulty et al. 2000). A review of each of these species' impacts, trends and management is provided in McEnnulty et al. (2000). Examples of species that have been introduced into Australia include toxic dinoflagellates (e.g. in Tasmania, Port Phillip Bay, and Port Adelaide), European Shore Crab (e.g. in South Australia), sea slugs, Japanese Kelp (e.g. in Tasmania), North Pacific Seastar (e.g. in Tasmania and Victoria), mysid shrimp species, Asian Mussel (e.g. in Perth), polychaete worm species, Japanese Sea Bass, Yellow-fin Goby, and Striped Goby (e.g. in Sydney Harbour, Port Phillip Bay) (Hallegraeff \& Bolch 1991, IMO 1998).

The possible environmental impacts associated with introduced marine pests in Australia and other parts of the world are numerous, and relate to threats to natural marine and coastal ecosystems, aquaculture industries and fishing, human health, and tourism (AQIS 1999). They can include, for example:

- disruption to natural populations and aquaculture, with introduced species occupying the niches of native species, competing for resources, or acting as new predators (EPA Vic 1999). In Tasmania, for example, Japanese Kelp has threatened the abalone industry and oyster and mussel farms (Paterson 1994, IMO 1998, T. Thwaites 1999)

- changes to nutrient pathways and physical environments (e.g. sedimentation by molluscs; EPA Vic 1999)

- $\quad$ spread of diseases, viruses and predators which affect fish species and aquaculture operations (EPA Vic 1999)

- $\quad$ spread of human diseases such as cholera (EPA Vic 1999)

- contamination of seafood which can result in paralytic shellfish poisoning. Contamination arises from toxic dinoflagellates or 'red tide' algal blooms, with impacts on human health, and declines in the diversity and/or abundance of fish and wildlife. Blooms can also have major economic impacts, such as the closure of marine farms and loss of income. For example, 15 shellfish farms were closed for six months in Tasmania due to these blooms, which were believed to have been transported from Japan (Hallegraeff \& Bolch 1991, Hutchings 1992, Paterson 1994, EPA Vic 1999) 
- reduced water quality from toxic algae blooms, and associated impacts on wildlife, human recreation and tourism (EPA Vic 1999).

Port Phillip Bay in Victoria is a particularly significant location in terms of marine species introduced by both ballast and hull fouling, and has been the subject of intensive research (EPA Vic 1999). Victoria receives the greatest number of ships from domestic or coastal shipping (Kerr 1994). According to McEnnulty et al. (2000), 165 introduced marine species have been identified solely in this location, of which eight are of major concern, the remainder having minimal impact (EPA Vic 1999). Those identified as pest species include for instance, the Northern Pacific Seastar, Asian Mussel (a fouling species that displaces native species and alters the physical environment via sedimentation), Japanese Kelp (threatens native algae, is a fouling organism in marine farms, and displaces natives species), and toxic dinoflagellate species (EPA Vic 1999). The Northern Pacific Seastar, which has a population of approximately 30 million in the Bay, was believed to have arrived in the Bay via domestic shipping from Tasmania (Paterson 1994, EPA Vic 1999). Despite attempts to manage the problem, the impacts associated with the seastar have been significant, with economic impacts on aquaculture, predation on bivalve molluscs, and the displacement of native species (Paterson 1994, EPA Vic 1999). They are also threatening the extinction of the Tasmanian Spotted Handfish (AQIS 1999).

The significance of this issue is gradually increasing in Australia and the rest of the world, particularly with the construction of new ports around the world, increases in international shipping movements and in ship sizes (and hence the amount of ballast), and faster travel times, which improves the chances of organisms surviving within the ballast (EPA Vic 1999). Once established, exotic species can proliferate rapidly and are expensive and difficult to control (compared to, for example, waste disposal or oil spills from shipping; IMO 1998, AQIS 1999). For example, in 1999, \$2 million was expended in Darwin to control an outbreak of the Black-striped Mussel that was threatening the multimillion dollar pearl industry (CSIRO 2000).

Australia has been at the forefront in developing voluntary guidelines for control of ballast, beginning in 1990, with an emphasis on prevention rather than clean-up (AQIS 1991, Raaymakers 1998). Guidelines were also prepared by the IMO in 1993 at an international level, but these still have a long way to go in terms of implementation (Paterson 1994; AQIS 1999). The lack of standard compliance to these guidelines by many countries makes it even more difficult for Australia to manage the problem, as marine pests continue to be transported from countries where management guidelines are not applied. 


\section{Commercial fishing}

Like the issue of shipping and ballast water, commercial fishing is a major international concern, with global harvests approximating 84 million tonnes in 1996 (DAFFA 2000). However, unlike shipping in Australia, which ranks fifth on an international scale, commercial fishing in Australia is ranked relatively low (50th to 55th) in terms of fishery production (Kailola et al. 1993, Zann 1995, DAFFA 2000). In the mid 1990s, approximately 200000 tonnes were caught annually in Australian waters, and although at least 3600 species of fish and at least 3000 species of crustaceans and molluscs are known to exist in Australia, less than $10 \%$ are harvested commercially (Kailola et al. 1993, DAFFA 2000, ABS 2002).

Australia thus has a relatively low productivity in commercial fishing, despite having the world's third largest fishing area of approximately 9 million $\mathrm{km}^{2}$, ranging from the coast to 200 nautical miles offshore (Kailola et al 1993, DAFFA 2000). The Australian Fishing Zone (AFZ) is managed by state governments (usually within 3 nautical miles of the high water mark) and by the Commonwealth government (to the 200 nautical mile limit). The primary reason for low productivity in the fishing industry is low nutrient levels in the marine environment (Kailola et al 1993, DAFFA 2000). Nonetheless, commercial fishing still has high economic value for Australia.

Many different areas are fished, including estuaries, mangrove creeks, shallow coastal bays, coral reefs, and the continental shelf and slope (Kailola et al. 1993). In addition to licensed foreign vessels, approximately 9000 commercial fishing vessels operate in the AFZ, with the direct employment of 21000 people and another 4000 in processing (DAFFA 2000). There is also illegal fishing, which is causing some concern in relation to the overexploitation of fish stocks, both in Australia and at a global level with unlawful fishing on the high seas (DAFFA 2000). Targeted species in Australia include 200 species of fish, 60 species of crustaceans, and 30 species of molluscs, but only a small number of species have particularly high economic value, including abalone, rock lobsters and prawns (Kailola et al. 1993, Zann 1995, DAFFA 2000). Trends in commercial fishing by State/Territory jurisdiction are summarised in table 3.10. The greatest economic value for fish species is evident in South Australia, and the greatest value in terms of crustaceans and molluscs is in Western Australia (Caton et al. 2000).

Like ballast, commercial fishing has numerous impacts on the coastal and marine environment, but in the past the focus has tended to be on declining fish stocks and the economic implications for the fishing industry (e.g. Somers 1990). Concerns in the fishing industry have also related primarily to the impacts of declining environmental quality on the fishing industry, rather than the impacts of the fishing industry on coastal and marine ecosystems (Somers 1990). Declin- 
Table 3.10 Commercial fishing by State-approximate annual catch and value

\begin{tabular}{llll}
\hline Jurisdiction & Species & Catch (tonnes) & Value (\$ million) \\
\hline Northern Territory & Fish & 3540 & 14 \\
& Crustaceans & 617 & 7.45 \\
& Molluscs & 190 & 59 \\
New South Wales & Fish & 11400 & 32 \\
& Crustaceans & 3000 & 35 \\
Queensland & Molluscs & 8000 & 47 \\
& Fish & 12000 & 63 \\
South Australia & Crustaceans & 14700 & 160 \\
& Molluscs & 5800 & 25.7 \\
Tasmania & Fish & 14800 & 107 \\
& Crustaceans & 6000 & 116 \\
& Molluscs & 3700 & 36 \\
Victoria & Fish & 25800 & 84 \\
& Crustaceans & 1600 & 48 \\
& Molluscs & 4600 & 82 \\
Western Australia & Fish & 5600 & 25 \\
& Crustaceans & 670 & 20 \\
& Molluscs & 2500 & 53 \\
& Crustaceans & 15800 & 39 \\
& Molluscs & 3200 & 275 \\
& & 231 \\
\hline
\end{tabular}

ing fish stocks have been attributed not only to unsustainable fishing loads through both commercial and recreational fishing, but also to habitat loss arising from land and marine-based water pollution, use of antifouling paint, mangrove and seagrass clearance, and the introduction of pest species and diseases (e.g. through ballast, as discussed above; Commonwealth of Australia 1991, Zann 1995). However, in more recent years the focus has turned toward the indirect impacts of fishing on habitats and broader marine ecosystems (e.g. Turner et al. 1999).

A key indicator of the impacts of commercial fishing is the decline in productivity that has been evident since the 1980s (Commonwealth of Australia 1991, Zann 1995). According to the Commonwealth government, 'Australia appears to have reached or gone beyond the maximum production achievable in the majority of its fisheries' (Commonwealth of Australia 1991, p. 17). Many marine species that are commercially harvested in Australia are fully exploited or overexploited, although knowledge about the conservation status of many 
Figure 3.4 Status of fisheries wholly or jointly managed by the Commonwealth government

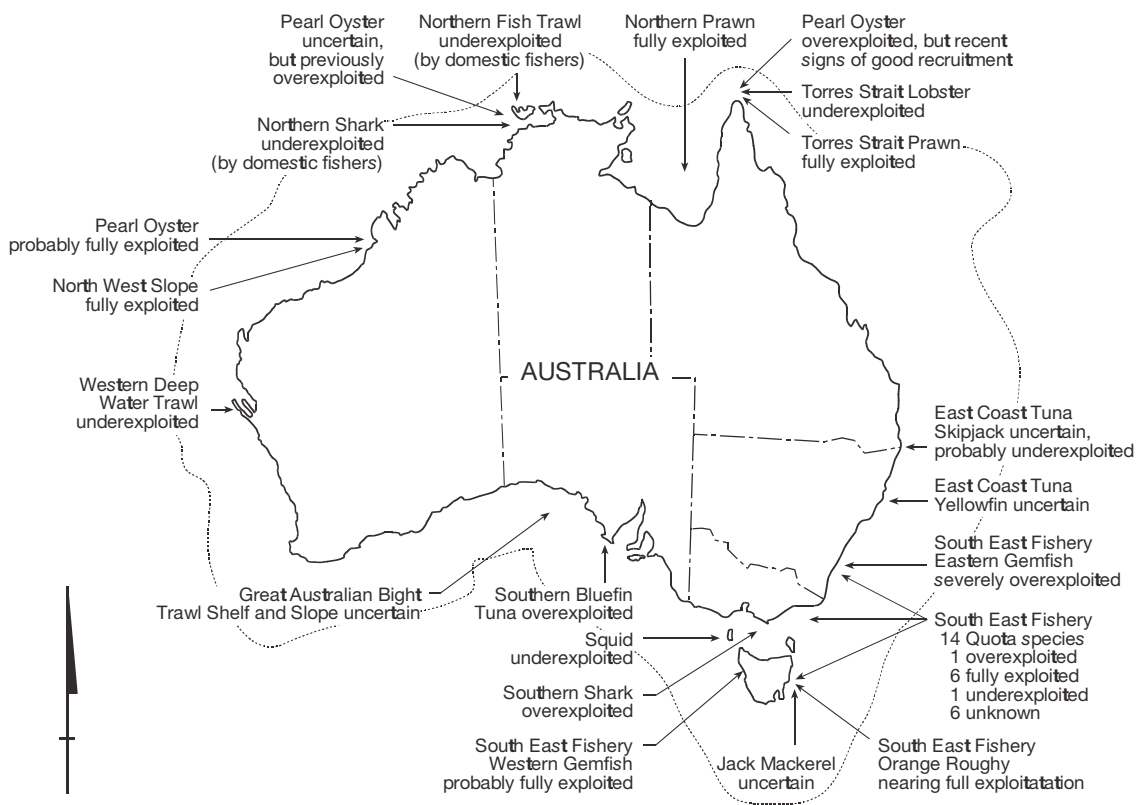

Source: Zann 1995

species is still limited (Caton \& McLoughlin 2000, DAFFA 2000). Zann (1995) noted, for example, that of 100 fisheries the status of 59 were unknown, 23 were fully fished, and 9 were overfished. Figure 3.4, which illustrates the status of commercial fisheries managed by the Commonwealth or jointly managed with the states, indicates that species such as the Southern Bluefin Tuna, Southern Shark, Eastern Gemfish, and Pearl Oyster are already overexploited in Australia (Zann 1995). Southern Bluefin Tuna stocks, for example, have declined to the point where less than $10 \%$ of the stock that was available in the 1970s remains (DAFFA 2000).

Depending on the fishing technique used (e.g. trawling, long-line fishing, lobster pots) and the particular environment they are used in, a number of indirect ecological effects will also occur. (For a summary of the effects of different techniques, see BRS 1999.) However, there is still much uncertainty about the significance, distribution and extent of the impacts, and the implications for coastal ecosystems over the longer term. In broad terms it is known that:

- Trawling (and anchors) can change the sea bed and benthic habitats as the net is dragged (Somers 1990, Laurenson et al. 1993, NRE 1998, BRS 1999, 
Turner et al. 1999). During this process, biological features (e.g. seagrasses, sponges, animals) and topographical features are removed or modified, and sediment dynamics, chemistry, and nutrient cycles are changed (Laurenson et al. 1993, Harris \& Ward 1999, Turner et al. 1999). In this way, habitats are destroyed and landscape patterns become fragmented

- Commercial fishing can change community compositions by the removal of natural predators or competition, thus encouraging the development of other species (Harris \& Ward 1999)

- Fishing of species lower on the food chain affects species higher in the food chain, through a loss or decline in food sources (NRE 1998, BRS 1999)

- Long-line fishing is linked to declines in bird populations, particularly the albatross species which is attracted to fishing lines and become entangled in them (BRS 1999, Harris \& Ward 1999)

- Like shipping, fishing generates considerable waste or marine debris such as plastics, ropes, nets and line, oils, and other waste discharges (Jones 1994, ANZECC 1996a, BRS 1999). At a global level, estimates of the waste associated with commercial fishing range from 1350 tonnes to 135000 tonnes per year, which highlights the considerable uncertainty about the actual quantities discharged into the marine environment (Jones 1994). The main effects of this waste, particularly plastics, include entanglement and often death of wildlife (e.g. dolphins, seals, whales), ingestion by wildlife (which prevents normal digestion), hazards to vessels and divers, and littering of coasts (Jones 1994; BRS 1999)

- Loss in marine species is caused by 'by-catch', which is incidental species caught in the fishing process, and also results from 'ghost fishing' whereby lost equipment continues to entrap marine species (BRS 1999).

The issue of by-catch is becoming an increasingly significant one both in Australia and at a global level (for Australian studies in this area, refer Gray et al 1990; Harris \& Poiner 1990; Poiner et al 1990; Wassenberg \& Hill 1990; Harris \& Ward 1999). By-catch 'includes all material, living or non-living, other than target species which is caught while fishing' (DAFFA 2000). At a global level, it has been estimated that 1.4 million tonnes of by-catch is caught each year from prawn trawling alone (Saila 1983 in Harris \& Poiner 1990). In a study on trawling in south-western Australia, it was discovered that in a harvest of 354 tonnes, 224 tonnes was discarded by-catch, and of this $67 \%$ was not expected to survive (Laurenson et al. 1993). In eight Commonwealth fisheries with a total catch of 61000 tonnes each year, between 47000 and 89000 tonnes of by-catch was discarded (Harris \& Ward 1999).

Although the direct links between marine species' decline and by-catch, and its significance, is still not clear, by-catch can threaten endangered species (e.g. 
turtles, dolphins, albatrosses, seals, seahorses, sharks, sawfish), and also has economic implications for other fisheries (i.e. where discarded by-catch in one fishery is the target species in another fishery; Gray et al. 1990, BRS 1999, Harris \& Ward 1999). This discarded by-catch also alters the food chain by removing benthic food sources and by adding an 'artificial' source of food which is transported from the sea bottom to the surface (Hill \& Wassenberg 1990, Harris \& Ward 1999). This in turn leads to increases in scavenger populations, and some species are now dependent on discarded by-catch (Wassenberg \& Hill 1990).

Given the uncertainty associated with the significance of many of these impacts, commercial fishing is becoming the subject of increasing research, monitoring and management. Moreover, there has been an increasing emphasis on aquaculture to overcome some of the problems of overfishing and declining wild stocks.

\section{Aquaculture}

Aquaculture has been around for thousands of years (Clarke 1996), but it was still a relatively new and growing industry in Australia in the early 1990s (Commonwealth of Australia 1991, Paterson 1994). Aquaculture has been defined as the "farming of aquatic organisms, including fish, molluscs, crustaceans, and aquatic plants. It includes the breeding, hatching, rearing and cultivation for sale of all aquatic organisms' (SARDI 1996, p. 1). It can be conducted in both fresh or marine water, and marine-based aquaculture is often referred to as 'mariculture' (DNRE 1998).

Some $25 \%$ of the world's fisheries production is derived from aquaculture, with approximately 26 million metric tonnes produced per year in the 1990s (DAFFA 2000). However, like commercial fishing in Australia, the productivity of Australia's aquaculture industry is low in terms of global standards, and contributes only $0.6 \%$ to world production (Carvalho \& Clarke 1998). Nonetheless, the industry is rapidly expanding, with a productivity increase of approximately $15 \%$ each year (Cordover et al. 2000). In South Australia, aquaculture has been described as a 'new gold mine' for primary industry (Marchant 1997, p. 29).

In 1997-98, 6000 people were employed in Australia's aquaculture industry, 27000 tonnes of aquaculture products were produced, and the value of aquaculture was placed at approximately $\$ 490$ million dollars (Gordon 1999, Caton \& McLoughlin 2000, DAFFA 2000). At a national level, the aim was to reach a value of $\$ 2.5$ billion by the year 2010 . Like commercial fishing, only a small number of species has particularly high economic value, including Pearl Oysters, Atlantic Salmon, Southern Bluefin Tuna, prawns and edible oysters (Gordon 
1999, Cordover et al. 2000). The fishery that has undergone the most rapid expansion is the Southern Bluefin Tuna fishery, which is significant in that wild stocks are becoming severely depleted (BRS 1999).

While there is still a relatively low productivity, Australia has an advantage over many other countries because of the length of the coastline, limited pollution, the variety of climates, and lack of major diseases (Commonwealth of Australia 1991). The location and types of aquaculture farms around Australia vary, depending on the local environmental conditions and the availability of food supplies and land and water resources. Unlike most overseas operations, which are primarily based in fresh water, most aquaculture in Australia (95\%) is based in coastal or estuarine waters (Cordover et al. 2000). Table 3.11 summarises the tonnage, economic value, and key species within

Table 3.11 Aquaculture by state or territory, showing approximate catch and value in 1997-98

\begin{tabular}{|c|c|c|c|}
\hline Jurisdiction & $\begin{array}{l}\text { Examples of key species } \\
\text { (includes some } \\
\text { freshwater species) }\end{array}$ & Catch (tonnes) & Value ( $\$$ million) \\
\hline Northern Territory & $\begin{array}{l}\text { Pearl Oyster } \\
\text { Saltwater Crocodile }\end{array}$ & n.a. & 43 \\
\hline NSW & $\begin{array}{l}\text { Sydney Rock Oyster } \\
\text { Black Tiger Prawn } \\
\text { Rainbow Trout } \\
\text { Silver Perch } \\
\text { Yabbies }\end{array}$ & n.a. & 50 \\
\hline Queensland & $\begin{array}{l}\text { Prawns } \\
\text { Barramundi }\end{array}$ & 2300 & 38 \\
\hline South Australia & $\begin{array}{l}\text { Southern Bluefin Tuna } \\
\text { Pacific Oyster }\end{array}$ & 7285 & 100 \\
\hline Tasmania & $\begin{array}{l}\text { Atlantic Salmon } \\
\text { Pacific Oyster } \\
\text { Trout }\end{array}$ & 9240 & 75 \\
\hline Victoria & $\begin{array}{l}\text { Rainbow Trout } \\
\text { Blue Mussel } \\
\text { Eels }\end{array}$ & 1900 & 13.7 \\
\hline Western Australia & $\begin{array}{l}\text { Blue Mussel } \\
\text { Yabbies } \\
\text { Pearl Oyster }\end{array}$ & 966 & 195 \\
\hline
\end{tabular}

n.a. = not available 
Australia's states and territories. The greatest economic value is generated in South Australia, and the greatest tonnage is produced in Tasmania.

Marine species in aquaculture can be either suspended in the water or placed on the seabed, and either contained within ponds (e.g. prawns), cages (e.g. tuna), trays (e.g. oysters in intertidal areas), raceways or recirculating systems (Cordover et al. 2000). Five types of farming techniques exist (Mather 1993, quoted in Clarke 1996):

- intensive aquaculture (fully controlled environment, artificial supplies of food and energy, concentrated in small area)

- semi-intensive aquaculture (most conditions controlled, supplementary feeding, high stocking density)

- extensive aquaculture (no food or energy supplied, low stocking density)

- polyculture (stocking variety of species)

- integrated aquaculture-agriculture (aquaculture integrated with agricultural activities).

Some species are collected from the wild and then farmed (e.g. eel larvae, mussels, Sydney Rock Oysters, Southern Bluefin Tuna), while others are fully domesticated (e.g. Pearl Oysters, salmon, Pacific Oysters; Cordover et al. 2000).

In addition to the economic benefits of aquaculture, a number of other advantages have been cited, including reduction in fishing pressures, the re-establishment of exploited species, improvements in scientific knowledge about wild stocks, and the establishment of programs to selectively breed resistance to diseases or to increase productivity (Zann 1995, DNRE 1998a, Cordover et al. 2000). There are also several adverse impacts on the coastal/marine environment associated with aquaculture, yet like the issue of ballast and fishing, these effects are still not fully understood because of the limited knowledge about coastal/marine ecosystems in Australia and the interactions with aquaculture operations (Clarke 1996, DNRE 1998, EPA 1998, CSIRO 2000).

It is also not possible to generalise research findings to all situations given that the impacts of aquaculture on the coastal/marine environment will vary depending on the farm's location (e.g. water depth, type of seabed such as seagrass, local currents, existing nutrients), the type of farming techniques (e.g. density of stock, species farmed, size of operation, feeding patterns, water flow), and the adequacy of management measures (Clarke 1996, Lewis et al. 1998, Cordover et al. 2000, CSIRO 2000). In South Australia, for instance, an inadequate knowledge and the planning/management framework was believed to be contributing to inappropriate aquaculture siting, and an unsustainable industry (Marchant 1997; Carvalho and Clarke 1998).

The main impacts associated with aquaculture relate, among others to:

- conflicts with other coastal uses, such as recreation

- loss of public access and visual amenity 
- increased traffic associated with land-based operations

- changes to existing coastal habitats, waste generation

- changes to sediments and local water quality with increased nutrient levels from fish food and excretions, e.g. resulting in algal blooms, possible declines in seagrass populations due to smothering by epiphytes

- reduced water oxygen content, culling of natural predators such as seals and sharks

- pressures on particular marine species used as food sources, such as pilchards and anchovies

- loss of other marine mammals when caught in cages or nets, use of chemicals and disease control agents

- spread of exotic species, e.g. introduced species escaping from an enclosed area, as occurred with the Pacific Oyster in South Australia

- navigation hazards from infrastructure such as buoys and jetties

- erosion resulting from pipes which transport seawater to land-based operations (Zann 1995, Clarke 1996, SARDI 1996, DNRE 1998, EPA SA 1998, Lewis et al. 1998, Cordover et al. 2000, CSIRO 2000).

While there has been relatively little research on the extent and significance of aquaculture impact in Australia, the Huon Estuary in Tasmania has been the subject of a three-year research project, resulting in a comprehensive report (CSIRO 2000). Aquaculture in this estuary is rapidly expanding (finfish, shellfish, seaweed), and most of Tasmania's salmon is produced there. In addition to some areas with reduced oxygen near the farms, elevated levels of nutrients and phytoplankton blooms were discovered, but the sources of these occurrences were unable to be determined. Modelling did, however, suggest that if aquaculture in the area doubled, nitrogen would increase by $50 \%$, thus enhancing the risk of algal blooms; and if operations were expanded 10 times, it was believed that the ecosystem would become eutrophic. Despite the extensive and detailed nature of this research on the estuary environment, few conclusions were reached about the long-term effects of aquaculture, and several more questions were raised. This highlights the need for ongoing research and monitoring in this area to reduce the impacts of aquaculture on the coastal/marine environment.

\section{Tourism and recreation pressure on the coast}

Tourism is of major economic significance in Australia and is overwhelmingly the major employer in coastal towns and cities outside the metropolitan areas. About three-quarters of economic activity in this sector can be attributed to domestic tourism, and one quarter to international tourism. This activity 
accounts for about $6 \%$ of the Australian economy: in terms of employment, tourism is dominant throughout coastal areas.

The coastal zone is the principal focus for tourism in Australia:

'In terms of accommodation nights, $47 \%$ of all tourism activity (international and domestic, 1990-91) in Australia takes place in the non-metropolitan coastal zone, $30 \%$ takes place in the capital cities, and the remainder is spread over the rest of Australia.'

Source: RAC (1993b), p. 56

A great deal of this activity is on the east coast; in fact, nearly threequarters of accommodation nights spent within the non-metropolitan coastal zone are in New South Wales and Queensland. The Gold Coast (2.3 million visitors per year on visits of more than one day) and the Sunshine Coast are the two most important regions.

Over 3 million international tourists come to Australia each year (Commonwealth of Australia 1997), the great majority include a visit to coastal locations. About half of the international tourists engage in activities in coastal waters, including swimming, surfing, scuba diving and snorkelling. Foreign exchange from international tourism earned $\$ 16$ billion per year in the mid 1990s, and was Australia's most important export industry.

For nearly all Australians the coast is where the annual holiday is taken, and it is the most frequented location for recreation. The numbers of participants generate significant industries for some activities; for example, recreational fishing (estimated at 1.5 million annually), water sports ( 2 million) and boating activities ( 80000 boat owners). Overwhelmingly, the weight of numbers is near the capital cities and along the length of the east coast of the continent.

The description by Bird and Cullen (1990) of the recreational uses of Port Phillip Bay and the management problems is one that might be applied to the coast near many Australian cities. Of the water-based activities, swimming is the most popular, undertaken by approximately a third of a million people. Many ramps, harbours, marinas, and moorings around the Bay serve the tens of thousands involved in fishing, power boating and water skiing. The conditions of the Bay are excellent for sailing, sailboarding and canoeing. Land-based activities are facilitated by the Crown coastal reserves, which back about half the total length of the Bay's foreshore. This ensures general public access to the shore as well as providing the space for sports facilities, showers, barbecue sites, designated camping areas, car parking and club facilities.

Management of the recreational activities and the impacts of the activities of the four million people who live around Port Phillip Bay is a challenge to the 
large range of state and local agencies who manage the coast. Coastal erosion of the recreational beaches is widespread around the bay, mainly due to the hard protection of the eroding cliffs, which formerly supplied sand to the beaches. Eighteen beaches have required sand nourishment by dredging and bulldozing sand from the Bay floor. Water quality has been a concern to all bay users. Sediment run-off from expanding suburbs as well as farmland has elevated turbidity levels after rainstorms. Raised nutrient levels and signs of eutrophication occur near sewage outlets. Concerns have been raised over heavy metal concentrations (mercury, lead and cadmium) as well as reports of pesticide and hydrocarbon levels. Water pollution has been regulated and in many cases reduced by state government intervention, but the benthic biota of the Bay itself appears to have assimilated raised nitrogen levels (see page 131). It could be argued that coastal recreation, as well as contributing to the degradation of the Port Philip Bay environment, has also been important in raising public awareness of change and deterioration. This awareness has been significant in motivating public responses to manage the problems.

Growth of tourism and recreational activities has continued around the Australian coast throughout the 1980s and 1990s. Not all of this has been near the centres of population; it has occurred in all but the most remote locations. Road improvement and the very rapid rise in ownership of off-road recreational vehicles means that significant numbers of people can spend the long weekend or the holiday camping at the elusive 'untouched' beach. As a result, on the remote beaches as well as near the towns there has been a rising demand for infrastructure, which increases pressure on the coastal environment. State and local governments are called upon to provide water, sewerage, waste disposal, power, roads, parking, landscaping, signs, rest rooms, camp grounds, lookouts, interpretation, barbecue, and picnic facilities. Remote beaches and estuaries, where few facilities are needed for most of the year, may see the regular influx of hundreds in January, and a failure to provide basic facilities can lead to gross environmental impacts. Frequently, local community groups are involved in the provision and maintenance of facilities within coastal reserves, thereby improving tourism's basic resource.

The Mecca for Australian off-road vehicle owners is Fraser Island, voted the nation's favourite 'Place of the Heart' in an Australian Heritage poll. A brief survey of the giant sand island by John Sinclair for FIDO (Fraser Island Defenders Organisation) in 1999 showed gross impacts on the bird numbers of the eastern beach, which has become a heavily used $4 \mathrm{WD}$ road, with a fatal impact on nesting sites (Sinclair 2000). Sand tracks and camping sites within the rainforest are reported to be causing sediment run-off into creeks and perched lakes, famous for their natural clarity. Sinclair ascribes much of the current damage to 
the island to poor management and lack of state government financial commitment, despite the National Park and World Heritage status of the island.

Around the Australian coast the off-road vehicle has not replaced, but added to, the impact of the holiday home. The impact of vehicles and homes depends on how the use of the coast is managed, rather than the nature of the use in itself, as the following case of South Australia's beach shacks illustrates.

\section{Box 3.2 Holiday homes in South Australia: The beach shack}

'If there is one thing that symbolises the Australian way of life it is leisure time in a weekend house, preferably near the sea.'

\section{Source: Harry Seidler: introduction to Beach Houses of Australia and New Zealand} by Stephen Crafti

Figure 3.5 Yorke Peninsula beach shacks

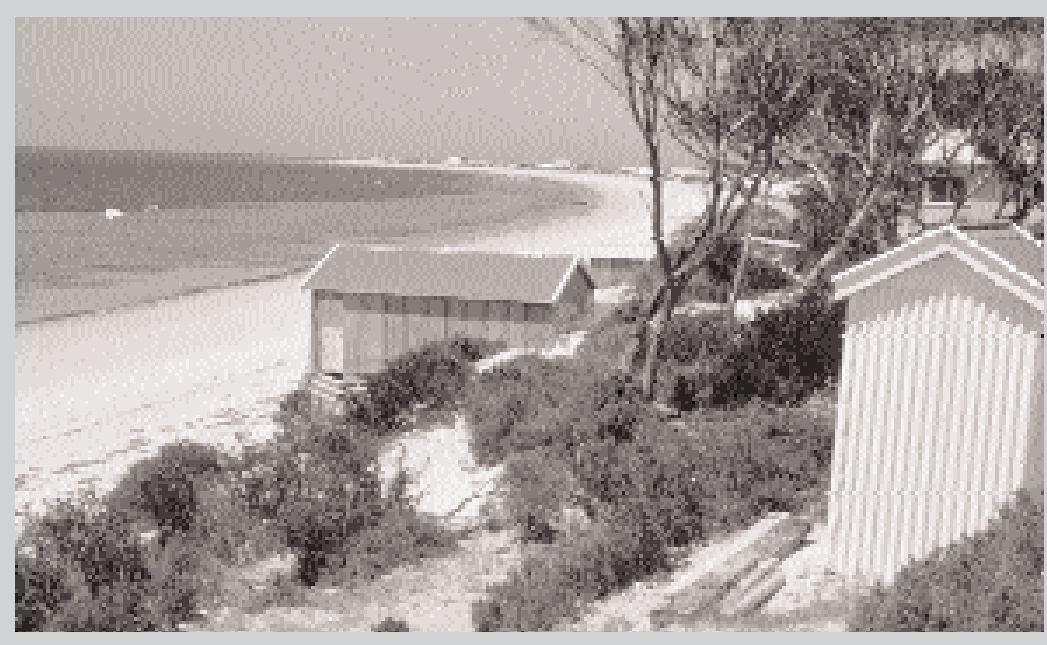

(photography Ken Bardsley)

South Australia is well endowed with beaches, and many of them have groups of holiday homes established as dwellings on leasehold allotments on Crown land: the holiday shacks. Many of the shack sites were leased by the state government (and a few by local councils) in the 1950s and 1960s, and by 1970 a state review found that there were approximately 7000 beach shack dwellings of varied quality: many were of fibro and tin, others were of more substantial construction. These groups of shacks constituted a series of small, unplanned summer settlements around the state's coast. The shacks also constituted significant places in the lives of several tens of thousands of South Australians: 
places of family memories, places visited at times of personal decisions and, for some, places to which to retire.

Concern over the impacts of these settlements and the difficulties of infrastructure provision led to a series of government reviews, and as a result there were some improvements in services, freeholding of many sites, and the removal of a few dwellings. By the time of the last state-wide review, in 1991, some 1600 leasehold coastal shack sites remained: the shacks with problems unresolved by previous review. The 1991 review was termed an 'Assessment of Crown Lease Coastal Shack Sites in Accordance with Environmental Sustainability Criteria' (PPK 1991). The criteria were applied to groups of shack sites and stated that sites:

- should have safe legal access

- should not inhibit public access and use of the foreshore

- should meet reasonable planning and health standards, such as those relating to the site acceptability for septic disposal

- should allow reasonable dune and beach management

- should not be threatened by coastal flooding or erosion

- the shack area should be visually acceptable and the structures sound.

These criteria are valuable in pointing up the common impacts of this form of coastal recreational land use. The 1991 assessment found that the great majority of shacks did not meet the criteria: only $5 \%$ did so, although some had the potential to meet the criteria.

This careful effort by agencies did not inhibit the newly elected state government of 1994, which decided to freehold all shacks (as a declared policy, which attracted no discussion before the election). As well as ignoring the 1991 review, the policy was a radical approach to coastal planning. The freeholding of sites contravened the objectives and principles within development plans for most coastal councils; in many cases it also contravened the state policy on flooding and erosion (with specific allowance for sea level rise) placed in the development plan the previous year. The radical nature of this approach was acknowledged in the planning instrument (PAR) to implement the shack freeholding (SA Department of Planning 1997, p. x): 'The PAR will, in effect, create a two tiered level of policies along the coastline ... New development generally will have to comply with the current planning criteria. On the other hand, the land division and upgrading of existing lawfully erected shacks on Crown land along the coastline will have to meet the criteria of this PAR.'

Thus, in an unintended way, the emotional regard for a traditional recreational use of the Crown coastal reserve completely undermined the credibility of a state's coastal planning policy. The significance of recreational use of coastal lands in Australia should not be underestimated. 


\section{Box 3.3 Managed tourism in a protected area: Great Barrier Reef}

The Great Barrier Reef (is one of Australia's top tourist destinations for international visitors. Tourist numbers have grown most markedly since the Reef gained World Heritage status in 1981. Tourist numbers have continued to increase through the 1990 s, notably the number of international visitors. The pattern of visitation is to stay at one of a number of coastal towns, or at one of the resort islands, and to visit the reef by boat to fish, dive, snorkel and swim. Major cruise companies often include the Reef in the itinerary of liners in the region.

Table 3.12 Total nights spent by tourists in Far North Queensland

\begin{tabular}{llcc}
\hline Domestic visitors & & \multicolumn{2}{c}{ International visitors } \\
\hline $1989-90$ & 5486000 & 1989 & 2702000 \\
$1991-92$ & 6482000 & 1991 & 3284000 \\
$1993-94$ & 6177000 & 1993 & 3326000 \\
\hline
\end{tabular}

Source: Bureau of Tourism Research, cited in ABS 1996

Table 3.13 Recreational activities permitted in the zones of the Great Barrier Reef Marine Park

\begin{tabular}{|c|c|c|c|c|c|c|c|}
\hline \multirow[t]{2}{*}{ Activity } & \multicolumn{2}{|c|}{ General use } & \multicolumn{3}{|c|}{ Marine National Park } & \multirow[b]{2}{*}{$\begin{array}{l}\text { Scientific } \\
\text { research } \\
\text { zone }\end{array}$} & \multirow[b]{2}{*}{$\begin{array}{l}\text { Preservation } \\
\text { Zone }\end{array}$} \\
\hline & Zone A & Zone B & AZone & Buffer & B Zone & & \\
\hline Boating & Yes & Yes & Yes & Yes & Yes & No & No \\
\hline $\begin{array}{l}\text { Collecting } \\
\text { (e.g. fish, shells) }\end{array}$ & Permit & Permit & No & No & No & No & No \\
\hline $\begin{array}{l}\text { Dive, swim, } \\
\text { snorkel }\end{array}$ & Yes & Yes & Yes & Yes & Yes & No & No \\
\hline $\begin{array}{l}\text { Line fishing } \\
\text { (by hand) }\end{array}$ & Yes & Yes & Yes & No & No & No & No \\
\hline Netting & Yes & Yes & Permit & No & No & No & No \\
\hline Trolling & Yes & Yes & Yes & Yes & No & No & No \\
\hline $\begin{array}{l}\text { Spear-fishing } \\
\text { (without scuba) }\end{array}$ & Yes & Yes & No & No & No & No & No \\
\hline Traditional fishing & Yes & Yes & Yes & Permit & Permit & Permit & No \\
\hline
\end{tabular}


Kelleher and Dinesan (1993) noted a number of potential and actual impacts of tourism on the reef, including:

- damage to coral from reef walking and intensive diving, and from anchors

- development involving land reclamation or mangrove destruction

- excavation and dredging leading to habitat destruction and raised turbidity levels

- the effects of fixed or moored structures on reefs and fish populations

- waste and litter from vessels

- the effects of fish-feeding on fish populations.

The impact on fish stocks from fishing is a significant management issue and a matter of ongoing review.

Kelleher and Dinesan (1993) stated that the major impact of visitors to the area is through raised water nutrient levels from the towns catering for the tourists.

The impact of visitor activities to the Reef itself is actively managed through interpretation, guidelines for visitors, codes of practice for tour operators, and regulation of some activities, including zoning of the reef. A range of monitoring, principally by the Great Barrier Reef Marine Park Authority, the James Cook University, and the Australian Institute of Marine Science, informs this process.

Research by the Great Barrier Reef Marine Park Authority has confirmed the economic significance of the Reef to the region; the small contribution of users to the management budget raises important questions about the appropriate responsibility for management costs (see chapter 4).

Table 3.14 Economic valuation of the Great Barrier Reef, 1991-92

\begin{tabular}{ll}
\hline Value of tourism and recreation & $\$ 776$ million \\
Other uses of the Reef & $\$ 147$ million \\
Total measured value & $\$ 923$ million \\
Management budget & $\$ 18.1$ million \\
Revenue from users & $\$ 0.8$ million
\end{tabular}

Source: Driml 1994

\section{Impacts and challenges for the management of coastal tourism}

The Marine and Coastal Community Network (Flaherty 1999) and the ESD Working Group (1991) have identified the principal impacts and challenges for tourism at the coast. Common impacts of coastal tourism and recreational use were:

- poorly planned coastal development (including holiday home development) and associated development of linked transport and service lines, leading to 
habitat degradation or loss. This often involved destruction or change to natural or cultural features that made the area initially attractive

- off-road recreation vehicle and camping activity causing coastal vegetation destruction and erosion, especially on coastal dunes, scenic cliffs and adjacent to coastal lagoons and small estuaries

- impact on seabird (including migratory species) and wildlife populations from disturbance and habitat destruction

- impact on terrestrial and marine biota of introduced species

- impacts of developments, including marina developments, on coastal waters, estuarine and coastal wetland environments. Mangrove and seagrass environments have been particularly impacted.

The Interim Bioregionalisation of Australia (IBRA) gives an indication of the regional concentration of the impacts. As part of the formulation of IBRA (Thackway \& Cresswell 1995), factors that had the greatest adverse impact on the biodiversity of a region were identified. Regions where tourism was identified as a dominant limiting factor were the Queensland coast from Cairns to Mackay and the east coast from the Sunshine Coast to East Gippsland, including the whole of the New South Wales coastal plain.

Contemporary challenges in the management of coastal tourism are:

- managing developments within environmental and aesthetic limitations

- involving Aboriginal communities in management of coastal and marine areas

- avoiding developments involving hard structures on the foreshore, leading to sand management, erosion and beach wrack problems

- promoting and integrating codes of practice for recreational fishing, offroad driving, whale watching, dive tourism, shark viewing, small island visiting, reef walking, yachting, and boating

- developing managed marine reserves to conserve habitat and promote and cater for low impact activities such as dive tourism, particularly of Australia's unique southern marine habitats

- developing rapid response strategies for the control of introduced marine pests in high visitation areas and marine reserves

- extensive education throughout the tourism industry about the coastal zone and its conservation values.

The industry has shown interest in promoting the concept of sustainable tourism development and in cooperating with other stakeholders. For example, the Australian Tourist Industry Association (now the Tourism Council of Australia) produced a code and guidelines relating to the environment. Guidelines to improve relations between tourism and other stakeholders are also needed. 
The principles which should guide sustainable tourist development at the coast, based on Commonwealth of Australia (1997), are as follows:

- Primary Asset: The natural environment is imbued with natural and cultural values and should be protected and enhanced for ecological, social and economic reasons.

- Interdependence: Economic, social and environmental factors are interdependent. This principle may be threatened by a lack of balance in determining the scope of a coastal tourism development, or by cumulative impacts on the environment.

- Areas of High Conservation Value: Some areas need to be left undeveloped, to protect these assets for present and future generations.

- Cultural Heritage: Appropriate coastal tourist development recognises the significance of cultural heritage, including indigenous heritage, and protects or enhances this heritage.

- Flexibility: Developers of sustainable coastal tourism ventures are willing to reconsider all features of their development in the light of market research, community concerns, or the environmental limits determined by the site. It is more cost-effective to be flexible in the pre-application stages of a development proposal than in the later stages.

- Integrated Planning: Sustainable coastal tourism ventures integrate and are compatible with activities and requirements of the region, local communities, local infrastructure, and plans for the region. In this way cumulative impacts of tourism growth may be reduced.

- Siting and Design: The siting and design of sustainable coastal tourism developments should be sensitive to the immediate area, water and energy efficient, and have minimal impact on the area.

- Environmental Management Systems: Part of the planning of a development includes the establishment of an environmental management system, including monitoring. Sustainable coastal tourism developments should be monitored and evaluated in both the construction and operational stages.

Environment Australia, the Royal Australian Planning Institute, the Tourism Council of Australia and the Australian Local Government Association have set out guidelines for sustainable tourism development at the national scale, in Coastal Tourism: A Manual for Sustainable Development (Commonwealth of Australia 1997).

While it is clear that a great deal of work has been done on codes of practice and on standards, there remains a need for implementation at the local level. In an industry devoted to image, it may be that ratings and labels are needed: perhaps a 'green star' system to identify environmentally friendly developments. In Europe a consumer-based 'Good Beach Guide', in which 
tourist beaches are rated for facilities and cleanliness of surf and sand, has proved an incentive to councils seeking to attract visitors.

There is also a need for strategic planning frameworks that allow coordination of tourism activities with other developments in the coastal zone. The process of working together with government and community in an ordered and strategic way, avoiding unwanted cumulative effects of development, is one of the greatest challenges facing the tourist industry. The strategic approach to marina development in South Australia provides an example of one such process (see Harvey 2002).

\section{Coastal mining and industry activities}

According to the Commonwealth agency Environment Australia, when compared with much of the world, Australia's coasts and oceans are in relatively good condition, but our marine environments are under increasing pressure (Environment Australia 2000c). Many coastal locations are characterised by a diverse and cumulative range of uses and environmental impacts (RAC 1993a), most of which have already been addressed in previous sections. In fact, approximately $80 \%$ of marine pollution comes from land-based sources (AIMS 1995), and this includes both coastal mining and industry operations, which are the subject of this section. The main contrast with some of the other coastal impacts already described is that pollution and other impacts from coastal mining and industries stems primarily from point sources rather than non-point sources. Batley (1995) argued, for example, that significant contamination in coastal estuaries can be 'directly traceable' to coastal mining and industries (although other activities such as urban run-off also contribute). Several mining activities and industries have an impact on the Australian coastal environment, such as sand and gypsum mining, salt evaporation industries, beta-carotene industries, and other industrial facilities such as lead smelters and iron and steel works.

The key issue is that many mining and industry operations along the coastal zone (and inland) are essential to our survival and to our quality of life. Mawby (1974, p. 111) notes, for example, that the 'prosperity of any in our cities can be directly traced to mineral development'. Mining and industry activities (not just in the coastal zone) provide us with a wide range of important products, such as construction materials, glass and ceramics, metals, paint pigments, detergents, oils, sealants, paper, transformers, abrasives, rubbers, and leather tanning products, and provide a basis for food and medical products (Brookes 1996, Burzacott 1996, DME 2000). Like commercial fishing, economic priorities also become important factors in determining the relative significance of 
environmental impacts and how the coastal zone should be managed for these activities (Hore-Lacey \& Webb 1996). For example, Australia is the world's largest provider of heavy metals and various other minerals (e.g. bauxite, alumina, diamonds, lead, ilmenite, rutile, and zircon) (Hore-Lacy \& Webb 1996).

As is the case for commercial uses of Australian coastal waters, however, the problem is once again a lack of complete knowledge about our impacts on the coastal environment, including from coastal mining and industries (e.g. see RAC 1993). Burton et al. (1994) and Brookes (1996) noted that most coastal studies in Australia (including studies on contaminants from coastal mines and industries) are simply descriptive in terms of the boundaries and nature of pollution (sometimes with questionable and dated study designs), and do not endeavour to understand the complex interrelationships between different and often conflicting coastal uses and their adverse effects on broader coastal ecosystems. Much of the literature on coastal mining and industry also relates to their operations in all parts of Australia, not just within the coastal environment.

With these data limitations in mind, this section addresses the general coastal impacts of mining and industry, and provides a more detailed case study of sand mining in Queensland's coastal environment (Fraser Island), followed by a case study of an industrial/harbour based development in Western Australia.

\section{Mining in the coastal zone}

\section{Types and locations of mining}

In Australia there are many mining sites, both inland and along coastal environments, but they cover less than $0.01 \%$ of the continent (Lewis et al. 1998). Figure 3.6 shows the locations of some Australian mines; most of these are inland, but a number occur along the coast. There are several coastal mines in Western Australia and on the western coast of Tasmania, where environmental controls on mining have been relatively unrestricted (Burton et al. 1994, Young 1996). Tasmania (with six major coastal mining locations) is prosperous in minerals, and many are exported (MRT 2000). There is also mining of heavy sands in Queensland (much of which is also exported), and several types of mining in New South Wales, where mining has been carried out along approximately $50 \%$ of the north coast (ACF 1981).

South Australia has had relatively little benefit from mining overall, contributing approximately $5.5 \%$ of overall production in Australia in the $1980 \mathrm{~s}$ (McFarlane \& Sheridan 1986). Mining is also less viable in economic terms, in 
Figure 3.6 Mining locations and mineral processing and export in Australia

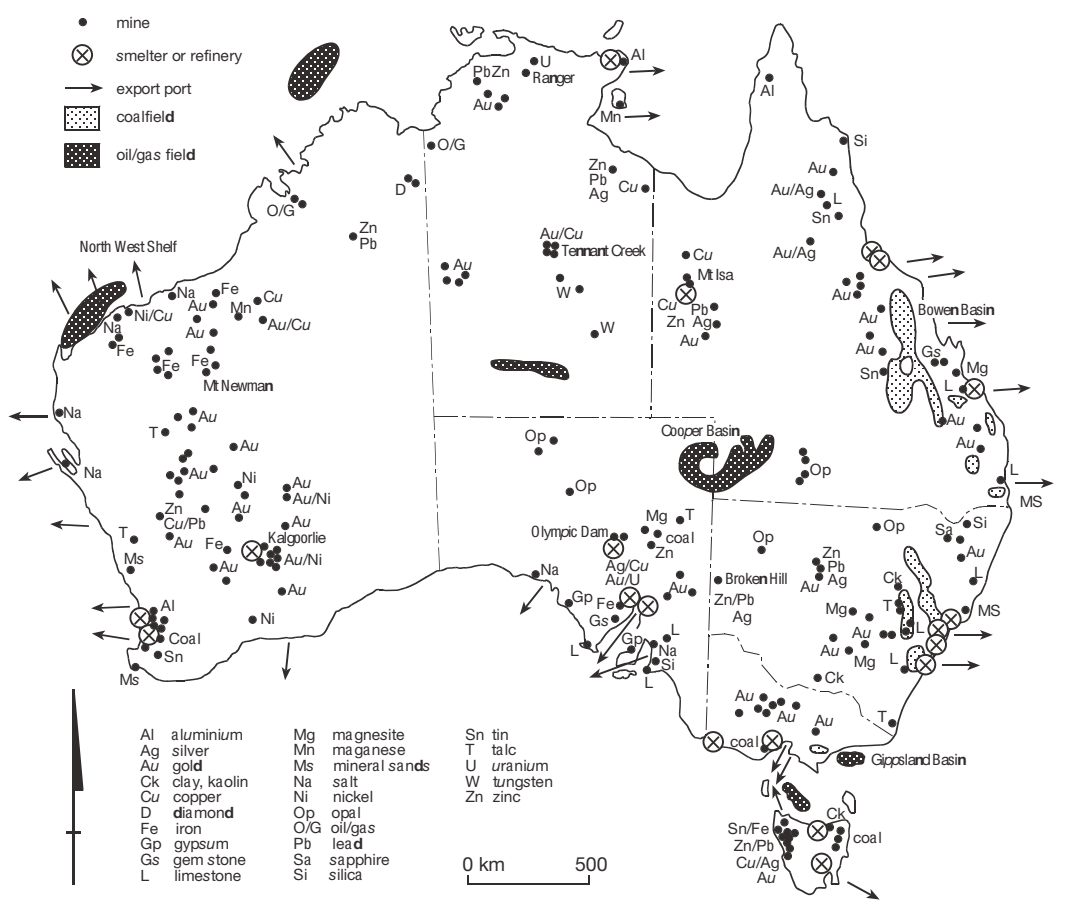

Source: Young 1996

Victoria, but mining does occur for basalt, salt, sand, oil, gas, and limestone, but not necessarily along the coastal zone (DNRE 1998). Examples of coastal mining operations around Australia overall include open-pit nickel mining on the eastern coast of Queensland (Hore-Lacy \& Webb 1996), bauxite mining on the Swan coastal plain in Western Australia, mineral sand mining in Shoalwater Bay, Queensland (Burton et al. 1994), mineral sand mining in Geographe Bay in Western Australia (Brooke 1996), copper mining in Macquarie Harbour in Tasmania (Young 1996), graphite mining near Port Lincoln in South Australia, salt production at Lake MacDonnell on the western coast of South Australia (DELM 1993), alluvial tin mining on Ringarooma River in Tasmania (Young 1996), a solar salt project at Onslow in Western Australia (EIA Network 1995), rutile-zircon-ilmenite mine near the silica sand mine on North Stradbroke Island (FCT 1999) in Queensland, heavy mineral mining in coastal forested zones (Agnes Waters-Middle Island-Hummock Hill Island) (FCT 1999), and heavy minerals mining at Beenup in Western Australia (EIA Network 1997). 


\section{General coastal mining impacts}

Coastal mining, and mining in general, have several adverse environmental impacts, although these are gradually being reduced with improved legislative controls, attitudes in the mining industry, technology, and management practices. A useful summary of the environmental effects of mining in general (not just in the coastal zone) can be found in Hore-Lacy and Webb (1996). Coastal mining and its associated infrastructure, such as road access, storage facilities, and power facilities, often have irreversible or long-term environmental effects, and affect both land and water. These effects can include:

- large open pits which provide opportunities for waste dumps

- transport and disposal of products (sometimes hazardous), and increased risks in the further spread of introduced species and diseases

- fuel and oil spills into coastal waters and groundwater

- low water permeability of mined sites, and impacts on groundwater regeneration and revegetation attempts for rehabilitation

- impacts of sand mining even after mine closure (e.g. groundwater movement or dam collapse)

- loss of biodiversity and coastal habitats (including the buffering and nursery roles of mangroves and seagrasses)

- visual impacts

- noise impacts from heavy machinery

- health effects for coastal residents who live near mines or industries (e.g. silica can be carcinogenic and can cause lung damage; consumption of contaminated seafood)

- loss of wilderness and public access areas in the coastal zone

- coastal erosion and loss of natural dune systems and soil profiles

- impacts on coastal archaeological sites

- impacts on water quality from the discharge or leaching from spoils or tailings (accidental or otherwise) of untreated or even treated waste water.

In the last effect listed, toxins from discharges into catchments, groundwater and coastal waters accumulate in sediments and biota, frequently are acidic and contain toxic heavy metals and excess nutrients, and can have high salinity levels. Increased discharge of particulates can also cause sedimentation and turbidity in coastal waters, and increased nutrients can cause or exacerbate eutrophication. A combination of these effects can cause habitat loss and death or other effects in flora and fauna, such as behavioural or genetic changes, reproductive failures, problems with photosynthesis, respiration and feeding, and subsequent effects on the broader food chain (Burton et al. 1994, Jia 1994, Batley 1995, Viles \& Spencer 1995, Young 1996, DME 1999). 
Although in the 1970s the Australian Conservation Foundation (ACF) believed that we were a 'mineral civilization', it stated: 'Mining by its very nature is always antagonistic to environmental values. It must dig holes, dump overburdens, discharge tailings, create dust and noise, rip open country to bring in power and water supples, construct roads, change drainage systems and even establish towns where there is no other reason for their existence' (ACF 1974, p. 116). In the 1980s it was strongly opposed to the impact of coastal mining on the east coast of Australia, and noted the significant and irreversible impacts on both aesthetic and scientific values (ACF 1981):

Miners claim that their operations are not permanently detrimental to the natural environment. However, the opposing sides have different standards. Miners claim to be able to rehabilitate to a semblance of naturalness acceptable to the general public ... To be fair, they have achieved just this in some 'easy' areas, assisted by increasing skill in later years. But they admit that they cannot restore to full pre-mining ecological conditions, and it is indeed obvious that they are unable to reconstruct the complex soil structures and water table level variations and the many plant associations which depend largely upon these factors. They have failed to return more than about $50 \%$ of pre-mining species ... Furthermore, mining destroys the geological and archaeological history of the area.

In contrast, there is a strong view from the mining industry that the impacts are substantially less than other activities (e.g. primary production, rural industries, city population growth, road and infrastructure construction; Mawby 1974, Lewis et al. 1998). It has been noted that: the 'compactness of any mining operation, in relation to its importance, creates relatively little disturbance to the environment. In certain mining, for example some sand mining operations, beach facilities are not despoiled but through the rehabilitation of foreshore areas improvements are often made ...'(Mawby 1974, p. 111). Lewis et al. (1998, p. 74) considered, for example, that mining's impact on biodiversity is low, and that there 'appears little reason why the same conclusion should not apply in marine and estuarine environments with appropriate management systems and objectives in place'.

\section{Case study: Sand mining on Fraser Island, Queensland}

The most commonly quoted coastal mining operation in the literature is sand mining (also called beach mining) or heavy minerals sand mining, primarily because this type of mining is restricted to areas of large sand deposits such as coastal beaches, dunes, or river borders (Commonwealth of Australia 1977, HoreLacey \& Webb 1996, DME 2000). Young (1996) noted that sand is mined from 
coastal regions as both a source of heavy minerals such as rutile, ilmenite, monazite, and zircon (the 'black sands') and a source of construction materials. Young also noted that dune sands, in the case of heavy mineral mining, are not permanently removed, and with the separation of the minerals the sand is restored into 'artificial' dunes which are then revegetated. However, in the case of sand for construction materials, the sand is completely removed.

According to the Queensland Department of Mines and Energy (DME 2000) Australia is the world's largest producer of heavy mineral sands, with the greatest amount being produced and exported by Queensland. Following stricter environmental controls on sand mining in Queensland, where approximately 50\% of deposits were suspended (Pope \& Duncanson 1989, Hore-Lacey \& Webb 1996), sand mining moved to Western Australia during the 1970s where it was believed that controls were less strict (Young 1996). Sand mining also occurs in northern New South Wales (Pope \& Duncanson 1989, Hore-Lacey \& Webb 1996, FCT 1999, DME 2000).

The effects of sand mining on the coastal zone are similar to many of those noted in previous sections, but can vary depending on whether it is 'black sand' mining or sand mining for construction materials. Sand mining can also produce low-level radioactive wastes (Burton et al. 1994). But a more important factor is that sand supplies to most Australian coastal zones have either stabilised or ceased, so that natural erosion is causing the loss of many of our beaches (RAC 1993a; see also page 62). Sand mining can only exacerbate this loss of sand, erosion and loss of buffer between land and sea, particularly the mining of sand for construction materials. Following mining disturbance, it may also take several years before native fauna returns to the site (Young 1996).

However, although there are some concerns about erosion (Hails 1982), much of the sand mining industry believes that the coastal impacts of heavy minerals sand mining are minimal. It has been noted, for example, that: 'Heavy mineral sands mining has some unique features that assist in rehabilitation. First, there is minimal volume loss, usually of the order of 1-5 per cent, thereby allowing for substantial reconstruction of the landform. Second, there are no toxic wastes from mining, the tailings consisting of soil components. Third, most ore bodies are shallow, so the mining is mobile and a relatively short-term land use' (Brookes 1996, p.556).

It is also believed by much of the mining industry that rehabilitated sand mining sites can be used for other coastal land uses, such as recreation, tourism, forestry, or conservation. Nevertheless, sand mining has been a long-term, highly public and controversial issue in Australia, and although this type of mining activity is claiming to be advanced in rehabilitation techniques, there have been several inquiries into the process which have found 'sand mining 
Figure 3.7 Fraser Island, Queensland

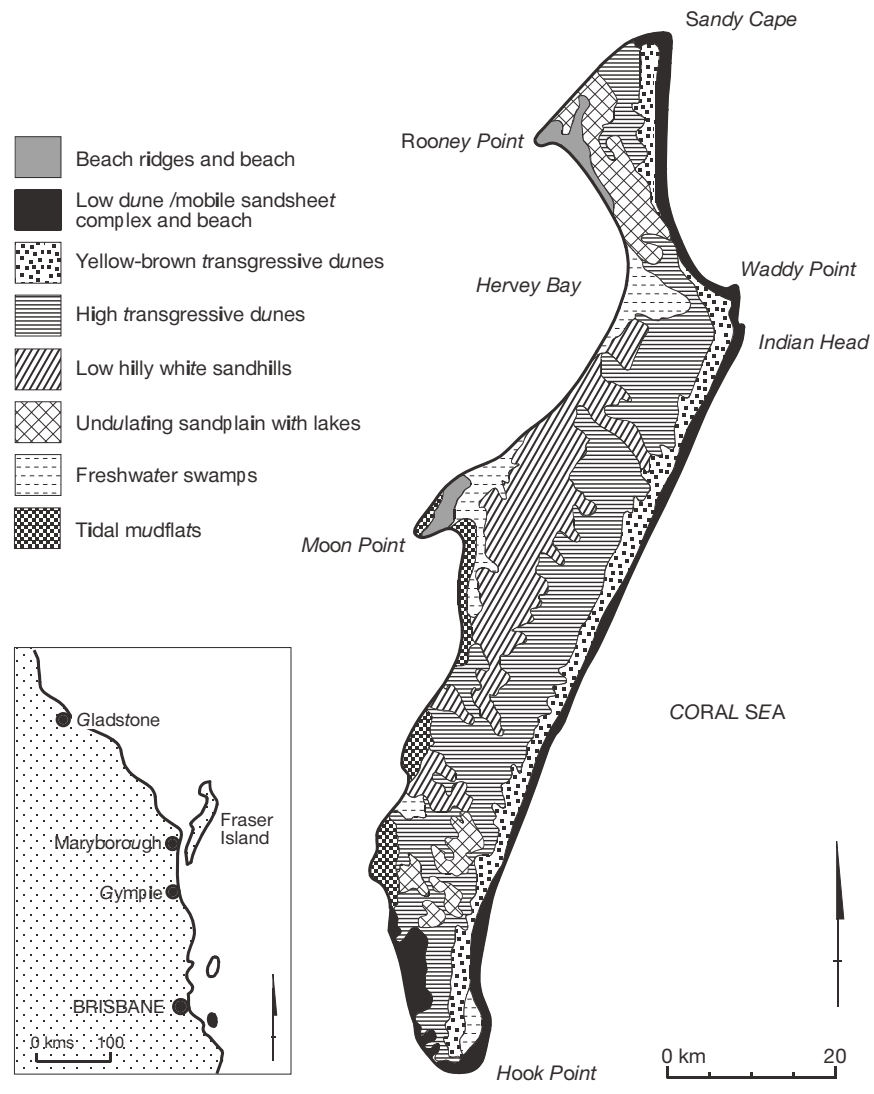

rehabilitation programs to be deficient for the purposes of biodiversity conservation and the protection of ecological diversity' (Burton et al. 1994, p. 22).

Sand mining on Fraser Island in Queensland is a good case study for sand mining. The island is the largest island of sand in the world, 122 kilometres long and 5-25 kilometres wide (figure 3.7). It comprises siliceous sand (and heavy mineral deposits of ilmenite, rutile, zircon on the east coast), significant stands of a wide range of delicately balanced native vegetation and fauna of 'scientific interest' (including mangroves, seagrasses and endangered Dugongs), high erosion rates, and natural sand blow-outs (Commission of Inquiry 1975).

Fraser Island is also primarily a State Forest Reserve and National Park, contains tourist facilities, a small permanent population, and commercial and recreational fishing, and is well known for its wilderness values, highly complex and migrating dune systems, streams, lakes and swampy systems, and its 'extraordinary beauty' (Commonwealth of Australia 1977). It was noted that 
'[one] of the most important features of Fraser Island from a geomorphological viewpoint is that it exhibits the greatest number of distinct and independent dune systems found anywhere in the world' (Commonwealth of Australia 1977, p. 10). It was also noted that '[most] of the Fraser Island lakes are highly unusual and of outstanding aesthetic importance and scientific interest, not only from the viewpoint of the Australian nation, but also in a world context' (Commonwealth of Australia 1976, p. 23).

As a result of some controversy during the 1970s, a Commonwealth government inquiry into the environmental effects of sand mining on the island was undertaken (Commission of Inquiry 1975, Commonwealth of Australia 1977). This inquiry was triggered by the Commonwealth's Environmental Protection (Impact of Proposals) Act 1974. Even though mining leases on Fraser Island were granted by the Queensland government, the Commonwealth government could intervene because of its constitutional powers over exports. The final report (Commonwealth of Australia 1977) presented very detailed evidence, although there was little detail about the actual effects on immediately adjacent coastal waters (e.g. effects on mangroves, fauna or seagrasses). However, the inquiry did find that many of the environmental impacts of sand mining on the coastal island were unacceptable. For example, it was noted:

While there was a conflict of evidence on many aspects of sandmining above the mean high-water mark on Fraser Island, three points were not in dispute. The first was that the immediate effect of sandmining is to destroy all the existing topography and vegetation in the mined areas. The second was that the original vegetation can never be restored in the sense of re-establishing the original number and distribution of species in their former relationships with one another. The third was that it is not practicable, and often prohibited by the Special Conditions of the Mining Leases, to restore the topography to its former state after mining. There is thus common ground both that the existing vegetation and topography of such areas will be destroyed by mining, and that they will not be restored to their former state.

Source: Commonwealth of Australia (1977), p. 85

Other coast-related impacts from the sand mining included:

- changes to the visual and physical nature of creeks due to water withdrawal

- physical damage from water pumps installed by dredging and blasting

- excessive withdrawal of water and changes to the groundwater table

- large areas of bare, unrehabilitated areas and human-induced sand blowouts in areas of high winds (these winds are characteristic of the island)

- changes in microclimates and wind patterns 
- impacts on lakes and groundwater by the possible puncturing of layers containing the water, resulting in a partial draining of lakes

- changes between water run-off, water permeability, and infiltration

- changes in soil profiles and nutrient and hydrological patterns

- changes in the nature of vegetation and fauna

- aesthetic impacts and loss of wilderness values; loss of complex dune system and micro and macro topography

- loss of archaeological and geomorphological sites

- run-off pollution associated with road construction, with the possibility for significant gullying, among other things (Commission of Inquiry 1975, Commonwealth of Australia 1977).

In terms of coastal waters and beach mining, it was also noted that organic slimes and particulates could be released into the sea, and although there was some uncertainty about the effects of this, it was stated that 'at the very least, it is likely that the sea would become so polluted locally whilst mining was proceeding that the benthic animals would be severely affected, and the fish would avoid the area' (Commonwealth of Australia 1977, p. 87). For these reasons (and the impacts noted above), sand export licences were refused, and Fraser Island was eventually protected following its listing as a World Heritage Area (Young 1996).

Although sand mining and other types of mining still continue in other coastal areas around Australia, Hails (1982, p.187) noted that 'many reserves of mineral sands are unlikely to be mined in the foreseeable future due to landuse conflicts with coastal settlement and conservation areas'.

One of the more important questions is, however, which of these coastal uses get priority (Cocks 1992). Burton et al. (1994, p. 28) noted that:

Although the mining industry is willing to admit past legacies of bad practice, it attributes these to prevailing community standards and maintains that the industry is now environmentally benign. What was once an uncontrolled, high impact industry has in recent times, the industry claims, been transformed into a highly disciplined, low impact industry ... It is true that many sections of the industry are striving to improve their environmental performance and overall the industry has made considerable progress on matters such as revegetation, pollution control and environmental management. Nevertheless, this improvement is by no means uniform. Unacceptable impacts, accidents, sloppy operators and antiquated operations all continue despite improved standards and stricter regulations. Also the likely longer term impact of many mining operations are still unknown.

This is likely to be the case for the coastal/marine environment also. 


\section{Coastal industries}

\section{Types and locations}

Like inland industries, coastal industries are frequently a source of heavy metal pollution, both globally and in Australia. On an international scale, heavy metals (also sourced from coastal mining) were 'identified as the major pollution threat facing mankind [sic]' during the late 1970s, because of a series of international disasters that involved mercury and cadmium (Batley 1995, Zann 1995). In the Australian context, a large number of submissions to a coastal zone inquiry in the early 1990s expressed concern about a broad range of pollution discharges into the marine environment, including discharges from industrial activities (RAC 1993a). Coastal industry examples of potential sources include iron and steel works, oil refineries, alumina refineries, cement works, chemical plants, meat and fish processing plants, power stations, lead smelters, pulp and paper mills, supporting port facilities, and other manufacturing plants (Hails 1982, Commonwealth of Australia 1991, Batley 1995).

Discharges from these industries vary, but can contain cadmium, lead, mercury, copper, zinc, chromium, nickel, cyanide, phenolics, ammonia, nutrients and food byproducts, polychlorinated biphenyls or PCBs (or organochlorines also used for chlorine paper and pulp mill bleaching), thermal pollution, and petroleum hydrocarbons, among others (Reilly 1991, RAC 1993, Zann 1995, Burzacott 1996, CSIRO 1996, Young 1996). Zann (1995) provided a useful summary of heavy metals in some estuaries in Australia, many of which can accumulate in coastal sediments over the long term (Batley 1995).

Most industrial pollution usually occurs locally or regionally, and around cities; areas that are distant from human populations usually remain relatively uncontaminated (RAC 1993, Batley 1995, Zann 1995, Young 1996). Unlike mining operations, there appears to be no broad map illustrating the locations of different coastal industries across Australia, so it also difficult to gain an appreciation of the overall trends of industrial activities and the impacts on the coastal environment. However, according to the RAC (1993a), the coastal zone contains most of Australia's manufacturing industries, and there is a useful summary of different coastal industries in Brookes (1996), and in AGC Woodward Clyde (1993) for Queensland, Western Australian, and Victoria.

It has been found in parts of some jurisdictions (e.g. New South Wales, South Australia, Victoria, Tasmania, Queensland), that contaminants from industries do not exceed ANZECC water quality guidelines (Batley 1995). But some of the 'hot spots' of heavy coastal industrial pollution are Cockburn 
Table 3.16 Example of coastal industries and their effects

\begin{tabular}{|c|c|c|}
\hline Industry & Location & Coastal impact examples \\
\hline $\begin{array}{l}\text { Series of } \\
\text { industries: cement, } \\
\text { Boyne smelters, } \\
\text { Alumina }\end{array}$ & $\begin{array}{l}\text { Gladstone, Qld } \\
\text { (deep-water port) }\end{array}$ & $\begin{array}{l}\text { - Ioss of coastal frontage land by industries not } \\
\text { necessarily requiring a coastal location } \\
\text { - inadequate buffers } \\
\text { - inappropriate siting of some industries in } \\
\text { relationship to townships } \\
\text { - } \text { toxic air emissions } \\
\text { - } \text { poor water quality \& impacts on fisheries }\end{array}$ \\
\hline $\begin{array}{l}\text { Lead and } \\
\text { zinc smelter }\end{array}$ & $\begin{array}{l}\text { Upper Spencer } \\
\text { Gulf, SA }\end{array}$ & $\begin{array}{l}\text { - largest smelter in the world } \\
\text { - exceeds ANZECC water quality guidelines } \\
\text { - aerial and liquid discharge to marine environment. } \\
\text { - a four-year study of marine pollution showed } \\
\text { sediments over a } 6000 \mathrm{~km}^{2} \text { area } \\
\text { contaminated by cadmium and lead, biota with } \\
\text { high level of cadmium, lead, zinc, but not above } \\
\text { health standards, although near limits; lesser areas } \\
\text { of copper, arsenic and manganese } \\
\text { - effect of contamination-growth deformities in } \\
\text { fish and health effects from fish consumption. }\end{array}$ \\
\hline BHAS smelter & $\begin{array}{l}\text { Upper Spencer } \\
\text { Gulf, SA }\end{array}$ & $\begin{array}{l}\text { - trace metals discharges with effects on the epibenthic } \\
\text { seagrass fauna (decrease in species richness and } \\
\text { reduced abundances of frequent species) } \\
\text { - bioaccummulation of metals in several species } \\
\text { causing deformity. }\end{array}$ \\
\hline $\begin{array}{l}\text { Redcliffe } \\
\text { Petrochemical } \\
\text { complex }\end{array}$ & $\begin{array}{l}\text { Upper Spencer } \\
\text { Gulf, SA }\end{array}$ & $\begin{array}{l}\text { - possible contaminant effects on surrounding } \\
\text { intertidal mudflats, sand cover, mangroves and } \\
\text { seagrasses around the project. }\end{array}$ \\
\hline Steelworks & $\begin{array}{l}\text { Upper Spencer } \\
\text { Gulf, SA }\end{array}$ & $\begin{array}{l}\text { - discharge contains suspended solids, metals, } \\
\text { cyanides, ammonia compounds, and phenols, } \\
\text { in addition to discharges from tailings dam with } \\
\text { dissolved iron entering into marine environment } \\
\text { - loss of seagrass and mangroves } \\
\text { - erosion } \\
\text { - nutrient enrichment. }\end{array}$ \\
\hline $\begin{array}{l}\text { Playford power } \\
\text { station }\end{array}$ & $\begin{array}{l}\text { Upper Spencer } \\
\text { Gulf, SA }\end{array}$ & $\begin{array}{l}\text { - thermal effluent from power station-no impact } \\
\text { on intertidal communities but some minor } \\
\text { reductions in seagrasses in growth characteristics } \\
\text { - entry of coal dust into marine environment in } \\
\text { windy conditions. }\end{array}$ \\
\hline Pt Stanvac & $\begin{array}{l}\text { Upper Spencer } \\
\text { Gulf, SA }\end{array}$ & $\begin{array}{l}\text { - largest oil spill in Australia in } 1992 \text { (300 } 000 \text { litres) } \\
\text { - impacted on mangrove-seagrass communities in } \\
\text { Gulf, with death and defoliation of mangroves }\end{array}$ \\
\hline
\end{tabular}


Table 3.16 Example of coastal industries and their effects (continued)

\begin{tabular}{|c|c|c|}
\hline Industry & Location & Coastal impact examples \\
\hline Pt Stanvac & $\begin{array}{l}\text { Upper Spencer } \\
\text { Gulf, SA }\end{array}$ & $\begin{array}{l}\text { - effect on fauna but no hydrocarbons in sediments } \\
\text { or in fish/crab specimens } \\
\text { - other studies inconclusive }\end{array}$ \\
\hline $\begin{array}{l}\text { Rare Earth } \\
\text { Treatment Plant }\end{array}$ & $\begin{array}{l}\text { Upper Spencer } \\
\text { Gulf, SA }\end{array}$ & $\begin{array}{l}\text { - derelict tailings and residue dams constructed in } \\
\text { intertidal zone } \\
\text { - dams left uncovered, leaching into adjacent marine } \\
\text { environment during high tidal surges }\end{array}$ \\
\hline $\begin{array}{l}\text { Torrens Island } \\
\text { power station }\end{array}$ & $\begin{array}{l}\text { Port Adelaide } \\
\text { River, SA } \\
\text { (Gulf St Vincent) }\end{array}$ & $\begin{array}{l}\text { - thermal effluent pollution and changes to the benthic } \\
\text { faunal communities in intertidal zone near thermal } \\
\text { discharge areas } \\
\text { - loss of plankton in withdrawal of cooling water } \\
\text { - juvenile salmonids open to heavier predation in } \\
\text { thermally affected areas } \\
\text { - owner's license for power station altered to allow } \\
\text { breach of ANZECC criteria and South Australian } \\
\text { water quality guidelines. A study found that after } \\
\text { temperature outfalls increased, 'there was decreased } \\
\text { species diversity, increased dominance of a 'tropical' } \\
\text { polychaete worm and increased area affected by the } \\
\text { thermal effluent' (Jones et al 1996, p796) } \\
\text { - changes in mangrove distribution and growth } \\
\text { - station uses PCBs-estuary has high levels of PCBs } \\
\text { (also from other effluent)-enters food chain with } \\
\text { toxic effects (e.g. fertility reduction, immuno- } \\
\text { suppression, hormone disruption, carcinogenicity) } \\
\text { - still a lack of data of full effects. }\end{array}$ \\
\hline Penrice Soda & Port Adelaide & - dust, noise, and discharge to Port Adelaide River \\
\hline $\begin{array}{l}\text { Products (includes } \\
\text { salt production } \\
\text { and refining) }\end{array}$ & $\begin{array}{l}\text { River, SA } \\
\text { (Gulf St Vincent) }\end{array}$ & $\begin{array}{l}\text { - } \$ 3 \text { million budgeted to improve marine discharge, } \\
\text { but still insufficient } \\
\text { - daily monitoring of discharge of the Port River. }\end{array}$ \\
\hline Pulp \& Paper Mill & Lake Bonney, SA & $\begin{array}{l}\text { - shallow coastal lagoons in south-east of SA } \\
\text { - } \text { pulp and paper effluent discharge into the lake in } 1939 \\
\text { - another mill later developed, both permitted to } \\
\text { discharge untreated wastes into drains into the Lake } \\
\text { - channel was made to the sea to discharge effluent } \\
\text { into the sea } \\
\text { - contaminants include halogenated organic } \\
\text { compounds, such as organochlorines-some } \\
\text { harmless, some toxic and persistent. Lake Bonney } \\
\text { used as a stabilisation lagoon, but resulted in scouring } \\
\text { action and enlargement of channel-lake level fell }\end{array}$ \\
\hline
\end{tabular}


Table 3.16 Example of coastal industries and their effects (continued)

\begin{tabular}{|c|c|c|}
\hline Industry & Location & Coastal impact examples \\
\hline Pulp \& Paper Mill & Lake Bonney, SA & $\begin{array}{l}\text { - toxicity in amphipods } \\
\text { - by } 1969 \text { 'Lake Bonney was a dusty brown colour, } \\
\text { turbid and occasionally had a strong odour. Wood } \\
\text { pulp containing large quantities of plastic material } \\
\text { and other solid wastes discarded by the mills, } \\
\text { accumulated around its north-eastern shore ...' } \\
\text { (Hailes 1982, p. 131) } \\
\text { - waste now monitored \& alternative discharge } \\
\text { methods considered (e.g. lack of chlorine bleaching } \\
\text { and discharge of waste processing liquids in 1992, } \\
\text { and secondary treatment to reduce toxicity in 1993) } \\
\text { - full effects inconclusive. }\end{array}$ \\
\hline $\begin{array}{l}\text { Series of industries: } \\
\text { BHP steel rolling } \\
\text { mill, ESSO-BHP } \\
\text { fractionation plant, } \\
\text { Shell/Mobil crude } \\
\text { oil storage }\end{array}$ & $\begin{array}{l}\text { Western Port, } \\
\text { Victoria }\end{array}$ & $\begin{array}{l}\text { - subject to RAMSAR treaty on international wetlands, } \\
\text { and contains many bird species } \\
\text { - impacts on mangrove/saltmarsh, and seagrass beds } \\
\text { - concerns about potential oil spills } \\
\text { - risks to public safety with product transportation. }\end{array}$ \\
\hline $\begin{array}{l}\text { Series of industries: } \\
\text { BP oil refinery, } \\
\text { Alcoa aluminium } \\
\text { refinery, Cockburn } \\
\text { Cement, power } \\
\text { station, Westarmers } \\
\text { LPG extraction }\end{array}$ & $\begin{array}{l}\text { Cockburn Sound } \\
\text { (deep-water } \\
\text { port), WA }\end{array}$ & $\begin{array}{l}\text { - } \text { effluent discharge and poor water quality } \\
\text { - heavy metals discharge (cadmium, lead, zinc, } \\
\text { chromium-exceeded standards of NH\&MRC) } \\
\text { - seagrass deaths (reduced from } 4000 \text { ha to } 900 \text { ha) } \\
\text { and dune erosion } \\
\text { - algal blooms } \\
\text { - incompatible with other coastal uses } \\
\text { - air emissions and impact on coastal residents } \\
\text { - visual impacts } \\
\text { - loss of public access to coastal zone } \\
\text { - storage or solid industrial waste on the site } \\
\text { near coast with possible soil and groundwater } \\
\text { contamination. }\end{array}$ \\
\hline Steelworks & $\begin{array}{l}\text { Pt Kembla } \\
\text { Harbour, NSW }\end{array}$ & $\begin{array}{l}\text { - discharges included high levels of heavy metals, } \\
\text { cyanide, phenolics and ammonia; } \\
\text { - pollutants retarded the settling of the larval stages } \\
\text { of bryozoans so that they remained as plankton for } \\
\text { longer and were reduced in numbers by predation. }\end{array}$ \\
\hline
\end{tabular}

Sources: De Guia 1982; Hails 1982; McFarlane \& Sheridan 1986; Reilly 1991: Rozenbilds 1991; AGC Woodward Clyde Pty Ltd 1993; Zann 1995; Batley 1995; Connell 1995; Brookes 1996; Burzacott 1996; Jones et al. 1996; Moran \& Grant in Young 1996; Lewis et al. 1998 
Sound in Western Australia, where there are several industries along a coastal strip, Botany Bay in New South Wales, and the north-western coast of Tasmania (see, for example, De Guia 1982). In the Tasmanian example, coastal waters are heavily polluted by metal discharges, partially treated sewage, and discharge from a chlor-alkali plant and pulp mill, and as a result, stricter monitoring controls have been established (Batley 1995, Zann 1995). But more importantly, Tasmania has been described, particularly in relation to the Derwent River, as one of the most polluted regions in the world (Batley 1995, Zann 1995 p. 59). Interestingly, water quality levels in this area were within ANZECC drinking water guidelines, but were outside levels established for the protection of aquatic ecosystems (RAC 1993a).

South Australia also has particularly distinct coastal industry locations, primarily in the Upper Spencer Gulf (Port Pirie, Port Augusta, and Whyalla), and in the Port Adelaide River area, the former being heavily contaminated by zinc, cadmium, chromium, cyanides, iron, manganese, ammonium, and lead in intertidal sediments (Reilly 1991, Brookes 1996). There is also a useful summary of pollutants in the Port Adelaide River in the South Australian State of Environment Report for 1998 (EPA SA 1998). Coastal industries in Victoria are located primarily around the western suburbs of Melbourne and Geelong, and while Port Phillip Bay in Victoria is particularly characterised by problems of ballast water and introduced species (see page 158), industrial infrastructure does not appear to be a major concern in this area. The exception is a major sewage treatment plant and the discharge of excess nutrients (DNRE 1998). Examples of other coastal industries, their locations and coastal impacts are summarised in table 3.16, particularly in terms of South Australia.

\section{General coastal industry impacts}

Heavy metal and other discharges/activities from coastal industries are potentially very damaging, and although usually requiring an environmental licence to do so, industrial waste frequently flows directly into the coastal/marine environment (Commonwealth of Australia 1991). The impacts of coastal industries on the coastal zone vary significantly between industries, but many impacts are similar in nature to those of mining activities which were summarised earlier, particularly 'black sands' mining. However, once again data on coastal impacts are limited. Although more studies have been undertaken on the topic of industrial coastal pollution when compared to other uses of the coastal zone, Batley (1995) queries the sampling methods used, and suggests that the data are unreliable in some instances. Most information is also drawn from international 
research which makes it difficult to place into the unique Australian context (Richardson 1995). There is little known, for example, about the full effects of PCBs (Richardson 1995, Zann 1995, Burzacott 1996), and there is still little information on the short-term and long-term effects of oil discharges on the coastal environment, despite the frequency of occurrence (Connell 1995). But in general, impacts from coastal industries and associated infrastructure, which are numerous and both direct and indirect (Young 1996), can be summarised as:

- generally poor groundwater and coastal water quality

- concentration of toxic chemicals in fish and other marine fauna, and the cumulative effects on the broader food chain

- long-term sediment contamination where toxins accumulate in the sediments, and can be re-released via dredging operations

- land subsidence and localised sea level rise (not just related to industrial development). As noted in previous sections, in the Port Adelaide area of South Australia, there is local sea level rise as a result of subsidence. This land subsidence is associated in part with land or wetland reclamation for industrial and other developments, groundwater extraction from industrialisation, and port development, among other things. Belperio (1993) noted that as a result of groundwater extraction from these reclamation and other activities, the result is soil compaction and soil acidification via substratum leaching

- loss of important ecological and economic resources including damage to fisheries due to the impacts of contaminants and the reclamation of mangroves and sea grasses; algae can also be lost in this process

- increased toxic algal blooms from excess nutrients and eutrophication

- creation of deformities and breeding abnormalities in fauna (e.g. organochlorines can cause deaths in fish and thinning of eggs, and the contaminants are passed on between generations, e.g. in dolphins)

- petroleum hydrocarbons or oil discharges from coastal petrochemical plants are usually only small-scale, but large discharges (also from shipping) can have severe adverse effects, for example, on coral reefs, seagrasses and mangroves (e.g. deaths in seeds, drowning of pneumatophores, defoliation), abnormal growths in gastropods, and death in fauna such as seals and birds. There may also be some effects on the larval stages of some marine species, but this has not yet been fully studied. In marine biota, levels of petroleum hydrocarbons are reported by Connell (1995) for seabirds, fish in the Great Barrier Reef, and clams, mussels and oysters; high contamination was found in fish and birds in Queensland, and low contamination in Port Phillip Bay, Victoria 
- increased water turbidity arising from sedimentation with the creation of ports (dredging) to support industry, in addition to port pollution by oil and toxic chemicals, litter, and the spread of antifouling paints (see also section on shipping impacts, page 156)

- greater strains on existing infrastructure, such as roads and power

- loss of public access and recreational amenity

- visual, aesthetic and noise impacts

- human health impacts for coastal residents from air emissions and consumption of contaminated seafood (RAC 1993, Connell 1995, Richardson 1995, Zann 1995).

While there is an understanding of the general types of coastal impacts that can occur from industries, the actual degree and nature of these impacts is not widely understood because it also depends on the nature of the immediate coastal environment. For instance, in Cockburn Sound, Western Australia, the coastal environment is unable to adequately mitigate industrial contaminants because of poor flushing conditions, and a minimal tidal influence which may dilute and draw the contaminants out to open sea (Hails 1982). Similarly, in the Upper Spencer Gulf of South Australia, aerial emissions from industries tend to be trapped over the Gulf's waters because of local climate conditions (Reilly 1991). In addition, limited fresh water inputs and minimal mixing of Gulf waters with the open sea has resulted in the accumulation of metals in the Gulf (Bell 1983).

\section{Case study: Jervoise Bay, Western Australia}

This case study is of a proposal to construct an industrial-based infrastructure development combined with a harbour development at Jervoise Bay in Western Australia, south of Perth (EIA Network, n.d.). The proposal was assessed by Western Australia's 'independent' Environmental Protection Authority (EPA) under Western Australia's Environmental Impact Assessment (EIA) process (Environmental Protection Act 1986). The development was proposed in a low wave energy area which already contained existing industries, and several other coastal uses, including fisheries, tourism, naval infrastructure, port facilities, and important recreational and conservation areas (EIA Network n.d.). Aspects of the proposal included:

- construction of an engineering and fabrication facility, with associated infrastructure

- servicing facilities for offshore oil, gas and other resource industries

- construction of a Marine Industry Technology Park for research and development

- reclamation of 60 hectares of waterfront land for berth construction 
- clearance of 80 hectares of land

- construction of wharves and onshore fabrication areas

- construction of an island breakwater $2 \mathrm{~km}$ long

- dredging of an approach channel and harbour basin

- realignment of an existing road (EIA Network n.d.).

There are already water pollution problems in the harbour (e.g. from existing industries, excess nutrients, sediment contamination, tributyl tin, and limited flushing conditions), but the EPA was concerned about a number of possible coastal impacts arising from the proposal, particularly the impact on water quality (EIA Network n.d.). Issues of particular concern included:

- a further reduction in water quality with increased entry of contaminants

- a loss of $40 \%$ of the existing reserve, loss of $40 \%$ of the coastal zone and associated loss of public access. The EPA noted that the "combination of landform and vegetation communities ... is unique in the Perth Metropoli$\tan$ Area ... The WA EPA has concluded that the landform and conservation value which would be lost through the impact on a portion of the reserve are not able to be replaced and the proposal is not able to meet the ... EPA's objectives in this regard' (EIA Network n.d.)

- effects of sedimentation in the harbour (and re-release of accumulated toxins), erosion, and turbidity (with poor light quality for marine species). This sedimentation was associated with the dredging of the approach channel and harbour basin, and a loss of seagrasses which reduces sediment stabilisation (only 750 ha of 3900 ha of seagrass remained in the area, with a further reduction of 2.1 ha associated with the proposal. It was also noted by the EPA that there were no guarantees with seagrass revegetation)

- use of dredged materials for land reclamation on the waterfront, and the possibilities of the further spread of exotic species which have been introduced through ballast waters

- impacts on two species of endangered turtles and other species (e.g. dolphins) associated with a further loss of seagrasses, habitats, and food sources. Also of concern were potential changes to patterns of migration and breeding abilities of the marine turtles

- enhancement of toxic dinoflagellate algal blooms with possible excess nutrient introduction exacerbated by changes to flushing times in the harbour, and the impact on water quality and hydrodynamics

- reduction in mixing of bottom and surface waters which could result in oxygen depletion

- impacts on 0.2 hectares of reef, which is a habitat for small invertebrates

- impacts associated with the road realignment, as a result of which run-off would be transported towards Lake Coogee via a 'closed' drainage system. 
Concerns related to excess run-off into the lake, and the inability of vegetation to absorb and prevent heavy metals from entering the lake (EIA Network, n.d.).

There was little mention of direct industrial waste discharges into coastal waters, probably given that the proposed development was primarily an industrial one which also provided supporting infrastructure for other coastal industries.

Although the EPA believed that the proposal could not meet its objectives for 'water quality, marine flora and reserves', the Minister for Environment approved the proposal anyway on the basis of adequate mitigation measures. The EPA noted:

As far as is practicable we consider that the environmental issues have been identified. However, the proposal does involve significant impacts and while mitigating measures proposed are supported, their effectiveness in some areas cannot be guaranteed. We consider that further Commonwealth assessment would not markedly add to the knowledge suite of environmental issues ... [The] EPA considers that [the] likely success of some of the mitigation measures identified by the WA Government, specifically involving the revegetation of seagrass and the remediation of the nutrient rich groundwater plumes entering the Jervoise Bay Harbour, cannot be taken as certain.

Source: EIA Network (n.d.)

This statement again highlights the lack of knowledge about complex coastal impacts associated with human activities such as mining and industrial developments along coastal zones. Nonetheless, like coastal mining, because mining and industries are usually associated with a point source of pollution, when properly managed, this makes it easier, at least for some types of coastal activities to resolve or at least alleviate some of the problems with the use of advancing pollution and clean-up technologies. There are still significant impacts occurring as a result of coastal mining and industries but, according to Young (1996), improvements have been made in reducing contamination levels, particularly with the introduction of pollution control legislation.

Greenpeace nonetheless believes that pollution control (e.g. by licensing) 'is a flawed concept, in that it implies that there is an acceptable level of pollution [at] which no damage will be done (Greenpeace 1995). Similarly, the South Australian Conservation Council believes that licences that control industrial discharges into the coastal zone are determined simply by arbitrary acceptable limits (Davies \& Flaherty 1995). Local community groups have 
also become more active about the industrial coastal pollution issue. For example, the 'Concerned Citizens for Industrial Control' group in Gladstone, Queensland, expressed concerns about industrial pollution and its impacts on fisheries, the limited controls on emissions, and the need for greater stringency in the event of breaches to pollution licences (AGC Woodward Clyde 1993). Clearly, there is still room for improvement in both coastal mining and industrial operations in the coastal zone, but this will need to be accompanied by further research in localised areas to surmount the already limited data on human impacts on the coastal zone which is associated with these and other types of coastal activities. 


\section{4}

\section{Managing the Australian coast}

The first chapter of this book examined some of the global imperatives for coastal management, pointing out that (1) most people live on or close to the world's coast, (2) the global population has a high dependency on coastal resources, and (3) human impact on the coast is already at significant levels and is increasing. The second chapter used a number of Australian coastal examples to stress the need to understand coastal processes in order to formulate effective coastal management strategies. The third chapter then illustrated various forms of human impact on the Australian coast, and noted that many of our coastal problems related to either increased human pressure, a poor understanding of coastal processes and/or inadequate planning and management.

This chapter turns to coastal management principles and practices, and examines how these operate within the complexity of the different roles of Australian governments and interactions with different community and interest groups. This is further complicated by the range of different legislative mechanisms and instruments for dealing with coastal management in each jurisdiction.

\section{The need for management}

Given that there is clearly a need for effective coastal management in Australia, how do we go about it? What is coastal management, and what is the difference between that and coastal planning? Are there well-defined methodologies or guidelines for coastal management, and what is considered 'best practice' in coastal management? 
The answers to these questions are not simple, since coastal management is not just about dealing with coastal impacts from identified coastal resource uses. It also involves political and economic considerations, which makes it difficult to discuss coastal processes in isolation from our cultural and organisational frameworks. For this reason Carter (1988), in attempting to bring coastal processes and management together in a key coastal text, discussed coastal management under five headings:

1 organisational frameworks

2 coastal water management

3 coastal land management

4 coastal ecosystem management

5 coastal hazards.

He also divided coastal management into three broad categories - policy, planning, and practice - with feedback loops between all three. However, one of the problems with his compartmentalised discussion between the different types of coastal management is the lack of integration. In fact, both Agenda 21 (UNCED 1992) and the subsequent World Coast conference in 1993 stressed the need for an integrated coastal management approach, as discussed in chapter 1 of this book. While Carter's approach is useful in recognising different types of coastal management problems, there is a danger in treating the coast in a sectoral fashion when it should be treated holistically. It is also useful to think about what is being managed, as it is not possible in reality to separate coastal water from coastal land or coastal ecosystems? We prefer to place the management emphasis back on to people, so in this book we define Australian coastal management as follows:

Coastal management is the management of human activities and sustain-

able use of Australia's coastal resources in order to minimise adverse

impacts on coastal environments now and in the future.

Thus the emphasis is on managing those people who are using coastal resources rather than the other way round. In fact, Australia's major coastal management inquiry conducted by the RAC in 1993 disagreed on where this emphasis should be placed. One of the three special commissioners disagreed to such an extent that the final report of the RAC Inquiry contains a 116-page separate report by special commissioner Graham. At the start of his report he states: 'What is needed is management of the ways in which people use and develop resources.' This may be an obvious point, but it seems to have been missed by the Inquiry (Graham 1993 p. iv). Before discussing the Australian coastal management imperatives outlined in the RAC Inquiry, it is important to examine how coastal management has evolved and see if there are any lessons for Australia. 
O'Riordan and Vellinga (1993) identify four key phases in the development of coastal management. First, the period from 1950 to 1970 was characterised by a sectoral approach which was largely reactive to coastal problems, had very little public participation, and lacked an ecological focus. It was towards the end of this period when the term 'coastal zone management' was created as part of the US Coastal Zone Management Act (Sorensen 1997). Second, there was a period from 1970 to 1990 when there was a growing environmental awareness and development of environmental impact assessment (also from the US; see Harvey 1998), increased public participation, greater integration between sectors, heightened ecological awareness, and a dominance of engineering solutions, but at times a forward-looking rather than reactive approach. O'Riordan and Vallinga's third phase is from 1990 to the time of their writing (1993) when the emphasis had shifted to sustainable development, integrated management, environmental restoration and public participation. Their final phase looks to the future, with a focus on ecological empathy, precautionary management and shared governance.

These phases in the development of coastal management around the globe are also evident in Australian coastal management approaches. For example, the very early coastal legislation such as the South Australian Coast Protection Act 1972 tends to be reactive in its approach and focuses on coast protection and engineering solutions. More recent legislation such as the Victorian Coastal Management Act 1995 incorporates the notion of sustainability, shared governance and public participation. At a broader scale, the various stages identified by O'Riordan and Vallinga are also reflected in the triggers for Australian coastal reform, as identified by Thom and Harvey (2000) and discussed in chapter 1 of this book.

At this point it is useful to consider the difference between coastal management and coastal planning, although there is more detailed discussion on planning later in this chapter. Kay and Alder (1999), in their book on Coastal Planning and Management, avoided the use of 'integrated' or 'coordinated' coastal management because of differing interpretations which they identified in the literature. They suggested that two valid definitions of coastal management could be either (1) directing day-to-day activities occurring on coastal lands and waters, or (2) the overall control of the government agencies (organisations) that oversee these day-to-day activities. However, this second definition appears to be restrictive by referring only to government, and lacks the community involvement and public participation that may be outside government control. They contrasted their 'control' oriented definitions of coastal management with coastal planning, which they suggest is more generically related to other forms of planning such as town planning. They noted that a distinctive element of 
planning is that it should essentially have two components: first, the determination of the aims for what is to be achieved in the future; and second, a clarification of the steps required to achieve these aims. They also noted that coastal planning concepts are much less developed than those for coastal management, but they also emphasised that coastal management per se is not unique, and that catchment management, for example, also uses various techniques to manage both land and water resources.

Australian coastal management, as outlined in chapter 1, has undergone extensive review, culminating in the RAC's Coastal Zone Inquiry in 1993. This inquiry indicated that we need better management and vision for the Australian coast. The report points to major problems such as urban sprawl and pollution of the coast. The Inquiry itself provided an assessment of the existing situation, but has left the action to others. The only guiding principle it used was the concept of ecologically sustainable development (ESD). (This is discussed further in relation to the coastal zone; see page 252.) The conclusion of the RAC report is that there is a lack of coordination between government agencies. Coastal management is different in every state, and the RAC suggested that all the states legislation should not be changed, but that a national approach be adopted, rather than a Commonwealth approach.

The Inquiry essentially concluded that there were numerous problems with the way in which coastal management was practised in Australia at that time (in 1993), and that it was time for a new approach. The Inquiry (RAC 1993, p 360) identified the major shortcomings of coastal management, as follows:

- Different and usually uncoordinated approval systems operate for public and private land

- Management and use of resources spanning marine and terrestrial areas is particularly impeded by a lack of integration and coordination of management systems

- Existing mechanisms do not provide for effective long-term management of coastal zone resources

- Approval procedures are complex, time consuming, and often sequential rather than concurrent, making them costly for applicants and governments

- Although some Commonwealth, state and local government agencies have developed policies to achieve coastal zone management objectives, the policies and objectives are often not implemented and they are rarely integrated with social, economic and environmental goals

Thus, in addition to the problems resulting from human impact on the Australian coast (as illustrated in chapter 3), there were inadequate or inefficient coastal management practices. Clearly there was an imperative for reform of Australian coastal management at the end of the 20th century. At about the same 
time, there were a number of international factors for reform (Thom \& Harvey 2000). Collectively, this has produced significant change at both the Commonwealth and state government levels, particularly in the 1990s but with a momentum continuing into the 21 st century (see chapter 1 ).

Although there have been a number of changes, such as the introduction of the Commonwealth's Coastal Policy (1995) and the reform of various pieces of state coastal management legislation or policies (e.g. in New South Wales, Queensland, Tasmania and Victoria), it is useful to revisit the four factors for coastal management reform as discussed in chapter 1: global change, integrated resource management, sustainability, and community particpation. Global change was discussed in chapter 2 , and sustainability and community particpation are the subject of separate discussion later in this chapter. The concept of sustainability or ESD was also a key aim of the RAC Inquiry. However, there is a need to expand on the concept of integration, as the lack of integration in Australian coastal management was a major finding of the RAC Inquiry.

According to Kay and Alder (1999, p. 57), the combination of adaptive, integrated, environmental, economic and social management systems that focus on coastal areas form the core concepts of coastal management. The concept of integration, as outlined in chapter 1, has a number of dimensions, such as intergovernmental, intersectoral, spatial, scientific management, and international. Of these, the first three are particularly relevant for Australia. Intergovernmental integration refers to vertical integration between Commonwealth, state and local governments. The RAC Inquiry found this to be lacking. Similarly, major problems were identified in relation to the lack of horizontal or intersectoral integration in Australian coastal management. Another major problem has been the lack of spatial integration between the land, ocean, and coast.

The concept of integrated coastal management (ICM) was outlined in some detail by Cicin-Sain and Knecht (1998), and there is evidence of management strategies designed to be integrative, but it is not so easy to find good examples of best practice. It appears that the Victorian coastal management system has a number of elements of ICM. A key element for establishing ICM in Victoria has been the creation of the Victorian Coastal Council (VCC), which is responsible for the planning and management of the Victorian coast. The VCC gives advice to the Minister for Environment and Conservation and has also been responsible for developing the Victorian Coastal Strategy (1997). This strategy is a statutory framework for the long-term sustainable management of the Victorian coast and is underpinned by principles of ESD and ICM. The Strategy has a clear statement of objectives and actions for coastal management, including the identification of the appropriate lead agency. 
At the regional level in Victoria there are Regional Coastal Boards which provide an additional mechanism for ICM at this level by developing strong community, industry and local government linkages. These Boards also report to the Minister for Environment and Conservation and have many similar functions at the regional level to those of the VCC at the state level. One reason for the apparent success of both the Boards and the VCC is the diverse range of backgrounds and skills of the members. Another factor in achieving ICM at the regional level is the development of Coastal Action Plans by the Boards which guide coastal planning and management.

A second example of the Great Barrier Reef provides an even clearer example of ICM and has been quoted as a good example of ICM best practice in Australia (RAC 1993, Harvey 1999). Although ICM was defined in chapter 1 of this book, it is worth repeating the definition (from the 1993 World Coast Conference) here and comparing it with the Great Barrier Reef example: 'Integrated coastal management involves the comprehensive assessment, setting of objectives, planning and management of coastal systems and resources, taking into account traditional, cultural and historical perspectives and conflicting interests and uses; it is a continuous and evolutionary process for achieving sustainable development' (IPCC 1994, p. 40).

The same conference outlined a number of key elements of integration in order to achieve ICM (IPCC 1994, p. 25). These are to integrate:

- responsibilities of agencies at different levels of government (vertical integration)

- responsibilities of different government sectors (horizontal integration)

- responsibilities of government and local groups

- policies across sectors of the economy

- economic, technical/scientific, and legal approaches to coastal problems.

Harvey (1999, p. 293) provided a full explanation of the reasons why the Great Barrier Reef is a good example of ICM. That case is summarised here. First, as noted in chapter 3 of this book, there is great complexity in the management issues of the Great Barrier Reef Marine Park and World Heritage Area. However, the successful ICM is largely due to the Great Barrier Reef Marine Park Act, which has been in place since 1975, and the Great Barrier Reef World Heritage Area 25-year strategic plan, established in 1994. A major management success has been the use of zoning plans in the marine park that attempt to balance the needs of different user groups by spatial separation of conflicting uses. Zoning plans are characterised by simplicity and minimal regulation of human activities while maintaining consistency with other zoning plans, providing buffer zones and basing zone boundaries on geographic features, with single zones around discrete areas. 
These zoning plans have been developed through an exhaustive process of consultation with community and stakeholder groups, using some basic principles:

- that the planning areas should be as large as possible

- that zones should encompass all acceptable usages

- that zones should grade from least through to most heavily protected zones, to buffer protected areas

- that traditional and customary users of the managed area should be consulted and involved in the development and implementation of the plans

- that traditional law and management practices should be incorporated to the greatest possible extent.

The levels of protection vary from preservation and scientific research zones which allow only some scientific research, to marine national park zones where most scientific, educational and recreational uses are permitted plus a marine park buffer zone, through to general use zones where uses are kept to sustainable levels. An example of an area that has been zoned, such as the Cairns region (figure 4.1) shows how this is applied. Across the whole of the marine park most of the park is zoned general use A and then B (see table 3.13, p. 171). The next largest section is the marine national park $B$.

Figure 4.1 Zoning of the Great Barrier Reef (Cairns Section)

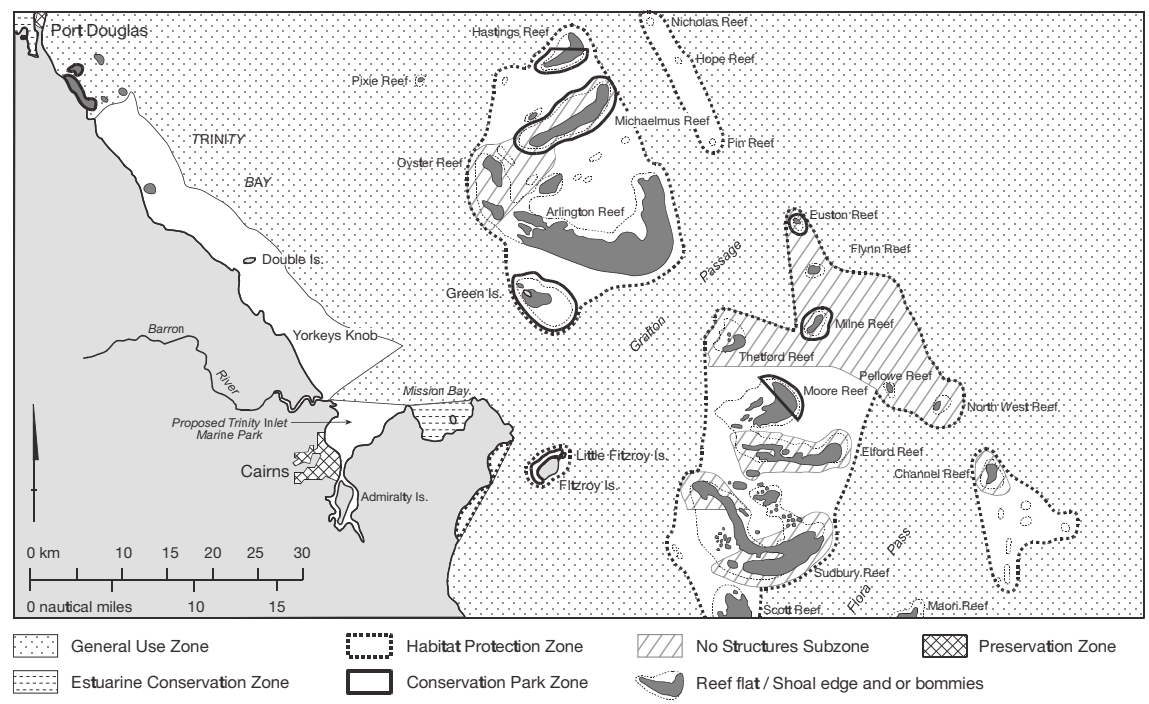

Source: modified from GBRMPA \& QNPWS 1992 
Harvey (1999) noted that some of the examples of ICM for the Reef have linkages with integrated catchment management principles (as another form of integrated resource management) as identified by Hollick and Mitchell (1991). For example the marine park is managed under a partnership approach, with stakeholder involvement and conflict resolution mechanisms. It also has a clear jurisdictional element by defining the area as a single system or subsystem. There is a systems component through the identification of interactions between humans and a biophysical system. There is also a strategic approach of evaluating and prioritising key activities, and a flexibility that allows for adaptive management. All of these elements are consistent with Hollick and Mitchell's integrated management approach.

Referring back to the key elements of integration for ICM identified at the World Coast conference, these can best be illustrated by examining the types of integration that occur with the marine park management (see box 4.1). For example, it can be seen that all levels of government are involved (vertical integration), there is integration between government and local groups (consultative and advisory committees).

\section{Box 4.1 Examples of integration, Great Barrier Reef}

- Ministerial Council-State/Commonwealth level; coordinates policy at the Ministerial level

- GBRMP Authority-State/Commonwealth level; principal advisor to the Commonwealth regarding the care and development of the Park

- Consultative Committee - All levels of government (including local government) and NGOs; provides independent advice to the GBRMPA

- Advisory Committees - multidisciplinary research bodies set water quality, management coordinators, fishing, etc.

In addition to the Great Barrier Reef Marine Park there is also evidence of ICM in the associated World Heritage Area 25-year strategic plan for the Reef. This plan makes specific reference to integrated management and aims to consider the ecological relationship between the area and other areas, particularly the mainland. The plan has eight sections, each of which clearly outlines the objectives and strategies. For example, the goal of resource management outlined in the strategy is to facilitate sustainable multiple uses of the resources of the World Heritage Area through integrated management systems. Similar ICM principles relate to mechanisms in the plan for integrating planning activities between the Great Barrier Reef, the wet tropics, and integrated catchment management, to name a few. 


\section{Conclusion}

Coastal management is about managing human activities and making sure that there is sustainable use of Australia's coastal resources in order to minimise adverse impacts on coastal environments now and in the future. A major problem in the past with various forms of management has been to treat different regions or zones in a sectoral rather than a holistic manner. This has been very true for coastal management. There is now a realisation that our use of coastal resources cannot be considered in isolation from, for example, catchments or marine environments. For this reason coastal management has to take a broader approach to managing the impacts of humans on the coast.

In addition to the need for a holistic approach to biophysical aspects of the coast, there is also a need to coordinate our various management agencies, authorities, different levels of government, and various stakeholders who have an impact on the coast. For this reason it is important to adopt the principles of ICM. The management of the Reef is a good example of ICM, where each dimension of integration needed for the coastal zone (as proposed by CicinSain 1993) has been addressed, including interactions among sectors, between regions, among government levels and the wider community, and between disciplines, all of which are essential requirements of integrated management (Harvey 1999, p. 295).

\section{Government roles and responsibilities}

This section deals with the roles and responsibilities of governments in Australian coastal management. The important managerial activities of private landowners and community organisations are dealt with elsewhere. During the 1990s there has been a re-examination of the coastal management roles of all spheres of Australian government as policy development has responded both to increasing awareness of pressures on the coast and to international concerns over the global environment. Changes in policy and in management arrangements have been the subject of detailed discussion in Haward (1995), Kay and Lester (1997), Thom and Harvey (2000), and Wescott (1998).

\section{Context}

Australia has a federal system of government, involving six states and two territories. At the coast, Commonwealth, state/territory and local governments all play a significant role. A fourth level of management, that of Aboriginal owners or custodians, is unique to the Northern Territory, where the traditional owners control $84 \%$ of the coastline (Zann 1995, p. 78). 
Under the Offshore Constitutional Settlement 1983-1990, the states generally have jurisdiction over marine areas to three nautical miles offshore; and, through international agreement (UNCLOS III, 1994), the Commonwealth controls an Economic Exclusion Zone that extend to 200 nautical miles (370 $\mathrm{km}$ ) offshore. There are necessary exceptions to this zonation; for example, the Torres Strait has been divided by international treaty, and gulfs and bays are under the care and control of the state government.

\section{Commonwealth responsibilities}

The Commonwealth has, under the Australian Constitution, few powers that relate directly to environmental management. However, it has an important role in coastal planning and management through its indirect financial and funding powers, by leading national policy-making in a range of related areas, and through its influence, particularly through the Council of Australian Governments (COAG). The changing overall patterns of Commonwealth and state government relations are especially salient to the actual role played by the Commonwealth in coastal management.

In the past the Commonwealth has used, or threatened to use, its constitutional powers to determine significant coastal decisions, in spite of state opposition. For example, in 1974 the Commonwealth forced an inquiry into sand mining on Fraser Island through its Environmental Protection (Impact of Proposals) Act 1974 and then, in 1976, determined the cessation of miningin the face of Queensland government outrage - through its withdrawal of export licenses to Dillingham Murphy Ores. In the 1990s the Commonwealth and the states have proceeded in a less confrontational manner.

The Heads of Government agreement in 1999 has the potential to make significant changes to Commonwealth-state relations over the environment. The resulting Act, the Environment Protection and Biodiversity Conservation Act 1999 (EPBC Act) came into effect on 16 July 2000. The Act replaced a number of Commonwealth statutes, including:

- Environmental Protection (Impact of Proposals) Act 1974

- National Parks and Wildlife Conservation Act 1975 (declaration and management of significant land and sea areas)

- World Heritage Properties Conservation Act 1983

- Endangered Species Act 1992

- Whale Protection Act 1990.

The EPBC Act gives the Commonwealth Minister for the Environment the power to regulate environmental impact assessment and approval of activities 
in an area, matter or item of 'national importance', or for which Australia has international obligations. The Act defines matters of national importance as:

- World Heritage Areas

- Ramsar wetlands

- threatened or endangered species

- migratory species

- Commonwealth marine areas

- nuclear actions.

Other matters could be added to this list by regulation. Actions affecting Commonwealth lands may also require approval.

Actions, commenced after 16 July 2000 that might have significant impact on matters of national environmental significance must be approved by the Minister. With regard to coastal areas, these could include, for example, coastal development, fishing, aquaculture, and vegetation clearance.

Commonwealth approval of actions runs in parallel with state processes, which still apply. Penalties for failure to comply with the EPBC Act can be severe: including imprisonment and fines up to $\$ 5.5$ million.

The Act specifically addresses biodiversity. The EPBC Act gives protection to listed threatened species, threatened ecological communities, listed migratory species, listed marine species and all cetaceans. The Act provides for the identification of threatening processes and critical habitats and for the preparation of recovery plans, threat abatement plans, and conservation plans. This appears to be a radical change to Commonwealth-state relations, giving the Commonwealth the powers to make direct management intervention in parts of a state's lands and waters.

Other Commonwealth legislation is directly significant at particular parts of the Australian coast, including:

- Australian Heritage Commission Act 1975. Entering a place of natural or cultural significance on the Register of the National Estate places obligations on Commonwealth decision-makers

- Great Barrier Reef Marine Park Act 1975. The Commonwealth has a direct role in managing the Great Barrier Reef in partnership with the Queensland government

- Native Title Act 1993. This Act deals with the recognition and protection of native title rights and interests.

The Commonwealth also has a direct role in managing coastal lands and waters of Defence establishments, such as part of Jervis Bay, and through the Australian Fisheries Management Authority (AFMA). The Commonwealth is the regulator for maritime safety and shipping and sea dumping and offshore resource exploration. The Commonwealth is the initiator of a great deal of 
research throughout the coastal zone, through the CSIRO, the Australian Institute of Marine Science (AIMS), the Australian Geological Survey Organisation (AGSO), and the Bureau of Resource Sciences. It also funds significant national data services through the Bureau of Meteorology, the Hydrographic Survey and the National Tidal Facility.

Australia has entered into a number of international declarations and agreements that deal with environmental issues at regional, national or international levels. Some of the more important conventions are shown in table 4.1.

Some international agreements require action primarily by the Commonwealth, for example a national state of the environment reporting process is both

Table 4.1 Some international conventions signed by Australia

\section{The Declaration of the United Nations Conference on Environment and Development (UNCED)}

Endorsed by the United Nations General assembly, 1992.

This is a declaration rather than a binding agreement. The declaration re-affirms and extends the UN Stockholm Declaration of 1972. New principles added to the 1972 document include: the polluter pays principle; the precautionary principle; environmental impact assessment; public participation; 'vital role' for indigenous people and women.

\section{Agenda 21}

(Part of the UNCED declaration, above).

This is an action plan which commits countries to implement the principles of UNCED, including national, regional and local strategies for ecologically sustainable development and state of the environment reporting.

Chapter 17 'Protection of the Oceans, all kinds of Seas, including enclosed and semi-enclosed seas, and coastal areas, and the protection, rational use and development of their living resources'. This lengthy chapter commits states to integrated management and sustainable development of coastal areas and their exclusive economic zone. This aim is explored in detail. It supplements and builds on LOSC, 1982 (below).

\section{Convention on Biological Diversity}

Signed: 5.6 .92

Entry into force for Australia: 29.12 .93

The objectives are the conservation and sustainability of biological diversity, and the equitable sharing of benefits arising out of the utilization of genetic resources.

\section{The Framework Convention on Climate Change}

Signed: 9.5 .92

Entry into force for Australia: 21.3.94

Aimed to achieve stabilization of Greenhouse Gas emissions. Monitoring and reporting on Greenhouse gas emissions; research on responses, including coastal vulnerability to sea level rise. 
Table 4.1 Some international conventions signed by Australia (continued)

\section{Convention for the Protection of World Cultural and Natural Heritage}

Signed: 23.11.72

Entry into force for Australia: 17.12.75

This is a legally binding treaty. Australia is obliged to protect World Heritage List sites.

The objective of this convention is to promote co-operation among nations to protect heritage which is of such universal value that its conservation is of value to all people. The Great Barrier Reef and South West Tasmania are examples of coastal or marine areas covered by this convention.

\section{Convention on Wetlands of International Importance (the Ramsar Convention)}

Signed: 2.2.71

Entry into force for Australia: 21.12.75

This convention originated as a way to protect wetlands important to migratory birds as habitats. In 1990 the name was changed to reflect the interest in the conservation and protection of all wetland values and to encourage their management in line with ecologically sustainable principles. Roebuck Bay, Western Australia, is an example of a significant coastal area listed under this convention.

\section{International Convention for the Regulation of Whaling (1946) and Protocol (1956)}

Signed: 2.12 .46

Entry into force for Australia: 10.11.48

This convention was originally an instrument for the controlled harvesting of whales, but has evolved into a means to effectively end commercial whaling. The Commonwealth Whale Protection Act, 1980, protects all cetaceans in Australian waters.

\section{Convention on the Conservation of Migratory Species of Wild Animals (1979)}

Signed: 23.6 .79

Entry into force for Australia: 1.9.91

This is a binding agreement to which Australia is a signatory. The convention commits signatories to take action to conserve migratory species. An agreement for the conservation of the albatross is currently being formulated.

\section{Bilateral Agreements on the protection of migratory birds (CAMBA, JAMBA)}

Australia has negotiated bilateral agreements with China and Japan to protect migratory species of Australian birds. The agreements also foster scientific and cultural interchanges between the countries involved, as well as reinforcing the Ramsar Convention.

\section{Apia Convention for the Protection of the Natural Resources and Environment of the} South Pacific Region (1986)

Signed: 12.6 .86

Entry into force for Australia: 26.6.90

Establishes a framework for nature conservation in the South Pacific, especially in relation to migratory and endangered species. This is a binding agreement on a number of conservation principles, but no targets are set to measure progress. 
Table 4.1 Some international conventions signed by Australia (continued)

\section{Convention for the Protection of the Natural Resources of the South Pacific Region (SPREP)}

Signed: 24.11.86

Entry into force for Australia: 22.8.90

This convention provides a binding umbrella agreement which requires parties to manage pollution. States are encouraged to identify issues of concern and to enter into agreements to address them.

\section{Torres Strait Treaty}

Signed: 18.12 .78

Entry into force: 15.2 .85

The treaty determines the maritime boundary between Australia and Papua New Guinea. The two countries have agreed to take special measures to protect the marine environment and the way of life of the traditional inhabitants of the Torres Strait.

\section{UN Convention on the Law of the Sea (LOSC)}

Signed: 1982

Entry into force for Australia: 16.11 .94

This a binding agreement which delimits states' jurisdiction at sea, primarily with regard to resource use and navigation.

This convention establishes conservation and management regimes for fisheries in exclusive economic zones. It imposes obligations to prevent, reduce and control marine pollution from land, the atmosphere, and vessels and from dumping. It also includes a regime for the enforcement of marine pollution laws.

\section{The International Convention for the Prevention of Pollution from Ships, 1973} (modifed 1978) (MARPOL 1973/78)

Entry into force for Australia: 14.1.88

A binding international convention that requires annual reporting of incidents involving ship-based pollution.

part of Agenda 21 and a condition of Australia's membership of the OECD. However, most issues involve state powers and need ratification by the states. Frequently the Commonwealth has set standards (as for example in the ANZEC Water Quality Guidelines), and required reports and management plans (for instance management plans for Ramsar sites). Most conventions involve reporting responsibilities, often involving the states and local government: this places a number of significant coastal conservation issues (e.g. wading bird habitat) on agendas for funding and action, from which they might otherwise be absent. Conacher and Conacher (2000, p.138) though has noted significant slowness in Australia's record of implementation of international agreements, involving many coastal and marine sites. 
The Resource Assessment Coastal Zone Inquiry (Commonwealth 1993a, p. 90) noted that the implementation of these treaties requires an integrated approach from all three tiers of government. It might also be noted that within the workings of the Australian system of cooperative federalism, there is an expectation that the Commonwealth will take the lead in such integrated action.

\section{The development of the Commonwealth Coastal Policy}

Commonwealth activity in coastal management before the mid 1990s has been described as policy development without action, or 'paralysis by analysis' (Haward \& Vanderswaag 1996, p. 283). In its summary of previous inquiries of relevance to the Australian coast, the Resource Assessment Commission (RAC 1993c) reviewed 29 previous national inquiries and also noted 34 inquiries by state governments.

By the end of the 1980s it was clear that there was a groundswell of concern in Australia over the degradation of coastal lands and the pollution of coastal waters. Prime Minister Hawke's Statement on the Environment in July 1989 mentioned that coastal management would be referred to the Resource Assessment Commission. This statement was made shortly after the House of Representatives Standing Committee on Environment Recreation and the Arts (HORSCERA) had begun its inquiry into 'the environmental degradation of the Australian coastline and coastal waters'. HORSCERA consulted widely, holding public hearings across the country, calling for submissions in response to a discussion paper and organising seminars. Its report, The Injured Coastline, tabled in Parliament in April 1991, provided a clear, short statement of the major problems of coastal zone management in Australia:

- piecemeal development and the failure to consider the cumulative effect of developments, 'the tyranny of small decisions'

- fragmentary and uncoordinated coastal management arrangements ; a multiplicity of agencies

- conflict amongst users of the coastal zone, and disillusionment with consultation

- lack of action by government agencies

- poor levels of knowledge of coastal processes and poor communication between scientists and managers.

While clearly stating the problems of the states and acknowledging the lack of resources of local government, the report did not refer to the fiscal imbalance between the tax-collecting sphere of government and the main coastal service providers. 
To deal with the problems enunciated, the Committee proposed:

- regional coastal management plans by State and local governments

- increased community involvement

- the development by the Commonwealth of a national coastal zone strategy

- the provision of Commonwealth funding to state and local governments for planning and management consistent with the national strategy

- the development of Commonwealth legislation supporting the above, with the proposed Commonwealth EPA as the lead agency.

A number of recommendations on research, national water and wastewater standards, public participation, and the development of coastal databases were also made. The HORSCERA report noted that it maintained contact with the Resource Assessment Commission.

Six months after The Injured Coastline was tabled, the Resource Assessment Commission was given its terms of reference 'to conduct an inquiry into building, tourism and mariculture and associated development in Australia's coastal zone'. While the inquiry was to be about the sustainable management of resource development and The Injured Coastline was about environmental protection, there were obvious links and overlap between these two reports. In April 1992, Environment Minister Kelly responded to The Injured Coastline report by announcing that the Commonwealth would prepare an integrated policy on the management and protection of the coastal zone. This would be complemented by the work of the RAC.

The RAC's Coastal Zone Inquiry, which was completed in November 1993 (RAC 1993a), was a large and complex process involving intensive and widespread public consultation, considerable research, and documentation. Together with background reports, issues papers and regional case study reports from each state, the Inquiry constituted a major national review. The Final Report covered coastal resource use, management arrangements, ways of improving management, funding and implementation and proposed a national coastal action program. The RAC made 69 recommendations, involving all spheres of government, including recommendations involving an integrated approach between governments. Twenty-one of the recommendations related to a national approach involving integration, coordination and consistency; 34 related to the Commonwealth; 25 to the states; and 15 to local government.

Many components of the proposed national approach did not receive political support, including a Coastal Resource Management Act and a National Coastal Management Agency. This may well have been a matter of timing as well as a lack of a clear constituency for such initiatives. The recommendations were at a time when governments were reducing rather than increasing num- 
bers of agencies, and there were no political or lobby groups to raise the priority of a national approach to coastal management. Also, this was not a time when traditional intergovernmental rivalry was any less than usual within the federation. The RAC Coastal Zone Inquiry has come to be regarded as something of a curate's egg: the good parts included raising a momentum which led to the Commonwealth Coastal Action Program and a variety of research and information-sharing activities by government agencies. The lack of followthrough on a national approach reflected the problems of the democratic system in dealing with a complex long-term issue.

The Commonwealth Coastal Policy of the Keating Government, Living on the Coast, was launched in May 1995, setting out the Commonwealth's contribution to the promotion of the ecologically sustainable use of Australia's coastal zone. The purposes of the policy were 'to provide a framework and guide for Commonwealth activities' and 'to provide a clear statement of the Commonwealth's position'. The policy also set out a number of management initiatives on funding, involving the states, local government, community groups and various institutions. Specific objectives were given, including sustainable resource use, resource conservation, and public participation. In 1997 the Howard Government revised the policy as part of the National Heritage Trust initiative. The changes included:

- improvement in the information base for coastal management (Coastnet and the Coastal Atlas)

- capacity-building through the Australian Coastal Management Conferences (1994, 1996, 1998, 2000, 2002), short courses for local government and community, and marine education and awareness building through Ocean Rescue 2000

- the production of a first State of the Marine Environment statement (Zann 1995) as part of the development of an Oceans Policy

- the Coasts and Clean Seas Program: a significant grants program to establish partnerships to reduce land-based pollution to marine waters, reduce threats to endangered marine species, and carry out marine monitoring

- the Coastal and Marine Planning Program

- a grants program for marine monitoring and projects to conserve endangered marine species

- the encouragement of community contribution to management through the Coastcare program

- a variety of programs concerned with marine management and pollution; integrated and strategic planning.

Funding for these programs is due to end in 2002 under the National Heritage Trust arrangements. 


\section{The development of the Commonwealth Oceans Policy}

The Commonwealth attempted to take the lead in marine management in releasing its Oceans Policy in December 1998, addressing the responsibilities and opportunities of the whole of the national marine jurisdiction (Commonwealth and states), as defined under the United Nations Convention on the Law of the Sea (LOSC). Figure 4.2 (from Commonwealth 1998, p. 41) defines Australia's maritime zones as distances offshore from low water. The areas of national jurisdiction, such as 'Territorial Sea' and 'Exclusive Economic Zone', are defined in parts II-VI of LOSC.

Figure 4.2 Australia's Maritime Zones

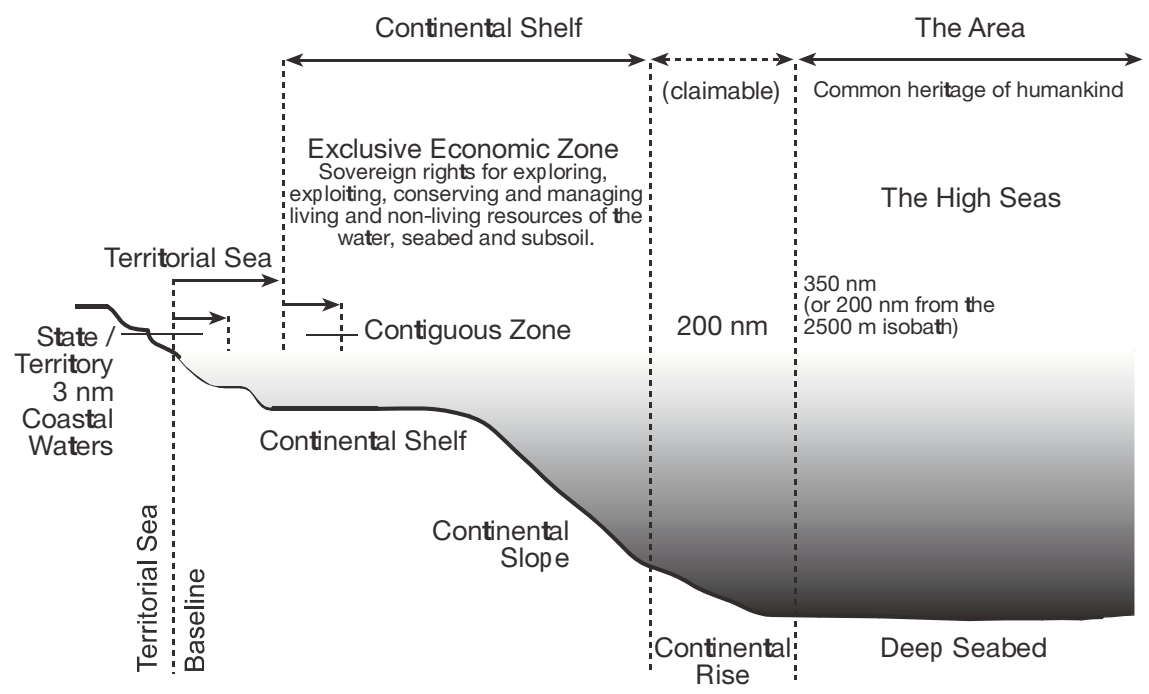

Source: Commonwealth of Australia 1998

The Oceans Policy was developed following some consultation with agency and industry stakeholders and the community, and was announced by the Prime Minister with a commitment to spend $\$ 50$ million in establishing the process. This Commonwealth commitment was, however, undertaken without the agreement of the states. The Policy includes a vision, a series of goals and principles, and policy guidelines, which promote the ecologically sustainable development of Australia's oceans. The Commonwealth has set up a National Oceans Office (reporting to the Federal Minister for the Environment and located in Hobart), and has also established a National Oceans Ministerial Board (comprising relevant Commonwealth ministers) and a stakeholders' National Oceans Advisory Group. 
The Oceans Policy declares the following goals:

- to protect Australia's rights over offshore areas

- to meet Australia's international obligations (under, for example, the International Convention on Prevention of Pollution by Dumping)

- to protect Australia's marine biodiversity (strategically, by supporting the notion of a representative marine reserve system; see page 277)

- to promote ecologically sustainable development

- to establish integrated oceans planning and management arrangements

- to accommodate community needs and aspirations

- to build capacity in ocean-related management, science, and technology

- to identify and protect natural and cultural marine heritage

- to promote public awareness and understanding of Australia's marine environments.

Figure 4.3 Preliminary large marine domains regionalisation and marine planning

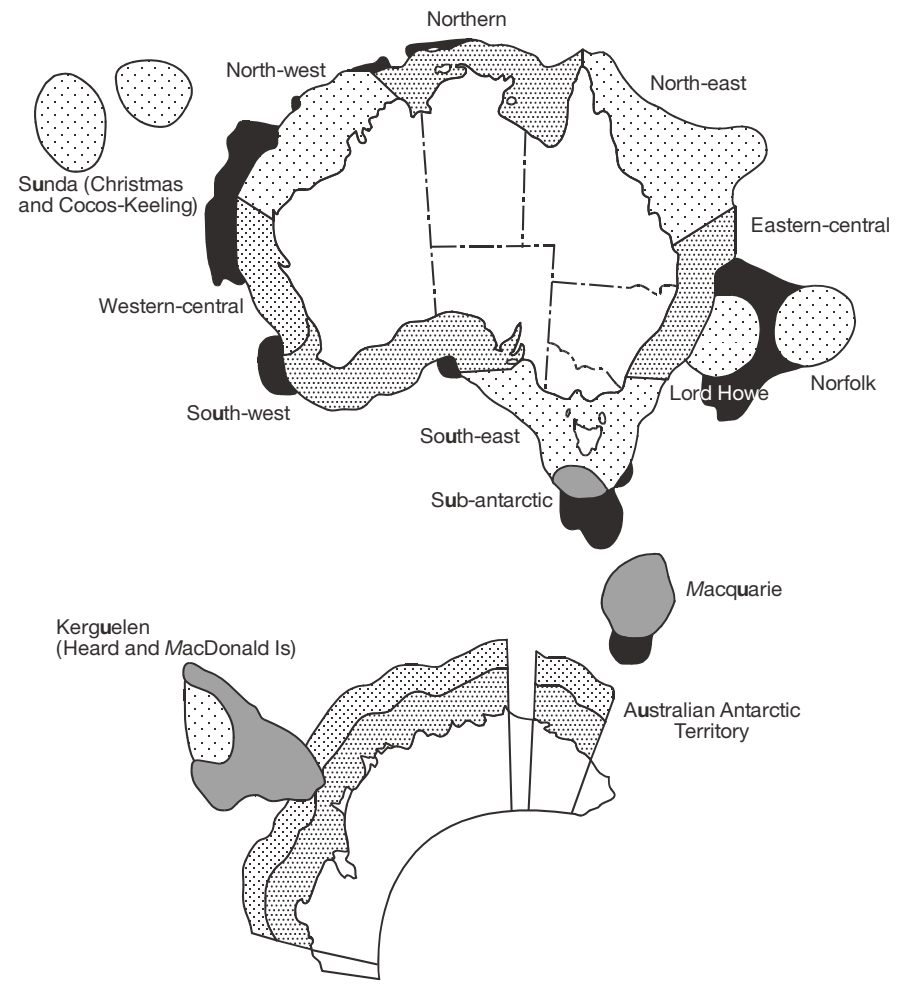

Note: see Commonwealth of Australia 1998, Australia's Ocean Policy, vol. 1 p. 19

Source: www.oceans.gov.au/regional_1.jsp (accessed 1 July 2002) 
The vehicle for implementing and developing the Oceans Policy is regional marine planning on a large scale: all of Australia's national seas have been divided into regions on the basis of broad ecological differences (figure 4.3).

The National Oceans Office has taken the lead in commencing the coordination of the first marine planning process under the policy, through the South-East Marine Region Plan, as a way of developing process and methodology. The South-east Marine Region is indeed large: it extends from low water to continental shelf waters beyond the EEZ, from southern New South Wales, around Tasmania, the whole of the coast of Victoria, and the south-east of South Australia, to Cape Jervis. The area of this marine region exceeds 2 million $\mathrm{km}^{2}$ - double the land area of Tasmania, New South Wales, and Victoria combined (Environment Australia 2001a, p. 11). The proposed methodology is integrated, ecosystem-based ocean planning and management. This concept, discussed by Grumbine (1994), is in active evolution; Tarte and Wescott (2001) suggested that it has the following attributes:

1 interactions between ecological levels (species, populations, habitats, regions) are taken into account in resolving issues

2 management acts within ecological boundaries and across administrative, political and jurisdictional boundaries

3 management's focus includes the maintenance of ecosystem integrity

4 management collects information beyond that required to manage individual sectors

5 monitoring of management uses measurable performance indicators to assess the success or failure of actions

6 adaptive and precautionary management is applied

7 interagency cooperation to integrate conflicting legal mandates, management practices, and priorities

8 organisational change to achieve interagency cooperation and adaptive management

9 management of human activities, recognising that human activities are fundamental influences on many systems, and are in turn affected by them

10 management recognises, accepts, and incorporates biodiversity values into all resource allocation processes.

A significant part of the evolution of the Commonwealth Oceans Policy will be the working out of the relationship with the states and local governments; to achieve effective results, all three spheres of government will need to be involved. The South-east Marine Region Plan process is a significant part of developing cooperation over this issue. 
Table 4.2 Major management instruments of states and territories

\begin{tabular}{|c|c|c|}
\hline New South Wales & Northern Territory & Queensland \\
\hline \multicolumn{3}{|l|}{ Coastal Policy } \\
\hline $\begin{array}{l}\text { NSW State Coastal Policy, } \\
\text { 1997. (Whole of } \\
\text { government.) Review } 2002 \\
\text { Re-formed Coastal Council to } \\
\text { give advice to the } \\
\text { government and to report } \\
\text { annually on the } \\
\text { implementation of the policy }\end{array}$ & $\begin{array}{l}\text { A review of the policy has } \\
\text { been proposed, as the } \\
\text { current system is largely } \\
\text { defunct }\end{array}$ & $\begin{array}{l}\text { The Coastal Protection and } \\
\text { Management Act } 1995 \\
\text { commenced } 1 \text { February } \\
\text { 1996. State coastal } \\
\text { management plan-State } \\
\text { Coastal Policy, August } 2001 \\
\text { Currently working to update } \\
\text { Coast Protection Act }\end{array}$ \\
\hline
\end{tabular}

to Parliament

\section{Outline of current or proposed coastal management system}

Policy implemented by state agencies and local governments. Applies to coastal lands and waters, except the 'metropolitan' area, from Newcastle to Wollongong

\section{Main instruments}

Coastal Protection Act, 1979

Environmental Planning and Assessment Act, 1979

Coastal Policy, 1997

Coastal Management Policy

Coastline Management Plans

Development Control Plans

Estuary Management Plans

Local Environmental Plans

Regional Environmental Plans

State Environmental Planning Policies
The coastal management system of the Northern Territory is based on the 1985 Coastal Management Policy which is implemented through coastal management plans for areas under pressure

Coastal Management Plans

Foreshore Protection Plan
Specific coastal management legislation provides for statutory plans. The plans use other instruments especially local government for delivery. The plans create control districts in which special coastal development controls and management apply

Coastal Protection and Management Act 1995

State coastal management plan 2001

Control districts

Regional coastal management plans (proposed) 


\begin{tabular}{llll}
\hline South Australia & Tasmania & Victoria & Western Australia
\end{tabular}

\section{Coastal Policy}

$\begin{array}{ll}\begin{array}{l}\text { Currently working } \\ \text { to update Coast }\end{array} & \begin{array}{l}\text { State Coastal Policy } \\ \text { came into operation 1 }\end{array} \\ \text { Protection Act } & \text { 0 October 1996. The } \\ \text { Coast Protection Board } & \text { policy provides for a } \\ \text { undertaking review of } & \text { State Coastal Advisory } \\ \text { coastal policy, 2001 } & \text { Committee. }\end{array}$

\author{
Created the Victorian \\ Coastal Zone Council \\ Coastal Council and 3
}

Regional Coastal

Boards

\section{Outline of current or proposed coastal management system}

Coast Protection Board advises on development plans and applications within the coastal zone. CPB has power of direction over coast protection structures and manages the Metropolitan Adelaide beach management scheme

\section{Main instruments}

Coast Protection Act 1972

Development Act 1993

Coast protection district management plans (advisory)

Plan Amendment Reports (local government development plans)

Policy on coast protection and new development

\author{
Statutory state-wide \\ coastal policy is \\ implemented through land- \\ use planning controls, \\ environmental \\ management and pollution \\ controls, marine farming \\ and development plans, \\ and local government plans
} State government in 1997 endorsed the Victorian Coastal Strategy by the Coastal Council. The Revised Coastal Strategy was authorised in January 2002

Coastal policy must be taken into account in local planning schemes and planning applications, regional and local area coastal management plans

Coastal Management Act
1995
Fisheries and Park plans
and strategies
Local Coastal Action Plans
(private and public land)
Management Plans for
foreshore areas and
National Parks
Melbourne Metropolitan
Strategy
Planning schemes for
coastal areas.
Regional Catchment
Strategies
Victorian Biodiversity
Strategy
Victorian Coastal Strategy

Coastal Management Position Paper (1983) 1988 Country Coastal Planning Policy DC.6.1 1996 Draft Coastal Planning Policy Local Area Coastal Management Plans Regional and local strategic planning documents Regional Coastal Strategies Statutory planning instruments

Continuation of current non-statutory coastal management system based on regional and local coastal management plans with the coastal activities of various government agencies coordinated by the Coastal Zone Council 
Table 4.2 Major management instruments of states and territories (continued)

\begin{tabular}{|c|c|c|}
\hline New South Wales & Northern Territory & Queensland \\
\hline \multicolumn{3}{|c|}{ Supporting instruments or strategies } \\
\hline Coastline Management Manual & & State coastal management plan \\
\hline Estuary Management Manual & & likely to contain guidelines \\
\hline
\end{tabular}

\section{Other closely relevant legislation}

Fisheries and Oyster Farms Act 1935

Crown Lands Act 1989

Land and Environment Court Act 1991

Protection of the Environment Administration Act 1991

Local Government Act 1995

Threatened Species

Conservation Act 1995

Water Management Act 2000
Beach Protection Act 1968

Marine Parks Act 1982

Integrated Resort Development Act 1987

Local Government (Planning and Environment) Act 1990

Nature Conservation Act 1992

Environmental Protection Act 1994

Fisheries Act 1994

\section{State government responsibilities}

Under the Australian Constitution, state governments have long-standing responsibility for resource management. In the past three decades the states have developed legislation and managerial instruments in resource use, environmental management, conservation, and pollution control. Today all the states have a range of legislation and agencies that regulate uses of the coastal zone. An example of multi-agency involvement in coastal resource management is illustrated in Figure 4.4.

All states and the Northern Territory have legislation that specifically addresses coastal management, and most have small agencies that have the lead responsibility for the coast. Table 4.2 attempts to identify the current major state coastal policies and lead agencies and the range of legislation that is sig- 


\section{\begin{tabular}{l} 
South Australia Tasmania \\
\hline Supporting instruments or strategie
\end{tabular} \\ Guidelines by State \\ Coastal Advisory \\ Committee}

\section{Other closely relevant legislation}

\begin{tabular}{|c|c|c|c|}
\hline National Parks and Wildlife & Land Use Planning and & NRE: Land Act 1958 & Local Government Act 1960 \\
\hline Act 1972 & Approvals Act 1993 & Environment Protection Act & Environment Protection Act \\
\hline Historic Shipwrecks Act & Local Government Act 1993 & 1970 & 1987 \\
\hline 1989 & State Policies and Projects & Parks Victoria: National & \\
\hline Aboriginal Heritage Act & Act 1993 & Parks Act, 1975 & \\
\hline 1993 & Historic Cultural Heritage & Committees of Manage- & \\
\hline Environment Protection Act & Act 1995 & ment: Crown Land & \\
\hline 1993 & Environmental & (Reserves) Act, 1978 & \\
\hline Harbours and Navigation & Management and Pollution & Environment Effects Act & \\
\hline Act 1993 & Control Act & 1978 & \\
\hline Heritage Act 1993 & & Planning and Environment & \\
\hline Water Resources Act 1997 & & Act 1987 & \\
\hline \multirow[t]{4}{*}{ Local Government Act 1999} & & Flora and Fauna Guarantee & \\
\hline & & Act 1988 & \\
\hline & & Fisheries Act 1995 & \\
\hline & & Local Government Act 1989 & \\
\hline
\end{tabular}

nificant in coastal management. The legislation illustrates something of the complexity of looking after the coast, involving the overlapping fields of resource management, conservation and pollution control.

Recently, four states have promulgated a 'whole of government' coastal policy-Tasmania (1996), New South Wales (1997), Victoria (1997) and Queensland (2001). South Australia and Western Australia are in the process of developing state coastal policies. These mark important steps towards the integration of coastal management in Australia.

\section{The Tasmanian State Coastal Policy}

The Tasmanian State Coastal Policy of 1996 (reviewed and confirmed in 1999) is a policy created under the State Policies and Projects Act 1993. State policies 
are a mechanism created under the Tasmanian Resource Management and Planning System, and they apply throughout the state. A state policy is a statutory document which is intermediate between the provisions of an Act and the provisions of planning schemes. Section 13(1) of the State Policies and Projects Act makes it clear that, where there are inconsistencies between a state policy and a planning scheme, the inconsistency must be rectified in favour of the policy. Compliance with the policy is enforced with penalties, under s.14(1). All state agencies and local governments are required to give effect to a state policy 'to ensure that a consistent and coordinated approach is maintained throughout the state' as set out in s.5(1)(c) of the State Policies and Projects Act.

The coastal zone extends seaward to the outer limits of the territorial sea, and extends inland to the extent necessary to embrace activities, uses and developments which may have a significant effect upon the amenity and environment of the coast. This definition led to a legal challenge of the Policy in 2002.

The Policy has a tiered structure, consisting of general objectives and principles followed by detailed policy 'outcomes'.

The objectives of the Tasmanian Coastal Policy are those of sustainable development. Three main principles are given for the policy:

- Natural and cultural values of the coast shall be protected

- The coast shall be used and developed in a sustainable manner

- Integrated management and protection of the coastal zone is a shared responsibility.

The policy statement attempts to implement these principles.

\section{The Victorian Coastal Strategy (revised October 2001)}

The Victorian Coastal Council (VCC) was appointed under the Coastal Management Act 1995 as the peak body for the strategic planning and management of the Victorian coast, and to provide advice on coastal issues to the Minister for Conservation and Environment. Three Regional Coastal Boards-West, Central, and Gippsland - support the Council.

The Coastal Management Act defines the preparation of the Strategy as the major duty of the VCC. The task was carried out following an 18-month period of consultation, with state agencies, local councils and the public.

The Strategy sets out four 'principles for action': Sustain, Protect, Direct, Develop. The draft revision retains this structure, with the four principles explained in terms of sustainable development. Under each of these four principles general objectives are defined, with policies to work towards the objectives; actions and the nomination of lead agents are added to the policies. 
Figure 4.4 Schematic view of zones of jurisdiction of Victorian state agencies, 1993

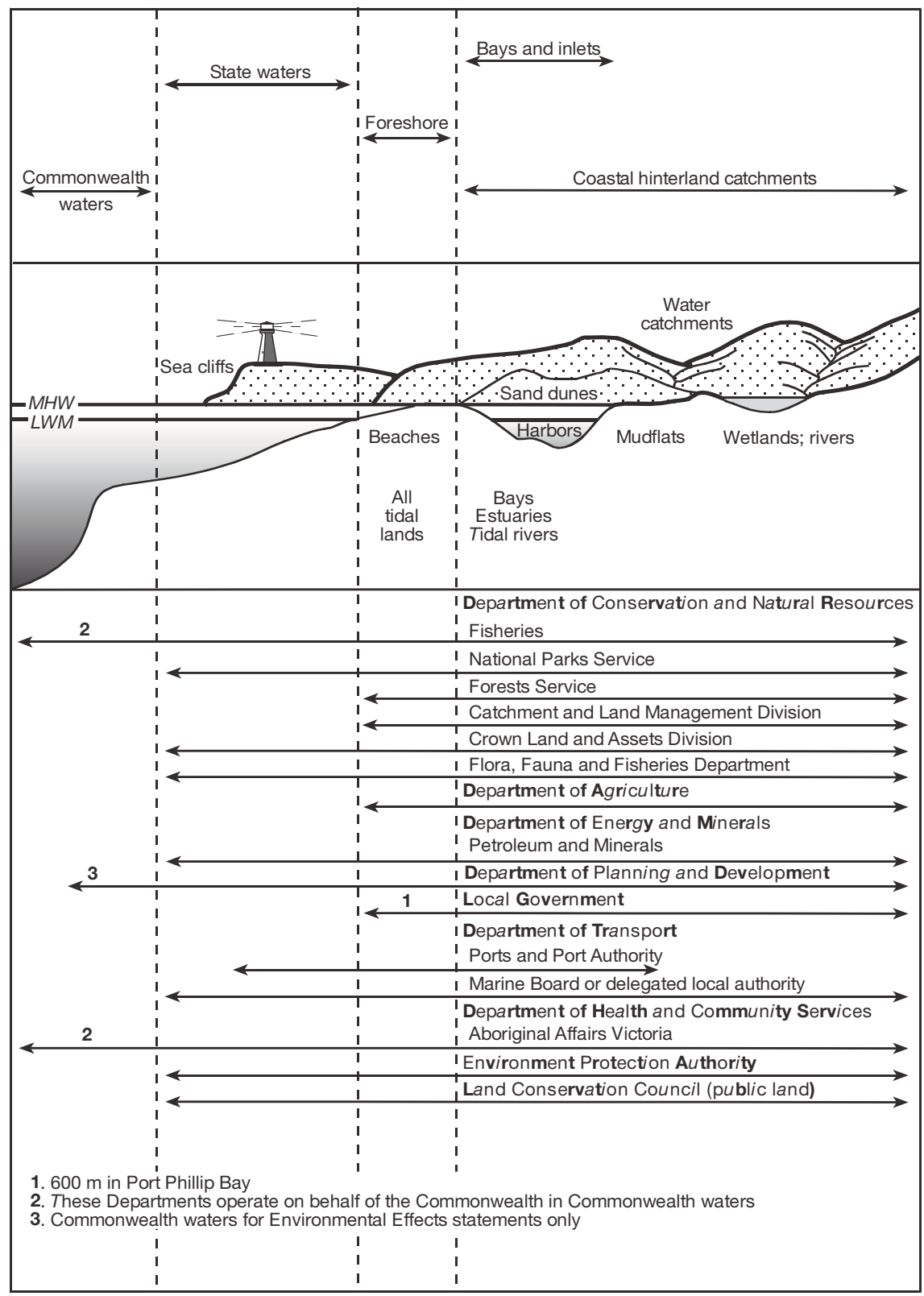

Source: State Government of Victoria 1994 
The coastal zone includes land and waters on the seaward side of coastal watersheds, and the sea and seabed to the limit of state waters.

The Coastal Strategy is a 'whole of government' statutory policy agreed and implemented by state agencies and local councils: under the Coastal Management Act, land managers must 'take all reasonable steps' to give effect to the Strategy. Actions are defined strategically and detailed through Local Action Plans. The Regional Coastal Boards oversee implementation of the Action Plans. Implementation is assisted by the fact that $96 \%$ of coastal lands in Victoria are in public hands.

\section{The New South Wales Coastal Policy}

The New South Wales Coastal Council was appointed under the Coastal Protection Act 1979 with a range of duties, which include advising the Minister on 'policies concerning the planning and management of the coastal region; and, the coordination of the policies and activities of the Government'.

The 1997 New South Wales Coastal Policy entitled A Sustainable Future for the NSW Coast, is a revision of the 1990 policy, and has evolved through an extensive process of public consultation (NSW Government 1990a, 1997). The 1997 Coastal Policy is government policy, and 'all New South Wales State Government agencies and local councils are required to take account of it in the preparation of their own specific policies and plans' (NSW Government 1997, p. 24). The policy builds upon a well-established system of regional and local environment plans, coastal and estuary management plans and on guidelines, such as the Coastline Management Manual (NSW Government 1990b).

The policy applies to the area encompassing waters three nautical miles seaward of the mainland and offshore islands, land one kilometre landward of the open coast high water mark, and land within one kilometre around all bays, estuaries, coastal lakes and islands and tidal waters of coastal rivers. However, the policy to date does not apply to the Greater Metropolitan Region.

The Policy defines goals and objectives and sets out strategic actions organised under the nine goals. The Coastal Council is required to report annually to the state parliament on the implementation of the policy, and to date three such reports have been made. The annual report to June 2001 details the large amount of work of coordination involved in implementing the policy, including notably the establishment of a seven-minister state cabinet subcommittee on the coast, as well as the task of ensuring that Local Environment Plans are compliant with the coastal policy. Among its key points, the 1999-2000 Annual Report noted: 'The Annual Report of the Coastal Council provides evidence of 
increasing co-ordination of actions between stakeholders to implement the Coastal Policy. However the process of gathering information for this annual report has highlighted the different understanding, appreciation and priorities of agencies and councils involved in coastal zone management' (Coastal Council of NSW, Annual Report 1999-2000, p. 4).

\section{The Queensland State Coastal Management Plan}

The Queensland Government gave this plan statutory effect under the Coastal Protection and Management Act 1995 in August 2001 (Qld EPA 2001); it is the state coastal policy. It follows a draft statement in October 2000, and an earlier document entitled Queensland's Coast: Managing its Future. A Position Paper on Coastal Management in Queensland, released for discussion in December 1999. The plan is also described as a policy response to the coastal issues described in the 1999 Queensland State of the Environment report.

The State Coastal Plan applies to the coastal zone as defined in s.11 of the Coastal Protection and Management Act: 'coastal waters and all areas to the landward side of coastal waters in which there are physical features, ecological or natural processes that affect, or potentially affect, the coast or coastal resources'. The coastal zone includes catchment areas where activities have impacts on coastal resources, as well as all the coastal waters of the state. The coastal plan is seen as having greater application to 'undeveloped' rather than urban areas (Qld EPA 2001, p. 3).

The plan delivers a vision and direction for coastal management within the state. The plan is envisaged as setting out the overall policy for coastal management, as well as specific policies for certain types of areas, such as erosion-prone areas. It defines 11 coastal regions, within which Regional Coastal Management Plans will apply the policy to specific geographical areas, and where the boundaries of control districts and key coastal sites will be defined. The plan indicates that a period of 10 years is needed to implement the regional plans.

The plan defines outcomes, principles and policies under 10 headings: coastal use and development, physical coastal processes, public access to the coast, water quality, Indigenous traditional owner cultural resources, cultural heritage, coastal landscapes, conserving nature, coordinated management, research and information.

The State Coastal Plan has the effect of a State Planning Policy under the Integrated Planning Act 1997. Local government must take the policy into account in making new plans and assessing developments. State agencies must have regard to the plan, and the Queensland EPA is given the task of working with other state agencies to implement the plan's provisions. 


\section{The 'whole of government' state policies compared}

\section{Coastal use and development}

- Tasmania, Victoria and New South Wales clearly state a goal of ecologically sustainable development and extend this as a policy theme. Queensland's policy statement does not elaborate this as a principle, though it appears to underlie the statement. Tasmania and New South Wales develop the precautionary principle in policy

- Whereas Tasmania uses a reactive policy in addressing competing demands for development, New South Wales, Victoria and Queensland adopt a more strategic approach in identifying areas ('activity nodes') for specific types of development

- All states have a policy on compact coastal settlements: Tasmania, Queensland as a principle, New South Wales and Victoria also outline specific processes. Queensland, Victoria and Tasmania give policy preference to coast-dependant development

- New South Wales (through detailed guidelines) and Queensland have developed specific policies on flooding and erosion (including site elevations, erosion setback lines, etc); Tasmania and Victoria policy is stated as principles in this area

- Further canal developments are opposed in New South Wales and Queensland

- All states have a policy on impact and rehabilitation with regard to extractive industry; New South Wales has banned sand mining in sensitive coastal areas

- Tasmania, New South Wales and Victoria have developed a strategic policy with regard to tourism development; Victoria has developed detailed priorities within a tourism growth policy

- Tasmania, Victoria, New South Wales and Queensland detail policy on fishing and aquaculture, including sustainable management plans

- climate change is recognised in policy by all four states; New South Wales has the most specific policy with regard to new developments.

\section{Public land}

- New South Wales has a proactive policy and program for the acquisition of coastal land for the reserve system; 60000 ha have been acquired since 1995

- The policies in all states support extending public access to and along the foreshore; Victoria details improved infrastructure. Victoria, Tasmania and New South Wales propose ways of improving facilities on public land 
- All states have a policy on coastal road patterns; Victoria outlines priorities for improvement. Victoria, New South Wales and Tasmania address ways of reducing $4 \mathrm{WD}$ pressure.

\section{Water quality}

All four states include a policy on:

- water quality management, monitoring and standards

- wastewater and stormwater discharges

- groundwater and acid sulfate soils (New South Wales and Queensland)

- catchment management (New South Wales has a extensive policy on estuaries and coastal wetlands and lakes)

- sea-based pollution.

\section{Cultural heritage}

All four states outline a policy on the identification and recording of Aboriginal sites and the involvement of indigenous peoples in decisionmaking processes.

\section{Coastal landscapes}

Tasmania, Victoria, New South Wales, and Queensland outline processes for identifying and protecting scenic coastal land through planning instruments and, in New South Wales, through acquisition.

\section{Conserving nature}

- Tasmania, New South Wales, Victoria and Queensland have a policy relating to acquisition and management of lands and waters of significance

- All states have a policy on biodiversity relating to the continued development of a representative protected area system for lands and waters.

\section{Coordinated management and institutional arrangements}

- Queensland, New South Wales and Tasmania include regional coastal plans as an integral part of their policy approach

- All states have a policy on integration and detail statutory mechanisms to achieve this.

- Tasmania and New South Wales have a policy supporting intergovernment cooperation and the development of a national approach to coastal zone management

- New South Wales, Tasmania and Victoria have a policy on funding to implement the coastal policy. 


\section{Research, information, community participation}

- All states have a policy supporting community participation in rehabilitation and restoration. All states support capacity-building

- Tasmania and Victoria have developed a policy on research

- Queensland, New South Wales and Victoria have a policy on information management and cooperation

- Queensland Tasmania and Victoria have a policy commitment to carry out monitoring.

As suggested above, state and territory governments have the most significant powers relating to coastal management in Australia, and this is expressed in a wide range of legislation. These powers are given effect by many agencies of various sizes, and because there is a diversity of resources and uses at the coast, a multiplicity of regulation is hardly surprising. See for example, the situation in Victoria in 1993 (figure 4.4), prior to its policy developments. The agencies have a wealth of expertise, and hold a wealth of data; the expertise of the state agencies is a significant part of Australia's capacity in coastal zone management. However, in this role the expertise and worthy objectives of the players have frequently been frustrated by the structures within which they work. The various agencies involved in coastal matters often have different agendas, objectives, and (most importantly) different priorities. At best these agencies have cooperated within interdepartmental structures to achieve specified aims; at worst they may be driven by an agenda based on a struggle for resources within government. Neither of these extremes, nor the many options in the middle, have assisted the integration of coastal management across the many agencies involved. The moves by the eastern states to establish 'whole of government' coastal policies are extremely significant in the establishment of integration at the state level.

\section{Box 4.2 Case study: Regulating a large coastal development- the redevelopment of the Strand, Townsville}

In the late 1990s, following storm damage, the City of Townsville rebuilt its main city beach and foreshore reserve. The scheme involved major land reclamation and protective works, carried out immediately adjacent to a major Dugong and turtle habitat within a World Heritage Area. It illustrates the role of a number of regulators, in the planning and management of a major development.

In 1997 and 1998, Cyclones Justin and Sid and associated tropical summer storms undermined $80 \%$ of Townsville's central main esplanade seawall, the Strand. By February 1998 the recreation beach was only a few metres wide at low water, and the hard protection for the Strand had almost completely collapsed. 
Figure 4.5 The Townsville foreshore beach before reconstruction


(photography Townsville City Council) 
Townsville City Council was faced at that time with the need to protect the city's premier esplanade before the next summer's storms, and to restore and improve the beach and foreshore reserve facilities as a key part of its tourism image and community recreation facilities.

\section{Key players}

\section{Townsville City Council}

The city was the proponent for the scheme, and was responsible for ongoing management. Design, project management, and works were carried out by 17 consultant firms, including architects, engineers, surveyors, and hydraulics, lighting, and street design specialists.

\section{State agencies}

State agencies were involved through the following acts:

- Harbours Act 1955 (Queensland EPA). The Strand redevelopment required development approval under this Act, since works below high water and land reclamation were involved.

- Fisheries Act 1995 (Queensland Department of Primary Industry). The Act regulates fish habitat. The works involved the removal of a number of mangroves and the destruction of some nearshore seagrass: the Act requires approval for the removal of these plants.

- Beach Protection Act 1968 (Queensland EPA, Beach Protection Authority). The Strand is contained within a designated Erosion Prone Area: the Act requires approval from the BPA for works contained within this area.

- Coast Protection and Management Act 1995 (Queensland EPA). Townsville City Council is required under this Act to liaise with the EPA in the redevelopment of the Strand for 'protection, conservation, rehabilitation and management within the coastal zone'.

- Environment Protection Act 1994 (Queensland EPA). The Act and its policy regulations related to materials supplied to the construction site, to ambient conditions during construction - especially noise and nearshore turbidityand to impacts of the works. In order that 'all reasonable and practicable measures be taken' to minimise environmental harm, very detailed plans for construction processes which addressed these concerns were agreed with relevant agencies.

- State Development and Public Works Organisation Act 1971 (Queensland Department of Economic Development and Trade). This Act required the council to consider the environmental effects of undertaking the redevelopment of the Strand.

\section{Commonwealth agencies}

Commonwealth agencies were involved because areas of the Strand redevelopment beyond low water are within the Great Barrier Reef World Heritage 
Area, and because of the potential impact on the nearby Great Barrier Reef Marine Park. Cleveland Bay contains significant habitat for the vulnerable Dugong and the endangered Green Sea-turtle. The primary environmental value of Cleveland Bay is its seagrass meadows, containing a great variety of seagrass species. There was also the potential for turbidity caused by the construction process to severely affect this area by reducing the light necessary for seagrass growth.

- Great Barrier Reef Marine Park Act, 1975 (Great Barrier Reef Marine Park Authority, located in Townsville).

- World Heritage Properties Conservation Act, 1983 (Environment Australia). This Act provides for the protection of areas recognised as world heritage. Entry to the World Heritage List is compiled under the authority of UNESCO's Convention for the Protection of the World's Cultural and Natural Heritage (1972), after application by the Government of Australia and evaluation.

A Scientific Advisory Group, which included the Queensland EPA, DPI Fisheries and the Great Barrier Reef Marine Park Authority, was set up by the Council to oversee compliance with environmental regulation.

The outcome of the redevelopment project is shown in figure 4.6.

\section{Figure 4.6 The Townsville foreshore beach after reconstruction}

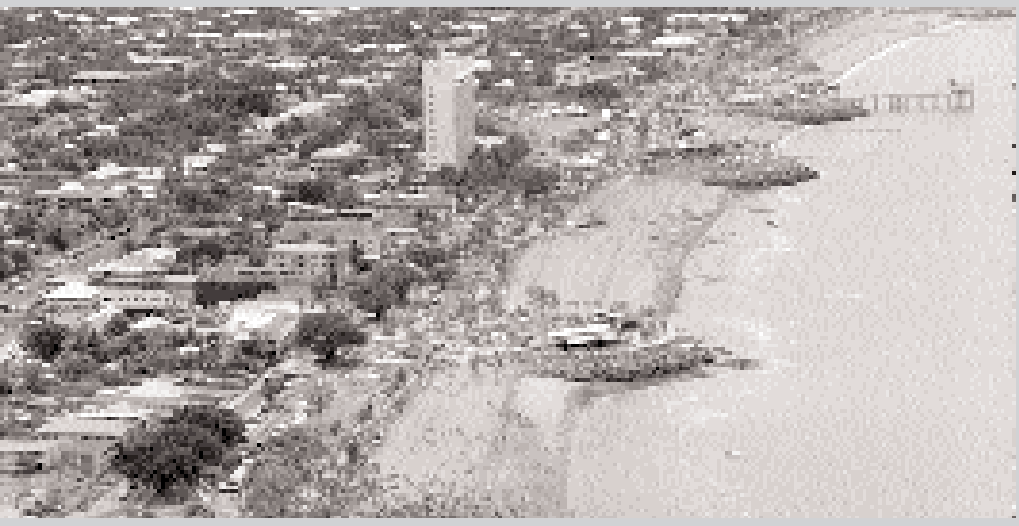

(photography Townsville City Council)

Four rock headlands were constructed to enclose and protect three bays. The beaches were constructed slightly forward of their previous position, and serve as the primary protection of the public facilities on the coastal reserve.

After this reconstruction, Townsville was awarded the 1999 Case Earth Award for 'innovation and best practice in the field of environmental management of civil construction'. 
The City reported that the major concerns with the scheme were not in relation to the technical problems of construction, but with minimising the impact on the biota of the nearshore waters and securing continued public support for the scheme. The latter was addressed through consulting and informing the public. Minimising turbidity involved a variety of technical adjustments during construction. These included ensuring the rock used in construction was cleaned of fine sediments, reducing the use of heavy machinery in water by carrying out work at low tide, and enclosing works with a silt curtain. In 2000 a Council report on the project noted that 'recent research by the CRC Reef Research Centre at James Cook University revealed that there is no indication of the Strand redevelopment significantly changing the distribution and abundance of seagrass meadows adjacent to the Strand foreshore'.

\section{Local government responsibilities}

Council functions in planning, development control, drainage and land management are vital parts of coastal management around the settled Australian coastline. Most councils face difficult and chronic problems in managing coastal resources, and most non-metropolitan councils lack the expertise and financial base to properly address these problems. Councils are also usually the first points of contact for complaint.

While council decisions are usually made in cognisance of state policies and priorities, and council decisions may be overridden by state governments, councils make the majority of planning and development decisions at the coast. Councils make decisions on developments at the coast in two ways:

- Through the evolution and promulgation of strategic and local plans. In all states, councils are required to set out their development plans with planning zones and objectives and principles for those zones. Setback or zoning may reflect residential, industrial areas, sensitive natural and heritage places, areas subject to coastal erosion or flooding, or areas with the potential for these hazards as a result of accelerated sea level rise

- Through individual decisions in response to development applications involving the interpretation of development plans.

However, there are great pressures on councils when decisions are being made about valuable coastal land. For example, it may be difficult financially for a small council to defend its decisions in the courts if there is a legal challenge over the interpretation of council plans or conflict over the merits of development applications.

State-wide consistency between plans of different councils and between council plans and state strategies and plans is achieved in different ways. For example, in New South Wales the state issues guidelines and develops regional 
strategies, but in South Australia councils must revise their plans every three years, each time securing the agreement of the Minister for Planning.

Council's development control role has strong links with the treatment, use and disposal of wastewater. The planning, construction and maintenance of stormwater and of sewage systems are either carried out by Councils, or closely involve councils. Decisions to avoid marine or estuarine disposal or to mitigate the impact of such disposal (see page 39) are often, in the first instance, a council matter.

Local government is responsible for the day-to-day maintenance of the beaches and coastal facilities, and it shares with state governments the task of shore protection. Councils are also involved in such decisions as location of access paths, roads and carparks, the keeping of public coastal land in public use, the development and maintenance of coastal reserve facilities, and the maintenance of many boat ramps and jetties. During the 19th century surveys of the Crown lands of the colonies of Australia, a narrow strip of coastal reserve was often left above high water mark, usually 30-60 metres wide. While many of these reserves have been lost through coastal erosion, most remain, and today they are of great importance in coastal management. Along the settled parts of the Australian coast these Crown coastal reserves are usually under the care and control of the local council, but community groups frequently play a vital part in their management. In the development of coastal management in Australia, these coastal reserves have created the expectation of a narrow buffer zone and the right of access along the shore. The expectation that there will be a coastal reserve, and that access to and along the shore will be assured, is a key part of the Australian attitude to the coast. In Australia the perception is that coast is a public place. This part of the coastal 'commons' is vigorously defended and incursions into it have been the cause of conflict around the continent. These narrow coastal reserves are a key part of the responsibility of maritime councils.

Councils are the housekeepers of the coastal zone. Cleaning, maintaining, improving, and regulating many activities and keeping them safe-all these functions fall to the local council or shire. Because coastal areas are so heavily used by residents and visitors and because catchment wastes end up at the coast, the costs of being the housekeeper are high. Nor are these costs likely to fall, since resident and visitor expectations with regard to facilities and pollution have risen sharply in recent years. Also, in an age of litigation, councils must be aware of a wide range of liabilities.

Thus councils are faced with rising recurrent coastal expenses with limited scope to raise revenue in ways that directly relate to use. For example, of the many carparks along the coast, it only appears feasible to charge for parking for 
some well-used urban parks, usually through a pay-and-display system. It is rare for a rural council to make money by charging for the use of facilities.

In these circumstances it appears that, with regard to the coast, councils must look to:

- ensure that development decisions today do not pass on high costs to the future, or compromise opportunities for public coastal use in the future; policies on coastal hazard and projected sea level rise, for example, are relevant to this consideration

- work with community groups to maximise the most efficient use of resources

- work with other councils to ensure the equitable distribution of any state funds that may be available

- work with other councils to ensure that opportunities to access state and Commonwealth grants for infrastructure and environmental improvement are maximised; e.g. working within a regional structure in accessing National Heritage Trust grants

- ensure that council has an environmental management system which is able to demonstrate agreed aims and to show how well they are being met; e.g. a Local Agenda 21 process, including monitoring of outcomes.

The key position of local government involves both strength and weakness: the concentration on local issues may bring with it the "tyranny of small decisions', but the local focus allows the possibility of strong and productive cooperation with the community to ensure the development of capable local management.

\section{Conclusion}

Within the Australian federal system, each of the three spheres of government plays an important role in coastal management. National and state reviews over the past decades have noted a sectoral approach to management within all three spheres. The 1990s saw the Commonwealth draw back from an opportunity to establish national legislation on the coast but increase its involvement in other ways. Meanwhile, the states have begun to integrate their coastal management through policy development: putting together existing and revised policies and practices from a variety of agencies to make a more coordinated approach. Yet their commitment of resources to implement policies is subject to increasing limitations, given priorities for the use of state funds. At the same time, an increase in pressure from rising numbers of residents, tourists and recreationists is placing great stress on the activities of all governments, but especially local government, in maintaining the coast as a safe and healthy place. 


\section{Coastal planning}

Earlier in this chapter we saw that there is a difference between coastal management and coastal planning, although there are similarities between the strategic approaches taken by both. In fact 'strategic' is also a term generally applied to policies, plans and programs, although these elements of planning are quite different. According to Wood (1991) a policy can be defined as an inspiration and guidance for action; a plan as a set of coordinated and timed objectives for the implementation of the policy; and a program as a set of projects for a particular area. Glasson et al. (1999) went further, suggesting that whereas policies, plans and programs (PPPs) can each be sectoral, spatial or indirect, there is a tiered relationship between them. They suggested that a policy provides a framework for the establishment of plans, plans provide a framework for programs, and programs lead to projects (Glasson et al. 1999). For example, a coastal policy might have a goal of sustainable coastal development which is then incorporated through various objectives and principles into a state's coastal planning framework. From this a number of detailed coastal programs may be drawn up at either the state or local council level, and these in turn give rise to a number of specific coastal projects.

Thus coastal planning is really about developing PPPs that have an underlying goal of the sustainable use of Australia's coastal resources. These PPPs have to be strategic in the sense that they look to the future and are integrative in nature. We therefore define coastal planning in Australia as follows:

Coastal planning is the formulation of coastal policies, plans and pro-

grams that promote the sustainable use of Australia's coastal resources.

It should be noted that unlike the more traditional forms of planning such as town planning or regional planning, which sometimes have major physical boundaries such as rivers or lakes, coastal planning will always have the problem of how to plan adjacent to the land-sea interface. In chapter 2 of this book, we discussed the complexity of coastal forms and processes around the Australian coast that have to be incorporated into various planning procedures. For example, development controls for residential development on a stable rocky coast may need to incorporate different principles, compared to similar controls on a fragile dune coast. It is also important for the traditional town planning to adopt a more integrative approach when considering interactions with coastal and marine processes. For example, poor coastal planning in Sydney resulted in sewage polluting the waters near the famous Bondi Beach, and poor coastal planning in Adelaide allowed development to encroach on the coastal dunes, resulting in reduced sediment supply for the beaches. 
Kay and Alder (1999) commented on various concepts of coastal planning and suggested that these are less developed than the concepts of coastal management. In part this relates to the fact that coastal planning draws on aspects of town planning, conservation planning, strategic environmental planning and marine planning. Kay and Alder noted that, although there is considerable literature on planning theory, there is no clearly defined set of planning theories. They suggested the coastal planning approaches borrow from a number of planning theories, the most important of which are rational, incremental, adaptive and consensual planning (Kay \& Alder 1999). They also quote unpublished material of King which identifies a change over the last 20 years from rational planning theories to more participative approaches such as adaptive and consensual planning, which reflects the overall changes to how societies, especially Western societies, relate to the environment (Kay \& Alder 1999, p. 68).

In Australia there is a variety of specific coastal planning legislation in some states but nothing in others, and the linkages with individual state planning procedures are also just as varied. Each state has its own planning legislation, with different linkages to coastal development. In 1977, in an attempt to produce better coastal planning in Australia, the Commonwealth government funded the Royal Australian Planning Institute to prepare 'good practice guidelines for integrated planning' as part of the capacity-building component of its Coastal Action Plan. The aim of these guidelines was to help planners understand coastal planning techniques and put better techniques into practice. The guidelines (Graham \& Pitts 1997) addressed two questions: (1) what are the desirable outcomes from the development, use and management of coastal resources? and (2) how can planners contribute to these outcomes?

The guidelines also recognised that the desirable outcomes should protect coastal resource values, including:

- natural values (environmental, ecological)

- lifestyle values (recreational, access, amenity)

- economic values (economic resources and activities)

- cultural values (traditional, pre-European culture, historic) and

- landscape values.

A key principle of the guidelines is the concept of ecologically sustainable development or ESD (see page 251) and its incorporation into decisions that impinge upon the use of coastal resources. The guidelines recognised that there is a well-developed philosophy for coastal planning, but point out that our current planning processes do not always deliver a good product because the principles of ESD have not been incorporated into the planning process.

In an attempt to incorporate key principles of ESD into objectives and guidelines for coastal planning, Graham and Pitts (1997) proposed a set of 
development objectives and guidelines to help decision-making for the development and use of coastal resources. They use four headings under which they give an objective, as follows:

\section{Natural processes}

Objective-Management consequences arising from the dynamic and fragile nature of coastal environments should be recognised and acted upon. This includes taking into account fluctuations in sea level and climate, changes in shoreline position, and species mobility within coastal ecosystems.

\section{Water quality}

Objective - The quality of coastal waters should be maintained or restored, so that there is no significant detrimental impact on the integrity of coastal ecosystems or on water-based economic and recreational activities.

\section{Biodiversity}

Objective-Local communities, and local and state governments have an obligation to protect biodiversity in the coastal zone. The biological diversity of marine and terrestrial ecosystems and natural processes within coastal biophysical regions should be maintained.

\section{Equity access and community involvement}

Objective - Coastal resources should be available for fair and equitable public and commercial use so that their use optimises the long-term benefit derived of the community. Adequate and appropriate public access to the coast should be maintained so that a range of recreation opportunities can be enjoyed, provided that they are consistent with these objectives. Suitable management practices should be established to protect coastal resources and public safety. Informed, appropriate public participation in open, consultative decisionmaking about the management of coastal resources should be ensured. Arrangements for attempting to resolve competing demands or aspirations should be established.

Under each of these objectives are a series of more specific guidelines. For example, under the water quality objective there may be a guideline that no outfalls for domestic or commercial waste should be constructed where any feasible alternatives exist, or the dumping of industrial waste at sea should not 
occur. Under the objective for natural processes may be guidelines such as giving protection to coastal wetlands, or not removing sand from the beach system if this would interfere with the maintenance of natural processes.

These good practice guidelines may be adopted to varying degrees by individual state agencies. In fact many pieces of state planning legislation have begun or have already incorporated the concept of ESD into their planning system. The mechanism for incorporating coastal objectives and principles into planning varies from state to state. In South Australia, for example, key coastal objectives and principles used to be contained within regional management plans. However, these plans lacked any statutory status, so that although they

Figure 4.7 Planning zones for the Port Elliot area of the South Australian coast, illustrating permitted uses for different coastal areas

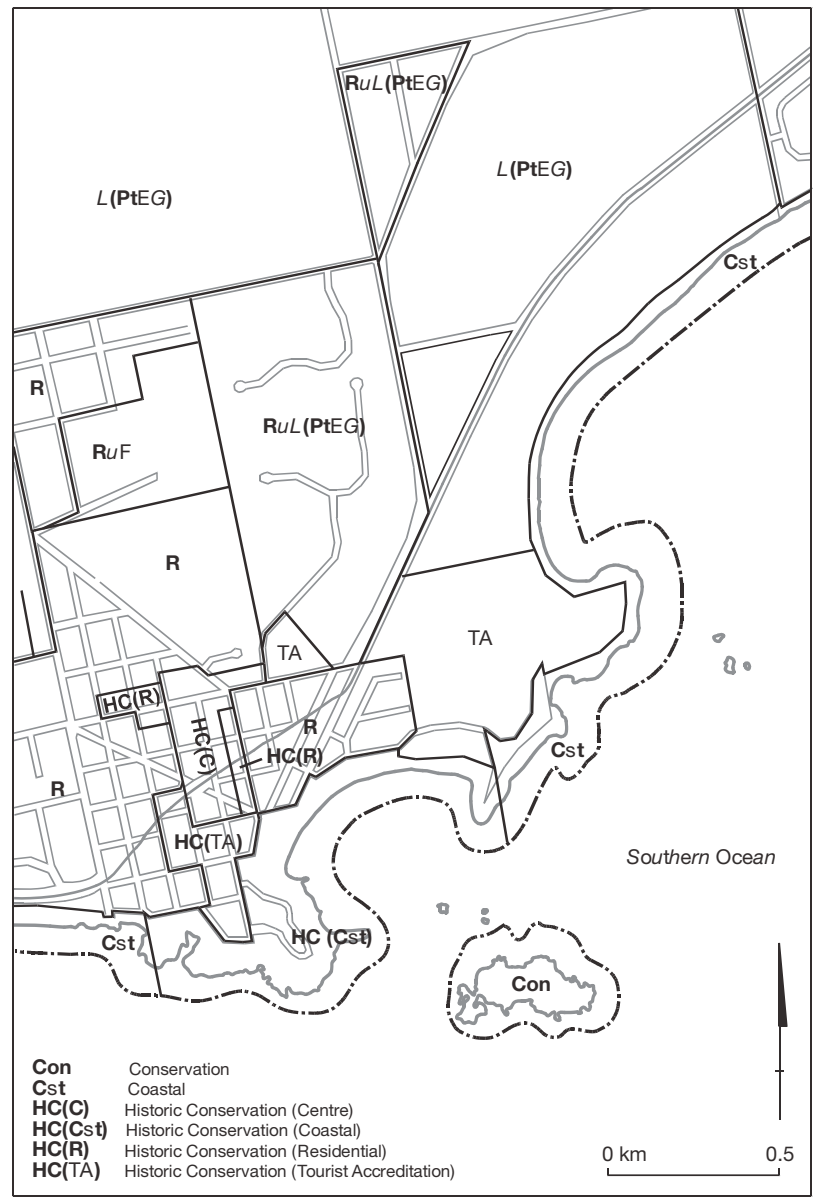

Source: modified from SA Department of Transport, Urban Planning and the Arts 2002 
contained useful background information they were less useful in terms of development control. For this reason the coastal objectives and principles were incorporated into the South Australian Development Plan, so that they must be considered along with the use of zoning for development control purposes. Zoning divides the coast into specific areas, each with its own objectives and principles and its own set of permitted and non-permitted land uses. This is illustrated in figure 4.7. Apart from the use of planning objectives and principles, it is also useful to examine the planning approval process in more detail, using a case study.

\section{Box 4.3 Case study: Coastal planning in Victoria}

The Victorian planning system has recently undergone major changes (J. Thwaites 1999). These include changes to planning schemes to reduce complexity and enhance consistency in state zoning provisions (Minister for Planning and Local Government 1998). The planning system applies to the entire state, but there is specific reference to coastal development (see below), with an aim to integrate principles of ESD into the planning process. As outlined by Thwaites (1999) a new integrated planning system for the coast is catered for. For example: 'The Government is committed to achieving for the first time an integrated state and local assessment process for use and development proposals in the coastal environment across public and private land. This means achieving better integration between the requirements under the Planning and Environment Act and the Coastal Management Act 1995.'

Thwaites went on to show how this requires a coordinated effort between the Department of Infrastructure and the Department of Natural Resources and Environment. An important part of the new integrated approach is the resolution of planning issues in the nearshore and marine environment. This is significant in terms of the global imperatives for integrated coastal and marine management. There is also the need for agreement on the appropriate controls for foreshore areas. The Regional Coastal and Marine Planning projects that have commenced across the Victorian coast are part of the mechanisms for progressing these initiatives. 'The projects are operating from Port Phillip Bay through the Association of Bayside Municipalities, and in the eastern and south-west regions' (J. Thwaites 1999, p. 24).

Within the aims to integrate the Planning and Environment Act and the Coastal Management Act, 'appropriate development' has also been defined in the Coastal Strategy (VCC 1997, p. 33). In addition to the siting and design guidelines, for example, strategy states that appropriate development should:

- be in keeping with the principles of this Strategy and be consistent with siting and design guidelines 
- $\quad$ satisfy the requirement of coastal planning strategies and plans, and relevant planning schemes

- not have serious and permanent negative impact on the environment or the natural processes, either on or off site

- be sensitively designed so that it visually complements the surrounding coastal landscape

- meet a demonstrated need

- result in upgrading or improving existing infrastructure where appropriate

- serves its intended primary function

- not lead to further pressure on existing infrastructure and utilities in the area

- result in measurable enhancement of the existing coastal environment

- not create a public risk, or management costs in terms of maintaining or removing private facilities and structures in the event of failure of the project

- generate a net public benefit to the community in both the short and long term

- maintain or enhance public enjoyment of the coast.

Environmental criteria are clearly used in this approach, and planning is required to 'recognise the dynamic nature of the coast and shall act to reduce and minimise long term risk to structures, assets and coastal values. Particular attention needs to be given to the identification of dynamic systems and potential risks and impacts from eroding cliffs or shorelines, interference with coastal processes, and rising sea levels and climate change' (VCC 1997).

The definition of appropriate coastal development, and the linkages between the planning and coastal system, are significant in the light of the strong development control powers contained within the Coastal Management Act. In this respect, the Minister responsible for the Coastal Management Act has the power of consent for proposals on coastal Crown land (s.37 and s.38 of the Act). For example: 'A person must not use or develop coastal Crown land unless the written consent of the Minister has first been obtained' (s.37) and:

If the responsible authority under the Planning and Environment Act 1987 gives the Minister the Secretary or the Department of Natural Resources and Environment, as a referral authority under that Act, a copy of an application under that Act for a permit for a use or development of coastal Crown land, that application is deemed also to be an application under this Division for that use or development (s.38(2)).

Within these rights, the Minister, after considering the Coastal Strategy and relevant Coastal Action Plan (including the activity nodes and environmental guidelines), has the power of refusal under s. 40 of the Coastal Management Act. 
There is also a cross-reference under s.61(3) of the Planning and Environment Act, whereby:

The responsible authority

(a) must not decide to grant a permit to use or develop coastal Crown land within the meaning of the Coastal Management Act 1995 unless the Minister administering that Act has consented under that Act to the use or development; and

(b) must refuse to grant the permit if the Minister administering that Act has refused or is deemed to have refused under that Act to consent to that use or development.

This is particularly significant because $96 \%$ of coastal land in Victoria is public land (NRE 2000). Clearly, the powers of development control in the Coastal Management Act are explicitly linked to Victoria's planning and environmental impact assessment system. This contrasts to South Australia where,

Figure 4.8 Integrated approvals process for private and public land

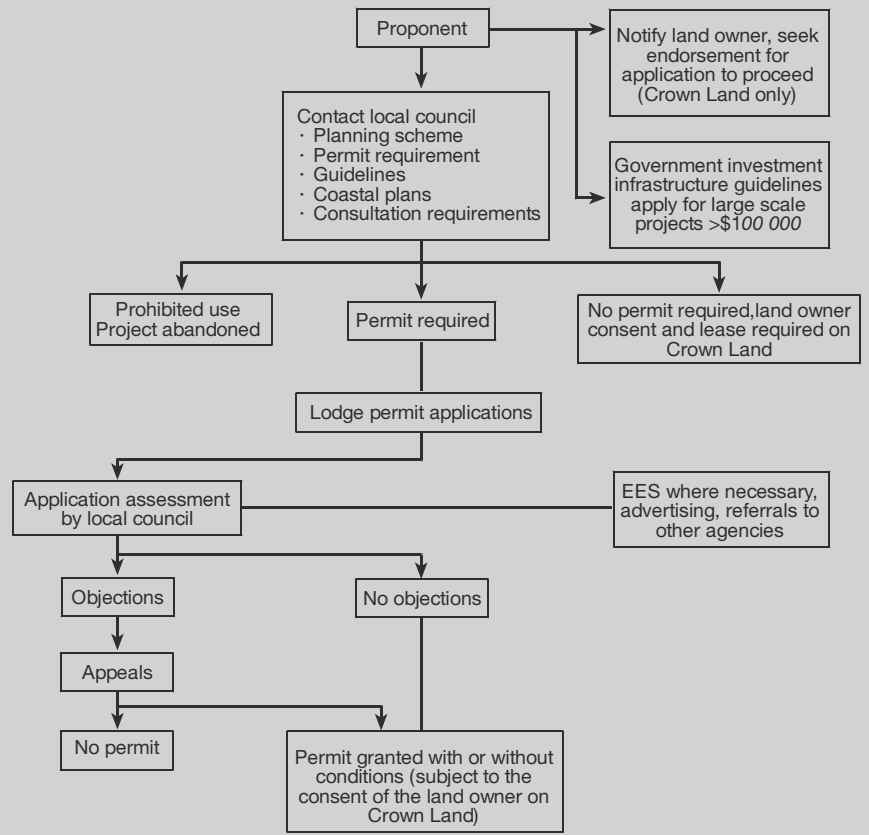

Source: VCC 1997, p.53 
for example, powers of development control and the links between coast protection legislation and planning legislation are less clear.

Thus, a more strategic and coordinated approach is being attempted, but this approach does provide much greater certainty to developers at a higher 'plan' level of decision-making which trickles down to the 'project' level of decision-making. The planning process for all types of developments is illustrated in figure 4.8 .

\section{Conclusion}

Coastal planning has been defined here as the formulation of coastal policies, plans and programs that promote the sustainable use of Australia's coastal resources. However, the actual mechanisms and planning instruments to achieve this differ around Australia. Some planning is conducted with longterm objectives across broad coastal areas or regions. This type of planning is usually strategic in nature and can provide the framework for more detailed localised planning in individual councils. At the other end of the scale, some coastal planning is more related to land use and development control involving simple zoning plans for development and land use in coastal areas.

Each state has its own planning legislation which is linked to varying degrees to specific coastal issues. The Victorian system provides a good example of where there are strong linkages with broader coastal plans, environmental impact assessment mechanisms, and an integrated state-wide approach to coastal planning. At the national level, there has been a recognition of the need for good practice guidelines in coastal planning which adopt the key principles of ecologically sustainable development.

\section{The role of the community}

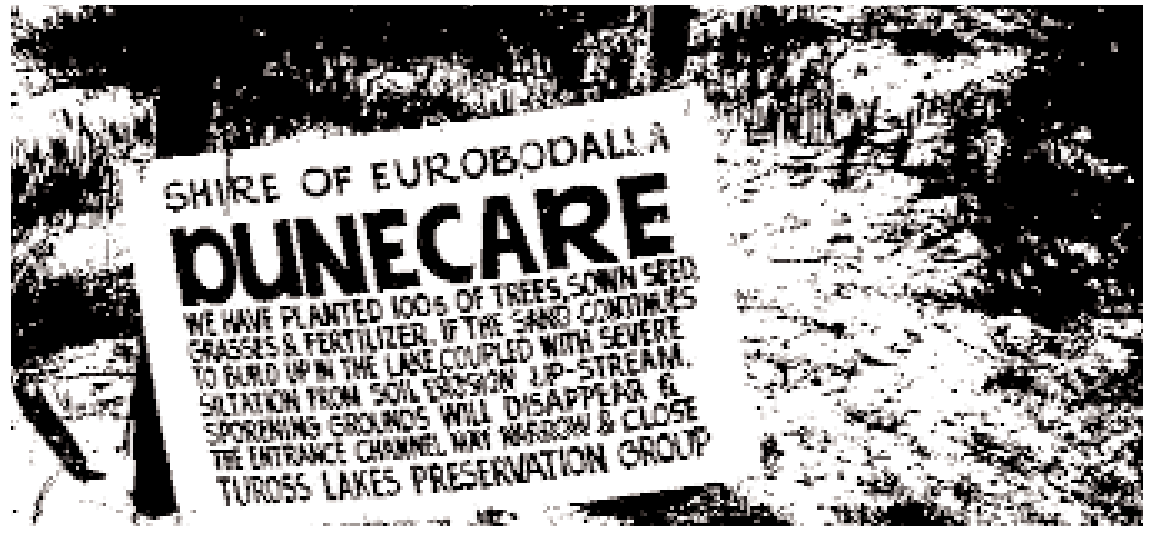


While the coast has not been a persistent peak national concern in Australia, many community-based organisations have focused on particular coastal places and issues. There is, moreover, a long tradition of community care and action at the coast, mainly linked to issues of clean and safe recreation beaches, foreshore facilities, beach access, and dune conservation. Voluntary groups have traditionally contributed directly to the management of beaches and coastal reserves up and down the country. The work of surf lifesaving clubs in beach safety is almost taken for granted in Australia, where the bronzed lifesaver is long-established as a national icon, a part of the nation's identity. The Surfrider Foundation extended this role to focus public attention on nearshore pollution, particularly from land-based discharges (see the results of The 1995 Save our Surf Survey; Wilkinson 1996). The work by service clubs in setting up basic facilities in coastal reserves is evident around the developed coast.

\section{The varied role of community groups}

Today, all around Australia, community groups play a great variety of roles in managing the coast: a surf lifesaving club concerned with beach safety; a conservation group involved with ecosystem protection; a dive club monitoring reef health; a coastal park friends group engaged in weed removal; a service group managing a foreshore reserve; or a professional fishers association managing a regional fishing zone.

Hale L. (1996) has pointed out a number of factors that lead to a varied role for community groups in coastal management; these include:

- geographic scale

- the nature of the issues involved

- the governance context

- the motivation of the community

- the relevant expertise within the community

- the style of coastal management systems currently in place.

In the past, state agencies, and sometimes local government agencies, have tended to keep community groups at arm's length and engage in closed planning and management processes, which tended not to involve the community. During the last 20 years there has been an increase in community willingness to participate and a greater readiness by governments to encourage such involvement. This has often been at the implementation stage, involving minor works, rather than in direction-setting. Many governments are extremely cautious about public involvement where it is perceived that sensitive economic or political issues are involved, or there are contingent links outside a local area. As a result, Hale L. (1996) points out that community management approaches are more likely to be successful at the local scale, where: 
- they are confined to a small geographic area

- they deal with issues that do not have strong contingent links to systems outside the control of the community

- ownership or management responsibility is located close by

- motivation is high, such as management involving the economic interests of the community

- communities have access to, or can acquire, appropriate expertise.

\section{The community's concerns}

One of the most visible roles of community groups in Australian coastal management is in drawing attention to issues of concern. A great deal of activity in coastal management in Australia (probably far too much) is driven by attention to the issue of the moment-issues as perceived by governments, bureaucracies, industry, small business, scientists, community groups, and individuals. These issues may be self-evident and persistent, such as the quality of bathing waters at certain Sydney beaches, or the erosion of parts of the urban foreshore of Port Phillip Bay. The issues may be insidious and cumulative, such as the loss of wetlands in south-eastern Australia; and an issue may be apparent only to certain groups, such as seagrass loss in particular areas. Coastal issues are diffuse and varied and the management systems that address them are complex and multilayered, and in this situation a key question is: what keeps a particular issue on the agenda, or as a priority on this year's budget? While even the asking of such a question might be interpreted as a criticism of a lack of a strategic approach in coastal management, it remains true that the profile, the definition and the understanding of issues maintains, or dissipates, the commitment of institutions, groups, and individuals to action in coastal management. Within this context the role of community groups in raising and maintaining awareness becomes a significant one in coastal management in Australia.

However, in spite of the high level of use, coastal issues in Australia have never maintained the level of interest accorded to rainforests, endangered species or large macropods. Part of the explanation for this can be found in the history of the conservation movement in Australia, which has been dominated by concern for wilderness. Doyle and Kellow (1995, p. 15) noted that 'the nature of the green movement in Australia must be appreciated. Of most importance here is its domination by concerns of wilderness preservation at the cost of urban issues or rural issues, such as land degradation ...' This comment applies well to the coast, where threats to pristine areas such as Daintree and Fraser Island rightly attract a great deal of concern, but widespread coastal issues such as loss of seagrass or loss of estuarine habitat draw little attention. 
For many years there has been an awareness of the loss of pristine coastal environments: and there is no doubt that, for example, Nancy Cato's voice has resonated more widely than over the despoliation of Noosa alone. These feelings, relating to loss, despoliation and overdevelopment, obtained some focus during the two Commonwealth inquiries of the early 1990s (HORSCERA 1991, RAC 1993a) and were demonstrated graphically by the coastal walk around south-eastern Australia organised by the Australian Conservation Foundation in 1993-94 (McLaren 1994). Nevertheless, in spite of a rise in profile during the 1990s, coastal and marine issues have not been core business for Australia's main green groups; however, they have been a particular focus for a multiplicity of resident local user groups around the continent, and in the Northern Territory for Aboriginal Australians.

While coastal issues have not been as glamorous as rainforests in national debate, over the last 30 years there has been a widespread groundswell of concern over nearshore marine and estuarine pollution. On occasions, particular coastal places have been the focus of national attention: it could be said that the Great Barrier Reef and Fraser Island have attained icon status within the national treasury of natural heritage places and have frequently been the subject of concern.

Table 4.3 Two scales of citizen control over planning and management

\begin{tabular}{|c|c|c|}
\hline \multirow[t]{2}{*}{ Ranking } & \multicolumn{2}{|l|}{ Scale } \\
\hline & Arnstein (1969) & Hale (1996) \\
\hline \multirow[t]{2}{*}{8} & Citizen control & Community control \\
\hline & & Collaborative management \\
\hline 7 & Delegated power & Delegated authority \\
\hline \multirow[t]{2}{*}{6} & Partnerships & Collaborative management \\
\hline & & Participation in planning \\
\hline 5 & Placation & Incorporation of concerns \\
\hline 4 & Consultation & Consultation \\
\hline 3 & Informing & Informing \\
\hline 2 & Therapy & Non-participation \\
\hline 1 & Manipulation & \\
\hline
\end{tabular}

\section{Participation, collaboration or management?}

A key factor in the nature of the community's role in coastal management is the power of the community within all stages of the planning and management 
process. Arnstein (1969) and Hale (1996) have produced similar graded scales of citizen control over planning and management, varying from complete community control over process and management to powerlessness (table 4.3).

Today most community activity in coastal management appears to fall into the areas of collaborative management and participation, as the following two examples illustrate.

\section{Box 4.4 Collaborative management: foreshore committees of management in Victoria}

The national Coastal Zone Inquiry recommended the more widespread use of local residents committees to manage small areas of coastal Crown land (RAC 1993a, p. 147). In Victoria such committees have been in operation for some time, maintaining reserves and raising money for this purpose by charging for the use of facilities, such as camping sites. In 1997 there were about a hundred committees managing foreshore reserves comprising $20 \%$ of the Victorian coast (Wescott 1998), although $60 \%$ of these were actually the local council acting as a committee of management and $40 \%$ were composed of members of the public. Wescott (1993) reported that between 1985 and 1992 the number of public committees directly managing coastal reserves dropped from 58 to 38 , a decline he ascribed to the lack of support from state agencies and the lack of opportunity for the committees to have input to planning decisions affecting the reserves. While some of these committees were seen as having problems such as over-parochialism, under-resourcing, a lack of expertise, and confusion over the extent of their powers, the RAC (1993a) wrote positively on their contribution to management.

The revision of coastal management arrangements for Victoria is leading to a re-examination of the role of the committees of management within a system placing far more emphasis on community involvement than previously. Under the Coastal Management Act 1995, the Victorian government has set up a lead agency, the Victorian Coastal Council, to prepare a coastal strategy and to advise the Minister on coastal matters. Three Regional Coastal Boards prepare coastal action plans and report to the Coastal Council. The community is strongly represented on the Council and the three Boards, and so has attained a voice within the revised system. Local Committees of Management are given a new role in preparing local management plans, consistent with the regional action plans. The Victorian Coast Action and Coastcare programs have given the opportunity for the committees of management to obtain resources for 
works, together with help through facilitators (six for the state). Wescott (1998) noted the continued need for support and technical input from state agencies.

The committees of management carry out their works on coastal reserves through authority delegated by the state Minister; the public is involved collaboratively throughout the revised coastal management process, though the extent of community power will depend upon the way the system is implemented. The design of the revised system has the potential to allow a working partnership with government and its agencies.

\section{Box 4.5 Participation: the case of the Trinity Inlet Manage- ment Program}

Trinity Inlet is a mangrove-lined estuary, bay and wetland complex adjacent to the rapidly growing and dynamic city of Cairns. The Inlet is a visual backdrop and a vital component of the central business district. The important tourism and fishing industries depend upon the health of the inlet.

The Trinity Inlet Management Program (TIMP) commenced in 1992 with widespread consultation for the development of a management plan by an independent consultant. The aim of the program reflects the strong public desire, expressed in the consultation, to ensure the maintenance of Trinity Inlet as an ecologically viable and sustainable ecosystem. The basis of the program is a contractual agreement between state government agencies and local government. These groups and local parliamentarians make up the steering committee, which gives overall and political direction to the program. The role of the community is to provide input to a consultative committee and to the program office and staff, who run a public contact process.

TIMP is a large program, regional in scale with state-wide ramifications. It involves a range of technical skills, is serviced by a professional staff, and has significance for the regional economy. The ongoing role of the community is to comment upon the direction of a program, which has largely been set out following technical and political deliberation. Processes for this community input were set out as a part of the ongoing program and have been resourced in the annual budgets. Within TIMP, public education and capacity-building are seen as an ongoing part of the program. The public is informed and has its concerns taken into account; it is not involved in delegated authority or ongoing partnership arrangements within the scale described by Hale (1996). (Sources: Kristensen 1996, RAC 1993a, p. 146.) 


\section{Coastcare}

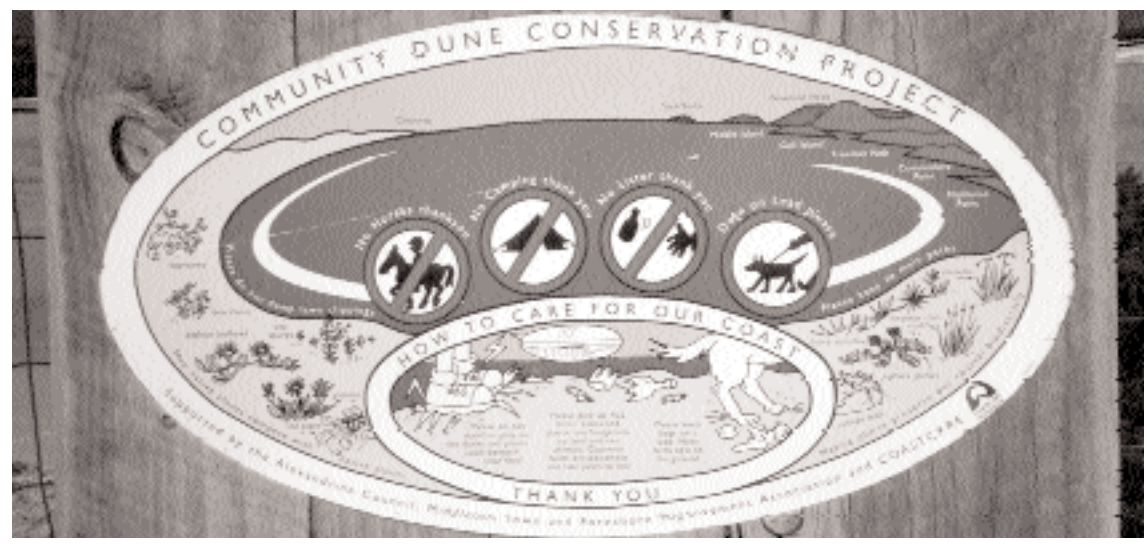

Photography: Brian Caton

Community-based activities have been given assistance and focus through the National Coastal Action Program, begun in 1995, of which Coastcare is an important component (see page 210). The Coastal Action Program was proposed by the Commonwealth in May 1995 as a vehicle for cooperation in coastal management between the three tiers of government, and its first major achievement was in the signing of a memorandum of understanding between the Commonwealth, states and territories, and local government in October 1995. The Coastcare component of this program set up assistance for community groups working on schemes to promote ecologically sustainable development at the coast. Coastcare continued as part of the Coasts and Clean Seas component of the National Heritage Trust (NHT; launched in July 1997) under a new memorandum of understanding, signed in 1998.

'The objectives of Coastcare are to:

- engender in local communities, including local industries, a sense of stewardship for coastal and marine areas;

- provide opportunities and resources for residents, volunteers, business and interest groups to participate in coastal management;

- support community identification of natural and cultural heritage resources; and

- facilitate interaction between the community and bodies with responsibility for managing coastal areas.' 
Under the Coastal Action Plan and then the NHT, the Commonwealth will provide a total of \$27.3 million (see Clarke 2002) to Coastcare from 1996 until 2001 when the NHT program runs out. Matching funds must be provided by the states, and in-kind contributions are sought from local government and industry. When these contributions are added to the value of voluntary work, the combined value of the projects completed is impressive: in the year $1997-98$ this totalled $\$ 28.4$ million. Coastcare continues in a modified form under NHT II, from 2002.

Essentially, Coastcare distributes small grants to community groups to carry out schemes of coastal restoration, community education, monitoring, and conservation (Harvey et al. 2001). A Coastcare Coordinator for each state administers the scheme within the states, and facilitators, organised on a regional basis, work with communities and groups to put together projects meeting local needs and aspirations. There are about 30 regional Coastcare facilitators.

Some examples of the works funded by Coastcare are dune weed control replanting and access control, monitoring waste water reuse in the coastal zone, walkways, cliff steps, community monitoring of marine indicator species, the development of community-based coastal management plans, the protection of areas of rare coastal species, the establishment of a marine and coastal interpretation centre, surveys of ocean-based litter. A national mid-term survey (Commonwealth of Australia 1999) showed clearly the dominance of onground works.

Table 4.4 Types of activities funded by Coastcare, 1995-96 to 1999-2000

\begin{tabular}{|c|c|c|}
\hline Type of Activity & Examples & $\begin{array}{l}\text { Percentage } \\
\text { of projects }\end{array}$ \\
\hline On-ground works & $\begin{array}{l}\text { Access control, sand drift fencing, revegetation, } \\
\text { interpretive signage }\end{array}$ & 71 \\
\hline Education or training & $\begin{array}{l}\text { Community education targeting specific coastal } \\
\text { environments or types of environment }\end{array}$ & 12 \\
\hline Planning & $\begin{array}{l}\text { Development of site-specific management plans } \\
\text { and community participation in the development } \\
\text { of regional plans }\end{array}$ & 9 \\
\hline Monitoring & Beach conditions, habitats, and water quality & 8 \\
\hline
\end{tabular}

The mid-term survey (Commonwealth of Australia 1999) showed that more than 700 community groups were involved in Coastcare-sponsored projects in 1998, and that the groups varied considerably in their nature (table 4.5). 
Table 4.5 Types of community groups funded by Coastcare, 1997-99

\begin{tabular}{|c|c|c|}
\hline Type of Group & Examples & $\begin{array}{l}\text { Percentage } \\
\text { of funds }\end{array}$ \\
\hline Local environment & $\begin{array}{l}\text { Local Coastcare, Landcare and Dunecare groups; } \\
\text { estuarine management groups, local branches of } \\
\text { environment groups }\end{array}$ & 38 \\
\hline $\begin{array}{l}\text { Citizen and } \\
\text { service groups }\end{array}$ & $\begin{array}{l}\text { Rotary, Lions, Progress Associations, Residents, } \\
\text { Ratepayers groups and town committees. }\end{array}$ & 16 \\
\hline $\begin{array}{l}\text { Regional/state } \\
\text { environmental } \\
\text { co-ordinating groups }\end{array}$ & State conservation councils; MCCN & 14 \\
\hline Indigenous & Lands councils, community co-operatives & 12 \\
\hline Recreational & $\begin{array}{l}\text { Surf lifesaving clubs, dive groups, ORRV groups, } \\
\text { arts centres, heritage groups }\end{array}$ & 5 \\
\hline Business/industry & $\begin{array}{l}\text { Tourism associations, fishing co-operatives, chambers } \\
\text { of commerce }\end{array}$ & 2 \\
\hline Educational institutions & $\begin{array}{l}\text { Primary and high schools, outdoor education } \\
\text { centres, universities. }\end{array}$ & 2 \\
\hline Other/no data & & 10 \\
\hline TOTAL & & 100 \\
\hline
\end{tabular}

Notes:

- based on Coastcare funding of $\$ 8909000$ from both Commonwealth and state contributions

- from Coastcare national database

Source: Commonwealth of Australia 1999

Most groups are working on public lands in cooperation with councils (50\%) or state government agencies (37\%), such as parks and wildlife departments, who are the land managers. Agencies and councils often provide equipment, expertise or administrative support. National evaluation suggested that the experience often led to partnerships between community groups and land managers, and increased commitment to coastal and marine management by local authorities.

The character and variety of Coastcare activities are illustrated by the following examples.

\section{Box 4.6 Buttlingara Aboriginal Corporation at Whyalla, South Australia}

A number of informal recreational camping sites on low dunes and shellgrit slopes at False Bay, between Port Augusta and Whyalla in South Australia, have over the years led to vegetation loss, erosion and weed invasion. The area has been used for camping for at least 40 years, but recently degradation has 
increased because of an increase in the use of off-road vehicles. Considerable damage had been caused to Pebble Dune, which is a site of significance to the Buttlingara Aboriginal Community. Over time the community had become increasingly concerned with the amount of damage being caused to the area.

The solution has been an alliance of the Buttlingara Community and the City of Whyalla, assisted by advice from the Regional Coastcare Coordinator and some Coastcare funding. Following a series of on-site planning meetings, campsites and paths have been defined, weeding and replanting has taken place, and access tracks avoid the sensitive locations of Pebble Dune. Wire fencing now defines the perimeter of seven different camps sites along the shore of Fitzgerald Bay. Further south at False Bay, a further five camp sites have been defined. Campers can still obtain access to the areas, but in a less damaging manner.

The on-ground labour for this project has been carried out voluntarily by the Buttlingara community, supported by technical advice from the Council, whose planning and works staff assisted in closing old vehicle tracks. Fencing materials and plant tubestock have been purchased with Coastcare funds.

Achieving a positive action in coastal environmental improvement often involves more groups than were needed at False Bay, but the essence is local hard work and the formation of alliances. Coastcare provides facilitation for the work (pers. com. Chris Coxon, Central Region Coastcare Facilitator, September 1999).

\section{Box 4.7 Middle Beach Education and Recreation Centre}

The saltmarsh and samphire habitat of the flat coastal plain north of Adelaide, north of Port Adelaide and Port Gawler, has traditionally been viewed as a 'wasteland' with no real value. It has been the dumping ground for rubbish, and cheap land for a number of extensive industrial ventures.

The community of Middle Beach felt there was a need to raise community awareness about the importance of samphire and its role in the local coastal ecology. The samphire near Middle Beach is in good condition, although it has suffered some weed invasions, rubbish dumping and uncontrolled vehicle access near to the roads.

During a series of community meetings in late 1997, it was decided to undertake a project that would enhance the region and raise general awareness about the unique aspects of the area. The project would consist of an 80-m boardwalk, a small bridge to cross a tidal creek, a hard rubble path, and a number of interpretive signs.

A \$15000 Coastcare grant was obtained for materials, and the District Council of Mallalla provided assistance with project engineering, particularly in the 
construction of a small bridge. The Australian Trust for Conservation Volunteers provided a work team to assist with the boardwalk, while most of the labour was undertaken by community volunteers, some of whom were retired tradespeople whose skills were important.

During the course of the project, the community and the local council staff found out a great deal about the samphire flats, particularly its bird populations. Capacity-building is a frequent positive effect of Coastcare activities for the community group, council staff and elected members and state agency staff (pers. com. Chris Coxon, Central Region Coastcare Facilitator, September 1999).

The significance of these activities and the numbers of people involved in Coastcare groups is considerable, not least in raising awareness and knowledge about coastal management issues. Coastcare activities receive considerable local publicity, often showing that non-government voluntary groups can have a significant direct impact on the management of public lands, or to influence government management through community monitoring projects. One challenge that emerges is to integrate this with other coastal management efforts, so that the benefits of coordination and timing can be secured.

After Coastcare had been running for barely a year, Tailby and Lenfer (1996) commented that Coastcare could lead to 'the triumph of small decisions': small decisions and small actions, while relatively insignificant in isolation, can add up to have a significant positive impact. It is also true that such a positive impact can flow on to neighbouring coastal areas, whereby the successful rehabilitation of one coastal reserve provides a model and inspiration for neighbouring reserves.

However, this effect should not be overestimated; many coastal management tasks need an ongoing commitment to sustainability in the face of continuing pressure, and not all community groups can maintain this commitment. Effective community groups often rely on a small number of key members to drive actions, making the group vulnerable to a diminishing effort. This is especially true of rural and remote coastal areas. It is there that the local government side of the partnership may fill the breach, by completing tasks and continuing maintenance.

This underlines the need for strategic planning at the regional level so that regional priorities can be assessed and agreed, and so that limited money and energy is directed where it may have best effect.

Coastcare is about local communities taking responsibility for their local coastal and marine environmental problems. Experience suggests that local 
energy within the community in taking on such responsibility will often be most effective where strong partnerships can be established with other groups, adding to local impetus and expertise. This has been a key aim in Coastcare and is well illustrated in the setting up of the integrated catchment management project for the small catchment draining to Swan Bay Marine Reserve, Victoria.

\section{Box 4.8 Swan Bay Marine Reserve}

Swan Bay, a marine reserve near Queenscliff at the southern end of Port Phillip Bay, is listed on the Register of the National Estate for its ecological, aesthetic and recreational values. It is an important area for juvenile fish and migratory wading birds, and is listed as a Ramsar site. The Swan Bay catchment is relatively small $\left(170 \mathrm{~km}^{2}\right)$ and mainly rural; most of the catchment has been largely cleared for intensive agriculture and urban settlement. There are a range of concerns over the degradation of the area, including extensive clearing of native vegetation, erosion and salinity control, pest plants and animals, and water quality. It is thought that addressing these concerns will improve the condition of the bay by reducing turbidity and siltation, nutrient run-off, excessive algal growth, and seagrass loss.

In 1997 a Coastcare/Coast Action (Vic.) community grant was obtained to assist in establishing an integrated catchment management approach to managing the lands and waterways within the area draining to the bay. This has involved community groups (with the assistance of a part-time facilitator) preparing and implementing local action plans and a community-based water monitoring strategy linked to a local Waterwatch program. Many stakeholders have been involved with the project: a local Landcare group, the Victorian Farmers Federation, local schools and conservation groups, and the state Department of Natural Resources and Environment.

Again, the significance of establishing alliances is clear; in this case with a variety of aims, but primarily to safeguard a marine reserve by improved catchment management. The small size of the catchment makes a community-based approach a feasible one. (This summary is based on Coastline winter 1997 edition; and Marine Group 1999.)

\section{Community roles in the new millennium}

Coastcare has been successful in involving thousands of people in actively looking after parts of the Australian coastline. However, uncertainty over its future funding casts doubt on the role Coastcare will play in the future. There is no doubt that Coastcare is funding-driven, with a great deal of planning focusing on the annual funding round and the relationship of the local issues to 
the funding criteria. There is clearly the possibility here that the short-term considerations of the funding round will detract from a strategic approach, resulting in an over-emphasis on a reactive 'on-ground-works' approach, rather than a visionary plan for the long-term future.

Coastcare has been criticised as 'coastal management on the cheap', allowing land managers, and particularly government agencies, to rely excessively on volunteer help. In at least two states the scheme has been challenged as simply a cost-cutting measure, replacing agency staff with sponsored volunteers. Wescott (1997) pointed out that continuation of work over a number of years by volunteers is only likely within a management process which is collaborative: that if volunteers are simply used to do jobs formerly done by paid staff and not as part of a process of community empowerment, then the approach is not sustainable. However, it must be noted that a great deal of agency cost-cutting around Australia had already taken place by the time the Coastcare scheme started in 1995.

Doyle (2000) has challenged the view that the projects are communitybased, seeing them as 'controlled and harnessed by bureaucratic and industry initiatives and arrangements'. To substantiate such a criticism requires detailed research into the origin of projects, the role of the regional facilitators, the influence of the guidelines and criteria, the role of the assessment panels, the (less public) roles of state and Commonweath ministers and agency staff, as well as patterns of funded projects compared with unfunded ones. This has yet to be done. Meanwhile, anecdotal evidence shows many more on-ground actions meeting needs that had previously been neglected, usually through lack of funds; increased knowledge and awareness of coastal issues; and many examples of strong community 'ownership' of the care of small coastal reserves.

The long-term challenge of continuation of care and the development of sustainable management systems, involving monitoring and evaluation, still remains.

\section{Sustainable coastal management and scientific uncertainty}

The Australian Government in 1992 released two key documents to coincide with the Earth Summit of the same year. These documents were the National Strategy for Ecologically Sustainable Development and the National Greenhouse Response Strategy (Commonwealth of Australia 1992a, NGWG 1992). Both documents related to a recognition of rapid global changes which require a different approach to our use of resources and also require planning for global change in the context of scientific uncertainty. 


\section{Sustainable coastal management}

Sustainable development was defined by the World Commission on Environment and Development (WCED) in Our Common Future as that which meets the needs of the present without compromising the ability of future generations to meet their own needs (WCED 1987, p. 8).

This publication (also known as the 'Brundtland Report') suggested that economic development and environmental well-being are not mutually exclusive goals. It also recognised that current economic development is not environmentally or socially sustainable and that action is necessary if there is going to be continuing economic development and the world is going to live within its ecological means.

The key elements of sustainable development relate to the concept of needs and the restricted environmental ability to meet these needs, both present and future. Sustainable development is a process of change in which the exploitation of resources, the direction of investments, the orientation of technological development, and institutional change are all in harmony and enhance both current and future potential to meet human needs and aspirations (WCED 1987, p. 90).

In order to achieve sustainable development objectives for environment and development policies, it is important to have strategies such as conserving and enhancing the resource base, reorienting technology and managing risk, and merging environment and economics in decision-making (WCED 1987, p. 93).

In 1990 the Commonwealth of Australia released a discussion paper entitled Ecologically Sustainable Development in which it used a slightly different definition of sustainability and features of an ecologically sustainable development (ESD) approach (DPMC 1990). Here it defined ESD as 'using, conserving and enhancing the community's resources so that ecological processes, on which life depends, are maintained, and the total quality of life, now and in the future, can be increased' and explained that some key features of an ESD approach are that:

- we need to consider, in an integrated way, the wider economic, social and environmental implications of our decisions and actions for Australia, the international community, and the biosphere; and

- we need to take a long-term rather than a short-term view when taking those decisions and actions.

It also defined the following broad areas of operational principles which it considered necessary for the implementation of a sustainable society:

- improvement in material and non-material well-being 
- intergenerational equity

- intragenerational equity

- maintenance of ecological systems and protection of biodiversity

- global ramifications, including international spillovers, international trade and international cooperation, and

- dealing cautiously with risk, uncertainty and irreversibility.

In the same document the Commonwealth government proposed the establishment of nine working groups to consider the implementation of ecologically sustainable development principles in sectors of Australia's economy that have major impacts on the environment. Notwithstanding major criticisms of the discussion paper by Australian conservation groups (Hare 1990), the nine working groups were set up in 1990 and their final reports were publicly released in December 1991 (ESDWG 1991a-i).

The coastal zone did not fall neatly into any one of these nine sectors of the economy. In fact, it was necessary to set up 37 additional intersectoral working groups, including one on coasts, in order to address ESD issues properly. By the time the national ESD strategy was released in 1992 it contained eight sectoral sections and an additional 22 intersectoral sections, including section 17 on coastal zone management. The key coastal objective in the ESD strategy is Objective 17.1: to develop coastal policies, consistent with ESD principles, within each jurisdiction (Commonwealth of Australia 1992, p. 70).

It is possible to identify some key areas of coastal management related to ESD principles, such as:

- the use of coastal resources by present generations is achieved while protecting the interests of future generations through, for example:

- maintaining and enhancing natural capital (e.g. pristine coasts, clean beaches, unpolluted coastal waterways)

- avoiding over-exploitation of coastal resources

- minimising waste in coastal environments

- protection of coastal biodiversity and ecosystem integrity

- provision of net community benefits from coastal proposals that are implemented

- social equity, for example through public participation in the decisionmaking process on coastal development

- reflection of full environmental costs of proposals in decisions on coastal resource use

- caution in dealing with environmental risk and irreversibility in the coastal environment (e.g. sea-level rise, coastal erosion, and coastal vulnerability).

The concept of ESD underpinned both the RAC Inquiry (1993) and the development of the Commonwealth Coastal Policy (1995). These are discussed 
elsewhere in this book. The Commonwealth government occasionally produces reports on the implementation of the national strategy on ESD. For example, the first of these (ICESD 1996) contains a six-page section (pages 122-7) dealing with coastal management. This report makes specific reference to the use of ESD principles through the RAC Inquiry and the Commonwealth Coastal Policy. It also outlines what actions on ESD had been taken at that time in six states, and comments on local government activities.

\section{Scientific uncertainty in coastal management}

As noted above, a key element of the 1992 Australian ESD strategy is dealing cautiously with risk, uncertainty and irreversibility. In the same year, the National Greenhouse Response Strategy was released in an attempt to address issues relating to global warming and the emission of greenhouse gases. Included in the greenhouse strategy is a recognition of three key issues relating to coastal management:

- the need to understand the science of climate change, in particular the predictions of sea-level rise, its implications and the level of uncertainty

- the need for climate change research, including monitoring of sea-level change

- the need to provide adaptation techniques and strategies for dealing with and assessing coastal vulnerability.

The first of these has been the subject of major international scientific investigations through the Intergovernmental Panel on Climate Change (IPCC), which has produced a number of reports (Houghton et al. 1991, 1992, 1996, 2001). One aspect of these reports is the examination of the effects of climatic change on sea level through global warming, thermal expansion of the ocean, and an increased contribution of meltwater from glaciers, and also the effects of a rising sea level on coastal environments.

The first of these IPCC studies caused great concern for coastal managers because of the extent of sea-level rise predicted and the potential for coastal flooding and erosion. Sea level was predicted to rise by a best estimate of $0.66 \mathrm{~m}$ rise by 2100 (Houghton et al. 1990). The later IPCC reports have provided a significant downward revision of earlier sea-level rise predictions, but more recent calculations have continued to produce similar best-estimate figures, either by more qualitative expert analysis ( $0.61 \mathrm{~m}$ by 2087: Woodworth 1993), or by detailed recalculation ( $0.46 \mathrm{~m}$ by 2100 : Wigley \& Raper 1993). The 1996 IPCC report (Houghton et al. 1996) further revised the best estimate to around $0.49 \mathrm{~m}$ by 2010 . The most recent IPCC report (Houghton et al. 2001) has not significantly changed this sea-level rise estimate and quotes the central value figure as a sea-level rise of $0.48 \mathrm{~m}$ by 2100 (see Figure 4.9). 
Figure 4.9 IPCC predicted sea level rise to 2100

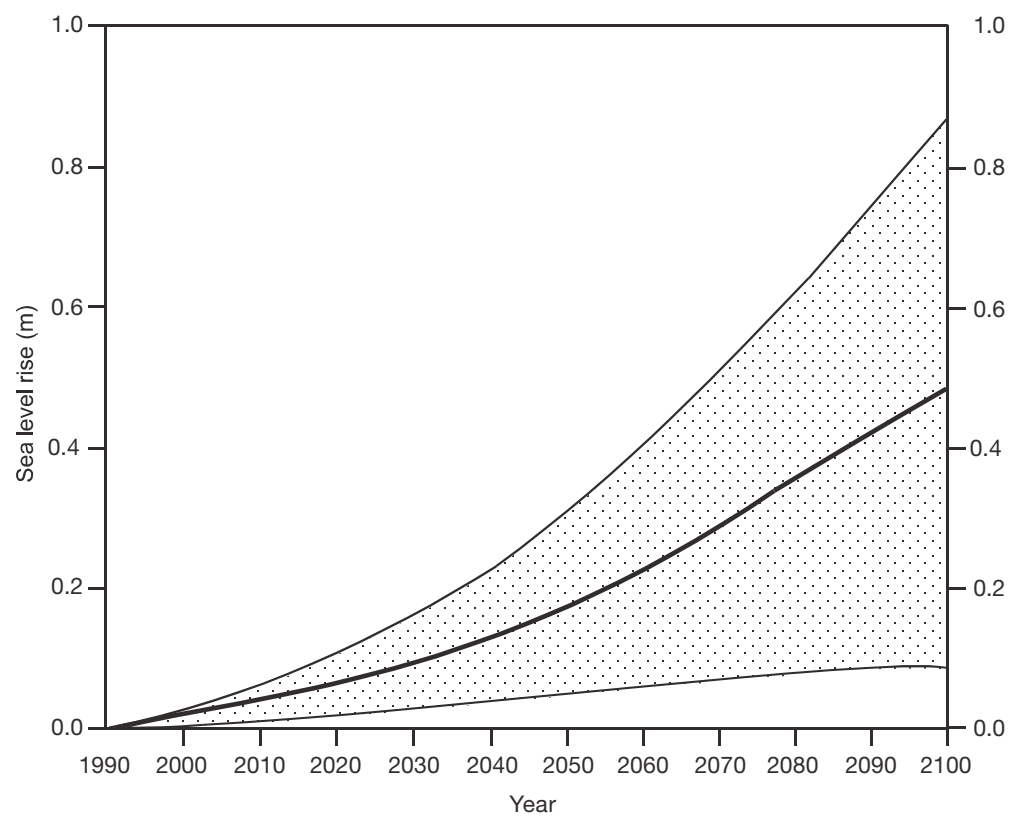

Source: modified from Church et al. 2001

Earlier in this chapter it was noted that a major problem in identifying the current rate of eustatic sea level change from tide gauge data in Australia is the influence of other effects such as human-induced subsidence or geological uplift, which may affect the tide gauge records. Some authors, such as Gornitz (1993), suggest that, after extracting long-term trends and data averaging, it is possible to obtain a true picture of sea level rise. Gornitz presents evidence based on 16 tide gauge data studies from overseas to suggest that the rate of global sea level rise over the last hundred years has been between 0.5 and $3 \mathrm{~mm}$ per year, with most estimates being from 1 to $2 \mathrm{~mm}$ per year (Gornitz 1993). However, as shown earlier in this book, it is possible to obtain quite different sea-level trend records from long-term tide gauge data sites that are relatively close to each other.

The problem for coastal managers is dealing with the level of uncertainty with the predictions and at the same time needing to have in place a good monitoring system. In Australia the National Tidal Facility (NTF) collects, compiles and analyses all the tidal records. The NTF has also developed a system of highly accurate tide gauges which are linked to satellite altimetry in order to obtain any evidence of vertical movement of the tide gauge site over time. 
The issue of scientific uncertainty appears most pronounced for the sealevel issue. Although the predictions for sea-level rise have been reduced over the last 10 years, some states decided to act earlier than others. For example, in South Australia a policy was developed in 1991 on coastal flooding and new coastal development. This policy was based on the earlier (1990) IPCC predictions. Consequently all new development in South Australia has to be protected from the threats of a $0.3 \mathrm{~m}$ sea-level rise to the year 2050 and the capability of protecting the development from an additional $0.7 \mathrm{~m}$ rise to 2100 . The policy incorporates the need to calculate the impact of erosion over this time and to allow for any localised factors such as subsidence. The fact that this policy is based on a $1.0 \mathrm{~m}$ sea-level rise to 2100 rather than the more recent central value of $0.48 \mathrm{~m}$ is a good example of using a precautionary approach in the face of scientific uncertainty.

Coastal ecosystems are strongly dependent on sea level. For example, some saltmarsh communities are adjusted to conditions within a few centimetres of high tide. Human use of the coast is also closely linked to tide levels. However, sea level is not the only significant change accompanying climate change. Change in storm frequency and wind direction, changes in run-off and watertable levels, and changes in disease vectors will all be significant at the coast. The World Coastal Conference in the Netherlands in 1993 concluded that climate change was a stress which could best be addressed by nations working to integrate their coastal management arrangements. Australian states have begun the task, including assessments of vulnerability to climate change, but to date a national response has not been forthcoming.

In recognition of the problem of coastal vulnerability from the predicted sea-level rise, the IPCC developed a 'Common Methodology for Coastal Vulnerability' assessment (see chapter 1). The intention was to conduct a rapid assessment of the capacity of different countries to cope with the impact of sealevel rise, particular the developing countries which may require international aid to assist them. But as noted by Harvey et al. (1999a), the Common Methodology had mixed results: many countries could not complete the necessary steps, and there was criticism of the methodology itself.

The Australian government funded some preliminary studies that lead to criticisms of the Common Methodology at the World Coast Conference. The Common Methodology was not considered appropriate for Australia because the economics-based assessment technique is inconsistent with the planning approaches used in this country. As a result of these criticisms an alternative methodology was proposed by Kay and Waterman (1993) and was incorporated into the brief for a nationally funded project, the National Coastal Vulnerability Assessment Case Studies Project. This project was carried out in each of the 
states and territories of Australia during 1994-95 through nine case studies funded by the Commonwealth government at a cost of $\$ 500000$ over two years. These studies were conducted at the following sites:

- Batemans Bay (New South Wales)

- Mackay (Queensland)

- City of Clarence (Tasmania)

- Gippsland and Port Philip Bay (Victoria)

- Metropolitan Perth (Western Australia)

- Kakadu and Darwin Harbour (Northern Territory)

- Upper Spencer Gulf (South Australia).

The location of these is shown in figure 4.10. One of the aims of the project was to meet Australia's international commitment under the Climate Change Convention (see table 4.1) to produce vulnerability assessments. The results of the project were taken to the IPCC meeting in Montreal in October 1995. These have also been subsequently published (Waterman 1996), including a CD containing all of the individual state studies.

However, it appears that very few of the states applied this revised Kay and Waterman (1993) methodology, as proposed. Tasmania attempted to use the Common Methodology but considered it to be too general, whereas Western Australia encountered problems in trialling a different methodology called Impact Zone - Connected Area Analysis. The Queensland case study attempted to develop a supplementary methodology to complement the Common Methodology; New South Wales used methods developed within its own Coastal Hazard Policy; and the Northern Territory study attempted to develop methods based on various existing databases (Waterman 1996).

The two states (Victoria and South Australia) that attempted to use the Kay and Waterman methodology both encountered difficulties. The Victorian study 'expressed major doubts over the usefulness of the methodology at anything but a local level' (Waterman 1996, p. 48). The South Australian study initially followed the Kay and Waterman methodology (as required by the project brief) but encountered several problems. These have been detailed in Harvey et al. (1999a) as the lack of predetermined spatial or temporal scales; the fact that the methodology included only the impacts of sea-level rise in Stage 1 and ignored other potential impacts of climate change, and the lack of context to present human-induced hazards on coastal zones. In addition, the methodology gave no guidance for ranking management and response option priorities.

For these reasons, Harvey et al. (1999a) proposed an alternative methodology which they applied to various sites in South Australia, and from this study a GIS-based methodology for vulnerability assessment was developed (Harvey 
Figure 4.10 Locations of the National Coastal Vulnerability Assessment case studies

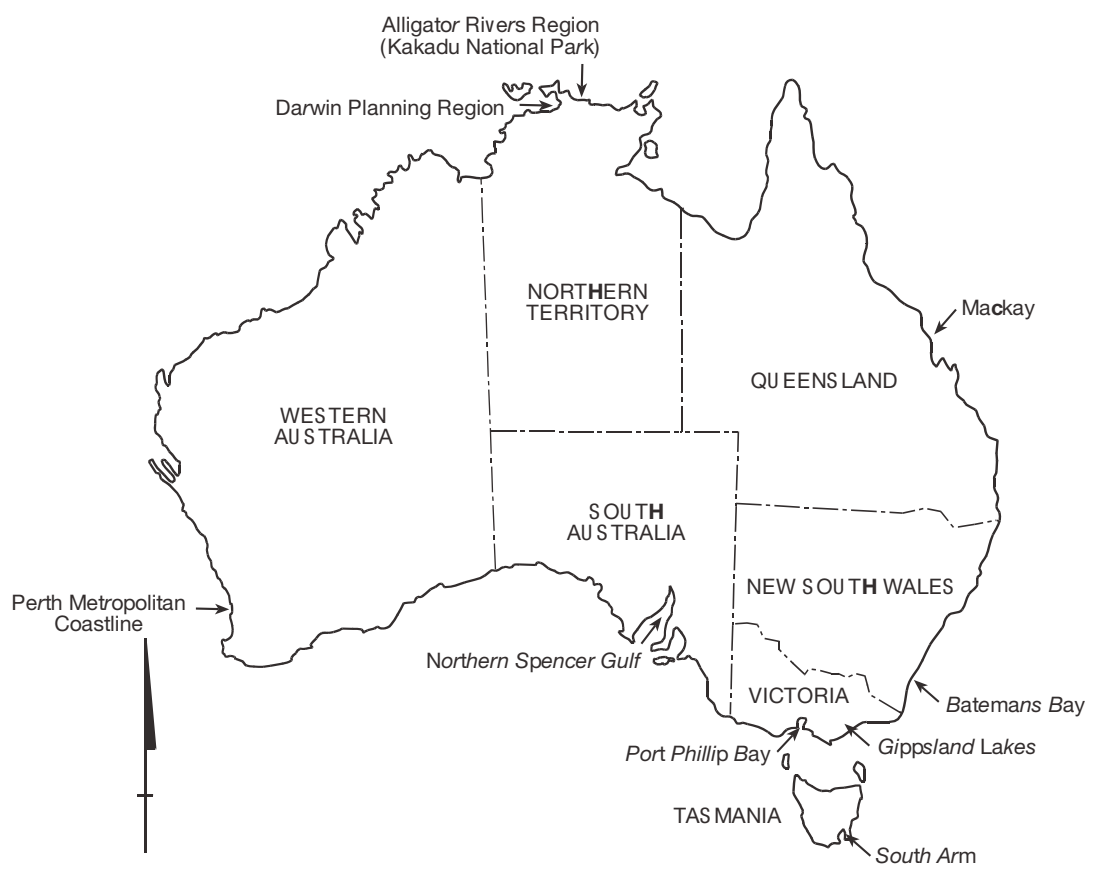

Source: Harvey et al. 1999a

et al. 1999). However, it appears that the Australian government has not progressed with any coastal vulnerability assessment studies or produced policy outcomes from the 1994-95 studies, as noted by McLean (2001).

\section{Conclusion}

The concept of ESD is understood to be a fundamental component of coastal management in Australia and has formed the basis for both the national coastal inquiry (RAC 1993) and the Commonwealth Coastal Policy (Commonwealth of Australia 1995). The ESD principles have also been incorporated into a number of state coastal policies, where they exist, and state planning legislation and regulations.

One aspect of the Australian ESD strategy which is linked to global warming is the issue of scientific uncertainty surrounding predictions of sea-level rise. This is a major issue for coastal managers, who need scientific data on which to base decisions for coastal planning, coastal development and coast 
protection strategies. In the face of such uncertainty, there is a need to take a precautionary approach and at the same time conduct research and monitoring in order to increase the confidence of scientific predictions relating to our future coasts. It is also apparent that while Australia conducted coastal vulnerability studies in the mid 1990 s, it has not produced anything significant since.

\title{
Coastal environmental management systems
}

\begin{abstract}
Environmental management in Australia is guided by the National Strategy for Ecologically Sustainable Development (ESD). The strategy defines ESD as a pattern of development that improves the total quality of life, both now and in the future, in a way that maintains the ecological processes on which life depends.
\end{abstract}

Source: Commonwealth of Australia (1996a)

There are as many coastal management systems as circumstances and managers demand. This chapter examines an approach to management that is adaptive and that stresses sustainability and the information needs of managers. This approach attempts to reflect both a number of initiatives by the Australian Local Government Association (see Alexandra \& White 1997, Thorman \& Heath 1997), as well as the local environment project of the Australian National University Centre for Resource and Environmental Studies (see Brown 1995).

\section{Commitments to sustainable management systems}

\section{Commitment}

- As was shown at the start of this chapter, there is no national or state legislation to ensure an integrated approach to management of coastal areas, comparable with, say, the New Zealand Resource Management Act 1991. However, Australia committed itself to Ecologically Sustainable Development (ESD) at the Rio Summit in 1992, and the Commonwealth and all states, territories and local governments have endorsed the National Strategy for Ecologically Sustainable Development (see page 252).

Closely linked to this is the National Strategy for the Conservation of Australia's Biodiversity, which has the goals of maintenance of ecosystems and processes and the protection of species. 


\section{Characteristics}

Sustainable development is development that delivers basic environmental, economic, and social services to all without threatening the viability of the systems upon which they depend.

A model that attempts to address this is outlined below. It is adapted from Dore and Woodhill (1999) and from ICLEI (1996).

Figure 4.11 Adaptive Management Systems

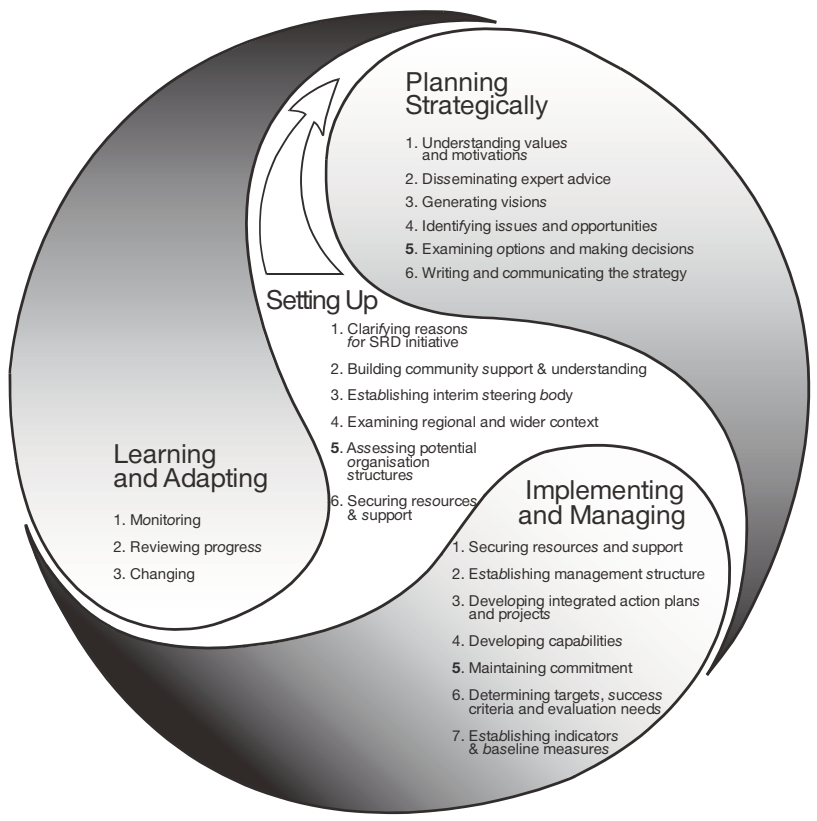

Source: modified from Dore \& Woodhill 1999, and ICLEI 1996

This process is iterative in as far as the information gained in monitoring and reviewing progress is used both to adapt in the short term and to revise strategies and actions. The process can be referred to as one of adaptive management: it recognises that strategies, programs and plans should be flexible, adaptive and responsive to learning from experience.

Such a process demands reliable information for adaptive response.

\section{Monitoring change}

Coasts are dynamic at all time scales. Management, which includes the active protection of ecosystems, requires information on change in the environment as 
a high priority. Monitoring of change is commonly carried out to establish a trend, or to establish the 'normal' range of seasonal, annual or interannual change. Management needs are to establish baselines, to show trends, to show the effects of management actions, and to establish targets and triggers for action. Gilmour (1999) cited Holling's (1978) book on adaptive environmental management, in which a number of significant points were made with regard to this situation:

- The available data and theories will always be inadequate and yet we are making management decisions all the time

- Conditions change rapidly and in a way, that is unpredictable

- The resulting uncertain environment requires an incremental and experimental approach to problem solving

- This involves a program of continuous monitoring and re-adjustment of our management strategies.

\section{State of the environment reporting}

State of the environment (SoE) reporting is an important way in which government decision-makers learn about the pressures on the environment, about the condition of the environment, and the responses to change in the environment. It is a significant part of accountability in environmental management, since it provides the public with information about the environment and human impacts on that environment. When reporting is carried on at a local or regional scale and incorporated into an efficient information system, it can be integrated with environmental management systems.

All three tiers of government are committed to state of the environment reporting, and most governments have placed their commitment in legislation.

Table 4.6 Commonwealth and state government commitments to SoE reporting

\begin{tabular}{lll}
\hline Jurisdiction & Timing of reports & Reports to date \\
\hline Commonwealth & Every 4 to 5 years & 1996,2001 \\
New South Wales & Every 2 years & $1993,1995,1997$, \\
& & 1999,2001 \\
Queensland & Every 4 years & 1999 \\
South Australia & Every 5 years & $1988,1993,1998$ \\
Tasmania & Every 5 years & 1997,2002 \\
ACT & Every year & 1997 (onwards) \\
Western Australia & Irregular & 1991,1997 \\
\hline
\end{tabular}


Local government undertakes state of the environment reporting throughout NSW and the ACT; in NSW this is a requirement under the Local Government Act 1993 (see EPA 1993). Some local governments in other states have reported for their council areas, sometimes as part of the adoption of Local Agenda 21.

National state of the environment reporting forms part of the National Strategy for Ecologically Sustainable Development, endorsed by COAG in 1992. Australian membership of the OECD includes a commitment to carry out reporting, and the Commonwealth government has carried out reports in 1996 and 2001. Both reports (SEAC 1996, ASEC 2001) were major documents, broadly based on numerous scientific workshops, papers and consultant reports, and extensively reviewed. The reporting was within seven themes: human settlements, biodiversity, atmosphere, land resources, inland waters, estuaries and the sea, and natural and cultural heritage. With regard to the coast, the 1996 report was significantly supported by the 1995 State of the Marine Environment Report for Australia (Zann 1995). The chapters on each of the seven themes are organised around the OECD's pressure-state-response model (figure 4.12). That is, the chapter begins with an account of the pressures that human activity has placed on the part of the environment of the theme, continues with an account of

Figure 4.12 The OECD's pressure-state-response model for state of the environment

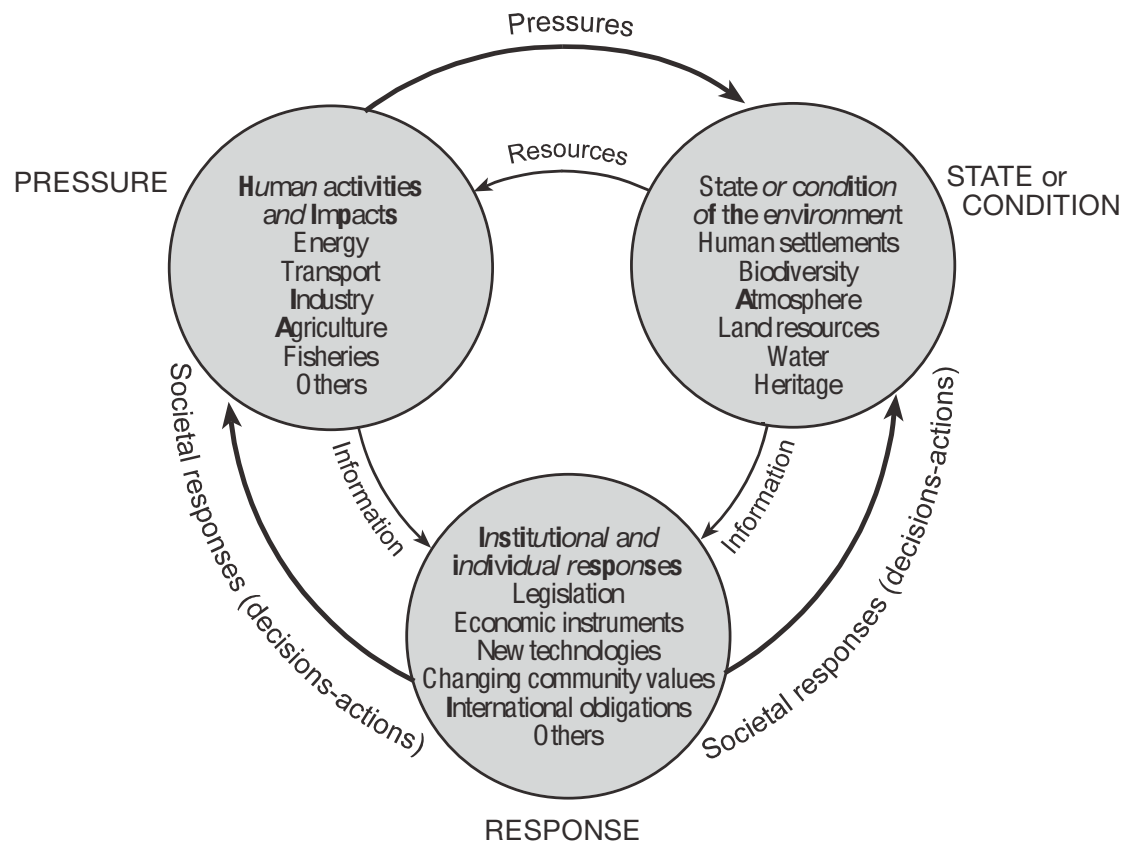

reporting 
Table 4.7 Selected key indicators for estuaries and the sea proposed by the Commonwealth indicators for national state of the environment reporting

\begin{tabular}{|c|c|c|}
\hline Issue or element & Indicator & $\begin{array}{l}\text { Condition }(C) \text {, } \\
\text { pressure }(P) \text { or } \\
\text { response }(R)\end{array}$ \\
\hline Class 1: & (species protected by name under & \\
\hline Cited species/taxa & Commonwealth or State legislation) & \\
\hline Protected species & $\begin{array}{l}\text { (number of) marine species rare, } \\
\text { threatened or endangered }\end{array}$ & $\mathbf{R}$ \\
\hline Cited species/ taxa & Protected species populations & C \\
\hline Cited species/ taxa & $\begin{array}{l}\text { Seabird populations (species which are } \\
\text { the subject of international agreements) }\end{array}$ & $\mathrm{C}$ \\
\hline Class 2: Habitat extent & (areal extent of major habitat types) & \\
\hline Habitat extent & $\begin{array}{l}\text { algal bed areas ( } \mathrm{km}^{2} \text { of macro-algal beds; } \\
\text { rapid change in response to disturbance) }\end{array}$ & C \\
\hline Habitat extent & $\begin{array}{l}\text { dune vegetation (area and main } \\
\text { assemblages; relates to dune stability) }\end{array}$ & C \\
\hline Habitat extent & intertidal sand/mudflat area & C \\
\hline Habitat extent & saltmarsh area & C \\
\hline \multicolumn{3}{|l|}{ Class 3: Habitat quality } \\
\hline Habitat quality & coral reef species & C \\
\hline Habitat quality & dune species & C \\
\hline Habitat quality & mangrove species & C \\
\hline Pests (exotic) & pest numbers & $\mathbf{P}$ \\
\hline Pests (native) & species outbreaks & $P$ \\
\hline \multicolumn{3}{|c|}{ Class 4: Renewable products } \\
\hline Aquaculture & aquaculture production & C \\
\hline Seafood & fish stocks & C \\
\hline \multicolumn{3}{|c|}{ Class 5: Non-renewable products } \\
\hline Mining & ocean exploration & $P$ \\
\hline Mining & ocean mining & $P$ \\
\hline \multicolumn{3}{|c|}{ Class 6: Water/sediment quality } \\
\hline Sediment quality & sediment quality (contaminants) & $\mathbf{P}$ \\
\hline Water quality & turbidity & $\mathbf{P}$ \\
\hline \multicolumn{3}{|c|}{ Class 7: Integrated management } \\
\hline Integrated management & coast care community groups & $\mathbf{R}$ \\
\hline Integrated management & coastal discharges & $\mathbf{P}$ \\
\hline Integrated management & coastal tourism & $\mathbf{P}$ \\
\hline Integrated management & ship visits & $P$ \\
\hline \multicolumn{3}{|c|}{ Class 8: Ecosystem level processes } \\
\hline Ecosystem process & sea level & C \\
\hline Ecosystem process & sea surface temperature variability & C \\
\hline
\end{tabular}


the condition or state of the theme, and concludes with a review of the responses being made to change within the theme.

Indicators are defined as physical, chemical, biological, or socioeconomic measures that can be used to assess natural resources and environmental quality. Within the use of the above model, there are separate indicators for pressures, state, and responses. Governments in Australia are working towards a common reporting format and the use of compatible indicator sets in order to facilitate comparisons, to provide information on bioregions across political boundaries, and to allow better national reporting.

The Commonwealth has undertaken considerable work within the scientific community to establish indicators for national SoE reporting, and has produced key sets within the seven themes of the 1996 report. The indicators (see Table 4.7) were chosen on scientific and technical grounds rather than on current monitoring practice, if any. The sets provide the basis for discussion on use within agencies and industry and community groups, rather than a statement on present practice or aspiration. The work on indicators provides a good example of the potential for a positive and unique role for the Commonwealth within cooperative federalism.

Within government this information is valuable in policy and priority setting, which is the major purpose of national and state SoE reporting. State of the environment reports form a valuable resource for all coastal managers, since they can be used to carry out a variety of tasks, notably:

- to show where human activities are exerting great pressure on the environment

- to identify situations where the condition or state of the environment is of concern

- to review management systems and policies as an adequate response to the changes identified as happening within the environment.

However, SoE reporting should be distinguished from monitoring as part of an ongoing local or regional coastal management process. Government statutory SoE reporting (see figure 4.12) focuses on change within the environment as a whole, across the realms of land air and water, whereas monitoring within a management system focuses on issues of concern to stakeholders, and on targets, triggers, and the effects of management. National, state, or local government SoE reporting may be valuable data sources for a management scheme, but within a management process, specific aims or objectives may warrant monitoring of indicators which may not be chosen within the more general approach of government reporting. A third approach, community monitoring, usually has the purpose of influencing management, either in general direction or with regard to specific management actions. 


\section{Community monitoring}

\section{Box 4.9 Case study: Bungala 2000}

The Southern Fleurieu Landcare have been working on the conservation and restoration of the over-cleared farmlands of the Southern Mount Lofty Ranges for a decade. Erosion control measures, revegetation, the establishment of riverine vegetation corridors, and the promotion of more sustainable land management practices should begin to result in a lower sediment and nutrient load being delivered to the coastal waters and small estuaries of the Fleurieu Peninsula. Recent work - the Bungala 2000 project - may clarify this. The Landcare work was extended in 1996 by volunteer scuba dive club members to monitor nearshore turbidity levels, seagrass health, and nutrient levels at the mouths of four of the catchments. Technical training has been provided by state government marine scientists (South Australian Research and Development Institute), and funding by Commonwealth grant. The combination of community action, state expertise, and seed funding is a potent force in raising awareness. It is hoped that the knowledge gained from monitoring and the community involvement will help drive future management. By monitoring turbidity and its effects near the mouths of the catchments, the Bungala 2000 group can establish a baseline picture of what is happening now, and then in the future show how things are changing (pers. comm. Alistair Christie, Normanville Landcare, South Australia, April 1998).

Community environmental groups have a strong focus on the changes going on around them. Everyone knows that change is going on, and often older members of the community report very considerable environmental changes over time periods of the order of decades. The national survey of community environmental monitoring groups by the Australian Conservation Foundation (Alexandra et al. 1996) illustrated the significant contribution such groups can make on a local scale. Local planning and education were the dominant uses. 'If monitoring and reporting are community driven, a sense of ownership is engendered, local knowledge is utilised, and a vast reservoir of untapped expertise and enthusiasm is released for the betterment of the environment.' (Alexandra et al. 1996, p. 17). The focus on issues of local concern, driving management, could be vital: 'We had 30 years of monthly water quality records from the government, but we weren't getting the information we needed for catchment management until we got the farmers involved' (Alexandra et al. 1996).

The national survey of community environmental monitoring groups showed that about $70 \%$ of the groups used standard methods of measurement, that the 
majority stored data on computer files, and that about a third of the groups used geographic information systems to produce customised maps.

\section{Box 4.10 Case study: The Queensland Seagrass-Watch moni- toring program}

More than 300 volunteers have been involved in monitoring seagrass health in Hervey Bay, the Great Sandy Straits and the Whitsunday Region. The program has been developed by the Queensland Department of Primary Industry (QDPI), the CRC for Reef Research, the Queensland Parks and Wildlife Service and community groups. A Coasts and Clean Seas (Natural Heritage Trust) grant supports the program. 'Seagrass-Watch aims to raise awareness on the condition and trend of nearshore seagrasses throughout Queensland, and to provide an early warning of major changes in seagrass abundance, distribution and species composition. Community groups and agencies were involved in the selection of monitoring areas, such as key Dugong feeding areas and places of high catchment input. The program is seen as scientifically credible through the training of volunteers in the use of rigorous monitoring techniques, including measurement at fixed sites of percentage seagrass cover, seagrass canopy height, seagrass species composition, algal cover and epiphyte cover. Immediate feedback is provided to observers on the information submitted from these observations. Data is entered in the QDPI's Seagrass-Watch database and GIS mapping systems.

Considerable effort is put into communication between all groups and agencies involved in this scheme, including a regular newsletter. A training manual and video have been developed. Communication to the wider community is achieved through the media, exhibitions and workshops.

To date the program has provided information on seagrass resources valuable to the management of fisheries, Dugongs and turtles. The data has been used in management plan development on dredging proposals, and the assessment of World Heritage Areas of the Great Sandy Region.

Source: Campbell 2000

\section{Monitoring and management}

The Australian Local Government Association (ALGA) pilot Regional Environmental Strategies provide an example of an attempted integration of monitoring to a management plan on a regional scale. The following table represented work in progress at the time in the pilot project in the Southern Region of Councils, Adelaide (Alexandra \& White 1997). The monitoring and management table was partially completed from discussion at a workshop for local government and community, but the targets could not be resolved at that time (Alexandra et al. 1998). 
Table 4.8 Monitoring and management table

\begin{tabular}{|c|c|c|c|}
\hline $\begin{array}{l}\text { The nature of the issue } \\
\text { (following the Regional } \\
\text { Environmental Strategy)* }\end{array}$ & $\begin{array}{l}\text { The cause of the } \\
\text { issue, noting the } \\
\text { indicator }\end{array}$ & $\begin{array}{l}\text { The current condition } \\
\text { of the environment, } \\
\text { noting the indicator } \\
\text { (RES) }\end{array}$ & $\begin{array}{l}\text { The objective for the } \\
\text { issue, as outlined in } \\
\text { the regional strategy }\end{array}$ \\
\hline $\begin{array}{l}\text { KEY ISSUE } \\
\text { (RES p. 112) }\end{array}$ & $\begin{array}{l}\text { CAUSE OF THE } \\
\text { ISSUE } \\
\text { [pressure indicator] }\end{array}$ & $\begin{array}{l}\text { CURRENT } \\
\text { CONDITION AND } \\
\text { TREND } \\
\text { [Condition indicator] }\end{array}$ & $\begin{array}{l}\text { OBJECTIVE/ } \\
\text { GOAL }\end{array}$ \\
\hline $\begin{array}{l}\text { Maintain and improve } \\
\text { the ecological health } \\
\text { of sand dune areas }\end{array}$ & $\begin{array}{l}\text { Recreational } \\
\text { activities. Weed } \\
\text { invasion. } \\
\text { [distribution and } \\
\text { abundance of } \\
\text { weed species] } \\
\text { [beach user numbers] }\end{array}$ & $\begin{array}{l}\text { Low species diversity; } \\
\text { many weed infested } \\
\text { areas; de-vegetated } \\
\text { areas common } \\
\text { [no. indigenous species] } \\
\text { [area of dune erosion } \\
\text { due to human activity] }\end{array}$ & $\begin{array}{l}\text { Protect, restore, } \\
\text { rehabilitate and } \\
\text { revegetate remnant } \\
\text { dune areas (p. 125) }\end{array}$ \\
\hline
\end{tabular}

Maintain and improve

Development

Saltflats of the

Protect and maintain

the ecological health

of saltflat areas

Onkaparinga Estuary

the biodiversity of

reduced by bank

coastal ecosystems of

enclosure; polluted and

high conservation

impacted by foot traffic.

value (p. 121)

(total area of saltflat, ha.)

Maintain and improve

Raised nutrient levels

Continued dieback,

Protect and maintain

the ecological health

due to land based

of seagrass areas

discharges

since1970s: caused by

reduced light (turbidity)

the biodiversity of

coastal ecosystems of

[Quantity of effluent

and epiphyte growth

high conservation

from Christies Beach

(nutrients).

value (p. 121)

WWTP]

Maintain and improve

Recreation,

[Area of seagrass, ha.]

the ecological health

development and

of coastal cliff heath areas

previous grazing

Coastal cliff heath

Protect, restore, vegetation in tiny

rehabilitate and

remnants only.

[recreation numbers]

[indigenous species

revegetate vulnerable

cliff areas (p. 125)

Maintain and improve

Combined pressure

numbers]

the ecological health

of recreational

Continued reduction in

Protect and maintain algal and mollusc species

[Species counts-

the biodiversity of

activity and pollution

Reefwatch]

coastal ecosystems of high conservation value (p.121) 


\begin{tabular}{lll}
\hline $\begin{array}{l}\text { A reasonable target } \\
\text { within your overall } \\
\text { objective; quantified }\end{array}$ & $\begin{array}{l}\text { Actions to meet this target } \\
\text { (RES) }\end{array}$ & $\begin{array}{l}\text { The measures which show } \\
\text { you are carrying out } \\
\text { appropriate processes to } \\
\text { address the issue }\end{array}$ \\
\hline
\end{tabular}

\section{PROCESS}

[response indicator]

Ensure remnant dunes are protected within coastal linear park

[Time and money spent on dune rehabilitation]

Ensure adequate management plans for remnant dunes

Work with community groups on dune conservation, including re-planting and protection

Promote interpretive schemes for dunes under particular pressure (p. 125)

Seek conservation status for the regionally scarce samphire flats of the Onkaparinga Estuary (p. 125)

Manage stormwater and effluent flow to the Gulf ( $p$. 125)

Ensure adequate management plans

Work with community groups to protect and restore (p. 125)

Undertake an audit (turbidity, reef health, reef species)

Collaborate with dive clubs and SARDI in monitoring aquatic reserves Support protected status of these areas by minimising stormwater flow Investigate impact of recreation and management strategies for intertidal reefs 
Table 4.8 Monitoring and management table (continued)

\begin{tabular}{|c|c|c|c|}
\hline $\begin{array}{l}\text { The nature of the issue } \\
\text { (following the Regional } \\
\text { Environmental Strategy)* }\end{array}$ & $\begin{array}{l}\text { The cause of the } \\
\text { issue, noting the } \\
\text { indicator }\end{array}$ & $\begin{array}{l}\text { The current condition } \\
\text { of the environment, } \\
\text { noting the indicator } \\
\text { (RES) }\end{array}$ & $\begin{array}{l}\text { The objective for the } \\
\text { issue, as outlined in } \\
\text { the regional strategy }\end{array}$ \\
\hline $\begin{array}{l}\text { KEYISSUE } \\
\text { (RES p. 112) }\end{array}$ & $\begin{array}{l}\text { CAUSE OF THE } \\
\text { ISSUE }\end{array}$ & $\begin{array}{l}\text { CURRENT } \\
\text { CONDITION AND } \\
\text { TREND }\end{array}$ & $\begin{array}{l}\text { OBJECTIVE/ } \\
\text { GOAL }\end{array}$ \\
\hline $\begin{array}{l}\text { Prevention/ containment } \\
\text { of oil spills }\end{array}$ & $\begin{array}{l}\text { Traffic of tankers to } \\
\text { major terminal at } \\
\text { Port Stanvac } \\
\text { [Number of tanker } \\
\text { calls at Port Stanvac] }\end{array}$ & $\begin{array}{l}\text { Many minor but no } \\
\text { major spills. No impact } \\
\text { on marine life or } \\
\text { recreational beaches } \\
\text { [Number of spills] }\end{array}$ & $\begin{array}{l}\text { Minimise impacts of } \\
\text { oil spills in the Gulf } \\
\text { (p. 121) }\end{array}$ \\
\hline $\begin{array}{l}\text { Loss of coastal reserves } \\
\text { over long term }\end{array}$ & $\begin{array}{l}\text { Demand for various } \\
\text { uses of coastal land }\end{array}$ & $\begin{array}{l}\text { At present there is a } \\
\text { discontinuous pattern } \\
\text { of coastal reserves. } \\
\text { In places access to } \\
\text { coast is restricted } \\
\text { [area of coastal reserves] }\end{array}$ & $\begin{array}{l}\text { Development of a } \\
\text { coastal linear park }\end{array}$ \\
\hline
\end{tabular}

\section{Information systems}

Australia lacks the integrated national systems and databases to measure environmental quality, manage it, and evaluate the effectiveness of that management. Until these deficiencies are rectified, we will remain unable to truly answer the question of whether our pattern of development is really sustainable (SEAC 1996, p. ES-5).

The efficiency of an ongoing coastal management system depends upon its information systems. Unless there is adequate collection, storage, and retrieval of reliable data that is available to managers, stakeholders, and the community, confidence in the system is eroded and costs are incurred that could have been avoided. Unless there is adequate feedback on triggers, targets, and the effects 


\begin{tabular}{|c|c|c|}
\hline $\begin{array}{l}\text { A reasonable target } \\
\text { within your overall } \\
\text { objective; quantified } \\
\text { if possible }\end{array}$ & $\begin{array}{l}\text { Actions to meet this target } \\
\text { (RES) }\end{array}$ & $\begin{array}{l}\text { The measures which show } \\
\text { you are carrying out } \\
\text { appropriate processes to } \\
\text { address the issue }\end{array}$ \\
\hline \multirow[t]{10}{*}{ TARGET } & STRATEGIES AND ACTIONS & PROCESS \\
\hline & $\begin{array}{l}\text { Support EPA to ensure regular } \\
\text { review of prevention measures to } \\
\text { minimise impact }\end{array}$ & \\
\hline & $\begin{array}{l}\text { Investigate feasibility of local oil spill } \\
\text { response capability }\end{array}$ & \\
\hline & $\begin{array}{l}\text { Manage access through vulnerable } \\
\text { reserves }\end{array}$ & \\
\hline & $\begin{array}{l}\text { Establish and maintain a sustainable } \\
\text { car park provision }\end{array}$ & \\
\hline & Support public access to foreshore & \\
\hline & $\begin{array}{l}\text { Support MOSS concept of a coastal } \\
\text { linear park through appropriate } \\
\text { development controls }\end{array}$ & \\
\hline & $\begin{array}{l}\text { Establish funds to acquire and maximise } \\
\text { the extent of reserves through Open } \\
\text { Space Grants }\end{array}$ & \\
\hline & Identify significant 'linkage' areas & \\
\hline & $\begin{array}{l}\text { Seek to acquire 'pocket parks' to enhance } \\
\text { coastal reserves }\end{array}$ & \\
\hline
\end{tabular}

* Hale, A. 1996, Strategy for a Sustainable Southern Region, Adelaide Southern Region of Councils (refers to indicator chosen).

Source: Alexandra et al. 1998, p. 20

of management actions, the system does not work sustainably. However, often management decisions must be made simply on the information that is available at the time. Kenchington (1993) pointed out that management frequently needs information within a far shorter time than science can provide it; or if the information has been gathered, it may not be available in a form accessible to managers. Clearly, managers and scientists constantly need dialogue on priorities for research, as well as dissemination of information.

The ALGA Regional Environmental Indicators Project (Alexandra \& White 1997) brought together, from a series of pilot indicator projects, the general characteristics of an ideal information system to serve the needs of sustainable management: 
1 Accessible - by a range of agencies and community groups

2 Flexible - can be applied at various scales; can be aggregated or disaggregated to regions and subregions; can be aggregated or disaggregated by information classes

3 Open - to involvement by agency and community monitoring groups. Can be used to identify these groups

4 Integrated - can be used to integrate and correlate information from outside the region

5 Spatial — can be used to display various data sets over various base maps. The workings of such a system would provide a number of significant benefits, assuming the following working characteristics:

- store, analyse, retrieve, and display regional environmental data

- gather primary data that has been collected using standard methods, measured using consistent units of measurement, and recorded using uniform, consistent terminology and attribute definitions

- automatically check records as they are entered to ensure that logical sequences have been followed, that necessary items are present, that specific values lie within valid ranges, and that relationships between items are within acceptable limits

- provide secure but readily available database access to regional councils, community environmental monitoring groups, government agencies, industry, schools, community groups, and the general public

- easy to use, preferably through a simple geographic information system interface, whereby users can use a map to identify areas of interest and interrogate the system straightforwardly to obtain the data required

- able to present time-series data in tables, charts, and reports in a variety of formats so that trends can be easily determined, and comparisons made against regional, state/territory, and national guidelines and standards

- provide hard copy as well as electronic forms of output that can be quickly imported into other computer-based applications

- provide for a standard data interchange format so that data can be sent to, and received from, data seekers and providers with little or no processing required

- provide a variety of statistical tools for assessing data, including graphical as well as non-graphical methods of analysis

- include a facility for attaching interpretive or contextual information to data so that users can obtain scientific and technical information on its significance. This may include reference to published reports or national and state/territory guidelines (adapted from Cugley 1994).

Geographical Information Systems (GIS) are especially significant in their ability to support local and regional coastal management systems because of 
their capacity to process and display large amounts of data on a spatial basis. GIS has the capacity to:

- record, store, and integrate data on a spatial basis and facilitate the communication and sharing of this data

- access existing spatial systems and reference sets and to record store and integrate data to these systems

- geo-reference site-specific information to the national grid and various published map series

- map the results of regional or local inventories, audits, and state of the environment reporting

- make site-specific information readily available for day-to-day management purposes by means of a location search

- create graphic images to highlight issues, explain and interpret data, and prompt responses

- create and display customised maps, displays, and submissions.

\section{Management costs and equity}

The effort by management depends in part on the perceived long-term value of the resource and the year-to-year return in income. Like most environmental resources, the coast suffers in both these respects: there is no agreed way to value the presence or absence of a dune or a beach, nor any way to assign a dollar value to an unpolluted beach or to a species-diverse dune complex. Some uses of coastal and marine resources have a clear dollar value, such as fishing; other uses, such as recreation, may have a less easily defined value. The cost of managing the coast may often be hard to establish as well, since often responsibilities are shared or overlap.

Many functions of coastal management are shared between state and local government: how to assign a fair proportional cost between these two bodies is a vexed question. Many local coastal assets are also state assets that have visitor catchments from a wide area, but management costs apparently paid for by local rates. Here the issue of equity emerges: ratepayers living close to coastal assets consider their advantages are recognised in their property value and hence their council rates. Where council rates are inadequate to manage the resource in the face of visitor pressure, there is resistance to the imposition of a local charge or levy to cover the shortfall. In this context, changes to the conditions of 'traditional use', such as charging for the right to camp on a council coastal reserve, are frequently causes of controversy. As there is no clear 'value' to the asset, common methods of dealing with this problem run into difficulties. 
The valuation problem is highlighted by the development of large projects at the shoreline. In an ideal world, marinas, boat harbours, seawalls, breakwaters, and groynes would be assessed in a long-term and precautionary manner for cost-benefit advantage, environmental responsibility and social acceptability. However, lack of conventional means of valuing the impact of change within the dynamic shoreline zone skews such a rational process (if the process is rational).

\section{Box 4.11 Paying for the Adelaide Beach}

While other coast protection schemes within South Australia are shared between local and state governments, Metropolitan Beach sand renourishment is paid for by the state. The rationale for this arrangement being that the beach is primarily a state asset, and also that agreement could not readily be obtained in apportioning costs between five relevant councils. The cost of maintaining sand on Adelaide's beaches and protecting the coastal suburbs has in the 1990s been approximately $\$ 2.0$ million per year. Costing alternatives, such as groynes, seawalls only, no action, larger replenishment, and offshore barriers, has shown the present strategy is the lowest cost option, at least until 2012 (DEPSA 1992). Further costs arise where the nearshore bar is broken: maintaining future navigation improvements at Glenelg and North Haven is estimated to average \$0.7 million per year. Because of the difficulties of removing seagrass detritus and sand from Holdfast Quays and West Beach harbour, the costs of harbour management associated with the sand management may blow out to near to \$2 million.

Protection costs arise because of past decisions on development by local government and the state government: decisions to allow building in threatened locations have continued in Adelaide until very recently. Many consider that until those authorities responsible for development control face the full liability of the consequences of their decisions, unsustainable decisions will continue to be made.

Keeping the beach as an acceptable recreational resource has other costs. Beach cleaning, dune and reserve maintenance, toilets, parking all falls to local councils: 'housekeeping' this beach has been shown to cost at least as much as protection, (Funding Working Party, 1993, appendix B). However, compared to the surrogate annual values economists have placed on the beach, of $\$ 16$ million to $\$ 20$ million (Evans \& Burgan 1992), the replenishment and maintenance costs appear small.

In the end, the role of beach recreation as an Australian institution may be more important than money in deciding the fate of the Adelaide beach. Strong public protests over alienation of coastal land; anger at proposals to charge beach users on a user pays basis; demonstrations over building across the shoreline, and 
beach and bathing water pollution. Such protests as these have occurred around Australia in the 1990's and are a strong reminder that in Australia free and unimpeded access to the beach and the surf are seen as important rights. It is clearly important that the beach is there, even though the nature of the sand is to move!

Public body budgetary systems and grants systems may or may not have a direct effect on decisions over shore protection: shore protection is an expensive matter, often needing state or special grant funding. Where funding is allocated for a few years only, soft protection-beach replenishment may not be seen as an option. This perception often arises because 'hard' protection is often seen as 'fixing' the problem, whereas 'soft' protection of sand renourishment is usually a recurrent cost.

\section{Conclusions}

Coastal management systems need to be technically sound, economically cost effective and socially equitable if they are to claim long-term sustainability. At all stages of an effective management process, information is critical: to show whether actions are proving effective, to calibrate costs and effects, and to inform the social processes associated with the system.

The beach is a spectacular example of natural and human-induced change and expensive intervention. Many more attempts to intervene and manage coastal biophysical systems exist. Often it is necessary to try to separate natural change from the impact of human use and intervention. More than most, coastal managers need a commitment to monitoring because of the rapid rate of natural change at the coast, and because of uncertainty about what has happened in the past. However, in a situation of uncertainty, it is inevitable that an experimental approach, which allows for change iteratively through testing and feedback, will be needed.

\section{Management of places of high conservation and landscape value}

Protected area: 'an area of land and/or sea especially dedicated to the protection and maintenance of biological diversity, and of natural and associate cultural resources, and managed through legal or other effective means.' 


\section{Protected areas on land}

This chapter is focused on those particular parts of the coast that have been acknowledged as significant in one way or another and hence have been accorded greater or lesser forms of legislative protection or recognition. Dedication to reserve status at the coast in Australia is driven by three themes: biodiversity, heritage, and aesthetics. For the terrestrial coast these three often overlap. Many areas retaining elements of biodiversity significance are often seen as attractive landscapes; sometimes these same areas contain sites of heritage significance, or landscapes that have been identified in these terms. Both terrestrial and marine coastal reserves are designated mainly for biodiversity reasons, including the protection of specific species, but all jurisdictions include reserves conserving all three themes. Some reserves, such as the Ningaloo Reserves of Western Australia, cross the shoreline, but most land-based parks extend to low water.

Recently the Commonwealth has reinforced its management powers over World Heritage Areas, Ramsar wetlands, threatened or endangered species, migratory species, and Commonwealth land and marine areas, through the Environment Protection and Biodiversity Conservation Act 1999 (see page 203). This replaces, among others, the National Parks and Wildlife Conservation Act 1975, which had been a key instrument in the Commonwealth's management of its protected areas.

On land and within territorial waters, reserves have been dedicated and defined under the separate legislation of the Commonwealth, the states and the Northern Territory. As a result, Australia has several different systems of reserves, and the varying management regimes differ between jurisdictions and run across the full range outlined within the IUCN guidelines listed in table 4.9.

\section{Marine protected areas}

The basis of conservation protection by legislation is the definition of coastal waters around Australia and its dependent territories (see figure 4.2). While Australia allows free passage of legal maritime traffic, it is party to the United Nations Convention on the Law of the Sea (LOSC), by which it claims an economic exclusion zone extending 200 nautical miles from the shoreline. Within this zone, and the enclosed states' waters, are 148 marine protected areas, totalling 38,908,358 ha., and including areas protected for science (IUCN Ia), ecosystem conservation (IUCN II), for habitat/species management, for landscape/seascape conservation (IUCN V) and for sustainable use of resources (IUCN VI). 
Table 4.9 IUCN guidelines for protected area management categories

\section{Category la}

\section{Strict Nature Reserve: protected area managed for science}

Area of land and/or sea possessing some outstanding or representative ecosystems, geological or physiological feature and/or species, available primarily for scientific research and/or environmental monitoring.

\section{Category lb}

\section{Wilderness Area: protected area managed for wilderness protection}

Large area of unmodified or slightly modified land and/or sea, retaining its natural character and influence, without permanent or significant habitation, which is protected or managed so as to retain its natural condition.

\section{Category II}

\section{National Parks: protected area managed mainly for ecosystem conservation and recreation}

Natural area of land and/or sea, designated to (a) protect the ecological integrity of one or more ecosystems for this and future generations, (b) exclude exploitation or occupation inimical to the purposes of designation of the area, and (c) provide a foundation for spiritual, scientific, educational, recreational, and visitor opportunities, all of which must be environmentally and culturally compatible.

\section{Category III}

\section{Natural Monument: protected area managed for conservation of specific natural features}

Area containing one or more specific natural or natural/cultural feature which is of outstanding value because of its inherent rarity, representative or aesthetic qualities or cultural significance.

\section{Category IV}

\section{Habitat/Species Management Area: protected area managed mainly for} conservation through management intervention

Area of land and/or sea subject to active intervention for management purposes so as to ensure the maintenance of habitats and/or to meet the requirements of specific species.

\section{Category V}

\section{Protected Landscape/Seascape: protected area managed mainly for} landscape/seascape conservation and recreation

Area of land, with coasts and seas as appropriate, where the interaction of people and nature over time has produced an area of distinct character with significant aesthetic, cultural and/or ecological value, and often with high biological diversity. Safeguarding the integrity of this traditional interaction is vital to the protection, maintenance and evolution of such an area.

\section{Category VI}

Managed Resource Protected Areas: protected area managed mainly for the sustainable use of natural ecosystems

Area containing predominantly unmodified natural systems, managed to ensure long-term protection and maintenance of long-term diversity, while providing at the same time a sustainable flow of natural products and services to meet community needs. 
Figure 4.13 Australia's territorial waters

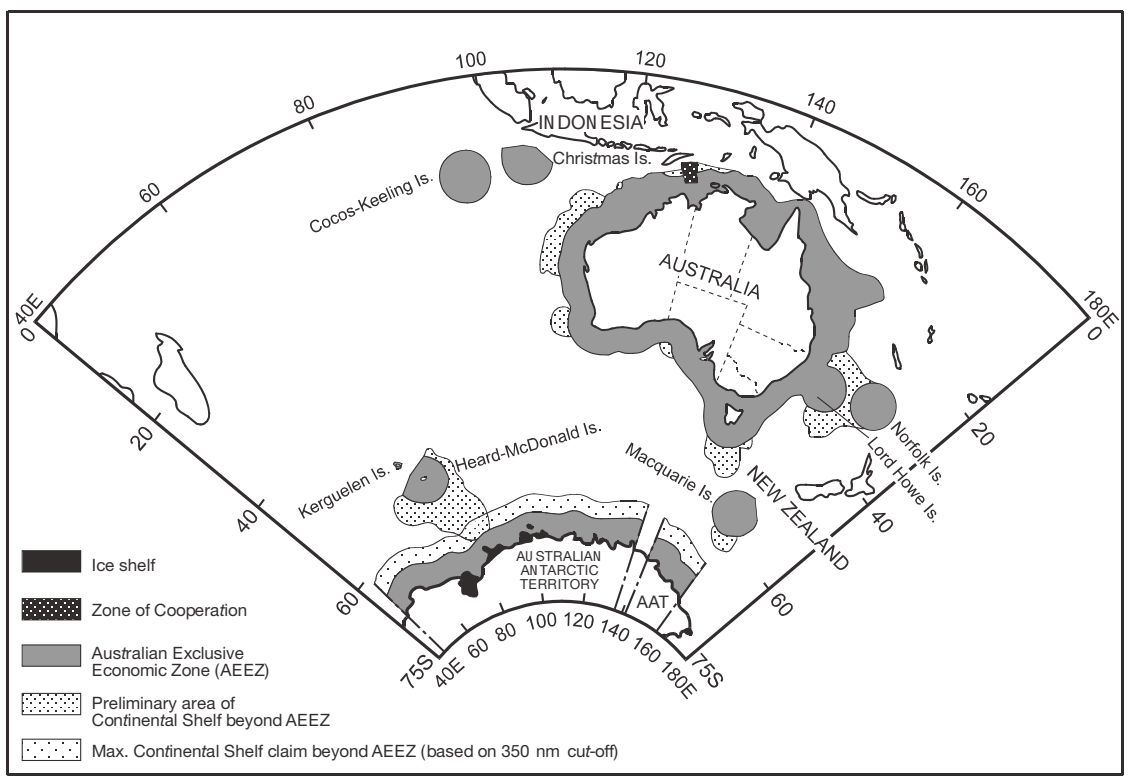

Source: Commonwealth of Australia 1988

Table 4.10 suggests that most Marine Protected Areas (MPA) are in the north of Australia; Cresswell and Thomas (1997, p. 15) noted that 'almost 90\% of marine protected areas lie north of the Tropic of Capricorn, with most of this area occurring within the Great Barrier Reef Marine Park'. About three-quarters of the total area of MPAs in Australian waters is within the Great Barrier Reef Marine Park.

In general terms it is clear that temperate Australian waters are under-represented within the marine reserve system. Zann (1995, p. 82), commented that the south has greater population pressure and therefore a greater need to undertake protection. Kriwoken (1996, p. 125) commented:

... the subtropical, temperate, cool and cold waters of Australia are under represented. The smallest number and size of MPAs are found in the southern and eastern half of the continent, where impact is greatest. Most MPA are less than 5 $\mathrm{km}^{2}$ and the majority of MPAs are multiple use zoning areas which allow a range of resource extraction activities. Strict no-take MPAs are not as extensive. The existing national system of MPAs does not adequately represent Australia's marine biodiversity. 
Table 4.10 Marine protected areas in Australia

\begin{tabular}{lllll}
\hline Jurisdiction & $\begin{array}{l}\text { Area of marine } \\
\text { jurisdiction }\left(\mathrm{km}^{2}\right)\end{array}$ & $\begin{array}{l}\text { Number } \\
\text { of MPAs }\end{array}$ & $\begin{array}{l}\text { Area of water } \\
\text { in MPA }\end{array}$ & $\begin{array}{l}\text { \% of waters } \\
\text { in MPAs }\end{array}$ \\
\hline Commonwealth & 10812400 & 18 & 367560 & 3.40 \\
New South Wales & 17400 & 8 & 858 & 4.93 \\
Northern Territory & 62300 & 3 & 2239 & 3.59 \\
Queensland & 60600 & 82 & 53029 & 87.50 \\
South Australia & 31500 & 15 & 596 & 1.89 \\
Tasmania & 27000 & 3 & 1.7 & .06 \\
Victoria & 14400 & 12 & 503 & 3.49 \\
Western Australia & 74400 & 7 & 11466 & 15.41 \\
\hline
\end{tabular}

Notes:

The figures differ from the State of the Marine Environment Report, because of definitional differences.

The figures are compiled as at June 1996, and do not include the state and Commonwealth components of the Great Australian Bight Marine Park.

Source: data from Cresswell \& Thomas 1997

The conservation significance of the lack of protection in the South is underlined by the high rate of endemism of Australia's temperate waters: reconnaissance surveys suggests this is as high as $80 \%$ (Edyvane 1998, p. 3). The long southern coast of the continent represents a vast shelf seafloor at one latitude, with a temperature gradient boundary at the eastern and western ends, due to the East Australian Current and the Leeuwin Current. These temperature boundaries have isolated the coastal waters of the Southern Ocean in the latter stages of the long drift north from Gondwanaland (Poore 1995). The uniqueness of the species of the South is due to long evolution in isolated circumstances. In contrast, over half the species found on the Barrier Reef are also found off Indonesia, an area with which there has long been a marine connection.

A tentative bioregionalisation (19 broad regions around continental Australia) of Australian shelf and ocean waters was used by the State of the Marine Environment Report (p. 81) to show 'that most marine bioregions have little or no protection'. The Interim Marine and Coastal Regionalisation of Australia (IMCRA Technical Group 1997) was undertaken to show how representative the marine reserve system is within 60 meso-scale regions on the continental shelf. Under the Commonwealth government's Oceans Policy, a National Representative System of Marine Protected Areas (NRSMPA) will be developed. This involves the Commonwealth, states and Northern Territory establishing 
MPAs in all 60 IMCRA regions; a draft strategic plan of action was released in 1998.

One distinctive feature of marine protected areas is that their management is commonly based on zoning, involving multiple use zones. Thus fishing, with the exception of seabed trawling, is allowed throughout the Great Australian Bight MPA; however, the Marine Mammal Protection Zone is closed to commercial fishing from May to October to avoid disturbance within the calving grounds of the Southern Right Whale. In addition, petroleum exploration and, potentially, mining is allowed in part of the Benthic Protection Zone of this MPA. Many visitors to the Great Barrier Reef Marine Park assume it is a strict nature reserve, or managed only for ecosystem conservation and regulated tourism, though only $4 \%$ of this large protected area is a 'no-take' area for fishing.

In view of the traditional approach to the ocean as a 'commons' with minimal regulation, it is hardly surprising that the issue of no-take zones is a controversial one, with fishers seeking to maximise their economic opportunities by opposing such zoning. However, there is a clear argument that minimal disturbance is necessary for certain areas in order to preserve biodiversity. Scientists and managers advance the argument that it is necessary to preserve some areas in an undisturbed state as a yardstick, to compare with those areas under pressure from a variety of uses. Also, evidence is accumulating as to the value of no-take areas to fishers as well as others, as a kind of replenishment area, where fish stocks can build and recover from harvesting elsewhere. Evidence from the Philippines and from Tasmania shows considerable increases in fish, invertebrate and algal numbers in monitored no-take zones (see Barrett \& Edgar 1998). This possibility of greater resource security, in an industry suffering considerable uncertainty, is a hopeful development.

\section{Box 4.12 Case study: Ningaloo Reef}

The Ningaloo fringing reef runs close inshore for some $260 \mathrm{~km}$, from Amherst Point to North West Cape near Exmouth, Western Australia (see figure 4.14). The shallow waters of the reef extend only about $20 \mathrm{~km}$ offshore, ending abruptly as the continental shelf plunges to deeper waters. The reef sits across the Tropic of Capricorn, at the overlap of tropical and warm temperate waters, and experiences the variable pulses of the Leeuwin Current from the north. The environmental gradient changes are sharp across the reef and on to the land: from the deep Indian Ocean across the narrow reef and on to the arid limestone hills of the Cape Range Peninsula. No run-off reaches the reef from the land. 
Figure 4.14 Location and boundaries of Ningaloo Marine Park

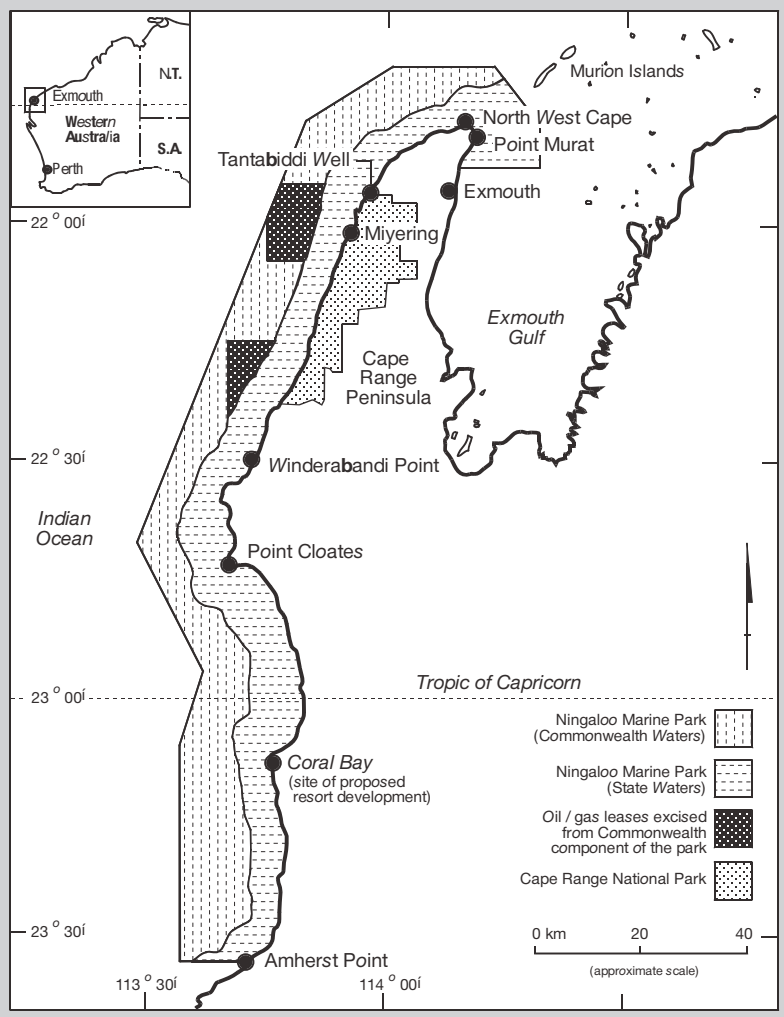

Source: modified from Commonwealth Waters Management Plan 1999

The Ningaloo Reef(Commonwealth Waters) Marine Park and the Ningaloo Reef (State Waters) Marine Park were both dedicated in 1987. The latter includes a small strip of coastal land. Contiguous with part of the boundary is the Cape Range National Park. The second Commonwealth Waters Management Plan (draft, October 2000) provides for management as an IUCN category II reserve by Environment Australia, Conservation and Land Management WA and Fisheries WA.

The Park was reserved because of the diversity of coral (200 species) and fish (500 species), the geographical uniqueness of the reef site and position, and the cultural significance of the area. The reef is visited by Whale Sharks and by a variety of marine mammals, including the humpback whale; it is home to the green backed turtle and to dugongs. The area is recognised as a protected migratory bird site. 
The Park is popular with tourists who camp along the shore, or stay at Coral Bay and Exmouth. Because the reef is so close to the shore, access for boating, snorkelling, diving or recreational fishing is easy. Potential threats to the reef are seen as pressure of visitation, commercial and recreational fishing, and the proximity of oil and gas exploration. The reef is at the southern end of the North West Shelf gas and oil field; exploration lease areas are within the state component of the park and contiguous with the Commonwealth section.

Ningaloo is almost entirely zoned for General and Recreational Uses. The Commonwealth waters are entirely recreational, and within the state waters there are a number of Sanctuary areas (no-take zones), which have been criticised by conservationists (Sutton 2000) as too small and as unrepresentative.

The second Commonwealth management plan for Ningaloo Marine Park lists its objectives as conservation, sustainable tourism, research and interpretation, and to be part of the NRSMPA. While protection in this protected area appears to receive little emphasis, the value of its status as an MPA appears to be in the emphasis placed on the sustainability of use. This is in the hands of the on-ground management by Conservation and Land Management WA and Fisheries WA.

\section{Terrestrial protected coastal areas}

In the lengthy history of dedication of terrestrial reserves in Australia, it is clear that the early phase was one of securing areas of great natural beauty. Some notable early examples were at the coast; for example, Royal National Park south of Sydney and Flinders Chase on Kangaroo Island were dedicated in the latter part of the 19th century.

Later the emphasis in securing parks was the conservation of significant or remnant ecosystems. It was the drive to conserve representative portions of significant ecosystems across the whole continent that led to the establishment of IBRA, the Interim Bioregionalisation of Australia.

Figure 4.15 shows the proportions of IBRA coastal regions that are protected; only those regions which are predominantly coastal are shown. While the proportion of protected area varies greatly, the average for all Australia is $7.6 \%$. Examination of the coastal figures shows they vary as a group only slightly from this (average 12\%), nor is there any clear continent-wide pattern, as is the case with marine protected areas.

Protected areas form a significant proportion of the coastal lands of Australia, and the various states' Parks and Wildlife agencies are important coastal managers. A recent check of the mapped data by DEHAA South Australia (T. Bond, pers comm.) showed the results listed in table 4.11. 
Figure 4.15 The interim marine and central regionalisation of Australia divides coastal waters into 60 bioregions, in an attempt to establish a basis for a representative system of marine protected areas

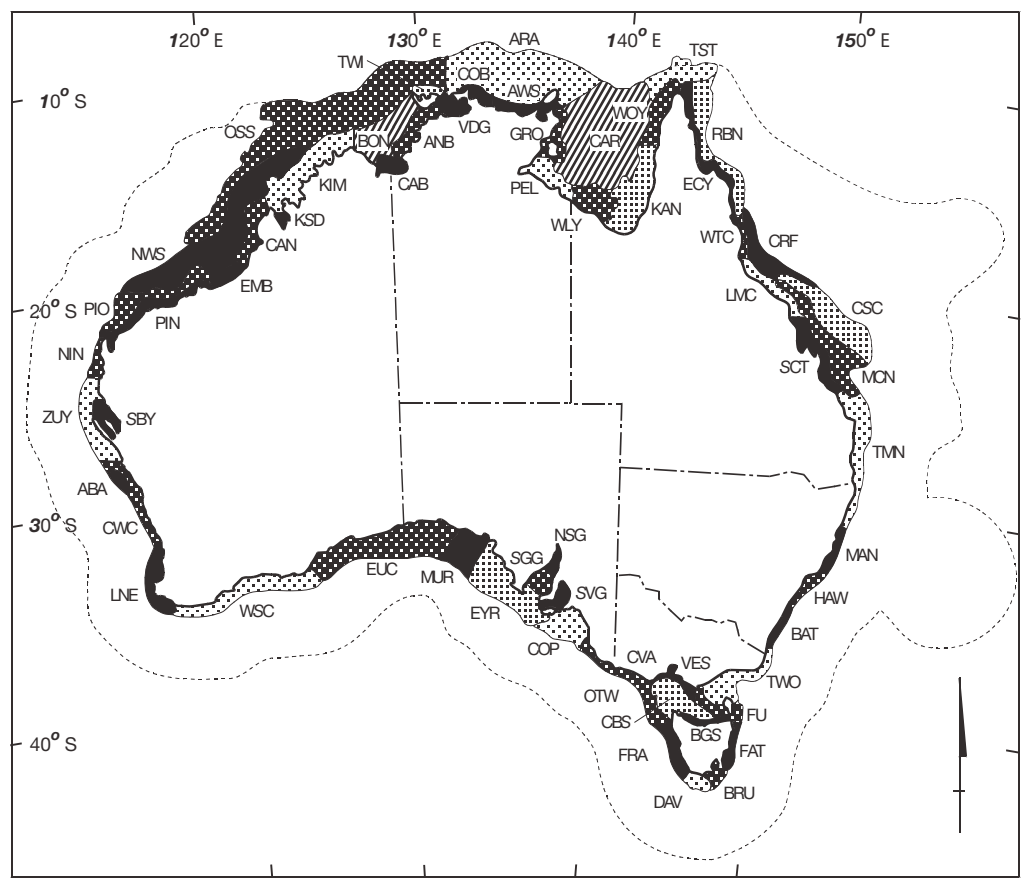

Source: Environment Australia 2001

Table 4.11 South Australian coastal parks

\section{SA Coastline}

Length of SA coastline

$5060 \mathrm{~km}$

Length of SA coastline in or adjacent to parks

$1711 \mathrm{~km}$

Percentage of SA coastline in or adjacent to parks

$33.8 \%$

\section{SA mainland coast}

Length of mainland coastline

$3817 \mathrm{~km}$

Length of mainland coastline in or adjacent to parks $1101 \mathrm{~km}$

Percentage of mainland coastline in or adjacent to parks

$28.8 \%$

\section{SA island coastline}

\section{Length of island coastline}

$1244 \mathrm{~km}$

Length of island coastline in or adjacent to parks

$611 \mathrm{~km}$

Percentage of island coastline in or adjacent to parks

$49.1 \%$ 
Table 4.11 South Australian coastal parks (continued)

Kangaroo Island coastline

Length of KI coastline

$483 \mathrm{~km}$

Length of KI coastline in or adjacent to parks

$183 \mathrm{~km}$

Percentage of $\mathrm{KI}$ coastline in or adjacent to parks

$37.9 \%$

\section{Other island coastline}

Length of non-KI island coastline

$761 \mathrm{~km}$

Length of non-KI island coastline in or adjacent to parks

$428 \mathrm{~km}$

Percentage of non-KI island coastline in or adjacent to parks

$56.2 \%$

Note: These data are measured at HWM as shown on the 1:100 000 map series, where the HWM is within or adjacent to parks. The shoreline lengths are considerably longer than the CSIRO coastal inventory, because of differences in methodology.

\section{Box 4.13 Case Study-Small offshore islands: special refuges}

There are numerous small offshore islands around the Australian coast. These are a special form of wilderness: their isolation reducing human influence and often freeing them from exotic predators, such as cats and foxes. These islands were connected to the mainland around 20000 years BP, at the time of the last Pleistocene glacial low sea level. As the sea level rose, the islands were separated, remaining as small arks for plants and animals, to follow special voyages of evolution.

The former linking of many islands to the mainland is recorded in Aboriginal tradition; for example the dreamtime hero of the Ramindjeri people, Ngurunderi, pursued his two unfaithful wives down the Murray River and caught up with them as they walked through the shallows to Kangaroo Island.

Some islands were invaded early by Europeans - sealers, whalers and settlers - usually to be abandoned. Where exotic plants and animals have been introduced, they have been devastating for islands. For example, on the Houtman Albrolhos Islands, Western Australia, fishing settlements and guano mining introduced rats, cats, rabbits and mice, leading to the extinction of sea lion and seabird colonies from the islands.

Today small offshore islands provide a home or vital stopping place for many animals; they are critical to nature conservation. They are major breeding grounds for seabirds turtles and seals, with some species only breeding on islands. They act as refuges for rare and endangered species:

- Ten species of terrestrial mammals either only occur on islands, or the last secure populations are found there, for example Tammar Wallaby, Eastern Barred Bandicoot 
Figure 4.16 Nuyts Archipelago. These islands have become cut off from the mainland as the sea rose at the end of the postglacial marine transgression. They form important refuges for plants and animals

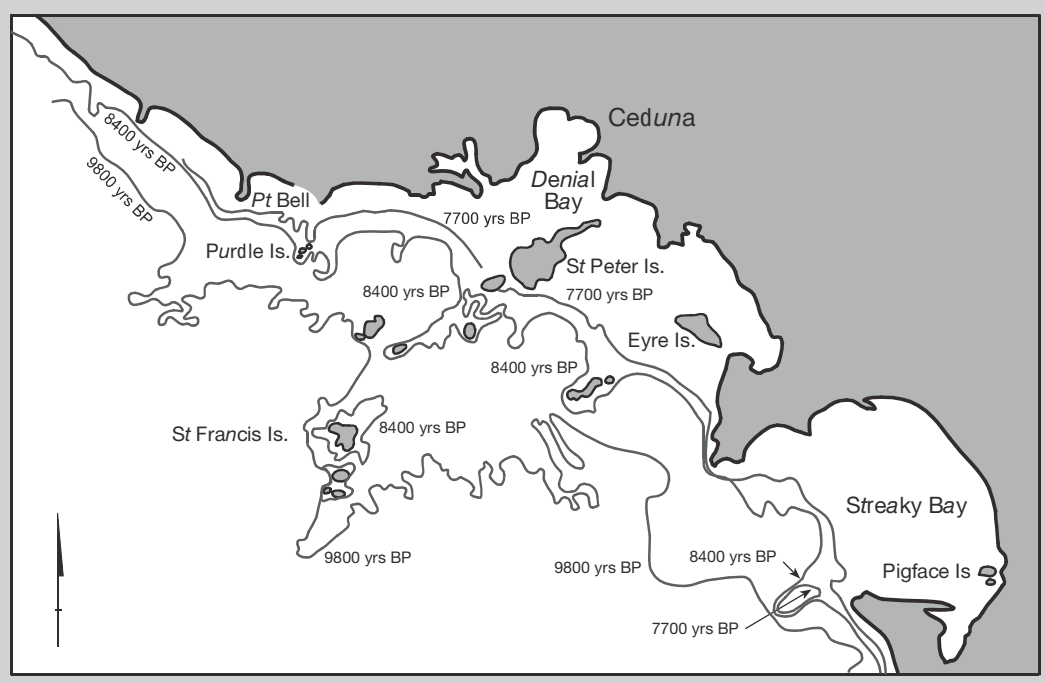

Source: Robinson et al. 1996, p. 13

- Several bird and other species are only found on islands, for example Gould's Petrel, Lesser Noddy, Rufous Hare-wallaby

- The islands of the Bass Strait support an estimated 18 million Short-tailed Shearwaters.

As important habitat, many islands have protected area status within the parks systems of the states, but their management has many problems. Islands provide a range of unique residential, commercial, tourism, scientific, and heritage opportunities. Island managers face a range of threats to conservation values:

- Some islands with conservation value do not have protected area status; other, protected islands, do not have management plans

- Islands attract tourist groups, cruising yachts, dive groups, fishers. Disturbance, trampling, exotic plants and animals, wastes and litter, and the use of vegetation as fuel result

- There are particular problems associated with fire on islands: often fires are undetected, or it is impracticable to put them out

- Island management is expensive: monitoring and good communication with user groups are always essential elements. 


\section{Box 4.14 Case Study: Across land and water-Aboriginal management on the Cobourg Peninsula, Northern Territory}

Almost the most northerly part of the Australian landmass, the Cobourg Peninsula is tenuously linked to the mainland by a narrow neck of land. Its deeply indented coastline is highly varied, with beaches, lagoons, dunes, plains estuaries and mangroves. The traditional owners acquired European title to the area under the Cobourg Peninsula Aboriginal Land and Sanctuary Act 1981. Under this arrangement the land was leased back to the Northern Territory Conservation Commission (now the Parks and Wildlife Commission) for management as a national park-now called Garig Gunak Barlu National Park - which is controlled by a board with an Aboriginal majority. The duties of the Garig Gunak Barlu Park Board are to:

- prepare a management plan

- protect and enforce the rights of the traditional owners

- determine rights of access to places

- protect spiritual sites

- carry out the management plan.

Thus Aboriginal involvement in the management of the area is legislated. The process attempts to address Aboriginal needs for sustenance from the land and to recognise the rights and responsibilities involved in the spiritual significance of the lands.

The Commission prepared a management plan involving considerable public consultation, but the language and length of the plan has proved baffling to the owners. In an operational sense, Aboriginal involvement has been slow.

Incorporated within Garig Gunak Barlu is the previously named Cobourg Marine Park, the first marine park to be jointly managed by the traditional owners and a government agency. Its controlling body is the Gurig National Park board of management, and day-to-day management is by the Parks and Wildlife Commission. The park consists of 229000 ha. of shallow coastal waters and islands, with extensive seagrass beds, turtle and Dugong habitats.

The context of these arrangements is important. In a Territory-wide survey, Ganter (1996) stated:

Aboriginal land comprises $84 \%$ of the Northern Territory coastline ... In Aboriginal culture the interdependence of marine and coastal environments is expressed by the absence of jurisdictional boundaries between land and sea. For coastal 'saltwater' people, the legal boundary between land and sea is meaningless in that it fails to recognise the 
importance of the intertidal zone as the basic source of their subsistence economy, nor to recognise their extensive spiritual responsibilities in relation to site and country.

While ownership under Northern Territory law finishes at the low water mark, Aboriginal concerns run well beyond this point. For traditional owners there are the possibilities of native title claims over the sea or application for sea closure under the Aboriginal Land Act 1978 (see, for example, Kearney 1988). Both these processes are long, costly and uncertain. For Northern Territory fishers also, uncertainty is a frustration.

Both in the protected area situation, and generally along the Territory coastline, successful coastal management depends upon good cooperation between Aboriginal owners, government agencies and the rest of the community.

\section{Evaluating and protecting coastal landscape values}

'Cultural heritage' denotes places and things that have aesthetic, historic, scientific or social significance, or other special value for future generations as well as the present community. 'Heritage' can refer to archaeological sites or buildings, or to the way in which 'natural' areas are interpreted as part of a way of life.

RAC (1993a), p. 33

Many coastal areas are valued for the scenic attractiveness of spectacular cliffs arches or stacks, great sand masses, patterns of islands, or the sweep of an estuary. This landscape value may be recognised in the dedication of a park: the IUCN category V (table 4.12) describes a reserve dedicated for this purpose. It is apparent from table 4.12 that this form of reservation is very unevenly used in Australia. However, it cannot be concluded that scenic coastal landscapes are not conserved in some states, since many other classes of reserve are also of high landscape value.

A major difficulty with securing scenic amenity in coastal areas is that many such areas encompass both private and public land: the preservation of all the elements of a particular landscape on private land implies the maintenance of a particular form of management. This concept has been developed over three decades in the English Heritage Coast system, as a project-based approach (see Caton 1993) which developed from the English National Parks system under the initiative of the former Countryside Commission. It is a 
Table 4.12 Numbers of coastal reserves by state in IUCN category V

\begin{tabular}{lll}
\hline Jurisdiction & $\begin{array}{l}\text { Number of reserves in } \\
\text { IUCN category V }\end{array}$ & $\begin{array}{l}\text { Number of coastal reserves in } \\
\text { IUCN category V }\end{array}$ \\
\hline Commonwealth & 0 & 0 \\
New South Wales & 5 & 2 \\
Northern Territory & $17^{\mathrm{a}}$ & 5 \\
Queensland & $19^{\mathrm{b}}$ & 16 \\
South Australia & 0 & 0 \\
Tasmania & 2 & 2 \\
Victoria & 0 & 0 \\
Western Australia & 0 & 0 \\
\hline
\end{tabular}

a Nine of these are small historical reserves.

b Includes seven marine parks, which overlap with the Great Barrier Reef Marine Park.

system based on private management within an elaborate framework of land management agreements between landowners and the Countryside Commission. No such tradition exists in Australia, where maintenance of particular land uses at the coast depends primarily on the planning system. The planning system, as an instrument designed for development control, is not efficient in securing landscape amenity. For example, the zoning of an area as 'Rural Coastal' might secure it for a while against the sprawl of real estate along the coast, but it cannot secure it against land use change within the category 'Rural Coastal'. In addition, at the coast there is often pressure to change the zoning. Scenic coasts, and particularly those that retain vestiges of naturalness, are under continuous pressure by developers with schemes for real estate, resort, and marina development. Land managers, both government and private, are continually faced with the dilemma of rising real estate values encouraging development growth, while scenic values are reduced by a decline of naturalness (Caton 1993).

Identification and definition of areas of high landscape value is another difficult problem. Researchers in the field of landscape evaluation disagree as to whether it is possible or desirable to attempt objective definition, the debate being split between those who favour an analytic method and those who maintain that a holistic approach is necessary. The lack of agreement over method in this area is a major problem where there is a need for a standard that can be sustained under challenge. As Lothian (1984, p. 1) stated: 'In the absence of an 
explicit policy to recognise landscape quality and complementary action to safeguard and enhance this quality, it will be gradually lost by default.' Kane (1976, p. 1), in a similar vein, suggested landscape should be treated as a resource: 'This reduction in landscape diversity is not only sad, but also dangerous because scenic landscapes should be regarded as a natural resource. Perhaps they are not as obvious a natural resource as forest, water supply, ores, soil, and fossil fuels, but they may in the long run be one of the most vital resources in helping to maintain stable and healthy societies.'

A variety of methods of landscape evaluation have been used to reduce or overcome the 'problem of subjectivity'. They have all been partially successful in terms of their validity (does the method measure what it is designed to measure?) and reliability (can the measurement be replicated?). For example:

- assessment in the field, for example Wright (1974)

- assessment of photographs, for example Revell (1982)

- the views of an individual, for example Porteus (1989)

- the views of groups of 'ordinary people', for example Kane (1976)

- the views of experts, for example Kane (1976)

- the views of 'landscape consumers', for example Shafer \& Mietz (1969)

- whole landscape (gestalt) assessments, for example Fines (1968)

- ratings of components within the landscape, for example Leopold (1986).

A persistent problem has been turning the ratings obtained for a particular view into defined areas on a map that can be used in protecting landscapes. State government agencies have made attempts to investigate methods of coastal landscape assessment in order to assist councils to take landscape quality into account in dealing with development applications. Ramsay and Butt (1989) undertook a qualitative visual analysis of the South Coast of New South Wales in 1989, proposing management zones and allowable building types compatible with visual amenity. Before this, the National Trust (1983 and 1984) had proposed planning policy guidelines for the NSW coast based on a visual amenity study. The NSW Government Coastal Management Policy of 1997 gives as one of its nine goals 'to protect and enhance the aesthetic qualities of coastal areas'; its strategic actions include a land acquisition policy and measures to ensure protection of areas of high aesthetic value is included in planning instruments.

The Queensland and Western Australian governments have both undertaken reviews (Brouwer 1993, Cleary 1997) of landscape assessment. The Draft State Coastal Management Plan for Queensland, released in October 2000, seeks to 'conserve the values of coastal landscapes, (policy 6A). The same plan defines areas of 'high scenic value' on a map (p. 35) and advises that regional plans and 
council development plans should take account of these. In South Australia, the Coast Protection Board placed emphasis on coastal scenic amenity in its Coastal Management Plans for the Coast Protection Districts of Kangaroo Island and the Fleurieu Peninsula (Coast Protection Board (SA) 1988a,b).

It is widely agreed that certain landscapes are attractive and as such are valuable, but defining what constitutes an attractive landscape and delimiting it on a map has proved a difficult task. Landscape has long been both a matter of private contemplation and satisfaction and a marketable commodity. These two are not unrelated, for there is no doubt that the media, and particularly the advertising industry, uses certain pieces of landscape as icons or symbols relating to our values and attitudes. Thus our perception of what constitutes valuable scenery is modified over time. Almost universally, certain pieces of countryside are acknowledged as scenically valuable, but the task of ranking the worth of a number of pieces of landscape has proved intractable. No system of landscape evaluation is at present universally endorsed. The conservation of scenic landscapes raises the problem of defining objectively what is a subjectively perceived quality.

\section{Protected coastal areas and nature-based tourism}

While protected areas are of great significance in the preservation of heritage and biodiversity in Australia, there are general concerns about the management of parks, especially at the terrestrial coast. Many areas have been secured within the protected areas system, and in some jurisdictions this is actively expanding, but in all jurisdictions the budget for management has been frozen for some while. It appears likely that government revenue for protected area management is not likely to show a substantial increase in the future. At the same time, pressure from tourism has been growing. Numbers of visitors, especially in coastal areas, have been increasing, with consequent impacts in parks. Also, expectations of management and for facilities have grown: for trails and interpretation, better roads and car parking, and better camping facilities. Nor do all visitors wish to camp, many look for accommodation to be available.

This situation has led to a deal of discussion over the role of the naturebased tourism industry in the management of protected areas. Many protected areas are the industry's core resource, while the parks lack the funds to provide adequate management. There have been a number of examples in the last decade of attempts to negotiate in-park or near-park facilities, which have had varied success. The Kingfisher Bay Resort on Fraser Island provides a case study of a situation where developers have gone to considerable lengths to minimise the impact of the resort on the environment. 


\section{Box 4.15 Case study: Kingfisher Bay Resort}

Kingfisher Bay Resort was opened on a 65 ha. freehold site on the western coast of Fraser Island in 1992. The resort is an enclave of freehold land on a large, forested, subtropical sandmass island which is largely reserved within the Queensland protected area system. In addition, Fraser Island is inscribed on the World Heritage List. The resort has accommodation for approximately 400 visitors, but unlike many resorts, which focus on their own facilities and activities, Kingfisher Bay centres its activities on its unique location. Visitors travel primarily to experience the environment of Fraser Island, not simply to stay at a resort by the sea.

The general location and the site of the resort have meant that a great deal of design work and site-specific planning has been necessary to achieve a credible nature-based tourism resort. Power, wastes, use of materials, and the impact on plants and animals, including weed and plant disease concerns, have been addressed in seeking to minimise impact. The cost, up to the opening of the resort, was approximately $\$ 90$ million. The purpose of the development has meant that some common resort activities, such as jet-skiing, have not been provided. Ongoing training for staff and interpretation for visitors is heavily emphasised. Current advertising for the resort lists interpretive walks, ranger-guided canoe and 4WD bus tours, whale-watching trips and fishing as major activities. It is clear that the protected area of Fraser Island is the core resource for this development. The developer has listed the following monitoring programs set up to test the impact of the resort on the sustainability of the area (Charters 1996):

- seabed biota near the discharge point of the Enviroflow sewage treatment system (at the centre of the channel between the island and the mainland)

- bat, bird, frog, and small mammal numbers near the resort

- weed numbers, compaction and drainage near adjacent trails and roads.

Kingfisher Bay illustrates that sensitive resort development can take place immediately adjacent to a fragile reserve. Given the demand to visit Fraser Island, it is clear that, for one segment of the market, Kingfisher Bay Resort provides a low-impact means of visitation. It also contributes to raising awareness of the special character and value of this piece of the Australian coast. This is not to argue that conservation is not a government responsibility, but to provide an example of one way in which profitable nature-based tourism and protected areas can be sustainably juxtaposed.

Figgis (1999) has argued that the trend to accommodate nature-based tourism and revenue-earning industries through multiple-use approaches is a dangerous one, leading to a series of compromises that threaten biodiversity in key areas. Rather, the effort should be to extend the conservation of biodiversity outside 
parks, into privately owned areas, while retaining key areas in the reserve system for their one main purpose. It is interesting that this argument is developed in different terms for marine protected areas, where the tradition is the zoning of reserves for multiple uses. Core areas become 'no-take', limited access areas; zoning and management are subjected, properly, to monitoring and review, leading to a more flexible approach. The debate is thus ongoing on the definition of MPAs, their zoning, and the identification of significant core areas. Such an approach is potentially more sustainable, being an adaptive management model rather than a static wilderness model.

The key question remains as to the focus on the purpose of the protected area: these areas have been protected in order to preserve their biota and heritage values. Where governments fail to manage them adequately, they are inevitably degraded in a variety of ways. At Australia's coastline there is great and increasing pressure to exploit the commercial potential of protected areas. Nature-based tourism clearly has many key contributions to protected area management, ranging from private sanctuaries, to improving reserves' cash flow, to providing interpretation. However, all causes are lost if the core resource is degraded through failure to maintain focus on the purpose of reservation.

\section{Conclusion}

Protected areas are designated for their biogeographic, heritage and landscape values; within coastal Australia these areas are under significant and increasing pressure of use, while they are distinctive also for the dynamic nature of their natural systems. The definition of biogeographical regions through the IMCRA and IBRA processes marks an important step in the process of obtaining a representative system of protected areas across Australia, including its coastal lands and waters. It is clear that presently the systems are far from representative, and this is clearly illustrated on the broadest regional scale for marine protected areas in the contrast between tropical and temperate Australia. As Edyvane (1998) pointed out, for Australia a further challenge remains in integrating the land-based reserve system with the marine one. In terms of practicality, there is a great deal to recommend working to integrate protected area definition and management across the shoreline. At the very least, a terrestrial reserve constitutes a significant buffer for an inshore marine protected area.

The Commonwealth and states' parks and wildlife agencies are significant coastal managers in Australia, since parks take up possibly a fifth (estimated) of the mainland shoreline and many offshore islands. Many outstanding coasts are managed by these agencies, but pressure to raise money through various 
forms of nature-based tourism is leading to new challenges in conserving the core values which led to their protected status.

While systematic attempts are being made to adequately represent Australia's biodiversity within the reserve system, protection of scenic coastal landscapes remains in an ambiguous position. A number of states have carried out studies to achieve conservation of scenic coasts through the planning system: such an approach faces considerable problems, including the difficulties of defining or rating such landscapes and delimiting them on maps, and the problem of using an inappropriate instrument to achieve a satisfactory outcome of conserving a semi-natural landscape. 


\section{Future Directions for Australian Coastal Management}

This chapter attempts to take stock of what has happened in Australian coastal management up to the end of 2001, particularly the major changes that took place in the 1990s, and comment on the prospects for managing the coast in the 21 st century. The book has, so far, focused on four themes:

1 global imperatives for integrated coastal management and the Australian response

2 the need to understand biophysical coastal processes before attempting to find solutions for anthropogenic coastal problems in Australia

3 the scale and magnitude of human impact on the Australian coast which raises a number of generic management issues together with the need for localised or regional approaches to specific pressures on coastal resources

4 the complexity of coastal management in Australia, involving different roles for the Commonwealth, state, territory and local governments, together with community participation.

First, this chapter of the book examines the current state of coastal management in Australia and comments on selected recent international and national discussions which could produce further change. Some of these are global initiatives such as the Rio +10 Coastal Conference which took place in Paris in December 2001, or national developments such as recent political discussions of the coastal elements of the future National Heritage Trust (Mark II) Program for 2002 onwards. By the time this book hits the shelves, there should also be further comment on coastal management from the UNCED 2002 Conference in Johannesburg, as a follow-up to the significant 'Earth Summit' held in Rio de 
Janiero 10 years earlier. At the national level, the fifth Australian coastal management conference in 2002 was hosted jointly for the first time by two states (New South Wales and Queensland) at their coastal border location where coastal process issues have required unique inter-state cooperation in coastal management. It is tempting to predict that such an event may provide a stimulus for national discussion on cooperation and integration.

\section{The state of coastal management in Australia}

As noted in chapters 1 and 4 of this book, the 1990s produced major changes in Australian coastal management both at the Commonwealth and the State government level. Although there had been previous calls for coastal management reform at a national level, the timing had never been right. More than 20 years ago the national coastal zone inquiry (HORSCEC 1980) concluded that there was a need for national coastal policies and objectives. However, nothing was done. By the time that the 1993 national Coastal Zone Inquiry was conducted (RAC 1993a) there had been so many previous coastal inquiries that the Resource Assessment Commission had to produce a separate report on the findings of all the former inquiries.

It is significant that the 1990s was a period of renewed global environmental awareness which involved Australian scientists and politicians. In particular, the 'Earth Summit' triggered Australian responses to the predictions for climate change through the National Greenhouse Strategy and the need for a more environmentally sustainable approach to development through the National Ecologically Sustainable Development Strategy. These national strategies were immediately followed by the RAC Inquiry in 1993 and then the Commonwealth Coastal Policy in 1995.

The RAC Inquiry summarised some of the major coastal management problems that needed attention, including:

- the fragmented nature of decision making within and between the three spheres of government

- inadequate management mechanisms for the coastal zone, such as the scope for greater use of prices and market mechanism

- inadequate public involvement

- lack of a national (and in some cases state) approach to management

- failure to implement procedures to ensure that decisions about the use of resources take account of the real value of resources to society as a whole. The RAC was aware of the need for action rather than further analysis of these problems. In response to a complex situation the RAC made the following recommendations: 
- national cooperation and action - a national coastal action plan (NCAP)

- agreement over the NCAP be endorsed by the Council of Australian Governments ("the importance of the coastal zone and the shared nature of management responsibilities between governments requires a separate agreement')

- the Commonwealth should take the lead in initiating and implementing national coastal zone objectives and principles, and pass legislation to guide funding allocations (A Coastal Resource Management Act)

- a national coastal zone management agency to facilitate the implementation of the NCAP

- the creation of a national professional coastal advisory group

- assistance by the Commonwealth to states to increase the resourcing to states' coastal coordinating committees.

Since the RAC Inquiry, the Commonwealth, states and local governments have moved on, taking on board some of the RAC recommendations and responding to continuing community demand for improved coastal management.

\section{The Commonwealth}

Although the Commonwealth did not take up the RAC proposal for a new Act and new agency, it has established and developed the Commonwealth Coastal Policy and Coastal Action Plan and published (though without the agreement of the states) the National Oceans Policy. A great deal of action, planning, research, and capacity building has been driven through all sectors by Commonwealth funding (and associated criteria) in the late 1990s. This has been detailed in chapter 4; some examples are:

- Coastcare

- Coasts and Clean Seas

- Urban Stormwater Initiative

- Ocean Rescue 2000

- coastal vulnerability assessment to projected climate change, carried out by all states and the Northern Territory

- professional and industry guidelines in coastal planning, coastal engineering, tourism development, and fishing

- the development of an Interim Marine and Coastal Bioregionalisation of Australia, IMCRA

- continued support of the Australian Institute of Marine Science, CSIRO oceanographic work, the National Tidal Facility, and Great Barrier Reef Marine Park Authority. 
At the same time, state of the environment reporting by the Commonwealth has made a significant contribution in developing a national view of the state of the coast. The State of the Australian Marine Environment Report (Zann 1995) and the State of the Australian Environment, reports (SEAC 1996, ASEC 2001) were important collaborative efforts that described the condition of the coastal environment, within the pressure-state-response (PSR) model. As a result, attempts have been made to describe the state of responses to impacts on the coast following the PSR model. Thus government state of the environment description processes have begun to routinely raise questions such as: How successful has management been and how can this success be measured? What are the best indicators of management response?

A variety of agreements and instruments have enabled this activity, including the Council of Australian Governments and, notably, memoranda of understanding between the Commonwealth and the states on the Coastal Action Plan (1995) and the National Heritage Trust (1997).

Within the Australian system of cooperative federalism, the Commonwealth would need to obtain broad agreement, through the Council of Australian Governments, to establish a national coastal policy or strategy. Given the complexity of the issues, the varied - and changing - attitudes of the states, and the low political profile of the organisation of coastal management, it is not surprising that an agreed national approach has yet to be established. More clear cut issues, such as dryland salinity or capping diversions within the Murray-Darling Basin, struggle for unanimous agreement within the federation, most especially at the borders of Queensland. It appears that in the 1990s the time had not come for a national approach to coastal management.

Meanwhile, states have continued to carry out the majority of coastal management regulation and progressed their efforts to establish a strategic and more integrated approach through policy development.

\section{The states}

At the state level, new coastal legislation was introduced in Queensland (1995) and Victoria (1995), and new statutory coastal policies were developed in Tasmania (1996), New South Wales (1997), Victoria (1997), and Queensland (2001). These policy initiatives appear to be directly linked to influential coastal lead agencies (see table 5.1) in the three states of New South Wales, Victoria, and Tasmania, along with strong leadership roles by the agency chairs. In the case of New South Wales and Victoria the agency chairs benefit from being independent of government, whereas in Tasmania the chair benefits from a strong integrative role within government. As shown in table 5.1, this 
leaves only South Australia and Western Australia without integrated statutory coastal policies. Both these states are in the process of producing such policies, although there is a danger of a lack of integration in Western Australia, where coastal responsibilities and policies are separated into the planning and environmental protection portfolios.

What is noticeable from this table is that three states, Tasmania, Western Australia, and the Northern Territory, do not have specific coastal legislation, although Tasmania does have an effective statutory coastal policy based on State-wide policy legislation although this was subject to legal challenge in 2002. Of the other states, Queensland and Victoria both have new coastal legislation and statutory coastal policies. In New South Wales, despite the older (1979) coastal legislation, the strength of the coastal policy with its own legislative powers has made it less necessary to update the legislation. On the other hand, South Australia, which was initially a leader in coastal management, now appears to lag behind with 30-yearold coastal legislation and no statutory integrated coastal policy.

This and other state based legislative reform, together with the Australian coastal reviews, have to be placed in the context of international responses to

Table 5.1 Coastal management arrangements in different states

\begin{tabular}{|c|c|c|c|}
\hline State & $\begin{array}{l}\text { Dedicated coastal } \\
\text { legislation }\end{array}$ & Lead agency & Strategic document \\
\hline South Australia & $\begin{array}{l}\text { Coastal Protection } \\
\text { Act } 1972\end{array}$ & $\begin{array}{l}\text { SA Coast Protection } \\
\text { Board }\end{array}$ & $\begin{array}{l}\text { Marine and Estuarine } \\
\text { Strategy, } 1998 \\
\text { (non-statutory) }\end{array}$ \\
\hline New South Wales & $\begin{array}{l}\text { Coastal Protection } \\
\text { Act } 1979\end{array}$ & NSW Coastal Council & $\begin{array}{l}\text { NSW Coastal Policy, } \\
1997 \text { (statutory) }\end{array}$ \\
\hline Queensland & $\begin{array}{l}\text { Coastal Protection } \\
\text { and Management } \\
\text { Act } 1995\end{array}$ & $\begin{array}{l}\text { Coastal Protection } \\
\text { Advisory Council }\end{array}$ & $\begin{array}{l}\text { State Coastal } \\
\text { Management Plan, } \\
2001 \text { (statutory) }\end{array}$ \\
\hline Victoria & $\begin{array}{l}\text { Coastal Management } \\
\text { Act } 1995\end{array}$ & $\begin{array}{l}\text { Victorian Coastal } \\
\text { Council }\end{array}$ & $\begin{array}{l}\text { Victorian Coastal } \\
\text { Strategy, 1997, } \\
\text { (statutory) }\end{array}$ \\
\hline Tasmania & no specific legislation & $\begin{array}{l}\text { State Coastal } \\
\text { Advisory Committee }\end{array}$ & $\begin{array}{l}\text { Tasmanian State Coastal } \\
\text { policy, 1996, (statutory) }\end{array}$ \\
\hline Western Australia & no specific legislation & Coastal Zone Council & $\begin{array}{l}\text { Coastal Zone } \\
\text { Management Policy } \\
\text { (in prep, 2001) }\end{array}$ \\
\hline Northern Territory & no specific legislation & $\begin{array}{l}\text { NT Coastal and } \\
\text { Marine Co-ordination } \\
\text { Group }\end{array}$ & $\begin{array}{l}\text { NT Coastal } \\
\text { Management Policy, } \\
1999\end{array}$ \\
\hline
\end{tabular}


coastal management and predictions of potential sea level rise by the Intergovernmental Panel on Climate Change (IPCC 1991), in particular the Common Methodology for Coastal Vulnerability Assessment. More recently, the World Coast Conference 1993, at which Australia was represented, developed agreed coastal management objectives stressing the need for integrated coastal management (ICM) and capacity building for local coastal managers.

\section{Local government}

In the 1990s local government maintained its role as the level of government with most day-to-day responsibility for local decisions on coastal management. The input of Commonwealth assistance was significant in the late 1990s in encouraging local government actions to reduce marine pollution by stormwater and wastewater. The Coast and Clean Seas and Urban Stormwater Initiatives have been important as demonstrations of improved systems for dealing with wastewater and stormwater, including new technology. The spread of adoption of integrated local area planning and Agenda 21 processes is leading to more sustainable outcomes in coastal as well as other areas.

\section{The community}

In 1995 the number of community groups in Australia engaging in practical activities to restore and improve coastal environments may well have been under 500. By the year 2000 this number had been increased to close to 1500 as a result of the Coastcare initiative. As a small grants scheme with an annual national budget of under $\$ 10$ million, this has proved extremely cost effective. The changes in coastal communities may be more important than the works: in the knowledge and experience gained and networks established. After all the dune fences have been constructed, the interpretive signs designed and Little Penguins counted, it may well be that the awareness-raising and capacitybuilding effects of this scheme are its long-term benefit. This 'sea change' is altering the way coastal management is conducted in all the states.

\section{Integrated coastal management}

The above headings of Commonwealth, state government, local government, and the community illustrate the different roles in Australian coastal management, but it is clear that there is a need for integration between all of these in addition to some key internal integration strategies. Leading experts in the field of coastal management (for example J.R. Clark and B. Cicin-Sain) have in the last decade argued at length that integrated coastal management can 
give significantly improved outcomes. Comparison of the coastal management arrangements with descriptions of integrated coastal management (ICM) provides a comparison or benchmark in assessing the state of coastal management within the states and the Commonwealth.

According to Kenchington and Crawford (1993) the following are necessary elements of ICM:

- Long-term goal. A dynamic goal or vision of the desired condition of the oceanic or coastal area and the integration of human use and impact for a period significantly longer than conventional economic planning horizons, say 25 or 50 years

- National objectives/local plans. National objectives are broad, commonly agreed aims or common purposes to which policies and management are directed. For regional and local plans, progressively more detailed objectives consistent with the national objectives are usually required

- Principles for decision-making. Guiding principles for managers or statutory decision makers exercising discretionary powers for planning, granting approvals, or making changes to the purpose or extent of use and access

- Policy agreement across agencies (horizontal integration). A strategy, commitment, and resources for the objectives to be met through detailed day-to-day management, which may involve several agencies and the community

- Authority and accountability. Clear, legally based identification of authority, precedence, and accountability for achievement of the strategy in relation to any other legislation applying to the area in question

- Use of performance indicators. Performance indicators and monitoring to enable objective assessment of the extent to which goals and objectives have been met.

- Commitment to implementation. Above all, political, administrative, and stakeholder will and commitment to implement the strategy.

In addition to the above list, summarised from Kenchington and Crawford (1993), it is relevant to add the following key points for achieving ICM.

- Vertical integration. Some evidence of vertical integration between three spheres of government and the community

- Lead agency. To initiate, maintain focus on coastal issues, undertake some major coastal management responsibilities, take responsibility for publishing performance indicators, and including staff with professional expertise in coastal management.

Each of the above key points has been incorporated into a report card approach for Australia in table 5.2. This table attempts to summarise the 
current situation in Australia in regard to the above criteria. The lack of national objectives, agreed between the Commonwealth, states and territory, is the most striking feature of the present situation. Coastal management in Australia stands at the end of a decade of increasing activity in response to international and community pressures, in response to rapid resource development and in response to environmental change. There is no reason to suppose that these pressures will decrease in the future; in fact there is every indication that they will increase. The information in table 5.2 is subject to rapid change; it has not been systematically researched, but is correct to the best knowledge of the authors at the time of publication.

Table 5.2 Success in meeting ICM criteria

\begin{tabular}{lllllllll}
\hline Element & CwIth & QId & NSW & Tas & Vic & SA & WA & NT \\
\hline Long-term goal & $(\checkmark)$ & $(\checkmark)$ & $(\checkmark)$ & $(\checkmark)$ & $(\checkmark)$ & $(\checkmark)$ & $(-)$ & - \\
National objectives & - & - & - & - & - & - & - & - \\
Principles & - & $(\checkmark)$ & $(\checkmark)$ & $(\checkmark)$ & $(\checkmark)$ & - & - & - \\
Policy agreement & $(-)$ & $(\checkmark)$ & $(\checkmark)$ & $(\checkmark)$ & $(\checkmark)$ & - & - & - \\
Authority & - & - & $(\checkmark)$ & $(\checkmark)$ & $(\checkmark)$ & - & - & - \\
Performance indic. & $(\checkmark)$ & $(\checkmark)$ & $(\checkmark)$ & - & - & - & - & - \\
Commitment & - & $(\checkmark)$ & $(\checkmark)$ & $(\checkmark)$ & $(\checkmark)$ & - & - & - \\
Vertical Integration & $(\checkmark)$ & $(\checkmark)$ & $(\checkmark)$ & $(\checkmark)$ & $(\checkmark)$ & $(\checkmark)$ & $(\checkmark)$ & $(\checkmark)$ \\
Lead agency & $(\checkmark)$ & - & $(\checkmark)$ & $(\checkmark)$ & $(\checkmark)$ & $(\checkmark)$ & $(-)$ & - \\
\hline
\end{tabular}

$(\checkmark)=$ indications that this is in place

- = indications that this is not in place;

$($ ) = significant qualifications compared with description above.

\section{Coastal management for the 21st century}

This book has raised some key issues which need addressing if we are to manage the coast properly in this century. These relate to our understanding of coastal processes, the human impact on coastal resources and how we manage the use of these resources. Whereas it is the people and their use of coastal resources that need managing, it is not possible to be effective unless we understand the coastal system and how it operates. Our understanding of the system and various coastal processes is always less than perfect, but the prospect of greater uncertainty has now been raised with predictions of global climate change and associated sea-level rise. This final chapter of the book has examined some of these predictions for coastal change; we now raise some issues for coastal management in the future. 


\section{The challenge}

In chapter 1 we discussed global imperatives for change in coastal management in Australia. Subsequent chapters outlined the dynamic nature of the coast and ways in which human use has led to a number of problems. Management practices have had varied degrees of success is addressing the problems. We emphasise here that many of the issues need management processes which are by their nature quite slow, needing adaptation and fine tuning over time. In addition, many coastal problems need a regional solution, although the concern may appear to be local. It is often possible to postpone decisions, but the failure to act now merely passes the costs on to future generations. For example, development within a natural coastal buffer zone, such as coastal dunes, may seem reasonable now, but it may incur a cost of protection and beach renourishment at a later date. In addition to the economic costs, the environmental impact of mining for rock and sand creates a new generation of problems in the hills and estuaries where these materials are obtained.

Globally and in Australia there is support among interested communities for improvements in coastal management, but the political will and timelines for action have constraints of their own. This can be illustrated by the recent debate over the sustainable management of the Murray-Darling Basin, where it is difficult to make changes within an intensively used system with multiple interest groups. In October 2001 at the Australian Water Association Annual Dinner, the then Federal Minister of the Environment, Robert Hill, addressed a very difficult problem. He reported that studies by the Murray-Darling Basin Commission showed that the only option that guarantees restoring the health of the Lower Murray is to reduce (irrigation) diversions by $40 \%$. If this was combined with more efficient use of the remaining diverted water, then an extra 4013 gigalitres could be sent downstream each year. The purpose would be to restore river and floodplain habitats, to dilute the increasingly saline water supply to Adelaide, and to provide environmental flows to the terminal lakes, the estuarine wetlands and the Murray mouth. Politically, this was shark-infested water. When the same Minister had proposed a mere $4 \%$ cut some six months previously, his National Party cabinet colleagues attacked him, and the Queensland branch debated a motion of no confidence in him as a minister.

The problem Minister Hill was addressing encapsulates some of the challenges facing effective coastal management in Australia in the 21st century: A number of challenges, adapted from a discussion of Landcare (Cullen 1999) are relevant for coastal management, and are listed below: 
1 The challenge of scale - the ability to recognise that natural systems at the coast are connected, and sometimes these connections may be over large distances. Change in one may be needed to benefit another, and real account must be taken of the wider region

2 The challenge of being inclusive - to be sustainable, coastal management must include all stakeholders. Some decisions may, in the short term, appear socially and economically difficult. Changes in long established use of a resource often causes great resentment. Where monitoring of change has not been carried out, or only undertaken briefly, there may be wide differences in perception of change and its implications. But to be effective, management actions must be understood and approved widely

3 The challenge of accessing knowledge - there is an enormous potential to take specialist knowledge, to test it within a management context and to come to new understandings. Such capacity-building, by all involved, is badly needed within coastal management. For ecosystems to remain healthy there are no shortcuts: measurement and understanding at a variety of timescales will always be necessary

4 The challenge of changing the paradigm-existing coastal management shows a lack of integration across agencies, across political and discipline boundaries. There are numbers of conceptual barriers to overcome to continue and advance good management. Integrated coastal management has to overcome compartmentalised thinking, rather than reshuffling agency functions

5 The challenge of being strategic - to make large and expensive changes to big systems set on an unsustainable course, strategic processes and efficient management systems are needed.

This book has discussed a number of difficult issues currently faced by coastal management in Australia, such as:

- Establishing clear pathways and residence times for pollutant movement through catchment, estuarine and marine environments, and then managing this process to minimise impacts. In addition to the Murray, the catchments draining to the Great Barrier Reef Lagoon are good examples (See page 148)

- Guiding coastal development to nodes, and preventing linear coastal sprawl. Guiding, in a precautionary way, new development away from locations that in the future are likely to be hazardous; such as from flooding, erosion, or acid sulphate soils. Rezoning private coastal land to prevent visually intrusive development in areas of high scenic value. (See pages 285-8)

- Protecting (within or outside Marine Protected Areas) habitat of high conservation value in the face of explosive industrial growth, for example 
aquaculture, and in the face of traditional use, for example fishing, of a publicly owned resource. (See pages 159-66)

- Dealing with urban wastewater and stormwater in ways which minimise marine pollution. This involves treatment, and where possible, storage and reuse. (See pages 130)

- The Commonwealth and states have undertaken vulnerability assessments in response to IPCC climate change scenarios; however, refining these assessments, determining priorities, and implementing decisions has advanced in only limited ways to date. (See page 257)

Many of these problems come together in estuaries, gulfs and coastal lakes where, in the heavily populated south-east of the continent, these environments have been severely affected. In all of the above examples Australia is making slow or very slow progress. These examples all demand a strategic process, require cooperation between agencies and jurisdictions, need a professional well-informed approach, and often need agreement and cooperation across many stakeholders and across wide distances. Smith et al. (2001) have argued that some areas with entrenched problems need high profile champions to kickstart the cooperation needed to reach a solution.

\section{The response}

This book has discussed a variety of different tools by which we address such problems; for example:

- plans - state strategies and policies, regional strategic plans, local development plans and action plans

- processes - ILAP, Local Agenda 21, a range of adaptive management systems

- industry guidelines, particularly for tourism development, fishing and aquaculture

- standards for estuarine and marine water quality

- a host of regulations by Commonwealth, states and local government.

Would it be sufficient to implement more fully the tools we already have to solve the persistent problems of coastal management? The authors feel that this would go a long way, but that the present situation needs some new initiatives. Greater drive and focus are needed to carry through the task of ensuring the sustainability of coastal areas. We offer the following suggestions as initiatives to overcome the problems:

1 a National Coastal Policy agreed by the Commonwealth and the states, to provide a vision, policies and the framework for national standards. One focus of the policy should be integrated coastal management 
2 following 1 above, a concerted attempt by all spheres of government to better integrate coastal management processes

3 the further establishment and implementation of standards, most notably for new development in relation to hazards, and in relation to scenic, conservation and heritage values

4 to further develop, and build into assessment processes, acceptable valuation methods for environmental 'goods' to allow a more balanced cost-benefit analysis of proposed actions.

\section{Conclusion}

It is often said that in Australia the coast enjoys an icon status. It is an integral part of the Australian way of life. It is holidays, growing up, a place of reflections and decisions, a sea change in people's lives. It is tradition and saltwater people. It is a place to retire. But the coast is taken for granted.

Surveys and reviews of the Australian coast and the way it is managed undertaken in the 1990s show that the time for hard decisions has come. To maintain a natural asset and a national icon, a higher priority for coastal issues is needed. This book suggests that the complexity of the issues, the natural dynamism of coastal environments, and the lack of integration of management arrangements have led to untimely delays. The pressures are evident, and further delays could well result in acceleration in the loss of coastal habitat and amenity. 


\section{References}

ABS (Australian Bureau of Statistics) 1974, Year Book of Australia 1974, AGPS, Canberra.

- 1996, Australians and the Environment, AGPS, Canberra.

2002, Forestry and fishing: fisheries resources, ABS website (www.abs.gov.au).

ACF (Australian Conservation Foundation) 1974, Conservation and mining in modern

Australia, in Dempsey R \& Cass M (eds), The Politics of Finding Out: Environmental Problems in Australia, Cheshire, Melbourne.

— 1981, Sand mining on the east coast of Australia, ACF website (www.acfonline.org.au).

Adams, P. 1995, Saltmarsh, in Zann, L. P. \& Kailola, P. 1995, State of the Marine Environment Report for Australia, Technical Annex 1-The Marine Environment, Great Barrier Reef Marine Park Authority, pp. 97-106.

AGC Woodward Clyde Pty Ltd 1993, Coastal Industry Case Studies: Gladstone Qld, Kwinanan WA, Western Port Vic. Report commissioned by the Coastal Zone Inquiry, Resource Assessment Commission, Canberra.

AIMS (Australian Institute of Marine Science) 1995, Marine pollution inquiry: response to the Senate Environment, Recreation, Communication and the Arts References Committee by the Australian Institute of Marine Science, in Submissions to the Senate Environment, Recreation, Communication and the Arts References Committee, Volume 5.

— 1998, Senate Inquiry on Hinchinbrook Channel: Submission from the Australian Institute of Marine Science, AIMS website (www.aims.gov.au).

AIS (Australian Information Service) 1974, Australian Handbook 1974, AGPS, Canberra. Alexandra, J., Haffenden, S. \& White, T. 1996, Listening to the Land: A Directory of Community Environmental Monitoring Groups in Australia, Australian Conservation Foundation, Melbourne.

Alexandra, J., Higgins, J. \& White, T. 1998, Environmental Indicators for National State of the Environment Reporting - Local and Community Uses, in Australia: State of the Environment (Environmental Indicator Reports), Department of the Environment, Canberra. 
Alexandra, J. \& White, T. 1997, Regional Environmental Indicators Project: Environmental Indicators for Reporting at Local, State and National Levels. Final Report to the Commonwealth State of the Environment Reporting Unit, Australian Local Government Association.

ANZECC 1996a, Working Together to Reduce Impacts from Shipping Operations: ANZECC Strategy to Protect the Marine Environment (Australia Marine Debris Status Review, Final Report), Australian and New Zealand Environment and Conservation Council, Canberra.

1996b, Review of Legislation, Management Strategies and Practices. Final Report, Volume I, ANZECC Working Party on Marine Debris, Australian New Zealand Environment and Conservation Council, Canberra.

AQIS 1999, Why does Australia have ballast water management requirements? Australian Quarantine Inspection Service website (www.aqis.gov.au).

Arnstein. S. R. 1969, A ladder of citizen participation, Journal of the American Planning Association 35(4), pp. 216-24.

ASEC (Australian State of the Environment Committee) 2001, Australia, State of the Environment 2001, CSIRO Publishing, Collingwood.

Australia, Division of National Mapping, 1980-90, Atlas of Australian Resources, Canberra.

Backshall, D. G., Barnett, J., Davies, P. J., Duncan, D., Harvey, N., Hopley, D., Isdale, P. J., Jennings, J. N. \& Moss, R. W. 1979, Drowned doline - the blue holes of the Pompey Reefs, Great Barrier Reef, BMR Journal of Australian Geology and Geophysics 4(2), pp. 99-109.

Baginska, B., Cornish, P.S., Hollinger, E., Kuczera, G., and Jones, D. 1998, Nutrient export from rural land in the Hawkesbury - Nepean Catchment, proceedings of the $9^{\text {th }}$ Australian Agronomy Conference, Wagga Wagga.

Baily, B. \& Nowell, D. 1996, Techniques for monitoring coastal change: a review and case study, Ocean and Coastal Management, 32(2), pp. 85-95.

Baldwin, C. 1990, Impact of Elevated Nutrients in the Great Barrier Reef, Research Publication No. 20. Great Barrier Reef Marine Park Authority.

Ball, M. C. 1998, Mangrove species richness in relation to salinity and waterlogging: a case study along the Adelaide River floodplain, northern Australia, Global Ecology and Biogeography Letters 7: 73-82.

Banham, B. J. 1992, The role of MFP Australia in mangrove conservation, Master of Environmental Studies thesis, Mawson Graduate Centre for Environmental Studies, University of Adelaide, South Australia.

Barnett, E. J. \& Harvey, N. 2001, Relative sea-level change and geologic corrections to South Australian tide gauge records, in Noye, B.J. \& Grzechnik, M.P. (eds), SeaLevel Changes and Their Effects, World Scientific Publishing, Singapore, pp. 95-124. 
Barnett, E. J., Harvey, N., Belperio, A. P. \& Bourman, R. P. 1997, Sea-level indicators from a Holocene, tide-dominated coastal succession, Port Pirie, South Australia, Transactions Royal Society of South Australia 121(4), pp. 125-35.

Barrett, N. S. \& Edgar, G. J. 1998, Marine reserves work for fish, Fishing Today, 11, pp. 23-7.

Batley, G. E. 1995, Heavy metals and tributyltin in Australian coastal and estuarine waters. Technical Annex 2, in Zann, L. P. (comp.), Our Sea, Our Future. Major Findings of the State of the Marine Environment Report for Australia, Ocean Rescue 2000, Department of the Environment, Sport and Territories, Canberra.

Bell, A. 1983, How marine life copes with a lead smelter, Ecos 36, pp. 17-22.

Bell, J. D. \& Westoby, M. 1986, Abundance of macrofauna in dense seagrass is due to habitat preference, not predation, Oecologia 68, pp. 205-9.

Belperio, A. P. 1993, Land subsidence and sea level rise in the Port Adelaide estuary: implications for monitoring the greenhouse effect, Australian Journal of Earth Sciences 40, pp. 359-68.

Belperio, A. P., Harvey, N. \& Bourman, R. P. in press, Spatial and temporal variability in the Holocene sea-level record of the South Australian coastline, Sedimentary Geology.

Bennett, I. 1974, The Fringe of the Sea, Rigby, Adelaide.

Bird, E. C. F. 1978, The nature and source of beach materials on the Australian coast, in Davies, J. L. \& Williams, M. A. J., Landform Evolution in Australasia, ANU Press, Canberra, chapter 6.

1985, Coastline Changes: A Global Review, John Wiley \& Sons, Chichester. 1993, The Coast of Victoria, Melbourne University Press, Melbourne, Vic. 2000, Coastal geomorphology: an introduction, John Wiley, Chichester, New York.

Bird, E. C. F. \& Cullen, P. 1990, Recreational uses and problems of Port Phillip Bay, Australia, in Fabbri, P. (ed.), Recreational Uses of Coastal Areas, Kluwer Academic, pp. 39-51.

Bloom, A. L., Broecker, W. S., Chappell, J., Matthews, R. S. \& Mesolella, K. J. 1974, Quaternary sea level fluctuations on a tectonic coast: new $\mathrm{Th}^{230} / \mathrm{U}^{234}$ dates from New Guinea, Quaternary Research 4, pp. 185-205.

Boto, K. G. \& Wellington, J. T. 1988, Seasonal variations in concentrations and fluxes of dissolved organic and inorganic materials in a tropical, tidally dominated, mangrove waterway, Marine Ecology Progress Series 50, pp. 151-160.

Bourman, R. P., Belperio, A. P., Murray-Wallace, C. V. \& Cann, J. H. 1999, A last interglacial embayment fill at Normanville, South Australia, and its neotectonic implications, Transactions of the Royal Society of South Australia 123, pp. 1-15.

Bowman, G. M. \& Harvey, N. 1986, Geomorphic evolution of a Holocene beach ridge complex, LeFevre Peninsula, South Australia, Journal of Coastal Research 2(3), pp. 345-62. 
Bridgwater, P. B. \& Cresswell, I. D. 1999, Biogeography of mangrove and saltmarsh vegetation: implications for conservation and management in Australia. Mangroves and Salt Marshes 3(2), pp. 117-25.

Brooke, C. 1996, Marine pollution management under the Environment Protection Act 1993 (SA). Master of Environmental Studies thesis, Mawson Graduate Centre for Environmental Studies, University of Adelaide.

Brookes, D.R. 1996, Heavy mineral sands, in Mulligan, D.R. (ed), Environmental Management in the Australian Minerals and Energy Industries: Principles and Practices, UNSW Press in association with Australian Minerals \& Energy Environment Foundation, New South Wales, Australia, chapter 15.

Brouwer, C. 1993, A Visual Assessment Procedure for the Queensland Coastline, Proceedings 11th Australasian Conference on Coastal and Ocean Engineering, pp. 433-40.

Brown, V. A. 1995, Turning the Tide: Integrated Local Area Management for Australia's Coastal Zone, Department of the Environment, Sport and Territories, Canberra.

BRS (Bureau of Rural Sciences) 1999, Aquaculture, BRS website (www.brs.gov.au).

Bryant, R. L. 1998, Power, knowledge and political ecology in the Third World: a review, Progress in Physical Geography 22, pp. 79-94.

Bucher, D. \& Saenger, P. 1991, An inventory of Australian estuaries and enclosed marine waters, Austr. Geogr. St. 29(2), pp. 370-81.

Buddemeier, R. W. \& Maxwell, B. A. 2000, Typology: Low-budget remote sensing, LOICZ Newsletter 15, pp. 1-4.

Bunt, J. S. \& Bunt, E. D. 1999, Complexity and variety of zonal pattern in the mangroves of the Hinchinbrook area, Northeastern Australia, Mangroves and Salt Marshes 3, pp. 165-76.

Burbidge, A. A. (ed.) 1989, Australian and New Zealand Islands: Nature Conservation Values and Management, Department of Conservation and Land Management, Perth.

Bureau of Meteorology, 1989, Climate of Australia, AGPS, Canberra.

Burnley, I. 1996, Migration, well-being and development in coastal New South Wales, 1976-91, Australian Geographer 27, pp. 53-75.

Burton, B., Kinrade, P., Amos, N., Giese, M. \& Krockenberger, M. 1994, Mining and Ecologically Sustainable Development: A Discussion Paper, Ecologically Sustainable Development Policy Development Unit, Australian Conservation Foundation, Melbourne.

Burzacott, S. L. 1996, An inheritance of pollution? An investigation into the presence of PCBs in the Port Adelaide River Estuary. Master of Environmental Studies thesis, Mawson Graduate Centre for Environmental studies, University of Adelaide.

Butler, A. \& Jernakoff, P. 2000, Seagrass in Australia: Strategic Review and Development of an R\&D Plan, CSIRO, Collingwood. 
Cambridge, M. L., Cittings, A. W., Brittan, C., Moore, L. \& McComb, A. J. 1986, The loss of seagrass in Cockburn Sound, Western Australia II: possible causes of seagrass decline, Aquatic Botany 24, pp. 269-85.

Cambridge, M. L. \& McComb, A. J. 1984, The loss of seagrasses in Cockburn Sound, Western Australia I: the time, course and magnitude of seagrass decline in relation to industrial development, Aquatic Botany 20, pp. 229-43.

Campbell, S. 2000, Seagrass-Watch: The development of a scientifically credible community-based monitoring program, Waves 7(3), 16, 19.

Carter, R. W. G. 1988, Coastal Environments: An Introduction to the Physical, Ecological and Cultural Systems of Coastlines, Academic Press, London.

1991, Coastal Environments: An Introduction to the Physical, Ecological and Cultural Systems of Coastlines, Academic Press, London.

Carter, R. W. G. \& Woodroffe, C. D. 1994, Late Quaternary Shoreline Morphodynamics, Cambridge University Press, Cambridge, UK.

— 1997, Coastal Evolution, Cambridge University Press, Cambridge, UK.

Carvalho, P. \& Clarke, B. 1998, Ecological sustainability of the South Australian coastal aquaculture management policies, Coastal Management, 26(4): 281-90.

Caton, A., Kailola, P. \& Garvey, G. 2000, Australia's state/territory-managed fisheries, in Caton, A. \& McLoughlin, K. (eds), Fishery Status Reports, 1999, Resource Assessments of Australian Commonwealth Fisheries, Bureau of Rural Sciences, Canberra, Australia, pp. 13-40.

Caton, A. and McLoughlin, K. (eds) 2000, Fishery Status Reports, 1999, Resource Assessments of Australian Commonwealth Fisheries, Bureau of Rural Sciences, Canberra, Australia.

Caton, B. 1975, Beach erosion resulting from Cyclone Pam, February 1974, Search 6, pp. $186-8$.

_ 1993, A Heritage Coast as a Means of Coastal Management, in Proceedings 11th Australasian Conference on Coastal and Ocean Engineering, Institution of Engineers, ACT, pp. 429-32.

- 1994, Coastal management arrangements: a state's perspective, in Kriwoken, L. \& McAdam, S. (eds), Proceedings of Coast to Coast '94: A National Coastal Management Conference, Coastal and Marine Program, Department of Environment and Land Management, Tasmania, pp. 31-3.

Chapman, D. M., Geary, M., Roy, P. S. \& Thom, B. G. 1982, Coastal Evolution and Coastal Erosion in New South Wales, Report for the Coastal Council of New South Wales.

Chapman, V. J. 1976, Coastal Vegetation. Pergamon Press, Oxford.

Chappell, J. 1974, Geology of coral terraces, Huon Peninsula, New Guinea: a study of Quaternary tectonic movements and sea level changes, Geological Society of America Bulletin 85, pp. 553-570. 
1987, Late Quaternary sea-level changes in the Australian Region, in Tooley, M. J. \& Shennan, I. (eds), Sea-Level Changes, Blackwell, New York, pp. 296-331.

Chapple, P., Tainsh, J. \& Book, J. 1999, Coast and Clean Seas initiative, in Proceedings of the 9th Annual NSW Coastal Conference, Great Lakes Shire Council, Forster, NSW, pp. 205-14.

Charters, T., 1996 Kingfisher Bay Resort \& Village, in Charters, T., Gabriel, M., Prasser, S. (eds), National Parks Private Sectors Role, USQ Press, Toowoomba.

Charters, T., Gabriel, M., Prasser, S. (eds) 1996, National Parks Private Sectors Role, USQ Press, Toowoomba.

Cicin-Sain, B. 1993, Sustainable development and integrated coastal management, Ocean and Coastal Management 21, pp. 11-43.

Cicin-Sain, B. \& Knecht, R. 1998, Integrated Coastal and Ocean Management. Concepts and Practices, Island Press, Washington.

Clark, J. A., Farrell, W. E. \& Peltier, W. R. 1978, Global changes in postglacial sea level, Quaternary Research, 9, pp. 265-87.

Clark, J. R. 1995, Coastal Zone Management Handbook, CRC Lewis Publishers, Boca Raton, Fla.

Clarke, B. 1996, Aquaculture management and planning in South Australia: Blue farming revolution or goldrush? Master of Environmental Studies dissertation, Mawson Graduate Centre for Environmental Studies, University of Adelaide, South Australia.

_ 2002, Towards measuring the success of Coastcare: Australia's communitybased coastal management program, in Holland, P,. Stephenson, F. \& Wearing A. (eds), 2001, Geography a Spatial Odysessy. Proceedings of the Third Joint Conference of the New Zealand Geographical Society and the Institute of Australian Geographers. University of Otago, Dunedin. New Zealand Geographical Society Conference Series No. 21, New Zealand Geographical Society, New Zealand, pp. 150-6.

Clarke, S. M. 1987, Seagrass-sediment dynamics in Holdfast Bay: summary, SAFISH 11(2), pp. 4-10.

Cleary, J., 1997, An 'all-of-government' approach to landscape management in Western Australia, West Australian Government Department of Conservation and Land Management, unpublished report summarised in Kay, R. \& Alder, J. 1999, Coastal Planning and Management, E \& FN Spon, London and New York, pp. 206-10.

Close, A. 1990, The Impact of Man on the Natural Flow Regime, in MacKay, N. \& Eastburn D., The Murray, Murray-Darling Basin Commission.

Coastal Committee of NSW 1994, Draft Revised Coastal Policy for New South Wales, Department of Urban Affairs and Planning, Sydney.

Coastal Council of NSW, 2001, Annual Report 1999-2000. A Sustainable Future for the New South Wales Coast, Coastal Council of NSW, Sydney. 
Coastline 1997, Newsletter of Coast Action/Coastcare, Victoria, Winter, 1997.

Coates, D. R. 1973, Coastal Geomorphology, SUNY Binghampton, chapters 11, 12.

Cocks, D. 1992, Use With Care: Managing Australia's Natural Resources in the Twenty First Century. NSW University Press, Sydney.

Cohen, L. 1968, 'Hey, that's no way to say goodbye' [Stranger Music, Inc.], on Leonard Cohen Greatest Hits, CDCBS 69161.

Coleman, P. S. J. 1998, Changes in mangrove/samphire community, North Arm Creek, South Australia, Transactions of the Royal Society of South Australia 122(4), pp. 173-78.

Commission of Inquiry 1975, Fraser Island Environmental Inquiry. First Report by the Commission of Inquiry, AGPS, Canberra.

Commonwealth of Australia 1977, Fraser Island Environmental Inquiry. Final Report of the Commission of Inquiry, Parliamentary Paper No. 333/1976. Commonwealth Government Printer, Canberra.

— 1992a, National Strategy for Ecologically Sustainable Development, AGPS, Canberra.

- 1992b, Intergovernmental Agreement on the Environment, AGPS, Canberra. 1995a, Living on the Coast: The Commonwealth Coastal Policy, AGPS, Canberra.

— 1995b, Green Cities Strategy Paper 3, Australian Urban and Regional Development Review May, 1995.

— 1996, The National Strategy for the Conservation of Australia's Biological Diversity, Department of Environment, Sport \& Territories, Canberra.

— 1997a, Australia's Oceans Policy, Background Paper 1, AGPS. 1997b, Coastal Tourism: A Manual for Sustainable Development, Commonwealth Coastal Action Program.

- 1997c, Review of International Agreements, Conventions, Obligations and Other Instruments Influencing Use and Management of Australia's Marine Environment, Australia's Oceans Policy, Background Paper 2.

- 1998a, Australia's Oceans Policy, Vols I \& II, Environment Australia, Canberra. 1998b, Memorandum of Understanding, South Australia, Environment Australia, Commonwealth of Australia, Canberra.

Conacher, A. \& Conacher, J. 2000, Environmental Planning and Management in Australia, Oxford University Press, Melbourne.

Connell, D. W. 1995, Occurrence and effects of petroleum hydrocarbons on Australia's marine environment. Technical Annex 2, in Zann, L. P. (comp.), Our Sea, Our Future. Major Findings of the State of the Marine Environment Report for Australia, Ocean Rescue 2000, Department of the Environment, Sport and Territories, Canberra.

Cordover, R., Caton, A. \& Shoulder, P. 2000, Australian aquaculture, in Caton, A. \& McLoughlin, K. (eds), Fishery Status Reports 1999: Resource Assessments of Australian Commonwealth Fisheries, Bureau of Rural Sciences, Canberra, pp. 41-51. 
Costanza, R., d'Arge, R., de Groot, R., Farber, S., Grasso, M., Hannon, B., Limburg, K., Naeem, S., O’Neill, R., Paruelo, J., Raskin, R., Sutton, P. \& van den Belt, M. 1997, The value of the world's ecosystem services and natural capital, Nature 387, pp. 253-60.

Coveney, J. 1993, Australia's Conservation Reserves, Cambridge University Press, Cambridge.

Cowell, P.J. and Thom, B.G. 1994, Morphodynamics of Coastal Evolution. In Cater, R.W.G. and Woodroffe, C.D. (eds.) Coastal Evolution, Late Quaternary Shoreline Morphodynamics, Cambridge University Press, Cambridge, pp. 33-86.

Craik, W., Glaister, J. \& Poiner, I. (eds) 1990, The Effects of Fishing, CSIRO, Melbourne. Creagh, C. 1992, What can be done about toxic algal blooms? Ecos 72, pp. 14-19.

Cresswell, I. D. \& Thomas, G. M. (eds) 1997, Terrestrial and Marine Protected Areas in Australia (1997), Environment Australia.

CSIRO 1996, Port Phillip Bay Environmental Study, Final Report, CSIRO, Canberra.

_ 2000a, Damaging marine pests 'on their way' to SA waters, CSIRO media release.

2000b, Huon Estuary Study -Environmental Research for Integrated Catchment Management and Aquaculture, Final Report to Fisheries Research and Development Corporation, Project 96/284, CSIRO Division of Marine Research, Hobart.

Cugley, J. 1994, Draft S.A. EPA Specifications for a Water Quality Monitoring Database, SA Department of Environment and Natural Resources.

Cullen, P. 1999, Environmental challenges at the regional scale, in Dore, J. \& Woodhill, J., Sustainable Regional Development: An Australia Wide Study of Regionalism, Highlighting Efforts to Improve the Community, Economy and Environment, Greening Australia Ltd, pp. 201-06.

Culver, R. 1970, Final Summary Report on Beach Erosion Studies, Report commissioned by the Seaside Councils Committee and the State Government of South Australia, University of Adelaide, Department of Civil Engineering, Adelaide.

DAFFA (Department of Agriculture, Fisheries and Forestry Australia) 2000, Fisheries Documents, DAFFA website (www.affa.gov.au).

Dare, R. J. 1978, A Landscape Study of the Fleurieu Peninsula. Stage I: The Inman, Hindmarsh and Back Valley Landscape Tract, National Trust of Australia (SA), Adelaide.

Davies, J. L. 1972, Geographical Variation in Coastline Development, Oliver \& Boyd, Edinburgh.

— 1977, The Coast. In Jeans, D.N. (ed) Australia: A Geography, Sydney University Press, Sydney.

- 1980, Geographical Variation in Coastal Development, Longman. 1986, The Coast. In Jeans, D. N. (ed.) Australia: A Geography, 2nd edn, Sydney University Press, chapter 8 . 
Davies, F. L. \& Flaherty, T. 1995, Conservation Council of South Australia: Submission to the Senate Marine Pollution Inquiry, in Submissions to the Senate Environment, Recreation, Communication and the Arts References Committee, Volume 5.

De Guia, M. B, 1982, Investigation of the effects of thermal effluents on mangrove stands at Torrents Island, South Australia. Master of Environmental Studies thesis, Mawson Graduate Centre of Environmental Studies, University of Adelaide.

DELM (Department of Environment and Land Management) 1993, The State of the Environment Report for South Australia 1993, DELM, Adelaide.

DENR (Department for Environment and Natural Resources) 1997, Report of the Review of the Management of Adelaide Metropolitan Beaches, DENR, Adelaide.

DENR Reference Group, 1997, The Management of Adelaide Metropolitan Beaches, Reference Group appointed by the Minister.

DEPSA (Department of Environment and Planning SA) 1992, Review of Alternatives for the Adelaide Metropolitan Beach Replenishment Strategy, DEPSA, Adelaide. 1997, Shacks (Land Division and Upgrading), Development Plan Amendment Report by the Minister, Government of South Australia.

Digby, M. J., Saenger, P., Whelan, M. B., McConochie, D., Eyre, B., Holmes, N. \& Bucher, D., 1999. A Physical Classification of Australian Estuaries, National River Health Program, Urban Subprogram, Report No 9, LWRRDC Occasional Paper 16/99.

Division of National Mapping, 1982, Atlas of Australian Resources, 2nd Series, Division of National Mapping, Canberra.

DME (Department of Mines and Energy, Queensland) 1999, Silica sand, Mineral Information Leaflet No. 3, DME, Brisbane. 2000, Mineral sands, Mineral Information Leaflet No. 9, DME, Brisbane.

DNRE (Department of Natural Resources and Environment, Victoria) 1998, Aquaculture, in The Coast Kit, 2: Human Use of the Coast, DNRE website (www.nre.vic.gov.au/coasts/coastkit).

_ 2000, Coasts and Marine, DNRE website (www.nre.vic.gov.au).

Dore, J. \& Woodhill, J. 1999, Sustainable Regional Development: An Australia Wide Study of Regionalism, Highlighting Efforts to Improve the Community, Economy and Environment, Greening Australia Ltd.

Doyle, T. 2000, Green Power. The Environment Movement in Australia, UNSW Press, Sydney.

Doyle, T. \& Kellow, A. 1995, Environmental Politics and Policy Making in Australia, Macmillan, Melbourne.

DPMC (Department of Prime Minister and Cabinet) 1990, Ecologically Sustainable Development. A Commonwealth Discussion Paper. AGPS, Canberra.

Driml, S. 1994, Protection for Profit, Economic and Financial Values of the Great Barrier Reef World Heritage Area and Other Protected Areas, Research Publication No. 35, Great Barrier Reef Marine Park Authority, Townsville. 
Duke, N. C., Ball, M. C. \& Ellison, J. C. 1998, Factors influencing biodiversity and distributional gradients in mangroves, Global Ecology and Biogeography Letters 7, pp. $27-47$.

Edyvane, K. S. 1998, Conserving Marine Biodiversity in South Australia. Part 1Background, Status and Review of Aproach to Marine Biodiversity Conservation in South Australia, South Australian Research \& Development Institute.

EIA Network 1995, Case Studies, Onslow Solar Salt Project, Western Australia, International Study of the Effectiveness of Environmental Assessment, Environment Australia website (www.environment.gov.au/epg/eianet).

- 1997, Case Studies: Protecting Our Marine Environment, International Study of the Effectiveness of Environmental Assessment, Environment Australia website (www.environment.gov.au/marine).

— n.d., Case Studies, Jervoise Bay Industrial Infrastructure and Harbour Development, Western Australia, International Study of the Effectiveness of Environmental Assessment, Environment Australia website (www.environment.gov.au/epg/eianet).

Emiliani, C. 1955, Pleistocene temperatures, Journal of Geology 63, pp. 539-78.

Environment Australia 1997, NRS-Terrestrial and Marine Protected Areas in Australia, Queensland, Environment Australia website (www.environment.gov.au).

— 2000, Protecting our Marine Environment. Environment Australia website (www.environment.gov.au/marine).

- 2001a, Snapshot of the South-East, National Oceans Office, Hobart. 2001b, The South-East Regional Marine Plan: Scoping Paper, National Oceans Office, Hobart.

— n.d., A Directory of Important Wetlands in Australia, Queensland, Section 3, 148. Hinchinbrook Channel WTO12QL, Environment Australia website (www.environment.gov.au).

EPA 1998, State of the Environment Report for South Australia 1998, Report for the Environment Protection Authority in cooperation with the Department for Environment, Heritage and Aboriginal Affairs, Natural Resources Council, South Australia.

- 1999, Protecting the Victorian Marine Environment from Marine Pests: Draft Industrial Waste Management Policy (Ship's Ballast Water and Hull Cleaning) and Draft Policy Impact Assessment, prepared by the Environment Protection Authority, Victoria, web site: (www.epa.vic.gov.au).

ESDWG (Ecologically Sustainable Development Working Groups) 1991a, Final Report-Energy Production, AGPS, Canberra.

— 1991b, Final Report_Energy Use, AGPS, Canberra.

— 1991c, Final Report-Fisheries, AGPS, Canberra.

— 1991d, Final Report_Forest Use, AGPS, Canberra.

—1991e, Final Report_Manufacturing, AGPS, Canberra.

—1991f, Final Report_Mining, AGPS, Canberra. 
— 1991g, Final Report-Tourism, AGPS, Canberra.

-1991h, Final Report-Transport, AGPS, Canberra.

1991i, Final Report-Agriculture, AGPS, Canberra.

ESDWG Chairs 1992, Intersectoral Issues Report, AGPS, Canberra.

Evans, M. D. \& Burgan, B. 1992, The Economic Value of the Metropolitan Adelaide

Beaches, Report to the SA Coast Protection Board from the Centre for South Australian Economic Studies, July 1992.

Ewel, K. C., Twilley, R. R. \& Eong Ong, J. 1998, Different kinds of mangrove forests provide different goods and services, Global Ecology and Biogeography Letters 7 , pp. 83-94.

Faulkner, J. 1994, Hinchinbrook workshop report by Federal Environment Minister, Senator J. Faulkner, Commonwealth Government.

FCT 1999, Assessment of Mineral and Extractive Materials Resources, Queensland CRA/RFA Steering Committee, Forests Taskforce Department of Prime Minister \& Cabinet, Canberra.

Ferguson, K. 1986, The Role of the Mangrove Wetlands in the Fisheries of South Australia, with Particular Relevance to the Port Adelaide Mangroves, Port AdelaideSt Kilda Mangroves Draft Management Plan, SA Department of Lands, Adelaide.

Ferrer, E. M. \& Nozawa, C. M. C. 1998, Community-based coastal resources management in the Philippines - key concepts, methods and lessons learned, website (www.idrc.ca/cbnrm/documents/ferrer.cfm), December 1998 update.

Figgis, P. 1999, Australia's National Parks and Protected Areas: Future Directions. A Discussion Paper, Australian Committee for IUCN, Occasional Paper No. 8.

Fines, K. D. 1968, Landscape evaluation: a research project in East Sussex, Regional Studies 2, pp. 41-55.

Flaherty, A. 1999, Ripples, Waves (newsletter of the Marine and Coastal Community Network).

Foale, S. 1993, An evaluation of the potential of Gastropod imposex as a bioindicator of tributyltin pollution in Port Phillip Bay, Victoria, Marine Pollution Bulletin, 26(10), pp. 546-52.

Funding Working Party 1993, Final Report on Funding Issues Related to the SA Coast Protection Act Review, Report to the SA Minister for Environment and Land Management and the SA Coast Protection Board.

Galloway, R. W. \& Bahr, M. E. 1979, What is the length of the Australian Coast? Australian Geographer, 14, pp. 244-7.

Galloway, R. W., Story, R., Cooper, R. \& Yapp, G. A. 1984, Coastal Lands of Australia, Natural Resources Series No. 1, Division of Water and Land Resources, Institute of Biological Resource, CSIRO.

Ganter, E. 1996, Indigenous participation in coastal management in the Northern Territory, Australia: issues and options, Ocean and Coastal Management 33(1-2), pp. $193-212$. 
GESAMP 1990, The State of the Marine Environment, UNEP Regional Seas and Studies No. 115, UNEP, Nairobi, Kenya.

Gill, E. D. 1982, The Eight Coasts of Australia, CSIRO Division of Applied Geomechanics, Mount Waverley, Victoria.

Gilmour, A. J. 1999, The Role of Scientists in the Management of Natural Resources, in Proceedings of a Conference on Integrated Natural Resources Management, 'New Solutions for Sustainability', Sydney, March 1999, pp. 13-21.

Glasson, J., Therivel, R. \& Chadwick, A. 1999, Introduction to Environmental Impact Assessment. Principles and Procedures, Process, Practice and Prospects, second edition, UCL Press, London.

Gordon, A. D., Lord. D. B. \& Nolan, M. W. 1978, Byron Bay-Hastings Point Erosion Study, Department of Public Works NSW, Coastal Engineering Report No. PWD 78026.

Gordon, S. 1999, Domestic Market Appraisal for the Australian Aquaculture Industry, report prepared for the Aquaculture Co-operative Research Centre, Australia.

Gornitz, V. 1993, Mean sea level changes in the recent past, in Warrick, R. A., Barrow, E. M. \& Wigley, T. M. L. (eds), Climate and Sea Level Change: Observations, Projections and Implications. Cambridge University Press, Cambridge, UK, pp. 25-44.

Graham, B. \& Pitts, D. 1997, Good Practice Guidelines for Integrated Coastal Planning, Royal Australian Planning Institute, Hobart.

Graham, R. J. 1993, Special Commissioner Graham's Views (Alternative Proposals for Reform), in RAC, Coastal Zone Enquiry: Final Report, AGPS, Canberra.

Gray, C. A., McDonall, V. C. \& Reid, D. D. 1990, By-catch from prawn trawling in the Hawkesbury River, New South Wales: species composition, distribution and abundance, in Craik, W., Glaister, J. \& Poiner, I. (eds) 1990 The Effects of Fishing, CSIRO, Australia.

Greenpeace 1995, Submission to the Senate Marine Pollution Inquiry, in Submissions to the Senate Environment, Recreation, Communication and the Arts References Committee, Volume 5.

Grumbine, R. E. 1994, What is ecosystem management? Conservation Biology 8, pp. 27-38.

Hails, J. 1982, The degradation of Australia's coastal environment: A review of competition, conflicts and compromises, in Hanley, W. \& Cooper, M. (eds), Man and the Australian Environment: Current Issues and Viewpoints, McGraw-Hill, Sydney, chapter 10 .

Hale, A. 1996, Strategy for a Sustainable Southern Region, Southern Region of Councils (Adelaide).

1997, Community management of water resources in the Southern Region, Master of Environmental Studies thesis, University of Adelaide.

Hale, L. Z. 1996, Involving communities, in Harvey, N. (ed.) Coastal Management, Proceedings of the Australian Coastal Management Conference, Glenelg SA, April 1996, pp. 101-8. 
Hallegraeff, G. M. \& Bolch, C. J. 1991, Transport of toxic dinoflagellate cysts via ships' ballast water, Marine Pollution Bulletin 22(1), pp. 27-30.

Hamilton, N., \& Cocks, D., 1994, Australia's Coastal Population: Environmental Impacts Today and Tomorrow, Paper to the Australian Population Association Workshop on Mobility in Australia.

Hansard 1999, Senate: Hinchinbrook Channel Inquiry, Parliament of Australia, Commonwealth Government, Australia.

Hare, W. L. (ed.), 1990, Ecologically Sustainable Development: A Submission, Australian Conservation Foundation, Fitzroy, Victoria.

Harris, A. \& Ward, P. 1999, Non-target Species in Australia's Commonwealth Fisheries: A Critical Review, Bureau of Rural Sciences, Canberra.

Harris, A. N. \& Poiner, I. R. 1990, By-catch of the prawn fishery of Torres Strait; composition and partitioning of the discards into components that float or sink, in Craik, W., Glaister, J. and Poiner, I. (eds) The Effects of Fishing, CSIRO, Australia.

Harris, G., Batley, G., Fox, D., Hall, D., Jernakoff, P., Molloy, R., Murray, A., Newell, B., Parslow, J., Skyring, G. \& Walker, S. 1996, Port Phillip Bay Environmental Study, Final Report, CSIRO, Canberra, 1996.

Harris, P. 1995, The seafloor, in Zann, L. P. \& Kailola, P. (eds), State of the Marine Environment Report for Australia: Technical Annex 1-The Marine Environment. Great Barrier Reef Marine Park Authority, Townsville.

Hart, D. 1997, Nearshore Seagrass Change 1949 to 1996, Mapped Using Digital Aerial Photography, Metropolitan Adelaide Area Largs Bay to Aldinga, South Australia, Resource Information Group, DENR.

Harvey, N. 1988, Coastal Management Issues for the Mouth of the River Murray, South Australia, Coastal Management 16(2), pp. 139-49.

— 1998, Environmental Impact Assessment. Procedures, Practice, and Prospects in Australia, Oxford University Press, Melbourne.

_ 1999, Australian integrated coastal management: a case study of the Great Barrier Reef, in Salomons, W., Turner, R. K., de Lacerda, L. D. \& Ramachandran, S. (eds), Perspectives on Integrated Coastal Zone Management, Springer-Verlag, Berlin, pp. 279-96.

2002, 'Linkages between project-based EIA and the use of 'Ad-hoc' SEA for Australian Coastal Development.' In Marsden, S. and Dovers, S. (eds), Strategic Environmental Assessment in Australasia. The Federation Press, NSW, pp. 114-40.

Harvey, N., Barnett, E. J., Bourman, R. P. \& Belperio, A. P. 1999a, Holocene sea-level change at Port Pirie, South Australia: implications for global sea-level rise, Journal of Coastal Research 15 (3), pp. 607-15.

Harvey, N., Belperio, T., Bourman, B. \& Bryan, B. 1999b, A GIS-based approach to regional coastal vulnerability assessment using Holocene geological mapping of the northern Spencer Gulf, South Australia, Asia Pacific Journal on Environment and Development 6(2), pp. 1-25. 
Harvey, N., Belperio, A. P. \& Bourman, R. P. 2001, Late Quaternary sea-levels, climate change and South Australian coastal geology, in Gostin, V. (ed.), Gondwana to Greenhouse: Australian Environmental Geoscience, Special Publication No. 21, Geological Society of Australia, Sydney, pp. 201-13.

Harvey, N., Belperio, A. P., Bourman, R. P., James, K. \& Brunskill, G. 2002, New evidence contributing to the debate on the Holocene high sea-level stand in North Queensland, Australia, in Proceedings of the New Zealand Geographical Society and Institute of Australian Geographers Joint Conference, Dunedin, New Zealand, 29 January-2 February 2001.

Harvey, N., \& Bowman, G. M. 1987, Coastal Management Implications of a Holocene Sediment Budget: LeFevre Peninsula, South Australia, Journal of Shoreline Management 3(2), pp. 77-93.

Harvey, N., Clarke, B. D. \& Carvalho, P. 2001, The role of the Australian Coastcare program in community-based coastal management: a case study from South Australia, Ocean \& Coastal Management 44, pp. 161-81.

Harvey, N., Clouston, B. \& Carvalho, P. 1999, Improving coastal vulnerability assessment methodologies for integrated coastal management: an approach from South Australia, Australian Geographical Studies 37(1), pp. 50-69.

Haward, M. 1995, Institutional design and policy making 'Down Under': developments in Australia and New Zealand coastal management, Ocean and Coastal Management 26, pp. 87-117.

Haward, M. \& Vanderswaag D. 1996, Implementation of the UNCED Agenda 21 Chapter 17 in Australia and Canada: a comparative analysis, Ocean and Coastal Management, 29(1-3), pp. 279-95.

Healthy Rivers Commission 1999, Independent Inquiry into the Shoalhaven River System, Healthy Rivers Commission NSW.

- 2000, Independent Inquiry into Coastal Lakes: Issues Paper, October 2000, Healthy Rivers Commission NSW.

— 2001, Independent Inquiry into Coastal Lakes: Draft Paper, August 2001, Healthy Rivers Commission NSW.

Hesp, P. A. 1984, Foredune formation in Southeast Australia, in Thom, B. G. (ed.), Coastal Geomorphology in Australia, Academic Press, Sydney, pp. 69-97.

Hildebrand, L. 1997, Introduction to the special issue on community-based coastal management, Ocean and Coastal Management 36(1-3), pp. 1-9.

Hildreth, R. 1994, Institutional arrangements for sustainable use of coastal and marine resources, in Kriwoken, L. \& McAdam, S. (eds), Proceedings of Coast to Coast '94: A National Coastal Management Conference, Coastal and Marine Program, Department of Environment and Land Management, Tasmania, pp. 105-22.

Hill, B. J. \& Wassenberg, T. J. 1990, Fate of discards from prawn trawlers in Torres Strait, in Craik, W., Glaister, J. \& Poiner, I. (eds), The Effects of Fishing, CSIRO, Australia. 
Hillman, K. 1986, Nutrient Load Reduction, Water Quality and Seagrass Dieback in Cockburn Sound, 1984-85, Technical Series 5, Department of Conservation and Environment, Perth.

Hinrichsen, D. 1998, Coastal Waters of the World: Trends, Threats and Strategies, Island Press, Washington.

Hollick, M. \& Mitchell, B. 1991, Integrated Catchment Management in Western Australia: Background and Alternative Approaches, Centre for Water Research, University of Western Australia.

Holling, C. S. 1978, Adaptive Environmental Assessment and Management, Wiley, New York.

Holm, M. C. 1993, An Overview of Legal Issues Relevant to Coastal Zone Management in Australia, Report for the Coastal Zone Enquiry, Resource Assessment Commission, Canberra.

Hopley, D. 1982, The Geomorphology of the Great Barrier Reef, Wiley-Interscience, New York.

Hopley, D. (ed.) 1983, Australian Sea Levels in the Last 15,000 Years: A Review, Monograph Series, Occasional Paper 3, Department of Geography, James Cook University of North Queensland, Townsville, pp. 37-47.

Hore-Lacy, I. \& Webb, B. P. 1996, Australia's minerals and energy resources, in Mulligan, D. R. (ed.) Environmental Management in the Australian Minerals and Energy Industries: Principles and Practices. UNSW Press, Sydney, with Australian Minerals \& Energy Environment Foundation, chapter 1.

HORSCEC (House of Representatives Standing Committee on Environment and Conservation) 1980, Australian Coastal Zone Management, Report of the House of Representatives Standing Committee on Environment and Conservation, AGPS, Canberra.

HORSCERA (House of Representatives Standing Committee on Environment, Recreation and Arts) 1991, The Injured Coastline: Protection of the Coastal Environment, Report of the House of Representatives Standing Committee on Environment, Recreation and the Arts, AGPS, Canberra.

Houghton, J. T., Callander, B. A. \& Varney, S. K. (eds) 1992, Climate Change 1992. The Supplementary Report to the IPCC Scientific Assessment, Cambridge University Press, Cambridge, UK.

Houghton, J. T., Ding, Y., Griggs, D. J., Noguer, M., van der Linden, P. J., Dai, X., Maskell, K. \& Johnson C. A. (eds), 2001, Climate Change 2001: The Scientific Basis, Cambridge University Press, Cambridge, UK.

Houghton, J. T., Jenkins, G. J. \& Ephraums, J. J. (eds) 1991, Climate Change. The IPCC Scientific Assessment, Cambridge University Press, Cambridge, UK.

Houghton, J. T., Meira Filho, L. G., Callander, B. A., Harris, N., Kattenburg, A. \& Maskell, K. (eds) 1996, Climate Change 1995: The Science of Climate Change, Cambridge University Press for IPCC, Cambridge, UK. 
Hutchings, P. 1992, Ballast water introductions of exotic marine organisms into Australia: current status and management options, Marine Pollution Bulletin 25(5-8), pp. 196-9.

ICESD (Intergovernmental Committee for Ecologically Sustainable Development) 1996, Report on the Implementation of the National Strategy for Ecologically Sustainable Development (1993-1995), AGPS, Canberra.

ICLEI (International Council for Local Environmental Initiatives) 1996, The Local Agenda 21 Planning Guide: An Introduction to Sustainable Development Planning, ICLEI, International Development Research Centre \& United Nations Enmvironment Program.

IGBP (Internation Geosphere-Biosphere Programme) 1993, The LOICZ Science Plan, IGBP Report No. 28, Stockholm, Sweden.

IMCRA Technical Group 1997, Interim Marine and Coastal Regionalisation for Australia: An Ecosystem Based Classification for Marine and Coastal Environments Version 3.2, Environment Australia, Canberra.

IMO (International Maritime Organisation) 1998, Safer shipping and cleaner oceans, focus on IMO, IMO website (www.imo.org).

Inman, D. I. \& Nordstrom, K. F. 1971, On the tectonic and morphologic classification of coasts, Journal of Geology, 79, pp. 1-21.

IPCC (Intergovernmental Panel on Climate Change) 1991, Common Methodology for Assessing Vulnerability to Sea-level Rise, Coastal Zone Management Subgroup, Ministry of Transport and Public Works, The Hague, Netherlands.

- 1994, Preparing to Meet the Coastal Challenges of the 21st Century. Report of the World Coast Conference, 1-5 November 1993, Ministry of Transport, Public Works and Water Management, The Hague, Netherlands.

IUCN 1994, Guidelines for Protected Area Management Categories, Commission on National Parks and Protected Areas with the assistance of the World Conservation Monitoring Centre, Gland, Switzerland.

Jensen, A., Good, M., Long, M., Tucker, P. 2000, River Murray Barrages: Environmental Flows, Murray Darling Basin Commission.

Jennings, J. N. 1971, Sea level changes and land links, in Mulvaney, D. J. \& Golson, J. (eds), Aboriginal Man and Environment in Australia, ANU Press, Canberra, pp. 1-13.

Jia, H. 1994, Environmental management of mining: rehabilitation at Brukunga Pyrite mine, South Australia and Ranger Uranium Mine, Northern Territory, Master of Environmental Studies thesis, Mawson Graduate Centre of Environmental Studies, University of Adelaide.

Jones, K. 1984-85, The importance of Barker Inlet as an aquatic reserve; with special reference to fish species. SAFIC 8(6), 8-13, cited in PPK 1992, Gillman/Dry Creek urban development proposal (Multifunctionpolis): Draft Environmental Impact Statement, prepared for the Premier of South Australia by Rust PPK consultants Pty Ltd supported by Hassell Group and CSIRO, South Australia. 
Jones, M. M. 1994, Fishing Debris in the Australian Marine Environment, Bureau of Resource Sciences, Department of Primary Industries and Energy, AGPS, Canberra. Kailola, P. J., Williams, M. J., Stewart, P. C., Reichelt, R. E., McNee, A. \& Grieve, C. 1993, Australian Fisheries Resources, Bureau of Resource Sciences and the Fisheries Research and Development Corporation, Canberra.

Kane, P. S. 1976, Evaluating Landscape Attractiveness: A Review of Problems and Methods and a Technique Developed for the National Trust of South Australia, National Trust of Australia (SA), Adelaide.

Kay, R. \& Alder, J. 1999, Coastal Planning and Management, E \& FN Spon, London and New York.

Kay, R. \& Lester, C., 1997, Benchmarking the future direction for coastal management in Australia, Coastal Management, 25, pp. 265-92.

Kay, R. C. \& Waterman, P. 1993, Review of the applicability of the 'common methodology for assessment of vulnerability to sea-level rise' in the Australian coastal zone, in McLean, R. F. \& Mimura, N. (eds), Vulnerability Assessment to Sea-Level Rise and Coastal Zone Management, Proceedings of the IPCC Eastern Hemisphere Workshop, Tsukuba, Japan, 3-6 August 1993, pp. 237-48.

Kearney, W. J. 1988, Closure of Seas: Castlereagh Bay/Howard Island Region of Arnhem Land, Report by the Aboriginal Land Commissioner, Justice Kearney, to the Administrator of the Northern Territory, NT Government Printer, Darwin.

Kelleher, G., Bleakley, C. \& Walls, K. 2000, Marine Region 18: Australia/New Zealand, In A Global Representative System of Marine Protected Areas, Environment Australia website (www.environment.gov.au).

Kelleher, G. \& Dinesan, Z. 1993, Marine based tourism in the Great Barrier Reef: environmental impacts and management, in Hopley, D. (ed.) Marinet Seminar: North Queensland Regional Development in Marine Industries, James Cook University of North Queensland, Townsville.

Kenchington, R. 1993, Conservation biology and coastal zone management, in Moritz, C. \& Kikkawa, J. (eds), Conservation Biology in Australia and Oceania, Surrey Beatty \& Sons, Sydney, chapter 23.

Kenchington, R. A. \& Crawford, D., 1993, On the meaning of integration in coastal zone management, Ocean and Coastal Management, 21(1-3), pp. 109-27.

Kerr, S. 1994, Ballast Water Ports and Shipping Study, Report No. 5, Australian Quarantine and Inspection Service (prepared by Bureau of Resource Sciences for the Department of Primary Industries and Energy), AGPS, Canberra, Australia.

Kinloch, M. 1999, Draft Management Plan for Harvesting Beachcast Seagrass and Marine Algae, Marine Habitat Program, Primary Industries and Resources SA.

Kinsey, D. W. \& Davies, P. J. 1979, Inorganic carbon turnover, calcification and growth in coral reefs, in Trudingar, P. \& Swaine, D. (eds), Biogeochemistry of Mineral Forming Elements, pp. 131-62. 
Knecht, R. W. \& Cicin-Sain, B. 1993, Earth Summit held: stage set for new global partnership, Ocean and Coastal Management 19, pp. 75-86.

Knighton, A. D., Woodroffe, C. D., Mills, K. 1992, The Evolution of Tidal Creek Networks, Mary River, Northern Australia, Earth Surface Processes and Landforms, 17, pp. 167-90.

Komar, P. D. 1976, Beach Processes and Sedimentation, Prentice-Hall, New Jersey.

Komar, P. D. (ed.) 1983, CRC Handbook of Coastal Processes and Erosion, CRC Press, Boca Raton, Fla.

Kristensen, K. 1996, in Harvey, N. (ed.) Coastal Management, Proceedings of the Australian Coastal Management Conference, Glenelg SA, April 1996, pp. 34-7.

Kriwoken, L. K. 1996, Australian biodiversity and Marine Protected Areas, Ocean and Coastal Management 33, pp. 1-132.

Kucan, U. M. 1979, Man-made changes in the coastal zone between Port Adelaide and St. Kilda, BA (Hons) thesis, Department of Geography, University of Adelaide.

Laurenson, L. J. B., Unsworth, P., Penn, J. W. \& Lenanton, R. C. J. 1993, The Impact of Trawling for Saucer Scallops and Western King Prawns on the Benthic Communities in Coastal Waters off South-western Australia, Fisheries Research Report No. 100, Fisheries Department of Western Australia, Perth.

Leadbitter, D., Lee Long, W., Dalmazzo, P. 2000, Seagrasses and their managementimplications for research, in Butler, A. \& Jernakoff, P., Seagrass in Australia, CSIRO, Collingowood, chapter 5.

Leopold, L. B. 1986, Landscape aesthetics, Natural History 78, pp. 36-45.

Lewis, R. K., Edyvane, K. S. \& Newland, N. (eds) 1998, The State of Our Seas and Coasts-Description, Uses and Impacts on South Australia's Marine and Estuarine Environment, a technical reference document for the Government of South Australia, Adelaide.

LOICZ 2002, LOICZ products, LOICZ website (www.kellia.nioz.nl/loicz), accessed April 2002.

Lord, D., Paling, E. \& Gordon, D. 1999, Review of Australian rehabilitation and restoration programs, in Butler, A. \& Jernakoff, P., Seagrass in Australia: Strategic Review and Development of an R\&D Plan. CSIRO Publishing, Victoria.

Lothian, A. 1984, Landscape Evaluation in South Australia, Report to Department of Environment and Planning, South Australia.

MacIntyre, I. G., Burke, R. B. \& Stuckenrath, R. 1977, Thickest recorded Holocene reef section, Isla Pérez core hole, Alacran reef, Mexico, Geology 5, pp. 749-54.

Marchant, P. 1997 Aquaculture heads into dangerous waters: Parliament to investigate poor coastal planning standards, Environment SA, 6(2), p. 29.

Marine Group (of Environment Australia) 1999, Improving Performance in Partnership: mid-term evaluation of Coasts and Clean Seas, 1997-1999, Final Report, October 1999. 
Marston, F. 1993, Diffuse source nutrient generation rates in the Hawkesbury-Nepean Basin, CSIRO Division of Water Resources, Technical Memorandum 93/3.

Mawby, M. 1974, Progress - mining and the environment, in Dempsey, R. \& Cass, M. (eds), The Politics of Finding Out: Environmental Problems in Australia. Cheshire, Melbourne.

McBriar, E.M. (ed.) 1977, Landscape Study, National Trust of Australia (SA).

McCulloch, E., 1996, Save our seaweed, The Bird Observer 764, pp. 2-6.

McEnnulty, F. R., Bax, N. J., Schaffelke, B. \& Campbell, M. L. 2000, A Rapid Response Toolbox: Strategies for the Control of ABWMAC Listed Species and Related Taxa in Australia, first draft, CSIRO Marine Research, Centre for Research on Introduced Marine Species, Hobart.

McFarlane, B. \& Sheridan, K. 1986, The minerals and energy sector, in Sheridan, K. (ed.), The State as Developer: Public Enterprise in South Australia, The Royal Australian Institute of Public Administration, Touche Ross, Adelaide.

McKinnon, K. R. 1993, Review of Marine Research Organisation, Report to the Australian Minister of Science and Technology.

McLaren, W. 1994, Turning the tide, Habitat, (May) pp. 12-19.

McLean, R. 2001, Australia's coastal vulnerability assessment studies: recent upscaling or downscaling? in Mimura, N. \& Yokoki, H. (eds), Global Change and Asia Pacific Coasts. Proceedings of APN/SURVAS/LOICZ Joint Conference on Coastal Impacts of Climate Change and Adaptation in the Asia-Pacific Region, Kobe, Japan, November 14-16 2000, Asia Pacific Network for Global Change Research and Center for Water Environment Studies, Ibaraki University, Japan, pp. 29-33.

Milankovitch, M. 1930, Mathematische Klimalehre und Astronomische Theorie der Kilmaschwankungen, in Köppen \& Geiger, Handbuch der Klimatologie, 1, A. Teil, Berlin.

Minister for Planning and Local Government 1998, Planning for the future: a brief guide to Victoria's new planning schemes, Victorian Department of Infrastructure website (www.doi.vic.gov.au), accessed 2000.

Mitchell, A. \& Furnas, M. 1997, Terrestrial Inputs of Nutrients and Suspended Sediments to the Great Barrier Reef Lagoon, in GBRMPA, Proceedings of Conference 'Science, Use and Management', November 1996, Great Barrier Reef Marine Park Authority, Townsville.

Mitchell, W. 1991, Sea level and climate change, in Proceedings of the Second Australasian Hydrographical Symposium, University of NSW, pp. 353-60.

Morvell, G. 1996, Two years on from Coast to Coast '94: how far have we come? in Harvey, N. (ed.) Proceedings of the Australian Coastal Management Conference. University of Adelaide, South Australia, pp. 301-7.

Moss, A. J., Rayment, G. E., Reilly, N. \& Best, E. K. 1993, A Preliminary Assessment of Sediment and Nutrient Exports from Queensland Coastal Catchments, Environmental Technical Report No. 5, Queensland Department of Primary Industries, Brisbane. 
MRT 2000, Tasmania's mineral industry, Mineral Resources Tasmania website (mrt.tas.gov.au).

Murray-Wallace, C. V. \& Belperio, A. P. 1991, The Last Interglacial shoreline in Australia: a review, Quaternary Science Reviews 10, pp. 441-61.

Murray-Wallace, C. V., Belperio, A. P. \& Cann, J. H. 1998, Quaternary neotectonism and intra-plate volcanism: the Coorong to Mount Gambier coastal plain, southeastern Australia: a review, in Stewart, I. S., \& Vita-Finzi, C. (eds), Coastal Tectonics, Geological Society Special Publication No. 146, Geological Society, London, pp. 255-67.

Nakada, M. \& Lambeck, K. 1989, Late Pleistocene and Holocene sea-level change in the Australian region and mantle rheology, Geophysical Journal 96, pp. 497-517.

National Trust of Australia (NSW) 1983, Sydney Region-Conservation of Natural Areas, Rural Landscape and the Coastal Zone, National Trust NSW, Sydney.

— 1984, The Conservation of Coastal NSW-Policy Paper, National Trust NSW, Sydney.

Neil, D.T. \& Galloway, R.W. 1989, Estimates of sediment yields from farm dam catchments, Australian Journal of Soil and Water Conservation, 2(1), pp. 46-51.

Neil, D.T. \& Yu, B., 1996, Fluvial Sediment Yield to the Great Barrier Reef Lagoon: Spatial Paterns and the Effects of Land Use, in Hunter, H. M., Eyles, A. G. \& Rayment, G. E. (eds), Proceedings of Conference on Downstream Effects of Land Use, Rockhampton, April 1995, Queensland Department of Natural Resources, Brisbane.

Neverauskas, V. P., 1987, Monitoring seagrass beds around a sewerage sludge outfall in South Australia, Marine Pollution Bulletin 18(4), pp. 158-64.

NGWG (National Greenhouse Working Group) 1992, National Greenhouse Response Strategy, AGPS, Canberra.

Nias, D. J., McKillup, S. C. \& Edyvane, K. 1993, Imposex in Lepsiella vinosa from southern Australia, Marine Pollution Bulletin, 26(7), pp. 380-4.

Noyce, T. 1993, Beach and Offshore Sand Modelling in South Australia. Part 1 Analysis Methodology and Data Problems, Geographic Information Systems Section, Information Systems Branch, South Australian Department of Housing and Urban Development.

NSW EPA 1993, NSW State of the Environment 1993, Environment Protection Authority, Sydney.

— 1995, Environmental Guidelines: State of the Environment Reporting by Local Government, Environment Protection Authority, Sydney.

— 1996, NSW State of the Environment 1995, Environment Protection Authority, Sydney.

NSW Government 1990a, Coastal Policy, NSW Government Printer, Sydney.

_ 1990b, Coastline Management Manual, NSW Government Printer, Sydney. 1997, New South Wales Coastal Policy 1997: A Sustainable Future for the New South Wales Coast, Department of Urban Affairs and Planning, Sydney. 
O'Riordan, T. \& Vellinga, P. 1993, Integrated coastal zone management: the next steps, in Beukenkamp, P., Günther, P., Klein, R., Misdorp, R., Sadacharan, D. \& de Vrees, L. (eds), World Coast Conference 1993, Coastal Zone Management Centre, Ministry of Transport, Public Works and Water Management and National Institute for Coastal and Marine Management/RIKZ, The Hague, Netherlands, pp. 409-13.

Open University 1989, Waves, Tides and Shallow-Water Processes, Pergamon Press, Oxford, UK.

Paling, E. 1999, Seagrass project restoring meadows, Murdoch University website (wwwcomm.murdoch.edu.au), accessed 10 December 1999.

Paterson, D. 1994, Ballast water: an Australian perspective, in Kriwoken, L. \& McAdam, S. (eds), Proceedings of Coast to Coast '94, A National Coastal Management Conference, Department of Environment and Land Management, Hobart, pp. 174-84.

Pearce, F. 1998, Washed up: clean beach is a lifeless one, New Scientist (25 July) pp. 32-5. Peltier, W. R. 1999, Global sea level rise and glacial isostatic adjustment, Global and Planetary Change 20, pp. 93-123.

Pernetta, J. C. \& Milliman, J. D. 1995, Land-Ocean Interactions in the Coastal Zone: Implementation Plan. IGBP Report No 33, Stockholm.

Poiner, I. R., Buckworth, R. C. \& Harris, A.N.M. 1990, Incidental capture and mortality of sea turtles in Australia's northern prawn fishery, in Craik, W. Glaister, J. \& Poiner, I. (editors) 1990 The Effects of Fishing, CSIRO, Australia.

Poiner, I. R. \& Peterken, C. 1995, Seagrasses, in Zann, L. P. \& Kailola, P. (eds), State of the Marine Environment Report for Australia: Technical Annex 1. The Marine Environment, Great Barrier Reef Marine Park Authority, Townsville.

Poiner, I. R., Staples, D. J. \& Kenyon, R. 1987, Seagrass communities of the Gulf of Carpentaria, Australia, Australian Journal of Freshwater Research 38, pp. 121-31.

Poore, G. C. B. 1995, Biogeography and diversity of Australia's marine biota, in Zann, L. P. \& Kailola, P., State of the Marine Environment Report for Australia, Technical Annex 1-The Marine Environment, Great Barrier Reef Marine Park Authority, Townsville, pp. 75-85.

Pope, J. \& Duncanson, M. 1989, Mineral sands growth in Western Australia. Mining Review (May) pp. 1-8.

Porteus, J. D. 1989, Landscapes of experience: Malcolm Lowry's British Columbia, in Dearden, P. \& Sadler, B., Landscape Evaluation: Approaches and Applications, Western Geographical Series No. 25, University of Victoria, British Columbia.

PPK 1991, Assessment of Crown Lease Coastal Shack Sites in accordance with Environmental Sustainability Criteria, SA Department of Lands 91/74 (7 volumes). 1992, Gillman/Dry Creek Urban Development Proposal (Multifunctionpolis): Draft Environmental Impact Statement, prepared for the Premier of South Australia by Rust PPK consultants Pty Ltd supported by Hassell Group and CSIRO, February 1992, South Australia. 
Psuty, N. (ed.) 1988, Beach and Foredune Interactions, Journal of Coastal Research Special Issue 3, 1988.

Quarto, A. 2000, The mangrove forest, Mangrove Action Project Working Paper, website (www.earthisland.org) accessed November 2000.

Qld EPA 2000, Mangroves_-more than mud and mozzies! Queensland Environment Protection Agency website (www.env.qld.gov.au).

Raaymakers, S. 1998, The Global Response to 'The Ballast Water Issue': Implications for Australian Bulk Exports, Australian Minerals \& Energy Environment Foundation (AMEF) Ecoports Monograph Series No. 16, Occasional Paper No. 10, in conjunction with Ports Corporation Queensland.

RAC (Resource Assessment Commission) 1993a, Coastal Zone Enquiry: Final Report, AGPS, Canberra.

- 1993b, Resources and Uses of the Coastal Zone, Coastal Zone Inquiry: Information Paper No: 3, AGPS, Canberra.

— 1993c, Coastal Zone Enquiry, South Australian Case Study, AGPS, Canberra. 1993d, Recommendations from Previous Reports and Inquiries Relevant to the Coastal Zone, Information Paper No. 2, AGPS, Canberra.

Radok, R. 1976, Australia's Coast: An Environmental Atlas Guide with Base-lines, Rigby, Adelaide.

Ramsay, J. \& Butt, J. 1989, Visual analysis of coastal protection lands on the Lower South Coast Region of NSW, NSW Department of Planning Southern Region, Quenbeyan (unpublished).

Reilly, J. D. 1991, Possible Sources of Marine Contaminants: Upper Spencer Gulf, Future Proposals-Possible Additional Sources of Marine Pollution, Draft II, Environmental Research Station, Winninowie Conservation Park, Upper Spencer Gulf, South Australia.

Revell, G. R. B. 1982, Further Studies in Evaluating the Landscape Attractiveness of the Fleurieu Peninsula, National Trust of Australia (SA), Adelaide.

Richardson, B. J. 1995, The problem of chlorinate compounds in Australia's marine environment, State of the Marine Environment Report for Australia, Technical Annex 2, AGPS, Canberra.

Robertson, A. I. \& Alongi, D. M. 1999, State of the Marine Environment Report for Australia, Technical Annex 1. Mangrove ecosystems in Australia: structure, function and status, Environment Australia website (www.environment.gov.au).

Robinson, A. C., Canty, P., Money, T., Rudduck, P. 1996, South Australia's Offshore Islands, Commonwealth of Australia, and SA Department of Environment \& Natural Resources.

SA Government 1992, Review of South Australia Coast Protection Act 1972: Green Paper May 1992, Report of the Ministerial Review Committee, South Australian Coast Protection Board, Government Printer, Adelaide. 
1993, Review of South Australia Coast Protection Act 1972 (Draft White Paper), Report of the Ministerial Review Committee, Coast Protection Board South Australia, Government Printer, Adelaide.

Saintilan, N. \& Williams, R. J. 1999, Mangrove transgression into saltmarsh environments in south-east Australia, Global Ecology and Biogeography 8(2), pp. 117-24.

SARDI 1996, Aquaculture research and development program, South Australian Research and Development Institute website (www.sardi.sa.gov/aquatic).

Schwebel, D. A. 1983, Quaternary dune systems, in Tyler, M. J., Twidale, C. R., Ling, J.K. \& Holmes, J.W. (eds) Natural History of the South East, Royal Society of South Australia, Occasional Publication No. 3, pp. 15-24.

SEAC (State of the Environment Advisory Council) 1996, Australia: State of the Environment 1996. CSIRO Publishing, Melbourne.

Shafer, E. L. \& Mietz, J. 1969, Aesthetic and emotional experiences rate high with northeast wilderness hikers, Environment and Behaviour 1(2), pp. 187-97.

Shaffron, M., Croome, R. \& Rolls, J. R. 1990, Water quality, in MacKay, N. \& Eastburn, D., The Murray, Murray-Darling Basin Commission, Albury.

Short, A. D., Beaches of the New South Wales Coast: A Guide to Their Nature, Characteristics, Surf and Safety, Australian Beach Safety and Management Program.

Short, A. D. (ed.) 1993, Beach and surf zone morphodynamics, Journal of Coastal Research, Special Issue No. 15.

Short, A.D. (ed) 1999, Handbook of Beach and Shoreface Morphodynamics, Wiley, New York.

Sinclair, J. 2000, The fatal shore, Habitat 28(1), pp. 26-8.

Smith, D. I. 1998, Water in Australia, Oxford University Press, Melbourne.

Smith, T.F., Sant, M. \& Thom, B. 2001, Australian Estuaries: A Framework for Management, Cooperative Research Centre for Coastal Zone, Estuary and Waterway Management.

Somers, I. F. 1990 Manipulation of fishing effort in Australia's penaeid prawn fisheries, in Craik, W., Glaister, J. \& Poiner, I. (eds), The Effects of Fishing, CSIRO, Melbourne.

Sorensen, J. 1997, National and international efforts at integrated coastal management: definitions, achievements, and lessons, Coastal Management 25, pp. 3-41.

State Government of Victoria 1994, Discussion Paper on Creating Coastal and Bay Management, issued by the Hon. Mark Birrell, Minister for Conservation and Environment.

Sutton, D. 2000, The treasures of Cape Range, Habitat 28(1) pp. 16-19.

Sydney Water 1995, Coastal Stormwater Study, Final Report, Sydney Water Board.

Sydney Water Board 1992, Coastal Stormwater Study: Final Report 1992, Environmental Projects Group, Environment Management Unit, Sydney. 
Tailby, M. and Lenfer, A. 1996, Coastcare: communities and governments caring for the coast, in Harvey, N. (ed.), Proceedings of the Australian Coastal Management Conference, University of Adelaide, South Australia, pp. 129-35.

Tarte, D. \& Wescott, G. 2001, Implementing ecosystem-based management through the Oceans Policy; What, how, when and whom? Discussion Paper for the National Oceans Advisory Committee.

Tasmanian Government 1996, Tasmanian State Coastal Policy, Department of Environment \& Land Management, Hobart.

Thackway, R. \& Cresswell, I. D. (eds) 1995, An Interim Biogeographic Regionalisation for Australia: A Framework for Establishing the National System of Reserves, version 4.0, Australian Nature Conservation Agency, Canberra.

Thom, B.G. (ed.), 1984, Coastal geomorphology in Australia, Academic Press, Sydney.

Thom, B. G. and Harvey, N. 2000, Triggers for late twentieth century reform of Australian coastal management, Australian Geographical Studies 38(3), pp. 275-90.

Thompson, C. H. 1981, Podsol chronosequences on coastal dunes of eastern Australia, Nature 291, pp. 59-61.

Thompson, C. H. \& Moore A. W. 1984, Studies in Landscape Dynamics in the Cooloola-Noosa Area, Publication No. 73, CSIRO Division of Soils.

Thorman, R. \& Heath, I. 1997, Regional Environmental Strategies: How to Prepare and Implement Them, Australian Local Government Association.

Thwaites, J. 1999, State planning agenda. A sensible balance. Department of Infrastructure website (www.doi.vic.gov.au), accessed 2000.

Thwaites, T. 1999, There's something in the water, New Scientist, 163(2205): 14.

Tobler, W., Deichmann, U., Gottsegen, J. \& Maloy, K. 1995, The Global Demography Project, National Center for Geographic Information and Analysis, Technical Report 95-6, Santa Barbara, Calif.

Totaro, P. 1998, Defence sites turn green in harbourside blueprint, Sydney Morning Herald, 12 May 1998, p. 1.

Turner, S. J., Thrush, S. F., Hewitt, J. E., Cummings, V. J. \& Funnell, G. 1999, Fishing impacts and the degradation or loss of habitat structure, Fisheries Management and Ecology, 6, pp. 401-20.

UNCED (United Nations Conference on Environment and Development) 1992, Agenda 21 and the UNCED Proceedings, Oceana Publications, New York (also published at www.un.org/esa).

US Census Bureau 2000, World POPClock Projection, US Census Bureau website (www.census.gov/cgi-bin/ipc/popclockw), accessed 27 March 2002.

van Rooyen, J. 2000, TBT-what is it? Australian Marine Conservation Society for the Rivermouth Action Group website (www.rag.org.au).

Victorian Coastal Council 1997, Victorian Coastal Strategy, Victorian Coastal Council, Melbourne 
2001, Victorian Coastal Strategy, draft for public comment April-June 2001, Victorian Coastal Council, Melbourne.

Viles, H. \& Spencer, T. 1995, Coastal Problems: Geomorphology, Ecology and Society at the Coast, Edward Arnold, London.

Wachenfeld, D. R., Oliver, J. K. \& Morrissey, J. I. (eds) 1998 , State of the Great Barrier Reef World Heritage Area 1998, Great Barrier Reef Marine Park Authority, Townsville.

Ward, T., Butler, E., \& Hill, B. 1998, Environmental indicators for national state of the environment reporting - Estuaries and the Sea, in Australia: State of the Environment Environmental Indicators Report, Commonwealth of Australia, Canberra.

Wassenberg, T. J. \& Hill, B. J. 1990, Partitioning of material discarded from prawn trawlers in Moreton Bay, in Craik, W., Glaister, J. \& Poiner, I. (eds), The Effects of Fishing, CSIRO, Melbourne.

Wasson, R. J. 1997, Run off from the land to the rivers and the sea, in GBRMPA, Proceedings of Conference 'Science, Use and Management', Townsville, November 1996, Great Barrier Reef Marine Park Authority, pp. 23-41.

Waterman, P. 1996, Australian Coastal Vulnerability Assessment Project Report, Department of the Environment, Sport and Territories, Canberra.

WCED (World Commission on Environment and Development) 1987, Our Common Future, Oxford University Press, Oxford.

Wescott, G. 1993, Policy without implementation. Victorian Coastal Zone Management in 1992/3, Environmental and Planning Law Journal 10, pp. 87-96.

— 1998, Reforming coastal management to improve community participation and integration in Victoria, Australia, Coastal Management 26, pp. 3-15.

2000, The development and initial implementation of Australia's 'integrated and comprehensive Oceans Policy', Ocean and Coastal Management, 43, pp. 853-78.

Western Port Rivers Management Study 1986, The State of the Rivers and Streams in the Western Port Region.

Whittington, J., Cottingham, P., Gawne, B., Hillman, T., Thomas, M. \& Walker, K. 2000, Ecological Sustainability of Rivers of the Murray-Darling Basin: CRC for Freshwater Ecology Technical Report, in Draft Review of the Operation of the Cap, March 2000, Murray-Darling Basin Ministerial Council, Canberra.

Wigley, T. L. M. \& Raper, S. C. B. 1993, Future changes in global mean temperature and sea level, in Warrick, R. A., Barrow, E. M. \& Wigley, T. M. L. (eds), Climate and Sea Level Change: Observations, Projections and Implications, Cambridge University Press, Cambridge, UK, pp. 111-35.

Wilkinson, D., 1996, The 1995 Save our Surf Survey, Surfrider Foundation.

Wilkinson, M. L. 1996, Human Impact on Australian Beaches: Results from the Save our Surf '95 Beach Survey, Surfrider Foundation Australia, Dee Why, NSW. 
Wolanski, E., Spagnol, S. \& Lim, E.B. 1997, The importance of mangrove flocs in sheltering sea grass in turbid coastal waters, Mangroves and Salt Marshes 1(3), pp. 187-91.

Wolman, M. G. \& Schick, A. 1967, Effects of construction on fluvial sediment, urban and suburban areas of Maryland, Water Resources Research 3(2), pp. 451-64.

Wood, C. 1991, EIA of policies, plans and programmes, EIA Newsletter 5, pp. 2-3.

Woodroffe, C. D. 1988, Changing mangrove and wetland habitats over the last 8,000 years, Northern Australia and SE Asia, in Wade-Marshall, D. \& Loveday, P. (eds), Northern Australia, Progress and Prospects, Vol 2: Floodplains Research, Northern Australia Research Unit, Australia Research Unit, ANU Press, pp. 1-33.

1993, Quaternary evolution of coastal and lowland riverine plains of SE Asia and Northern Australia: an overview, Quaternary Geology 83, pp. 163-75.

2003, Coasts: Forms, Process and Evolution, Cambridge University Press, Cambridge.

Woodroffe, C. D., Mulrennan, M. E. \& Chappell, J. 1993, Estuarine infill and coastal progradation, southern van Diemen Gulf, northern Australia, Sedimentary Geology 83, pp. 257-75.

Woodworth, P. L. 1993, Sea level changes, in Warrick, R. A., Barrow, E. M. \& Wigley, T. M. L. (eds), Climate and Sea Level Change: Observations, Projections and Implications, Cambridge University Press, Cambridge, UK, pp. 379-91.

WRI (World Research Institute) 1995, WRI Indicator Brief: Coastlines at Risk: An Index of Potential Development-related Threats to Coastal Ecosystems. WRI, Washington DC.

Wright, G., 1974, Appraisal of Visual Landscape Qualities in a region selected for accelerated growth, Landscape Planning 1, pp. 307-27.

Wright, L. D., Neilson, P. \& Short, A. D., 1982, Morphodynamics of a macro-tidal beach, Marine Geology, 50, pp. 97-128.

Wright, L. D. \& Short, A. D. 1984, Morphodynamic variability of surf zones and beaches, Marine Geology, 56, pp. 93-118.

Young, A. R. M. 1996, Environmental Change in Australia Since 1788, Oxford University Press, Melbourne.

Zann, L. P. 1995, Our Sea, Our Future: State of the Marine Environment Report, Great Barrier Reef Marine Park Authority, 1995.

Zann, L. P. (comp.), 1995, Our Sea, Our Future. Major Findings of the State of the Marine Environment Report for Australia. Ocean Rescue 2000, Department of the Environment, Sport and Territories, Canberra.

Zann L. P. \& Kailola, P. 1995, State of the Marine Environment Report, Technical Annex 1. AGPS, Canberra. 
Entries in bold are to figures that are photographs while entries in italics are to all other figures and boxes

access to coast, coastal planning and equity $233-4$

acid sulfate soils $\quad 86,142$

Adams, P. 92

Adelaide beaches

population impact 133-6

seagrasses $104-5$

Adelaide metropolitan beach $\quad 67-72$, 104,272

aeolianite 122

Agenda 21 1, 5, 195, 205, 207

agricultural drainage 130,142

Murray River 152

Shoalhaven 86

Alder, J. 196, 198, 232

Alexandra, J. 265, 269

algae $100,109,131,189$

algal blooms $157-8,191$

antifouling paints 155,158

Apia Convention 206

aquaculture 44, 163-6

Australian Conservation Foundation

(ACF) 179, 241, 264

Australian Fisheries Management

Authority (AFMA) 204

Australian Fishing Zone 159

Australian Geological Survey

Organisation (AGSO) 205
Australian Institute of Marine Science (AIMS) 205

Australian Local Government

Association (ALGA) 258, 265, 269

Australian Quarantine and Inspection Service (AQIS) 157

Australian Tourist Industry Association 173

Backstairs Passage, SA 55

Bahr, M.E. 14

ballast 154-8, 191

Barker Inlet 96-9

Barnett, E.J. 53

Bass Strait islands 283

Batley, G.E. $\quad 175,184,188$

Beaches

and dune sediment 24-8, 26, 63,

$$
\text { 69-70, } 72
$$

cleanliness $\quad 62,130,174$

model of processes 71

nearshore processes and $\quad 62-74$

replenishment $104,134-5,272$

ridge systems $56,69,74$

shacks 169-70

wrack 108

Bellefrin Prong, WA 40 
Belperio, A.P. $\quad 49,59,189$

Bennett, I. 108

Benthic Protection Zone 278

Bilateral Agreements on the Protection of Migratory Birds 206

biodiversity 93, 204, 205, 274

coastal planning 233

Cockburn Sound 191

Coorong 153

National Strategy for the

Conservation of 258

offshore islands and 282-3

tourism 173, 289-90

bioregions 173, 277, 280, 281, 290

Bird, E.C. 77

blue holes $\mathbf{4 6}, 47$

bluefin tuna fishery 164

Bond, T. 28

Bondi Beach 231

Brisbane River 132

Brookes, D.R. 180

Brundtland Report $\quad 4,251$

Bucher, D. 88

Bungala 2000264

Bureau of Resource Sciences 205

Burton, B. 183

Buttlingara Aboriginal Corporation 246-7

by-catch, loss of species and 162

Byron Bay 62-7

Cable Beach, WA 72-3

Cairns, Qld 243

calcarenite 122

camping 173

see also tourism

Canada 8

Cape Bauer, SA 41

Cape Dombey 123

Cape Flattery, Qld 38

Cape Pillar, Tas. 43

Cape York Peninsula 76

carbon sinks 95
Carter, R.W.G. 195

Case Earth Award 227

Cato, Nancy 241

Cicin-Sain, B. 5, 6, 198

city expansion $\quad 126-8$

wastewater 128-33

Clean Waterways Program 132

cliffs and platforms $120-5,124$

climate change $\quad 8-9,13-14,205,251$

Earth's orbit and 45-6

climate 24, 25

coast

definitions of 13-16

importance of 1-3

length of 14

LOICZ typology 34-45

variety of landform, climate and vegetation 20

Coastal Action Plan 11, 294

Coast and Clean Seas program 13

coastal catchments 144-53, 301

nutrients $147-8$

Great Barrier Reef 148-51

Murray River 151-3

sediment loads $\quad 144-6$

suspended solids 145-7

Coastal Council of NSW 221

coastal development 2-3

environment movement and 240-1

impact on fisheries $159-60$

impact on mangroves $95-6$

impact on saltmarshes 91

impact on Shoalhaven River estuary 85-6

population growth in cities and 126-36

population growth in nonmetropolitan areas 136-43

styles of and impact on coast $137-8$

tourism 166-75

Townsville 224-8

Victorian approval processes 237 
whole of government approach 222

coastal dunes $\quad 74-80$

Cooloola 78-80

Noosa beaches 141

coastal environmental management

systems $\quad 258-73$

commitments to 258-9

high conservation and landscape

value places 273-91

information systems $\quad 268-71$

management costs and equity 271-3

monitoring change 259-68

coastal landscape $\quad 223,285-91$

coastal management 292

changes in the 1990s $8-13,9$

community participation $\quad 238-50$

coral reefs 108,118

current state of 293-4

defined 195

development phases 196

global influences 3-8, 292

government roles and responsibilities

202-30, 294-9

issues for the future 299-302

legislation, state governments 198

major management instruments

$$
\text { 214-16 }
$$

monitoring and 265-8

need for 194-202

ocean management and 6

planning and 196

Port Campbell coast 124

preserving seagrasses 108

shortcomings of 197

state based 9, 295-7

see also sustainable coastal

management

coastal mining $\quad 175-83$

coastal parks, South Australian 280-1

coastal planning 196, 231-9

development objectives and

guidelines 233-5 policies, plans and programs (PPPs) 231

Victorian case study $\quad 235-8$

coastal processes, Australian coastal

types and 52-3, 292

coastal region classifications $\mathbf{3 3}, \mathbf{3 4}$, 35-6, 37-45

coastal reserves 229

coastal resources 2

coastal systems, dynamics of 19-45

beach and dune sediment 24-28

climate and run-off 24

lithology 22-4

tectonics 21-2

tides and currents 28-31

waves 31-4

Coastal Tourism: A Manual for

Sustainable Development 174

coastal urban infrastructure 138-9, 301

coastal warping 56

Coastal Zone Inquiry 9-12, 197, 209-10, 293

coastal management emphases 195

cultural heritage and 285

industrial discharges and 184

international conventions and 208

population growth $126,136,143$

Coastal Zone Management Act (USA)

196

Coastcare 13, 244-9, 297

coastline changes, interglacial period 48-52

Cobourg Peninsula 284-5

Cockburn Sound

industrial pollutants in 190

seagrasses $101-2,103,191$

Cohen, Leonard 19

collaborative management, community participation and 241-4

collision coasts 21

commercial fishing 159-63 
Common Methodology for Assessing Coastal Vulnerability (IPCC) 4, 297, 302

Commonwealth Coastal Action

Program 131

Commonwealth coastal policy 12 , 198, 203-13, 252, 294-5, 302 action plan $12-13,294$ definition of coast $14,15-16,17$ development of 208-11 legislation 203-4 management responsibilities 203-13

Commonwealth Oceans Policy 211-13, 277, 294

community concerns $\quad 240-1$ community monitoring, sustainable coastal management and 264-5 community participation, in coastal management 7-8, 9, 198, 238-50, 297

coastal planning, equity and access 233-4

Coastcare 244-9 collaboration or management 241-4 into the future 249-50,301 two scales of 241 whole of government approach and 224

'Concerned Citizens for Industrial Control' 193

conservation movement, wilderness coast and coastal development 240-1

Convention for the Protection of the Natural Resources of the South Pacific region 207

Convention for the Protection of World Cultural and Natural Heritage 206

Convention on Biological Diversity 205
Convention on Wetlands of International Importance 206

Cooloola Sand Mass, Qld 78-80

coordinated management, federal system and 223

Coorong 153

coral reef coasts $\quad 108-19$

biological processes in development 108

threats and impacts on 108

costs, of sustainable management systems 271-3

Council of Australian Governments (COAG) 11, 295

Countryside Commission 285-6

Coxon, Chris 248

Crawford, D. 298

Creswell, I.D. 276

crown land community involvement in management of 242-3 protection of by reserve system 229 crown-of-thorns starfish 108 crustaceans 90

CSIRO 205 seagrass research 99 south coast of NSW study 138 survey of Australian coasts 23, 142 Cullen, P. 300 cultural heritage 223, 285

Culver Report 134

Cyclones coastal dunes and overdevelopment 141

seagrasses and 107

Townsville redevelopment and 224-8

Davies, J.L. $\quad 32,34,120$

Davies, P.J. 109

deep ocean outfalls 102

denitrification 131 
Dinesan, Z. 172

discharges, industrial 184

Dore, J. 259

Doyle, T. 240, 250

drainage see agricultural drainage

'Drupella' snails 108

Dugongs 99

Earth Summit $1,3-8,10$

Earth's orbit, climate change and 45-6

East Coast Swell $\quad 32,62$

East Ocean Current 31

ecologically sustainable development 4-5, 9, 10, 172, 196, 197, 232, 251 community participation and 248 Murray-Darling Basin and 300 principles of 251-2 scientific uncertainty and $250-8$ see also sustainable coastal management

Ecological Sustainable Development (ESD) Working Group 172

Edyvane, K.S. 277

EIA Network 190, 192

El Niño 20

Emiliana, C. 46

English Heritage Coast system 285

Environment Australia 175

Environment Protection and

Biodiversity Conservation Act 1999 203-4, 274

Environment Protection Authority WA (EPA) 191-2

environmental impacts, of mining $176-7,178$

environmental protection 223

coastal reserves 229

mangroves at Hinchinbrook 95

equity, and costs of sustainable management systems 271-3

estuaries 81-90, 302 condition of Australian $\quad 89-90,142$, 146-7

geomorphology of 82-3

river flow, tides and mixing 83-4

Shoalhaven River 84-6

South Alligator River $\quad 86-9$

State of the environment reporting key indicators 262

eutrophication 144

evolutionary processes, coastal dynamics and 19-20, 292

exotic species $155-7,158,173$

False Bay, SA 246-7

Ferrer, E.M. 7-8

Figgis, P. 289

fish stocks $\quad 159-60$

toxic chemicals and 189

fisheries

Barker Inlet 98

commercial 159-63

Gulf of Carpentaria 106

fishing $108,118,278$

techniques, impact on coastal environment 161-2

Fleurieu Peninsula 264, 288

Floodplains

Lower Murray 148

South Alligator River 87

foreshore committees 242-3

forests, Cooloola sands $79-80$

Framework Convention on Climate Change 205

Frankston, Vic. 137

Fraser Island 168-9, 179-83, 203, 288, 289

Fremantle, WA $\mathbf{4 0}$

fringing reefs 116

Galloway, R.W. 14

Ganter, E. 284-5

Garig Gunak Park Board 284 
Geographical Information Systems

(GIS) 270

geological warping 49

glacial-interglacial cycle fluctuations 46-8

Glasson, J. 231

global environmental change $\quad 4-8$, 198, 292

Quaternary period $\quad 45-8$

global warming 50

Gold Coast 137

'Good Beach Guide' 174

Gordon, A.D. 65

Graham, B. 232

Graham, R.J. 195

grasses 90

Great Australian Bight $\quad$ 41, 278

Great Barrier Marine Park Authority

118-19

Great Barrier Reef 47, 108, 110,

$$
\text { 112-19, 113-15 }
$$

catchment area damage and impact on 148-51

different reef and island types

113-15, 116-18

integrated coastal management

199-201

tourism management $\quad \mathbf{1 7 0}-\mathbf{2}$

World Heritage Area 118-19

zoning and protection 278

Great Ocean Road 123-4

Green Island $\mathbf{1 1 4}$

Green Turtles 99

Greenpeace 192

Guichen Bay, Robe 122

Gulf of Carpentaria 39

Gulf St Vincent 55-61, 102-5

Hails, J. 180, 183

Hale, L.Z. 239

Hallett Cove, SA 24, 124

Harvey, N. 53, 199-200, 256

Hastings Point 62-7
Hawke, Bob 208

Healthy Rivers Commission 85

heavy metals $176,178,180$, 184

hermatypic corals 109

high conservation and landscape value places 273-91, 301-2

Hildebrand, L. 7-8

Hill, Robert 300

Hinchinbrook Island 93-6

Hinrichsen, D. 2

Holocene sea levels $\quad 53,54,56,112$

Hopley, D. 110

Hore-Lacey, I. 176, 178

House of Representatives Standing

Committee on Environment and

Conservation (HORSCEC) 10, 143, 208-9, 241

Howard government 210

Huon Estuary, Tas. 44, 166

Huon Peninsula, New Guinea 50

hydro-isostatic loading 56

indicators, State of the environment

reporting and 262,263

information

sustainable coastal management and 268-71, 301

whole of government approach and 224

'Injured Coastline' report

(HORSCERA) 143, 208-9

Inman, D.I. 21

inner reef flat 111

integrated coastal management (ICM) 5-7, 9, 198, 297-9, 302

Coastal Zone Inquiry and 11

good practice guidelines 232, 234

Great Barrier Reef 199-201

necessary elements of 298

sustainable coastal environmental management systems 258

Victoria 198-9 
interglacial period, coastline changes during 48-52, 50, 51

Intergovernmental Panel on Climate Change (IPCC) 4, 253, 255-6, 297

Interim Bioregionalisation of Australia $173,277,280,281,290$

International Convention for the

Regulation of Whaling 206

international conventions 205-7

International Council for Local

Environmental Initiatives (ICLEI) 259

International Council of Scientific Unions 13

International Geosphere-Biosphere Programme (IGBP) 13, 34

International Union for the Conservation of Nature (IUCN) 274, 275, 286

inter-reef channels $\mathbf{1 1 5}$

Jervoise Bay, WA 190-2

Kane, P.S. 287

Kangaroo Island $51,282,288$

Kay, R. $\quad 196,198,232$

Kay, R.C. 256

Keating government 210

Kelleher, G. 172

Kellow, A. 240

Kelly, Ros 209

Kenchington, R. 269, 298

Kingfisher Bay Resort, Fraser Island 288,289

Kinsey, D.W. 109

Knecht, R. 5, 6, 198

Kriwiken, L.K. 276

lagoons, reef 111

land degradation $\quad 145-6$

land subsidence $\quad 59,98,189$

Land-Ocean Interaction in the Coastal Zone (LOICZ) 13-14 typology of coasts $\quad 34-45$

landscape value places 285-91, 303

leeward margins, on reefs 111-12

Lefevre Peninsula $\quad 56,57,134$

Lenfer, A. 248

Leuwin Current 31

Lewis, R.K. 179

lithology 22-4

Living on the Coast 12,210

Lizard Island $\mathbf{1 1 3}$

Local Agenda $21 \quad 6$

local government

Agenda 21 and 6

coastal development 143

coastal planning $\quad 224-8,228-30$

sustainable coastal management and 258, 265-8, 297

long-line fishing 162

macrotidal conditions 28

magnetic reversal 47

Mallalla District Council 247-8

mangroves $90,92-9,189$

acid sulfate soils and 86

Barker Inlet 96-9

fish stock and 160

Hinchinbrook Island 93-6

migration 59

marginal seacoasts 21

marina developments 173,175

Marine and Coastal Community

Network 172

Marine Mammal Protection Zone 278

marine protected areas $\quad 274-80$

marine species, transfer by ballast $155-7,158$

Mary River 88

Mawby, M. 179

Melbourne Waterways Program 132

microtidal conditions 28

Middle Beach Education and

Recreation Centre 247-8

mineral sands $77,179-83,188$

mining 175-83 
Molar Reef (Qld) 46, 47

molluscs 90

monitoring, of coastal changes 259-65, 266-8

Moreton Bay 132

Morning Inlet, Qld 39

Mount Lofty Ranges 49

Murray River 77, 148, 151-3, 300

Murray-Darling Basin 300

Murray-Wallace, C.V. 49

Nambucca Heads, NSW 37

National Coastal Action Program 244-5

National Coastal Vulnerability Assessment Case Studies Project 255-6, 257, 302

National Ecologically Sustainable Development Strategy 250, 261, 293

National Greenhouse Response Strategy 250, 253, 293

National Heritage Trust 210, 244-5, 292, 295

National Oceans Office 213

National Representative System of

Marine Protected Areas

(NRSMPA) 277-8

National Strategy for the Conservation of Australia's Biodiversity 258

National Tidal Facility $\quad 28,29,57-9$, 254-5

National Tide Tables 28

nearshore processes

Adelaide metropolitan beach 67-72

Byron Bay to Hastings Point $\quad 65-74$

Cable Beach 72-4

Ningaloo Fringing Reef 108, 119, 278-80

nitrogen 131

Noosa Heads 140-2, 241

Nordstrom, K.F. 21

Northern Territory, definition of coast no-take zones $\quad 278,290$

Nozawa, C.M. 7-8

NSW

coastal policy $214,216,220-1$

definition of coast 15

nutrient levels 144, 147-8, 168, 178

weeds 98, 101, 108

nutrient recycling 98

Nuyts Archipelago 283

O'Riordan, T. 196

ocean and coastal management, integrating 6

ocean currents $\quad \mathbf{3 0}, 31$

oceans policy $211-13,277,294$

off road vehicles, impact on coasts 168,173

Offshore Constitutional Settlement 203

oil discharges 189

Organisation for Economic

Cooperation and Development (OECD)

definition of coast 14

guidelines for integrated management 5-6

pressure-state response model 261, 261-2

Our Common Future (WCED)

$$
4,251
$$

outer reef crest 110

parabolic dune forms 76

partnership approach, to ICM

201, 249

see also community participation, in coastal management

PCBs 189

Pearce, F. 108

petroleum exploration 278

Pitts, D. 232

Point Malcolm, SA 70

pollutants and impact on coasts 128-33, 144, 147, 301 


\author{
Barrier Reef 148-9 \\ Cockburn Sound 191 \\ commercial fishing 162 \\ control concept, flawed 192 \\ industrial 184, 188-9 \\ mining and 176 \\ Port Phillip Bay 168 \\ shipping and ballast $154-8$ \\ Pompey Complex 46, 47, 115 \\ Population \\ city expansion and coastal impacts \\ 128-36 \\ coastal living $\quad 1-2,127,126-8$ \\ non-metropolitan expansion \\ 136-43
}

Port Adelaide 59

Port Adelaide River 96-9

Port Campbell coast 123-5

Port Elliot, SA 234

Port Hedland, WA 39

Port Phillip Bay 130-1, 132, 137

ballast and anti-fouling paints 158

recreation and tourism $167-8$

Port Pirie 60

prawns $106-7,162$

protection, of high conservation value

areas $273-85,301-2$

marine protected areas $\quad 274-80$

management categories 275

terrestrial areas $274,280-5$

public infrastructure, coastal industry

expansion and 190

public lands, coastal policies compared 222-3

public participation, in coastal management 196, 232

see also community participation

pulp mills, pollutants from 188

Queensland

coastal management plan 221

definition of coast 15

landscape assessment $\quad 287-8$

seagrass monitoring case study 265
Ramsar Convention $\quad$ 206, 207, 274

real estate values 133

recreation

impact on coast and 166-75

valuing and coasting protection and $272-3,303$

reef flat 110

reef islands 112

reef morphology 110

reef subsidence 111

reef-building corals 109

regional coastal planning 218,228

community participation and 248

monitoring and management and 266-8

Regional Environmental Indicators

Project 265, 269-70

regional marine planning 213

research and information, whole of

government approach and 224

residential development 86 see also suburbanisation

Resource Assessment Commission (RAC) 9-12, 126, 136, 143, 167, $175,197,252,285,293$

Resource Management Act 1991 (New

Zealand) 258

ribbon reef $\mathbf{1 1 5}, 116-17$

river flows, estuaries and 83-4

Robe, SA 42, 121-3

Royal Australian Planning Institute

232

run-off $24,139-40$

Saenger, P. 88

salinity levels 150,153

salmon fisheries 166

saltmarshes $\quad 90-2,97$

sand budget

Adelaide metropolitan beach $70-2$, 104, 134

Byron Bay to Hastings Point $\quad 66-7$

Cable Beach 73 
sand cays $\quad \mathbf{1 1 4}$

sand dune sediment $\quad 24-8,26$

Adelaide metropolitan beach $\quad 69-70$

Byron Bay 63-5

Cable Beach, WA 72

European impact on 74,141

soil and vegetation development 77-8

South Australia $\quad 47,48,47-8$

types $74-7,75$

sand mining $\quad 179-83,188$

sand movement, Adelaide metropolitan

beach $68,104-5,133-4$

sand nourishment 134-5, 272

scientific uncertainty and sustainable

coastal management 253-8

sea level changes $51,52,57$

Barker Inlet 98

geological evidence of 58

ice age rises $\quad 23-4,54-61,83$

Quaternary period $45-8,47,77$

sustainable coastal management and 253-7

seabirds $108,173,206$

seagrasses 99-108, 189

Cockburn Sound 101-2, 191

dieback 100-1, 105

fish stocks and 160

Gulf of Carpentaria 106-8

Gulf St Vincent 102-5, 135

Queensland monitoring case study 265

Townsville 228

seaweed 108

secondary industry, impact on coasts 184-93

sediment loads 144-6

Cockburn Sound 191

contamination 189

Great Barrier Reef catchment area

$$
\text { 149, 149-50 }
$$

mining and 178

Murray River 153

Seidler, Harry 169 septic tanks 139

sewerage 302

Bondi Beach 231

Murray-Darling Basin 152

non-metropolitan expansion 138-9

overflow points 130

seagrass and 102

Shoalhaven 84-6

shipping, impact on coastal waters 154-8

Shoalhaven River 84-6

shore platforms 120-1

Port Campbell 123-5

Robe, SA 121-3

Short, A.D. 71

Sinclair, John 168

small offshore islands $\quad 282-3$

Smith, D.I. 144

soil erosion 145-6

Sorensen, J. 14

South Africa 8

South Alligator River 86-90

South Australia

beach shacks 169-70

Coast Protection Act 1972196

coastal parks 281-2

coastal policy 215,217

Coastcare 247-8

coastal vulnerability assessment 256-7

coastline changes $\quad 47-8,49-50$

community monitoring case study 264

definition of coast $\quad 15$

landscape assessment 288

planning zones 234

sea level changes and coast changes 55-61

South Australian Conservation Council 192

south coast NSW, coastal development impacts 138

South-East Marine Region Plan 213

Southern Fleurieu Landcare 264 
Southern Queensland 76

species diversity $93,277,282-3$

species loss 138

Spencer Gulf $\quad 60,138-9,190$

state governments

coastal management control by 9 , 203, 208

coastal management legislation 198 coastal management responsibilities 216-24, 295-7

definition of coast and 15 general planning polices and coastal plans 232

State of the Environment Advisory

Council 91, 146, 153, 268, 295

State of the environment reporting (SoE) 260-3, 295

State of the Marine Environment report (SOMER) 128, 139, 144, 261, 295

stormwater 302

and cliff erosion $\mathbf{1 2 4}, 125$

non-metropolitan expansion and 138

pollutants and impact on coasts 128-33

Streaky Bay, SA 139

suburbanisation 137, 301

Sunshine Beach, Noosa 140-2, 241

Sunshine Coast 137, 140-2

Surfers Paradise, Qld 38

Surfrider Foundation 133

suspended solids 145-7

sustainable coastal management

251-3

high conservation and landscape value places 273-91, 301-2 scientific uncertainty and $253-8$ systems 258-73 see also ecologically sustainable development

sustainable development 4-5, 9, 196 characteristics of 259 see also ecologically sustainable development

sustainable tourism development 173-4, 288, 289, 290

swales 75

Swan Bay Marine reserve 249

Sydney Region 130-2, 132

Tailby, M. 248

Tarte, D. 213

Tasmania

coastal policy $\quad 217-18$

definition of coast 15

tectonics 21-2, 22

temperate waters, lack of protection of 276-7

Ten Mile Drift (Beachport, SA) 76, 77

terrestrial protected coastal areas $280-5$

Thomas, G.M. 276

Three Isles $\mathbf{1 1 4}$

Thwaites, J. 235

tidal movements $20,27,28-31$

Adelaide metropolitan beach $\quad 67-8$

Byron Bay 63

Cable Beach 72

estuaries 83-4

Hinchinbrook Channel 93-4

Torres Strait Treaty 207

Tourism

Great Barrier Reef 171-2

coral reefs 108,118

coastal management and 166-75

Fraser Island 288, 289

Port Campbell coast 124

protecting coastal landscapes and 285-91

Tourism Council of Australia 173

Townsville, Qld 224-8

trailingedge coasts 21

transgressive dune sheets 75

trawling 161-2 
Triabunna Woodchip Mill, Tas. 44

Trinity Inlet Management Program 243

tropical waters, protection of 276

turbidity $89,100,190$

Great Barrier Reef $146-7,150$

Murray River 151

Tweed Heads, NSW 37

Twelve Apostles, Vic. 42

UN Convention on the Law of the Sea 207, 211, 274

United Nations Conference on Environment and Development (UNCED) 1, 10, 205, 292

United States of America 196 urban design, water sensitive 132

value

of coasts $271-3,303$

of marine protected areas $\quad 274-80$

of protected coastal landscape 285-91

of terrestrial protected coastal areas $280-5$

vegetation

dune development and 77-8

loss of and dune erosion 75, 134

loss of and sediment load 145

Vellinga, P. 196

Victoria

Coastal Management Act 1995

196, 218-20, 235-6

coastal planning $\quad 235-8$

definition of coast 16

foreshore committees, collaborative management and 242-3, 249

integrated coastal management 198-9, 218

Victorian Coastal Council 198-9, 218 voluntary groups, coastal planning and 239

vulnerability assessment $\quad 4,255-8$, 297, 302
Waitpinga Dunes, SA 78

Wasson, R.J. $\quad 146,150$

wastewater disposal

Adelaide beaches 104

city expansion and 128-33, 302

non-metropolitan expansion 138-9, 302

Shoalhaven $85-6$

water quality 207, 223

and conservation 131

coastal planning 233

Great Barrier Reef and 150-1

industrial discharges and 184, 191

water recycling 131

waterbird breeding 87

Waterman, P. 256

wave action $\quad 31-4,32$

weather patterns 20

Webb, B.P 176,178

Wescott, G. 213

West Coast Swell 32

Western Australia

definition of coast 16

landscape assessment 187

wetlands 59,206

White, T. 265, 269

whole of government coastal policy 217, 222-4, 302

Whyalla, SA 138, 246-7

Willunga Basin, SA $\quad 139-40$

Wilsons Promontory, Vic. 43

wind action 75

wind records 67,72

wind systems $\mathbf{2 5}$

windward reef front 110

Wood, C. 231

wooded island reefs $\mathbf{1 1 4}, 115$

Woodhill, J. 259

Woodroffe, C.D. 87

World Resources Institute 2

Wright, L.D. 71

Young, A.R.M. 192 
Zann, L.P. $\quad 89,128,139,144,184$, 188, 261, 276, 295

Zoning

Barrier reef management and 200

marine protected areas and multiple use 278,290 